University of New Hampshire

University of New Hampshire Scholars' Repository

Doctoral Dissertations

Student Scholarship

Spring 1999

\title{
Confronting the war machine: Draft resistance during the Vietnam War
}

Michael Stewart Foley

University of New Hampshire, Durham

Follow this and additional works at: https://scholars.unh.edu/dissertation

\section{Recommended Citation}

Foley, Michael Stewart, "Confronting the war machine: Draft resistance during the Vietnam War" (1999).

Doctoral Dissertations. 2068.

https://scholars.unh.edu/dissertation/2068

This Dissertation is brought to you for free and open access by the Student Scholarship at University of New Hampshire Scholars' Repository. It has been accepted for inclusion in Doctoral Dissertations by an authorized administrator of University of New Hampshire Scholars' Repository. For more information, please contact Scholarly.Communication@unh.edu. 


\section{INFORMATION TO USERS}

This manuscript has been reproduced from the microfilm master. UMI films the text directly from the original or copy submitted. Thus, some thesis and dissertation copies are in typewriter face, while others may be from any type of computer printer.

The quality of this reproduction is dependent upon the quality of the copy submitted. Broken or indistinct print, colored or poor quality illustrations and photographs, print bleedthrough, substandard margins, and improper alignment can adversely affect reproduction.

In the unlikely event that the author did not send UMI a complete manuscript and there are missing pages, these will be noted. Also, if unauthorized copyright material had to be removed, a note will indicate the deletion.

Oversize materials (e.g., maps, drawings, charts) are reproduced by sectioning the original, beginning at the upper left-hand corner and continuing from left to right in equal sections with small overlaps. Each original is also photographed in one exposure and is included in reduced form at the back of the book.

Photographs included in the original manuscript have been reproduced xerographically in this copy. Higher quality $6^{\prime \prime} \times 9^{\prime \prime}$ black and white photographic prints are available for any photographs or illustrations appearing in this copy for an additional charge. Contact UMI directly to order.

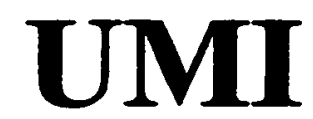

A Bell \& Howell Information Company

300 North Zeeb Roed, Ann Arbor MI 48106-1346 USA

$313 / 761-4700 \quad 800 / 521-0600$ 
CONFRONTING THE WAR MACHINE:

DRAFT RESISTANCE DURING THE VIETNAM WAR

BY

MICHAEL S. FOLEY

B.S., Florida Institute of Technology, 1986

M.A., University of New Hampshire, 1994

\section{DISSERTATION}

Volume I

Chapters I-V

Submitted to the University of New Hampshire in Partial Fulfillment of

the Requirements for the Degree of

Doctor of Philosophy

in

History

May, 1999 
UMT Number: 9926017

Copyright 1999 by

Foley, Michael stewart

All rights reserved.

UMI Microform 9926017

Copyright 1999, by UMI Company. All rights reserved.

This microform edition is protected against unauthorized copying under Title 17, United States Code.

\author{
UMI \\ 300 North Zeeb Road \\ Ann Arbor, MI 48103
}




\section{ALL RIGHTS RESERVED}

c 1999

\section{Michael S. Foley}


This dissertation has been examined and approved.

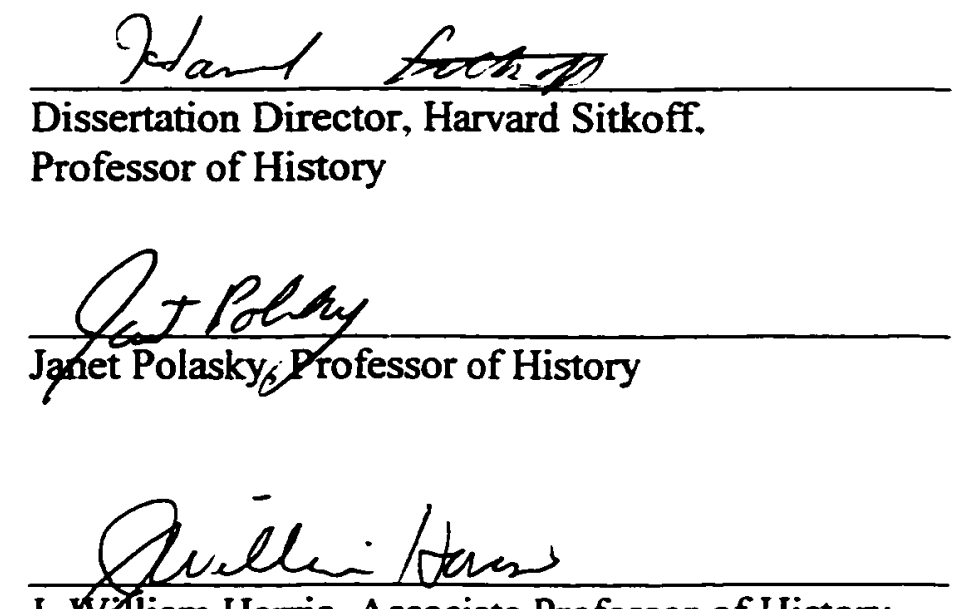

J. Lliam Harris, Associate Professor of History

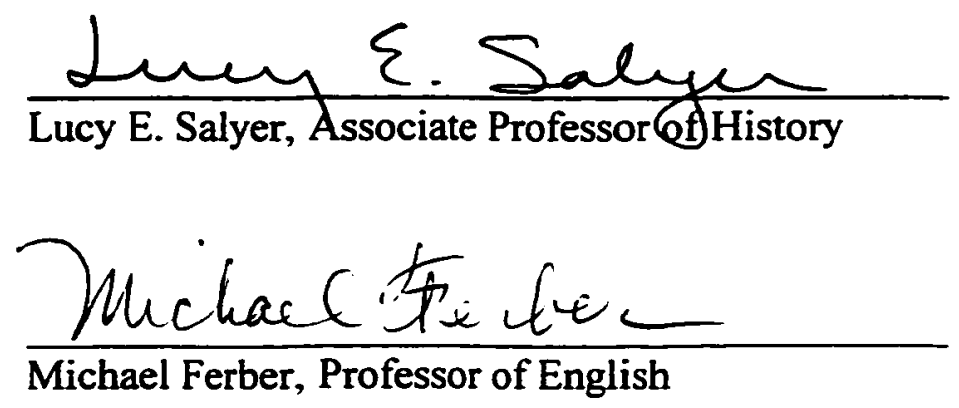

20 Aprie 1999 


\section{FOR MARIA}

Reproduced with permission of the copyright owner. Further reproduction prohibited without permission. 


\section{ACKNOWLEDGMENTS}

In many ways the research conducted for this dissertation has been a collaborative effort. I cannot overstate, for example, the importance of everyone who participated in this study by sitting for an interview or completing the questionnaire. Those who agreed to interviews often welcomed me, a stranger, into their homes and their offices; they often fed me in their own kitchens when I overstayed my welcome, or took me out for a meal. Most important, they told me the stories that are at the center of the dissertation. Not only would this project have been impossible to complete without their cooperation, it would have been impossible to start. Their hospitality and generosity were unanticipated bonuses. I also benefitted from the hospitality of friends and family who gave me a place to stay when I traveled to do research: my sister Erin Foley and her husband Bob Mocharnuk in Los Angeles; Penny Blair in San Francisco; and Pam Gubuan and Bobby Robinowitz in New York.

I owe a tremendous debt to those who helped me with all phases of the questionnaire. My sociologist friends, Carrie Yodanis, Sean Lauer, and Barrie Thorne, provided essential advice on conceptualizing and writing the questionnaire itself. Doug McAdam, whose book on Mississippi Freedom Summer inspired me to use a survey in this project, offered encouragement and important tips on administering the questionnaire through alumni offices. Howard Zinn and Michael Ferber endorsed the survey in a letter that several respondents credited with moving them to complete it. David Clennon subsidized the cost of copying and mailing more than 300 copies with a generous grant. 
My parents, Bill and Judy Foley, mailed most of the questionnaires for me as I ran off to California to conduct interviews. Most important, I thank the 185 people who returned completed surveys; their cooperation has proven invaluable.

Finding former draft resisters and other activists thirty years after the fact proved difficult, and I am immensely grateful to the following people for helping me to locate others (I apologize if I leave anyone out): Michael Ferber, Howard Zinn, Barrie Thorne, Noam Chomsky, Ray Mungo, Alex Jack, Connie Field, Neil Robertson, Bill Hunt, Michael Colpitts, Joel Kugelmass, Roxanne Dunbar-Ortiz, Sue Katz, Charles Fisher, Saul Slapikoff, Louis Kampf, Hilde Hein, Shawn Donovan, Ellen DuBois, Rob Chalfen, Ramsey Clark, Mark Mostow, Penney Kurland-Lagos, and James Carroll.

I owe an additional measure of gratitude to James Carroll for publishing a timely column on the Boston draft resistance movement in his weekly Boston Globe column. At the end of the piece, he asked readers to contact me with information that might be useful to this project. My phone rang all day with leads that gave my research an immediate and much needed boost.

One of the calls I fielded in response to the Carroll piece came from Alex Jack, who, it turned out, kept six large archival boxes of papers in his basement all these years. Little did I know how well draft resisters and their comrades understood their moment in history; eighteen different draft resistance activists gave me access to their personal private collections: Bill Bischoff, Rev. Jack Bishop, Fred Bird, Rev. John Boyles, Rob Chalfen, Michael Colpitts, Michael Ferber (papers now at Swarthmore College Peace Collection), Charles Fisher (papers now at Swarthmore), Dick Hughes, James Hunt, Alex 
Jack, Chick Marston, Jim Oestereich, Dave Satz, Bob Shapiro, John Sisson, Nan Stone, and Michael Zigmond. I owe special thanks to Deborah Jelmberg and Ellen Ford for providing access to and copies of a scrapbook chronicling Chick Marston's experience. All of these collections have proven to be extremely important to my research. In addition, Stanley Moss at the Arlington Street Church went above and beyond the call of duty in making records from the church available to me. Finally, archivists at Michigan State University, Syracuse University, the Lyndon Johnson Presidential Library, Swarthmore College, and Trinity College were exceedingly helpful.

At the University of New Hampshire, I have been incredibly fortunate to be associated with the finest group of advisers, colleagues, and friends one can hope to have in the academic world. I received excellent feedback on chapters-in-progress from faculty and fellow students at a series of dissertation seminars. In particular, Gretchen Adams, David Chapin, Scott Hancock, and Dave Cecere helped me to refine ideas and smooth the rough edges. Jeff Bolster, who organized most of these seminars, consistently offered cogent advice on structure, organization, and the rewards and pitfalls of writing a narrative. As everyone who has had the privilege to work with him knows, Jeff is a wonderful adviser who never fails to dispense wise counsel from his tiny office (or while standing in the department's corridors) - balanced with the right mixture of cheerleading and prodding.

My dissertation committee has been wonderful throughout. Harvard Sitkoff, my mentor and chair of the committee, has been exceptionally supportive of this project since the day we first discussed it. He encouraged me when I needed encouragement,

vii 
challenged me when I thought I knew everything, and applauded me when I earned it. Through it all, he gave me the breathing room to think for myself, make my own mistakes (and learn from them), and shape the dissertation into its final form. When he went to Ireland on a Fulbright this year - in addition to creating a one year job for me - he continued to read chapters and provide valuable feedback. I cannot thank him enough.

For being equally supportive, I am grateful to the other members of my committee: Lucy Salyer, Janet Polasky, Bill Harris, and Michael Ferber. All four read drafts of chapters along the way, and made themselves available for advice and moral support. Maybe most important, each read the final draft closely and made excellent suggestions for preparing the manuscript for publication. Michael Ferber warrants special mention for getting me involved in the subject of draft resistance in the first place. His visit to Harvard Sitkoff's course on Vietnam in 1994 inspired me to investigate draft resistance further and led to a unique relationship in which Michael has played the parts of historical source, adviser, and, most of all, good friend; he even helped to get me to the airport on time for my trip to the Johnson Library in Texas when my car broke down.

Katie Porter, a senior history major, provided essential research assistance in the latter stages of the project. She also gave the dissertation its first thorough proof-reading, which helped in preparing a much cleaner copy for consideration by the dissertation committee. I could not have finished on time without her efforts.

The History Department and the Graduate School at the University of New Hampshire provided much needed financial assistance in the form of graduate assistantships, summer research fellowships, and several small grants that paid for trips to viii 
Michigan and California, and the purchase of a tape recorder and transcriber. In addition, I thank the Lyndon Johnson Library Foundation for the Moody Grant that made travel to Austin possible.

To acknowledge the next group of people will seem odd only to those unaccustomed to writing alone late at night. I once read that the novelist William Styron - who often writes through the night - enlists the aid of two constant companions as he crafts his work: alcohol and music. I have not had much success with drinking and writing late at night, but I do feel indebted to a wide assortment of bands and solo artists who have kept me company and sustained me through research and writing: John Coltrane, Miles Davis, Charles Mingus, Bob Marley, the Grateful Dead, Bob Dylan, Jimi Hendrix, Dave Matthews, Ronnie Earl, Ani DiFranco, and Sleater-Kinney. Their music runs through these pages - at least when I read them.

My daughter Emma was born when I had completed only three chapters. The day before she arrived, Ramsey Clark wished my wife and me well and said, "If your baby brings you have as much joy as ours have to us, you'll be a rich man." He was right, of course; despite three months of colic, she has been a daily source of joy - especially over this last semester, when we have needed it most. Emma, above all, has put the little things in perspective.

Finally, there is Maria. When I told her that I would soon be struggling to put into words the full measure of her contribution to this dissertation, she said (in characteristic fashion), "Just make it brief. Get it over with already!" I am tempted to follow her advice, but I know it would not satisfy either of us. Few can understand all that the 
spouse of a doctoral candidate must endure, and it is not always easy to explain to outsiders. Like most young scholars, I have made a habit of reading the many thousands of ways that dissertation and first book writers have thanked their spouses, and I've read enough to know that there are not too many original ways left to do it. Still, I will try. Maria's support is not like the kind for which so many other academics thank their spouses. She has read only a handful of pages of this dissertation, and although she says she will read the whole thing eventually, I don't believe her. I also don't mind. She has supported me in so many other ways. She has been the driving force behind our household economy for the last seven years, making the purchase of this laptop computer and a decent office chair (among many other things) possible. Much more important, though, Maria has consistently offered psychological and emotional support, too. While she has never failed to push and prod, she has reassured, encouraged, cheered, and applauded when necessary. She has tolerated my absences from home, too few weekends and vacations together, and countless nights of me saying "good night" to her from my desk chair as I prepared for another long night of writing. Some mornings she even let me sleep late. Amazingly, she has maintained this level of support despite the additional demands placed on her over the last two years by her own part-time graduate program, pregnancy, childbirth, and motherhood. It is in these gestures, large and small, that she has been so selfless. I dedicate this dissertation to her knowing that it is but a tiny payment on a sizeable debt that I doubt can ever be repaid in full. 


\section{TABLE OF CONTENTS}

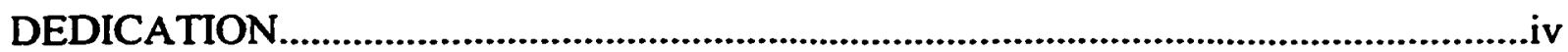

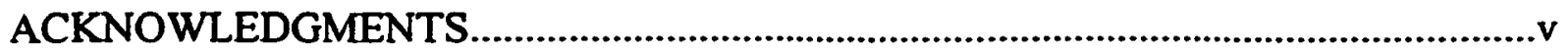

ABSTRACT

$\begin{array}{ll}\text { CHAPTER } & \text { PAGE }\end{array}$

INTRODUCTION

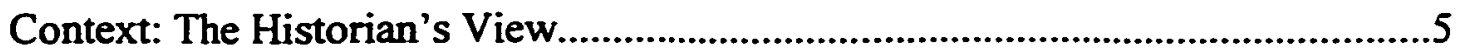

Context: The Vietnam War and the Selective Service System, 1950 to $1965 \ldots . . . .13$

Confronting the Draft and the War in Boston......................................................22

PART I: TOWARD A DRAFT RESISTANCE MOVEMENT

I. IN THE BEGINNING: A "LITTLE BAND OF BOLD PIONEERS”.............................40

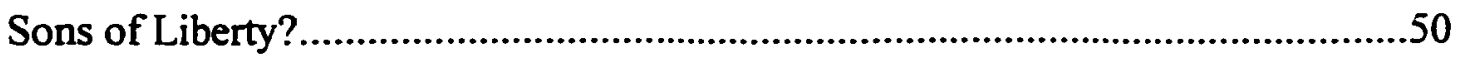

Pacifists' Progress................................................................................................63

America and Conscription..................................................................................68

"I Fought the Law, and the Law Won"...................................................................75

II. THE DRAFT AS A POLITICAL ISSUE AND MOVEMENT TARGET .....................88

The Draft as a Political Issue...................................................................................92

"We Won't Go".......................................................................................................103

Draft Reform?

$\mathrm{xi}$ 
The Boston Draft Resistance Group....................................................................112

The Early Morning Show and the Horror Show...................................................122

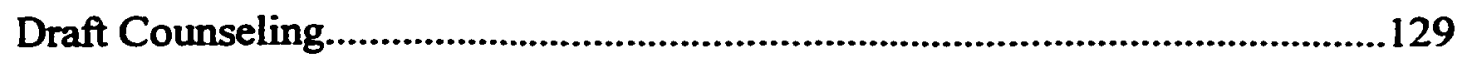

III. OCTOBER 16!: “A RESOLUTE SHOW OF MORAL FORCE”...............................137

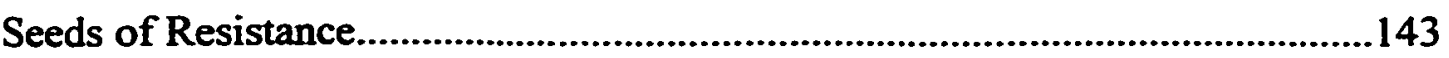

Intellectual Roots and Debates on the Left......................................................147

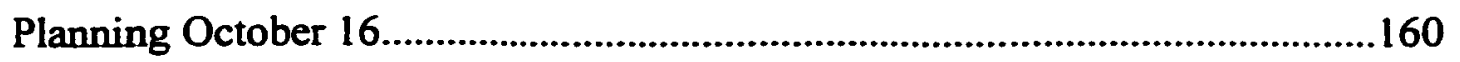

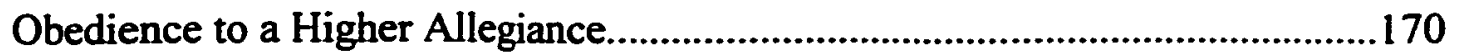

PART II: CONFRONTATIONS AND MISCONCEPTIONS

IV. FILTERED RESISTANCE: RESISTERS' IMAGE AND REALITY.....................193

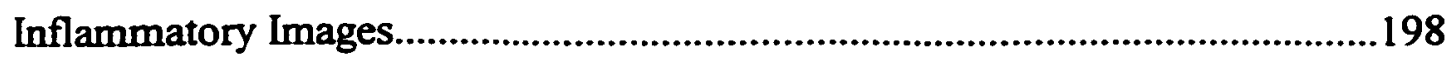

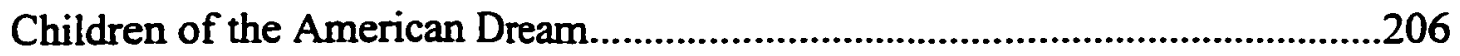

V. UNEASY WAITING: DRAFT RESISTERS AND THE JOHNSON

ADMINISTRATION........................................................................................222

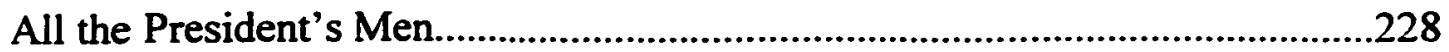

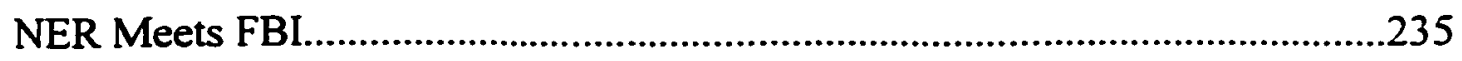

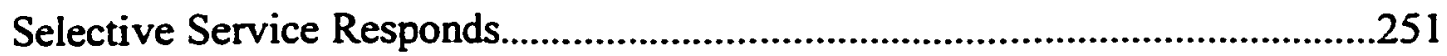

VI. GETTING BY WITH A LITTLE HELP FROM THEIR FRIENDS........................274

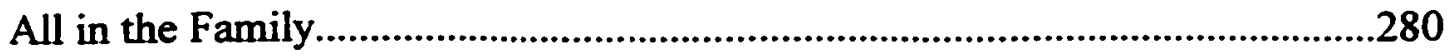

Unexpected Consequences...................................................................................286

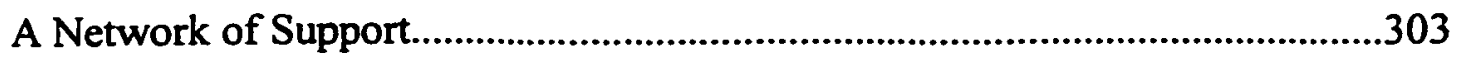

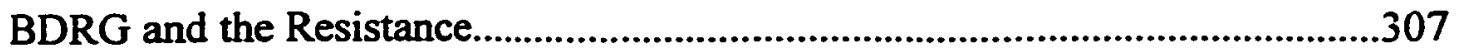

xii 
"Girls Say 'Yes' to Guys Who Say 'No'”...............................................................309

“A Child Has Spawned Parents"............................................................................315

November 16 and December 4.........................................................................325

\section{PART III: PEAKS AND VALLEYS}

VII. "A NEW BEGINNING": CONFRONTATION, RENEWAL, AND TRIUMPH...336

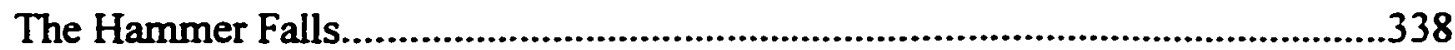

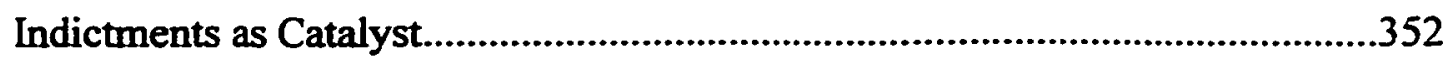

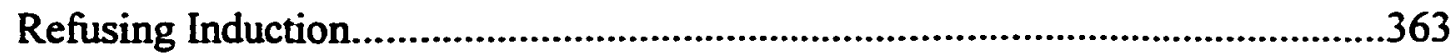

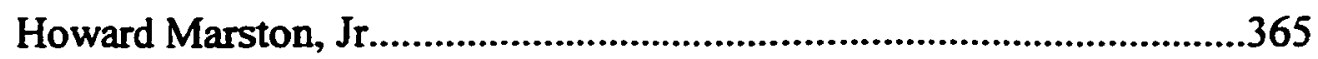

James Oestereich and Richard Hughes......................................................373

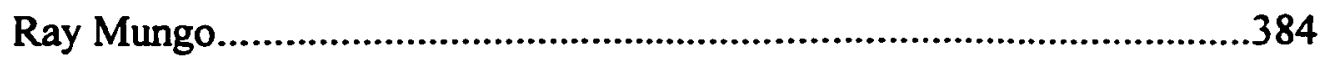

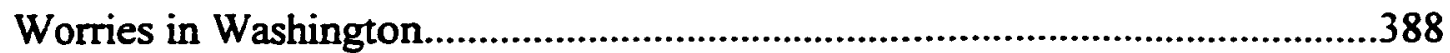

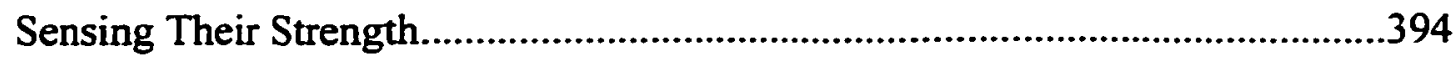

VIII. SPRING 1968: A "HOTHOUSE ATMOSPHERE"...............................................401

Death of a King and a World Upside Down.......................................................404

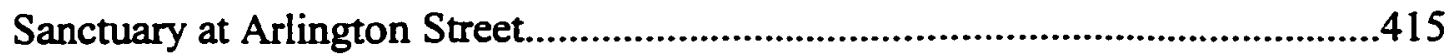

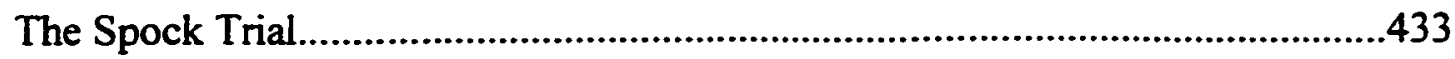

DX. BEYOND DRAFT RESISTANCE: NEW STRATEGIES AND LOOSE ENDS....460

So, You Say You Want a Revolution...................................................................466

Hippies and High Schoolers.............................................................................472

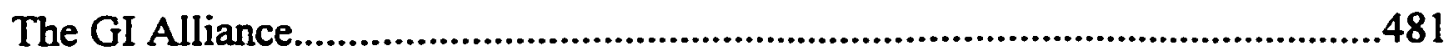

SUPPORT and Forgotten Resisters.................................................................510

xiii 
EPILOGUE

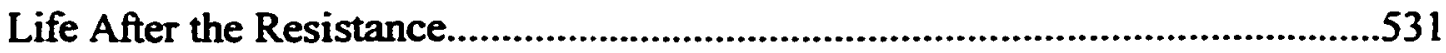

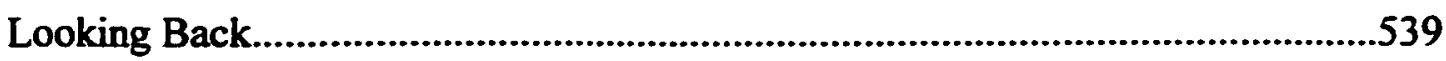

APPENDIX A: TABLES

APPENDIX B: STATEMENT ON METHODOLOGY............................................561

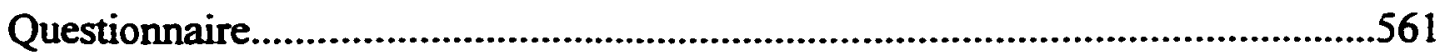

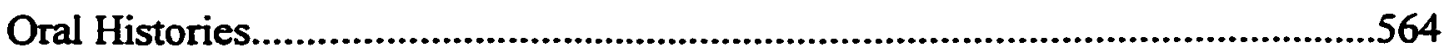

Sample Cover Letter and Questionnaire...............................................................566

APPENDIX C: A MEDITATION ON DRAFT RESISTANCE RESEARCH AND

PUBLIC MEMORY

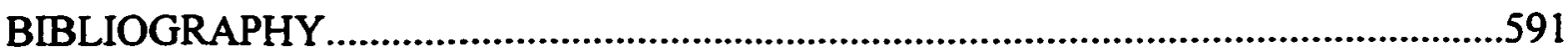

xiv 


\author{
ABSTRACT \\ CONFRONTING THE WAR MACHINE: \\ DRAFT RESISTANCE DURING THE VIETNAM WAR \\ by \\ Michael S. Foley \\ University of New Hampshire, May 1999
}

This dissertation recovers the history of the draft resistance movement in Boston during the Vietnam War. It is a blend of social, political, and cultural history that seeks not merely to assert the importance of draft resistance to our understanding of the antiwar movement and the Vietnam War era, but also to capture the experience of draft resisters and their supporters.

It is an actor-oriented history. The sources used include the personal private manuscript collections of participants, court records, underground newspapers, a 1997 survey administered to 310 former resisters and draft resistance activists (185 responded). and interviews with more than 60 movement participants. The resulting analysis, consequently, captures the backgrounds, motivations and justifications of resisters and their friends, how their draft resistance work affected their lives at home, at school and at work, and, more broadly, how it affected the rest of their lives.

Ultimately, this history, told largely in narrative form, recounts the story of those who violated draft laws as a way of confronting the war machine rather than dodging it. By openly defying Selective Service laws and inviting the government to prosecute them, 
draft resisters and their allies raised the stakes for everyone opposed to the war. Draft resistance, unlike other forms of protest at the time, mobilized the local antiwar community to take positive action against the administration and against the war in ways that marches and teach-ins could not. Moreover, by returning draft cards to the Justice Department, draft resisters forced the Johnson administration to take the antiwar movement seriously for the first time.

Draft resistance activists possessed a certain moral clarity that created in them an impatient sense of citizenship. It was the most striking characteristic of the movement. In the earliest days, it caused resisters and supporters to advocate a strategy of protest that resulted in personal risks ranging from beatings at the hands of a mob to government prosecution and incarceration. They chose to disrupt their lives and those of their loved ones to protest the war in the strongest way possible. Eventually, that impatience also led to the movement's dissolution. 


\title{
INTRODUCTION
}

\section{DRAFT RESISTERS AND DRAFT DODGERS: \\ MUHAMMAD ALI. BILL CLINTON, AND CONSCRIPTION DURING THE \\ VIETNAM WAR}

Nothing can bring you peace but yourself. Nothing can bring you peace but the triumph of principles.

\author{
Ralph Waldo Emerson \\ Self-Reliance, 1841
}

On April 28, 1967, the best known Vietnam War-era draft resister refused induction into the United States Army. Amid unprecedented media scrutiny and public attention, Muhammad Ali. the heavyweight boxing champion of the world, entered the United States Armed Forces Examining and Entrance Station in Houston, Texas. For months, Americans had listened to Ali say that he would not answer his country's call to serve, and now the day of reckoning arrived. Following the customary physical examinations and the completion of endless paperwork, Ali and 25 other draftees stepped into the induction ceremony room. The officer in charge of the induction, Lieutenant Steven Dunkley, stood at the podium and explained to the recruits that each man should step forward after hearing his name called; that single step, he said, would mark one's official entry into the Army. He started to read the list alphabetically and soon came to Ali's name. When he called out "Muhammad Ali," however, the champ did not move. He called "Cassius Clay," Ali's birth name, and again the boxer stood still. As Lt. Dunkley continued with the ceremony, two other officers led Ali out of the room and 
explained the penalties for induction refusal. When Ali indicated that he would not change his mind, the officers asked him to draw up an explanatory statement. "I refuse to be inducted into the armed forces of the United States because I claim to be exempt as a minister of the religion of Islam," Ali wrote. Then they let him go. As the United States Army's newest recruits boarded a bus to Fort Polk, Louisiana, Muhammad Ali emerged from the induction center a hero to some and a traitor to others.'

For this individual act of draft resistance, the boxing establishment and the federal government did what none of Muhammad Ali's opponents in the ring could do: they punished him and took away his title. Within an hour of his induction refusal, the New York State Athletic Commission, unwilling to wait for the outcome of Ali's inevitable trial, announced that they no longer recognized him as the World Boxing Association heavyweight champion and revoked his license to fight. Ten days later, a Houston grand jury indicted Ali, and on June 20,1967, a jury of six men and six women (all white) heard Ali's case; at the end of the day. after twenty minutes of deliberation, they returned with a verdict of guilty. The judge sentenced Ali to five years in prison and a $\$ 10,000$ fine, both the maximum allowed.'

Although he stood at the threshold of his best years as an athlete, the heavyweight champion gave up the promise of millions of dollars of income to make a point.

1 Steven Dunkley interview in Henry Hampton and Steve Fayer, Voices of Freedom: An Oral History of the Civil Rights Movement from the 1950s through the 1980s (New York: Bantam, 1990), pp. 331-333.

2 Thomas Hauser, Muhammad Ali: His Life and Times (New York: Touchstone, 1991), pp. 172, 179. 
Officially, the statement Ali scribbled at the induction center argued that he should be awarded a ministerial deferment from the draft because of his membership in the Nation of Islam (all male members are considered ministers of the faith), but his public statements exposed deeper roots to his disobedience. "Why should they ask me, another so-called Negro," he said, "to put on a uniform and go 10,000 miles from home and drop bombs and bullets on brown people in Vietnam while so-called Negro people in Louisville [his hometown] are treated like dogs and denied simple human rights?"י? While he did not at first perpetrate this act of defiance as a protest against the war per se, his resistance to the machinery of the draft and the war was an act of principle, and it set an important precedent for a budding movement of men prepared to resist the draft - not dodge it - as a form of mass civil disobedience aimed at undermining the nation's conscription efforts and ending the war.

The American public, the media, and the government regarded Muhammad Ali's draft resistance as an isolated case, unlikely to garner widespread support from his fellow citizens; nevertheless, the broader significance of his act did not escape some commentators. In the wake of Ali's induction refusal, for example, New York Times columnist Tom Wicker speculated on the impact of thousands of Muhammad Alis refusing to comply with the draft. Referring to Ali as a "strange pathetic Negro boxer, superbly gifted in body, painfully warped in spirit," Wicker argued that Ali's act of defiance exposed the "ultimate danger to a government that outrages a powerful and passionate minority." What could the government do, Wicker asked, if 100,000 draft age

3 "Clay Says He Will Not Step Forward," New York Times, 21 April 1967, p. 29. 
men "flatly refused to serve" in the military? "A hundred thousand Muhammad Alis...could be jailed. But if the Johnson administration had to prosecute 100,000 Americans in order to maintain its authority, its real power to purse the Vietnamese war or any other policy would be crippled if not destroyed." Here Wicker anticipated the logic that draft resistance leaders would adopt in inaugurating a nationwide draft resistance movement in the fall of 1967. In fact, resisters later used excerpts from Wicker's editorial - the figure of 100,000 draft resisters, in particular, became a movement target - to promote their massive campaign to disable the draft and stop the war.

To date, draft resistance has been virtually forgotten or, at best, understated by historians of this period. And thanks to several high profile draft "dodger" cases, the public's distinction between draft evaders and draft resisters is imperceptible; anyone who violated a draft law, it seems, was and is a draft dodger. This dissertation charts the history of the draft resistance movement in Boston, where its impact was greatest. It argues that at the height of American prosecution of the war in Vietnam, draft resistance raised the stakes for the antiwar movement (and the administration) by emphasizing personal risk for the war's opponents and by pushing it toward more radical tactics of civil disobedience and direct confrontation with the government. As a result, the Johnson administration found itself taking the antiwar movement seriously for the first time.

4 Tom Wicker, "In the Nation: Muhammad Ali and Dissent," New York Times, 2 May 1967, p. 46. 


\section{Context: The Historian's View}

Since the end of the Vietnam War, historians have written a number of very solid accounts of the antiwar movement. All of these have attempted to provide a national view of what was, essentially, a very decentralized movement made up of hundreds, if not thousands of organizations, many of which acted as their own movements within a movement. ${ }^{5}$ The production of national narratives like these is fairly typical in the early stages of historical analysis on any subject, but in an attempt to provide a cohesive picture of a national movement, they inevitably direct most of their attention toward the famous names and largest organizations; the local context in which most social movements thrive gets lost. For example, with the exception of Tom Wells's The War Within, each of these histories of opposition to the war interweaves brief discussions of draft resistance with discussions of the rest of the antiwar movement, thus minimizing its import. This has occurred, no doubt, because of the localized emphasis of the draft resistance movement; though the Resistance existed in name as a national organization, in reality it was made up of dozens of largely independent, local draft resistance organizations who, at most.

5 Thomas Powers, Vietnam: The War at Home (Boston: G.K. Hall \& Co., 1984); Nancy Zaroulis and Gerald Sullivan, Who Spoke Up?: American Protest Against the War in Vietnam. 1963-1975 (Garden City. NY: Doubleday, 1984); Melvin Small, Johnson. Nixon, and the Doves (New Brunswick. NJ: Rutgers University Press, 1988); Charles DeBenedetti, An American Ordeal: The Antiwar Movement of the Vietnam Era (Syracuse: Syracuse University Press, 1990); Tom Wells, The War Within: America's Battle Over Vietnam (Berkeley: University of California Press, 1994). For a broader trajectory of the peace movement since the 1930s, see Lawrence S. Wittner, Rebels Against War: The American Peace Movement, 1933-1983 (Philadelphia: Temple University Press, 1984). And for a national overview written by an active leader in the antiwar movement, see Fred Halstead, Out Now! A Participant's Account of the American Movement Against the Vietnam War, $2^{\text {nd }}$ ed. (New York: Pathfinder, 1991). 
stayed in touch with one another and, on occasion, coordinated protests for the same day. Wells gives the most attention to draft resistance, but even he understates its impact. Although he credits draft resistance with affecting the rest of the antiwar movement and American policy in Vietnam, he provides comparatively few details about the lives and motivations of rank and file draft resisters and, instead, relies on a few interviews with former Resistance leaders. ${ }^{6}$

Now that a preliminary understanding of the national organizations and their leaders has been achieved, it makes sense to turn our attention toward the antiwar movement in smaller geographic areas or toward individual strains of protest within the broader antiwar movement. ${ }^{7}$ Kenneth Heineman's study of the antiwar movement on several state college campuses, Amy Swerdlow's history of Women Strike for Peace, and Richard Moser's analysis of GI and veteran protest against the war are excellent examples of the new directions antiwar scholarship has taken. This study will add a history of the draft resistance movement to that list. ${ }^{8}$

6 Wells, The War Within, pp. 191-195, 268-270. Even Wells's chronology of the entire antiwar movement in 1967 and 1968 (the period, he argues, of the antiwar movement's most effective influence on government policy) shows that draft resistance dominated antiwar activity at that time, pp. 584-585.

7 See Christian Appy, "Give Peace Activism a Chance," Reviews in American History 23 (March 1995), p. 142.

${ }^{8}$ Kenneth J. Heineman, Campus Wars: The Peace Movement at American State Universities in the Vietnam Era (New York: NYU Press, 1993); Amy Swerdlow, Women Strike for Peace: Traditional Motherhood and Radical Politics in the 1960s (Chicago: University of Chicago Press, 1993); Richard Moser, The New Winter Soldiers: GI and Veteran Dissent During the Vietnam Era (New Brunswick: Rutgers University Press, 1996). See also, James Tracy, Direct Action: Radical Pacifism From the Union Eight to the Chicago Seven (University of Chicago Press, 1996), which, although it deals with a 
What is most surprising about the scant level of attention paid to draft resistance in the history of the Vietnam War era is that historians have had several significant studies on the subject, produced in the years immediately following the movement's demise, available to them as an indication of its importance. First among these is The Resistance, written by historian Staughton Lynd with Michael Ferber, a founder of the New England Resistance, in 1971. Like the larger antiwar movement histories that followed it, that book presented a national view of draft resistance that likewise emphasized the experience of leading organizers and strategists but which, at least. demonstrated its significance to the movement.9 In addition, two significant sociological studies analyzed the draft resistance movement of the Vietnam era as well. ${ }^{10}$ And two collections of resister accounts appeared in 1968 and 1970: Alice Lynd's We Won't Go and Dr. Willard Gaylin's study of war resisters in prison, In the Service of Their Country. Both books made it into paperback and found a wide audience among the general

broader period, deserves to be put in this category of new antiwar scholarship as well. 1971).

9 Michael Ferber and Staughton Lynd, The Resistance (Boston: Beacon Press,

10 Barrie Thorne, "Resisting the Draft: An Ethnography of the Draft Resistance Movement." Ph.D. diss., Brandeis Univ., 1971; Michael Useem, Conscription, Protest, and Social Conflict: The Life and Death of a Draft Resistance Movement (New York: Wiley, 1973). Unlike the present study, both of these projects, rooted in solid sociological analysis, examined draft resistance organizations especially regarding strategies, tactics, and backgrounds of the activists. They have both been important to my conceptualization of this project. In addition, I have benefitted from the use of an unpublished manuscript about the Boston Draft Resistance Group, written in the early 1970s by sociologist Charles S. Fisher. 
public." Except for a 1967 book on teach-ins and a 1975 study of GI protest against the war, no other subgroup within the antiwar movement became the focus of such extensive scholarly and public interest as draft resistance did in the years during and immediately after the war. ${ }^{12}$

In spite of the availability of such sources, draft resistance has only barely made it into our histories of the 1960 s and, as a result, has not begun to make inroads into the college textbooks that American students read in their surveys of American history. Todd Gitlin's influential history/memoir called The Sixties, for example, describes draft resistance as just one of the "varieties of antiwar experience." Likewise, Terry Anderson's popular book, The Movement and the Sixties, devotes approximately two of its 423 pages to draft resistance. ${ }^{13}$ Even the books on the events of 1968 contain few

"Alice Lynd, We Won't Go: Personal Accounts of War Objectors (Boston: Beacon, 1968); Willard Gaylin, M.D., In the Service of Their Country: War Resisters in Prison (New York: Viking, 1970).

${ }^{12}$ Louis Menashe and Ronald Radosh, ed., Teach-ins USA: Reports, Opinions, Documents (New York: Praeger, 1967); David Cortright, Soldiers in Revolt: The American Military Today (Garden City, NY: Anchor/Doubleday, 1975).

13 Todd Gitlin, The Sixties: Years of Hope, Days of Rage (New York: Bantam, 1988), see pp. 291-292; Terry Anderson, The Movement and the Sixties: Protest in America From Greensboro to Wounded Knee (New York: Oxford, 1995); David Burner, Making Peace With the 60s (Princeton: Princeton University Press, 1996) treats draft resistance in one paragraph; James Miller, Democracy is in the Streets: From Port Huron to the Siege of Chicago (New York: Touchstone, 1987) focuses primarily on Students for a Democratic Society and draft resistance is all but ignored; Allen Matusow, The Unraveling of America: the History of Liberalism in the 1960s (New York: Harper \& Row, 1984), like Anderson, gives draft resistance a couple of pages; John Morton Blum, Years of Discord: American Politics and Society, 1961-1974 (New York: Norton, 1991), p. 278, places draft resistance earlier than it actually occurred and makes it seem more like an SDS effort than it was; David Farber, The Age of Great Dreams: American in the 1960s (New York: Hill and Wang, 1994), gives a brief, incorrect representation of draft 
references to draft resistance, which is most puzzling given the amount of space it occupied in big city newspapers acrosis the country that year, especially from January to July. ${ }^{14}$ Furthermore, critics of the sixties generation or of the antiwar movement emphasize the most militant factions of the New Left and Civil Rights Movement and, consequently, suspend attention to draft resistance. ${ }^{15}$

By the time the history of draft resistance filters down from studies on the antiwar movement to surveys about the 1960 s and then textbooks, the portrayal is often absent or incorrect. To the extent that some textbooks or syntheses on the 1960 s discuss the draft and protest against it, the emphasis inevitably centers on draft card burning or draft evasion - which were not at all synonymous with draft resistance. Although early draft resistance events sometimes included a small proportion of resisters burning their draft cards, the movement quickly realized that card burning was easily misinterpreted by the public (see chapter 4) and abandoned it. Likewise, although some in the draft resistance movement certainly extended their definition of resistance to men who avoided service,

resistance: "A group called the Resistance urged young men to burn their draft cards in public. Thousands did."; Terry Anderson, The Sixties (New York: Longman, 1999) ignores draft resistance altogether.

It David Caute, The Year of the Barricades: A Journey Through 1968 (New York: Harper \& Row, 1988), pp. 127-135, Caute provides a breezy summary of draft resistance in 1968 and directs almost all of his attention to the Spock Trial rather than to the tactic of resistance; Ronald Fraser, ed. 1968: A Student Generation in Revolt (New York: Pantheon, 1988); Jules Witcover, The Year the Dream Died: Revisiting 1968 in America (New York: Warner Books, 1997).

is See, for example, Peter Collier and David Horowitz, Destructive Generation: Second Thoughts About the 60s (New York: Summit, 1990) and Adam Garfinkle, Telltale Hearts: The Origins and Impact of the Antiwar Movement (New York: St. Martin's, 1995). 
the majority of resisters made a sharp distinction between the two and resented sweeping generalizations that characterized resisters and dodgers in similar terms. Even so, it is the burners and dodgers who appear most prominently in textbooks and other general studies of the 1960 s. ${ }^{16}$

${ }^{16}$ An unscientific sampling of 14 of current college textbooks reveals the emphasis on the more controversial burning of draft cards and draft dodging. Only James Henretta, et al, America: $A$ Concise History (Boston: Bedford Books, 1999) actually name the Resistance and its Omega symbol. Even so, they emphasize draft card burnings and make it seem as though the Resistance supported draft dodgers: "Several thousand young men ignored their induction notices risking prosecution for draft evasion. Others left the country, most for Canada or Sweden. The Resistance, started at Berkeley and Stanford and widely recognized by its omega symbol, supported these draft resisters." For other textbooks which either ignore or barely mention draft resistance. see the following: George Brown Tindall and David E. Shi, America: $A$ Narrative History, $4^{\text {th }}$ ed. (New York: Norton, 1996), Vol. II, p. 1441, mention draft resistance but lump it together in a paragraph mostly about draft dodging; James West Davidson, et al, Nation of Nations: A Narrative History of the American Public, $3^{\text {rd }}$ ed. (Boston: McGraw-Hill, 1998), Vol. II, p. I105, emphasizes burnings, no mention of resistance; John A. Garraty. The American Nation (New York: Harper Collins, 1995), Vol II., p. 833, discusses the draft only, not draft resistance; Carol Berkin, et al, Making America: A History of the United States (Boston: Houghton Mifflin. 1999), Vol. II, pp. 957-958. addresses draft evasion, not resistance; Mary Beth Norton, et al, $A$ People and a Nation: $A$ History of the United States, $5^{\text {th }}$ ed. (Boston: Houghton Mifflin, 1998), Vol. II, p. 941, discusses draft dodging and protests at draft boards, but not draft resistance; Gary Nash, et al, The American People: Creating a Nation and a Society, $4^{\text {th }}$ ed. (New York: Longman, 1998), Vol. II, p. 981, mentions Muhammad Ali and a "campaign" against the draft without being more specific; Paul Boyer, et al, The Enduring Vision (Lexington, D.C.Heath, 1996), Vol. II, pp. 986, 983, briefly mentions draft resistance (though they incorrectly state that hundreds of protesters at the Spring Mobe in New York on April 15, 1967 threw their cards into a bonfire. In reality, fewer than one hundred lit their cards with cigarette lighters and dropped them in a coffee can that people passed around); Alan Brinkley, American History: A Survey, $10^{\text {th }}$ ed., (New York: McGraw Hill, 1999), p. 1070, and Alan Brinkley and Ellen Fitzpatrick, America in Modern Times: Since 1890 (New York: McGraw Hill, 1997), p. 513, although they make the distinction between resistance and draft dodging, they emphasize draft dodging: American Social History Project, Who Built America?: Working People and the Nation's Economy, Politics, Culture \& Society (New York: Pantheon, 1992), Vol. II, p. 569, does not discuss draft resistance but, consistent with its emphasis on the experience of working people, emphasizes the inequitable draft deferment system; David Burner, et al, Firsthand America, $4^{\text {th }}$ ed., (St. James, NY: 
More recently, several new collections of oral histories have been published which focus on conscientious objectors and draft dodgers. All are sympathetic portrayals and two of them, Sherry Sherson Gottlieb's Hell No. We Won't Go!: Resisting the Draft During the Vietnam War and Alan Haig-Brown's Hell No, We Won't Go: Vietnam Draft Resisters in Canada, use the term draft resister in their titles to describe men who, by draft resistance standards, dodged the draft - either by fleeing the country or by carrying out some ploy that got them rejected by the Selective Service. The blurring of this distinction is profoundly annoying to former draft resisters who today find themselves stressing the difference whenever they talk about it. Part of the reason they chose to resist the draft, after all, derived from a sense of unfaimess in the Selective Service System, the machinery of which provided "safety valves" that channeled potential troublemakers or recalcitrants out of the system while others took their places on the battlefield; to accept one of the deferments that marked a man ineligible for service or even to leave the country was tantamount to letting the system win. The confusion of draft resister and draft dodger labels has become so frustrating that one draft resistance leader has said on several occasions (only partially in jest) that when he dies, his epitaph should read, "I Didn't Dodge, I Resisted."17

Brandywine, 1996), Vol II, p. 958, emphasizes draft card burning and the Berrigan brothers; John M. Murrin, Liberty, Equality, Power, $2^{\text {nd }}$ ed., (Orlando: Harcourt Brace, 1999), Vol. II, p. 1006, focuses on draft card burnings; Thomas Bailey, et al, The American Pageant, $11^{\text {th }}$ ed., (Boston: Houghton Mifflin, 1998), p. 953, mentions draft card burnings only.

17 James Tollefson, The Strength Not to Fight: An Oral History of Conscientious Objectors of the Vietnam War (Boston: Little, Brown, 1993); Sherry Sherson Gottlieb, Hell No, We Won't Go!: Resisting the Draft During the Vietnam War (New York: Viking, 
The primary aim of this dissertation is to recover a history that is at risk of being lost altogether. More than that, the type of history that is recovered is of even greater importance than its resurrection. This dissertation is a blend of social, political, and cultural history that seeks not merely to assert the importance of draft resistance to our understanding of the antiwar movement and the Vietnam War era. but also to capture the experience of draft resisters and their supporters. It is an actor-oriented history. The sources used range from the written materials of draft resistance organizations to United States District Court records, from underground newspapers to a 1997 survey administered to 310 former resisters and other draft resistance activists ( 185 responded),

1991); Alan Haig-Brown, Hell No, We Won't Go: Vietnam Draft Resisters in Canada (Vancouver: Raincoast Books, 1996). Epitaph quote from Michael Ferber.

Note: More encouraging is that draft resistance sources are slowly making their way into the document readers that history professors so frequently use in upper-level courses on the Vietnam War and the 1960s. For examples of document readers that include draft resistance, see Marvin Gettleman, et al, Vietnam and America: $A$ Documented History, $2^{\text {nd }}$ ed. (New York: Grove Press, 1995) and Alexander Bloom and Wini Breines, Takin' It To the Streets: A Sixties Reader (New York: Oxford, 1995). Even so, the same cannot be said for the standard syntheses on the war, which generally include one chapter out of ten or more on the antiwar movement. Just as draft resistance is marginalized in college textbooks, it receives less attention than draft card burnings and draft evasion in these surveys of the war. For syntheses of the Vietnam War, see Marilyn Young, The Vietnam Wars (New York: Harper, 1991); George Herring, America's Longest War, $3^{\text {rd }}$ ed., (New York: McGraw-Hill, 1996); Gabriel Kolko, The Anatomy of a War: Vietnam, the United States and the Modern Historical Experience (New York: Pantheon, 1985); George Donelson Moss, Vietnam: An American Ordeal, $2^{\text {nd }}$ ed., (New York: Prentice-Hall, 1994); Stanley Karnow, Vietnam: A History (New York: Viking, 1983); Gloria Emerson, Winners and Losers (New York: Penguin, 1976). In addition, no entry on draft resistance appears in either Paul Buhle, et al, Encyclopedia of the American Left (Chicago: University of Illinois Press, 1992), or Stanley Kutler, Encyclopedia of the Vietnam War (New York: Macmillan, 1996). Likewise, entries on the Antiwar Movement, Conscientious Objectors, and Selective Service in Kutler barely mention draft resistance (see pp. 30-46, 148, and 493-494), though it receives one paragraph in the entry on the Supreme Court. 
and from personal papers to interviews with more than 60 participants in the movement. A considerable portion of the resulting analysis is, consequently, directed at capturing the backgrounds, motivations and justifications of resisters and their friends, how their draft resistance work affected their lives at home, at school and at work, and, more broadly, how it affected the rest of their lives. That said, the dissertation does not neglect the organizational structure of draft resistance groups, the strategies conceived and tactics employed, as well as the contests for power within those organizations. These topics raise important issues, too.

In addition, much of the dissertation is concerned with the response to draft resistance by the public, the press, and most important, the federal government. It is especially attentive to the manner in which both the Selective Service System and the Department of Justice reacted to the open defiance of draft laws by resisters and their supporters. and how many of their cases - famous and not-so-famous - played out in the courts.

To begin to understand the varieties of historical experience generated by the draft resistance movement in the late 1960 s, one must first grasp the context in which they were created. To do that, a brief history of the war and the draft are in order.

Context: The Vietnam War and the Selective Service System. 1950 to 1965

American intervention in Vietnam dated to the years immediately following the Second World War. Under President Harry Truman, the United States supported French efforts to reestablish colonial hegemony in Southeast Asia and, by the early 1950s, provided eighty percent of the funds spent by France in fighting the Viet Minh, the 
nationalist, communist, guerrilla movement led by Ho Chi Minh. When, in 1954, the French suffered their final defeat at Dien Bien Phu, the United States witnessed the signing of the Geneva Accords, an agreement which called for the temporary separation of Vietnam into two regions, north and south, at the $17^{\text {th }}$ parallel. In 1956 , the Accords stipulated, a national election would be held to reunite the country as one independent nation.

Almost immediately, the Eisenhower administration intervened in Vietnam to prevent its reunification. Recognizing that Ho Chi Minh might win as much as 80 percent of the vote, and fearing that a communist Vietnam might lead neighboring countries to fall to communism, too, Eisenhower approved the CIA-directed build-up of a separate, permanent government in South Vietnam under Ngo Dinh Diem. Although he received little support from the majority of citizens living in southern Vietnam. Diem disavowed the planned elections for 1956 and declared South Vietnam's independence. This turn of events effectively planted the seeds for a second Indochina war. By 1960, more than 600 American military advisers lived in South Vietnam, training the new Army of the Republic of Vietnam (ARVN) for a war with the North. That figure climbed to nearly 17,000 by the time both Ngo Dinh Diem and John F. Kennedy were murdered in November 1963.

The United States Congress gave President Lyndon Johnson permission - though without a declaration of war - to escalate the war in Vietnam following an alleged attack by North Vietnamese torpedo boats on the USS Maddox in the Gulf of Tonkin in early August 1964. Johnson began a sustained bombing campaign on the North and, following 
Vietcong attacks on American advisers in early 1965, made the decision to send ground troops to South Vietnam. By December 1965, Johnson increased the American presence in South Vietnam to almost 185,000 American combat troops. That kind of rapid escalation required greater mobilization of manpower, and it could come from only two places: the reserves or a draft.

The president and his advisers believed that activating the reserve armed forces would be more disruptive to the homefront than increasing draft calls. so the Selective Service quickly swung into action. Prior to 1965, Americans had grown used to the peacetime draft system in place since 1948. For more than ten years, monthly draft calls were kept to fewer than 9,000 men (as compared to almost 40,000 men a month in 1967 and 1968), and a complex system of draft deferments made it easy for many draft-age men (especially middle class draft-age men) to stay out of the service altogether. The drafting of more than 170.000 men between September 1965 and January 1966 and more than 300,000 men every year for the next three years snapped Americans back to reality and the nation's system of conscription soon came under scrutiny for the first time in a long time. Many Americans did not like what they found.

Muhammad Ali's encounters with the draft illuminated much of what was unfair and unjust with America's system of conscription. In April 1960, when he turned 18, Ali (still known as Cassius Clay) registered for the draft just like every other draft-age man in Louisville, Kentucky through Selective Service Local Board 47. Draft registrants did not detect a war on the horizon, and the steady, familiar operation of a peacetime draft that called proportionately few men to the service minimized anxiety. Two years later, in 
March 1962, Local Board 47 classified Ali 1-A, eligible to be drafted. Almost another two years passed before he heard from the Selective Service again, however, and this time they ordered him to take the standard pre-induction physical and mental examinations just weeks before he won the heavyweight title from Sonny Liston. The gifted athlete passed the physical exam with no difficulty, but he scored very poorly on the 50 minute mental examination. The Army rated his IQ at 78 , which put him in the $16^{\text {th }}$ percentile, far below the $30^{\text {th }}$ percentile score required to pass. A second mental test proved that Ali did not fake the first exam, and in March, 1964, he received a new classification of $1-Y$, not qualified for service. The publicity that followed his deferments humiliated Ali. "I said I was the greatest," he told reporters, "not the smartest."18

Given his test scores, however, Ali believed he could now proceed with his boxing career without fear of the draft. He was wrong. Early in 1966, as the demand for troops increased with the escalation of the war in Vietnam, the United States Army lowered its standards on the mental examination to make anyone with a score in the $15^{\text {th }}$ percentile or better eligible for the draft. In February, his local board reclassified Ali 1-A. To the champ, it seemed arbitrary.

As a puzzled Ali struggled to deal with this turn of events, reporters descended on him from all over the country. They asked him questions about Vietnam, the war, the president, and the Gulf of Tonkin Resolution, but the champion boxer known as much for his mouth as his punch found himself speechless. Finally, frustrated, Ali spoke the quote

18 Thomas Hauser, Muhammad Ali, pp. 142-143; David Remnick, King of the World: Muhammad Ali and the Rise of an American Hero (New York: Random House, 1998), p. 285. 
heard around the world: "Man, [ ain't got no quarrel with them Vietcong." The media and the public recoiled; by the time he refused induction over a year later, he had become so controversial that some state boxing commissions moved to bar closed-circuit broadcasts of his fights. Although Ali appealed the reclassification, arguing for conscientious objector status, few seemed to take it seriously. Many viewed his membership in the Nation of Islam as insincere, a ruse to help him dodge the draft. But Ali had joined the Nation in 1961, long before the draft issue came up, and if the public did not believe his claims, the retired judge who ruled on his appeal did. The judge recommended that the Appeals Board classify Ali as a conscientious objector. By late fall 1966, Ali's case had become politicized. however, and the Appeals Board denied his request for $\mathrm{CO}$ status. Several months later, Ali refused induction. He did not fight again until $1971 .^{19}$

The apparent inconsistency in the Selective Service System's handling of Ali's classification was not unique to his case. As draft calls increased, it grew increasingly obvious that the men being called to serve in this war came primarily from minority and working class homes and often were undereducated or close to illiterate. Where, for instance, were the white professional athletes? Unlike World War II system, this draft called few national celebrities. Elvis Presley answered the call of the armed forces in the late 1950s during a period of relative peace. In 1966, George Hamilton, the handsome Hollywood actor who was then dating one of President Johnson's daughters, escaped

${ }^{19}$ Hauser, Muhammad Ali, pp. 144-145, 154-155; Remnick, King of the World, pp. 286-287; "TV of Clay Fight Banned in 3 Cities," New York Times, 19 Mar. 1966, p. 22. 
conscription by claiming his mother needed him to care for her. But famous, wealthy, white men were not the only safe ones; more glaring were the millions of college and graduate students who held deferments while those who could not go to college faced the draft.

Bill Clinton, a young Arkansan studying at Georgetown University, benefitted from just such a deferment. As an undergraduate, the future president dodged the draft the same way millions of other college men did: legally. As part of its program of "manpower channeling," the Selective Service maintained its peacetime system of deferments for vocations deemed to be in the "national interest." Students in college, they assumed, were being educated for the future benefit of the nation whereas stock boys in a supermarket or gas station attendants were not. Even if a gas station aftendant was every bit as bright as thousands of college students his age, but could not afford to go to school, he would be much more likely to be drafted. The system seemed to be saying that some men were better than others and therefore warranted protection from the indiscriminate violence of war. Others could be sacrificed.

Those with deferments became very skilled at keeping them or securing others. Students, especially, had access to information about the myriad ways to beat the draft. and the leisure time to conceive and carry out plans that would keep them out of the Army. Bill Clinton is a perfect example. Like thousands of other men who graduated from college in the middle of the war (1966), Clinton "pyramided" a graduate deferment on top of his undergraduate one. Before graduate deferments were eliminated in 1968, registrants could conceivably use this tactic until they reached the age of 26 and were 
much less likely to be drafted. Clinton might have adopted a similar strategy but he came along too late; in the middle of his Rhodes scholarship at Oxford University, Congress eliminated graduate deferments. Despite the example of the draft resistance movement and his Rhodes scholar roommate who chose to accept prison over induction, Clinton manipulated the system as well as he could to avoid being drafted. After receiving an induction notice in May 1969, he sought and gained acceptance into an advanced Reserve Officer Training Corps (ROTC) program at the University of Arkansas Law School. This move successfully pushed him out of the 1-A pool into the 1-D classification for reserves and kept him from being inducted. Despite some pangs of guilt, Clinton held that deferment until late October when he reneged on his ROTC commitment and asked to be reclassified as 1-A. By that time, President Nixon had changed draft regulations to allow graduate students to finish the entire school year if called (which meant Clinton would be safe until July 1970) and was strongly hinting that a random selection process would soon be instituted. When the Selective Service held its first draft lottery on December l, 1969, Clinton's number was so high (311) he knew he would never be called..$^{20}$

During the 1992 presidential campaign, a copy of Clinton's 1969 letter to the ROTC director at Arkansas provided evidence that Clinton knew he had avoided the draft even though he admired his Oxford friend who had chosen to resist the draft as "one of the bravest, best men I know." To see him regarded as a criminal, Clinton wrote, was "an obscenity." And even though he viewed the draft system as "illegitimate," he

${ }^{20}$ David Maraniss, First In His Class: A Biography of Bill Clinton (New York: Simon and Schuster, 1995), pp. 150-151, 165, 167-168, 173-175, 179-180, 190-193, 198199. 
acknowledged that he could not take the same course and expect to maintain his "political viability within the system." Future political campaigns were more important than principled protest against the war and the draft. ${ }^{21}$

Bill Clinton's Selective Service saga is important not simply because he is now seen (along with Dan Quayle and Phil Gramm, among others) as one of the nation's best known draft dodgers, but because it illustrates how the draft, which so efficiently marched some off to war, could be so easily subverted and ignored by others. In New York City and Cleveland, Ohio, 38 fathers and sons were arrested for paying up to $\$ 5,000$ for false papers used to get deferments. One New York draft board official was convicted of selling deferments and exemptions for as much as $\$ 30,000.2$ The parallels with the Civil War era practice of buying substitutes to fight on one's behalf are obvious. As unscrupulous parents bought bogus medical records to keep their sons out of Vietnam, working class men vanished from their neighborhoods only to land in Southeast Asia. The same could be said of the thirty to forty thousand draft-age men who emigrated to Canada and an additional ten thousand who went to Sweden, Mexico, and other countries. Asylum in these places cost money and resulted in someone else bearing the burden of fighting in Vietnam. Most important, students who wrote annual checks to their university's bursar's office not only paid their tuition but ensured that other draft age men - in effect, substitutes - took their places in the Army.

At its heart, draft resistance turned on this question: What could a man do when

${ }^{21}$ Maraniss, First In His Class, p. 199.

22 Myra McPherson, Long Time Passing, pp. 381-382. 
his country expected him to participate in a system of conscription that sent some of his fellow citizens to fight in a war he regarded as immoral and illegal, and yet protected him? It is a complicated issue of conscience versus obligation. Those who, like Bill Clinton, opposed the war but manipulated the system to evade service in Vietnam, served neither their conscience nor their sense of obligation. James Fallows is another case in point. A few years after the war ended, Fallows, a Harvard graduate and today a highprofile editor for a national news magazine, wrote about the sense of guilt he felt for evading the draft. On the day of his pre-induction physical, Fallows and all of the other registrants from Harvard and Cambridge arrived at Boston Army Base with letters from doctors and psychiatrists that would keep them from being drafted. In the weeks leading up to the physical, Fallows dropped his weight to 120 pounds, making him virtually useless to the Army. Meanwhile. as the Harvard men were being processed, a busload of strapping working-class kids from Chelsea arrived and Fallows quickly realized that they knew nothing about draft loopholes. On that day, the middle-class kids escaped the draft as the Chelsea boys went off to serve in the Army. ${ }^{23}$

During wartime, political scientist Michael Schaefer has argued, the obligation of citizenship is not merely to serve. "It is." he writes, "an obligation to active involvement whether in pursuit of policy or protest against it." Those who opposed the war but accepted the Selective Service System and their privileged places within it, Schaefer charges, did not fulfill their responsibilities as citizens. Two other men were drafted into

${ }^{23}$ James Fallows, "What Did You Do in the Class War, Daddy?" originally published in The Washington Monthly, October 1975. It is reprinted in Walter Capps, ed., The Vietnam Reader (New York: Routledge, 1991), pp. 213-221. 
the Armed Forces instead of Bill Clinton and James Fallows. They may have served in Vietnam. They may have died there. - Draft resisters cannot claim to have prevented other men from being drafted in their stead, but they can take some comfort in knowing that their actions fully exemplified their opposition to the war. In the end, the Selective Service moved to a more equitable lottery system (though some deferments remained) and in time, an All Volunteer Force replaced conscription altogether. Even so, if as many draft age men resisted the draft as opposed the war, the war effort might have crumbled before $1968 .^{24}$

\section{Confronting the Draft and the War in Boston}

Small numbers of dissenters began to protest against the war and the draft immediately following the Johnson administration`s escalation of American aggression in Vietnam in 1964 and 1965. For the most part, however, the antiwar movement evolved in restrained fashion until 1967 . With the exception of a few radical pacifists, the war's opponents avoided confrontation; most limited their protest to marches and teach-ins. The draft resistance movement that emerged in 1967 and 1968 changed all that. "From Protest to Resistance" became the slogan that gained popularity throughout the antiwar movement in 1967 , but it might have been more accurately phrased "From Protest to Confrontation," for the strategy conceived by draft resisters constituted an open challenge to the administration to prosecute them for violation of draft laws in hopes that the system would break down under the weight of so many court cases.

${ }^{24}$ D. Michael Schaefer, "The Vietnam-Era Draft: Who Went, Who Didn't, and Why it Matters," in D. Michael Schaefer, ed., The Legacy: The Vietnam War in the American Imagination (Boston: Beacon, 1990), pp. 57-76. 
This dissertation slows down the usual narrative pace of the period from late 1967 to early 1968. It picks up the story of the antiwar movement at a time when it began to develop a sense of its growing strength and credits the civil disobedience of draft resisters as the driving force behind this shift. Although the marches in Washington and the large organizations such as the National Mobilization to End the War received most of the national press, on the local level draft resistance formed the leading edge of the antiwar movement.

By openly defying Selective Service laws and inviting the government to prosecute them, draft resisters and their allies raised the stakes for everyone opposed to the war. Going to teach-ins, picketing Dow Chemical and ROTC. and getting on buses bound for marches in Washington or New York undoubtedly helped antiwar activists to educate their fellow citizens about the war, but those events occurred only periodically and could not sustain an ongoing grass-roots effort to oppose the war. Draft resistance, on the other hand, mobilized the local antiwar community to take positive action against the administration and against the war in ways that marches and teach-ins could not. At least one historian reminds us, for instance, that most antiwar students did not belong to any organization, but joined marches. demonstrations, and teach-ins. ${ }^{25}$ Draft resistance activists recognized this but guessed that some proportion of those people would be willing to take greater risks if they thought it could hasten the end of the war. They were right. Hundreds of men and women in Boston and thousands of people across the country moved from protesting against the war to more direct confrontation with their

25 Heineman, Campus Wars, p. 270. 
government over its policies in Vietnam.

On one level, then, the history of the draft resistance movement during the Vietnam War raises questions about the place of individuals in a civil society and one's freedom and right to disagree with a government that theoretically represents the views of the majority. Eric Foner, the Columbia University historian who has recently authored a landmark study of freedom in America, charts a history of contested meanings of that most American of words. In the nineteenth century, Foner argues, freedom meant every American having the "opportunity to develop to the fullest his or her innate talents,"26 and in many ways, that definition held sway through the civil rights movement of the 1950 s and 1960s. The "rights revolution" that followed the civil rights movement, however, changed that idea. Within the last thirty years or so, Americans have invoked the concept of freedom more often in their defense of more narrowly defined rights that they hold sacred. ${ }^{27}$

Even so, the example of draft resistance highlights Foner's warning that freedom is a protean idea that "overspills the scholar's carefully constructed boundaries." First. although the Vietnam-era draft resistance movement emerged at the dawn of the "rights revolution," it viewed the government and the draft system as impediments to attaining the older sense of freedom that Foner describes as developing every citizen's potential. The Selective Service, through its policy of manpower channeling, seemed to have more xviii.

${ }^{26}$ Eric Foner, The Story of American Freedom (New York: Norton, 1998), p.

27 Foner, The Story of American Freedom, pp. 299-305. 
say about a draft registrant's future than he did himself. Draft resisters, therefore, targeted the draft not only because they saw it as an instrument of the war machine, but because they sought to reassert the freedom of every citizen to chart his future for himself. Second, although Foner writes that many Americans viewed the "generational rebellion" of the 1960 s as a "massive redefinition of freedom as a rejection of all authority," draft resisters made it clear that their rebellion targeted only illegitimate authority; that is, authority that ceased to be legitimate when it deviated from Constitutionally mandated provisions for declaring and fighting a war, and engaged in military policies that a reasonable person would regard as immoral or criminal..$^{28}$

Finally, in a more general way, draft resistance represented a continuation of the idea, more prominent in the nation's early history, that freedom means an "active engagement in public life." ${ }^{\text {.29 }}$ There are many ways to engage in public life, of course. and the experience of draft resisters and their allies raised additional questions about American definitions of citizenship. Resisters and their supporters acted on the assumption that when the nation's government sets illegal or immoral policy, citizens are obligated to disagree with those policies, to disobey them if necessary, and accept the legally prescribed punishment. But while they emphasized dissent and (civil) disobedience to one's government as a necessary duty of citizenship, critics of the movement charged it with being unpatriotic; they likened refusal to answer the government's call to service as an act of disloyalty. True patriots, they asserted, are not

${ }^{28}$ Foner, The Story of American Freedom, pp. 292-293.

29 Foner, The Story of American Freedom, p. xvii. 
disloyal to the government. Perhaps in no other part of the antiwar movement did the battle over citizenship and patriotism become so pitched. In this debate, however, the draft resistance movement took a page from the civil rights movement which had, after all, produced citizens who, despite repeated jailings. were counted among America's finest in the 1960s. But even most civil rights activists had not refused their country's call to service.

Just like their counterparts in the civil rights movement, however, draft resistance activists possessed a certain moral clarity that informed their sense of citizenship. If other antiwar activists were ambivalent about the administration and the war, draft resisters and their supporters were not. By late 1967, when thousands of men and women, young and old, gravitated to draft resistance, their minds were made up: the war in Vietnam was not only illegal and immoral, but :-obscene." They had studied Vietnamese history and culture and believed the United States had upset an indigenous drive for independence led by Ho Chi Minh and established a puppet government in South Vietnam. In creating and perpetuating the conflict in Vietnam. draft resistance activists reasoned, American forces killed thousands of noncombatants and did incalculable damage to the rural countryside. In short, the war offended them in every possible way.

That sense of outrage fueled a movement that attracted activists who were both politically and religiously motivated. It combined tactics of moral witness (e.g., turning in draft cards in a church) which galvanized religious opponents of the war. with the political goals of confronting the war "machine" and undermining it, which attracted secular, political protesters. For some of the religious protesters, draft resistance and the 
mass civil disobedience it required created an opportunity to build community, an "ecclesia" dedicated to the "struggle for the renewal of man." Today, with the possible exception of the Reverend Jesse Jackson, Americans are more accustomed to hearing the rhetoric of morality and values come from conservative political activists on the right. but in the late 1960s, draft resistance represented one of the last times where religious and political activists on the left invoked those themes. In later years, former draft resisters lamented the failure of the left to continue to tackle moral issues as they had with the Vietnam War and the draft. One draft resister commented: "I think that open and aggressive efforts to take moral stands, [that] articulate what real values (family and otherwise) are...would - or could - bring about significant social change and spiritual renewal" in America. ${ }^{30}$

Although draft resisters were, at the time, considered the radical wing of the antiwar movement, their ideas and tactics derived in many ways from well-worn American traditions of dissent. In particular, the emphasis on obedience to one's conscience over allegiance to one's government had roots that reached as far back as the abolitionist movement and more directly to the writings of Henry David Thoreau. The movement made frequent reference to Twentieth Century peace heroes such as Gandhi. Albert Camus, and Martin Luther King, Jr., but draft resistance organizers quoted no one as often as they did Thoreau.

It is not surprising, then, that critics of the New Left and the antiwar movement

${ }^{30}$ Christian Resistance letter to Michael Ferber, 1 Mar 1968, Papers of Michael Ferber; 1997 Survey of Boston draft resisters, respondent \#64. 
have ignored the draft resistance movement in their characterizations of the sixties generation as "destructive." Draft resisters and their supporters do not, for instance, fit David Horowitz's and Peter Collier's claim that sixties activists "assaulted and mauled" the American system, destroying that collection of values that provide guidelines for societies as well as individuals." Neither do they match historian Stephen Ambrose's portrayal of the antiwar movement as choosing "to print a license to riot, to scandalize, to do drugs and group sex, to talk and dress dirty, to call for revolution and burn flags, to condemn parents and indeed anyone over 30 years of age, in an excess of free will and childish misjudgement seldom matched and never exceeded." Although draft resistance activists sought to confront the government. they tried as much as possible to avoid alienating the public and, in both their rhetoric and appearance, they cut a sharper, cleaner image than anyone who might have fit Ambrose's generalization. ${ }^{31}$

The community that was formed around draft resistance, religious and otherwise, included many more people than the resisters themselves. Dozens of people, many of them women, contributed to the cause. The demographics of draft resistance supporters debunks the commonly held myth that student radicals in the 1960 s did not trust anyone over thirty years of age. Although most draft resistance supporters were in their twenties, many professionals, academics, and ministers in their thirties, forties, fifties, and sixties, participated in the movement, too. Many turned out at demonstrations and draft card turn-ins, some raised money, some did draft counseling, monitored trials, cooked food. or

31 Peter Collier and David Horowitz, Destructive Generation, p. 15; Stephen Ambrose, "Foreword," Adam Garfinkle, Telltale Hearts, p. v. 
wrote editorials or letters to newspapers. Like the resisters themselves, they were outraged by the war and possessed a moral certainty that fueled their commitment to the more radical approach of draft resistance.

The moral clarity that characterized draft resisters and their allies created an impatient style of citizenship - again with antecedents in the civil rights movement - that became the most striking characteristic of their movement. A sense of urgency permeated the draft resistance movement over the course of its relatively short life. In the earliest days, it caused resisters and supporters to advocate a strategy of protest that resulted in personal risks ranging from beatings at the hands of a mob to government prosecution and incarceration. They chose to disrupt their lives and the lives of their loved ones to protest the war in the strongest way they knew. Other antiwar activists continued to be satisfied with occasional marches and demonstrations, or began to do outreach to working-class and minority neighborhoods. For draft resisters, however, the issues were always more clear and more urgent, and, thus, demanded more radical action.

That moral clarity and the impatience it fostered also account for the sudden fragmentation and dissolution of the draft resistance movement. After an initial period of sensing that their defiance of draft laws attracted the attention and concern of the Johnson administration, they concluded in the spring of 1968 that, despite Johnson's decision to forgo another term as president, their strategy of confronting the government did not seem to be working. Even though returning a draft card constituted a crime, the Justice Department refused to indict men for it; they waited instead until registrants refused induction. It would take a long time for thousands of registrants just to be called 
for induction and, meanwhile, the war in Vietnam continued unabated. American troop strength was at its peak and thousands of Americans and Vietnamese continued to die. The resulting frustration within the movement began to undermine its effectiveness. As the rest of the world seemed to be spinning out of control in the wake of assassinations and student-led rebellions, draft resistance activists began turning to other methods of protest, especially outreach to enlisted men and high school students.

Without any more draft card turn-ins or other acts of civil disobedience to plan, the rank-and-file base of draft resisters quickly eroded. By the end of the summer only a core group of organizers made up the draft resistance "movement" in Boston. The Justice Department prosecuted very few of the draft resisters who had turned in their draft cards months before; this happened in part because local draft boards had violated Selective Service regulations themselves - making such cases unwinnable - and in part because the case load grew so large at the U.S. Attorney's office that many "feil through the cracks." In addition, however, some draft resisters found their perceptions of the war and the draft changing. The moral clarity and impatient sense of citizenship that once informed their actions receded as a new sense of exasperation and confusion about what to do next took over. Some accepted new deferments from their draft boards (which were only too happy to oblige). Many continued to oppose the war and worked with antiwar organizations to that end, but their more personal confrontations with their government were over.

In 1978, Lawrence Baskir and William Strauss, two analysts of the Vietnam Warera draft, asserted that "the most severe punishment suffered by draft resisters...has been the condemnation and misunderstanding of their fellow citizens." True forgiveness, they 
wrote, could not come from any government program, but "only from understanding." Today, a lack of understanding regarding draft resisters persists (see Appendix C); one goal of this dissertation is to provide a basis for that understanding by exploring the contested notions of morality, citizenship and freedom that fueled the draft resistance movement during its brief but influential history.

Although draft resistance grew into a national movement, this dissertation focuses primarily on the movement in Boston. An analysis of grassroots organizing and rankand-file resisters on a national scale would be almost impossible, whereas an in-depth study of one particular region uncovers the often dramatic experiences of draft resisters in sharp detail.

In many ways, of course, Boston is unique. First, there is the long heritage of disobeying authority that dates to before the Revolution and which resurfaced especially during the antebellum period, when Boston led the nation's movement to abolish slavery. One draft resistance activist later remarked that the importance of Boston's history should not be overlooked in understanding draft resistance. "You could just feel it," he said. "There was something in the bricks." In addition, the religious tradition in Boston made it atypical among other draft resistance communities. Across most of the country, the location for draft card turn-ins and other public events mattered little, but in Boston they often took place in churches, where the actions of draft resisters appeared to be more solemn. Finally, the concentration of colleges and universities in Boston also meant that more than 100,000 students lived within a very small area, thus providing a ready-made base for protest. 
In spite of these uncommon characteristics, Boston makes sense as the focus of this analysis for several reasons. First, although the Resistance grew to over 75 chapters across the country, the New England Resistance, centered primarily in Boston, quickly became the largest single chapter. The Boston branch published the national newsletter and later a national newspaper called The Resistance. Indeed, a March 1968 issue of The Resistance characterized the New England Resistance as the country's "coordinating center for the movement." ${ }^{32}$ In addition. several United States Supreme Court decisions evolved out of Boston draft cases. and the widely followed trial of Dr. Benjamin Spock, the famed pediatrician, and his four co-defendants for conspiracy to aid and abet draft resistance took place in Boston in 1968. By 1969, the city had become so clearly identified with draft resistance that when the Rolling Stones performed at the Boston Garden, Mick Jagger strutted out onto the stage in a tight long sleeve T-shirt emblazoned with a hand-painted Omega symbol. the mark of the Resistance, on his chest. ${ }^{33}$ Although Resistance groups in Philadelphia. New York, Chicago, Madison. the Bay area, and elsewhere also thrived and, in some cases, outlasted their New England counterpart, Boston led the way through the movement's most effective period.

The dissertation is divided into three parts. The first three chapters trace the history of draft resistance from small groups of individual pacifists in early 1966 to a fullscale grassroots movement by late 1967 . The next three chapters examine the range of responses to draft resistance by the press, the public, the government, and resisters'

\footnotetext{
32 "Resist!" The Resistance, 1-15 Mar 1968, p. 9

33 Old Mole \#28, 5 Dec 1969, pp. 1, 9.
} 
families and friends during the fall of 1967. The final portion of the dissertation picks up the chronological narrative and follows the movement through its peak period in the spring of 1968 through its subsequent decline in late 1968 and early 1969. An epilogue catches up with draft resisters and their supporters thirty years later.

When Muhammad Ali told the press that he did not have a quarrel with the Viet Cong, he shocked a nation whose citizenry in 1966 overwhelmingly supported the war. Ali's pronouncement came just weeks before the first "little band of bold pioneers" in Boston confronted the draft by publicly burning their draft cards. This act, too, horrified many of the residents of greater Boston and the nation, and they were tried and convicted very quickly. Chapter One recounts the story of these few early resisters and argues that the expeditious fashion with which the Justice Department handled their cases, set a precedent of firmness and efficiency that led later draft resistance organizers to believe their mass protest would be punished with equal dispatch. And that was exactly what they wanted.

As the first Boston resisters went off to prison, protest against the draft subsided. But as Chapter Two shows, attention to the draft was growing. With draft calls swelling, many Americans grew concerned with its obvious unfairness. The president appointed a blue-ribbon commission to review the Selective Service System and make recommendations to improve it. As the nation's interest turned toward conscription (thanks in part to Ali's case), draft counseling organizations formed in the spring of 1967 and began disseminating information to men who wanted to avoid the draft. In part their strategy aimed to impair the draft through overcooperation, that is, by filing every piece 
of available paperwork with one's draft board as a way of wasting its time and resources. In addition, draft counseling organizations like the Boston Draft Resistance Group moved the antiwar movement toward direct confrontation by staging raucous demonstrations inside the Boston Army Base.

For some in the antiwar movement, however, draft counseling and these other types of protests were not enough. They were better than marches and teach-ins, but draft calls and the war continued to escalate throughout 1967 and antiwar protest did not appear to have any material effect on the administration. Chapter Three introduces those in the movement who were growing impatient with these tactics as they plotted more radical, confrontational protest strategies centered around large scale draft resistance. By returning their draft cards to the government (alone a violation of the draft law), those who chose to become draft resisters raised the stakes for themselves as opponents of the war and upped the ante for the administration by inviting it to prosecute them. They would not dodge or take a deferment of any kind. On October 16, 1967, the nearly 1.000 men who returned their draft cards nationwide set a new standard for protesters by risking imprisonment and backed up their opposition to the war with direct action.

In response to the October 16 draft card turn-in at the Arlington Street Church, the Boston newspapers emphasized the small number of cards burned (rather than those turned in) at the ceremony and readers quickly characterized them as "unpatriotic," "misguided," and "hippies." Chapter Four describes the press and the public's reaction to draft resistance in the fall of 1967 and the image they held of draft resisters. The chapter also provides profiles of draft resisters based on a 1997 questionnaire that shows, among 
other things, that resisters did not fit the image that the public and media seemed to believe. Most were white, middle class college students who held deferments at the time of their resistance. Most had activist experience in civil rights and other peace protests and decided to resist the draft only after they believed they had exhausted all other legal means of lodging their protests. When nothing else worked, after careful consideration, they pushed harder. Most important, they did not see their acts as disloyal.

Most draft resisters were reminded of the serious nature of their offense when the FBI got involved. Within a week after the draft cards arrived at the Justice Department, FBI agents descended on Boston's college campuses, interviewing resisters and their friends. But as Chapter Five demonstrates, government interest in draft resistance extended far beyond the local FBI office to Washington, where the Selective Service, Justice Department, and President Johnson himself wrestled to find an appropriate response. In the end, a feud developed between the Selective Service and the Justice Department over punitive reclassification of draft resisters to $1-A$ and drafting them to serve in Vietnam. It soon became obvious to those involved with draft resistance that the right people were hearing their message.

The parents of most draft resisters were very concerned about their child's safety and his future; few openly supported their sons' actions. As a result, when draft resisters recognized that the people to whom they thought they could turn for support were not stepping up to provide it, they found encouragement and assistance elsewhere. Chapter 6 describes the wide range of people who joined draft resistance and other organizations as a way of providing moral and financial support to resisters while also doing something to 
end the war. Like many of the resisters, supporters were mostly white and middle class. Often they were older than the resisters and included professionals and academics among their ranks. In the end, they proved to be of critical importance to the long-term health of the draft resistance movement.

The draft resistance movement that blossomed in the late 1967 demanded a response from the federal government. They expected to be arrested for their defiance of draft laws and brought to trial but it did not work out that way. Instead, on January 5 , 1968, a Boston grand jury indicted five men (including nationally known critics of the war, Dr. Benjamin Spock and the Reverend William Sloane Coffin) for conspiracy to counsel, aid, and abet men to resist the draft. The indictments seemed designed to crush draft resistance and undermine opposition to the war, but rather than stifle the movement, it invigorated it. Between January and April, as the "Boston Five" prepared for their trial. and as those who returned their draft cards in October began to refuse induction, draft resistance intensified. Chapter 7 charts that period of the movement and examines the effect draft resistance had on policy makers considering even further escalation in Vietnam. In the end, several administration officials argued that fulfilling a request for another 206,000 troops would lead to even greater levels of draft resistance. The request was denied.

Just as draft resistance seemed to be peaking, however, external events beyond the control of the movement changed the context in which draft resistance took place. The assassination of Martin Luther King, Jr., the strike at Columbia University, and student riots around the world created an almost apocalyptic atmosphere in which draft resisters' 
impatience with the war began to extend to a broader indictment of American society for injustices and inequities at home and àbroad. Chapter 8 describes the early fragmentation of the draft resistance movement in Boston as the urgency that had always characterized the movement began to extend to other causes. Meanwhile, the trial of the Boston Five. the one event with the potential to hold the movement together, became mired in legalistic arguments over free speech and other issues while largely losing sight of the war and the draft. The movement had reached its twilight.

By the summer of 1968 , the New England Resistance shrank to a much smaller number of activists as the organization moved away from draft card turn-ins toward grassroots organizing among high school students and GIs. Chapter Nine follows this final stretch in the history of the movement and also rejoins rank-and-file resisters as they wrestled with the prospect of continuing their confrontation with the government by refusing induction. Some went to prison, some reconsidered their resistance and accepted new deferments, while others did nothing and never heard from a prosecutor. Ultimately, by the end of 1968, draft resistance began to fade from view in Boston. Many activists faded from view, too, but the epilogue reports that draft resisters and their allies have, for the most part, maintained activist lives, especially in their communities, since the war ended.

Thirty years have passed since the heyday of Vietnam-era draft resistance and until now it has gone almost forgotten. This dissertation argues that the Resistance is worth remembering. Although their numbers never amounted to a significant portion of the American population, draft resistance activists dominated the antiwar movement at a 
time when Johnson administration policy in Vietnam approached a crisis state. Like so many nonviolent American dissenters before them, their clear-eyed interpretation of the problem (in this case, the war) fueled an intense urgency to act. Draft resisters and their allies, like the abolitionists and the young civil rights activists, pushed their movement toward confronting their own government and demanding an end to the violence of war. Draft resisters were, as their opponents charged, radicals, but they were home-grown radicals who, despite their faults, represented the best American traditions of dissent. 
PART I

TOWARD A DRAFT RESISTANCE MOVEMENT

Reproduced with permission of the copyright owner. Further reproduction prohibited without permission. 


\section{CHAPTER I}

\section{IN THE BEGINNING: A "LITTLE BAND OF BOLD PIONEERS"}

Law never made men a whit more just; and, by means of their respect for it, even the well-disposed are daily made the agents of injustice. A common and natural result of an undue respect for law is, that you may see a file of soldiers, colonel, captain, corporal, privates, powdermonkeys and all, marching in admirable order over hill and dale to the wars, against their wills, aye, against their common sense and consciences, which makes it very steep marching indeed, and produces a palpitation of the heart. They have no doubt that it is a damnable business in which they are concerned; they are all peaceably inclined. Now, what are they? Men at all? or small moveable forts and magazines at the service of some unscrupulous man in power?...

The mass of men serve the State thus, not as men mainly, but as machines, with their bodies...A very few, as heroes, patriots, martyrs, reformers in the great sense, and men, serve the State with their consciences also, and so necessarily resist it for the most part; and they are commonly treated by it as enemies.

Henry David Thoreau, "On the Duty of Civil Disobedience" (1848)

In times of war, pacifists rarely escape unscathed. On March 31,1966 , a handful of Bostonians learned this lesson the hard way. Despite the raw, early spring weather, hundreds of people gathered in the early morning shadow of the South Boston District Courthouse all because they had heard something offensive on the radio. Or maybe someone else had heard it. Certainly, the man in a dark suit holding a motion picture camera at the front of the throng had heard it. And so, too, the few other men who, similarly dressed, were trying to blend in with the crowd. They were not altogether successful in this, but the larger group didn't seem to care. Most in the crowd were high school students; nearly all were residents of Southie and probably could spot a 
government man as well as anyone. In any case, the multitude anxiously waited for the "cowards" and "commies" to make their appearance on the steps of the grand old building - a "natural stage" for the first act in what would become a three year long morality play.

A few minutes before the appointed hour of 9:00 AM, eleven young men and women arrived, filed by the edge of the crowd, and silently climbed the steps of the courthouse. Their physical appearance no doubt surprised some in the crowd. The men in the group had short haircuts and wore suits and ties. The women wore neat-looking dresses and, like some of the men, also were clad in overcoats to beat the chill. These were not the bearded beatniks that some in the Southie crowd expected.

Four of the men - David O'Brien, John Phillips, David Reed, and David Benson stood in the middle of the group and, as they had promised in their press release, produced their draft cards. The other members of their group looked on from behind them as the crowd, now numbering more than 250 , drew nearer and grew louder, shouting "cowards!" and calling the four "yellow!" The smaller group's clean-cut appearance, if it had affected the crowd earlier, no longer mattered.

One of the four pulled out a small portable gas burner and ignited it. Each of the men then held his Selective Service document to the fire, corner first, and watched as the orange flame grew larger and brighter. Amid the sudden, unmistakable expressions of hostility from the mob - some were now yelling "Shoot them!" and "Kill them!" - John Phillips began to speak: "I am a pacifist," he said. "I do what I believe as an individual. I believe in the law but when the law violates my conscience..." He did not finish. Just 
then a gang of about 75 high school boys broke from the rest of the crowd and rushed up the steps.

The eleven pacifists had little opportunity to brace themselves for the attack and seven of them went down quickly. As the mob punched and kicked them, most tried to cover their faces; others, consistent with their training in nonviolence, went limp and fell to the steps as the youths stomped on their backs. Someone repeatedly slapped 18 yearold Suzanne Williams in the face. David Benson clung to the cold steel rail that bisected the steps while at least four young men pounded him at once. Phillips later remembered: "I saw one person going down in front of me so I grabbed him and...pulled him around so he could be pushed into the courthouse." Three government agents who had infiltrated the crowd to witness the card burning (two from the FBI and one from the Army's Criminal Investigation Division) were knocked down as they attempted to guide the pacifists up the stairs away from the mob and into the building. Their actions may have saved someone's life. As some of the high-schoolers ran into the courthouse chasing two of their quarry, FBI agent Thomas McInerney shoved David O'Brien through the door and ran with him through the lobby to the janitor's room some 75 feet away from the

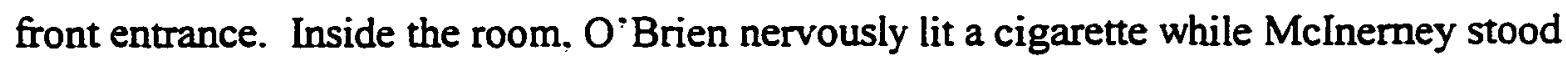
watch outside the door, waiting for the mob to be dispersed. John Phillips was not as lucky. Before anyone could prevent it, a fist - augmented by a class ring - slammed into the side of his nose, breaking it. As he finally stumbled into the courthouse, blood spilled 
from his face.

The police at last arrived as the melee wound down, but they arrested no one. They sealed the entrance to the building, scattered the crowd, and took Phillips to the hospital; Williams accompanied him. Inside the courthouse, a young woman, holding the hand of her toddler, approached one of the mob's victims and apologized on behalf of the community of South Boston, saying the assailants were not representative of the people who lived there. ${ }^{2}$ Outside the building, however, a police officer told one reporter, "Anyone foolish enough to commit such an unpatriotic gesture in South Boston can only expect what these people got." ${ }^{3}$ Nearby, State Representative James F. Condon commented that 'this wouldn't have happened if these were South Boston boys; our boys are patriotic." Activists in the incipient draft resistance movement came to expect this kind of reception in 1966.

In the huge public outcry that followed in the wake of the beatings, opinions were

${ }^{1}$ The description of the South Boston incident is pieced together from several sources: "7 War Protesters Beaten in Boston," New York Times, 1 Apr. 1966, p. 5; "Pacifist Group, Card Burners, Struck, Kicked," Manchester Union-Leader, 1 Apr. 1966, p. 1; "Boston Draft Card Burnings, Beatings Jar Mayor, Police," Boston Globe, 8 Apr. 1966, p.1; "Draft Protester Thanks FBI Agent," Boston Globe, 1 Jun. 1966, p. 1; "The Wrong Place," Time, 8 Apr. 1966, p. 28; John Phillips, telephone interview with author, 29 Aug. 1997; Xenia (nee Suzanne) Williams, interview with author, Barre, Vt., 28 Aug. 1997; Transcript of United States v. O'Brien, Cr-66-91-S, 1966, National Archives, Waltham, Mass.

2 "Boston Draft Card Burnings, Beatings Jar Mayor, Police," Boston Globe, 8 Apr. 1966, p. 8; Editorial, Boston Globe, 8 Apr. 1966, p. 14.

3 "The Wrong Place," Time, 8 Apr. 1966, p. 28.

4 "7 War Protesters Beaten in Boston," New York Times, 1 Apr. 1966, p. 1. 
sharply divided. For the next month. Boston's public officials, newspaper editors, and residents debated and discussed the meaning of draft card burning as a method of protest and appropriate responses to it. Because the timing of the event coincided with a monthlong strike that had shut down Boston's three daily newspapers, many of the city's residents awoke two days later to read a front page editorial on the subject in the Manchester, New Hampshire, paper, which was trying to make inroads in the Boston market during the strike. William Loeb, the publisher of the Union-Leader, one of the most vehemently conservative and anticommunist papers in the country, called the card burners "Anti-American "kooks"" who had not only "thumbed their nose deliberately and spat in the face of American patriotism" but also insulted "our soldiers fighting in Viet Nam." Their assailants, according to Loeb, responded with "the type of natural patriotic reaction that they SHOULD have had." In fact, he said, "there were probably millions of Americans all over the United States who said to themselves: 'Give them another one for me.",s

Few of those who sympathized with the attackers would go as far as Loeb in their characterizations of those involved, yet they did see the issue in terms of loyalty and disloyalty, patriotism and traitorous behavior. In a letter to the Boston Globe (which began printing again on 8 April), one woman complained about the paper's criticism of the South Boston mob: "There is something drastically wrong," she wrote, "when our country's defenders are condemned and vilified" for beating up draft card burners who

\footnotetext{
${ }^{5}$ Editorial, Manchester Union-Leader, 2 Apr. 1966, p.1.
} 
"most likely provoked the attack in the first place." Another young woman argued that the South Boston students "could not have reacted in any other way in order to preserve the American image of red-blooded patriotism." The demonstrators, she said. "were asking for trouble," and those who assaulted them "showed their love for America by not standing by apathetically while their government's dignity and authority was being desecrated" by a "defiant, selfish minority." "They are heroes," she finished. ${ }^{7}$ The Globe also printed a letter from an Army private stationed in Vietnam: “...it's difficult to suppress the feeling I have for Boston and this patriotic display," he said. "It is indeed gratifying to know that the draft card burners who aren't men enough to face the responsibilities and hazards of defending their country...now face a hazard they didn't bargain for - outraged, patriotic citizens."

In contrast, those who criticized the South Boston mob did not view the event as a question of patriotism or loyalty, but of freedom, morality, and especially legality. For instance, although the editors of the Boston Globe referred to the card burners as "misguided" and suggested that "few will support or justify" their actions, they condemned even more harshly "those who took the law into their own hands" as "more criminal" because "it could have amounted to murder." Such lawlessness, they said, and the subsequent blaming of the pacifists for "inciting riot" (as one city councilor charged)

\footnotetext{
${ }^{6}$ Letter, Boston Globe, 12 Apr. 1966, p. 36.

${ }^{7}$ Letter, Boston Globe, 24 Apr. 1966, p. A4.

${ }^{8}$ Letter, Boston Globe, 25 Apr. 1966, p. 12.
} 
came "straight from the handbook of the Southern segregationist." Others agreed but were more generous to the pacifists. One letter writer believed that those "who had their heads cracked recently probably know far more about the concept of freedom and care far more about what America is and is becoming than all the punks who attacked them."10 Still others suggested that the "bullies" were deluding themselves because they could not "face the possibility that the war in Viet Nam might be both immoral and futile, and the consequent thought that those who have given their lives there may have done so in vain." More than that, another argued, the private who wrote so glowingly of the beating proved that even GIs knew that rather than fighting for "freedom and democracy," they were "defending the right to beat to the ground, with no fear of arrest, anyone with whose opinions they disagreed." "I

Although Boston's newspaper editors printed such opinions in relatively equal numbers for each side of the debate, other indications made obvious the ongoing hostility that early draft resisters faced. One week after the incident at the courthouse, a group of ministers calling themselves the Clergy Group for the Right to Dissent sponsored a march to protest the treatment of the draft card burners and the complete lack of police protection. Estimates vary, but somewhere between 175 and 300 people marched to the Boston Common from two different starting points: the South Boston District Courthouse

${ }^{9}$ Editorial, Boston Globe, 8 Apr. 1966, p. 14. Editorial, Boston Globe, 23 Apr. 1966, p. 12.

${ }^{10}$ Letter, Boston Globe, 29 Apr. 1966, p. 12.

"Letter, Boston Globe, 26 Apr. 1966, p. 16; Letter, Boston Globe, 28 Apr. 1966, p. 16. 
and the Arlington Street Church in the Back Bay. Although the police department, stung by criticism of its absence a week earlier, provided 150 officers (some on horseback and motorcycles) to escort the two groups, it could not keep some counter-demonstrators from expressing their views, sometimes in dramatic fashion. From apartment windows in South Boston, several residents pelted the marchers with eggs, occasionally missing and hitting a police officer. People on the sidewalks threw things, too, and yelled "coward" and "maggot" as the demonstrators walked by. One heckler walked up to the group with a live chicken and broke its neck in a less-than-subtle warning; he then followed the group with the dead animal dangling from the end of a stick. The marchers made it to the Common safely and, thanks to the police presence, held a small rally without incident. Later, Mayor John Collins told the press that he would continue to take measures to ensure greater police presence at such events, noting that "precisely because any protest against U.S. foreign policy in Viet Nam is unpopular among some of the citizens of Metropolitan Boston, it is even more urgent to protect this right."12

The events of March and April 1966 came as something of a shock to the city of Boston. The protest in Southie, along with a few others the week before, constituted some of the earliest demonstrations against the war in Vietnam - and certainly the first public challenge to the draft - that the city had seen. The mob response also took counterdemonstrating to a new, more frightening level, thus mirroring the reaction that so many

12 "Marchers Pelted in Boston Protest," New York Times, 7 Apr. 1966, p. 5; "Boston Pacifist Parade Pelted," Manchester Union-Leader, 7 Apr. 1966, p. 1; "Boston Draft Card Burnings, Beatings Jar Mayor, Police," Boston Globe, 8 Apr. 1966, p. 8; Jerome Grossman speech, ACLU annual meeting, 2 Oct. 1993. 
social movements experience in their formative stages. More important, however, the public's perception of these events as articulated in letters to the editor and comments made on the street quickly established the terms of debate that people not only in Boston, but across the country, would settle upon in evaluating draft resisters. Despite the great lengths to which the resisters would go to appeal to the public's sense of morality, its sense of justice, and its sense of tradition (as exemplified by figures such as Thoreau) in the coming years, resisters constantly found themselves accused of disloyalty and of being unpatriotic. Even in early 1968 , when draft resistance became a national movement unto itself, and draft card burnings were being discouraged in favor of draft card turn-ins held in churches, the words "draft resister" conjured up images of flaming cards that, like the Stars and Stripes afire, caused many Americans to cringe.

This chapter demonstrates that the nascent draft resistance of 1966 and reaction to it also established other important trends that would extend into the subsequently much wider resistance movement, or at times set precedents that would prove to be instrumental in the way organizers shaped the later movement. For Gandhian pacifists, the act of civil disobedience - burning one's draft card - served both as an act of moral witness and as a vehicle for confronting the government. Unlike draft "dodgers" who sought ways to protect themselves from the draft by fleeing or making themselves ineligible through some act of subterfuge, resisters openly defied the law and awaited the state's punishment. They were impatient. unsatisfied with marching and attending teach-ins. Likewise, they possessed a certain moral clarity that made evading the draft unconscionable and, at the same time, drove them to fight the administration and the 
Selective Service System. In their challenge to the draft and to the policy makers responsible for America's presence in Vietnam, these protesters raised the question of the individual's place in a civil society in a way that few others in the antiwar movement could. For them, individual dissent was not inconsistent with good citizenship.

That said, moral witness had its shortcomings, too. Particularly because it seemed to be carried out primarily by children of privilege - white, middle and upper class college students - the act of resistance took on an air of condescension for some working class observers. Although draft resisters successfully sought to expose the inequities of the Selective Service System, the same system that sent a disproportionate number of working class and minority men to fight in Vietnam for much of the war, the draft resistance movement never attracted significant numbers of men from those groups to join in severing their ties with the draft.

Finally, this chapter shows how the Department of Justice, through its efficient handling of early draft violators' cases, actually encouraged the formation of a broader movement against the draft. Although the early resisters, so few in number anyway, never attempted wide ranging recruitment efforts aimed at bogging down the courts and filling jails with enough potential draftees to hamper the operations of the draft, the speedy work of prosecutors and the federal courts in dispatching the first burners and returners to prison made that notion seem possibte. The later draft resistance movement of 1967 and 1968 fully expected mass arrests and imprisonment thanks to the example set by the first draft resisters and the Department of Justice in 1966.

Indeed, the government seemed well-prepared to penalize those who resisted 
fulfilling roles that men their age had ostensibly performed in earlier wars. And they were supported by the majority of the population who, in April 1966, continued to approve of Lyndon Johnson's management of the war in Vietnam. ${ }^{13}$ Those old enough to remember the Second World War and Korea had grown used to a peacetime draft and at the outset, it seemed, viewed Vietnam as the younger generation's tum to go and do what those before them had done. As Jöseph, the mair character in Saul Bellow's first novel, Dangling Man, might have said, it was an "era of hardboiled-dom." The first Vietnam era draft resisters, beaten and bloodied in the city that liked to call itself the "the cradle of Liberty," could understand Joseph"s assertion that "most serious matters are closed to the hard-boiled. They are unpracticed in introspection, and therefore badly equipped to deal with opponents whom they cannot shoot like big game or outdo in daring."14

\section{Sons of Liberty?}

Since the revolutionary era. of course, Boston has fostered a reputation as a hotbed of protest and resistance to unjustifiable authority. Long before and long after the Sons of Liberty dumped tea into the harbor, however, the legacy has, in fact, been fairly mixed. In 1707, for instance, more than a thousand soldiers and sailors, many of whom had been "pressed" into (not-so-selective) service during Queen Anne's War, returned to Boston from two failed attacks on Port Royat, Jamaica that had ended in chaos, mutiny,

${ }^{13}$ In a Gallup poll, 54\% approved of Johnson's handling of the war, $31 \%$ disapproved, and 15\% had no opinion. "LBJ Viet Policy Still Endorsed," Boston Globe, 20 Apr. 1966, p. 25. 1996), p. 9.

${ }^{14}$ Saul Bellow, Dangling Man (New York: Vanguard, 1944; New York: Penguin, 
and what one historian described as "craven retreat." Their performance so angered their fellow citizens that, not unlike the egg-throwing tenement dwellers of South Boston in 1966, many emptied the contents of their chamber pots onto the troops as the marched by. "Is your piss-pot charged, neighbour?" yelled one woman. "So-ho, souse the cowards."15

By the middle of the eighteenth century, however, Bostonians turned toward radical resistance to authority. Impressment of local sailors for the King's navy became such a threat to the city that, despite the encouragement of several ministers to take up arms against the Catholic French to the north, Bostonians were more likely to arm themselves against ship captains suspected of pressing men into service. In 1741, a mob of 300 men wielding "axes, clubs and cutlasses" terrorized the commander of the man-ofwar Astrea when they suspected that he planned to sweep the city's docks for men. Four years later, another crowd assaulted the commander of H.M.S. Shirley and "beat him and the Suffolk County deputy sheriff senseless in Milk Street in retaliation for pressing." In November 1747 , in response to a massive press sweep, crowds quickly abducted several ship's officers and surrounded the governor's mansion where some others had taken refuge. When the governor called out the militia and issued a proclamation to disperse the crowd, the mob answered by smashing all of the windows in the government house and dragging a royal barge from the harbor to the governor's house where, in his courtyard, they torched it. ${ }^{16}$ In the middle of the eighteenth century, few Bostonians

is Gary B. Nash, The Urban Crucible: Social Change, Political Consciousness, and the Origins of the American Revolution (Cambridge: Harvard University Press, 1979), p. 59.

${ }^{16}$ Nash, The Urban Crucible, pp. 171, 221-222. 
would countenance being conscripted. especially by force, into military service for the crown.

Twenty years later, mob rule became common place as the tensions between colonists and British authorities - those that would lead to revolution - took root and grew. In a clear message of their resistance to the passage of the Stamp Act in 1765, a mob of 40 to 50 tradesmen demolished a brick building believed to be the future office of the stamp distributor in a half-hour. That night, the crowd moved to the stamp distributor's house and spent four hours destroying everything in his house. Twelve days later, while Chief Justice (and future provincial governor) Thomas Hutchinson and his family were eating dinner, the crowd took axes to his front door, chased the family out of -

the house and. as historian Gary Nash recounts it,

then systematically reduced the furniture to splinters, stripped the walls bare, chopped through inner partitions until the house was a hollow shell, destroyed the formal gardens in the rear of the mansion, drank the wine cellar dry, stole Z900 sterling in coin, and carried off every moveable object of value except some of Hutchinson's books and papers, which were left to scatter in the wind.

When they were through, they razed the building. ${ }^{17}$ Surely, by 1773 , the nighttime dumping of 342 casks of tea into Boston harbor should not have surprised anyone.

In the nineteenth century, Bostonians took pride in their revolutionary heritage and invoked it in other campaigns to right injustice. In nearby Concord, Henry David Thoreau went to jail rather than pay taxes that he knew were subsidizing the Mexican War. In an essay that influenced few of his contemporaries but profoundly inspired later

${ }^{17}$ Nash, The Urban Crucible, p. 294. 
twentieth century proponents of civil disobedience from Mohandas K. Gandhi to Martin Luther King, Jr., Thoreau wrote: "Under a government which imprisons any unjustly [e.g., fugitive slaves, Mexican prisoners], the true place for a just man is also a prison," he wrote. One hundred twenty years later, draft resisters would be inspired by such rhetoric:

A minority is powerless while it conforms to the majority...but it is irresistible when it clogs by its whole weight. If the alternative is to keep all just men in prison, or give up war and slavery, the State will not hesitate which to choose. If a thousand men were not to pay their tax-bills this year, that would not be a violent and bloody measure, as it would be to pay them, and enable the State to commit violence and shed innocent blood. $^{18}$

Thoreau was the nagging conscience of his fellow citizens and set the example that obedience to one's moral principles took precedence over allegiance to one's government.

Soon after the end of the Mexican War, following passage of the Fugitive Slave Act of 1850 , abolitionists in Boston took their protests to a new level as they actively planned to prevent fugitive slaves from being recaptured in their city and, failing this, preventing their transport back to the South. In February 1851, a mob rushed through the doors of the courthouse in Court Square seeking a captured fugitive slave named Shadrach. When they emerged with him on their shoulders and quickly spirited him out of harm's way to Canada. Theodore Parker, one of several abolitionist ministers on the Boston Committee of Vigilance, described the mob's action as "the noblest deed done in Boston since the destruction of the tea in 1773." A few months later, when authorities

${ }^{18}$ Henry David Thoreau, "On the Duty of Civil Disobedience," in Walden and Civil Disobedience (New York: Signet, 1980) pp. 230-231. 
captured another fugitive slave and housed him in the courthouse, they surrounded the building with chains to prevent another raid. James Brewer Stewart tells us that resistance to authority was in the air: "Antislavery politicians of all shadings were openly opposing federal authority, debating the limits of peaceful dissent, and exploring the imperatives of forcible resistance." Indeed, in May 1854, a mob assembled at Faneuil Hall after hearing of the imprisonment of another fugitive slave, Anthony Burns, at the courthouse. When one minister counseled the crowd to wait until morning to free Burns, the crowd responded "No! No! Tonight! Tonight!" They immediately marched from Faneuil Hall to the court building and battered down the front door only to hear shots ring out as the first few men crossed the threshold. A guard was shot, but the crowd was forced to leave without Burns. On the day that authorities escorted Burns to a ship that would take him south, many of the city's buildings were shrouded in black and all the armed forces available lined the route to prevent any attempt to free him. Parker, disgusted by the whole ordeal, said: "We are the vassals of Virginia. It reaches its arms over the graves of our mothers, it kidnaps men in the city of Puritans, over the graves of Samuel Adams and John Hancock."19

In the twentieth century, however, Boston's history of resisting authority mostly seemed a distant memory. The city's campaigns to root out all manner of vice led to

${ }^{19}$ Marion Gleason McDougall, Fugitive Slaves (first published Boston, 1891; New York: Bergman, 1967), pp. 44-48; Alice Felt Tyler, Freedom's Ferment: Phases of American Social History from the Coloniai Period to the Outbreak of the Civil War, (1944; reprint, New York: Harper, 1962), pp. 538-540; James Brewer Stewart, Holy Warriors: The Abolitionists and American Slavery (New York: Hill and Wang, 1976), 154-159. 
book bannings that made famous the phrase "Banned in Boston." During the red raids that followed the Great War, Department of Justice agents and local police arrested six hundred alleged communists ("in most instances," one judge later said, "perfectly quiet and harmiess working people"), handcuffed them in pairs and paraded them through Boston's streets where the masses of citizens who witnessed it jeered and taunted them. ${ }^{20}$ After World War II, Boston's place as home to numerous colleges and universities and its stature as a liberal, free-thinking town did not insulate it from the same kind of Cold War conformist attitudes that affected the rest of the country. The city sent John F. Kennedy, a committed cold warrior, to the White House and soon after helped elect his like-minded youngest brother, Ted, to fill his vacant Senate seat. Like most Americans. Bostonians were fervently anticommunist and supported Kennedy's policies in Laos and South Vietnam as essential to holding back the spread of the Red menace. In 1965, when Kennedy's successor, Lyndon Johnson, took steps to escalate American involvement in Vietnam, few protested. Even in July, when Johnson made the decision to use the draft rather than the reserves to increase military manpower, few balked. Nationally, $63 \%$ of Americans continued to favor the draft against only $13 \%$ who opposed it. There is no indication that the people of Boston felt any differently, even though the doubling of draft calls soon began to affect more and more families. ${ }^{21}$

In fact, when early opponents to the war first attempted a march and rally on the

${ }^{20}$ Howard Zinn, A People's History of the United States, Rev. and updated ed. (New York: Harper, 1995), p. 366.

${ }^{21}$ George Q. Flynn, Lewis B. Hershey, Mr. Selective Service (Chapel Hill: University of North Carolina Press, 1985), p. 234. 
Boston Common (as part of the International Days of Protest) on October 16,1965, they received very little serious consideration from the media and saw counter-demonstrators easily dash their meeting. The day before the march, the Boston Globe ran an article by Gordon Hall, an apparent expert "observer and reporter of extremist movements" which suggested that the scheduled march and demonstration would be dominated by communists. He noted that of the 14 sponsoring organizations, all but ten were "tightly knit permanent organizations of left-wing persuasion," and that even when apparently benign organizations such as the Cambridge Committee to End the War in Vietnam (the primary sponsor) "are not the actual creations and front groups of the extreme Left, they are custom tailored for infiltration and control by extremists." Hall argued that "their paper-mache structure and general informality are no match for the militancy, and superior organization of the extremist." He offered no evidence that militants were, in fact, taking over the CCEWV, but quoted Young Socialist Alliance memos that urged members to become active in the antiwar movement. Readers of the Globe, then. most likely viewed the march not as a legitimate expression of opposition to the escalating war made by concerned citizens, but instead a communist front. ${ }^{22}$

Things only got worse for the demonstrators on the day of the march. A total of 3000 people had assembled at three separate locations - the Cambridge Common, the Massachusetts Institute of Technology administration building on Massachusetts Avenue ("Mass. Ave.," to locals), and Boston University's Marsh Plaza on Commonwealth

22 Gordon Hall, "Viet Protest Influenced by Left," Boston Globe, 15 Oct. 1965, p.5. 
Avenue ("Comm. Ave." to locals) - before marching to Boston Common where they met at the Parkman Bandstand. At the Mass. Ave. Bridge, where the three groups joined for the final leg of the march, six Harvard freshman held a banner that read, "We Support LBJ in Viet Nam." The six followed the marchers to the common where they joined another group, numbering 300, the core of which were members of William F. Buckley's Young Americans for Freedom; there they waited until the marchers settled in in front of the bandstand and until the speakers took their seats before making their move. This smaller crowd, made up largely of students who came from Boston University, Harvard, MIT, Northeastern University, Boston College, and Emerson College, then pushed their way through the demonstrators until they positioned themselves directly in front of the platform. To the relief of the speakers, 50 police patrolmen had already posted themselves at the bandstand, with six men guarding the steps. The counter-protesters carried signs that said "Stay in Viet Nam." "Draft the Pinkos," "Drop the Bombs," and "Send the Draft Dodgers to Viet Nam." Seeing this, the antiwar marchers, began to chant "We want peace in Vietnam. We want peace," only to have the counter-demonstrators respond with "We want victory in Vietnam. We want victory." Finally, Russell Johnson of the American Friends Service Committee attempted to speak, but be could outshout the insurgents only briefly. State Representative Irving Fishman from Newton and Noam Chomsky, the MIT linguistics professor, couldn't even match Johnson's performance and police ended the rally before it turned violent. Chomsky later remembered that he 'wasn't unhappy that there was a large contingent of police, who didn't like what we 
were saying...but didn't want to see people murdered on the Common.."23

The placard urging that draft "dodgers" be sent to Vietnam must have seemed incongruous to many in attendance because, at that point, very few people had dared to challenge the draft as a method of protesting the war. Indeed, after the publication of a Life magazine photograph of Catholic Worker Chris Kearns burning his draft card on July 29,1965 , Congress quickly passed a law making draft card destruction punishable by up to five years in prison and a $\$ 10,000$ fine. Since then, antiwar activism had been largely limited to marches and rallies. But on the same day that the counter-protesters broke up the Boston Common rally, David Miller, another Catholic Worker from Syracuse, stood on a platform in Manhattan and said, "I believe the napalming of villages is an immoral act." As he held his draft card aloft, he declared, "I hope this will be a significant political act, so here goes," and set his card on fire. ${ }^{24}$ Miller was the first to challenge the new law against card burning and his picture ran on front pages across the country. In reaction, the senior senator from Massachusetts, Republican Leverett Saltonstall, urged support for the men serving in Vietnam "who are exposed to danger," and not for "those who are trying to avoid their duty to their country." He had clearly missed Miller's point. As evidenced by his easy submission to arrest, trial, and imprisonment, Miller did not try to "avoid" anything; rather, he intended to set an example for others who viewed the war

23 "Cheers, Jeers, Eggs, Paint Greet Marching Thousands," Boston Globe, 17 Oct. 1965, p. 1; "Some Students Demonstrate FOR LBJ's Policy," Boston Globe, 3 Nov. 1965, p. 26; Noam Chomsky, letter to author, 6 December 1996.

${ }^{24}$ Michael Ferber and Staughton Lynd, The Resistance (Boston: Beacon, 1971), p. 23. 
as immoral and who believed it was their duty as citizens to disobey any laws that perpetuated that immorality. Saltonstall could only say, "We want freedom of speech, but we want patriotism," too. ${ }^{25}$

If the tremendous increase in parcels sent to the Pentagon for forwarding to GIs in Vietnam is any indication, the International Days of Protest did little to persuade most Americans that they should protest the war. Thousands of packages and letters arrived at the Pentagon in the weeks following the demonstrations, creating a logistical problem for the military. Newspapers that featured a "Women's Page" ran helpful hints on what to send to soldiers ("send anything that can be mixed with water because the water there has a foul taste and the boys can't drink it"). ${ }^{26}$

In Boston, public officials dismissed the protesters and reaffirmed their support for U.S. policy. "Those who question the U.S. policy," said Ted Kennedy, "ought to be just as quick to condemn the terrorist activities of the Viet Cong, such as assassination and kidnaping." Governor Volpe said "Let those misguided individuals who protest our actions in South Vietnam know that the frontiers of freedom do not stop at the territorial limits of the United States of America. They extend around the world, to all people of all races, customs and beliefs." State Representative Patrick W. Nee stood in Park Square a few days after the protests and distributed 2000 bumper stickers with the message, "We

4.

25 "Draft Card Burning is Shocking - Saltonstall," Boston Globe, 19 Oct. 1965, p.

26 "Viet Gifts Clog Pentagon," Boston Globe, 7 Nov. 1965, p. 50; "Draft Protest Backfires As G.I. Mail Swells," Boston Globe, 8 Nov. 1965, p. 1; "Helpful Hints: What To Send G.I. in Viet Nam," Boston Globe, 8 Nov. 1965, p. 11. 
Support Our Boys in Viet Nam." "The way they were snapped up by motorists," he said, "shows how the real Americans feel." Truly, it was a time of hardboiled-dom." Interestingly, college students seemed to be the most outspoken critics of the antiwar protesters. In an early example of deriding the appearance of those with whom one disagrees, one of the Harvard freshman who held the "We Support LBJ in Viet Nam" banner remarked that the idea to do so came about because they "wanted people to know that all students aren't unwashed beatniks." Meanwhile, at Boston University, members of the Young Republicans and the Young Democrats collected 6,000 student signatures for a petition pledging support to Johnson's Vietnam policy and presented them to Assistant Secretary of State William P. Bundy. (At the time, BU had only 8,000 day students and a total enrollment of 15,000$).^{28}$

The protesters had their defenders, too, but they were few and found themselves most often defending the marchers from charges of being communists (as they had been called by several congressmen and senators). Howard Zinn, an Associate Professor of Government at Boston University decried the name calling, saying that the student "radicals" were a "new breed," one without "commitment to any other country" or "fixed loyalties to any dogma." In a Globe opinion piece, he wrote that although students realized that "the Communists will use any means to gain their ends," they also

27 "Ted Back, Predicts Long, Tough War," Boston Globe, 11 Nov. 1965, p. 10; "Veteran's Day Voices Rise Against Pacifists' Protests," Boston Globe, 11 Nov. 1965, p. 19; "Answering the Anti-Warriors," Boston Globe, 21 Oct. 1965, p. 2.

28 "Some Students Demonstrate FOR LBJ's Policy," Boston Globe, 3 Nov. 1965, p. 26; "B.U. Viet Support Signed by 6,000," Boston Globe, 19 Nov. 1965, p. 6. 
concluded, after seeing "American planes bombing Vietnamese villages, and Marines throwing grenades down tunnels in which crouch helpless women and children," that the United States would do the same. "Force and deception," he said, "are found on all sides" and then quoted Randolph Bourne who, at the outbreak of the Great War, offered this critique of American patriotism:

The moment war is declared...the mass of the people, through some spiritual alchemy, become convinced that they have willed and executed the deed themselves. They then with the exception of a few malcontents, proceed to allow themselves to be regimented, coerced, changed in all environments of their lives, and turned into a solid manufactory of destruction toward whatever other people may have, in the appointed scheme of things, come within the range of the government's disapprobation. ${ }^{29}$

Like Zinn, most supporters of the protesters tried to focus attention on what they perceived to be the immoral nature of the war by invoking examples from an earlier generation. In a letter to the Globe, one person wrote: "We really should humbly remember that Hitler's and Tojo's obedient, patriotic, brave soldiers were considered murderers by us because of their government's stand... Those who demonstrate for peace want a firm, defensible basis for this war. Please give them your patience, tolerance, and consideration." Another person, a potential draft resister, wrote: "The Nuremburg Trials established that it was the responsibility of each individual to refuse to participate in any activity which violated moral standards." For that reason, he said, he would have to refuse induction if called. Echoing Thoreau, he said: "I hold allegiance to one thing

${ }^{29}$ Howard Zinn, "Don't Call Students Communists When They Protest Against Viet Nam War," Boston Globe, 24 Oct. 1965, p. A4. 
higher than the government of the United States, and that is my own conscience."30 In the fall of 1965, such appeals to conscience persuaded few. In another Gallup poll, $58 \%$ of Americans described the degree of communist involvement in Vietnam protests as "a lot" and another $20 \%$ said "some," while only $4 \%$ answered "not at all." It was a lonely time to oppose the war. In Boston, over 300,000 people turned out on the streets of the Back Bay to see the longest parade the city had held in 27 years - it lasted 2 $1 / 2$ hours - on Veteran's Day. Mayor John Collins and 11 servicemen wounded in Vietnam led the parade of 17,000 marchers. According to one reporter, "pro-Viet Nam fervor infused" the day. ${ }^{31}$

Within the budding antiwar movement disagreement over tactics further limited effectiveness. Mainstream New Left groups planned more marches and teach-ins but shied away from non-compliance with the draft as a tactic, fearing such direct confrontation with the federal government. At the national convention of Students for a Democratic Society held in June in Kewadin, Michigan, SDS decided that attacks on the draft were too radical and instead chose to focus on "stopping the seventh war from now." Activists in the National Coordinating Committee to End the War in Vietnam thought draft resistance would undermine other antiwar work and allow the administration "to convince everybody that our main objective is to be a bunch of professional draft-dodgers." A small groups of individuals disagreed. Emboldened by p. 4.

${ }^{30}$ Letter, Boston Globe, 24 Oct. 1965, p. A4; Letter, Boston Globe, 1 Nov. 1965,

31 "Link Reds to Protests," Boston Globe, 20 Nov. 1965, p. 7; “Pro-Viet Nam Fervor Infuses Longest Parade Here in 27 Years," Boston Globe, 12 Nov. 1965, p. 6. 
David Miller's public defiance, a crowd of 1500 sympathizers including Dorothy Day and A. J. Muste turned out in New York's Union Square in November to watch five pacifists burn their cards. Although someone with a fire extinguisher "bolted from the crowd and doused the pacifists and their cards," they managed to burn them anyway. ${ }^{32}$ More and more, radical pacifists began to see the draft as the ideal point of entry for protesting the war.

\section{Pacifists' Progress}

A newly formed branch of the Committee for Non Violent Action (CNVA) can be credited for initiating what became the draft resistance movement in Boston. In 1957, members of several pacifist organizations came together to form the original CNVA as a way "to go beyond words" in protesting the escalating nuclear arms race. On August 6, the twelfth anniversary of the bombing of Hiroshima, eleven members were arrested for trespassing at a nuclear test site at Camp Mercury, Nevada, seventy miles west of Las Vegas. After a quick trial resulting in convictions and suspended sentences, they went back to the entrance of the test site to pray. There they saw the giant mushroom cloud of the blast and it convinced them that they "could never rest while such forces of evil were loose in God's world." The following year, several CNVA members led by Albert Bigelow, a former World War II naval officer, attempted to sail a thirty foot ketch named "The Golden Rule" into an American hydrogen bomb test site at the Eniwetok atoll in the

32 Thomas Powers, Vietnam: The War at Home (New York: Grossman, 1973; Boston, G.K. Hall and Company, 1984), p. 186. Charles DeBenedetti, An American Ordeal: The Antiwar Movement of the Vietnam Era (Syracuse: Syracuse University Press, 1990), pp. 129-130. 
Marshall Islands. They were twice intercepted by the Coast Guard and, after the second attempt, spent sixty days in jail in Honolulu. The events garnered national headlines and led the Boston Herald to characterize the mission as "Thoreau-esque."

In 1960, Bradford Lyttle, the son of a Unitarian minister and a pacifist-Socialist mother, established the New England CNVA in Groton, Connecticut, at a time when he was moving the organization toward a more confrontational "obstructionist" approach to protest. As historian James Tracy describes it, this move showed "that radical pacifists privileged individual cathartic action over pragmatic efficacy," a practice that would later prove significant in Boston. In Groton, CNVA activists focused their attention on protesting the manufacture of the Navy's most powerful weapon: the Polaris nuclear submarine. Each time the shipbuilders launched a new Polaris, CNVA activists would row their boats and paddle their canoes out into the Thames River in a symbolic attempt to block the sub. One person actually managed to swim out to a sub and climb aboard the hull as if to demonstrate his willingness to sacrifice his own body for peace. On land. occasional violence broke out: In the first week of operation someone shattered all of the windows in the CNVA office. Later, an angry shipyard worker knocked out Lyttle as he distributed leaflets. ${ }^{34}$

By 1965, New England CNVA had moved to Voluntown, Connecticut, where members continued to plan its submarine protests, demonstrations at the Sikorski

${ }^{33}$ James Tracy, Direct Action: Radical Pacifism From the Union Eight to the Chicago Seven (Chicago: University of Chicago Press, 1996), pp. 99-104; DeBenedetti, An American Ordeal, pp. 31, 35; Zaroulis and Sullivan, Who Spoke Up?, p. 9.

${ }^{34}$ Tracy, Direct Action, pp. 107, 113-114. 
helicopter plant in Stratford, and peace marches, including one from Quebec to Guantanamo in 1963. Their activities were well known within pacifist circles; in fact, membership tended to overlap among groups such as CNVA, the War Resisters League, the Workshop in Non Violence (later WIN magazine), the Fellowship of Reconciliation, and the American Friends Service Committee. In time, the CNVA's work gained the attention of two Boston University students, John Phillips and David O'Brien. Both were members of the War Resisters League and had been active at BU, but were looking for an opportunity to make a more powerful personal commitment to ending the war in Vietnam. They spent much of their free time participating in CNVA-sponsored demonstrations and at the farm in Voluntown where they received permission to form a Boston branch of the organization in January $1966 .{ }^{35}$

For Phillips and O'Brien, much of the attraction to CNVA lay in the "spiritual underpinnings" of Lyttle's Gandhian pacifism and the sense that CNVA had a utopian vision of operating as an alternative society within a society. According to Phillips, compared to the "reactive" nature of many antiwar groups, the CNVA focused on building a new society. He felt "the presence of God" all through that time. "You couldn't help it...there were all these Unitarian Ministers, Friend Service Committee [members]...I felt a strong spiritual identity throughout the experience."

Unlike New England CNVA, the fifteen or so hardcore members of Boston

35 Phillips interview, 29 Aug. 1997; John J. Phillips letter to CNVA-West, 24 Feb 1966, Boston CNVA folder, New England CNVA papers, Swarthmore College Peace Collection (hereafter cited as SCPC).

${ }^{36}$ Phillips interview, 29 Aug. 1997. 
CNVA directed their attention exclusively toward the Vietnam war. Although they were pacifists and were deeply concerned about the proliferation of nuclear weapons, the worsening situation in Vietnam, they felt, deserved all of their attention. They set up their first office in Roxbury but because of inadequate plumbing and wiring, later moved to an old barn in Brookline, complete with "milk-crate-modern furniture" and mimeograph machines for producing leaflets. They were extremely well-informed regarding the Geneva Accords and could, in conversation or leaflet form, detail the history of American involvement in Vietnam since the 1940s. One of their regular activities involved going to the movie theater where Doctor Zhivago played and passing out leaflets that stressed the peace theme in the film and applied it to Vietnam. They also planned their own peace marches in which they inevitably ran into the usual intolerant bystanders. On a Boston to Provincetown march, they were regularly jeered and occasionally beaten up. Phillips: "I remember going through Plymouth...very naive....walking through the center of town and finding the whole center of town mobbed with people ready to do all kinds of things to mess us up...one lady in particular squirting us with a water pistol full of mustard because we were yellow."137

On March 25, 1966, the group turned its attention to the Boston Army Base as its contribution to the Second International Days of Protest. The strategy involved leafleting and sitting in the road to block buses of draftees and anyone else from entering or exiting. In general they hoped to be able to "gum up the works." It did not last long. At the army

${ }^{37}$ Williams interview, 28 Aug. 1997; Phillips interview, 29 Aug. 1997; "Dear Fellow American," and "We Support Our President," leaflets, Boston CNVA folder, NECNVA papers, SCPC. 
base, which is located in South Boston near the waterfont, hundreds of longshoremen and other onlookers spat on the demonstrators, yelled obscenities, and called them all "cowards." One burly longshoremen approached the group and offered them a gallon of gasoline, "so you can burn yourself," as Norman Morrison, a Quaker, had done outside the Pentagon several months before. This prompted David Benson to take out his draft card and burn it. As he attempted to light it, a longshoreman knocked the matches from his hands. The police quickly stepped in and arrested the demonstrators - eleven of them - and hauled them off to the police wagon. As two officers dragged Benson away from the gates of the Army base, he ripped up the card and tossed the pieces to the ground. Several hecklers yelled sarcastically to the police: "Be careful. Don't hurt them." As Suzanne Williams remembers it, they were arraigned for "sauntering and loitering in such a way as to engender a breach of the peace and likely to endanger passersby." They were released on their own recognizance and ordered to appear for trial at the South Boston Courthouse on March 31, thus setting in motion the events that would lead to their beating. ${ }^{38}$

Benson did not destroy his draft card lightly. The Boston CNVA had quickly recognized the draft as a potentially ideal target for the kind of confrontational direct action about which they had been learning in Voluntown. It required more than the usual commitment to standard civil disobedience; one had to be prepared to face the penalties

${ }^{38}$ New York Times, 26 Mar. 1966, p. 2; "Pacifists Stage Boston March," Manchester Union-Leader, 26 Mar. 1966, p. 1; ":Punchers at Court," Boston Globe, 10 Apr. 1966; Phillips interview, 29 Aug. 1997; Williams interview, 28 Aug. 1997; Boston CNVA newsletter, c. early April 1966, Boston CNVA folder, NECNVA papers, SCPC. 
of the draft card destruction law and, for those who had deferments, face the inevitable change of draft status to 1-A (draftable) by one's local board. One also had to face the hostility of those whose sons and brothers were being conscripted.

The Boston resisters' emphasis on the draft coincided with a sharp increase in the number of men being called for induction. By the end of 1965 , between 35,000 and 45,000 men were being drafted every month nationwide; in contrast, monthly calls in 1962 and 1963 had averaged between 6,300 and 9,400 men. Americans had grown comfortable with the peacetime draft but the sudden intrusion of the Selective Service System on their lives brought the war home and made the draft a subject of heightened scrutiny. 39

\section{America and Conscription}

Not until after World War II did the American people tolerate a peacetime draft. During the Revolution, the War of 1812, the Mexican War, and the Spanish-American War, the armed forces of the United States relied on volunteers - as they do today. The behavior of British troops stationed in the thirteen American colonies in the 1760 s and early 1770 s convinced most Americans of that era. and for generations after, that standing peacetime armies encroached on the liberties of the citizenry and, at their worst, could be used as forces of repression. Moreover, to Americans who embraced classical republican notions of service to one's community, conscription seemed unduly coercive. Instead, throughout most of the nineteenth century, Americans expected that all free citizens

\footnotetext{
${ }^{39}$ Flynn, Lewis B. Hershey.
} 
would spring to the defense of the nation during periods of crisis. ${ }^{40}$

The earliest uses of conscription in America were, therefore, carried out with caution. President Lincoln introduced the first draft in 1863 - and saw bloody riots as a result - but terminated it soon after Lee's surrender at Appomattox. Woodrow Wilson, too, initiated conscription in 1917 , upon American entry into the war in Europe, but ended it once victory was achieved. The draft that Franklin Delano Roosevelt signed into law in 1940 (long before the Japanese attack on Pearl Harbor) created the first of its kind in peacetime, but hardly seemed necessary after 7 December 1941 when millions enlisted to fight. In what was by then the custom, that draft, which resulted in ten million inductions, ended on March 31, 1947. This did not stop policy makers from openly contemplating renewal of the draft law even without an attendant national emergency. Soon after the expiration of the old law, the loss of 15,000 men from the armed services each month amid growing tensions with the Soviet Union (exacerbated by the Communist coup in Czechoslovakia), led to revived calls for a peacetime draft. On June 24, 1948 Congress passed the Selective Service Act. ${ }^{+1}$

The establishment of a draft in peacetime did not occur without criticism. In 1947, the War Resisters League sponsored the first public draft card burning and turn-in

${ }^{40}$ Richard Gillam, "The Peacetime Draft: Voluntarism to Coercion," in Martin Anderson, ed., The Military Draft, p. 101.

${ }^{41}$ John Whiteclay Chambers II, To Raise An Army: The Draft Comes to Modern America (New York: Free Press, 1987), pp. 254-260; Lawrence M. Baskir and William A. Strauss, Chance and Circumstance: The Draft, The War and the Vietnam Generation (New York: Knopf, 1978), p. 19; William H. McNeill, "The Draft in the Light of History," in Martin Anderson, ed., The Military Draft: Selected Readings on Conscription (Stanford: Hoover Institution Press, 1982), pp. 59-65. 
in New York City. More than 400 people participated, including social critic and essayist Dwight MacDonald, who spoke againist conscription under any circumstances:

When the State...tells me that I must 'defend' it against foreign enemies - that is, must be prepared to kill people who have done me no injury in defense of a social system which has done me considerable injury - then I say that I cannot go along. In such a serious matter as going to war, each individual must decide for himself; and this means civil disobedience to the State power that presumes to decide for one. ${ }^{42}$

In addition, ongoing segregation within the military led A. Philip Randolph, the black labor leader and civil rights activist, to tell the Senate Armed Services Committee in 1947 that he would "personally pledge...to openly counsel, aid and abet youth...in an organized refusal to register and be drafted" should a peacetime draft be enacted. A month after passage of the new draft law, President Truman issued Executive Order 9981, which ended segregation in the military. ${ }^{+3}$

The administration of the Selective Service remained essentially the same as it was during the war, but Congress did make some key changes in writing the new law. First, they reduced the draftee's term to 21 months (in World War II, draftees served for the duration of the war) and placed a two year limit on the life of the draft; after that, Congress would have to reevaluate the need to continue it. (Eventually, the draft came up for review every four years through the fifties and sixties and Congress extended it every time.) As Congress reviewed a possible extension of the Act in 1950, North Korean armies streamed across the $38^{\text {th }}$ parallel into South Korea, leading the United States,

\footnotetext{
${ }^{42}$ Zaroulis and Sullivan, Who Spoke Up?, p. 9; Ferber and Lynd, The Resistance, pp. 4 .
}

${ }^{43}$ Ferber and Lynd, The Resistance, p. 5; Flynn, Lewis B. Hershey, p. 170. 
under the auspices of the United Nations, to take action against North Korea. Congress quickly extended the draft law and the Selective Service sprang into action, drafting 220,000 men by the end of 1950 . Such events seemed to confirm the need for - and the practical advantage of - an ongoing Selective Service Act. ${ }^{44}$

As the Korean conflict wound down and manpower needs declined, some in Congress worried about the structure of the draft. They feared that the armed forces qualification test resulted in the rejection of too many draftees and that, consequently, the nation was sending too many of its brightest and healthiest off to fight while its weakest and least intelligent stayed home to procreate. L. Mendel Rivers, a Congressman from South Carolina, suggested lowering the standards of the qualification exam because, he said, "Korea has taught us one thing if it has taught us anything. You don't need a Ph.D. degree to fight those Chinks." At approximately the same time, Selective Service inaugurated the implementation of a system to distribute draft deferments to America's best and brightest. Starting in 1951, draft boards began granting deferments to college students who placed in the top half of their class or who scored well on a national aptitude test. Soon, more than $75 \%$ of the nation's college students were effectively put out of harm's way. ${ }^{45}$ During the rest of the decade and well into the 1960 s, very few Americans were drafted and no draftees were killed; thus, Americans seemed willing to tolerate not only a peacetime draft but the concomitant inequities assured by a complex

${ }^{44}$ Flynn, Lewis B. Hershey, p. 176-177.

- $\quad{ }^{45}$ Baskir and Strauss, Chance and Circumstance, p. 21; Flynn, Lewis B. Hershey, pp. 182, 201. 
system of deferments. ${ }^{46}$

Attitudes toward the draft did not change substantially until the American escalation in Vietnam. Up to that point, the Selective Service enjoyed considerable approval among policy makers. In 1962, President John F. Kennedy praised the state directors of the Selective Service, saying that, "the pressures upon them are tremendous, yet I cannot think of any branch of our government in the last two decades where there have been so few complaints about inequity." Furthermore, in 1963 the Pentagon acknowledged the importance of the draft in noting that one third of all enlisted men and $41 \%$ of its officers would not have entered the service if not for the draft as a motivator. ${ }^{47}$

Much of the popularity of the agency could be traced to its director, General Lewis B. Hershey, who after supervising the draft during World War II, served as director of Selective Service from 1948 to 1970 . Hershey personified his agency in a way unequaled by anyone, save J. Edgar Hoover. Politicians loved him for the folksy Will Rogers style he brought to his testimony before Congressional committees. In 1966, syndicated columnist Mary McGrory described him as "everybody's grandfather" and noted that "if the system is inhuman, its director at least is not."

Hershey liked to promote the agency's flexibility and the fact that rather than being run as a massive government bureaucracy out of Washington, the Selective Service

${ }^{46}$ Chambers, To Raise An Army, p. 256.

${ }^{47}$ Flynn, Lewis B. Hershey, pp. 218, 221.

${ }^{48}$ Flynn, Lewis B. Hershey, p. 181; Mary McGrory, "Everybody's Grandfather," Boston Globe, 18 Apr. 1966, p. 14. 
was decentralized, administered by over 4,000 local boards made up of "little groups of neighbors." Naturally, this made it into a much larger bureaucracy and the neighbors on local boards were hardly representative of mainstream America. As Lawrence Baskir and William Strauss pointed out after the Vietnam War, Hershey shaped the agency in his own image, "converting what was originally a civilian agency into a paramilitary organization, 90 percent of whose top-ranking officials and state directors were officers in the armed forces. In turn, they appointed local board members with perspectives like their own." Indeed, a 1966 study of over 16,000 draft board members across the country found that more than 70 percent were middle and upper class professionals (managers, proprietors, public officials, white collar workers) over 50 years old while only 25 percent held blue-collar or agricultural jobs. ${ }^{+9}$

From the end of the Korean War until 1965, these draft boards oversaw - under the direction of Hershey - the implementation of a deferment system based on a theory that they called "manpower channeling," in which the Selective Service extended its mission beyond merely delivering men to the armed forces but also, through the use of attractive deferments and the threat of induction, "channeled" men into fields of study and occupations deemed to be in the nation's interest. Thus, in the mid-1960s if one had the grades and planned to study physics (scientists were important in the arms and space races), one could expect a deferment for four years of undergraduate work. additional deferments for graduate study, and a final occupational deferment if successful in

49 Baskir and Strauss, Chance and Circumstance, p. 16; James W. Davis, Jr. and Kenneth M. Dolbeare, Little Groups of Neighbors: The Selective Service System (Chicago: Markham Publishing Co., 1968), p. 58. 
securing a the right kind of job. Such a system could easily ensure the safety of a man from age 18 to 26 and beyond: Of coarse, it was completely unfair, and its discovery by the antiwar movement early in 1967 proved very useful [see Chapter 2], but Hershey argued that the protection of "vital activities and scarce skills" were keys to national security. Those who were ineligible for such deferments, because they were poor or not as smart or worked in their fathers' businesses, more likely saw things as Bellow's character Joseph when he said "personal choice does not count for much these days." 50

Despite the inequities, by July 1965 the deferment system had long been accepted by the public as an integral part of the draft. More than that, Hershey's biographer notes, after twelve years of relative dormancy, "deferments had been translated into exemptions in the minds of many. To now revive the draft in order to fight a limited war in Southeast Asia might prove troublesome." It did. Early protests against the war included the occasional draft card burning which resulted in the August 1965 passage of legislation (sponsored in the House by Mendel Rivers and in the Senate by Strom Thurmond) prohibiting the destruction of draft cards. In addition, General Hershey began using reclassification as punishment for antiwar protesters. After more than 30 people, many of them students at the University of Michigan, staged a sit-in at a Local Board 85 in Ann Arbor in October, Hershey revoked the deferments of 13 male students and made them eligible for the draft. This invited considerable criticism from editorial boards across the country, but Hershey argued that "reclassification is quicker at stopping sit-ins than some Man, p. 125.

${ }^{50}$ Davis and Dolbeare, Little Groups of Neighbors, p. 154; Bellow, Dangling 
indictment that takes effect six months later." When a reporter from the Michigan campus paper interviewed him about this decision, he responded, "I'm one of those oldfashioned fathers who never let pity interfere with a spanking." Some months later, Mendel Rivers told Hershey, "God bless you, you did right."st

Suddenly, in a matter of months, public interest in the draft had heightened considerably. Between September 1965 and January 1966, 170,000 men had been drafted and another 180,000 enlisted after being classified 1-A. Men seeking deferments quickly became fathers or enrolled in college. By January, two million men had college deferments, effectively becoming the first draft dodgers. That spring, the eighth edition of The Handbook for Conscientious Objectors, published by the Central Committee for Conscientious Objectors and "designed to serve the committed objector, not to challenge the draft system," sold 11,000 copies in less than five months and went into a second printing. At the same time, Hershey, in an attempt to tap into the student population, resurrected the long unused Selective Service Qualification Test in order to target the poorest students. In 1963, when the test was offered last, only 2,145 men sat for it. In 1966, however, 767,935 men - all anxious to secure deferments - took the exam. ${ }^{52}$ "I Fought the Law, and the Law Won"

Into this atmosphere of increased attention to the draft stepped the Boston

${ }^{51}$ Flynn, Lewis B. Hershey, 234-236, 243; Powers, The War At Home, p. 86; Zaroulis and Sullivan, Who Spoke Up?, p. 54; Baskir and Strauss, Chance and Circumstance, p. 25.

52 Flynn, Lewis B. Hershey, p. 234, 241; DeBenedetti, An American Ordeal, p. 166. 
Committee for Non-Violent Action. As they quickly discovered, however, few others shared their commitment to challenging the war and its system of conscription. On March 26, 1966, the day after their arrest at the Boston Army Base for "sauntering and loitering," many of them participated in a march from the Cambridge Common to the Arlington Street Church. Organizers decided to hold the rally in the church in hopes that they would be able to avoid the kind of hostility that had caused the October demonstration on the Common to end. It made no difference. Marchers were jeered and pelted with eggs for much of the march. A group of counter-protesters marched ahead of them chanting derogatory epithets and calling the parade the "long yellow line." When they arrived at the church, a group of 1,500 unsympathetic onlookers awaited them. As the marchers entered the building, dozens of eggs and several beer cans rained down on them. Many of the eggs splattered on the doors of the church staining them a slimy yellow. On the steps of the church Noam Chomsky asked a police officer "Don't you think you ought to stop this?" The officer just smiled until an egg connected with his uniform, rapidly changing his demeanor. "Then they cleared everybody away in about three seconds," Chomsky recalled..$^{53}$

For two straight days, the members of Boston CNVA had faced considerable enmity as they protested against the war. Still, several of them decided that on the day of their "trial" for the sit-in at the Army base, they would use the courthouse steps as a "natural stage" for a draft card burning. Part of their training in civil disobedience taught

53 "Eggs Hurled At Hub Marchers in War Protest," Manchester Union-Leader, 27 Mar. 1966, p. 1; New York Times, 27 Mar. 1966, p. 32; Chomsky interview, 20 May 1997. 
them to seek to make every event into an opportunity for protest, to get the message out. Therefore, they wrote press releases and distributed them to as many newspapers, and radio and television stations as they could, never realizing that it could result in the beating that they received. Years later, John Phillips said, "For some reason, I think we were oblivious to the possibilities there. This was something we never expected to happen." 34

After the attack, the victims went inside to be sentenced each to a $\$ 20$ fine for their roles in the sit-in. Standard nonviolent tactics included refusal to pay fines and the eleven convicted loiterers did as much. They believed that rather than giving money to the system that they were fighting, it would be better to have that system incur some expenses to support them for 20 days in jail. The judge told John Phillips that, given his broken nose and two black eyes, he had already paid a sufficient penalty, but Phillips insisted on going to jail, too. There the group quickly learned, however, that the Massachusetts correctional system did not spend much money to house and feed them. Their cells at the Charles Street Jail were overrun with cockroaches and they were served disgusting meals. Suzanne Williams recalled that,

There were these phenomenal...women's fist sized, meatballs that were served there which were $100 \%$ inedible....I have no idea what they were made of...We were given only, in the security trappings of a jail, large spoons to eat with. And it was not possible to penetrate those objects with that spoon. It was some kind of double boiled gristle or something....we all referred to them as hand grenades....Some of the other things they served there, too, were quite questionable in origin.

On the day that they were released from jail (an uncle had paid bail to get Phillips out the

${ }^{54}$ Phillips interview, 29 Aug. 1997. 
first night, but the others stayed), a crowd of reporters, about ten police officers, and five FBI agents waited outside. To their sätisfaction, Gary Graham Hicks, one of the eleven from CNVA, and one of the few black men in the movement, burned his draft card. As he did so, two FBI agents stood directly behind him, peering over his shoulder; one relayed information that he read off the card to the other who wrote it down in a notebook. After Hicks dropped the burning remains to the ground, the first agent snuffed out the flame and collected the pieces. Even though Hicks, like his four friends before him, had openly broken the law - and said so to the media as they did it - the FBI agents diligently collected evidence at the scene as if it were a clandestine deed, evidence that would put Gary Hicks in prison within a year. ${ }^{5 s}$

The government wasted no time in taking legal and possibly illegal action against the Boston CNVA men who had burned their draft cards. On April 15, 1966, two weeks after the draft card burnings on the South Boston Courthouse steps, a grand jury in U.S. District Court in Boston indicted David O'Brien, John Phillips, David Benson, and David Reed each for violating the Federal law prohibiting the destruction of one's draft card (Hicks's indictment came down later). At almost the same time, each man heard from his draft board. By April 22, two of the men - Phillips and O'Brien - had been reclassified to 1-A. By mid-May, two of them - Phillips and Reed - had been called for their preinduction physicals (which they ignored) and by mid-June both had been called for

55 "Pacifist Group, Card Burners, Struck, Kicked," Manchester Union-Leader, 1 Apr. 1966, p. 10; Phillips interview, 29 Aug. 1997; Williams interview, 28 Aug. 1997; Transcript of United States v. Hicks, Cr-66-103-J (1967), National Archives, Waltham, Mass. 
induction (which they also ignored). On August 18, Phillips and Reed were indicted for failure to comply with the Selective Service laws directing them to appear for their physicals and to submit to induction. These were the early days of draft resistance, and a determined Federal government brought its full force to bear on those that challenged its authority.

When each of the CNVA cases came to trial, the defendants and the government argued their cases from two completely different perspectives. The prosecution, led by Assistant U.S. Attorney John Wall, a former paratrooper who served in Korea, stuck to proving that the defendants did "knowingly and willfully" burn their draft cards or refuse induction. These facts were easily proven as the defendants had generally perpetrated the acts in public or announced their intentions in letters to their draft boards. In contrast, the defendants, all of whom served as their own counsel, used some of the evidence introduced by the prosecution against them - their letters to their local boards - not to dispute the government's presentation of the facts, but to make an argument to the jury based on the moral value of their acts as compared to the immorality of the "war machine" and, sometimes specifically, American efforts in Vietnam.

David O'Brien faced the government first. In his trial of June 1, 1966, he did not object to any of the evidence presented by Wall and, after hearing the testimony of FBI agent Thomas McInerney, thanked the man for saving his life. In his cross-examination of the state's assistant director of Selective Service, Col. Paul Feeney, O'Brien read aloud the letter that he had sent to his Local Board 18 in March. He told them that he was severing his ties to the Selective Service because, he wrote, 
...I feel that it is the only moral course I can follow. I could never serve in the armed forces in any capacity for I consider the existence of the war machine the furthest step taken toward the demise of mankind, not only physically but morally.

I cannot accept a position of civilian alternative service in place of the military requirement you want me to perform. This would amount to my being placed in a special category, and I am not special. This would be saying that there is a right to draft others in the killing machine....to draft those who don't have special religious training and belief. I feel this right does not exist; it is a wrong.

During his one-day trial, O'Brien's arguments rested more on his pacifist beliefs than on his particular dislike for the Vietnam War. He acknowledged that he could have applied for conscientious objector (CO) status - which would have kept him from being drafted into a combat role but probably would have resulted in having to fulfill noncombat responsibilities for two years - but such exemptions were generally given only to those who were Quakers or could demonstrate a religious basis for their pacifism.

O'Brien could not. Moreover, he felt that even to accept $\mathrm{CO}$ status would be tantamount to acceptance of and participation in an institution designed to kill others. "I could not go along with the system," he said in his final statement to the jury. "I had to refuse to cooperate with what I considered to be evil." 56

John Phillips agreed. But in a letter that he wrote to President Johnson (a copy of which he sent to his draft board, thus making its way into the trial as evidence), he went beyond O'Brien's expressions of pacifism to address more Thoreau-like questions of the place of the individual in a civil society. He started by stating that he, too, objected conscientiously to all wars. "To participate in the war effort," Phillips wrote, "whether in

\footnotetext{
${ }^{56}$ Transcript of United States v. O'Brien, Cr-66-91-S (1966), National Archives, Waltham, Mass.
} 
combat or as a noncombatant, would be a betrayal of my moral beliefs." As a result, he did not seek $\mathrm{CO}$ status through his draft board. "I am really a conscientious affirmer," he said, "for I wholeheartedly affirm the values of life and conscientiously pursue the good of all men." But, equally important, Phillips said, he found the Selective Service System intolerable because it sought "to coerce a man to do the bidding of his state, under threat of punishment should he refuse." In a truly free society, he argued, "individuals will act from a genuine desire to attain a better life for their fellows, not from an acceptance of standards imposed by the government." Without room for individual conscience, men, as Thoreau said, "serve the State...not as men mainly, but as machines." Phillips and the others would not accept that. He concluded by pledging to continue his efforts to convince his fellow citizens that "war is senseless and immoral," and that in Vietnam, "as in all wars men are being made their brothers' murderers for the selfish interests of political leaders." He said he knew the president would "recognize the urgent need for such a task," and would encourage him in his "mission for peace."

In the letters that they wrote to their draft boards and in statements made at their trials, David Reed and Gary Hicks - as if to prove Thoreau's point that by means of men's respect for the law, "even the well-disposed are daily made the agents of injustice" expanded on the critiques of O'Brien and Phillips to directly question the morality of American policies with respect to Vietnam. In early 1966, Reed wrote to his local board and reminded them that he faithfully registered for the draft in 1964 , but that since then,

57 John J. Phillips letter to Lyndon B. Johnson, 8 Feb. 1966, introduced as evidence in United States v. John J. Phillips (1966), National Archives, Waltham, Mass. 
he had "seen the government of the United States rain bombs upon the people of Vietnam" and "American soldiers burn the homes of Vietnamese peasants with cigarette lighters, with flame-throwers, and with napalm bombs." He also referred to the American invasion of the Dominican Republic and government threats to "wage total war - nuclear war - against the people of the Soviet Union and China." All of these actions. Reed charged, "are crimes under the Constitution of the United States; they are crimes under the Charter of the United Nations, and under international law; and, most importantly, they are crimes against humanity..." As a result, he wrote, "I refuse to participate in these crimes, and I declare my intention to do all that I can, as one citizen, to stop my government from behaving in this manner." Reed told the local board that he would henceforth refuse to participate with the Selective Service System. "I think it is the duty of every American to say 'NO' to the government," he wrote, "and face jail rather than fight in a brutal war of aggression against the people of Vietnam." When his board called him for induction in May, Reed responded: "I refuse to serve in the armed forces because... my loyalty to humanity lies above my loyalty to any government."

Hicks, too, used his trial to highlight the apparent hypocrisy of the government in expecting its citizens to obey the law while the American government "openly violate[d] "international law, the Geneva convention and the Nuremberg decisions and the Charter of the United Nations" in prosecuting its war in Vietnam. Furthermore, in a way that the other card burners did not, he emphasized his perspective as an African American in

${ }^{58}$ Exhibits A and C, United States v. David Reed, Cr-66-168-C (1966), National Archives, Waltham, Mass. 
outlining his charges. Hicks said to the judge during sentencing:

I have openly violated the law. This country has openly violated the law. But there is a qualitative difference, your Honor. I have not done any public harm by breaking the law. This country has committed and is committing genocide in Viet Nam by breaking the law.

I would like to say that I live in a very unique country... This is the only country in the world that can maintain an army to protect what is known as a free world. This same country can't send Federal Marshals to protect people who try to vote in Alabama. Instead they send their Federal Marshals to shuttle me back and forth to Charles Street Jail for burning a draft card.

This is the only country in the world that has the courage - and I use the word courage very loosely, your Honor - to talk endlessly about freedom and democracy and justice and human rights and then does everything to stand in the way of attaining these conditions. This is the only country in the world that says that I should deal nonviolently with the $\mathrm{Ku}$ Klux Klan. This same country will actually pay me to go out and commit genocide against someone whom I don't even know.

Hicks concluded by telling the court that "carrying a draft card in this country is equal to a black man carrying a draft card in South Africa or of a Jew being forced to wear a Star of David on an armband in Nazi Germany." The law prohibiting the burning of draft cards, he said, was made to "suppress legitimate political expressions of legitimate American dissenters to foreign policy." When Americans start enacting and tolerating such laws, he finished, "then we no longer live in a democracy and we may as well stop pretending that we do." 59

In the fall of 1966 and early 1967, when Reed and Hicks were tried, such charges were gaining currency at home (albeit among a limited number of people) and especially abroad. During much of 1966 , Bertrand Russell, the aging British philosopher and

${ }^{59}$ Transcripts, United States v. Gary G. Hicks, Cr-66-103-J (1967), National Archives, Waltham, Mass. 
mathematician, almost single handedly organized an International War Crimes Tribunal to hear evidence of possible American war crimes in Vietnam. After refusals from Prime Minister Harold Wilson and President Charles DeGaulle to hold sessions of the tribunal in either Britain or France, the tribunal finally got down to business in Stockholm in May 1967. There, consistent with the charges levied by Americans like David Reed and Gary Hicks, international researchers presented evidence that American planes had bombed civilian targets in both North and South Vietnam including, for example, 13 separate bombing runs on a leprosarium in Quinh Lap over nine days in June 1965. Such acts led the tribunal to find the United States guilty of war crimes and caused a growing number of draft resisters to invoke the Nuremberg principles as support for their decisions to defy orders to commit immoral acts. ${ }^{60}$

The American media and the Johnson administration, despite being invited to defend itself before the tribunal, largely ignored the proceedings. Secretary of State Dean Rusk, referring to Russell, told reporters that he had no intention of "playing games with a 94-year-old Briton." Jean Paul-Sartre, executive president of the tribunal, had trouble understanding this comment, coming as it did from "a mediocre American official." The American press seemed even less interested, calling it an "anti-American propaganda ploy," and claiming that the tribunals members were "not interested in peace." At this early date, one historian has noted, the American media could be depended upon to view

${ }^{60}$ John Duffet, ed., Against the Crime of Silence: Proceedings of the International War Crimes Tribunal (New York: Simon and Schuster, 1968; Clarion, 1970), see especially pp. 180-185. 
the tribunal as "a political circus orchestrated by left-wing nuts." The evidence presented to the tribunal would be confirmed by Vietnam veterans at the Winter Soldier hearings in 1971, but in 1967, such stories had no effect on American war policy.

Similarly, the early appeals to morality by draft card burners had no impact on the way their cases were handled by the judicial system. By early 1967, all five of the Boston CNVA draft resisters were serving prison sentences of anywhere from two to five years, except for David O'Brien who, after two months in prison, secured bail while his case went through the appeals process. The judges who heard the cases allowed the defendants to make their cases in closing statements but would not tolerate trying to put American war policy on trial. Consequently, all such cases were easily processed. At the end of 1966 , the government had secured 450 draft related convictions, a substantial increase over the 262 convictions of 1965 and 227 of $1964 .^{62}$

Charles DeBenedetti, perhaps the most insightful scholar of the Vietnam era antiwar movement, has noted that "the draft issue provided the link between political action and personal commitment and life-style for which radical pacifists had been seeking. "'63 CNVA members sought to challenge the nation's war policies on the issue of morality as one way of calling attention to the growing callousness and attraction to violence that they saw in American culture. David O'Brien got to the heart of the matter

6I Tom Wells, The War Within: America's Battle Over Vietnam (Berkeley: University of California Press, 1994), p. 142.

62 “450 Convicted in "66 as Draft Violators," New York Times, 6 Jan. 1967, p. 2.

${ }^{63}$ DeBenedetti, An American Ordeal, p. 167. 
in his statement at sentencing:

I feel that the draft card burning symbolizes my choice to work for the betterment of our society in a very radical way, radical in that all our motivations, all our actions, all our beliefs must be reexamined and those that are incompatible with the well-being of the individual and those that deny love must be changed.

The horrors of a war are so great that I am mystified that so many people, even those who have fought in wars, seem unable to feel any compassion for those who are affected. The cry we have heard in the past to bomb Hanoi with its thousands of innocents has been acted upon, and now the same people cheer over the cries and screams of their victims. I cannot understand how the warriors fail to see in this the rape of their own sensitivity. There is no more true saying than that war makes us all victims. But must we all be executioners as well?

Such pleas did little to affect policy makers in Washington, Selective Service officials, the courts, or the public at large. Soon the Boston CNVA ceased to exist, as the men who comprised much of its core found themselves in federal prison. ${ }^{65}$

In spite of their organization's demise, the Boston CNVA draft resisters set important precedents for future resisters to follow. In addition to raising questions about individuality and freewill in a republic at war, they framed their dissent as an issue of citizenship, an impatient brand of citizenship that justified confronting one's government when circumstances warranted it. Furthermore, the rapid, effective response of the federal government to the draft resistance threat set an example of prosecutorial zeal that led later draft resistance leaders to believe that they could rely on the Department of

${ }^{64}$ Transcripts, United States $v . O^{\prime}$ Brien.

65 The life of the Boston CNVA always was tenuous. Even before the trials of the draft card burners, a June newsletter desperately appealed for funds and complained of "the lack of support by those whom we thought were our supporters." Newsletter, 7 Jun. 1966, Boston CNVA folder, NECNVA papers, SCPC. 
Justice to attempt to prosecute thousands of draft resisters at once, thus clogging the courts and straining the Selective Service System.

On October 16, 1967, John Phillips, then over twelve months into his sentence, watched the nightly news in the prisoners' lounge at the federal pen in Petersburg, Virginia and, to his amazement, saw hundreds of men turning-in (and some burning) their draft cards in an elaborate ceremony at the Arlington Street Church in Boston. "I remembered," he later recalled, "our little band of bold pioneers," and the beatings they received for doing essentially the same thing as these men who now were backed by thousands of supporters. Much had changed in eighteen months, but in that intervening period, many opponents of the war must have remembered the experience of the Boston CNVA, for public draft resistance disappeared between April 1966 and October 1967 in Boston. Although some resurrected the idea in other parts of the country in the spring of 1967, Boston's leading protesters turned to other means of undermining the Selective Service System and the war effort before October 16. 


\section{CHAPTER II}

\section{THE DRAFT AS A POLITICAL ISSUE AND MOVEMENT TARGET}

Sarge, Im only 18, I got a ruptured spleen, and I always carry a purse / I got eyes like a bat, my feet are flat, and my asthma's getting worse / Yes, think of my career, my sweetheart dear, my poor old invalid aunt / besides, I ain't no fool, I'm going to school, and I'm working in a defense plant.

\section{Phil Ochs \\ "Draft Dodger Rag," 1965}

For more than a year after the beatings of the CNVA draft card burners, protests targeting the draft faded from public view. The impatience exhibited by the early draft resisters receded as the courts consistently ruled against the burners and sent them off to prison quickly and quietly. Protest against the war continued, but sporadically and still on a small scale. On the morning of April 15, 1967, however, draft resistance resurfaced in dramatic fashion. As 100,000 to 400,000 people (estimates varied) gathered in New York for a march that organizers called the Spring Mobilization To End the War in Vietnam (more than 60,000 also marched in San Francisco), about 170 men, most from Cornell University, plus several women, and one former Green Beret, burned their draft cards together in Central Park's Sheep's Meadow. Newspapers across the country splashed their images across their front pages. The following day, Martin Luther King, Jr., the main speaker at the New York march, told panelists on television's "Face the Nation" news program, that although he didn't condone the draft card burning in the Park, he did support resistance. "In the true spirit of non-violence," he said, "I have only advocated 
doing what we do to resist it openly, cheerfully, and with a desire to reconcile rather than to estrange and really appeal to the conscience of the nation on what I consider a very unjust and immoral involvement" in Vietnam.'

On the same day of the marches in New York and San Francisco. a full page "We

Won't Go" statement appeared in the Harvard Crimson:

We, the undersigned, as American men of draft age, may be asked by our government to participate in the war in Vietnam. We have examined the history and the nature of this war, and have reached the conclusion that our participation in it would be contrary to the dictates of our consciences.

We therefore declare our determination to refuse military service while the United States is fighting in Vietnam. Our intention in signing this statement is to unite with other draft-age men who share our convictions, in order to turn our personal moral rejection of this war into effective political opposition to it.

That eighty-six men signed this statement on a day when one hundred seventy others burned their cards in New York made it significant. Noncompliance with the draft reemerged as one of the primary strategies of antiwar protest, but this time on a larger

'Face the Nation, transcripts, April 16, 1967; David J. Garrow, Bearing the Cross: Martin Luther King, Jr., and the Southern Christian Leadership Conference (New York: Vintage, 1986), p. 557. Note: Garrow writes that during King's appearance on Face the Nation, he "pointed out that he advocated draft resistance, not draft evasion." In fact, King did not state this outright, though it can be inferred. The discussion went like this: King: “....I do not at this point advocate civil disobedience. I think we have to do a lot of groundwork in massive education before that. I have only urged young men to study their possible status as conscientious objectors. And there is nothing evasive or illegal about this. It is actually guided by and endorsed by the Selective Service Act, which is a perfect constitutional right." Martin Agronsky (CBS News): "Dr. King, am I to understand, then, that you do not advocate resistance of the draft by any American?" King: "Well, it depends on what you mean by resistance." Agronsky: "Refusing to serve." King: "Well, I have certainly advocated this, because I myself would be a conscientious objector if I had to face it..." 
scale. Gone were the days of fighting the draft individually or even in small groups. This new brand of defiance recognized the power of numbers.

Nevertheless, even with its emphasis on converting moral outrage into "political opposition." the Harvard We Won't Go statement did not commit the signers to action or even a clearly defined strategy of resistance. "Our policy is open," admitted one spokesman for the group (tentatively calling themselves the Harvard Draft Resistance Group). "Draft resistance could include applying for draft deferments as conscientious objectors, emigrating to Canada or accepting prison sentences rather than undergoing induction." He estimated that between 500 and 700 men had signed similar statements nationwide and - as if to demonstrate the absence of risk - mentioned that he knew of no resulting prosecutions.' In a strategy that was altogether different than the CNVA practice of open confrontation with the government, the We Won't Go signers deliberately chose to be vague because, as one of them later noted, they were still debating their plans; they discussed numerous strategies, but did not want to commit to anything beyond the statement. ${ }^{3}$

The example of the Boston CNVA exposed the inherent risks of open draft law defiance and, perhaps more important, appeared to be ineffective. One key figure in the draft resistance movement that developed a year later recalled that the actions of Phillips, O'Brien, Reed, Benson, and Hicks, seemed "politically very dumb." Although one had to

2 "We Won't Go Statement," Harvard Crimson, 15 Apr 1967, p. 8; "Harvard Group Pledges Not to Enter Military," Harvard Crimson, 17 Apr 1967, p. 1.

3 Bill Hunt, telephone interview with author, 31 Oct 1997. 
respect their pacifist, nonviolent stand, he said, the "stupidly provocative" incident in South Boston did not win many converts among the larger citizenry. ${ }^{\dagger}$ Consequently, the We Won't Go statement promised no such violations of the law nor did the mere signing of it constitute a crime.

This more cautious - perhaps ambivalent - approach of courting confrontation without actually confronting the government did, however, represent the beginning of a shift back toward more radical defiance of the government's will regarding conscription. This chapter shows that despite the absence of draft resistance through most of 1966 and the winter of 1967 , the impulse to challenge the draft never completely died. Indeed, the draft remained a constant concern for the American people and, consequently, continued to loom as an obvious target for the growing antiwar movement. As Selective Service escalated draft calls, more and more Americans began to question the faimess of a conscription system that appeared to play favorites; local draft boards, it seemed, valued some draft-age citizens more than others. Increasingly, as the military inducted disproportionate numbers of working-class, poor, and minority men (while upper and middle-class men hid behind deferments), more and more antiwar activists saw an opportunity to expose the nation's system of conscription as both unfair and unAmerican. Making the draft the focus of their protest, it followed, could form the foundation for a massive grassroots movement against the war.

The Harvard We Won't Go statement and dozens of others like it derived from this rationale. And if the We Won't Go statements did not outline a clear program of

4 Hunt interview, 31 Oct 1997. 
protest, the organizations they spawned did. This chapter, therefore, also addresses the formation of the Boston Draft Resistance Group which relied on the grassroots community-organizing model practiced by Students for a Democratic Society, rather than on the tactics of moral witness pursued by religious activists and radical pacifists. Instead of aiming for dramatic confrontations that were sure to gamer media (and government) attention, these individuals adopted a more low-key approach that focused on building grass-roots support through campus and community organizing.

\section{The Draft as a Political Issue}

In the autumn of 1966 , as John Phillips and David Benson tried to adjust to their prison cells and as David Reed and Gary Hicks prepared for similar arrangements, an article in the Harvard Crimson reported that the war in Vietnam had "had virtually no effect on the graduate plans of Harvard seniors." The university's Office of Graduate and Career Plans, the article noted, had determined that $74 \%$ of graduating seniors from the Class of 1966 had gone on to graduate school while only $7 \%$ went into the military. These figures virtually matched those of the Class of 65 . At the same time, however, the editors predicted that the 1966-67 school year would be the "Year of the Draft." Events would prove them right. ${ }^{5}$

In fact, for some conscription-age men, 1966 had already become the "year of the draft" as Selective Service calls climbed to 40,000 a month. But students at universities such as Harvard did not have to worry. for they were protected by deferments issued by

S "Impact of the War and the Draft," Harvard Crimson, Registration issue, 1966, p.7; the Class of 1965 sent $71 \%$ going to graduate school and $8 \%$ into the military. "The Year of the Draft," Harvard Crimson. 30 Sep 1966, p.4. 
their local draft boards. As long as they scored well on the Selective Service mental aptitude test or attained rankings in the upper half of their classes, deferments were practically guaranteed. Such deferments raised serious questions about the fairness of the draft; working class men who lacked the financial resources to attend college full-time, for example, were more likely to be drafted than middle class, full-time students. Meanwhile, a host of deferments continued to protect some while others were left exposed [see Table 1]. The draft had operated this way since the late forties, but with an escalating ground war taking place in Southeast Asia, more and more Americans began to examine the draft more critically.

At Harvard in the fall of 1966 , however, few students questioned the legitimacy of the 2-S (student) deferment. When the Harvard Undergraduate Council sponsored a referendum to gauge student opinion on the draft and, in particular, on the requirement that the university provide class rankings to the Selective Service, only $43 \%$ turned out to vote. Those who did cast ballots overwhelmingly opposed the computing of students' rank for the Selective Service. More telling is that $65 \%$ indicated that they believed they deserved draft deferments "solely because they were students," while $70 \%$ expressed their aversion to proposals for a more equitable lottery system to replace the existing process. Insofar as they were willing to see changes made, $84 \%$ favored some kind of alternative service system in which one could fulfill one's duty to the country by accepting a nonmilitary appointment in lieu of being sent to boot camp and possibly Vietnam. Clearly, these results reflected a strong instinct on the part of the students to keep themselves from being drafted; any concern for those who went in their place - those who were not as 
privileged - was not immediately discernible. ${ }^{6}$

\section{Table 1: Selective Service Classifications}

\begin{tabular}{|c|c|}
\hline Class & Definition \\
\hline $\mathbf{I}-\mathbf{A}$ & Registrant available for military service. \\
\hline I-A-O & Conscientious objector registrant available for noncombatant military service only. \\
\hline I-C & Member of the Armed Forces of the United States. the Coast and Geodetic Surver, \\
\hline I-D & Qualified member of reserve component. or student taking military training. \\
\hline$[-0$ & Conscientious Objector available for civilian work contributing to the maintenance \\
\hline I-S & Student deferred by law until graduation from high school or artainment of age 20 . \\
\hline I-W & Conscientious objector performing civilian work contributing to the maintenance \\
\hline I-Y & Registrant qualified for military service only in time of war or national emergency. \\
\hline II-A & Occupational deferment (other than agricultural and student). \\
\hline II-C & Agricultural deferment. \\
\hline II-S & Student deferment. \\
\hline III-A & Extreme hardship deferment or registrant with a child or children. \\
\hline IV-A & Registrant with sufficient prior active service or who is a sole surviving son. \\
\hline [V-B & Official deferred by law. \\
\hline IV-C & Alien not currently liable for military service. \\
\hline IV-D & Minister of religion or divinity student. \\
\hline IV-F & Registrant not qualified for any military service. \\
\hline $\mathrm{V}-\mathrm{A}$ & Registrant over the age of liability for military service. \\
\hline
\end{tabular}

Source: In Pursuit of Equity: Who Serves When Not All Serve? Report of the National Advisory Commission on Selective Service (1967)

This is not to say that Harvard students were apathetic regarding the Vietnam

War. Since 1965 the campus had seen a fairly steady stream of speakers, leafleters, and

6 "Students Vote NO on Class Ranks in HUC Poll on Selective Service," Harvard Crimson, 13 Oct 1966, p. 1. The article noted: "Most of the students who repudiated the policy of ranking students in compliance with Selective Service requests indicated that they objected for reasons of 'educational policy' rather than any opposition to student deferments in general." 
other activists (many from the May $2^{\text {nd }}$ Movement and Students for a Democratic Society) coordinating teach-ins and campaigning against the war. These events occurred sporadically, though, and the numbers of students involved remained relatively low.

There were some exceptions. In early November 1966, several hundred antiwar students, largely led by SDS, managed to comer Secretary of Defense Robert McNamara on the hood of a car. McNamara had come to campus to lunch with a group of undergraduates as part of the Kennedy Institute's Honorary Associates program. In anticipation of his appearance, SDS had tried to arrange a debate on the war between the Secretary and Robert Scheer, managing editor of Ramparts magazine. McNamara refused and, as a result, roused SDS to action. Using walkie-talkies to communicate, they monitored the exits of Quincy House waiting for McNamara's departure. A decoy car failed to fool the students and they quickly surrounded McNamara's vehicle as it tried to leave Mill Street. They began rocking it. As demonstrators sat down in front of and behind the car, the driver slammed the car into gear and started driving forward into the students. Thinking better of it, he stopped before anyone got hurt. Finally, an obviously annoyed McNamara edged out of the car. Hal Benenson, a junior and co-chair of SDS, persuaded the Secretary to stand on the hood of a convertible parked at the curb. McNamara, impeccably dressed, hair neatly greased back in his trademark style, scrambled onto the front of the car and shouted into the SDS microphone: "I spent four of the happiest years at Berkeley's campus doing some of the same things you're doing here. But there was an important difference. I was tougher and more courteous." This brought catcalls of "fascist!" and "murderer!" to which McNamara responded, "And I was 
tougher then and I'm tougher now!"

He then asked Benenson to organize a non-violent meeting that he promised to attend but hastened to add that he had another meeting in five minutes on the other side of the Charles River. The crowd was in no mood for a later meeting. Finally, he relented: "O.k. fellas, I'll answer one or two of your questions." Michael Ansara, the chair of SDS, called for two questions from the crowd. Someone immediately asked why the Administration kept insisting that the war resulted from aggression by North Vietnam in 1957. "The war didn't begin in '57," McNamara answered, "it started in '54-55 when a million North Vietnamese flooded into South Vietnam." Another student then yelled, "Yeah, and they were all Catholics." "A report from the International Control Commission states that it was aggression," the Secretary replied. "I didn't write it. All you have to do is read it. You haven't read it and if you have, you obviously didn't understand it." "We've seen it," someone shouted. Now McNamara was irritated: "Why don't you guys get up here since you already seem to have all the answers?" It soon turned into a shouting match. Someone asked "How many South Vietnamese civilians have we killed and why doesn't the State Department disclose the figures?" When

7 The student who made this remark was well-informed. One million North Vietnamese did stream into South Vietnam following the establishment of Ngo Dinh Diem's government in South Vietnam. Just as Diem's rise to power was orchestrated by the American Central Intelligence Agency, so too was this exodus of Catholics, who fled North Vietnam at the urging of - and with assistance from - American operatives there. American agents used propaganda to portray the Viet Minh (in the North) as hostile to Vietnamese Catholics, while portraying Diem, himself a Catholic, up as a kind of savior. See CIA operative Edward Lansdale's report excerpted from the Pentagon Papers in Marvin E. Gettleman, et al, eds. Vietnam and America, $2^{\text {nd }}$ ed., (New York: Grove Press, 1995), pp. 81-96. 
McNamara responded with a weak "We don't know," another in the crowd yelled, "Why don't you know? Don't you care?" The jeering reached such a level that McNamara could not have been heard even if he had answered. To his relief, ten Harvard and Cambridge police pushed their way toward him. helped him from the car and ushered him into McKinlock Hall where he escaped the throng through an underground tunnel. ${ }^{8}$ Harvard officials and others in positions of authority condemned the students for their behavior, but the event electrified the campus - if only briefly.

Within a couple of weeks, life returned to normal at Harvard. Even the dramatic confrontation with one of the architects of the American war effort did not galvanize more students to sustained protest. Indeed, this was symptomatic of all antiwar efforts in the Boston area up to that point. Certain groups and individuals held demonstrations, organized occasional marches, teach-ins. and rallies, but taken together these events constituted little more than spasms that were easily ignored by those running the war. They failed to create a cumulative effect that even approached comparison with the civil rights movement or other precedent-setting political activism. Antiwar activists continued to seek ways to unify their efforts and attract greater numbers of citizens to their cause.

8 "McNamara Mobbed, Jeered by 800; Monro and Watson Are Appalled," Harvard Crimson, 8 Nov 1966, p. 1; Robert McNamara, In Retrospect: The Tragedy and Lessons of Vietnam (New York: Times Books, 1995), 254-256. In his recollection, McNamara claims that he kept his driver from pushing forward, saying "Stop! You'll kill someone!" He also suggests that after taking the two questions, "the danger was only increasing" so he simply "concluded his remarks, jumped off the car, [and] rushed through a Quincy House door..." In fact, it seems clear that he concluded his remarks only when his reenforcements arrived to provide safe passage. 
The decision to make the draft the target of antiwar dissent grew organically out of a national political atmosphere in which the operations of the Selective Service System (SSS) were coming under increased scrutiny. By the end of 1966 , the number of draftees being called for induction numbered more than four times that of 1964 levels. As a result, the draft (and the war) touched the homes of a far greater number of families than it had since the end of the Korean war. But as the Harvard Crimson made clear, it did not affect everyone equally. That fact alone led many to believe that the complex system of deferments that had evolved over a decade of relative peace warranted closer examination.

Rumblings about the Selective Service had started as early as 1964 when Barry Goldwater, the Republican nominee for president. had called for the end of the draft. In response, President Johnson announced that he would launch a comprehensive study of Selective Service. Historian George Q. Flynn notes that Johnson recognized that the "draft issue was politically sensitive because of the class bias of the deferment system." One labor official wrote to the president in 1964, that "when Walter Reuther realizes his people are doing the dying while the auto executives sons keep getting school deferments, there could be hell to pay." Johnson won in a landslide in 1964 but the results of the study were not released. Only in April 1965 did Robert McNamara receive the Department of Defense report ordered by Johnson. McNamara concluded that the draft must continue and that, since the study showed that $40 \%$ of all enlistees joined because of fear of the draft, any notion of an All Volunteer Force (as some were suggesting) should be dismissed. McNamara made his recommendations to Johnson, but the DOD report 
remained unpublished until July 1966 when increased criticism of the draft in the wake of sharply increased calls for mañpower forced its release. McNamara himself grew uneasy with the inequities of the existing system of conscription and in one speech even floated the idea of two years of "national service" as a solution.

One of the most obvious cases of Selective Service unfairness involved George Hamilton, the handsome Hollywood actor. Hamilton lived a fairly public social life most notably as a frequent date of President Johnson's older daughter, Lynda Bird - and news of his deferred status caused controversy. On 23 June 1966, Congressman Alvin O'Konski, a Republican from Wisconsin and a member of the House Armed Services Committee, told his fellow committee members that although all of the 100 men drafted from his Congressional District over the previous six months came from families with annual incomes under $\$ 5,000$, George Hamilton, "a young Hollywood actor with a $\$ 200,000$ home, a $\$ 30,000$ Rolls Royce. and a $\$ 100,000$ income," continued to receive a hardship deferment to support his mother. a woman, the congressman noted, who had been married four times. "The system is undemocratic and un-American," O'Konski concluded. "It nauseates me. How can I defend it to my people?" Although O'Konski carefully avoided accusing the White House of arranging preferential treatment for the first daughter's boyfriend, Hamilton's deferment made the president look bad. Muhammad Ali's lawyer, Hayden Covington. told the champ, "George Hamilton gets out [of the draft] because he's going with the president's daughter, but you're different. They 
want to make an example out of you."9

To placate critics of the draft, Johnson issued Executive Order 11289, creating the National Advisory Commission on Selective Service under the chairmanship of Burke Marshall, the former head of the Justice Department's civil rights division. Johnson instructed the commission to review draft "fairness" (especially student deferments), classification methods, the appeals system, and the impact of the draft on society, among other things, and to submit their report to him early in 1967 , so that he and the Congress might be fully informed when they took up the renewal of the Selective Service Act in the spring. ${ }^{10}$

More than any of America's previous armed conflicts, the Vietnam War relied mostly on the working class to fight it. Christian Appy, an historian at MIT, estimates that enlisted ranks in Vietnam were "comprised of about $25 \%$ poor, $55 \%$ working class, and $20 \%$ middle class, with a statistically negligible number of wealthy." In fact, he shows that the inequities of the SSS were not limited to its structure of deferments. Appy explains that in the early 1960 s, half of the men called by local boards failed one or both of their physical or mental exams; most failed the intelligence exam called the Armed Forces Qualification Test. Of those who failed this test, almost half came from families

9 "O’Konski Asserts Draft Takes Poor," New York Times, 24 Jun 1966, pp. 1-2; David Remnick, "King of the World: Muhammad Ali and the Rise of an American Hero," (New York: Random House, 1998), p. 289.

${ }^{10}$ George Q. Flynn, The Draft. 1940-1973 (Lawrence, KS: University Press of Kansas, 1993), pp. 189-191.

"Christian G. Appy, Working-Class War: American Combat Soldiers in Vietnam (Chapel Hill: University of North Carolina Press, 1993), p. 27. 
with six or more kids and an annual income of less than $\$ 4,000$. Daniel Patrick Moynihan, then the Assistant Secretary of Labor for Policy Planning, viewed this as "de facto job discrimination" against "the least mobile, least educated young men." Intent on putting such men to work in careers that would teach them skills that could be useful outside the service, he called for reform that would facilitate such training through military service. Then, as draft calls increased dramatically in 1965, Appy tells us, the military, "with no intention of engaging in any social uplift...simply accepted more and more men with terribly low scores on the mental examination."'12

Shortly thereafter, in 1966. Robert McNamara created Project 100,000, a program which would address Moynihan's concerns by admitting 100,000 men who failed the exam into the military every year. "The poor of America," McNamara said, "have not had the opportunity to earn their fair share of this nation's abundance, but they can be given an opportunity to serve in their country's defense and they can be given an opportunity to return to a civilian life with skills and aptitudes which for them and their families will reverse the downward spiral of decay." Appy tells us that officials in the Johnson administration fashioned this program as part of the War on Poverty and Great Society initiatives more than as one strand of manpower mobilization. Of course, to reap the promised rewards one might have to first survive the fighting in Vietnam. Ultimately, "the promised training was never carried out," and half of the 400,000 men who joined the military through Project 100,000 went to Vietnam. Worse, they had a death rate twice as high as American forces as a whole, and $40 \%$ of them were black - compared to $10 \%$

\footnotetext{
${ }^{12}$ Appy, Working Class War, p. 31.
} 
for the military overall. ${ }^{13}$

The Marshall Commission went to work in the summer and fall of 1966, then, just as Project 100,000 unfolded, sending even greater numbers of poor and poorly educated men off to fight in place of better educated. middle and upper class men. The inequities at least those resulting from deferments - and the public's view of them were apparent to Commission members from the start as they received over 500 unsolicited letters from the public, the majority of which urged the abolition of all deferments. As a result, George Flynn notes, by their second or third meeting, Marshall and others had successfully shifted the focus from a critique of the existing system toward a new plan for national service. ${ }^{14}$

${ }^{13}$ Appy, Working-Class War, pp. $31-33$.

${ }^{14}$ Flynn, The Draft, p. 191. It is curious that Flynn, probably the leading historian on the draft, disputes the notion that the draft was unfair. In fact, he argues that "the draft worked against social inequalities." He cites evidence that the proportions of college students and non-college students who served were relatively the same. For example, in $1964,70 \%$ of high school dropouts served; $74 \%$ of high school graduates (who apparently didn't go on to college) served: $68 \%$ of college drop outs served; and $60 \%$ of college graduates served. Likewise, in $1967,60 \%$ of high school graduates served; $50 \%$ of non-high school graduates served; and $40 \%$ of college graduates served. Flynn, The Draft, pp. 194-195.

Unfortunately, such statistics are misleading. We cannot judge their validity without knowing the total population for each category, though it is obvious that the number of men who were college graduates or even college dropouts is probably much smaller than the number of men who had graduated only from high school. For example, if in a pool of 1500 men, 1000 had graduated from high school and the other 500 had graduated from college (a reasonable proportion, I think), by the 1964 percentages that Flynn provides, the number of privileged men (college graduates) to serve is less than half the number of underprivileged who would serve: 300 college graduates to 740 high school graduates. 


\section{"We Won't Go"}

Although the strategy of confronting the Selective Service directly had lost some of its appeal among the war's opponents, the heightened level of attention focused on the draft served to hold it aloft as an ever-present, tempting target. By late 1966, a certain momentum developed that brought even the recalcitrant SDS to move toward draft resistance. Following two small meetings in New Haven, a national discussion of noncompliance took place in late August at the AFSC building in Des Moines, Iowa. There, about 50 participants from various student organizations discussed plans for community antidraft unions which would counsel and organize men around the issue of the draft. In addition, they resurrected the idea of a "We Won't Go" pledge - first used by the May $2^{\text {nd }}$ Movement in the spring of 1964 - and made plans for a national We Won't Go conference in the fall..$^{15}$

Before the We Won't Go conference could take place, another national meeting produced a statement of noncooperation. Over two hundred people, mostly with roots in pacifist organizations, met in New York in late October and issued a signed pledge called 'Saying 'No' to Military Conscription, for Draft-Agers Who Have Shunned, or Broken Their Ties to, the System." David Reed, just weeks away from his trial and inevitable imprisonment, authored the earliest drafts of the statement and the end result seemed to reflect a mature understanding that, as he told a reporter from the Harvard Crimson, "Non-violent non-cooperation is most successful when large numbers of people are

${ }^{15}$ Michael Ferber and Staughton Lynd, The Resistance (Boston: Beacon, 1971), pp. 55-56. 
involved." He knew better than most that the consequences of individual noncooperation could be severe. ${ }^{16}$ The statement said:

We, the undersigned men of draft age (18-35), believe that all war is immoral and ultimately self-defeating. We believe that military conscription is evil and unjust. Therefore. we will not cooperate in any way with the Selective Service System.

We will not register for the draft.

If we have registered, we will sever all relations with the Selective Service System.

We will carry no draft cards or other Selective Service certificates.

We will not accept any deferment. such as $2-S$.

We will not accept any exemption, such as 1-O or 4-D.

We will refuse induction into the armed forces.

We urge and advocate that other young men join us in noncooperating with the Selective Service System.

We are in full knowledge that these actions are violations of the Selective Service laws and are punishable by up to 5 years imprisonment and/or a fine of $\$ 10,000 . " 17$

The statement had obvious roots in pacifism (non-pacifists in the New Left would not necessarily have agreed with the argument that "all war is immoral," for example, often stating that they would have fought in World War II) and it attempted to extend the spirit of individual acts of moral witness such as those carried out by the CNVA to a larger community.

Suddenly, draft resistance as a tactic began picking up steam. A few weeks later, on December 4, the national We Won't Go conference took place in Chicago, and as

16 "Former Harvard Student Faces Trial Tuesday for Failure to Accept Draft," Harvard Crimson, 27 Oct 1966, p. 1.

${ }^{17}$ Ferber and Lynd, The Resistance, pp. 49-50; Note: this statement later appeared in the 15 July 1967 issue of The Peacemaker. Significantly some of the signers included members of the CNVA (Reed, Chuck Matthei. Lou Waronker), future draft resisters (Don Baty, Rick Boardman, George Jalbert, Marty Jezer), and future members of the New England Resistance (Alex Jack, Ray Mungo, Robert Talmonson). 
Ferber and Lynd described it, it "brought together representatives of every significant strain of antidraft activity-at a moment when that activity was on the verge of assuming mass proportions." Over 500 representatives from across the country left the meetings planning to start dozens of local We Won't Go projects. ${ }^{18}$

Most significant, the Students for a Democratic Society were poised to join the battle at last. SDS originated at a conference of sixty two college students in Port Huron. Michigan in 1962. That conference produced a manifesto, the Port Huron Statement, that became the most enduring intellectual contribution of the New Left. Authored primarily by Tom Hayden, a 22 year-old former editor of the University of Michigan's student newspaper, the statement chastised American society for failing to live up to its potential. In particular, it expressed the students' horror at the treatment of African-Americans in the segregated South, and their anxiety over the threat of a nuclear holocaust (their fears were almost realized several months later when the United States and the Soviet Union nearly went to war over missiles in Cuba). Most important, the manifesto indicted modern conceptions of man as "a thing to be manipulated... inherently incapable of directing his own affairs." It called for the establishment of "a democracy of individual participation" in which "the individual share in those social decisions determining the quality and direction of his life." This notion of "participatory democracy" would allow individuals to escape the alienation and conformity of modern society, and instead encourage independence and creative fulfillment of all citizens. For thousands of college

${ }^{18}$ Ferber \& Lynd, The Resistance, p. 59. 
students in the 1960 s, these ideas struck a chord. ${ }^{19}$

Still, in spite of the Selective Service's power over the direction of so many young American lives, SDS had a long history of ambivalence regarding draft resistance. Kirkpatrick Sale writes that, by fall 1966, when some in SDS were thinking of coming out against the 2-S deferment or refusing induction, "even many of those willing to take such personal risks - and there were a number in SDS - tended to acknowledge that this was more an expression of middle-class guilt, or a 'politics of masochism,' than an effective way to build up a mass antidraft organization." When the National Council met in Berkeley in December, however, "everyone wanted to talk about the draft." In part, this shift in attitudes could be attributed to the participation of some of its prominent members in both the Des Moines meeting and the We Won't Go conference, but also to a growing sense that the timing made sense given the government's need to review and probably renew the Selective Service Act within six months. Just before the National Council met, John Spritzler of Dartmouth SDS, sensing the mood, wrote an essay in New Left Notes, SDS's national newspaper, proposing a mass draft card burning by 10,000 men. ${ }^{20}$

Thus, after more than a year of doubt regarding the political efficacy of protesting the draft, and after 19 hours of debate over two days, the National Council of SDS adopted a militant antidraft resolution:

${ }^{19}$ The Port Huron Statement has been reprinted in dozens of anthologies. See, for example, Alexander Bloom and Wini Breines, Takin' It to the Streets: A Sixties Reader (New York: Oxford, 1995), pp. 61-74.

${ }^{20}$ Kirkpatrick Sale, SDS (New York: Random House, 1973), p. 313. 
SDS reaffirms its opposition to the United States Government's immoral, illegal and genocidal war against the Vietnamese people in their struggle for self-determination.

SDS reaffirms its opposition to conscription in any form. We maintain that all conscription is coercive and anti-democratic, and that it is used by the United States Government to oppress people in the United States and around the world.

SDS recognizes that the draft is intimately connected with the requirements of the economic system and the foreign policy of the United States.

SDS opposes and will organize against any attempt to legitimize the Selective Service System by reforms [a clear reference to the Marshall Commission]. The proposals for a lottery or for compulsory national service would not change the essential purpose of the draft - to abduct young men to fight in aggressive wars...

Since individual protest [like CNVA-style burnings] cannot develop the movement needed to end the draft and the war, SDS adopts the following program:

SDS members will organize unions of draft resisters. The members of these unions will be united by the common principle that under no circumstances will they allow themselves to be drafted. The local unions will reach out to all young men of draft age by organizing in the high schools, universities. and communities. Courses of action will include (a) direct action during pre-induction physicals and at the time of induction, (b) anti-draft and anti-war education among potential inductees and their families, (c) demonstrations centering on draft boards and recruiting stations. (d) encouraging young men already in the military to oppose the war, and (e) circulating petitions stating that the signer will refuse to serve in Vietnam or submit to conscription in any form. National SDS will coordinate the local unions on a regional and national level, providing staff (including travelers), supplies, and financial resources. ${ }^{21}$

With this statement. SDS took a bold step, moving, as one of its leaders said, "from protest to resistance." In protesting against the war. SDS would no longer be content with the spasmodic occurrence of marches and sit-ins; they had now made a commitment to action. Soon, members began wearing buttons expressing one word: "Resist." The Berkeley statement effectively set the course for antidraft activity across the country for

${ }^{21}$ Ferber \& Lynd, The Resistance, p. 60; Sale, SDS, pp. 312-315. 
the next six to eight months.

Certainly, its impact became obvious in Boston and especially at Harvard.

Although many students seemed to take what one future draft resistance leader called the "morally opaque" view of the draft as an inconvenience early in the 1966-67 school year, by the end of the fall semester, discussions took a more sober turn.22 The influence of some members of the faculty proved significant in this regard. On December 6, just two days after the national We Won't Go conference opened in Chicago, sixteen members of the Departments of Government and Philosophy offered a resolution for consideration to the entire faculty. The resolution characterized the 2-S (student) deferment as "unjust" and stated that "it strikes us as implausible to suppose that it is in the national interests that students, regardless of their fields, should be deferred while the disadvantaged are compelled to enter military service." Philosophy professor John Rawls proposed working as a group to get a "proper law through Congress in the spring." But before the issue could even be debated, Oscar Handlin of the history department introduced a motion to table the resolution. Handlin felt that "on a matter of principle," the faculty should not vote on issues of "either educational, social or political policy," and favored faculty members expressing their views individually rather than as one corporate body. This argument proved sufficiently persuasive as the faculty table the resolution by a 141-88 margin. $^{23}$

22 The future draft resistance leader who described some students' view of the draft as an inconvenience as "morally opaque" is Bill Hunt; Hunt interview, 31 Oct 1997.

23 "Faculty Debate on 2-S Opens at Meeting Today," Harvard Crimson, 6 Dec 1966, p.1; "Faculty Avoids Deferment Debate. Tables Resolution Attacking 2-S," 
If the majority of the faculty seemed unwilling to tackle the draft, the students soon began to dedicate more attention to the issue. After another failed attempt by some professors to bring their resolution to a vote early in the spring semester, the editors of the Harvard Crimson, though notoriously timid on such issues, published an editorial in support of a lottery system. It anticipated the release of the Marshall Commission report and laid out the arguments for and against the 2-S deferment: "The best defense of the student deferment is that it is economical." the editors wrote. They challenged the proposition that without the student deferment, the United States would suffer the "decimation of a generation of college students" as Great Britain did during the First World War. "America," they wrote. "has simply too great a wealth of human resources to justify a procedure based on the premise that a loss of some portion of its students would be catastrophic." The paper acknowledged that there are times when a nation "must ignore moral principles" and put self-preservation first. "Now is not such a time," they concluded. "Because of it's clear social inequity. the 2-S deferment should be discarded." ${ }^{24}$ It turned out that the Marshall Commission agreed.

\section{Draft Reform?}

Within a week of the Crimson editorial. two competing commission reviews put the draft on the front pages again. The first report resulted from a Congressionallyordered review of the SSS led by retired Army general Mark Clark. Essentially, it argued that the existing Selective Service Act and its attendant policies and procedures were

Harvard Crimson, 7 Dec 1966, p.l.

24 "The Draft: The Equity of a Lottery," Harvard Crimson, 25 Feb 1967, p.2. 
basically fair and, therefore, that the law should be renewed. Like General Lewis Hershey, the Director of Selective Service, the Clark commission advocated continued use of local draft boards, keeping the undergraduate deferment, and opposed any kind of lottery. The only significant change recommended by Clark was the calling of the youngest men - rather than the oldest - in the pool first. In addition, it urged that draft card burners and other draft violators be "severely and expeditiously punished," and pushed for the application of tighter standards on conscientious objectors. ${ }^{25}$ Under these proposals, the system would change little.

The Marshall Commission report, released the next day, advocated more sweeping reforms, including the elimination of the 2-S. They named it, In Pursuit of Equity: Who Serves When Not All Serve? and reported that they had "sought to find the means of securing the manpower needed for our national security in a manner as consistent as possible with human dignity, individual liberty, faimess to all citizens, and the other principles and traditions of a democratic and free society." Its major recommendations included inducting men at age 19 , selecting them "through a system of impartial random selection among those equally vulnerable," and the elimination of occupational and student deferments. On this last point, they noted that "student deferments have become the occasion of serious inequity...Even though educational opportunity is increasingly widespread, the opportunity to go to college still reflects a degree of social and economic advantage not yet shared by all." Therefore, the majority 1967, p. 7.

${ }^{25}$ Flynn, The Draft, p. 198; "Draft Panel Calls for a Crackdown," NYT, 4 Mar 
of the Commission voted to recommend eliminating student deferments. ${ }^{26}$

Equally interesting; the Commission recommended the elimination of local draft boards, and centralization of power in regional offices that would use a computerized system; in this way the capricious nature of local board decision-making could be replaced by a more uniform process. They bolstered their recommendation with a telling analysis of draft board composition: most local board members were middle-aged and elderly ( $71 \%$ were 50 or older, $22 \%$ were 70 or older), had military backgrounds (66.3\%), and were overwhelmingly white $(96.8 \%)$. These "little groups of neighbors" were not representative of the people most Americans counted as their neighbors. ${ }^{27}$

Two days later, on March 6. 1967, Lyndon Johnson went to the Congress and asked for a renewal of the Selective Service Act. In his address, he pushed many of the Marshall Commission's proposals. He acknowledged the inequity of the deferment system: "Deferred for undergraduate work, deferred further to pursue graduate study, and then deferred even beyond that for fatherhood or occupational reasons," he said, "some young men have managed to pile deferment on deferment until they passed the normal cut-off point for induction." Therefore, he urged the elimination of graduate deferments except in the fields of medicine, dentistry, and the ministry. On the termination of undergraduate deferments, however, the president balked. He cited the split vote of the Commission and asked for Congressional and public debate on the subject. In addition,

26 "In Pursuit of Equity: Who Serves When Not All Serve?," The Report of the National Advisory Commission on Selective Service," (Washington: U.S. Government Printing Office, 1967), pp. III, 38-42.

27 “In Pursuit of Equity," pp. 73-75. 
Johnson's message called for the induction of 19-year-olds first, urged centralization of the SSS administration into regional boards, and the implementation of a "Fair and Impartial Random (FAIR) lottery system to be in place by 1 January $1969 .^{28}$ Between March and June, then, the fate of the draft lay with Congress and the American people.

\section{The Boston Draft Resistance Group}

The contrasting perspectives of Congress and the incipient draft resistance movement regarding the new proposals could not have been more opposed. By March and April, Ferber and Lynd note, "We Won't Go statements and antidraft unions mushroomed from coast to coast, some of them instigated by SDS, some arising independently."29 Promises of draft reform meant little to the protesters. In fact, the growing number of students supporting draft resistance had grown so suspicious of the administration and the Selective Service that nothing short of the abolition of the draft and American withdrawal from Vietnam would have satisfied them.

Much of this cynicism was well-founded. Shortly after SDS made its commitment to draft resistance, Peter Henig discovered a Selective Service document that stunned even the most hard-line opponents of the draft and the war. Dubbed the "channeling memo" and published in the January 1967 issue of New Left Notes, the piece became one of the draft resistance movement's best recruiting tools. Selective Service

\footnotetext{
28 "Text of President Johnson's Message to Congress on the Selective Service System," NYT, 7 Mar 1967, p. 32; "Johnson Plans Draft By Lottery" NYT, 7 Mar 1967, p.1; Flynn, The Draft, pp. 202-203.

${ }^{29}$ Ferber \& Lynd, p. 62-63.
} 
included the memo in training kits. and activists assumed that it came from the desk of

General Hershey; as they read it most imagined the wizened, half-blind, old man writing it - a sinister Gepetto of sorts - sitting at his desk typing out the ominously matter-of-fact phrases:

Delivery of manpower for induction, the process of providing a few thousand men with transportation to a reception center, is not much of an administrative or financial challenge. It is in dealing with the other millions of registrants that the System is heavily occupied, developing more effective human beings in the national interest...

Throughout his career as a student, the pressure - the threat of loss of deferment - continues. It continues with equal intensity after graduation. His local board requires periodic reports to find out what he is up to. He is impelled to pursue his skill rather than embark upon some less important enterprise and is encouraged to apply his skill in an essential activity in the national interest. The loss of deferred status is the consequence for the individual who acquired the skill and either does not use it or uses it in a non-essential activity.

The psychology of granting wide choice under pressure to take action is the American or indirect way of achieving what is done by direction in foreign countries where choice is not permitted.

To the surprise of even the most jaded. this document offered evidence that the Selective Service System's primary purpose was not inducting men into the military, but the kind of social engineering practiced by America"s totalitarian enemies ("foreign countries where choice is not permitted"). The channeling memo implied that those who could not afford to go to college but worked as, say, an electrician's apprentice or a gas station attendant were much more likely to be drafted. Likewise, those who did manage to go to college but graduated only to pursue careers in music or the arts, for example, could expect their local boards to regard their career choices as something short of being "in the national interest." These were stunning revelations. Certainly, the channeling memo 
highlighted the kind of manipulation of lives that SDS criticized in the Port Huron

Statement. Any innocence retained by the nascent draft resistance movement surely now was lost. "At last, 'the American way' laid bare," wrote Kirkpatrick Sale. 30

In the face of such deceit, draft resistance attracted more and more men who were willing to organize against the SSS and to do so in bold fashion. Despite the initially unclear mission of the Harvard We Won't Go group, a sense of solidarity quickly developed. Within ten days, at a meeting on April 25, a number of the We Won't Go signers organized themselves into the Boston Draft Resistance Group (BDRG) and brought their objectives into focus a little more sharply. Using the statement as their primary recruiting tool, the men (no women yet worked with the Group) "set out to mobilize the Harvard campus" by going door-to-door and inviting other students to meetings where they could discuss the draft and the war. A few days later, 60 people turned out for the first meeting."

The tactic of canvassing the campus for more men made sense at the time. Just days before, Martin Luther King, Jr. and famed pediatrician Benjamin Spock had come to Cambridge to launch Vietnam Summer where they visited a few homes to talk to families about the war as television cameras captured it all on film. The organizers of Vietnam Summer aimed to fuse politically inactive middle class Americans into a powerful

${ }^{30}$ Sale, SDS, 319-320; Mike Ferber and David Harris, "On the Resistance," leaflet distributed by the U.S. National Student Association;'Papers of Michael K. Ferber (hereafter, MKFP).

31 "Signers of 'We Won't Go' Petition Organize Draft Resistance League," Harvard Crimson, 26 Apr 1967, p.1; "Anti-Draft Group Seeks to Mobilize Harvard Around Resistance Issue," Harvard Crimson, 5 May 1967, p. 1. 
antiwar lobby by sending thousands of volunteers into thousands of communities across the country to talk about Vietnam. The idea had been conceived by Gar Alperovitz, a fellow at the Kennedy School's Institute of Politics at Harvard. He modeled it on Freedom Summer, the 1964 civil rights project which injected over 1,000 college students and civil rights activists into Mississippi to run Freedom Schools and to register blacks to vote. Organizers chose Cambridge as the national headquarters for Vietnam Summer, and staffed it with 11 people and 100 recruiters. Eventually, over 4,000 volunteers took to the streets of 770 of their own communities as part of the nationwide project. It is virtually impossible to gauge the impact of Vietnam Summer, though most scholars have concluded that it did not prove as successful as its Movement forebear. According to Charles DeBenedetti, the far-flung engagement of the project made it difficult to manage: "People [volunteers] worked sporadically. Staff members were not consistent. Ideological animosities were all too predictable" in a project more or less supported by the American Friends Service Committee, the Committee for a SANE Nuclear Policy, the Student Nonviolent Coordinating Committee, the Southern Christian Leadership Conference, and some factions of SDS. ${ }^{32}$

Even with its shortcomings. the national office of Vietnam Summer exerted a heavy influence on the Boston Draft Resistance Group. A booklet called "Vietnam

32 "King Calls for Vietnam Summer Volunteers," Harvard Crimson, 24 Apr 1967, p. 1; John Herfort, "Vietnam Summer," Harvard Crimson, Pre-Registration issue, 1967. p. 8; DeBenedetti, An American Ordeal, pp. 182-183; Kenneth Keniston, Young Radicals: Notes on Committed Youth (New York: Harcourt Brace, 1968). Note: When King and Spock canvassed two homes in Cambridge, they were heckled by a group of young men with signs and a tape player blaring a recording of "God Bless America." Meanwhile one carried a sign that said, "King Get the Hell Out of Chicago and Harvard." 
Summer: Project Profiles," described antiwar projects allied with Vietnam Summer, including BDRG. The still small draft resistance organization's own depiction of itself demonstrated the impact of Vietnam Summer: "The Boston Group's program is built on the view that constructing a radical constituency through draft resistance is the tactic most likely to mobilize opposition to the war where it will be felt. Draft-age men and their parents, especially parents in the middle class, meet the war most closely through the draft system; draft resistance hits them at their present concerns." The emphasis on constructing a movement from the middle-class while reaching out to the working-class directly echoed the Vietnam Summer approach, but BDRG soon found its own identity. In just a matter of months, the Boston Draft Resistance Group transformed itself into one of the most important antiwar organizations in the city, largely due to the efforts of three organizers: Bill Hunt, Tim Wright, and Harold Hector. All three were older than typical draft protesters. Hunt and Wright both were Ph.D. candidates in the Harvard history department and were both married. Wright was an Army veteran and Hunt had children. Hector, 26 and African-American, came from Roxbury, and so brought a much needed working-class background to the organization. Hunt essentially recruited the other two. As Wright later noted, Hunt was a "spellbinding storyteller and charismafilled visionary in style" who "seduced" Wright into taking a leading role in BDRG. Hector agreed. Once he talked with Hunt, he became committed to fighting the draft and the warmakers. ${ }^{33}$

But the commitment of the three ran deep for other reasons. Bill Hunt, for

33 Tim Wright, interview with author, 25 Aug 1997. 
instance, possessed a fairly long record of social activism before he took up draft resistance. He had participated in the civil rights movement, marching with Martin Luther King, Jr. and SNCC in Selma, Alabama in 1965 and had been concerned about Vietnam since before John F. Kennedy's assassination. When he arrived at Harvard, he joined the May $2^{\text {nd }}$ Movement because it was the only group doing anything to protest the war, they had issued the first We Won't Go statement in 1964 and at Harvard regularly manned tables distributing leaflets about the war (Eventually Hunt would tire of M2M's Maoist/Leninist rhetoric, and join SDS as it grew more radical). Draft resistance for Hunt, then, became a logical extension of his other activist interests. ${ }^{34}$

Tim Wright, on the other hand. had not been much of a social activist before he went to Harvard. Instead he looked to his time in the Army as "the most politically educational experience" of his life "because it was a situation in which [the Army] put people of radically different social class and ethnic background into an identical environment." This resulted in what he called a "kind of barracks socialism" in which class origins were not important. Before going into the service, he had been a very "provincial suburban kid," but the "latently radicalizing experience" of serving in the Army changed all that. He figured that by the time Vietnam heated up, he would have been "urging most middle-class people I knew to go into the Army to learn about their own provinciality." Under the circumstances, however, the escalating war in Vietnam made it inappropriate to urge anyone into the Army. he thought, and so he found himself

${ }^{34}$ Hunt interview, 31 Oct 1997. 
working with BDRG to keep men out. ${ }^{35}$

Harold Hector, one of the few blacks to participate in the draft resistance movement in Boston, did not have either the activist or military background of Hunt and Wright, but was ripe for protest in 1967 . Hector had grown up in Roxbury and sought to join the Navy in 1959 but was rejected because he was overweight. He watched civil rights workers on television as they were beaten. attacked by dogs. and sometimes murdered. He and his friends knew that they could not be non-violent if they went south. "We go south, we [will] kick ass," they thought. But they never did. Instead, Hector met Bill Hunt and Tim Wright whose convictions regarding the war easily dovetailed with his own views of America as an oppressive society. Soon, he joined the other two as one of the leaders of the Group. ${ }^{36}$

At first, the Boston Draft Resistance Group - made up of about 30 signers of the We Won't Go statement - operated out of a room in Harvard's Memorial Hall, but over the summer of 1967 , with $\$ 1,000$ in seed money from Vietnam Summer, the BDRG opened an office on River Street in Cambridge that they staffed at first for 3 hours every day. In the early days, the Group's work focused primarily on legal research regarding the draft and on organizing through canvassing. They targeted other Boston area college campuses, and soon had over 400 signatures on the We Won't Go pledge. That summer, one worker noted, BDRG was a "talking machine." They talked to draft age men

\footnotetext{
${ }^{35}$ Wright interview, 25 Aug 1997.

${ }^{36}$ Harold Hector, interview with author, 9 Apr 1997.
} 
wherever they could find them, distributed leaflets, and visited army bases. ${ }^{37}$

For the most part, the talking aimed to engage and provoke others to do something - anything - to protest the war. An early leaflet challenged draft age men to make choices:

\section{WE WON'T GO $\rightarrow$ WILL YOU?}

Right Now

Americans are killing in Vietnam - and are being killed

What will you do about it?

Will you kill?

Will you be killed?

What can you do about it?

- silence is inexcusable

Are you going to fight, kill, and die for an unjust war?

Can you let others die?

We Won't

We Won't Go

We refuse to be silent

We, the Boston Draft Resistance Group, have signed a statement declaring our rejection of the war, and a refusal to serve in the armed forces while the Vietnam War continues. So strong a stand is necessary now. A faculty supporting statement is now in circulation. We hope to turn our individual rejection of the war into effective group opposition to it. What is your stand? Are current means of dissent effective for you in your position as a draft age man? Come discuss your views: We invite you to discuss the issues that led us to sign this statement.

Those who read the leaflet were encouraged to stop by the BDRG office to speak with one of the organizers or to come to one of the regularly planned meetings designed to provide information on the war and the draft. ${ }^{38}$

${ }^{37}$ Ferber \& Lynd, The Resistance, p. 169-1 70; "Peace Movement Strives To Reach Working Class" Harvard Summer News. 11 Jul 1967, p. 5 ; Charles S. Fisher, Midwives to History: The Boston Draft Resistance Group, unpublished manuscript, p. II16.

${ }^{38}$ Leaflet announcing 4 May 1967 meeting, Papers of Charles S. Fisher (to be deposited at Swarthmore Peace Collection). 
In May and June 1967, students at Harvard paid attention to appeals made by groups like BDRG, especially as debates over the future of the draft took place in Washington. When Congress finally voted to extend the draft in late June, they did little to change the existing system. In spite of the President's message to them and the recommendations of the Marshall Commission. Congress rejected a lottery system and dictated that the President could not institute such a change without Congressional approval. They did include language stating that graduate deferments (except for medical and dental school students) would be eliminated sometime in 1968, but set no timetable. Meanwhile, undergraduate deferments remained in tact. ${ }^{39}$ The most significant change involved the ending of marriage and fatherhood deferments for men married after 1965. Still, all of the fundamental inequalities about which there had been so much concern when Johnson appointed the Marshall Commission remained. Yet his aides urged him to sign the bill. "Congress went a long way towards meeting the recommendations in your message," Joseph Califano told the President. He calculated that by limiting graduate deferments and eliminating marriage deferments. "some 200,000 additional men will be made eligible for the draft in 1968."40

Although the system remained basically the same, the possibility of change continued to cause anxiety among many men. That one might not be able to expect continued safety when entering graduate school caused many men to seek out BDRG.

${ }^{39}$ Flynn, The Draft, p. 204-205.

${ }^{40}$ Memo to LBJ from Joseph Califano, 29 Jun 1967, Office papers of Joseph Califano, Box 55, LBJL. 
The Group often received mixed responses, however, from those who might join. As one BDRGer wrote. "almost immediately we realized the need to make a clear distinction between draft evasion and draft resistance." Doing so was necessary, he said, to avoid "misrepresentation as affluent draft dodgers whose political dissent was a function of class privilege." ${ }^{\$ 1}$ They decided. therefore. to issue a statement opposing all conscription while the war continued; but this did not clarify matters. They still lacked a plan. They still had not developed any ideas that emphasized action.

By mid-summer, BDRG started to address these shortcomings. First, the organization decided to "minimize" the act of signing the We Won't Go statement "as an end in itself," and instead sought to make signing one's name "a symbol of commitment to work actively against the war through other activities of the Group." This decision reflected a desire on the part of organizers to treat draft resistance "as a unique issue around which to organize people who opposed the war for widely divergent reasons." As one wrote, they were concerned, "to reach those who were anti-war out of self-interest as well as those who had firm moral and political conviction." There would be no application of any kind of moral litmus test because. ultimately, they aimed "to help ordinary young guys move from fear and alienation to active radical commitment." The draft, then, because it touched every young man in some way, offered the perfect opportunity to organize protest against the war and "the social and political structure which makes such wars possible." In addition, part of that goal involved trying to reach 
working class Bostonians, again with the idea that once galvanized, they would learn how to "flex their own political muscle."

As the organization experimented with strategy and new tactics, eventually there evolved a strategy of meddling with the draft. "We are unabashedly using every means possible to inhibit, retard, and be dishonest with the Selective Service System," said Ray Mungo, the outgoing editor of the $B C$ News. signer of the We Won't Go pledge, and early BDRG activist. "Our position has been philosophically anarchistic. That is, we make no moral judgements about why a kid wants out. If he wants out, we get him out the best way we can." He made it clear that the Group did not specialize in helping men obtain conscientious objector status (those who wanted it were referred to the American Friends Service Committee), and that instead "loopholes" were BDRG's specialty. "It is perfectly legal," he explained "to refuse to sign the security oath at the pre-induction physical, and you don't even have to give a reason for refusing. The army generally doesn't want anything to do with non-signers and classifies them 1-Y."43 Mungo could speak with some authority on this last point for, by then, the BDRG knew the Army well - and the Army was getting to know BDRG.

\section{The Early Morning Show and the Horror Show}

Two of the most ingenious programs developed by the Boston Draft Resistance

42 "Vietnam Summer: Project Profiles," Papers of Alex Jack; BDRG Newsletter, 1 Feb 1968, Ferber papers: Fisher, p. II-16; Bill Hunt, "Boston Draft Resistance Group," New England SDS Conference Newsletter, c. Aug 1967, Fisher papers; "Peace Movement Strives To Reach Working Class," Harvard Summer News, 11 Jul 1967, p. 5.

43 "Peace Movement Strives To Reach Working Class," Harvard Summer News, 11 Jul 1967, p. 5. 
Group came to be known as the Early Morning Show and the Horror Show. Almost every day in the suburban Boston area. a draft board would send a group of men to the Boston Army Base either for induction or for pre-induction physicals (usually done a few weeks before the call for induction). The Early Morning Show got its name from the practice of BDRG staff and volunteers who rose very early in the moming to drive out to draft boards and meet and speak with potential draftees before the bus arrived for the trip downtown. The name for the Horror Shows came from a related program in which BDRG members would pose as potential draftees and, upon entry into the induction or physical examination proceedings, create a disruption by making political speeches, questioning Army officials about the war in Vietnam, or something similar (often Horror Shows took place when a BDRGer had himself been called for a physical).

Early Morning Shows began when members of BDRG recognized that potential draftees felt most vulnerable and anxious during the time period between the preinduction physical and the induction itself. "This gives us a crucial opportunity to reach them before it is too late," they wrote. "Therefore BDRG has set up a program to hit each local board when they send in their quota." Dozens of local boards operated in the greater Boston area, making an Early :Morning Show possible on almost any weekday. Consequently, through some "forever secret" ploy, the BDRG would obtain a schedule noting when each draft board planned to send its men. Five or six staff and volunteers would arrive before the board opened. careful to park far away (after the first few episodes, the police in some towns began taking down license plate numbers). Generally, some pre-inductees would be waiting there already. A few of the BDRGers would 
approach the young men, while the others stayed behind. They learned not to appear at a local board all at once for several reasons. First, they did not want to overwhelm the men they hoped to counsel. Equally important, however, they wanted to avoid making the impression that they were an organized group; as long as the draft board clerks and bus drivers thought that the BDRGers were simply friends of the pre-inductees, the prospect of ejection from the premises remained remote.

Once there, the BDRG men and women tried to engage the potential draftees in conversations about the war and'specifically about the draft. Sometimes, if space and time allowed, one of them would make a speech. Either way, one BDRG newsletter reported, "many of these guys want to talk; a good percentage of them are already consciously against the war, and a lot more are badly confused. We tell them about deferments, exemptions, and their right to refuse the Security Questionnaire. We also hand out Draft Fact Cards with our address and phone and even make appointments for them to come in for counseling." Generally, the conversations with these men involved informing them that they had certain rights under the draft law and that they might qualify for certain deferments. If that seemed likely, the young man would be invited to stop by the BDRG office for counseling on how to make his case to his draft board. By the fall, a full complement of draft counselors staffed the BDRG office and they were supported in their work by researchers who continuously looked for "loopholes" in the Selective Service regulations. They also maintained lists of sympathetic doctors and psychiatrists who would be willing to see clients who could be candidates for physical or mental deferments. 
After conversing at the draft board, the counselors would try to board the bus for the ride into Boston. When successful, this gave them more time to talk to the preinductees. Getting on the bus could be difficult. Sometimes, the bus driver worked for a charter company and held no particular loyalty to the Selective Service; getting on these buses required little ingenuity. But frequently it required some kind of clever maneuver like those listed in a special memorandum for Early Morming Show participants:

1. Board the bus when the driver is not nearby. Often if you get on, several of the pre-inductees will follow.

2. If clerk instructs everyone to show a bus token for return trip to bus driver, show a token

3. If checking names at the bus door, get to the end of the line and try to see the list to see whose name has not been checked, and say, while pointing: 'that's my name.'

4. Sometimes you can get on using your own old papers. Tell the clerk that you're going for induction and want to ride down to induction center on the bus (because you just moved there).

Upon arrival at the Army base, BDRGers would inconspicuously leave the base and catch a regular city bus back to town. Later that afternoon, if they had collected the names of any of the pre-inductees, they would call them to see how things went and to again offer them assistance. ${ }^{+4}$

Early Morning Shows became an essential element in BDRG operations and in the Group's identity. By early February 1968, an available pool of more than 100 volunteers helped to pull off the EMS at more than 20 draft boards each month. ${ }^{+5}$ The

44 Boston Draft Resistance Group Newsletter, 1 Feb 1968, Ferber papers; “Anti Draft Organizing at Pre-Induction Physicals." undated memo, Fisher papers. II-21.

${ }^{45}$ BDRG Newsletter, March 1968, Thorne papers; Fisher, "Midwives to History," 
program continued for over two years. until the breakup of the organization in the summer of 1969. In reality, however. the proportion of men approached under such circumstances who then came to BDRG for counseling was quite small. As Tim Wright later reflected, "Mostly we were not successful. Probably half of the kids who showed up [for the bus] were openly hostile. Another third were kind of passive and maybe two or three or four in each group were openly sympathetic...those were the people we would try to work with. We would give them support numbers, of doctors and stuff and we would encourage them to come to the office afterward..." But mainly, as one BDRG staffer wrote, "the basic rationale for the 'early morning show' is to broaden the anti-war movement. Unless you get a man's name and phone number we can't see if he knows other men who need counseling or whether he or his friends will help us with anti-draft and anti-war work in his area." Thus. even the activists who participated in the Early Morning Shows had limited expectations for actually helping the men they met there to escape the draft; instead, the education and politicization of young men mattered most. ${ }^{46}$

The BDRG sought to educate and politicize in the Horror Shows, too, but they also aimed to have a little fun at the Army's expense. Whenever the Selective Service called a male BDRG member for his own pre-induction physical and whenever BDRGers could pose as potential draftees, they did everything possible to "demystify the nature of power as it affects the guys who are being forced to fight." They did this by talking to the other draftees about the war and the draft during the proceedings, and by constantly

${ }^{46}$ Tim Wright, interview with author, 25 Aug 1997; "Anti Draft Organizing at Pre-Induction Physicals," undated memo. Fisher papers. 
challenging the authority of the Army officials running the physicals. These men gained access to the base easily. Tim Wright, the veteran, in an early newsletter:

As the military-industrial complex goes, the Boston Army base is a pretty bush-league operation, considering its crucial role in the lives and deaths of the young men of Boston. Jutting out into the grim waters of Boston Bay, it's a conglomeration of warehouses, offices, recruiting and induction chambers. At ten minute intervals, a public bus leaves South Station, carrying army personnel, civilian workers, inductees, pre-inductees, and the Boston Draft Resistance Group to their appointed iasks. There is thus public access to the interior of the Base - a fact of considerable legal significance, as we have lately learned. The security (!?) guards are civilian, with what seems to be a median age of 86 , who can often be bullied and/or cajoled. So far we have allowed ourselves to be sluggishly evicted, although not without making a vivid impact on incoming draftees and passers-by. Our purpose is, in the classical formula, to instruct, to inspire, and to delight.

This kind of witty description conveyed an accurate sense of the spirit that BDRG members brought to their work. Early descriptions of Horror Shows include frequent use of adjectives like "entertaining," and "provocative." Tales of BDRG exploits made antiwar work seem fun and bred confidence in activists who might otherwise hesitate to take part in such bold confrontations. ${ }^{47}$

Horror Shows did not occur with the same frequency as Early Morning Shows. They were much more difficult to organize and to sustain. Usually, it required a few men because once one began a political speech during the physical, he would be hauled off; others were needed to carry on after the first one or two were taken out of the room. Most of the time leaflets had been distributed to all of the men in advance. As one BDRGer noted,

\footnotetext{
${ }^{47}$ BDRG Newsletter \#1, 29 Jun 1967, Fisher papers.
} 
Our leaflets and conversations convey a few very simple ideas. 1) If you're worried about going to fight in the Vietnam war, you're not alone. More and more guys are coming to feel this war isn't worth one American life. and the draft resistance movement can stop it. 2) You have legal alternatives to the draft. (Most working-class pre-inductees are absolutely ignorant about their rights under the draft -- many could legitimately qualify for physical, mental or occupational deferments, not to speak of C.O. Most workers barely know that $\mathrm{CO}$ status exists.) The BDRG will provide free counseling and legal aid in resisting the draft, and stick with you down the line. 3) We support the boys in Vietnam. We need them to build a decent society right here.

The Army confiscated such documents at first. But the BDRG soon learned that the Army could not legally take the leaflets and began each subsequent leaflet with the declaration, "This is yours to keep! The Army may not take it away from you!"

Those who participated in Horror Shows, then, did attempt to engage preinductees in serious discussions about the war and the draft - but only on a limited basis. For the most part, they tried to disrupt the Army's proceedings and to do on-the-spot education by making speeches and arguing with Army officials. By one account, the BDRG nearly took over a physical one day. "adroitly turning a menacing harangue by an army officer into a debate on the war. and calling for a straw vote on it." Forty eight out of fifty voted against the war." ${ }^{, 48}$ Occasionally, a scuffle would break out. One time, in 1968, Sergeant Brown, the man in charge of inductions and pre-induction physicals. lost his tie to a BDRG man in such an altercation. Later the tie graced the wall of a coffee house started in Cambridge by BDRG: they named the establishment "Sgt. Brown's Memorial Necktie."

As a political tactic, Horror Shows never attained even the minimal level of

${ }^{48}$ Ferber and Lynd, The Resistance. p. 172. 
effectiveness as the Early Morning Shows, though they became legendary throughout the movement and were copied in other parts of the country. Quite often, a kind of moratorium on Horror Shows would have to be instituted because the Army grew better prepared for them. After a couple of months of successful Early Morning Shows and several Horror Shows in the summer of 1967. the raids on the induction center were suspended because "the Army got very hip very quickly, and our last two or three visits ended in almost instantaneous eviction." Curiously, they were never arrested for such stunts (some speculated that the Army did not want to make martyrs out of them in a court case)..$^{49}$

As the fall of 1967 approached, the BDRG began its first real self-evaluation. At the 8 August Steering Committee meeting, members discussed group ideology and asked the "burning" question: "does the BDRG gain more effectiveness by (a) encouraging the idea that it is committed to a hard-core, direct-action, somewhat alienated brand of radicalism, or by (b) underplaying the alienation and seeking a surface alliance with more 'acceptable' anti-war groups, such as Vietnam Summer, the AFSC, etc.?" Their answer, it turned out, fell somewhere in between. BDRG continued to conduct its "direct action" programs (the Early Morning Shows and the Horror Shows), but also decided to become much more involved in community oriented draft counseling. ${ }^{50}$

\section{Draft Counseling}

While the Boston Draft Resistance Group had always been influenced in part by

${ }^{49}$ BDRG Newsletter, undated, c. August 1967, Ferber papers.

${ }^{\text {so }}$ BDRG newsletter, undated, c. August 1967, Ferber papers. 
the work of the Students for a Democratic Society, it became more so in the fall of 1967. At that time Nick Egleson, Vernon Grizzard, and John Maher joined BDRG and turned it more toward counseling and the Early Morning Shows. Egleson and Grizzard both were national SDS officers and Maher had been heavily involved with Viemam Summer. ${ }^{51}$

Their training in these organizations had stressed community organizing and they brought this perspective to the young and still malleable BDRG. It also resulted in continued emphasis on the poiiticization and radicalization of everyone with whom they came in contact. Implicitly, they offered each "client" a deal: in exchange for draft counseling the BDRG expected a personal commitment against the war.

BDRG recognized an opportunity in draft counseling because the primary provider of draft counseling in the area, the American Friends Service Committee, focused on preparing conscientious objection appeals. "The AFSC counseling course is no longer adequate for our purposes" wrote one BDRGer, "because it is non-political, not aimed specifically at the War in Vietnam and. in consequence, somewhat out of date." Consequently, BDRG quickly established its own counselor training course with the help of a couple of AFSC counselors and using all of the research that the first small group of BDRG counselors had gathered over the summer. ${ }^{52}$ Soon the new office on Columbia Avenue in Cambridge was open six days a week. staffed with dozens of volunteer counselors tending to the long lines of men seeking information on the draft.

Unlike the AFSC or the individual resisters from the Committee for Non-Violent

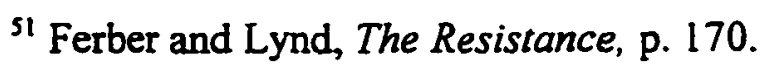

${ }^{52}$ Ferber and Lynd, The Resistance, pp. 172-173. 
Action, BDRG counselors advised men to take advantage of the system any way they could. If a counselee felt that he could not in good conscience participate with the Selective Service System at all, outright resistance became an option; but this occurred very infrequently. Instead, counselors sought to find something in the young man's life that made him eligible for a deferment. Even though popular artists like Phil Ochs had described nearly every available escape from conscription in songs like "Draft Dodger Rag," many men remained unaware of their options. Counselors, then, would lay them out as Ochs had, looking for men who were still too young ("Sarge, I'm only I8"); had physical ailments ("I got a ruptured spleen...I got eyes like a bat, my feet are flat, and my asthma's getting worse"); were homosexual ("I always carry a purse"); could get a hardship deferment ("think of my...sweetheart dear, my poor old invalid aunt"); were enrolled in college or graduate school full-time ("I'm going to school"); or were qualified for work in the national interest ("and I'm working in a defense plant"). Therefore, rather than refusing to cooperate with the draft, men who came to BDRG for help were told to overcooperate by applying for a deferment allowed by the system. In addition, local board decisions could be appealed, sometimes repeatedly, in hopes that eventually a bureaucratic error would occur; if that happened, the process could be dragged out for years and chances of such individuals being inducted became very small.

BDRG was not satisfied with simply helping individuals stay out of the service, however. From the start, BDRG counselors maintained a broader agenda. One directive issued in September 1967 cautioned counselors to "be always conscious of the total situation -- every deferment that you get for someone else, for yourself, just means that 
another ghetto cat who can't get deferments, gets drafted." It then reinforced the aim of moving as many counselees toward more radical action as possible:

Don't respect the law. Use it. Try to awaken the guy you are counseling to how the SS System works, etc. Touch, expand his consciousness.

Stay aware of the draft's relationship to the war, and that just getting people who come in for help a deferment is not doing anything to halt the war and the ever increasing militarism in the country. We must hit these guys so they don't just take their deferments and forget about the draft. We must look for ways to politicize them, to get them indignant about the draft. ${ }^{53}$

As part of this counseling philosophy, counselors took great care in providing information about the draft. "You don't tell a guy what to do, you don't make decisions for him," remarked one counselor. "Lay out the decisions open to him, but he should make the decisions. Force him to think about what he's going to do and what his choice means....the only way you'll get him to work against the war is if he's convinced it's the right thing to do." Ultimately, counselors hoped that they would not only provide useful information that would help his or her client to escape the draft but also convince them of the importance of continued action against the war and move them "toward a more radical perspective." Although it didn't happen as often as BDRG would have liked, some counselees went on to organize in their own neighborhoods, become counselors themselves, or even volunteer for Early Morning Shows. ${ }^{54}$

Counselees were not always receptive to the political 'rap' that they received

53 Thorne, "Resisting the Draft."p. 311.

${ }^{\text {s4 }}$ Fisher, "Midwives to History,"p. III-9; Thorne, "Resisting the Draft," p. 88; Ferber and Lynd, The Resistance, p. 173 
when they came for draft information, however. Most just wanted service without expectation of any further commitment on their part. Some counselors had little patience for such individuals. ${ }^{55}$ The records that the BDRG kept for each man it counseled no longer survive, but in 1973, Charles Fisher, a sociologist at Brandeis University and himself a former BDRG counselor, used more than 5,000 counselee forms to make some conclusions about these individuals. According to Fisher, despite the efforts of BDRG to reach into the working-class community, $60 \%$ of the men that they counseled were college students and, therefore, mostly middle-class. Overall, however, $50 \%$ were classified 1-A (draftable) and 35\% were 2-S (student deferment). Another sociologist and former BDRG counselor. Barrie Thorne, estimated that most of BDRG's clientele were "middle-class students who came for technical advice on how to avoid the draft." Moreover, she wrote, "at least two thirds and perhaps even 80 or 90 percent were white, middle class college students." 56

Thorne noted that draft counselors preferred to work with working-class and minority clients because of the obvious imbalance in who was drafted. These counselees were few in number, however. As a result, the most favored clients were "registrants who were similar to the counselors - white, middle-class, college-educated, and concerned about the war and the draft as political issues." Conversely, Thorne reported,

The clients whom counselors most disliked were typified by an upperclass, pampered, college senior, politically apathetic and trying to evade

s5 Thorne, "Resisting the Draft,"p. 91.

${ }^{56}$ Fisher, "Midwives to History," p. III-2l; Thome, "Resisting the Draft," pp. 85, 112. 
the draft for reasons of self-interest...they were already in a privileged relationship with the draft. so the BDRG was not furthering distributive justice by helping them to continue to evade conscription. If these clients weren't radicalized through the draft counseling process, BDRG counselors were hard-pressed to offer a political justification for giving them service. ${ }^{57}$

Harold Hector, a BDRG founder and a master counselor, hated it "when a Harvard guy would come in and want to get out, wanting to get out to spend more time at Harvard. [That] used to piss me off. I'd say, 'hey man. there are a lot of guys who don't have that student deferment, you know, who are really in trouble with going [to Vietnam], who need this counseling." "558

Counselors never imposed a plan of action on their clients. Rather, they limited themselves to providing as much information as possible about the Selective Service System and all of the legal ways to avoid being drafted. If it seemed impossible for a client to take advantage of one of the legal loopholes, then they were left with three choices: accept induction, refuse induction and go to prison, or leave the country. In examining thousands of client records, Charles Fisher found that $40 \%$ of the men counseled by BDRG tried to fail their physicals; $30 \%$ applied for conscientious objector status; only 3 to $4 \%$ considered induction refusal or leaving the country. (These figures do not add up to $100 \%$; the choices made by the remaining men are unclear. Many, no doubt, attempted to fail the mental examinations, acted crazy, or claimed to be

57 Thorne, "Resisting the Draft," pp. 299-300.

${ }^{58}$ Harold Hector, interview with author, 9 Apr 1997. 
homosexual - all of which could get one disqualified). ${ }^{59}$ Ultimately, however, as one BDRG counselor noted, the course of action taken by an individual client on his own draft case did not matter as much as his outlook, "as whether or not he was strongly opposed to the Vietnam War and could be mobilized for radical political activity." Measuring the success of moving young men to such levels of activism proved difficult. No one knew what most counselees did after they left the BDRG office. Certainly, few started their own neighborhood anti-draft programs and most were not heard from again. As a result, there began to develop among some BDRGers a sense that the counseling and Early Morning Shows were too tame. On the one hand, organizers could claim that, even in that first summer of operation, they had "been able to expose the draft as merely the more conspicuous symptom of a broader pattern of corporate manipulation. In doing so, we help to transform alienation and fear into conscious political radicalism." On the other hand, to a large extent BDRG continued to play by rules set by the Selective Service and did so in an almost unnoticed fashion. Very few of their actions received significant press coverage (as the draft card burnings of 1966 had) and any sense that they were making progress was difficult to gauge. Furthermore, the moral and ethical challenges pushed by the CNVA the year before seemed to get lost in BDRG's willingness to work the system to its advantage. As the war raged on, some men began to resurrect the idea of total non-compliance as another complementary response. Michael Ferber and Staughton Lynd noted that "a means had yet to be found that would

${ }^{59}$ Fisher, "Midwives to History," p. III-22.

${ }^{60}$ Thorne, "Resisting the Draft," p. 88 
tie together in one political process the hundreds of signers of We Won't Go statements and the bold tactics of the draft card burners." A new strategy was needed. one that would openly confront the government on a massive scale. As summer slipped into fall. momentum quickly gathered for what would become the driving force of Boston's antiwar movement. ${ }^{61}$

${ }^{61}$ New England SDS Conference newsletter, Fisher papers; Ferber and Lynd, p. 65. 


\section{CHAPTER III}

\section{OCTOBER 16!: "A RESOLUTE SHOW OF MORAL FORCE”}

If any man would come after me, let him deny himself, and take up his cross, and follow me. For whosoever would save his life shall lose it; and whosoever shall lose his life for my sake shall find it. For what shall a man be profited, if he shall-gain the whole world, and forfeit his soul? Or what shall a man give in exchange for his soul?

Matthew 16: 24-26

As the Boston Draft Resistance Group refined their draft counseling and draft meddling tactics, plans for an ambitious national confrontation with the Selective Service originated in California and began to move east. On April 15,1967, the same day that the We Won't Go advertisement ran in the Harvard Crimson, former Stanford University student body president David Harris announced the formation of an organization called The Resistance to a capacity crowd assembled for the National Mobilization in San Francisco's Kezar Stadium. From the stage, Harris, who had returned his draft card to his local board the previous August and pledged total noncompliance with the Selective Service, told the crowd that the war in Vietnam was "a logical extension of the way America has chosen to live." He called on the draft age men in the crowd to join him on

October 16 when men in cities across the country would sever their ties to the Selective

Service by returning their draft cards to the government:

As young people facing that war, as people who are confronted with the choice of being in that war or not, we have an obligation to speak to this country, and that statement has to be made this way: that this war will not be made in our names, that this war will not be made with our hands, that we will not carry the rifles to butcher the Vietnamese people, and that the prisons of the United States will be full of young people who 
will not honor the orders of murder.'

As he spoke, Harris himself expected to receive his own induction notice at any time. He had already appeared at the induction center in his hometown of Fresno for his preinduction physical. But, as he told the crowd, he planned to refuse induction and accept a prison sentence instead.

David Harris and several friends with whom he lived in a sort of commune in Palo Alto arrived at their personal decisions to resist the draft after many months of discussion in 1966. One of these men, Dennis Sweeney, an experienced activist who had worked with the Student Nonviolent Coordinating Committee in Mississippi, remembered their discussions about noncompliance beginning in the spring of 1966 when Robert McNamara commented on the army as one of the best tools for educating the poor and minorities. "It became obvious," Sweeney noted, "that it was pointless to say you 'won't go' if you weren't being asked to."' But he also knew it would be pointless to refuse induction if only a few people did it. "I was sure I was going to do it but I was sure I wasn't going to do it by myself," he said, "because I believed that to have an impact, to have some kind of political effect, it had to be a number of people doing it together."

' David Harris, Dreams Die Hard: Three Men's Journey Through the Sixties (New York: St. Martin's, 1982), p. 181.

${ }^{2}$ Michael Ferber and Staughton Lynd, The Resistance (Boston: Beacon, 1971) p. 81. Ferber and Lynd quote Sweeney as citing McNamara's comments on the poor and minorities in a speech in Montreal (May 1966), though the text of that speech did not include any such reference. Such a comments, however, would be consistent with McNamara's views on Project 100,000 (see Chapter 2). See "The Text of Address by McNamara to American Society of Newspaper Editors," New York Times, 19 May 1966, p. 11. 
Although the timing did not seem right in 1966, David Harris went ahead and returned his card anyway.

Early in March 1967, Harris and Sweeney met Lennie Heller and Steve Hamilton from Berkeley. Heller and Hamilton had independently arrived at the same idea for a draft resistance movement as Harris and the others in Palo Alto. In fact, they carried leaflets that they had produced which bore the name of their budding organization: The Resistance. The name had important historical antecedents. First, it most obviously referred to resistance to Nazi occupation in Europe during the Second World War. The reference to fascism was deliberate: Heller and Hamilton feared that the Vietnam War might lead to the dawn of an American style of fascism designed in part to crush dissent. Bettina Aptheker, another activist at Berkeley, later recalled that "when you said the word resistance [in 1967], it was with a capital $R$, and you meant the resistance to fascism in Europe...People had a sense of very great repression in this country...like fascism was creeping in on us from a lot of different directions." General Hershey's channeling memo and the obvious inequities in the draft only fueled this perception. Second, in the early sixties, French students used the term "Young Resistance" to describe their protest of their country's colonial war in Algeria. This group included several thousand men who refused induction into the French army. The American resisters saw clearly the parallels between the French students' outrage over the Algerian war and their own anger over Vietnam. $^{3}$

${ }^{3}$ Harris, Dreams Die Hard, pp. 175-176; Ferber \& Lynd, pp.2-3, 88-90; Tom Wells, The War Within: America's Battle Over Vietnam (Berkeley: University of California Press, 1994), p. 125. 
In California, the Resistance distributed its first leaflet in early April, prior to the

Mobilization, and in it they articulated the basis for recruiting more members:

We will renounce all deferments and refuse to cooperate with the draft in any manner, at any level...The war in Vietnam is criminal and we must act together, at great individual risk, to stop it. Those involved must lead the American people, by their example, to understand the enormity of what their government is doing... To cooperate with conscription is to perpetuate its existence, without which the government could not wage war. We have chosen to openly defy the draft and confront the government and its war directly.

This is no small decision in a person's life. Each one realizes that refusing to cooperate with Selective Service may mean prison....To do anything but this is to effectively abet the war... We prefer to resist. ${ }^{4}$

With such rhetoric, the Resistance raised the standards for antiwar protest. To keep a student deferment while protesting the war, to flee to Canada, to seek conscientious objector status, to intentionally try to fail a physical, or even to counsel a potential draftee to do any of these things was "to effectively abet the war." As another early leaflet argued, "the American military system depends upon students, those opposed to war, and those with anti-Vietnam war politics wrangling for the respective deferments. Those opposed to the war are dealt with quietly, individually and on the government's terms." The draft, they suggested, used deferments as built-in safety valves to disarm dissenters. A genuinely universal draft. as writer Michael Walzer noted, "would almost certainly be a major restraint upon peacetime warmaking, if only because it would mean that the sons of politically articulate and effective classes would die in greater numbers, though for no more significant purposes." Or, as Staughton Lynd pointed out in April

${ }^{4}$ Harris, Dreams Die Hard, p. 176.

${ }^{5}$ Ferber \& Lynd, p. 90. 
1967, if there were not student deferments, "a little arithmetic makes clear the immense and sobering fact that...100,000 men would refuse to go and the war would end." Thus, by refusing to be pigeonholed into one of those safety valves, the members of the Resistance sought confrontation, the kind of confrontation the government would find uncomfortable. ${ }^{6}$

Resistance organizers, then, not only argued for draft resistance as a matter of conscience, but as a strategic breakthrough, too. The prospect of thousands of middleclass men being marched off to prison for failure to carry their draft cards would bring terrible publicity to the government and enrage countless other Americans. They anticipated a ripple-effect for every resister in which more and more people (family, friends - and then their family and friends, etc.) would learn of his plight as he went through each stage of resistance; by the time the government sent him to prison, dozens of people would have turned against the war. Furthermore, organizers believed that if they mobilized ten to twenty thousand draft resisters, it would be sufficient to swamp the relatively small federal court and penitentiary systems. Draft resistance, therefore, combined an act of moral witness with a new practical approach to ending the war. And it appealed to a lot of people who opposed the war and felt guilty about their privileged place in the Selective Service System.

Over the next year, draft resistance became the driving force of Boston's antiwar movement. On October 16, Resistance leaders collected more cards in Boston than in

${ }^{6}$ Michael Walzer, "Democracy and the Conscript," Dissent, Jan/Feb 1966, p. 16; Staughton Lynd, essay, Liberation, April 1967. 
any other city in the country, save San Francisco. This chapter outlines the intellectual origins of draft resistance strategy, and charts the rapid rise of the movement in Boston. The men and women who organized Boston's October 16 draft card turn-in - most of whom were Vietnam Summer and BDRG veterans - had been protesting the war in Vietnam for more than a year, but in the summer and fall of 1967 , they grew impatient. In spite of their letters to Congress and their participation in teach-ins, marches, and other demonstrations, the war ground on unabated. The time had come, they decided, for more radical action. By returning their draft cards to the government, those who chose to become draft resisters raised the stakes for themselves as opponents of the war, and placed the administration in the uneasy position of having to consider the prosecution of almost 1,000 young men nationwide.

Within the broader New Left, draft resistance generated considerable controversy. Consequently, this chapter also navigates the ideological debates between proponents of draft resistance and their critics in SDS and other organizations. Like a child striking out on her own for the first time, the Resistance owed much of its view of the world to its ideological parents in the New Left; at the same time, however, an interesting amalgam of anarchist, existentialist, and especially religious thought distinguished the New England Resistance, in particular, from other New Left organizations. Most significant, despite SDS accusations of "bourgeois moralism," Resistance faith in building a mass movement of mostly middle-class students (as opposed to leading the poor and working-class to revolution) complicated what it meant to be a New Leftist. Resistance organizers sought only to end the war - not foment revolution - and supposed that if thousands of articulate, 
educated, middle-class young men confronted their government through a series of somber draft card turn-ins, and began filling the courts and prisons, they could apply enormous public pressure on the Johnson administration to withdraw from Vietnam. If they had any doubts about this approach, they were erased by the success of October 16 .

\section{Seeds of Resistance}

The rise of the Resistance took place as the public's views of the war started to turn against the Johnson administration. A Gallup Poll taken in the middle of the summer for the first time showed the majority of Americans (52\%) disapproving of "the way President Johnson is handling the situation in Vietnam."7 For years the White House and Pentagon had been able to claim that despite protests, the majority of Americans supported their actions in Southeast Asia. But now those days were gone, and the timing for large scale draft resistance could not have been better.

In Boston, however, the Resistance did not at first find a receptive audience. Lennie Heller, to whom the task of organizing draft resistance efforts east of California had been assigned, arrived there in the late spring, shortly after the publication of the Harvard We Won't Go statement and the formation of the Boston Draft Resistance Group. The men and women behind those efforts had little time between Early Morning Shows and Horror Shows to consider further dramatic action. Moreover, it was not at all clear that they would not be rounded up and arrested for their current activities, so to contemplate upping the ante at such an early stage seemed premature. In the late spring

${ }^{7}$ George H. Gallup, The Gallup Poll: Public Opinion, 1935-1971, Vol. III (New York: Random House, 1972), p. 2074. 
and early summer, few besides Robert Talmanson seemed interested in turning in draft cards. Talmanson had burned his draft card in Post Office Square in April 1966 to demonstrate his solidarity with the CNVA men and women who were beaten in South Boston; in June 1967, the government convicted him for failing to report for induction and sentenced him to three years in prison. Although he responded positively to Heller's plan for a national draft card turn-in, by the end of the summer, despite setting up shop in BDRG's office, he had compiled only a short list of names of Boston men who were interested in October $16^{8}$

In September the situation changed dramatically. The concentration of colleges and universities in Boston were full of potential activists and it took only a few to spark a movement. In previous months, several graduate students, all experienced organizers, gravitated independently toward resistance. Alex Jack, a seminarian at the Boston University School of Theology, had been active with BDRG and Vietnam Summer. Before that, as an undergraduate at Oberlin College, he had twice gone to Mississippi (where he narrowly escaped death at the hands of segregationists) and spent a week in Selma, Alabama doing civil rights work. He also had been editor of the school newspaper, a job that led to three months of reporting from South Vietnam early in 1967 where he wrote two to three articles a week for 25 to 30 school and small town newspapers. There he met the American ambassador, Henry Cabot Lodge, and flew with American forces on combat missions. But he also became close to the Buddhists and interviewed the Zen master, Thich Tri Quang, who profoundly influenced his own life

\footnotetext{
${ }^{8}$ Ferber \& Lynd, pp. 104-105.
} 
because Quang was so "completely calm and clear" about the war. Equally important, Jack also managed to visit hidden hospital wards where he saw children who had been burned in American napalm attacks and were kept away from the mainstream press. Such experiences affected him deeply. ${ }^{9}$

Over the summer, Alex Jack's father, Homer Jack (then social action director of the Unitarian Universalist Association and former head of SANE - the Committee for a Sane Nuclear Policy) introduced Alex to Michael Ferber, a Harvard graduate student in English. Like Jack, Ferber grew up in the Unitarian church. As a high school student in Buffalo, New York, he had peppered his representatives in Congress with letters protesting nuclear testing and participated in a march across the Peace Bridge to Canada on Hiroshima Day in 1959. Later, as a student at Swarthmore College, Ferber got involved in civil rights work in nearby Chester, Pennsylvania. His first arrest came as he participated in protests at the city hall there calling for better funding of schools in black neighborhoods. After graduating summa cum laude with a degree in Greek, he went on to Harvard in 1966. During his first semester, Ferber participated in the blocking of Robert McNamara's car and other antiwar activity. In 1967, he took part in Vietnam Summer, worked a little with BDRG, and moved toward resistance. ${ }^{10}$

Sometime in late August, during a demonstration at the Boston Army Base, Ferber introduced Alex Jack to Bill Dowling, another Harvard graduate student in English. Dowling and Ferber had discussed noncompliance several times over the

\footnotetext{
${ }^{9}$ Alex Jack, interview with author, 21 Mar 1997; Ferber \& Lynd, p. 106.

${ }^{10}$ Michael Ferber, interview with author, 10 Feb 1997; Ferber \& Lynd, p. 105.
} 
summer, though Dowling, like Alex Jack, was more committed to the idea. Ferber took a more gradual path to resistance. Earlier in the year, feeling guilty about his student deferment, he wrote to his draft board and told him that he should be categorized as a conscientious objector. "I was about as close to a pacifist as I could be without having really been put to the test," he later remarked. But since the Selective Service did not recognize Unitarianism as a denomination with the kind of pacifist tradition of, say, the Quakers or the Mennonites, they rejected his claim and reclassified him 1-A. By the end of the summer, he remembered, "I got more and more kind of sick of it and felt guilty for even trying to be a CO. On the one hand I wanted to get the claim so I could have it as a fall-back position, but on the other hand, I began to feel bad for even trying to get it. I was quite torn." So when Alex Jack and Bill Dowling started talking resistance, Ferber grew more interested."

Soon the three attracted others to help organize for October 16. Alex Jack recruited Nan Stone, a young Methodist minister then also attending the School of Theology at Boston University, to help organize as well. Although she could not be drafted, Stone, who grew up in a conservative farm family in Iowa, had a long history of social activism and had been outspoken in her opposition to the war. Over the next two years, despite her "continual struggle" with the male organizers for equal participation in strategic decisions, Stone became the backbone of day-to-day operations of the New England Resistance. In addition, Bill Dowling rounded up three former schoolmates from his undergraduate days at Dartmouth: Neil Robertson, Steve Pailet, and Ric Bogel.

"Ferber interview, 10 Feb 1997; Ferber \& Lynd, pp. 105-107. 
Bogel had gone on to graduate school in the English department at Yale and, thus became the point man in New Haven (hence the name New England Resistance). Robertson, who had dropped out of Dartmouth, came to Boston to study jazz drumming under the legendary Alan Dawson, and Pailet, Robertson's best friend and also a superb musician. soon followed. ${ }^{2}$ Bill Hunt of the BDRG also joined the effort. Within weeks this small group of activists, almost all of whom were 22 to 24 years old and enrolled in graduate school, planned the largest - and most dramatic - antiwar demonstration Boston had ever seen.

\section{Intellectual Roots and Debates on the Left}

The New England Resistance, and indeed the national Resistance effort, differed from other New Left, student, and antiwar organizations in its unusually complex intellectual grounding. Although the Resistance owed much to the early ideals of the New Left, the draft resistance movement in Boston, in particular, derived its theoretical underpinnings from a blend of existentialism, anarchism. nonviolence, and especially religion. In some ways, this mix of influences made the movement appealing to certain people, but it also led to very public disagreements with other influential New Left and antiwar organizations.

Existentialism most obviously influenced Resistance organizers on the west coast who seemed to adopt the trappings of modern day existential cowboys. They wore their hair long, rode motorcycles, and read Kierkegaard, Sartre, and Nietzsche. As Bill Hunt

${ }^{12}$ Nan Stone, interview with author, 28 Mar 1997; Neil Robertson, interview with author, 24 Aug 1997; Neil Robertson, interview with author, 22 Dec 1997; Ferber \& Lynd, p. 107. 
recalled, "there was a real kind of Western, gun-slinger, macho style" to the Bay Area resisters. ${ }^{13}$ It was very glamorous. The New England Resistance lacked that flair but still showed similar influences. Literature promoting October 16 often included one quote or another from Albert Camus. For example, a campus newspaper ad for October 16 used the following Camus quote as an epigraph:

Whether these men will arise or not I do not know. It is probable that most of them are even now thinking things over, and that is good. But one thing is sure: their efforts will be effective only to the degree they have the courage to give up, for the present, some of their dreams, so as to grasp more firmly the essential point on which our very lives depend. Once there, it will perhaps turn out to be necessary, before they are done, to raise their voices. ${ }^{14}$

In addition, as Michael Ferber later noted, existentialism inspired in many resisters a sense for the "unexpectedness and absurdity of life, the contingency of life, and the importance of living life with passion." These were vague concepts, but they inspired some in the educated leadership ring of the Resistance to plunge into certain causes without worrying about the probability of success. "It sort of discouraged waiting until you got a whole correct theory," Ferber concluded. ${ }^{\text {Is }}$

Most important, however, draft resistance philosophy in Boston distinguished itself as a merger of religious and political belief; the group reflected their own geographical ties in being, as one said, much more "Unitarian and transcendentalist" in its

${ }^{13}$ Ferber and Lynd, pp. 82-86; Hunt interview, 31 Oct 1997.

14 Advertisement for October 16 draft card turn-in, BU News, 11 Oct 1967, p. 5.

15 Ferber interview, 21 Apr 1998. 
philosophical grounding. ${ }^{16}$ The influence of the two organizers from the BU School of Theology ( Jack and Stone) and lifelong Unitarian (Ferber) set the group apart from the more typical New Left strain of Resistance chapters popping up all over the country. Alex Jack, in particular, pushed the organization in this direction. In his efforts to reach out to clergy and laity in the weeks leading up to October 16 , he produced his own newsletter which, on behalf of the Resistance, first articulated a strategy of not simply undermining the draft, but of building a community of religious people who would continue to work to reshape America into a more compassionate society. In his call to clergy and laity, he wrote:

The Resistance is conceived as a first step in building a mass movement that can aspire to win the respect of young people and their active support. It will be several months probably before any arrests are made. During this interval, we will organize other waves of young men to non-cooperate. First 3000 , then 10,000 , then 30,000 , then 100,000 . We will make the government either end the war, or fill the jails. The major objective, however, is not prison. Rather it is to stop serving the system of conscription, without whose smooth functioning the war in Vietnam could not be waged. Prison is the price we may have to pay for effective resistance... We must be willing at least to live (however restrictedly in jail for a few years) for our supreme convictions. Prison is not the end of our activities. Both in jail and afterwards, we will create a community of men to transform the society into a fully human one. We choose to stay and struggle for the kind of America we believe in.

He concluded by quoting the great Jewish theologian, Martin Buber, who, when asked why protests against social injustice so often failed, responded, "They are only addressed to other people and do not involve any personal commitment." Through draft resistance, Alex Jack argued, clergy and laity could demonstrate their personal commitment, end

${ }^{16}$ Hunt interview, 31 Oct 1997. 
American involvement in Vietnam and, simultaneously, begin to transform America itself. $^{17}$

Jack's focus on personal commitment resulted not only from his own religious upbringing, but from his experience in Vietnam earlier in the year. He returned from Vietnam believing that the "thousands of burned villages and Vietnamese deaths" caused by American forces constituted "no less a crime against humanity than Nazi genocide of the Jews." He likened the napalm and phosphorus burning of Vietnamese civilians to the use of German death camp ovens in World War II. Jack told of seeing Vietnamese hamlets "encircled, their inhabitants massacred, and the remains bulldozed over by US Marines," thus paralleling the 1942 Nazi destruction of Lidice, Czechoslovakia where German forces killed the town's entire male population, shipped women and children to concentration camps, and burned the town to the ground. Michael Ferber would later describe Alex Jack as "modest and quiet in his behavior, almost inscrutable in his oriental calm." That kind of personality, combined with his experience in Vietnam, made him that much more persuasive when he appealed to fellow seminarians by saying, "we must now act, as well as speak."18

The religious foundation of the New England Resistance also fostered a continued commitment to Gandhian teachings of nonviolence among the organization's founders.

17 "A Call for Boston Clergy and Laity to Support Draft Resistors," undated (c. late Sep 1967), MKFP.

18 "Seminarian Refuses Ministerial (4-D) Exemption," press release included with "A Call for Boston Clergy and Laity to Support Draft Resistors," undated (c. late Sep 1967), MKFP. 
Although, by 1967, many in the civil rights movement had begun to move toward the more radical Black Power perspective and away from nonviolence, the Resistance remained confident in the potential for nonviolent protest to end a violent war. The organizers' strong belief in this strategy evolved in part from their own experiences as activists in the civil rights movement and their reverence for Martin Luther King and his commitment to nonviolence; at least a few of them had attended the 1963 March on Washington, and heard King's "I Have a Dream" speech. In addition, Alex Jack's father, Homer Jack, knew King quite well and had, himself, published a widely-read edition of Gandhi's writings. ${ }^{19}$ So, although they recognized that they might be attacked physically attacked - for resisting the draft, there was never any question that the movement had to remain nonviolent.

In addition to the existential and religious influences on Resistance philosophy and strategy, the organization reflected a unique blend of political ideologies. For example, some organizers possessed an uncommon affinity for anarchist theorists of the late Nineteenth and early Twentieth Centuries. They preferred the arguments of Mikhail Bakunin, for example, over those of Karl Marx, and were well aware of the critiques of the Russian Revolution made by Peter Kropotkin, Rosa Luxemburg, and the American anarchist Emma Goldman. And the anarchist spirit also served as a way to make the serious work of confronting the government fun. Dan Tilton, a 28 year-old Coast Guard veteran and constant presence in the New England Resistance office after October 16, 1956).

${ }^{19}$ Homer Jack, The Gandhi Reader (Bloomington: Indiana University Press, 
successfully encouraged a number of his Resistance colleagues to form a chapter of the anarcho-syndicalist organization, the Industrial Workers of the World. Although the government all but crushed the IWW in the early 1920s, the Resistance felt an historical connection. Organizers liked the Wobblies' "willingness to do anything to make their point," Tilton later reflected. "It was a fun link to the past."20

Resistance founders also were influenced by the original Port Huron-era SDS anarchist spirit. SDS's call for participatory democracy - that is, for all citizens to participate in making decisions that affect their lives - illuminated a distrust of centralized government that derived from anarchist principles. Indeed, what made the New Left new was, in part, its recognition that the Soviet model was a betrayal of Marxist ideals. In general, then, the New England Resistance rejected any kind of concentrated power, and, instead, hoped to build a broad-based draft resistance movement, one that operated from the grass-roots, and did not turn on the whims of a small core of leaders. Organizational decisions were made at meetings not by majority vote, but by consensus, thus making the meetings more democratic but also notoriously long.

Finally, like other New Left organizations, the New England Resistance showed the influence of Frankfurt School social theorist Herbert Marcuse, who until 1965, had taught at nearby Brandeis University. Marcuse's writings, especially One-Dimensional Man, Essay on Liberation, and Negations, urged his readers to "negate" the totallyadministered world, to overcome the ideological waves of the establishment, and to assert 1997.

${ }^{20}$ Ferber interview, 21 Apr. 1998; Dan Tilton, interview with author, 16 Jun 
their individuality in the face of the technologized status quo. Most important for the student generation of the 1960 s, Marcuse saw in the civil rights movement and the Berkeley Free Speech Movement of 1964 reasons to believe that young people (as opposed to, say, the proletariat) might be the ones to lead the revolution against onedimensional society in America. As Marcuse scholar Douglas Kellner has noted, OneDimensional Man showed that the problems confronting radicals in the 1960 s "were not simply the Vietnam War, racism or inequality, but the system itself."21 Resistance founders recognized this, and saw the Selective Service, with its channeling strategy, as one of the most hideous examples of the one-dimensional "system" at work. They did not need Marcuse to confer legitimacy on their planned confrontation with the government - after all, students across the country had been leading social movements throughout the decade - but his ideas were important to shaping the way they viewed their society, their government, and the Vietnam War. ${ }^{22}$

Although the Resistance shared these ideological influences with other New Left and antiwar groups, not everyone in those larger movements agreed on the efficacy of draft resistance. Within national and local antiwar organizations the Resistance endured considerable criticism in the early days. The Boston Draft Resistance Group, for instance, remained aloof until just days before the planned action. Even though the words “draft resistance" made up half of the organization's name, the BDRG's attitude toward

21 Douglas Kellner, "Introduction to the Second Edition," in Herbert Marcuse, One-Dimensional Man, $2^{\text {nd }}$ ed., (Boston: Beacon Press, 1991), p. xxxv.

22 Ferber interview, 21 Apr. 1998. 
complete noncompliance with the Selective Service made it clear that "resistance" meant different things to different people. In their first newsletter of the summer, BDRG described noncompliance as an act of "foolish bravado" and although they admitted that draft resistance represented "a serious intensification of anti-war activity" they feared that it presented just as many "new pitfalls" as opportunities. ${ }^{23}$

An August newsletter seemed to indicate that the BDRG had become sarcastic in expressing its doubts about the value of resistance. "The Resistance," they wrote, "has so far announced its presence in Boston only by the somewhat cryptic 'October 16' button worn by a few BDRG members. (Too cryptic, maybe: Resistance people have been finding out that the button is mostly a good way to meet passers-by with birthdays in midOctober)..." They went on to point out that in some cities, the Resistance had become the "major focus of anti-draft activity." but that in Boston it remained "only an unofficial project of the BDRG." Such a portrayal implies a kind of turf war between the two groups, yet the rest of the newsletter's description of the Resistance made it clear that the real source of contempt arose from a disagreement over tactics:

Simplicity of concept makes the Resistance...the most obvious target for the curious cynicism which is just now inseparable from radical protest as a whole. It might be called the phenomenon of the fullyrationalized II-S [student deferment]: a classification which is still, on the group discussion level, a moral blight, but which seems to be viewed functionally as a great radical labor-saving device ('If I'm safe, I can use my time better to fight the war...'). The October 16 protestor will have to withstand, right up to the last moment, the argument that he is set on an act of useless martyrdom. The task of locating and enlisting those people committed to radical protest at great personal risk is the major job that lies CSFP).

${ }^{23}$ BDRG Newsletter \#1, 29 Jun 1967, p. 1, Papers of Charles S. Fisher (hereafter, 
before the Resistance in the weeks ahead. But beyond this, there is the problem of creating a unity of purpose and belief which is the only final answer to cynicism and doubt. ${ }^{24}$

The BDRG, therefore, grudgingly continued to accept student deferments, and steadfastly kept its focus on trying to organize the working class and the inner cities through community outreach. Unlike the Resistance, they professed no interest in mobilizing the middle-class either in the suburbs or on Boston area campuses.

The Boston Draft Resistance Group's adherence to community organizing mirrored that of Students for a Democratic Society, who were then also busy debating the pros and cons of draft resistance in their weekly national newspaper, New Left Notes. In late June, Mark Kleiman wrote that "The prospect of putting 200 to 500 of our people in jail for such a long time in such a reckless fashion concerns me. I have no desire to expend either the organizational or human resources required in such an action. We are not the Wobblies - we cannot fill the jails." Although Kleiman acknowledged the value of the Resistance's "militant national action," he urged its expansion into other anti-draft activity. The following month, the issue of resistance came up at the national SDS convention. Discussion resulted in a new resolution which stated that "a draft resistance program must move beyond individual protest to collective action." That said, the resolution reaffirmed SDS's call for "the formation of draft-resistance unions" and argued that Resistance-like tactics "such as civil disobedience and disruption of the Selective Service System are among those advocated" but only "when they complement the overall strategy of resistance to the draft and to other forms of oppression." Just what SDS

${ }^{24}$ BDRG Newsletter, undated (c. August 1967), MKFP. 
meant by an "overall strategy of resistance" was not clear, however. And although the resolution clearly stated that "SDS does not urge going to jail as a means of resisting the draft," it persisted in its ambiguity by expressing support for "all those whose actions result in imprisonment." 25

In the weeks leading up to October 16, though, criticism from SDS grew more strident. Steve Hamilton, one of the original Berkeley founders of the Resistance, broke ranks and wrote a blistering column in .Vew Left Notes, in which he condemned what he saw as middle-class elitism at work in the Resistance: "I don't think moral witness on our part can have any concrete effect on those who cannot afford to make a moral witness...no revolution is built on bad consciences but on the organizations of those who are exploited. Middle-class tears and money mean very little." Instead, he called on those who had "the perspective of being political organizers" to "get off the campus and do draft resistance work... in communities, on high school and junior college campuses." As Hamilton saw it, the goal of the Resistance had shifted from political organization to "public effect," and consequently the "primary mistake" of such an approach lay in "building a movement that hoped to stir one more wave of middle-class liberal sentiment against the war and American militarism" in lieu of crganizing "those who can make revolutionary change - black, poor white and working-class people."26

Locally, SDS leaders agreed with both Kleiman and Hamilton. Steve Shalom of

${ }^{25}$ Mark Kleiman, "Resistance and Non-Cooperation," New Left Notes, 26 Jun 1967, p. 8; "Draft and Resistance," New Left Notes, 16 Jul 1967, pp. 4-5.

${ }^{26}$ Steve Hamilton, “October 16...A Moral Witness?," New Left Notes, 2 Oct 1967, p. 3. 
MIT SDS: :Whether we get out [of the draft] with...bizarre behavior [at a pre-induction physical] or whether we get out by a student deferment or whether we get out by going to jail, a Cambridge working class kid - that slot is still made available for him." So, for SDS, the goal became "how can we best bring the war to an end so that Cambridge kid's not going to have to go? And a lot us thought that probably the best way was not to be in jail, but to be out organizing... it wasn't an easy decision, because we realized...the moral conflict of interest that not going to jail was also very personally pleasing." But the overriding concerns involved organizing not the middle class, but the working class, and staying out of jail to do so. ${ }^{27}$

Hamilton's and Shalom's argument against widespread draft resistance by middleclass college students reflected an Old Left kind of faith in the working-class that remained strong in SDS. Just a few years earlier, from 1963 to 1965 , the organization had focused much of its attention on an Economic Research and Action Program intended to galvanize the poor and working-class in northern cities to see their potential political power, much like the civil rights movement had done in the South. In the fall of 1967, although many in SDS, faced with persistent inequality between the races and the ongoing escalation of war in Vietnam, began to swerve away from a more moderate Leftliberalism toward Marxism-Leninism, that emphasis on mobilizing the masses in their neighborhoods toward some kind of leftist revolution remained prominent.

The key difference between SDS and the Resistance, then, arose from an issue of ultimate objectives. Whereas Steve Hamilton and others in SDS urged continued

\footnotetext{
27 Steve Shalom, interview with author, 18 May 1997.
} 
appeals to the poor and working-class as a way to create "revolutionary change," the Resistance sought more specifically to end the war. Although Resistance founders in Boston and elsewhere held out some hope of attracting working-class men to their movement, making the mobilization of large numbers of poor and working-class men to revolution the primary objective of an antiwar movement seemed an unnecessary distraction away from their primary goal of stopping the war. While the Resistance sought to instigate an uprising against the Selective Service, it harbored no illusions about creating a revolution against the government.

The New England Resistance organizers, therefore, found the arguments of SDS and BDRG unpersuasive. The notion of keeping oneself out of jail to continue one's antiwar work sounded, as Bill Hunt (one of the few BDRG - NER crossovers) put it, "a little bit like you're saving yourself for the junior prom." As he later recalled, the question came down to an individual's view of politics, history, and morality:

Who the fuck are we, frankly?...I mean, if you really see yourself building a conspiratorial network that's eventually going to overthrow the world (and this is what Lenin would, of course, have done...Lenin was quite unscrupulous about protecting his own butt, because he figured he was Lenin), [that is one thing]. But if you didn't view yourself like that...and didn't really support that notion of social change, then it seemed to us that our power to go to jail was probably the best weapon that we had in a sense that it was going to be embarrassing [for the government] to do that. We were educated, we were articulate, we could make good speeches in the courtroom... We might be nuts, but we were clearly not selfinterested here - that could come across.... There's not all that much that a 21, 23 year old, even Harvard graduate could do directly except stand up and put the government in a situation in which [they] either had to start locking up fair numbers of people or it would spread...28

${ }^{28}$ Hunt interview, 31 Oct 1997. 
Thus. proponents of resistance recognized that, for the most part, they came from positions of relative privilege that were tied to their middle class upbringing. In acknowledging their class status, they hoped to preempt charges of elitism and, in turn, use it to their advantage in garnering big headlines. As they told the media. "we will not be bought off with draft deferments and exemptions that keep most of us who are white, middle-class, and educated free and alive, while blacks, poor people, and working-class people who could not afford an education are sent to the war and die."29

Ironically, the Johnson administration's decision to maintain student deferments gave Resistance leaders reason to be confident. According to James Reston of the New York Times, the administration chose to continue the 2-S deferment because they estimated that without it, one out of every four male undergraduates might refuse induction. Knowing that the White House feared such a development and had taken positive action to try to prevent it, the Resistance sought to make it happen anyway. Citations from Reston's article appeared in the New England Resistance's first newsletter along with a widely quoted piece written by Tom Wicker in May 1967 in reaction to heavyweight boxing champion Muhammad Ali's induction refusal. Wicker wondered what would happen if "enough citizens simply refuse to obey the positive commands of government and of the national majority...if only, say, 100,000 young men flatly refused to serve in the armed forces?" The result, he theorized, would be that the government's "real power to pursue the Vietnamese war or any other policy would be crippled if not

29 "The Resistance Begins in Boston," Press Release, MKFP; Eventually, Harvard SDS reluctantly endorsed the Resistance - but only after Michael Ferber attended three of their meetings seeking help, Ferber \& Lynd, p. 109. 
destroyed. It would then be faced not with dissent but with civil disobedience on a scale amounting to revolt. ${ }^{30}$

Crippling the government's ability to prosecute the war became the primary objective of the New England Resistance and other Resistance chapters around the country. No one expected to get 100,000 men to pledge refusal on October 16 , and even if they thought they could, Resistance organizers were not so naive as to believe that the military could not go on without those 100,000 men. Too many acquiescent conscripts prevented that. Still, the scale of dissent was important. Thousands of middle class college students breaking the Selective Service laws would cause an uproar not only in Washington but in suburbs across the country. The administration would have to react. And when they did, the resisters believed that the resulting confrontation would shatter public support for the war, once and for all. America would have to get out of Vietnam.

\section{Planning October 16}

At first, the New England Resistance went to work trying to mobilize campuses across the region for October 16 . The numerous colleges and universities in Boston alone occupied most of the organizers' time, but they also sought to reach out to the state universities in Rhode Island, Connecticut, Vermont, New Hampshire and Maine. They sent speakers to Brown, Dartmouth, Middlebury, Amherst, Williams, Yale, and the Rhode Island School of Design. At most of those schools, they relied on SDS chapters for assistance, but given the ambivalence of the national SDS, such efforts were rarely

${ }^{30}$ James Reston, NYT, 5 May 1967; Tom Wicker, "In the Nation: Muhammad Ali and Dissent," NYT, 2 May 1967, p. 46; "October 16!," Newsletter of the New England Resistance, undated (c. Sep 1967), MKFP. 
enough. The second and final newsletter put out before October 16 boasted that the NER planned to distribute 50,000 leaflets "in a serious effort to hit everyone in the New England area who holds the II-S deferment." 31

Resistance organizers divided up assignments and spoke with each other daily. Bill Dowling and, to a lesser degree, Bob Talmanson ironed out the details for October 16, getting permits for the demonstration planned for Boston Common, arranging speakers and doing outreach to other antiwar groups. Michael Ferber promoted October 16 on college campuses, thus doing most of the public speaking for the group. Alex Jack and Nan Stone focused on the religious community, reaching out to clergy, seminarians, and lay people for support. In this last respect, especially, the Boston plan for October 16 developed much differently from other cities. ${ }^{32}$

In late September, Alex Jack suggested that the Boston draft card turn-in take place in a church. The others loved the idea immediately, for as Michael Ferber later wrote, "what better way to underscore the moral gravity of the act we were embarking on than to hold it in a place of worship? It was a little like a confirmation or a baptism: a rite of passage into manhood, from slavery and 'channeling' to the promised land of peace and freedom." The difficult task, they thought, would be in finding a church that would allow such a controversial ceremony to take place in its sanctuary. As usual, though,

31 "October 16!," second newsletter of the New England Resistance, undated (c. 1 Oct 1967), MKFP.

32 "October 16!," Newsletter of the New England Resistance, undated (c. Sep 1967), MKFP; Ferber and Lynd, p. 107. 
Alex Jack had a plan. ${ }^{33}$

Jack and Ferber arranged a meeting with the Rev. Jack Mendelsohn of the Arlington Street Church, a Unitarian-Universalist church adjacent to Boston's Public Gardens. At the time, Jack and his parents were parishioners there and the minister was an old family friend. Mendelsohn had been preaching against American involvement in Vietnam for a long time and could be counted upon to be sympathetic. Even so, he hesitated when first asked to hold the draft card turn-in in his church. His reluctance stemmed not from any misgivings about the nature of the ceremony, but from his appraisal that everyone in Boston would expect such a ceremony at Arlington Street. "It was assumed that things of that nature would occasionally be held there," he later remarked. Therefore, he suggested that the organizers approach some of the more establishment churches in town, Trinity or Old South Church, to see if they might consider hosting the event. Newspaper and television images of hundreds of draft resisters assembling in Copley Square and marching into Trinity Church. Henry Hobson Richardson's great architectural masterpiece and a monument to Boston's rich intellectual and cultural legacy, would have stunned the city. To be welcomed in such a place would imply that even the most powerful families in Boston so firmly opposed the war that they were willing to approve a plan of radical civil disobedience. In the end, however, it did not happen. Those establishment churches rebuffed Resistance organizers and they

\footnotetext{
${ }^{33}$ Ferber \& Lynd, p. 108.
} 
returned to Arlington Street. ${ }^{34}$

The history of the Arlington Street Church made it an ideal site for a draft card turn-in. The church itself was constructed in 1861 , the first public building built on the newly filled Back Bay. But, in fact, three congregations from other churches had combined to create the one that the Rev. Mendelsohn led in the 1960s. The first parish, started by Scots-Irish immigrants who had moved to Boston from Londonderry, New Hampshire, in 1729, named itself the Church of the Presbyterian Strangers. Eventually, it relocated to Federal Street, where, in 1803, the parish recruited a young minister named William Ellery Channing. Channing transformed the church by applying its ministry to social justice causes and a more liberal theology. In 1825, he founded the American Unitarian Association in the vestry of the Federal Street Church, and he himself later became an articulate champion of the Abolitionist movement. In ensuing decades, the Arlington Street Church played an integral role in the development of Unitarianism. In the twentieth century it eventually merged with two other churches: First Unitarian, and the Church of the Disciples. During the Vietnam era, draft resisters and parishioners alike found reassurance in the history of the Church of the Disciples as well. Under minster James Freeman Clark, the Church issued the following resolution, signed by Clark and 130 others, in opposition to the Mexican War:

We the undersigned members of the Church of the Disciples, or religiously connected therewith, wish by a solemn declaration to free ourselves, as far as possible, from the responsibility of the war of invasion now waged by the United States against Mexico.

${ }^{34}$ Alex Jack, interview with author, 21 Mar 1997; Jack Mendelsohn, interview with author, 19 Dec 1997; Ferber \& Lynd, pp. 107-108. 
We take this step because we believe this war to be unjust + inhuman, + to be carried on from the lust of territory and for the extension of slavery, because the attitude of silence in which this country stands before the nations with regard to this war is one of approval + because thus our influence and character individually + collectively, as Americans and Christians goes to strengthen a scheme of oppression and blood.

We therefore, as far as by this public act we can, absolve ourselves before God + the Christian world of all participation in or approval of this deed of violence, + we protest in the name of humanity + religion against the existence + continuance of this war, as dishonorable to our name + race, as the forfeiture of our mission as a people + as one of the great crimes of modern history.

During the 1960s the original copy of that resolution hung, framed, on the wall of the entry foyer of the Arlington Street Church's offices at 355 Boylston Street. One needed little imagination to apply that 1846 resolution to 1967 , and many in the church looked to it for inspiration during the difficult days of draft resistance. ${ }^{35}$

Despite this legacy of commitment to social activism in the nineteenth century, the Arlington Street Church grew fairly conservative in the twentieth century through the late 1950s. It had itself become an establishment church. During the thirties, forties, and fifties, many of the church's Brahmin members who had moved to some of the affluent suburbs outside Boston still came in on Sundays to hear "one of their own," the Rev. Dana McLean Greeley, preach. But when Jack Mendelsohn came to Arlington Street, that changed. Mendelsohn entered the Unitarian ministry because it was turning its attention toward social issues and he wanted to work in an institution that would apply

35 "The Century and the Quest," centennial pamphlet (c. 1961), Arlington Street Church Archives; "Arlington Street Church," brochure, undated (c. late 1960s), Arlington Street Church Archives; Mendelsohn interview, 19 Dec 1997; original copy of the Mexican War resolution hangs today in the James Freeman Clark room in the Arlington Street Church. 
itself to "trying to find better approaches to solving human problems." He quickly set to work transforming Arlington Street into a vibrant urban church, one that reached out to the city's diverse population. ${ }^{36}$

Most important for the Resistance organizers, Jack Mendelsohn and the Arlington Street Church already possessed a record of commitment to antiwar activity. The march that ended with counterprotesters hurling eggs at antiwar activists on the steps of the church in the spring of 1966 had firmly established Arlington Street as a home for such activity. Alex Jack and Michael Ferber were not too surprised, then, when the Rev. Mendelsohn agreed to host the draft resistance service and also volunteered to participate. "The notion of the 'bully pulpit,' which we apply generally to the President of the United States," the minister said years later, "equally applies to a downtown religious institution. It's a great place for great thoughts and people who express great thoughts - or at least who express unconventional thoughts." Certainly, the notion of returning Selective Service documents in an elaborate church ceremony did seem unconventional.

The plan for October 16 now included a rally on the Common to be followed by a march to the church where the draft card turn-in would take place. Organizers recruited from among the usual suspects of the antiwar movement to speak on the Common: Boston University professor Howard Zinn, MIT professor Noam Chomsky, former SDS national president Nick Egleson, and former Boston University News editor, Ray Mungo.

${ }^{36}$ Stanley Moss, telephone conversation, 24 Feb 1998; Mendelsohn interview, 19 Dec 1997; G. Robert Hohler, interview with author, 11 Dec 1997.

${ }^{37}$ Mendelsohn interview, 19 Dec 1997. 
In contrast, the service outlined for the church leaned, appropriately, toward the religious community: Alex Jack and Michael Ferber planned to speak in addition to Yale chaplain William Sloane Coffin, Jr., Father Robert Cunnane of the Boston Committee of Religious Concern for Peace, and George Hunston Williams, Hollis Professor of Divinity at Harvard Divinity School.

The inclusion of several older sympathizers in the plans for October 16 runs counter to the popular belief that participants in the student movements of the sixties trusted no one over thirty. In fact, the Resistance, both locally and nationally, benefitted from the invaluable support of a deeply committed group of older men and women who were not subject to the draft but wanted to register their disgust regarding the war in Vietnam by supporting draft resisters. The most obvious example of this resulted in the "Call to Resist Illegitimate Authority." a statement published in the New York Review of Books and the New Republic in early October and signed by 320 people. Much like the student We Won't Go statements of the previous spring, dozens of such petitions circulated among intellectuals and prominent antiwar activists in 1966 and 1967. Each expressed the intention of the signatories to counsel and assist young men in resisting the draft and were therefore presented to the public (and the government) as complicity statements, sufficient evidence for indictment under Section 12 of the Selective Service Act.

The Call to Resist became the most successful and widely known of these complicity statements, eventually attracting over 2,000 signatures over the next year. The statement itself turned out to be rather lengthy, but its underlying theme underscored 
the "moral outrage" felt by a growing number of citizens regarding the war in Vietnam.

Its authors, Marcus Raskin and Arthur Waskow, both of the Institute for Policy Studies, a

Washington think tank, and Robert Zevin, professor of economics at Columbia

University, argued that the war was unconstitutional and violated the United Nations

Charter and the Geneva Accords of 1954. They cited examples of American war crimes:

The destruction of rice, crops, and livestock; the burning and bulldozing of entire villages consisting exclusively of civilian structures; the interning of civilian non-combatants in concentration camps; the summary execution of civilians in captured villages who could not produce satisfactory evidence of their loyalties...; the slaughter of peasants who dared to stand up in their fields and shake their fists at American helicopters..."

These deeds, they argued, were exactly like those determined to be crimes against humanity by the Allies following World War II. As a result, they argued, "every free man has a legal right and a moral duty to exert every effort to end this war, to avoid collusion with it, and to encourage others to do the same." They acknowledged the "excruciating choices" facing young men in the military or threatened by the draft and praised the courage of those resisting the "illegitimate authority" of those institutions. They pledged to support those who resisted the war by raising money, organizing draft unions, and supplying legal defense and bail. And in the most eloquent passage of the statement, they justified their actions by saying,

We feel we cannot shrink from fulfilling our responsibilities to the youth whom many of us teach, to the country whose freedom we cherish, and to the ancient traditions of religion and philosophy which we strive to preserve for this generation. We call upon all men of good will to join us in this confrontation with immoral authority...Now is the time to resist.

Despite the length and what poet Allen Ginsburg called its "humorless prose," the list of 
signatures gathered over the summer included names that most Americans and, in particular, readers of the New York Review and New Republic recognized. Among the signatories were poets Ginsburg, Lawrence Ferlinghetti, Grace Paley, Robert Lowell, and Denise Levertov; artists Raphael Soyer and Alexander Calder; columnists Nat Hentoff and Jack Newfield; clergymen Philip Berrigan, James Bevel, Robert McAfee Brown, William Sloane Coffin and Dick Mumma; famed pediatrician Benjamin Spock; and scholars and writers - the largest group - Gar Alperovitz, Noam Chomsky, Paul Goodman, Mitchell Goodman, Gabriel Kolko, Christopher Lasch, Paul Lauter, Staughton Lynd, Dwight MacDonald, Herbert Marcuse, Ashley Montagu, Conor Cruise O'Brien, Linus Pauling, Hilary Putnam, Philip Roth, Edgar Snow, Susan Sontag and Howard Zinn. $^{38}$

During the summer, as organizers of the Call to Resist realized that enthusiasm for their statement overlapped with growing interest in the national draft card turn-in planned for October 16, they sought a way to bring the two together. Specifically, Mitch Goodman, the writer and teacher, conjured up the idea of delivering the cards collected across the country on October 16 to the Justice Department on October 20, the day before the massive march on the Pentagon. On October 2, several of the educators, clergy, and literary figures who signed the Call gathered for a press conference in New York. They discussed the statement and Goodman's plans for returning the draft cards to the Justice Department. The Rev. William Sloane Coffin promised that resisters would be granted

38 "A Call to Resist Illegitimate Authority," New York Review of Books, 12 Oct 1967, p. 7. See also "320 Vow to Help Draft Resisters," NYT, 27 Sep 1967, p. 13; Ferber \& Lynd, pp. 122-123. 
sanctuary in churches and synagogues across the country and the group issued a statement that again combined their sense of history with their moral outrage: "We hope that by using traditional American tactics of nonviolent civil disobedience against conscription and militarism, we will spur further antidraft activity and help to build the tidal wave of revulsion that will lead to the withdrawal of our Army from Vietnam and an end to the unconstitutional intrusion of the Pentagon into policymaking." On the same day, a Louis Harris poll indicated that only 31 per cent of Americans supported President Johnson's handling of the war, while continued support for the war dropped from 72 per cent in July to just 58 per cent. ${ }^{39}$

In Boston, the kind of backing evident in the Call to Resist had been present in Boston for some time. The ubiquitous professors Zinn and Chomsky could be heard at almost all antiwar demonstrations, and an organization started by Harvard philosophy professor Hilary Putnam, the Boston Area Faculty Group on Public Issues (BAFGOPI), laid the ground work for continued interaction between the two generations of activists. Since 1965, BAFGOPI had been running antiwar ads in the New York Times and working with students to organize teach-ins and other protests. By the time the New England Resistance began to organize for October 16, a well established antiwar infrastructure the kind needed for large scale activism - made planning easier. ${ }^{40}$

39 "War Foes Are Promised Churches as Sanctuary," NYT, 3 Oct 1967, p. 5; "Harris Poll Shows a Decline to $58 \%$ in Support for War," NYT, 3 Oct 1967, p. 5.

40 Hilary Putnam, interview with author, 18 Dec 1997. 


\section{Qbedience to a Higher Allegiance}

October 16 dawned clear and bright. Although Boston attracts tourists by the thousands in summertime, it is in September and October that the city can come closest to attaining a certain barometric perfection. The humidity of summer is replaced by dry air; crisp mormings often give way to splendid warm afternoons. On the Monday of the planned demonstration, crystalline skies held out the promise of a glorious day.

Organizers carried chairs and sound equipment from the basement of the Arlington Street Church to the dewy, green rise of Flagstaff Hill, the only remaining hill on the Common. Flagstaff Hill and the parade grounds on its western slope (approaching Charles Street) have played host to innumerable public events in Boston's history, and in some ways, it was the ideal choice for the location of a rally aimed at encouraging resistance to conscription. The city once stored its gun powder supply on top of the hill, and the Marquis de Lafayette, hero of the Revolution, ceremonially fired a cannon from the hill during a visit in 1824 . Most significant for the Resistance, Army officers used Flagstaff Hill as their recruiting station during the Civil War - the war to preserve the Union. Although the organizers who now set up chairs and a speaker system on that hallowed ground did so in preparation for an event that those Union officers might have found puzzling, the hill's patriotic heritage dovetailed seamlessly with their own sense of the Resistance's adherence to - and desire to preserve - the best of American traditions."

By 10:00 a.m., small groups of young people began approaching Flagstaff Hill

${ }^{41}$ On the history of Flagstaff Hill, see John Harris, Historic Walks in Old Boston (Chester, Conn.: Globe Pequot Press, 1981), pp. xv, 9, 11, 17. 
from all directions. When speeches began at 11:00, over 5,000 people stood or sat on the now dry grass, listening. Buses filled with students from Dartmouth, Yale, Brown, the University of Rhode Island, the University of Massachusetts, and nearly every Boston area college circled the Common looking for places to park. Uniformed officers stood by with police dogs to cope with any potential violence. On the hill, in the middle of a group of seated young people, a middle aged woman, blonde, wearing sunglasses, held a sign that read "LBJ KILLED MY SON." Dozens of people held signs. Some of the slogans included, "Suppose They Gave a War and Nobody Came?"; "The Resistance: Don't Dodge the Draft, Oppose It"; "Wars Will End When Men Refuse to Fight"; "The Resistance Shall Not End"; "UMB [UMass-Boston] Veterans Against the War"; "They Are Our Brothers Whom We Kill”; “No Draft - Don't Enlist - Refuse to Kill”. Counterdemonstrators came armed with placards, too. One said "Tough Enough to Criticize, Too Weak to Defend - USMC," another. "Draft the Draft Dodgers - Yes LBJ." Two others, held by self-described Polish Freedom Fighter, Josef Mlot-Mroz, said "Lets Fight Communism, Red Dupes, Vietniks, Peaceniks, and Clergy," and "Fight Communism and Zionist Stooges, Peaceniks, Vietniks, and Anarchists." Police eventually took Mlot-Mroz into "protective custody," when he began disrupting the speeches. ${ }^{+2}$

Several speakers took turns at the microphone in the shadow of the Soldiers' 
Monument. Homer Jack chaired the rally and introduced each speaker. Everyone who addressed the crowd emphasized morality, conscience, and the responsibilities of citizens. The Rev. Harold Fray, of the Eliot Church in Newton and chair of the Committee of Religious Concern for Peace stood first before the vast crowd in his clerical robe. "What does it profit a nation," he asked rhetorically, "to impose its military might upon peoples of the world, while in so doing it loses its soul?" He called it a dark period in the nation's history, but added, "the light will shine again when the moral conscience of America will not submit to national policies that violate honor, decency, human compassion and those qualities of life which alone make a nation strong." Fray praised the "great courage" of the men who would resist the draft on this day, but told them that, henceforth, they would have to "bear the penalty of adverse public opinion and the long arm of government suppression." Better to endure those penalties, he concluded, "than to allow your consciences to atrophy because you were afraid to give expression to them." Ray Mungo, former editor of the $B U N$ News, and director of Liberation News Service, took up the issue of draft resistance, telling the crowd that the prospect of going to jail should not be feared; indeed, he saw it as "an honorable alternative to serving in Vietnam." "*3

Nick Egleson was not as sanguine about the prospects of a protest rooted in "individual conduct." Egleson possessed extensive Movement credentials. He had been national president of SDS, and in the fall of 1967 he assumed a leadership position in the Boston Draft Resistance Group. The thrust of what he said to the crowd sounded much

43 "67 Burn Draft Cards in Boston," Boston Globe, 17 Oct 1967, pp. 1, 12; Harold Fray, Mimeographed copy of statement on Boston Common, 16 Oct 1967, papers of James Hunt. 
like the SDS line - only more persuasive. First, he lamented the antiwar movement's lack of a "base of power" and what he saw as the resulting shift toward "moral acts" of protest. Specifically, he warned of the temptation to "measure actions in the movement by a code of individual conduct," to establish certain moral acts as minimum standards for appropriate dissent:

Some refuse to enter the army because no moral man could engage in combat in Vietnam; some dissociate themselves from the Selective Service System because association with the machinery of slaughter is unconscionable; others assume the jeopardy of draft refusal even if they are not subject to the draft because no moral man can let others suffer injustice alone.

He argued that "such an individual code easily becomes the primary or only standard for political conduct" and pointed to the nation's "individualist ethic," the "religious frame of reference" that so many protesters had adopted, and the "absence of widespread political experience" as factors that pushed the movement toward an individual code and closed off the possibility of other political standards.

Ultimately, Egleson acknowledged that that standard of individual conduct might be useful in organizing people on campuses - those not immediately threatened by the draft - but noted that "all the while the men of Charlestown and South Boston and Riverside, of Roxbury and Dorchester and of the working-class parts of cities all over the country are threatened by the draft and are more gently coerced by the security of enlistment." To address this issue he urged a prescription more consistent with the missions of BDRG and SDS:

Our solution must be to begin to organize those most threatened by the US armed forces. How many people gave out information about the 
October 16 rally in Boston in poor and working-class neighborhoods? Who put up posters speaking the language of those communities? Who tried to counter, thereby, the image the press promotes of us as hippies, cowards, and peace finks? Who suggested in those places that we - not the US Army - speak to people's immediate and long-range interests?

BDRG, of course, had already been working in this direction for several months through the Early Morning Shows and their counseling efforts. Although some crossover in membership existed between BDRG and the New England Resistance, and relations were generally cordial, the Resistance did not plan to duplicate BDRG's work. ${ }^{\text {H }}$

For the assembled crowd, however, Egleson's speech caused a bit of a startle. Suddenly, they had to come to terms with one of the day's main speakers choosing not to provide the kind of ringing endorsement of draft resistance offered by the others. In fact, Egleson implied that it might amount to the kind of "useless martyrdom" that BDRG had warned of in its recent newsletter. Although he did not address one of the Resistance's central strategies - that widespread resistance might actually create the base of power for which he longed (through the imprisonment of thousands of resisters and the resulting outrage of their parents) - his arguments gave some potential resisters reason to pause and reassess their plans for the day. David Clennon, a third year graduate student at the Yale School of Drama, for instance, recalled that Egleson's speech caused him to completely rethink his reason for being there. "When I heard Nick Egleson make his speech, I really began to have some serious doubts about what I was doing. Here was a guy who...had a lot of political savvy, much more than I had [and he disagreed with the draft resistance strategy]." Clennon, who "came at it mostly from a kind of politically naive point of

\footnotetext{
${ }^{44}$ Ferber \& Lynd, pp. 112-113.
} 
view [and] a very strong moral point of view" found himself "easily confused and easily swayed" by such arguments. 4 -

Just in time for Clennon and others, though, Boston University professor and World War II veteran Howard Zinn strode to the microphone. Zinn, like Noam Chomsky, was by then a well known critic of the war. He frequently participated in antiwar teach-ins on area campuses, and his recently-published book, Vietnam: the Logic of Withdrowal, attracted a wide readership. Zinn did not respond directly to Egleson's critique of draft resistance as creating an uncomfortable standard of individual conduct by which all antiwar activity might be judged, however. Instead, the older man raised issues of a govermment's responsibilities to its citizens and the citizen's loyalty to his government (he was, after all, a professor of Government at BU). "Ever since governments were first formed and tyranny, the natural companion of government, began," he observed, "people have felt the need to gather in the forest or the mountains or in underground cellars, or, as here, under an open sky, to declare the rights of conscience against the inhumanity of government." The tyranny of the present administration had already killed 13,000 Americans, men who "died in Vietnam because they were sent there under the orders of politicians and generals who sacrificed them on behalf of their own ambitions," he said. Zinn criticized those men in positions of power for appointing themselves "guardians of every spot on the earth against Communism." He derided them for trying to save people everywhere from Communism "whether the people want to be saved or not, and even if they have to kill them all to save them," and assailed President

4s David Clennon, interview with author, 12 Jun 1997. 
Johnson for breaking his pledge to those who supported him in the 1964 election on a peace platform. A government guilty of such betrayals and abuse of power, Zinn reasoned, no longer deserved the allegiance of its citizens. "I don't believe we owe loyalty to a government that lies to us," he said. "I do believe we owe loyalty to our fellow Americans who are in danger of being killed by the incompetence of this government."

Rather than emphasize the individual principled acts of defiance decried by Nick Egleson, therefore, Zinn argued for holding the government to a reasonable moral standard. He said he felt ashamed, "deeply ashamed" to call himself an American.

When I read, and in the most conservative newspapers, that the U.S. Air Force has bombed again and again the residential areas of North Vietnamese cities, that it has bombed, again and again - too often to be an accident - villages that are devoid of military significance - that it has bombed a hospital for lepers in North Vietnam 13 times...I am ashamed, and I want to disassociate myself from these acts. That is not my idea of what America should stand for.

In the end, although individual morality surely intertwined with responsibilities of citizenship, for Zinn the latter provided the most compelling reason for draft resistance. "We owe it to our conscience, to the people of this country, to the principles of American democracy," he concluded, "to declare our independence of this war, to resist it in every way we can, until it comes to an end, until there is peace in Vietnam."

As the last speaker at the demonstration, he called on those who planned to resist to assemble in one area of the hill from which they would be directed to take their places

46 "Youths Burn Draft Cards on Boston Altar," Boston Globe Evening Edition, 16 Oct 1967, pp. 1-2; "67 Burn Draft Cards in Boston," Boston Globe, 17 Oct 1967, pp. 1, 12. 
in the column of marchers that would walk to the Arlington Street Church. David Clennon, his doubts assuaged, joined the line. Zinn "spoke so eloquently about the horrors of the war," he remembered, "that I was convinced all over again that turning in my draft card was the right thing to do." He felt so committed, he began to weep. "I was crying with relief I think...that I was about to do the right thing as dangerous and controversial as it seemed to be...I was just overcome emotionally but I really felt solid then in my decision about what I was doing."

Most marched purposefully, quietly. Others were more expressive and playful. Marshals organized the marchers into distinct groups. The clergy led, followed by Veterans for Peace (in uniform), then the resisters. This order gave the march a wellplanned look of respectability. Moreover. the resisters themselves did not look like "hippies, cowards, and peace finks." The hair on some men touched their ears and collars, but most were fairly clean cut. A few beards could be seen, but the vast majority had bare faces. Many wore coats and ties, perhaps because they were going to church, or because they wanted to somehow demonstrate the gravity of the act they were about to undertake. The second Resistance newsletter told its readers to "smile as you march, but think defiance." They marched across the Common to Tremont Street, down Tremont to Boylston Street, and down Boylston to the church at the southwest corner of the Public Gardens. A woman crossing Tremont Street saw the marchers and, obviously disgusted, turned to a police officer and said: "Why don't you send them all back to Cambridge?" "Oh, they're from all over," he answered. As the marchers approached their destination,

\footnotetext{
${ }^{47}$ Clennon interview, 12 Jun 1997.
} 
the carillon in the tower of the church played "We Shall Overcome."

The church filled quickly, leaving nearly 3,000 others outside waiting to hear the service over loudspeakers. The actor Peter Ustinov, in town for a performance, mingled with the crowd. (When reporters asked him if he was with the Resistance, he responded: "No, because I am British. But if I were an American I would be part of the group." ) Like some of the oldest churches in New England, the pews at Arlington Street are separated into boxes that the church's earliest parishioners (or "Proprietors") could purchase. About 1,000 people squeezed into these boxes and the balconies above, and sat on the lumpy cushions filled with horsehair. Reporters took notes, flash bulbs flashed, and an NBC News photographer standing in the balcony with correspondent Sander van Ocur trained his camera on the sanctuary below. The atmosphere was hushed, respectful - and electric.

The printed programs called it "A Service of Conscience and Acceptance," and all of the speakers emphasized moral and religious justifications for civil disobedience. After Jack Mendelsohn gave the invocation, the congregation sang Once to Every Man and Nation:

Once to every man and nation Comes the moment to decide In the strife of truth with falsehood, For the good or evil side;

48 "Youths Burn Draft Cards on Boston Altar," Boston Globe Evening Edition, 16 Oct 1967, p. 2; "October 16!," second newsletter of the New England Resistance, undated (c. 1 Oct 1967), MKFP; Skip Ascheim, "Resistance: Boston Style," Avatar, No. 11, p. 4.

49 "4000 Defy Draft in Common Rally," Boston Record American. 17 Oct 1967, p. 3. 
Some great cause. God's new Messiah, Offring each the bloom or blight, And the choice goes by forever

Twixt that darkness and that light.

A responsive reading ("The Young Dead Soldiers") followed and, after that, Alex Jack read a Vietnamese prayer.

The real power of the service, however, derived from the four addresses - or sermons - given. Like the speeches on the Common, the statements given in the church are worth considering in detail because of their incomplete coverage in the press. Two graduate students spoke first. Jim Harney, a Catholic studying for the priesthood at St. John's Seminary in nearby Brighton, told the congregation that he had spent the last few weeks reading about German "men of faith" who stood up to the Third Reich and paid for it with their lives. "Their witness," he said, "has affected my life enormously." $\mathrm{He}$ quoted Father Alfred Delp, a German priest who did not survive the concentration camps:

The most pious prayer can become a blasphemy if he who offers it tolerates or helps to further conditions which are fatal to mankind, which render him unacceptable to God. or weaken his spiritual, moral or religious sense.

Harney then cited the German peasant, Franz Jagerstatter, who also died "in a solitary protest":

For what purpose did God endow all men with reason, and free will, if, in spite of this, we are obliged to render blind obedience, or if, as so many also say, the individual is not qualified to judge whether this war started by Germany is just or unjust? What purpose is served by the ability to distinguish between good and evil?

Forced by his country's actions in Vietnam and by the burden of a conscience that would not allow him to study quietly for the priesthood while his ministerial deferment protected 
him from the draft. the 27 year old seminarian found inspiration in the example set by these little known German heroes. Hé explained to the crowd:

For me, these words from the past have great meaning: my faith is put on the line, and above all, my life is directed to the cross-roads of the living. They are hard words to live; for, they point to the very crucibles of life and death. Now I must take a stand on behalf of the living. Conscience must prevail. Man's transcendent dignity brings him not only inalienable rights but also an awesome responsibility. I must not stand by, while the very survival of the Vietnamese people is in jeopardy...

I come here today, a Catholic seminarian, to be obedient to my God, to conscience, and to the pleas of the Vietnamese people...I take my stand in the Spirit of the Franz Jagerstatters, the Father Delps, the [Dietrich] Bonhoeffers, who opted for life rather than for death...I join my voice to the 2,500 ministers, priests and rabbis who urged President Johnson: "In the Name of God, Stop It!" and further than this, on this October the $16^{\text {th }}$, I resist. ${ }^{50}$

Harney later went on to greater notoriety as a member, with Bob Cunnane, of the

Milwaukee 14, a group of Catholic pacifists who, following the examples of Daniel and Philip Berrigan, raided a Milwaukee draft board and destroyed thousands of files. As a seminarian about to break the law on October 16, however, he risked the priesthood for which he had been preparing himself for so long.

Michael Ferber followed Harney to the pulpit. The lifelong Unitarian felt comfortable in such situations. He had delivered sermons at his home church in Buffalo, and as one of the main speakers for the New England Resistance (for whom he gave talks or "raps" almost daily), his "low key Harvard style" seemed ideally suited for this moment. In what Howard Zinn later called an "extraordinary, passionate, personal

so Jim Harney, address delivered at Arlington Street Church, 16 Oct 1967, mimeographed copy circulated by New England Resistance, MKFP. 
statement," ${ }^{\text {s1 }}$ the 23 year old graduate student began:

We are gathered in this church today in order to do something very simple: to say No. We have come from many different places and backgrounds and we have many different ideas about ourselves and the world, but we have come here to show that we are united to do one thing: to say No. Each of our acts of returning our draft cards is our personal No; when we put them in a single container or set fire to them from a single candle we express the simple basis of our unity.

But what I wish to speak about now is what goes beyond our saying No, for no matter how loudly we all say it, no matter what ceremony we perform around our saying it, we will not become a community among ourselves nor effective agents for changing our country if a negative is all we share. Albert Camus said that the rebel, who says No, is also one who says Yes, and that when he draws a line beyond which he will refuse to cooperate, he is affirming the values on the other side of that line. For us who come here today, what is that we affirm, what is it to which we can say Yes?

Before answering that question, Ferber told the congregation that they must acknowledge the differences that existed within the inchoate Resistance community. For one, many of those assembled might feel a sense of hypocrisy for participating in the religious trappings of the day's ceremonies, because they themselves were not churchgoers. In response, he told of the "great tradition within the church and synagogue which has always struggled against the conservative worldly forces that have always been in control." In modern times, he said, that radical tradition "has tried to recall us to the best ways of living our lives: the way of love and compassion, the way of justice and respect, the way of facing other people as human beings and not as abstract representatives of something alien and evil." He continued with an example:

As a part of this service we will break bread together. We do this,

sı Howard Zinn, You Can't Be Neutral On a Moving Train: A Personal History of Our Times, (Boston: Beacon, 1994), p. 116. 
however, not because some churches happen to take Communion; we do this for one of the root reasons for Communion itself: that men around the world and for all time have found it good to eat together when they are sharing in something important.

The radical tradition is still alive: it is present here in this church. Those of us who disregard organized religion, I think, are making a mistake if they also disregard this tradition and its presence today. This tradition is something to which we can say Yes.

Ferber then warned the assembly not to "confuse the ceremony and symbolism" of the service with the "reality" that they were only a few hundred people "with very little power." He told them that American policy would not change overnight, that, indeed. the "world will be in pretty much the same mess it is in today" and because they, as a community, would have to "dig in for the long haul," October 16 represented not the End, but the Beginning. To change the country, he said, would mean "struggles and anguish day in and day out for years...it will mean people dedicating their lives and possibly losing them for a cause we can only partly define and whose outcome we can only guess at."

As he moved toward his conclusion, in the most important part of the sermon, Ferber engaged the critique of "moral acts" as protest made by his old friend and former roommate at Swarthmore, Nick Egleson:

Earlier today, Nick Egleson spoke out against the kind of resistance whose primary motivation is moralistic and personal rather than political. He is saying that we must make ourselves relevant to the social and political condition of the world and must not just take a moral posture for our own soul's sake, even though that too is a risk.

To some extent this argument depends on terminology rather than fact. Today we have heard our situation described in religious terms, moral terms, political terms, legal terms, and psychological terms... What is happening today should make it clear that these different modes of speech all overlap one another and they often all say the same essential things. 
Albert Camus, who struggled in a more serious Resistance than ours, believed that politics is an extension of morality, that the truly moral man is engaged in politics as a natural outcome of his beliefs.

To return to Nick's concern, the real difference is not between the moral man and the political man, but between the man whose moral thinking leads him to political action and the man whose moral thinking leads him no farther than to his own "sinlessness." It is the difference between the man who is willing to go dirty himself in the outside world and the man who wishes to stay "clean" and "pure."

Ferber, therefore, acknowledged the potential damage that moral actions could have on the antiwar movement. This kind of "sinlessness" and "purity," he said, is "arrogant pride," and "we must say No to it." "The martyr who offers himself meekly as a lamb to the altar is a fool," he warned. "We cannot honor him...unless he has helped the rest of us." The morally pure act of draft resistance would be useful in ending the war only if it produced a tangible political effect beyond cleansing the souls of those who carried it out.

"So what then are we to do?" Ferber asked.

We must look at ourselves once more. We all have an impulse to purification and martyrdom and we should not be ashamed of it. But let us be certain that we have thought through the consequences of our action in the outside world, and that these consequences are what we want to bring about. Let us make sure we are ready to work hard and long with each other in the months to come, working to make it difficult and politically dangerous for the government to prosecute us, working to help anyone and everyone find ways to avoid the draft, to help disrupt the workings of the draft and the armed forces until the war is over. Let us make sure we can form a community. Let us make sure we can let others depend on us.

If we can say Yes to these things, and to the religious tradition that stands with us today, and to the fact that today marks not the End but a Beginning, and to the long hard dirty job ahead of us - if we can say Yes to all this, then let us come forward together and say No to the United States Government.

Then let our Yes be the loudest No our government ever heard. ${ }^{52}$

\$2 Michael Ferber, "A Time to Say No," in Jessica Mitford, The Trial of Dr. Spock (New York: Knopf, 1969), pp. 262-265. Ferber's sermon also appeared in several 
Michael Ferber's emphasis of community formation as the key to supporting the moral purpose of the Resistance into the political arena highlighted an issue about which organizers truly worried. Up until the end of the ceremony, planners thought that everyone who resisted might well be rounded up and arrested on the spot. When that did not happen, they sought to maintain the solidarity felt in the church among the now scattered brethren of the Resistance. It would not be easy. They would soon learn that the government would not go after them as a community, but individually. Building a community under such circumstances could be difficult, but in the church, on that day, the sense of fellowship engendered by Ferber's speech and the simple feeling of being surrounded by others who were equally passionate about ending the war inflated their hopes.

For the keynote address of the service, Alex Jack had recruited the Rev. William Sloane Coffin, himself a veteran of the Second World War, a former CIA operative, and now chaplain at Yale University and a tireless antiwar protestor. He also had a playful sense of humor. When he arrived that morning and encountered Jack Mendelsohn, he told him that he wished the service were taking place in a Presbyterian church, but said, "I have to hand it to you Unitarians: you really know how to combine a thin theology with a thick ethic." 53

religious journals at the time, such as Respond, the magazine of the Unitarian Universalist's Laymen's League; portions of it have more recently been reprinted in Alexander Bloom and Wini Breines, Takin' It To the Streets: A Sixties Reader (New York: Oxford, 1995) pp. 245-248.

53 William Sloane Coffin, Jr., Once to Every Man (New York: Atheneum, 1978), p. 242. Note: this is Coffin's version of the story. Jack Mendelsohn remembers it 
For nearly two years, Coffin had been one of the leading lights of Clergy and Laymen Concerned About Vietnam (CALCAV), and gained considerable notoriety as one of its most articulate spokesmen. ${ }^{54}$ That quality was in evidence on October $16 . \mathrm{He}$ began by quoting Socrates and St. Peter, both of whom chose to follow their consciences before obeying others. Their words, Coffin said,

tell us that because there is a higher and hopefully future order of things, men at times will feel constrained to disobey the law out of a sense of obedience to a higher allegiance. To hundreds of history's most revered heroes, not to serve the state has appeared the best way to love one's neighbor. To Socrates, St. Peter, Milton, Bunyon, Gandhi, Nehru, it was clear that sometimes bad subjects make good neighbors.

Coffin then answered the charges of critics who argued that civil disobedience is the first step on the road to anarchy. The "heroes" he listed did not try to "destroy the legal order," Coffin said. In fact, "by accepting the legal punishment, they actually upheld it." Furthermore, like those assembled before him, these men broke the law as "a last, not as a first resort"and once they did. "they were determined to bend their every effort to the end that the law reflect and not reject their best understanding of justice and mercy."

The central force driving the incipient Resistance, Coffin argued, was the issue of conscience: "Let us be blunt. To us the war in Vietnam is a crime. And if we are correct, if the war is a crime, then is it criminal to refuse to have anything to do with it? Is it we

slightly differently. As Coffin entered the church with his robe over his arm, he shook Mendelsohn's hand and shaking his head, said, "You Unitarians...So thin in your theology, so thick in your social ethics!" This is how Mendelsohn recounted it at the Arlington Street Church thirty year reunion service on 18 Oct 1997.

${ }^{54}$ In addition to Coffin's memoir, see Mitchell K. Hall, Because of Their Faith: CALCAV and Religious Opposition to the Vietnam War (New York: Columbia University Press, 1990). 
who are demoralizing our boys in Vietnam, or the Administration which is asking them to do immoral things?" He then called on churches and synagogues to provide sanctuary for draft resisters. He quoted from the $23^{\text {rd }}$ Psalm ("Thou spreadest a table before me in the presence of mine enemies") and explained that the passage referred to "an ancient desert law which provided that if a man hunted by his enemies sought refuge with another man who offered him hospitality, then the enemies of the man had to remain outside the rim of the campfire light for two nights and the day intervening." In the Middle Ages, Coffin explained, this practice expanded until every church in Europe was considered a sanctuary even for common criminals. Coffin acknowledged that if the American government decided that "the arm of the law was long enough to reach inside a church," the church would be unable to prevent an arrest. "What else can a church do?" he asked. "Are we to raise conscientious men and then not stand by them in their hour of conscience?" He concluded by noting that the resisters assembled that day were taking action within two weeks of the $450^{\text {th }}$ anniversary of the Reformation. He urged them on in their new reformation, their reformation of conscience and said: "You stand now as Luther stood in his time. May you be inspired to speak, and we to hear, the words he once spoke in conscience and in all simplicity: 'Here I stand, I can do no other. God help me."י'ss

The Rev. George H. Williams, also recruited by his nephew, Alex Jack, spoke last and gave the call for draft cards, the "Call to Acceptance." The appearance of this very

${ }^{55}$ William Sloane Coffin, Jr., "Church and Synagogue: Sanctuary of Conscience," in Mitford, The Trial of Dr. Spock, pp. 266-269. 
distinguished looking man, the Hollis Professor of Divinity at Harvard Divinity School, and one of the nation's leading scholars in religious history, shocked many of the faculty and students at Harvard. Few would have expected him to align himself so publicly - and so forcefully - with the leading edge of the antiwar movement. Alex Jack remembers that "the general feeling about my uncle was that he was trapped in the $12^{\text {th }}$ century...people would assume he was conservative." Williams himself stated on October 16 that he was one of the more "conservative" members of the clergy to participate. On this day, though, he displayed a moral outrage that belied that image. ${ }^{56}$

Williams began by explaining that in a just war scenario, he would view the exemption of clergy and conscientious objectors favorably, as an act representative of "a high degree of moral sensibility" on the part of the society in question. That said, he did not believe the war in Vietnam to be a just war. Therefore, he agreed to stand with the resisters in their protest. He told the congregation that like "countless others," he had sought to register his opposition to the war in Vietnam through all the "appropriate channels of democratic, academic, and religious activity." When that failed, however, Williams concluded that the Administration would "only take notice of a resolute show of moral force." Therefore, he said,

I am driven to show my solidarity with fellow seminarians in an act of civil disobedience out of moral indignation at the miscarriage of American ideals of international behavior. What we are doing in Vietnam is not appropriate for a great society with a long religious heritage...

${ }^{56}$ Jack interview, 21 Mar 1997; "280 New Englanders Turn in Draft Cards," Harvard Crimson, 17 Oct 1967, p. 1. Note: Alex Jack's comment on George H. Williams might more appropriately have referred to the $16^{\text {th }}$ century as Williams is most noted for his scholarly work on the Radical Reformation. 
Our military action is in my judgement immoral whether one argues as a pacifist or as a proponent of the just and necessary war...A decent respect for the opinions of mankind requires ever more of us in this nation under God - a democracy of the people, by the people, for the people - to declare the reasons for our separation from the ill-conceived and now ruthless policy in Vietnam, lest our form and conduct of government perish as an ideal among the nations of the earth.

...we interpret the action of these seminarians as moral courage; and we trust that the democratic society of which we are a part will look upon this solemn action of moral dissociation as redemptive for our society, that the Church herself in all lands and in times to come will count these young men as true servants of the peaceable kingdom, and that Jesus Christ and the Sovereign of the universe will acknowledge them as His true sons and subjects...

Without intending to detract from the heroism of our men fighting in Vietnam as they understand their duty and without minimizing the anguish of all those at war and at home who, feeling as do we that this war is somehow wrong, nevertheless, consider it also their solemn civic duty to abide by our national policy until it is officially modified - I, for my part, support these seminarians who, relinquishing their clerical immunity, in an orderly and solemn manner disavow this war...An orderly nation has the right to make grave demands upon its citizens in time of conflict or emergency. But a citizen also has the ultimate right to determine what constitutes licit demand upon him and his life, in other words what constitutes a just war. ${ }^{57}$

As he neared the end of his address, perhaps anticipating that in addition to the collection of draft cards, some men might burn their cards, he argued against such an act.

"I deplore the burning of draft cards," he said.

The more solemn and responsible act is to withdraw from the social covenant on this specific issue of conscience against a barbaric, unnecessary war being waged between pitifully unmatched opponents in quite disparate stages of national and social evolution. The manner of dissociation from this unjust war should be solemn and not impetuous,

${ }^{57}$ George H. Williams, "Vietnam: October 11 and October 16, 1967," mimeographed copy of address circulated by New England Resistance, MKFP. 
anguished but not disorderly, respectful but resolute. ${ }^{58}$

He then asked the resisters to come forward and stepped down from the pulpit to the edge of the chancel where the Reverends Mendelsohn and Coffin, Father Cunnane, and Harvard philosopher Hilary Putnam (who had been recruited to accept cards from the nonreligious resisters) joined him. Each held an offering plate for the collection of draft cards.

All eyes (and cameras) turned toward the forward pews. Flashes popped as the first man rose, jiggled the stubbom latch on the old door at the end of the pew, and stepped out into the aisle. As he walked forward, several other men stood and began moving toward the aisle and their moment of truth. Although the promotional leaflets predicted that 500 men would turn in their draft cards and join the Resistance in Boston, organizers had commitments from only about 20 to 25 men. They were hopeful for maybe 50 . It soon became apparent that many, many more would resist on this day. The

${ }^{58}$ Williams, "Vietnam: October 11 and October 16, 1967;" Note: I believe this portion of Williams's address (which comes from the widely distributed mimeographed copy of it that was circulated by the New England Resistance in the weeks following October 16) is accurate. The quoie, "I deplore the burning of draft cards," appeared in several news reports: "67 Burn Draft Cards in Boston," Boston Globe, 17 Oct 1967, p. 12; and "280 New Englanders Turn in Draft Cards," Harvard Crimson, 17 Oct 1967, p. 1. Having said that, the Rev. William Sloane Coffin, Jr., who spoke just before Williams during this ceremony, recalls Williams saying something that actually led to the burning of more draft cards: 'Suddenly, I heard his [Williams's] voice rise. I saw an excited finger shaking in the direction of the single candle on the table below. 'There,' he shouted in words I recall as follows, 'there is Channing's own candlestick, the one he used night after night to illumine the progress of his writing. I am certain that were he also here for this occasion, its flame, illuminating as it does the faces of you resisters, would seem to him almost pentecostal. For you, gentlemen, are the very pillar of fire this nation needs to lead it our of the darkness now covering its people." To date, I have been unable to corroborate this recollection of the Williams address. 
first trickle of men quickly became a steady stream that continued to swell for over twenty minutes. They came not just from the pews reserved for resisters but from all corners of the church. At some point, someone pushed open the massive church doors to let resisters in from outside. One woman, the Reverend Nan Stone, joined the long line as it moved slowly, quietly. When she reached the altar, she burned Steve Pailet's card in the flame of a candle held by one of William Ellery Channing's own candlesticks. As they turned over or burned their cards, some of the men smiled. Others wept softly. No one spoke above a whisper. The loudest sounds came from the TV cameras whirring away in the balcony. It seemed like it would never end. There were brief exchanges of encouragement between the resisters and their older accomplices holding the plates. When a student he recognized from the law school at Yale handed him his card, though, Coffin tried to give it back. "Don't be a fool," he said. "With this on your record you would destroy a law career." The resister replied, calmly, "I don't care. I know I'm not going to become a lawyer." Then he broke the law. ${ }^{\text {s9 }}$

When the last man placed his card on top of the pile sprouting from one of the collection plates, elated Resistance organizers hugged one another. "The most irreligious of us," Bill Dowling later said, "perhaps, are ready now to believe in miracles." After the service ended, they counted 214 cards turned-in with another 67 burned at Channing's flame. NBC News correspondent Sander van Ocur, tears in his eyes, descended from the balcony to speak to his friend, Bill Coffin. "What a country this would be," he said, "if

${ }^{59}$ Zaroulis and Sullivan, Who Spoke Up?, p. 134; Jack interview, 21 Mar 1997; Stone interview, 28 Mar 1997; Coffin, Once to Every Man, p. 243; "The Draft Resisters: In Search of a New Morality," Yale Alumni Magazine, Dec 1967, p. 47. 
something like this were now to take place in every church. ${ }^{.60}$

Indeed. it had been-a surprisingly moving day for many of those in attendance, and a gratifying culmination to many long hours of planning by New England Resistance organizers. As the strategy of noncompliance came under attack by other antiwar and New Left groups in preceding weeks, few could have predicted the success of October 16. The call for draft resistance resulted in the mobilization of the largest antiwar rally the city had yet seen, and a much greater number of returned draft cards than anyone anticipated. More important, the day signaled the successful transformation of the CNVA pacifists' individual defiant acts into a large-scale, mass protest that organizers believed would have lasting political effect. Moreover, as Sander van Occur's reaction indicated, the moral clarity of the participants came through in a serious, respectful, and thoughtful confrontation with the government. In the days and weeks that followed, the media and the public often missed that point. but leaders of this new driving force in the antiwar movement were heartened by the extensive coverage they did receive. Draft resistance, it seemed, could not now be ignored.

${ }^{60}$ Newsletter, New England Resistance, 25 Oct 1967, MKFP; Coffin, Once to Every Man, p. 244. 
PART II

CONFRONTATIONS AND MISCONCEPTIONS

Reproduced with permission of the copyright owner. Further reproduction prohibited without permission. 


\section{CHAPTER IV}

\section{FIL TERED RESISTANCE: RESISTERS' IMAGE AND REALITY}

Naturally. the common people don't want war; neither in Russia, nor in England, nor for that matter Germany. That is understood. But after all, it is the leaders of the country who determine the policy, and it is always a simple matter to drag the people along, whether it is a democracy, or a fascist dictatorship, or a parliament, or a communist dictatorship. Voice or no voice, the people can always be brought to do the bidding of the leaders. That is easy. All you have to do is tell them they are being attacked, and denounce the pacifists for lack of patriotism and exposing the country to danger. It works the same in every country.

Herman Goering, testifying at Nurmeberg ${ }^{1}$

New England Resistance planners attempted to shape public opinion regarding their protest almost as soon as the service at Arlington Street ended. They issued a press release that linked the day's events to some of the city's most celebrated historical precedents and emphasized the patriotic underpinnings of the rally and the service. "The site of the Boston Tea Party, Garrison and Parker's Abolitionist crusade against slavery, and Thoreau's refusal to support the Mexican War," they wrote, "the Hub of the Universe today witnessed the launching of a nationwide campaign of civil disobedience against the Selective Service System and the war in Vietnam." In a brief article for Avatar, one of Boston's "underground" papers, Bill Hunt wrote that the resisters who were at the Arlington Street Church might have said "no" to the laws of the country, but simultaneously, they said "yes, everlastingly yes, to the spirit of America." Indicative of

' In the spring of 1968, the New England Resistance used this quote liberally in its newspaper, The Resistance, and in other literature. 
his training as a graduate student in history, he invoked the names of American heroes in describing the way he felt on October 16:

I sat in the Arlington Street Church and I could not tell if we were the names and the bodies we are known by now or if we were Paine and Franklin and Jefferson or Emerson, Lincoln, and Thoreau. We were all of them, all of them on our way to becoming more of them, for the knowledge that was theirs is yet for us to learn, but we are learning, the pure vision that was theirs we must yet see, but we are seeing, and the strength to manifest that vision that was theirs, must be ours also - and yet we do not have it, but we will.

For Hunt, one of the most appealing sides to the Resistance grew from the way in which it could so easily be associated with "an indigenous, patriotic, American tradition of protest and dissent."2

In the end, few news outlets bought this line. The Resistance took some pleasure in seeing NBC Nightly News anchor, John Chancellor, turn to the camera after viewing the van Ocur report from Boston and say, "If men like this are beginning to say things like this, I guess we had all better start paying attention." But such comments from the media came few and far between. ${ }^{3}$

The Boston press, for instance, took a completely different approach, emphasizing the burning - not turning-in - of draft cards. The headline on the front page of the Boston Globe's October 16 evening edition said, "Youths Burn Draft Cards on Boston Church Altar." The next morning, surrounded by no less than three photographs of flaming draft cards, the Globe headline read: "67 Burn Draft Cards in Boston." The sub-headline, in

2 Bill Hunt, "Resist the Draft," Avatar, \#1 1, p. 5; Hunt interview, 31 Oct 1997.

${ }^{3}$ Coffin, Once to Every Man, p. 244. 
much smaller type, said, " 214 Turn in Cards, 5000 at Rally." The Boston Herald

Traveler and the Boston Record American also ran images of cards being burned and similar headlines. The Record American echoed the Globe, saying "67 Burn Draft Cards at Hub Peace Rally." while the Herald's headline read: "291 [sic] Youths Burn. Turn in Draft Cards."

In addition, reporters from each newspaper emphasized the speeches of Howard Zinn, William Sloane Coffin, and, to a lesser degree, George Williams. Not even the briefest snippets from the statements of Jim Hamey, Michael Ferber, or Nick Egleson appeared in any of the three papers. In fact. the articles did not mention the three men at all. Each newspaper instead provided details on the physical appearance of the resisters. Although the Herald Traveler said they looked more "mod" than "typical American," "scholarly rather than athletic," and that some were even "neatly attired in suit and tie or in casual college wear," the Record American (which boasted the "largest daily circulation in New England") focused their readers' attention on a few "shaggy-haired, bewhiskered youths," that they photographed burning draft cards at the altar. Several of the men in the photograph were "shaggy-haired" and "bewhiskered," though no more so than Peter Ustinov, whom the paper did not describe in the same way. In the accompanying story's lead sentence, Record American reporters Tom Berube and Al Horne characterized the church service as a "macabre ceremony."

4 "Youths Burn Draft Cards on Boston Church Altar," Boston Globe (Evening Edition), 16 Oct 1967, p. 1; "67 Burn Draft Cards in Boston," Boston Globe, 17 Oct 1967, p. 1; "67 Burn Draft Cards at Hub Peace Rally," Boston Record American, 17 Oct 1967, p. 1; "291 Youths Burn, Turn in Draft Cards," Boston Herald Traveler, 17 Oct 1967, p. 1; "The Youths Tell Why," Boston Herald Traveler, 17 Oct 1967, p. 1. 
Only the Herald Traveler attempted to address the motivations of the resisters but did so superficially. Reporter Earl Marchand quoted several resisters saying things like "the war is wrong," and "it's an immoral and illegal war," but offered no follow up on how the resisters had arrived at those conclusions or why they believed draft resistance would be an effective way to protest the war.

In an October 17 editorial, the liberal Boston Globe doubted that the Resistance had accomplished anything for their cause. The editors acknowledged the inequities of the draft system, but argued that a better way to challenge it would be to "obey the law and seek to change it." Like a condescending father talking to his wayward son, they cited Gandhi in waming that a campaign of civil disobedience would only succeed "if a large majority of the people support it." They concluded that "the Resistance will result only in making martyrs out of some students who have great courage but little judgement." In contrast, the Record American, the paper favored by Boston's working class, argued that the demonstrators "once again inevitably will be helping to prolong the war instead of shortening it." American forces, they said, were "clearly winning in Vietnam," but the enemy, encouraged by the antiwar movement in the United States, still had reason to keep fighting. ${ }^{6}$

On the whole, New England Resistance organizers were elated with the extensive press coverage that October 16 received, and essentially indifferent to its generally

\footnotetext{
5Earl Marchand, "The Youths Tell Why," Boston Herald Traveler, 17 Oct 1967, p. 26.

6 "The Resistance," Editorial, Boston Globe, 17 Oct 1967, p. 16; "Paradox of Protest," Editorial, Boston Record American, 20 Oct 1967, p. 34.
} 
negative tone. Media attention, any media attention, they believed, served their purposes. But in the weeks following October 16 , it became clear that the press proved more successful at shaping public opinion than the Resistance did. And public opinion was often unfavorable. Without the benefit of scientific polling data, it is impossible to say just how the public's view of draft resisters broke down statistically, but evidence from letters to the editor and other newspaper sources indicates that a significant segment of the population either misunderstood or disagreed with draft resisters. Those who participated in the Arlington Street service were widely regarded as hippies, cowards, or communists, and were accused of being disloyal and unpatriotic.

This chapter examines these images of draft resisters and compares them with actual demographic data on the resisters themselves. Ultimately, it becomes clear that the media's tendency to focus on the more unusual aspects of a story contributed to the development of a false image of the typical draft resister. In fact, very few of Boston's draft resisters were hippies or communists, and they were not cowards either; a coward would more likely dodge the draft than openly resist it and risk a five year prison sentence. Instead, the men who turned in their cards, many of whom were seminarians and theology students (and many more who were not religious), did so because they saw it as their moral and civic duty to commit civil disobedience. They did not commit draft resistance thoughtlessly. Most came to their decision after months, if not years, of protesting the war through legal channels and, more significant, after lengthy periods of soul searching. The majority of these resisters viewed the war and the draft with a moral clarity that derived in part from earlier civil rights and antiwar work. The civil rights 
activists, especially, felt comfortable confronting authority.

Perhaps most important, the overwhelming majority of draft resisters came from ordinary, middle-class homes. Their parents were not communists, but professionals who lived in the suburbs. Consequently, at the time of the turn-in, most of them held deferments that protected them from the draft; by protesting in this way they risked losing those deferments (as most did) and made themselves subject to immediate prosecution. They chose resistance in part because they believed the country could not tolerate seeing its government lock up the sons of the middle class, particularly if their actions were rooted in a conscientious adherence to values that their parents had taught them were consistent with the best American traditions.

\section{Inflammatory Images}

Some readers of the Boston papers were so outraged by what they saw and read in their daily paper regarding the October 16 events, that they immediately wrote to the editors condemning the protesters. Every single critical letter that the Globe printed (6 letters attacking the resisters were published compared to two supporting them), consistent with their own reporting of the original story, emphasized the burning of draft cards. Central to their themes were issues of patriotism, loyalty, and duty to country. Letters published in the other two papers were similar. The Record American printed only 3 letters, all attacking the antiwar demonstrators, and two of which specifically condemned draft card burning. "All those who participated in the demonstrations," one writer said, "should go to Russia and see how they would like living under Communism." Likewise, the Herald Traveler printed seven letters, all negative, and six of which 
focused on card burnings. "Must the meaning of unity, loyalty, and love of country," one Unitarian woman wrote, "go out the window with the burning of draft cards on a church altar?" Another woman, exasperated, asked the Herald Traveler to run weekly articles about the "nice young people of our wonderful country." She had grown tired, she said, of all the stories about "hippies and draft card burners."7

Another reader, Paul Christopher of Wakefield (a suburb north of Boston), saw photographs of draft cards being burned and became so angry that he decided to organize a rally to demonstrate support for the war. The Boston papers carried numerous stories on the 19 year-old Christopher in the days leading up to the event. Like the letter writers. Christopher emphasized responding to the unpatriotic draft card burners. A promotional leaflet read:

Outward rebukes of our nation's policies with relation to the draft and Vietnam cannot go unchallenged. To be silent when confronted with draft card burning, sit-ins, and other demonstrations only consoles those hippies and others who are bent upon desecration of our great country.

Senator Saltonstall and even the White House called to praise Christopher. Entertainer Wayne Newton offered to sing at the rally. Ultimately, after just two weeks of planning, Christopher hosted a demonstration that brought 25,000 to 50,000 people (estimates varied) to the Wakefield Common where, across the street from a memorial to the "Spanish American War, Philippine Insurrection, and China Rebel Expedition," attendees

${ }^{7}$ Letters, Boston Globe, 21 Oct 1967, p. 6; Letters, Boston Globe, 24 Oct 1967, p.20; Letters, Boston Record American, 20 Oct 1967, p. 34; Letters, Boston Record American, 21 Oct 1967, p. 18; Letters, Boston Herald Traveler, 19 Oct 1967, p. 10; Letters, Boston Herald Traveler, 20 Oct 1967, p. 18; Letters, Boston Herald Traveler, 21 Oct 1967, p. 4; Letters, Boston Herald Traveler, 23 Oct 1967, p. 12; Letters, Boston Herald Traveler, 25 Oct 1967, p. 34; Letters, Boston Herald Traveler, 27 Oct 1967, p. 20. 
waved flags, recited the Pledge of Allegiance, and heard the bells in the Congregational Church across the green play the Battle Hymn of the Republic.

The role of the Boston draft resistance ceremony as a catalyst for this rally should not be overstated, of course; the large Wakefield crowd probably would have turned out for the demonstration anyway. But the rally's speakers made repeated reference to the Arlington Street event. Joseph Scerra, National Commander of the Veterans of Foreign Wars, proclaimed: "All of our young people are not burning up their draft cards. All of our young people are not tearing up the flag. All of our youth are not supporting North Vietnam and carrying Viet Cong flags." As young men in the crowd waved signs that said, "We Will Carry Our Draft Card Proudly" and "Draft the Anti-Demonstrators," Scerra told the crowd. "It's too bad we can't give pictures of what's happening here today to every individual in the country who asks for a pause in the bombing." A photographer captured one man in the crowd kissing his draft card as his sweetheart smiled her approval. Massachusetts Governor John A. Volpe also spoke briefly, and in an obvious reference to draft resisters, said that some Americans were "forgetting their duty and responsibility to their country" and accused them of being unpatriotic. "Patriotism," he said, "may be old fashioned today to some, but it should never be out of fashion." Nearby, an effigy of Ho Chi Minh - holding a gun marked "USSR" - hung from a maple tree with an arrow through its chest and a knife stuck in the back of its head. ${ }^{8}$

8 "Students to Stage Pro-Vietnam Rally," Boston Herald Traveler, 24 Oct 1967, p. 8; "Johnson Hails Wakefield Rally," Boston Herald Traveler, 27 Oct 1967, p. 3; "100,000 Expected for Viet Rally," Boston Herald Traveler, 28 Oct 1967, p. 1; "Rally Boss Paul Bans Birchers," Boston Herald Traveler, 29 Oct 1967, p. 62; "50,000 Hail Red, White 'n Blue," Boston Herald Traveler, 30 Oct 1967, p. 1; "25,000 Shout Support 
In contrast to their coverage of the Resistance events, Boston newspapers openly supported the Wakefield rally: John Sullivan, a columnist for the Boston Record American, revealed that the rally moved him to tears. The Wakefield demonstration, he wrote, "told a nation and a world that we are united and that we are proud and that we are Americans. And we are - you and I - and, by golly, a Wakefield kid proved it." The Boston Herald quoted several high schoolers in the crowd who, like Paul Christopher, were disgusted with the draft card burnings of October 16. They told reporters that they thought resisters were "mostly hippies," "cowards [who] should be drafted"or "banished if they don't want to fight for their country." And the Boston Globe sent a reporter, Alan Lupo, to Wakefield to profile the young man behind the rally. Lupo wrote glowingly of Christopher, describing him as "good-looking," and possessing "maturity uncommon for his age." He also noted that Christopher hoped to join the Special Forces. Despite trying to portray themselves as the heirs of a patriotic American legacy, members of the New England Resistance could not get the kind of media coverage afforded Paul Christopher.' In the decades since the end of the Vietnam War, defenders of American policy have long viewed the media as a "major factor in the United States' failure in Vietnam." According to Clarence Wyatt, one side of this popular perception argues that the press fulfilled the role of a "savior" that "pulled aside the veil of official deception" and led the

of War Effort," Boston Globe, 30 Oct 1967, p. 1; "“We Wanted to Be Heard in Vietnam," Boston Globe, 30 Oct 1967, p. 8.

9 John Sullivan, "Tears Flow at Huge Pro-Viet Rally," Boston Record American, 30 Oct 1967, p. 2; "Teenagers Voice Solid Support," Boston Herald Traveler, 30 Oct 1967, p. 8; “We Wanted to Be Heard in Vietnam," Boston Globe, 30 Oct 1967, p. 8. 
American people to demand an end to the war. On the other hand, others have seen the media as the "villain" that, "inspired by political and ideological biases," intentionally misrepresented the nature and progress of the war, "thus leading the American people to turn their backs on a "noble cause."' If such charges are valid, it follows that the press should have been at least mildly sympathetic to the antiwar movement, and especially to a group of educated, articulate young men who saw themselves as heirs of Thoreau. But as the articles and letters published in the Boston papers demonstrate, the press did little to help draft resisters win a more favorable public view. This was entirely consistent with media treatment of the antiwar movement nationwide. In Covering Dissent (1994), historian Melvin Small shows that "time and time again," the nation's newspapers, magazines, and television networks concentrated on the most "colorful" behavior (which sometimes meant emphasizing violence or some other displays of fringe radicalism) and "ignored political arguments the protesters" leadership presented." Readers of the

${ }^{10}$ Clarence R. Wyatt, Paper Soldiers: The American Press and the Vietnam War. (New York: Norton, 1993), p. 7; Melvin Small, Covering Dissent: The Media and the Anti-Vietnam War Movement, (New Brunswick: Rutgers University Press, 1994), p. 2. See also, Todd Gitlin, The Whole World is Watching: Mass Media in the Making and Unmaking of the New Left (Berkeley: University of California Press, 1980). Gitlin applies Antonio Gramsci's theories of hegemony in explaining the role of the media in covering opposition to government policies. He argues that in a liberal capitalist state, the media, owned by elites and operated by the upper-middle class and middle class college graduates they hire, "quietly invoke the need for reform - while disparaging movements that radically opposed the system that needs reforming." During the Vietnam War, for example, the mainstream press portrayed those young people working on Eugene McCarthy's presidential campaign as "respectable opposition," in contrast to the "radical, confrontational Left." Gitlin's view is consistent with that of Edward S. Herman and Noam Chomsky who use a "Propaganda Model" to argue that the media serves "to mobilize support for the special interests that dominate the state and private activity." The media, through its "manufacture of consent" acts as a propaganda arm of the government. Edward S. Herman and Noam Chomsky, Manufacturing Consent: The Political Economy 
Boston papers learned little about the motivations of the resisters or even that most were giving up the security of deferments to risk prosecution for their beliefs. Mostly, they saw flaming draft cards.

Just why draft cards were burned at all on October 16 is a point worth exploring. In the weeks leading up to the service. and even during the proceedings that day, Resistance organizers emphasized the returning - rather than burning - of draft cards. Most of those who decided to participate in the day's events recognized that by turning in one's card - with the understanding that it would be delivered to the Department of Justice - the government would know the identity of the resister and could take measures to punish him. Burning a draft card essentially destroyed the evidence of one's protest and greatly minimized personal risk. David Clennon later reflected: "I was persuaded that turning them in was the better way to go because it was a way of saying this is who I am, this is where I can be found, and if you are serious about enforcing the laws that you have passed, then come and get me. And so that's what I did..."i

At the same time, however, the Resistance planners made allowances for cards to be burned at the altar. They knew that some men, because they were required to carry two cards (a registration certificate and a classification certificate) at all times, would want to turn-in one card and burn the other. In addition, they did not feel that they could deny those who saw the burning of one's card at the altar as a kind of sacramental act the opportunity to follow through on that belief. Moreover, no one knew how the police or

of the Mass Media (New York: Pantheon, 1988).

"Clennon interview, 12 Jun 1997. 
FBI were going to react to the ceremony. It seemed quite possible that everyone who burned or turned in a draft card could be arrested immediately following the service. Simple failure to carry one's draft card could lead to arrest, in which case it did not matter if the evidence had been destroyed. Finally, for Nan Stone, the only woman to participate in the ceremony, burning a draft card was the only act of protest available. ${ }^{12}$

Perhaps the most persuasive case for burning - but the one that received the least mainstream exposure - came from seminarians and theology students who favored the tactic as "symbolic identification with Buddhist monks and American immolators like [Quaker pacifist Norman] Morrison." Alex Jack, in particular, offered a vigorous defense of card burning on these grounds. "Draft card burning," he wrote in an early position paper, "is designed to challenge and change people's perspectives." Since most American war resisters did not express their protest by setting themselves on fire, destroying one's draft card in this way demonstrated "symbolic understanding and support" for those who did. In addition, burnings were useful in dramatizing American war crimes:

The crime at issue in America is the burning of people, not a piece of paper. Those who enflame the Vietnamese countryside with napalm and white phosphorus and burn down villages and entire forests, not those who put the match to the ticket that stands for their compliance and service of this inhuman system - they are the real non-cooperators.

Jack invoked the historical precedents of abolitionist William Lloyd Garrison's burning of the American Constitution, and the burning of passbooks in South Africa to support his argument that torching symbols of "oppression and inhumanity" have long been judged as

${ }^{12}$ On chance of immediate arrest, see Stone interview, $28 \mathrm{Mar} 1997$. 
acceptable forms of protest. He saw no reason to "abandon the historical significance of fire" just because the Ku Klux Klan burned crosses and the Nazis burned books. ${ }^{13}$

Of course, not everyone agreed. In addition to George Williams, neither Jack Mendelsohn nor William Sloane Coffin approved of draft card burnings. Coffin was quite distressed when the burning of cards began, because he believed it to be "needlessly hostile." He later recalled that, as he stood there accepting cards, he could see Sander van Ocur "pushing his cameraman to zero in on these cards that are in the flame. [I thought], 'Aw, shoot, we lost it." The following week, when many regular members of the Arlington Street Church expressed their unhappiness over the burning of draft cards in their church, Jack Mendelsohn, who had final authority to allow it in the first place, addressed it in his sermon. "It may come as surprising news to some that I react very negatively to the burning of draft cards." he said. "It is too flamboyant for my taste, too theatrical, too self-indulgent." He went on to tell his flock, however, that although he did not encourage the burnings, he did not forbid them either. He decided that because the leaders of the Resistance possessed such a great degree of "integrity and moral depth," he agreed to go along with whatever plan of action they chose. And since they felt compelled by the moral outrage of a minority who would want to burn their cards and "made orderly, respectful provision for it." Mendelsohn permitted it. Therefore, the handout distributed to resisters when they arrived at the church included a "Suggested Procedure" section that said: "Hand your draft card to the clergy member of your choice,

${ }^{13}$ Alex Jack, "The Case For Burning," undated position paper (c. Sep/Oct 1967), AJP; "100 Seminarians and Ministers Turn In 4-D Ministerial Exemptions, New England Resistance Newsletter, 25 Oct 1967, MKFP. 
or, burn it in the altar candle. Make it smooth." That the card burnings were orderly and respectful did not, however, make it into the press accounts. ${ }^{14}$

\section{Children of the American Dream}

For draft resistance organizers, the overwhelming success of October 16 greatly overshadowed the inflammatory headlines. They had pulled off the largest antiwar rally in the city's history, greatly exceeded their expectations in collecting so many draft cards, and were thrilled that a real sense of solidarity seemed to have developed over the course of the day; they had, it seemed, built the foundation for a powerful movement that would not only challenge their government to rethink its policies in Southeast Asia but that likewise dared their fellow citizens to consider the moral implications of tacit acceptance of the war.

When authorities failed to take any resisters into custody immediately following the service at Arlington Street, Resistance organizers went back to their office in Cambridge and began sorting through the collected draft cards. They created a "Master File" that included key information on each resister (since the cards themselves were destined for the Justice Department by the end of the week, most participants filled out a brief form for this purpose). Using these cards, they produced a mailing list so that everyone could stay in touch and begin building the kind of community that Michael Ferber described in his sermon. Fortunately, a sizeable portion of the Master File has survived thanks to Alex Jack, who has held on to it for 30 years. These records are very

${ }^{14}$ Coffin interview, 28 Aug 1997; Jack Mendelsohn, "The Church and Draft Resisters,"sermon, 22 Oct 1967, Archives of Arlington Street Church; "67 Burn Draft Cards in Boston," Boston Globe, 17 Oct 1967, p. 12. 
revealing in beginning to construct a kind of group biography of rank and file draft resisters.

First, it is important to note that. in standard Movement fashion, the chore of typing up index cards with pertinent information for each resister fell mostly to the one woman working in the office, Nan Stone. In 1967, even organizations dedicated to principles of fairness and equality continued to exhibit sexist tendencies. In Boston, not only did a considerable debate develop over Stone's participation in the October 16 service, but in the week that followed. male organizers argued over Stone's status again, disagreeing on whether or not an index card with her name on it should be kept in the Master File of resisters. What did one have to do to be considered a "resister?" As a woman she could not be drafted, but as a Resistance organizer she had been complicit in "aiding and abetting" violation of Selective Service laws. Furthermore, she had clearly broken the law when she burned that draft card at the aitar. In the end, it took the appearance of FBI agents - then investigating all of the October 16 resisters and showing interest in Nan Stone at the same time - for Stone's index card to find a place in the Master File. ${ }^{15}$

The Master File that Stone created shows that most of the men who resisted on October 16 were white college and graduate school-age men - educated at some of the more prestigious schools in New England - who were willing to give up the security of

${ }^{15}$ Stone interview, 28 Mar 1997; see also Sara Evans, Personal Politics: The Roots of Women's Liberation in the Civil Rights Movement and the New Left (New York: Vintage, 1979), pp. 179-185; and Barrie Thorne, "Women in the Draft Resistance Movement: A Case Study of Sex Roles and Social Movements," Sex Roles 1 (1975), pp. 179-195. 
the draft deferments assigned by their draft boards. The average (and median) age of the men who turned in their cards in New England that fall was 22. Students made up 76 percent of the resisters who took part, with the largest contingents coming from Harvard, Boston University, and Yale. The Selective Service classifications assigned to these students varied, however (Appendix A, Table 4.1). 49 percent were classified either 2-S (the standard student deferment) or 4-D (the deferment for ministers and divinity students). Most telling, though, is that only $17.5 \%$ of resisters were classified l-A, available for military service. Therefore, at least 82 percent of the men who resisted in Boston risked their deferments by breaking the law, an important detail never reported to the public by the media. ${ }^{16}$

What the draft cards that were collected could not say was that the resisters who returned them were children of the American Dream. This is apparent from a 1997 survey administered to former resisters and resistance activists. For the most part, they grew up in comfortable homes, raised by parents who were better educated than previous generations and who worked at professional careers. Nearly $50 \%$ of resisters' fathers

${ }^{16}$ New England Resistance Master File, papers of Alex Jack (hereafter AJP); The Master File that has survived is not complete. The extant version includes 203 resisters from October 16 and 59 others from three smaller turn-ins between November 16, 1967 and January 29, 1968. Significantly, it contains no names from the one other major Boston draft card turn-in of April 3, 1968. Of 262 records, 215 include the age of the resister. The average age is 22.3 years old and the median age is 22 . Of 226 resisters for whom an occupation was listed, $173(76.5 \%)$ were students. They attended a total of 31 schools, but 45 (26\%) came from Harvard, 33 (19\%) from Boston University, and 26 (15\%) from Yale. No more than 8 students came from any other single school. Statistics gleaned from the 1997 survey of resisters roughly confirm these figures. Of 121 resisters who responded to the survey, the average age was 23.2 years old; the median was 23 . 89 (73.6\%) of the 121 were students, $24.7 \%$ of whom came from Harvard, $16.9 \%$ from BU, and $14.6 \%$ from Yale. 
graduated from college with a total of $37 \%$ going on to graduate school; $22 \%$ held professional (M.D., J.D., etc.) or doctoral degrees (Table 4.2). 40 percent of resisters' mothers were college graduates with 15 percent possessing advanced degrees. These educational achievements meant that most resisters' fathers (70\%) held professional jobs as physicians, attorneys, accountants, engineers, academics, scientists, and ministers, etc., or ran their own businesses as real estate and insurance brokers or another kind of small business proprietor (Table 4.3). Not surprisingly, more than half of their mothers were homemakers but another nearly 30 per cent held professional positions (most as teachers, librarians, and nurses). Nearly 80 per cent of resisters in Boston identified themselves as coming from middle class $(44 \%)$, upper middle class $(33 \%)$, or upper class families $(2 \%)$ (Table 4.4). This, they believed, was their greatest strength: they came from families that were quite ordinary. They grew up in the years following the Second World War as children of a burgeoning middle class and lived in middle class neighborhoods all across America. They were the boys next door.

The men who resisted the draft in Boston also do not seem to have been bred for this kind of activism any more than other middle class children. Although most resisters identified their parents ( $84 \%$ of fathers and $91 \%$ of mothers) with one or another religious denomination (Table 4.5), none were members of the historically pacifist (and antiwar) sects such as the Quakers or Mennonites. Four of the resisters themselves were Quakers. but had not been raised so. In fact, 40 percent of them came from homes in which one or both of their parents were veterans of the Armed Forces and many of whom had seen combat duty during World War II (Table 4.6). Most significant, however, is that few 
resisters' parents ever took part in any kind of social activism or protest themselves. Only 25 percent of Boston's resisters grew up with a parent who had a history of activism, including only $15 \%$ with a union member for a parent. ${ }^{17}$

If, as Polish Freedom Figher Josef Mlot-Mroz believed, the draft resisters had been "duped" by "Reds," it is clear that it did not happen under their parents' roofs. While many draft resisters saw themselves as members of the New Left, they were not "red diaper babies," that is, children of Old Left communists. Indeed, the majority of resisters' parents were Democrats and the rest Republicans (Table 4.7). Of 121 resisters surveyed, only five identified both of their parents as either socialist, communist, or anarchist (Table 4.8). In 80 percent of resisters' homes. both parents belonged to the same political party; ${ }^{18}$ the vast majority $(62 \%)$ were Democrats. Thus, by challenging the draft and Lyndon Johnson's foreign policy, most resisters confronted an administration voted into office by their own parents. Even among the resisters, 46 percent called themselves Democrats; less than 2 percent were Republicans (Table 4.7). That said, it is true that a significant minority of resisters (39\%) thought of themselves as either socialists, communists, or anarchists. Yet it is apparent that this did not mean that these New Leftists were hell-bent on revolution. Actually, only about 20 percent of them felt

${ }^{17}$ From the 1997 survey of Boston draft resisters: Out of 121 respondents, 31 (25.6\%) indicated that they had at least one parent who participated in some form of social activism or social protest before they (the resister) got involved with draft resistance. This includes $18(14.9 \%)$ resisters who had a parent who was a union member.

18 Out of 121 draft resisters, 113 listed political affiliation of both parents. Thus, the $80 \%$ figure was calculated by dividing 90 (number of couples with the same political leanings as shown in Table 4.8 ) by $113=79.6 \%$. 
comfortable with radical labels like "revolutionary" or "politico." Rather, more than two thirds of Boston's draft resisters saw themselves as "activists." Most felt very American and like Michael Ferber, "fully engaged in a big struggle with my country...having what Coffin always called 'a lover's quarrel with my country." This distancing from their parents' political ideology no doubt originated in some of their earlier social activism, not a love of the Soviet Union. ${ }^{19}$

For the overwhelming majority of the Boston draft resisters, the decision to join the Resistance followed an earlier track record of participation in protest movements. Three fourths of them had a history of prior activism including working with campus or community peace and civil rights organizations. More than half of the resisters in Boston (50.4\%) had been involved in either campus or community civil rights work. Likewise, 53 percent worked in either campus or community peace efforts before coming to the Resistance. A smaller number of these men, 15.7 percent, worked on Vietnam Summer in the months before October 16. In addition, even though the official SDS line remained dubious on the value of draft resistance, 30 percent of the resisters in Boston were present or former members of that organization. Such experiences helped to demystify civil disobedience and going to jail for many. Michael Ferber, who had spent a night in jail during the civil rights movement. noted that by the time he helped launch the New England Resistance, he "no longer cared that [he] had an arrest record." "Some of the

${ }^{19}$ From the 1997 survey of Boston draft resisters: Resister labels: Out of 121 resisters, $25(20.7 \%)$ saw themselves as "politicos," 25 (20.7\%) saw themselves as "revolutionaries," and $82(67.8 \%)$ saw themselves as "activists." 
finest people in America," he said, "are now getting arrested for one thing or another."20

These figures notwithstanding; the statistics still peg nearly one quarter of Boston's resisters as men who were participating in a protest movement for the first time. And although more than half of the men who turned in or burned their cards knew friends in the movement, 45 percent did it on their own and knew no one else among the hundreds who resisted with them. These individuals were so highly motivated by their outrage regarding the war that they were willing to take the risky step of defying the draft to make their protest. And they did it all by themselves."

For weeks, Resistance leaders tried to make plain the degree of potential peril that participation in the October 16 service might bring. Leaflets included warnings that turning in one's card could result in arrest and, if found guilty of breaking Selective Service laws, a possible five year prison sentence and a $\$ 10,000$ fine. They hoped that no one would turn in or burn his card without having thought it through completely, in advance, in the cool light of reason and not in the emotional atmosphere of the ceremony

${ }^{20}$ From the 1997 survey of Boston draft resisters: Activist backgrounds of resisters: Out of $121,61(50.4 \%)$ had been involved with civil rights on either campus and/or in their communities, $64(52.9 \%)$ had been involved with peace issues either on campus and/or in their communities, and 19 (15.7\%) had participated in Vietnam Summer on campus and/or in their communities. Out of 121 resisters, $36(29.8 \%)$ were members of SDS; Ferber interview, 10 Feb 1997. See also, Staughton Lynd, "The Movement: A New Beginning," Liberation, May 1969, p. 14. Lynd theorizes that much of the connection between civil rights and the Resistance derived from white radicals being forced out of civil rights with the onset of the Black Power movement: "We were looking for something white radicals could do which would have the same spirit, ask as much of us, and challenge the system as fundamentally as had our work in Mississippi."

${ }^{21}$ From the 1997 survey of Boston draft resisters: 29 out of 121 resisters (24\%) had no previous activist or protest experience. 66 resisters out of 121 respondents (55\%) had close friends in draft resistance when they got involved; $55(45 \%)$ did not. 
itself. For the most part, they were successful in this. More than half of Boston's resisters $(54 \%)$ planned in advance to turn in or burn their draft cards. An additional onethird said they had been considering resistance carefully in the weeks before they did it, but only decided to turn in their cards on the day of the event. Therefore. only 13.4 percent spontaneously turned in or burned their cards in the heat of the moment. In some ways, organizers were unrealistic in expecting that no one would resist on the spur of the moment. The quality of the speakers assembled at each turn-in, coupled with the atmosphere of a church (as on October 16), made these services a little like revival meetings. Some could not help having, as Alex Jack described it, "a conversion experience." For example, Bill Bischoff, a Harvard graduate student in history and a veteran, recalls that the array of passionate, reputable speakers assembled on October 16 made him think of it as a kind of test of his commitment to protesting the war. "Well," he thought to himself, "I don't know how I can stay out of this when I feel as strongly [about the war] as I do." Similarly, Harold Hector, a leader in the Boston Draft Resistance Group and one who did not advocate risking jail through open confrontation with the Selective Service, turned in his card on the same day. He did it because it was "one of the most moving days" of his life, so moving that he thought he "would have done anything that day." "I could not not turn it in," he said. "I couldn't walk out of there with my card in my pocket... You knew there were FBI agents up in the balcony; I felt like I wanted to wave it under their nose - that's how I felt that day....there were moments when you just 
couldn't hold back." 22

The vast majority of resisters, though, came to their decisions after long periods of careful consideration. Just as William Sloane Coffin, George Williams, and Michael Ferber had criticized and protested the war through other more moderate means in previous years, many of the resisters now felt that the time for civil disobedience had arrived. As Coffin noted, for each person, a time arrives when,

having done everything legal, you really have to decide...you've done what you could, so you can now tuck your conscience into bed, and sort of move on. Or you can say, 'alright, we've exhausted the legal possibilities'...so, you have to look into possibilities of civil disobedience, which challenge the injustice of the law and it's a way of...being more dramatic about calling attention to the horrors of whatever you're opposing. $^{23}$

Draft resisters had marched. They had written letters and attended teach-ins. They had protested more than most of the war's opponents and they did not want to tuck their consciences into bed. Instead, they chose to act in the strongest way they knew, short of violence, to protest the inequities of the draft and what they believed to be the illegality and immorality of the war in Vietnam. In making the emotional, life-altering decision to resist the authority of their government, resisters justified and rationalized their acts using moral and political arguments.

${ }^{22}$ From the 1997 survey of Boston draft resisters: Out of 112 respondents, 15 men (13.4\%) say they turned in or burned their cards spontaneously; 37 men $(33 \%)$ say they had been considering turning in their cards beforehand, but only decided to actually do it when the moment arrived; meanwhile, 60 men (54\%) did not resist spontaneously at all: they had made their decisions to resist in advance; Jack interview, 21 Mar 1997; Bischoff interview, 5 Jan 1998; Hector interview, 9 Apr 1997.

${ }^{23}$ Coffin interview, 28 Aug 1997. 
First, most resisters recognized the potential political impact of widespread draft resistance. They aimed to make the government face the prospect of jailing thousands of middle class sons in order to continue on the same course in Vietnam, and they gambled with their own freedom believing that enough men would join them and the costs of the war would become too high to continue the war. The greatest cost, one resister argued, would be "the criminalization of large numbers of elite college students - future 'leaders," Eventually, they believed, "upright, respectable, middle class citizens," the kind who were potentially influential. would not stand for too many of their children going to prison. ${ }^{24}$

More important, draft resisters - both leaders and the rank and file - recognized their place within society, within the system of conscription, as symptomatic of an existential dilemma that needed to be addressed. Instead of being asked to serve in the military alongside their less fortunate fellow citizens, many of them were being protected through an unfair draft apparatus. As working-class and minority men died each day in rice paddies and jungles on the other side of the world, they breathed in the aroma of the drying leaves then blanketing the grounds of their picturesque New England campuses. They felt guilty. Most holders of deferments could live with that guilt. ${ }^{25}$ But those who would resist the draft could not ignore it or the reality that their own sense of good and evil, morality and immorality, spawned that guilt. Many of them, therefore, committed

${ }^{24}$ Respondent Number 40, 1997 survey of Boston draft resisters; Daniel Brustein, interview with author, 30 Dec 1997.

${ }^{25}$ For a notable exception, see the outstanding essay by James Fallows: "What Did You Do in the Class War, Daddy?, The Washington Monthly, October 1975. 
themselves to the risky business of openly defying their elected government out of a sense of personal integrity and a deep sense of morality. For Michael Zigmond, a 26 year old postdoctoral fellow at MIT, the decision to resist resulted from "at least equal parts trying to be more effective and just trying to get the weight off." Zigmond, who attended the October 16 service but did not return his card until the following month, felt a "need to respond somehow and also to basically come out of the closet from being this protected...kind of person." He felt like his draft card "was getting very heavy...it was really heavy," and the opportunity to resist relieved the moral strain of keeping it. Similarly, David Clennon felt like he had to "do something personally to help to end the war."26

Many resisters report similar experiences of agonizing over their decision to resist and then being overwhelmed with emotions at the moment of resistance. For Larry Etscovitz, a 21 year old junior at Boston University, October 16, 1967 became the culmination of two years of anguish over the Vietnam War. Since entering BU with a deferment in 1965 , he and many of his friends had grown more and more involved. emotionally and intellectually, with the war. The war "was just getting worse and worse," he said. "After a while, it. was the only thing any of us talked about." On October 16 he went to the Common because he had heard that a huge antiwar rally was scheduled and that Howard Zinn, the BU professor, would be speaking. Despite Resistance publicity, he did not know about the scheduled draft card turn-in. When Zinn finished his speech and Jun 1997.

${ }^{26}$ Michael Zigmond, interview with author, 29 Dec 1997; Clennon interview, 12 
told the resisters where to line up, Etscovitz, not fully aware of what this meant, simply thought, "Yes, I'm a resister. Ok, I'm going to line up over there." He marched with the group to the church and took a seat in one of the forward pews. "Even then," he said, "I had no idea or knowledge or intention of taking my draft card out; I felt I just needed to be there and be a part of this event." But when the call was made, Etscovitz turned in his draft card. He was scared but resolute. "Everything was leading up to this moment and...this is the moment when I was going to let my voice be counted. Up until that moment, whether I was at a demonstration or not, was not a matter of record. I wanted it to be a matter of record, that I was there...That was my protest." When he caught a ride back to BU with some friends, one of them, a woman, told him: "Today, you are a man."27

Like Etscovitz, many draft resisters later saw the moment of their turn-in as a kind of rite of passage into manhood. In resisting the draft publicly, they overcame tremendous anxieties and fears stemming from the unnatural act of openly defying the will of one's government. They were, after all, middle class children, raised in an era of confidence and taught to revere the promise of the American Dream. But suddenly that Dream seemed tainted by a war they found repulsive. James Oestereich, a seminarian at Andover Newton Theological Seminary recalls debating the merits of draft resistance with one of his professors while taking a Green Line trolley car from Newton Centre on the way to the service at Arlington Street. Oestereich emphasized to his mentor that by turning in his card he would be making a statement, and that was what mattered. "I mean

${ }^{27}$ Larry Etscovitz, interview with author, 12 Aug 1997. 
I was definitely taking a step to criticize my government." Despite his firm belief that he planned to do the right thing that afternoon, he could feel the knots in his stomach tighten as they got closer to downtown. The prospect of challenging the authority of one's government chilled him. "It's hard," he later said. "You know, we know how to pay our taxes...but we don't know how to oppose our government in a way that's responsible and that will be listened to. None of us knew that." When he walked up the aisle toward the Rev. Coffin, draft card in hand, he felt his emotions swirl unexpectedly around him. On the one hand, he felt strongly that through this act he was saying, "whatever this movement is, I'm in...I'm not going to read about it, I'm not going to be this isolated sort of graduate student on the hill; I'm in." At the same time, though, he could not ignore the gravity of the act. "When I dropped that card in the tray...I really just had a very emotional reaction to it. I was very moved at what we were doing. It hit me just that, my God, this is important. I don't think it was fear or anything, I was just very emotional about it. [ had a lot of tears in my eyes." 28

Others simply felt fear. On October 16 , no one knew what would happen to those who chose to resist the draft. "We knew that the faster the movement grew, the better off we'd all be," explained Bill Hunt. "But if you found yourself out there, you know, just a handful of us out there alone, that was going to be a lonely experience." Very few draft resisters knew what it would be like to experience the full force of the government's law enforcement powers. Some had been arrested at other peace and civil rights demonstrations, but at their worst, those resulted in minimal fines. Those choosing

${ }^{28}$ James Oestereich, telephone interview with author, 20 Dec 1997. 
resistance knew that the penalties for not cooperating with the Selective Service, if enforced, would be severe. "So it wassn't a lark," recalled Hunt. "It wasn't something people did as a gag." Years later, William Sloane Coffin echoed Hunt as he reflected on the resisters he encountered. "I was very moved by the seriousness with which they were organized, the seriousness with which they took their actions," he said.

This wasn't something they decided to do when they were high on dope or something like that. They were very conscientious. And there were some very fine students in the group. These weren't the far Left or the flakiest at all. So I was impressed by the quality.... What was courageous about them is that they had an out (staying in college) and they refused to take the out. And that was really fine. ${ }^{29}$

Critics of the sixties generation and the antiwar movement, in particular, have been successful in using stereotypes of smaller, radical Movement minorities to portray the whole Movement. but it would have been difficult for an observer of the October 16 rally on Boston Common and the service at Arlington Street Church to confuse the assembled protesters with the hippies, Yippies, and Weathermen that dominate those histories. ${ }^{30}$ True, a significant number of resisters (50\%) thought of themselves as members of the "counterculture" - undoubtedly because they grew their hair longer than their fathers', listened to Bob Dylan, and smoked an occasional joint - but far fewer called themselves "hippies" (16.5\%). Similarly, although the majority of resisters claimed

${ }^{29}$ Hunt interview, 31 Oct 1997; Coffin interview, 28 Aug 1997.

${ }^{30}$ For critical appraisals of the sixties generation and the antiwar movement, see Peter Collier and David Horowitz, Destructive Generation: Second Thoughts About the 60s (New York: Summit Books, 1989); and Adam Garfinkle, Telltale Hearts: The Origins and Impact of the Vietnam Antiwar Movement (New York: St. Martin's, 1995); see also Stephen Ambrose, "Foreword," in Garfinkle, Telltale Hearts. 
membership in the New Left (66\%), only one fifth of them felt like "revolutionaries." As historian David Farber has argued, the myths that portray antiwar protesters as either stoned hippies or dupes of an international communist conspiracy - both "officially promoted by guardians of the standing order" - die hard in America. At least in Boston, draft resisters did not fit either stereotype. ${ }^{31}$

The men (and woman) who chose to resist the draft rather than submit to it or "dodge" it do not seem to fit the traditional perceptions about Vietnam era antiwar protesters. They came from stable homes, had parents who were professionals and who had inculcated their children with mainstream, not radical, political ideas. They were, themselves, well-educated and often in the process of pursuing graduate degrees. As a result, most were protected from the draft and, like millions of beneficiaries of an unfair Selective Service System, could have ignored both the war and the draft. Before 1967, many resisters gained experience in other types of social protest, including the Civil Rights Movement. Just as civil rights leaders sought nonviolent moral confrontation with state and federal authorities, draft resisters hoped to use similar tactics in confronting what they saw as a war machine out of control in Southeast Asia. Also like civil rights leaders, members of the New England Resistance, because of the efforts of certain organizers, created a unique blend of religious and political rationales for their work. In

"From the 1997 survey of Boston draft resisters: Out of 121 resisters, 60 (49.6\%) saw themselves as part of the counterculture, and $20(16.5 \%)$ saw themselves as "hippies" at the time they resisted the draft. Likewise, $25(20.7 \%)$ saw themselves as "politicos," and $25(20.7 \%)$ as "revolutionaries." $80(66.1 \%)$ considered themselves members of the New Left. David Farber, "The Counterculture and the Antiwar Movement," in Melvin Small and William D. Hoover, eds., Give Peace A Chance: Exploring the Vietnam Antiwar Movement, (Syracuse: Syracuse University Press, 1992), p. 21. 
the days and weeks that followed October 16, resisters would be faced with the reaction of the federal government and with the task of sustaining a movement that burst onto the Boston antiwar movement like a supernova but which might easily be snuffed out in the face of official pressure. 


\section{CHAPTER V}

\section{UNEASY WAITING: DRAFT RESISTERS AND THE JOHNSON ADMINISTRATION}

What really prevents the great majority from refusing to take part in military service is merely fear of the punishments which are inflicted by the governments for such refusals. This fear, however, is only a result of the government deceit. and has no other basis than hypnotism.

Leo Tolstoy, "Carthago Delenda Est," 1899

On October 20,1967, four days after Boston's most stunning antiwar demonstration to date, Michael Ferber delivered the draft cards collected at the Arlington Street Church (along with the charred remains of those burned) to the United States Department of Justice in Washington. Early that morning, 500 draft resistance activists from across the country gathered at the Church of the Reformation at 212 East Capitol Street in anticipation of the march to Justice. Like Ferber, other resisters brought draft cards with them from ceremonies held on October 16.

Many older advisers joined them. including William Sloane Coffin, Benjamin Spock, Mitch Goodman, Robert Lowell. and Dwight MacDonald. After marching the mile and a half to their destination, they arrived to find three rows of policemen, outfitted in helmets and other riot gear, guarding the building's massive bronze doors. Across the street a crowd of reporters and photographers jostled one another for the best viewing positions. Once again, Coffin filled the role of featured speaker. On the steps of the gleaming white building, he spoke into a bullhorn, telling the crowd and the mass of reporters that he and other older supporters intended to "aid and abet" draft resisters in 
every way possible. - To stand up in this fashion against the law and our fellow Americans is a difficult and even fearful thing," he said, echoing some of the themes in his Arlington Street sermon. "But in the face of what to us is insane and inhumane. we can fall neither silent nor servile." He stressed that the resisters and their supporters, many of whom were veterans. felt the "highest sympathy" for the men fighting in Vietnam and their families at home, but he asked those who backed the war out of loyalty to their "sons or lovers or husbands" in Vietnam to understand that "sacrifice in and of itself confers no sanctity." -"There can be no cleansing water," he said, "if military victory spells moral defeat. ${ }^{-1}$

Mitch Goodman then issued the call for draft cards. Young men from within the crowd walked up the stairs of the Justice Department, stated their names, announced the city or college that they represented. and told how many cards they carried on behalf of their fellow resisters. Each then turned to the tall man holding a plaid fabricoid briefcase open before them. Dr. Spock. wearing his trademark three-piece suit, smiled as the men took turns dropping the retumed Selective Service documents into the satchel that he held in his hands. Norman Mailer. the novelist who later won a Pulitzer Prize for Armies of the Night, his book chronicling the events of this weekend in Washington, stood in awe of the number of draft cards put in the bag and especially of the young men doing it:

As these numbers [of draft cards collected] were announced, the crowd...gave murmurs of pleasure, an academic distance from the cry they had given as children to the acrobats of the circus. but not entirely unrelated, for there was something of the flying trapeze in these maneuvers

' William Sloane Coffin, Once to Every Man, pp. 247-248; Norman Mailer, Armies of the Night (New York: Signet, 1968), p. 86. 
now; by handing in draft cards, these young men were committing their future either to prison. emigration. frustration. or at best. years where everything must be unknown, and that spoke of a readiness to take moral leaps which the acrobat must know when he flies off into space - one has to have faith in one's ability to react with grace en route, one has, ultimately, it may be supposed, to believe in some kind of grace.'

For the Resistance representatives and their supporters. the time to confront their government, their moment of truth, had arrived. Although every resister had taken the personal step toward outright resistance on the sixteenth, their identities remained unknown to those in power - until now. When the line of resisters finished, Spock's briefcase held 994 draft cards from across the country. To complete whar Alex Jack later called the "largest collective act of civil disobedience in modern American history," the cards needed only to be delivered to United States Attomey General Ramsey Clark. ${ }^{3}$

A small group of resisters and supporters. including Spock, Coffin. Marcus Raskin, Arthur Waskow, and Bay area resister Dickie Harris. thus entered the Justice Department building. There they hoped to be greeted by the attorney general himself. An escort led the group down a long hall to a conference room where. instead of finding Ramsey Clark. they were introduced to Assistant Deputy Attorney General John McDonough and John Van de Kamp, the deputy director of the Executive Office of U.S. Attorneys. Clark, it turned out, decided to send McDonough in his stead because he believed that receiving "evidence of potentially criminal conduct." would be irresponsible and "not the role of the attorney general." McDonough, on leave from his teaching post

${ }^{2}$ Mailer, Armies of the Night, pp. 88-90.

${ }^{3}$ Alex Jack, "Press Ignores Trial Issue," Boston Free Press, undated (c. 11 Jul 1968), p. 11, Papers of Rob Chalfen (hereafter cited as RCP). 
at Stanford Law School, had joined the Department of Justice only six weeks before.

Although he greeted the group cordially. he disagreed with their tactics. Specifically, McDonough thought that the "solicitation" of young men to resist the draft "was not appropriate behavior." and. more generally, he saw civil disobedience as a precursor to "anarchy."»

After offering coffee to the group. McDonough told them that he represented the attorney general in this meeting, and that Clark had instructed him to report back to him on the substance of the discussion. He then recorded the names and addresses of each visitor. He sat through brief statements made by each protester and conspicuously ignored Marc Raskin when he asked if the Justice Department planned to investigate alleged war crimes in Vietnam. Years later. McDonough acknowledged that he did not "undertake to discuss with them on the merits of the points which they raised:" he simply wanted to make an accurate report to Clark. Finally, after being subjected to an intense "rap" by the flamboyant Harris, McDonough pulled a piece of paper from his pocket and read a brief statement warning the group that they might be breaking the law. Then. he began an unusual verbal tango with Coffin. He turned to the Yale chaplain and asked,

+ John McDonough, interview with author, 3 Jun 1998. McDonough explained his skepticism about the value of civil disobedience in this interview: "I am skeptical, quite skeptical, about civil disobedience. You see, its logical consequence has to be anarchy. Now, one says, "well, but this is only small, only relates to this particular matter, whether it's abortion or something else, and we, because we hold this set of views, are entitled to disobey the law because we hold those views of our own, are superior morally to the law, and command our first allegiance.' There's no logical stopping point for that, so I find it difficult intellectually to defend it. However appealing the cause may be, it is, I would think, justified only under the most extreme circumstances - not likely to occur in our society." 
"Am I being tendered something?"

"Tendered something?" Coffin responded.

"Yes, tendered something."

Coffin suddenly understood. "Yes, Mr. McDonough," he said, "you are herewith being tenderly tendered these draft cards and supporting statements." and he held the briefcase out for the assistant deputy attorney general. Perhaps McDonough thought that, after the reading of the draft law, the group would take their fabricoid briefcase and go home.

When they did not, he refused to accept the bag. Indeed. according to Coffin, he nearly recoiled. Coffin tried again, but McDonough kept his hands in his lap. Coffin later recalled that when he finally put the briefcase down on the table in front of McDonough. the assistant deputy attorney general "stared back as though it contained hot coals."

Such accounts of McDonough's response are probably exaggerated. for although Ramsey Clark later speculated that participation in this meeting made $\mathrm{McD}$ Donough uncomfortable, the Stanford legal scholar knew what he was doing. As John Van de Kamp understood, McDonough refused to accept the cards because he "did not want to give countenance to the turn-in of draft cards." To do so only would have encouraged more protesters to seek meeting with the attorney general for similar purposes. ${ }^{6}$

Nevertheless, on this day, the activists were nonplused. Even after Arthur Waskow exploded, demanding that McDonough fulfill his duties as a law enforcement

${ }^{5}$ Wells, The War Within, pp. 194-195; Coffin. Once to Every Man. pp. 247-251; McDonough interview, 3 Jun 1998.

${ }^{6}$ Ramsey Clark, interview with author, 29 Apr 1998; John Van de Kamp, interview with author, 9 Jun 1998. 
officer (and collect the evidence of a probable crime), McDonough did nothing. Disgusted, the activists left the building to tell the crowd what had happened. As they walked down the hall to the door. two FBI agents burst into the conference room and scooped up the fabricoid briefcase. The following week, FBI agents began their investigations of draft resisters by swarming down on college campuses across the country, including Harvard, Yale, and Boston University. The government, it appeared, had taken an interest in the resisters' protest.'

The Johnson administration had been aware of opposition to the war for some time; they had seen the marches and demonstrations. Some cabinet members (Robert McNamara, for instance) had been targeted personally by these protests. But the episode at the Justice Department marked a new phase of antiwar protest and a new challenge to the administration. For the first time. the antiwar movement brought their protest to the seat of power and confronted the administration directly. Just as resisters raised the personal stakes for opponents of the war. their mass civil disobedience likewise upped the ante for the administration. Now, the White House could no longer ignore the antiwar movement. The president's men would have to act. The Resistance counted on it.

Draft resisters soon learned. however, that the government's response would not be as quick and decisive as they imagined. Just as John McDonough surprised the Resistance emissaries with his reaction to them at the Justice Department, the administration did not follow the course most resisters believed - and hoped - it would

'Wells, The War Within, pp. 194-195; Coffin, Once to Every Man, pp. 247-251; McDonough interview, 3 Jun 1998. 
follow. Most expected to be arrested, perhaps swiftly. once the government received their draft cards, the evidence of their crimes. But their showdown with the administration did not work out that way.

This chapter follows the reaction of President Johnson and his advisers to draft resistance in the two months following October 16. It charts the disagreements between key administration officials that contributed to an ambivalent, sometimes conflicted response. This uneven and inconsistent reaction. to the extent that it was tangible to outsiders, caught the Resistance off-balance; as the FBI investigated resisters and local draft boards moved to punish some of them, the Resistance scrambled to respond - while still anticipating arrests or indictments. Ultimately. the chapter demonstrates that in the weeks after October 16, resisters and the administration engaged in a kind of uneasy dance, like two prize fighters sizing each other up in the first round; as each side tried to evaluate the other, both showed signs of uncertainty regarding their next move. The confrontation the resisters sought, therefore, simmered a while before reaching full boil.

\section{All the President's Men}

News of the meeting at the Justice Department infuriated the president of the United States. At 7:30 that evening, Lyndon Johnson pulled Joseph Califano, his top assistant for domestic affairs, into the Oval Office. Next to the president's desk, a teletype machine pumped out wire reports from news organizations. Obviously agitated, Johnson tore off the United Press International report from the tape spitting out of the machine. He read the news to Califano that nearly 1,000 draft cards had been left at the Justice Department. "I want a memo to the Attorney General tonight," he told Califano. 
"I want the FBI investigating." Soon after, attorney general Ramsey Clark received a terse memo from the president:

With reference to reports that several individuals turned in their draft cards to an official of the Department of Justice this afternoon. I would like you to inform me promptly. as well as periodically, thereafter, concerning:

- The progress of investigations by the Federal Bureau of Investigation of any violations of law involved.

-- Steps you are taking to prosecute lawbreakers in accordance with established procedures.

It is important that violations of law be dealt with firmly, promptly, and fairly.

\section{LBJ}

On separate copies of the same memo sent to J. Edgar Hoover and Lewis Hershey, the president wrote, "I want you to be personally responsible for keeping me informed on this." Johnson did not know that, a few hours earlier. at 4:30 p.m., John McDonough and John van de Kamp. head of the Executive Office of U.S. Attorneys, had already handed over the briefcase full of draft cards to FBI agents. The following day. a teletype went out to all FBI field office Special Agents in Charge instructing that individual cases be opened up on each person who turned in his card. "Indices are to be searched, respective Selective Service files reviewed. and registrants interviewed...," the memo said. The battle had been joined. ${ }^{\mathrm{s}}$

Meanwhile, Johnson and his administration focused on a more pressing matter: the march on the Pentagon scheduled for October 21. The National Mobilization to End

${ }^{8}$ Joseph Califano. The Triumph and Tragedy of Lyndon Johnson (New York: Simon and Schuster, 1991), pp. 198-199; Memo to Ramsey Clark from LBJ, 20 Oct 1997, WHCF, IL, Box 26, LBJL; Melvin Small, Johnson, Nixon, and the Doves, New Brunswick: Rutgers University Press, 1988), p. 113; FBI memo, 23 Oct 167, William Bischoff's Freedom of Information Act papers, author's files; FBI teletype, 21 Oct 1967, Bischoff FOIA papers, author's files. 
the War in Vietnam (Mobe), had organized the protest under the direction of David Dellinger. In addition. Dellinger recruited Jerry Rubin to be program director. In hoping to fuse antiwar activism with countercultural flair, Rubin publicized the march by announcing plans to levitate the Pentagon. The Administration feared much worse. Some advisers believed that coordinators of the event planned to encourage rock and eggthrowing at the windows of the Pentagon, and possibly breaching the massive building's security through basement windows. Defense Secretary Robert McNamara suggested on October 3 that the president might consider being somewhere other than Washington on the day of the march, but Johnson responded. "they are not going to run me out of town!"s

The president did feel sufficiently concerned, however, to ask Ramsey Clark for daily updates on plans for the demonstration. For his part, Clark assigned the responsibility of planning for the event to his deputy. Warren Christopher. By 8:00 p.m. every night for the next two weeks. reports from the Justice Department appeared on Johnson's desk. He read not only of the administration's preparations for the march, but also details of the protesters' plans, including who would speak at various locations. details on the Mobe's leadership. and their ties to other organizations. Although the president spent most of the day of the march in the Rose Garden, fashioning for reporters an image of a chief executive with a full schedule of meetings (and with only a slight interest in the demonstrations), Joe Califano fed Johnson frequent updates on the progress

9 Memo to Ramsey Clark from Walter Yeagley, Asst. AG, 3 Oct 1967, attached to memo from Clark to LBJ, 4 Oct 1967, personal papers of Warren Christopher, Box 8, LBJL 
of the protests throughout the day and night. ${ }^{10}$

The president learned that perhaps as many as 100,000 people congregated in front of the Lincoln Memorial that day to hear speeches condemning his policies in Vietnam. It constituted the most significant antiwar demonstration in the nation's capital to date. Although the rally and the march that followed it did not have any direct ties to the draft resistance movement. the rhetoric used by speakers that day reflected the influence of October 16. - This is the beginning of a new stage in the American peace movement." David Dellinger told the crowd, "in which the cutting edge becomes active resistance." $" 1$

But if organizers intended to send a message of "active resistance," it got lost in the media's attention on the clash between marchers and the federal troops assigned to protect the Pentagon. As approximately 35.000 marchers approached the Pentagon from the Arlington Memorial Bridge following the earlier rally, they could see that U.S. marshals and Army regulars surrounded the building. It marked the first time since the Bonus March of 1932 that the federal government called out the armed forces to protect itself against its own citizens. Almost everyone in the crowd assembled in the Pentagon 's north parking lot, a space for which march organizers had secured a permit. Several small groups of militants, however. charged the troops and attempted to gain entry to the

${ }^{10}$ Memo to Ramsey Clark from Walter Yeagley, attached to memo from Clark to LBJ, 4 Oct 1967, personal papers of Warren Christopher, Box 8, LBJL; Minutes of meeting, 3 Oct 1967. Tom Johnson's Notes of Meetings, Box l, LBJL; Wells, The War Within, pp. 184, 201. 178.

"Terry Anderson, The Movement and the Sixties (New York: Oxford, 1995), p. 
Pentagon (a few did, and were beaten and arrested for their efforts). When these flare-ups settled down, the afternoon actually took on a "festival atmosphere" as more musicians played for the crowd and speakers conducted what amounted to an impromptu teach-in. Still, that night, events turned ugly.

After midnight, when only a few hundred demonstrators remained on the plaza in front of the Pentagon - most sitting and sleeping directly in front of the troops - those in charge of security ordered the marshals and soldiers to form a wedge and begin driving the protesters away from the building. As one official later reported to the attorney general, in some cases the marshals "used more force than was warranted."12 The troops used batons and their rifle butts to club the protesters. A number of women, in particular. suffered the most severe beatings - apparently as part of a strategy to provoke male protesters into attacking the troops. The demonstration fizzled the next day and, at the end of the weekend. the Justice Department counted 683 arrests. 51 jail terms (of up to 35 days), and $\$ 8,000$ in fines. ${ }^{13}$

Most significant for the draft resisters who had taken their fateful step of defiance the previous week. the media coverage of the march completely obscured the previous day's events at the Justice Department. The 100,000 participants at the Lincoln Memorial

12 Stephen Pollack to Ramsey Clark, 22 Oct 1967, Personal Papers of Ramsey Clark, box 29, LBJL.

13 The story of the March on the Pentagon has been told by many historians and participants. Perhaps the most engaging and least objective of these accounts is told by Norman Mailer in The Armies of the Night (New York: Signet, 1968). See also: Zaroulis and Sullivan, Who Spoke Up?, pp. 136-142; DeBenedetti, An American Ordeal, pp. 197 198; Wells, The War Within, pp. 195-203; Anderson, The Movement and the Sixties, pp.178-179. 
made the 500 people who turned out for the demonstration at the Justice Department on Friday seem comparatively puny. Moreover, as historian Charles DeBenedetti has observed, Rubin's provocative thetoric and the violent clashes between a small number of protesters and the soldiers and marshals guarding the Pentagon "reinforced the image of the antiwar movement as a radical fringe and pushed it further to the political margin." By Monday, October 23, the papers and television newscasts reported only on the wild events of the past forty-eight hours; Friday afternoon's draft card turn-in had been forgotten. ${ }^{14}$

In Boston the following week. however, resisters soon learned that, despite the attention focused on the Pentagon demonstrations. the Federal Bureau of Investigation did not overlook the receipt of their cards in Washington. Beginning on October 24, FBI agents from the Boston field office visited dozens of resisters at their homes and on campus. They also appeared at the homes of resisters' parents. Out of 121 former resisters surveyed, 62 (51.2\%) remember their FBI encounter, while only $21(17.4 \%)$ recall their parents receiving a similar visit. Generally, agents pressed resisters to respond to three questions: 1) Did you turn-in your draft card purposefully and knowingly?; 2) were you coerced in any way?; 3 ) and why did you do it? Parents were asked if they knew of their sons' activities and if they were aware of the possible consequences. Most resisters and their families had always been law-abiding citizens and had no experience with being questioned by federal authorities. Few had ever even seen an FBI agent

${ }^{14}$ DeBenedetti, An American Ordeal, pp. 188-189; For more on the march on the Pentagon, see Mailer, Armies of the Night; Wells, The War Within, pp. 195-204; For more on media coverage of the demonstration, see Melvin Small, Covering Dissent, pp. 70-84. 
before. Opening one's door to find two FBI agents displaying their credentials could, therefore, be a little unnerving. ${ }^{\text {is }}$

The New England Resistance, knowing that many resisters might be easily intimidated when confronted alone by FBI agents, scrambled to respond. Several pages of a hastily-produced newsletter dated October 25 , the day after the first FBI visits, addressed the issue. Organizers warned all resisters that the federal agents were visiting people singly, "with a heavy emphasis on parents." The goals of such "harassment," they argued, included trying to "intimidate or frighten" resisters, "split families," and scare off others who might consider becoming resisters. They noted that the FBI arrested no one on its first day and in their first efforts at maintaining solidarity, urged rank and file resisters to stay committed to the cause and to one another:

THE SINGLE MOST IMPORTANT WE.APON WE HAVE IS OUR COMMITMENT AND UNITY AS A GROUP. WE MUST LET THEM KNOW THAT HARASSMENT OR ARREST OF ONE OF US WILL MEAN A RESPONSE BY ALL OF US. WE ARE FREE MEN NOW AND WILL NOT BE INTIMIDATED. WE WILL STAND UP FOR OUR LEGAL RIGHTS AND MORAL CONVICTIONS. WE HAVE TOLD THE ADMINISTRATION AND SELECTIVE SERVICE SYSTEM WHERE IT [sic] CAN GO, AND THE FBI AND JUSTICE DEPARTMENT CAN FOLLOW THEM...NOT WE, BUT THE GOVERNMENT WILL BE FORCED TO BACK DOWN.

Next, they included a lengthy section on how to handle an FBI visit. First, they reminded resisters that they did not have to speak with them or let them into their homes (unless they were equipped with a search warrant); resisters should submit to interviews only with an attorney present. Second, the newsletter provided tips on how to handle an FBI

is "FBI Questioning Campus War Foes," New York Times, 25 Oct 1967, p. 8; "FBI Queries Students Who 'Resist' Draft," Harvard Crimson, 25 Oct 1967, p. 1. 
search. recommending that resisters only allow agents in after getting a lawyer or minister on the phone so that he could describe everything the agents did. They also recommended keeping the agents together to "make sure nothing is planted or taken." The newsletter did not, however, indicate how compliant one could expect the FBI agents to be with such demands. Finally. Resistance organizers counseled their brethren never to be on the defensive. "The FBI is generally a bunch of political hacks," they wrote. "who threaten loudly but back down when their bluff is called." Interviews by FBI agents constituted standard operating procedure for the Justice Department, the newsletter said, noting that civil rights workers in the south had been subjected to the same kind of treatment. $^{16}$ Most important, they concluded, no one had yet been arrested.

\section{NER Meets FBI}

That the FBI arrested no one in that first fortnight following October 16 surprised the New England Resistance: they had expected "rapid and massive prosecutions" of the first resisters. Not only did resisters remain free and uncharged of crimes, but the FBI did not even interview some of them. The slow pace and inconsistency of government response bewildered resistance organizers. In fact, when representatives of Resistance groups from across the country met to discuss strategy following the scene at the Justice Department on October 20. they made few plans. Other than agreeing on responsibilities for maintaining a communications network through newsletters and setting December 4 as the target date for the next national action (though Michael Ferber indicated that Boston would probably do something earlier), the resisters made no significant decisions

${ }^{16}$ NER Newsletter, 25 Oct 1967, MKFP. 
about how to move forward over the following weeks and months. They waited for a government crack-down they believed to be imminent. ${ }^{17}$

Only in rare instances did resisters feel the force of the government's wrath in the first two months following the turning in of their draft cards. In Boston, authorities singled out one resister. Chris Venn, and even that took six weeks. Venn had grown up in the Back Bay neighborhood of Boston, and in the fall of 1967 had taken a semester off from the University of Colorado. On October 16, he worked as part of a painting crew on the Mystic River Bridge. At work the next day, when the draft card turn-in came up in conversation. Venn found himself supporting the resisters in a heated argument with the rest of the crew. Eventually, one of his coworkers asked Venn why, if he felt so strongly. he did not turn in his own card. That did it. Venn tracked down Michael Ferber at his Phillips Street apartment on Beacon Hill and gave him his draft card in time for it to be conveyed to Washington with the rest. He immediately began working in the New England Resistance office in his spare time. A few weeks later, FBI agents interviewed him with his parents in their four-story house on Gloucester Street in the Back Bay. The meeting was civil. In fact. Venn today remembers the agents being surprised that someone who lived in one of the nicest neighborhoods in the city might have participated in such law-breaking behavior. The agents left and Venn continued to work with the Resistance.

Chris Venn's personal history, however, made him more vulnerable than other resisters to an accelerated reaction to his draft card turn-in. Venn had been arrested

${ }^{17}$ Ferber \& Lynd, p. 149. 
earlier that year for drug possession as he reentered the United States on his way back to Colorado following a vacation in Mexico. The judge in El Paso saw that Venn did not have a prior record and gave him a suspended sentence, but required him to see a federal probation officer on a regular basis. On Friday, December 1, 1967, when Venn made his monthly visit to the federal building in Boston's Post Office Square, U.S. Marshals arrested him and locked him up. They immediately began preparing him for extradition to Texas, but Venn's lawyer interceded and demanded a hearing to review whether or not probation had been violated. In a hearing held the following Tuesday, Venn was found guilty of violation of probation. His lawyer filed an appeal to have his case transferred from Texas to Boston. but when it was denied. the state of Texas extradited him. After a couple of weeks in jail in Boston, two marshals put him in a car with some other prisoners and started off down the Massachusetts Turnpike toward Texas. The trip to El Paso took several days with stops at several federal penitentiaries where Venn and the other prisoners slept at night. Among other places, Venn remembers being locked up in St. Louis, Oklahoma City. Abilene (Texas) and, finally, in El Paso. Venn's parents appeared in court with him and again the judge let him go. Venn returned to Boston and resumed his work with the Resistance. He continued to fulfill his probation obligations and never heard from the FBI again.

Chris Venn's arrest and cross-country odyssey demonstrated that federal authorities would at least exploit opportunities to punish draft resisters when additional circumstances made it possible. Resistance organizers seized on Venn's story to warn fellow resisters about law enforcement officials. That the marshals tried to ship Venn to 
Texas without a probation hearing, in particular, alarmed them. It demonstrated that the authorities were willing to-"completely disregard a person's rights in favor of their 'law enforcing' instincts," a notion that most resisters found frightening. "We must always be on the defensive," the newsletter read, "in the event that any of us are arrested."18

When it became clear that the authorities did not have plans to move swiftly and decisively against most other draft resisters, however, a flaw in Resistance planning revealed itself: they did not know how best to proceed. As Michael Ferber and Staughton Lynd later wrote, "beyond the single tactic of draft card turn-ins, [the Resistance] had no political program, no plan of day-to-day work (comparable to. say, voter registration in the South) which could help individuals and groups keep themselves together." According to Neil Robertson, one of the original organizers and a full-time paid staffer by late October, after being "catapulted into notoriety" by the remarkable success of October 16, Resistance leaders "were totally confused about what to do next." They believed they had created an organization, "or the beginnings of one," Robertson later recalled, "but that was always a misunderstanding." Just because 281 men had "in one way or another

${ }^{18}$ NER Newsletter, 15 Dec 1967, MKFP; Chris Venn, interview with author, 12 Jun 1997; Note: In an interesting postscript, Chris Venn himself did not ultimately stay on the defensive against being arrested. In 1969, after moving from Boston to San Francisco, he took part in the demonstrations to save People's Park in Berkeley. When the police fired tear gas canisters into the protesters, Venn lobbed one back at the police. The police continued to advance and, as Venn ran down the street away from them, an Alameda County Sheriff's Deputy shot him in the buttocks with bird shot. Venn managed to escape and had most of the bird shot removed by a sympathetic doctor. But the FBI tracked him down a few days later and arrested him for violating his probation. This time he spent a year in the federal penitentiary in El Reno, Oklahoma. For more on People's Park, see W. J. Rorabaugh, Berkeley At War: the 1960s (New York: Oxford, 1989, pp. 155-166. 
divested themselves of their draft cards" did not mean they had an organization of that many men. In Robertson's view, the Resistance possessed 'more of an appearance of solidity in the newspapers than it did in reality."19

Indeed, mobilizing the first rank-and-file resisters to sustained levels of protest proved to be very difficult. Just keeping track of all the resisters and other supporters could be a challenge: in the first post-October 16 newsletter, organizers listed more than 30 men who had turned in or burned their draft cards that day for whom addresses remained unknown. By the time the third newsletter after October 16 went out, Resistance organizers pleaded with rank-and-file resisters to maintain a higher degree of activism. They were beginning to conclude that the "majority" of resisters treated the Resistance as little more than "another extracurricular activity:"

It's really quite alarming when guys are called...and asked to be members of a squad of men willing to demonstrate at any time, and they reply 'I can't be bothered.' or 'I don't want to be awakened at weird hours.' or 'I have papers and exams.' All of us have papers and exams, or something that takes up our time...nevertheless. we have lots of work to do and everyone should be doing something.

Neil Robertson later concluded that by turning in a draft card, by committing "that defiant act," most men had taken "an incredible step....that was a really pivotal event in their lives," or a "watershed event." and that alone made many men feel like they had done their part - and risked enough - to end the war. "For a lot of guys it summarized many, many different things, a good deal of which were not articulated or even fully conscious." Trying to build community among "such a disparate group of people," each of whom had

${ }^{19}$ Ferber \& Lynd, p. 149; Robertson interview, 24 Aug 1997. 
moved toward Resistance for individual reasons, Robertson believed. may have been "doomed to failure."20

In some respects, the decision to participate in draft resistance activism beyond turning-in one's own card depended on temperament. As Robertson suggested, some rank-and-file resisters wanted to resist quietly, alone. They turned in their cards like everyone else and chose to simply wait for an official response. Bob Bruen, an undergraduate at Northeastern University later remarked that resisting "was something $\mathbb{l}$ was going to do and take a stand at that point, but I wasn't going to go around getting people all excited. giving speeches. and participating in all the other stuff. I thought a lot of that was a waste of time." Others chose to work on draft resistance in their own communities. For example, many of the seminarians offered draft counseling in the parishes where they conducted youth ministries rather than out of the Resistance office. In addition. some resisters were intimidated by the Resistance ringleaders. Howard Marston, Jr., a resister from the North Shore town of Rockport remembered that when he visited the Resistance office in Cambridge, "they all made me very nervous" because they were "just so gung-ho." To some 18 or 19-year-old resisters, an encounter with a Harvard graduate student who worked 12 hours a day almost every day on draft resistance activity could be a little overwhelming."

In several ways, however, Resistance organizers did make efforts to reach out to

${ }^{20}$ NER Newsletter. 15 Dec 1967, MKFP; Robertson interview, 24 Aug 1997.

21 Bruen interview, 13 Aug 1997; J. Michael Jupin, interview with author, 28 Dec 1997; Oestereich interview, 20 Dec 1997; Howard Marston, Jr., interview with author, 13 Dec 1997. 
their brother resisters. Every Monday night. they held pot-luck dinners in the basement of the Arlington Street Church. They invited all resisters and supporters and, although the conversation almost always revolved around the war and protest against it, it remained a social occasion where anyone might feel at home. As one resister later put it, "Mike Ferber, Bill Hunt. and the Community feeling in the resistance were probably more convincing than the war as reasons to hand in your draft card." On October 31 , the New England Resistance hosted a masquerade party to raise money for future draft resistance events and also to try to keep bringing rank-and-file resisters together in one place. A few weeks later, they arranged some football games between the New England Resistance and the Boston Draft Resistance Group. or the "Peace Creeps" and the "Commie Dupes," as they facetiously called themselves. Anyone could play for the Resistance and when they won, they joked that "rumors have it that BDRG men were weighted down by the mass of their draft cards." Finally, the New England Resistance also adopted the Greek letter Omega. $\Omega$, as a svmbol of their "determination to resist the draft and the war machine until the last." Omega is the symbol for an Ohm, the unit of electrical resistance in physics, and as Michael Ferber later wrote. it suggested many useful metaphors: "friction in the machine, attrition in the supply lines. turbulence in the conduits to Vietnam." Moreover, the omega is also the last letter - or the end - of the Greek alphabet. and therefore, stood for the end of the draft and the end of the war; it made an ideal symbol for the Resistance and eventually Resistance chapters nationwide adopted it, too. Dozens of white buttons with a large black Omega printed on each were distributed to resisters as another way of making everyone feel like they were part of a much larger, growing 
community. Rather than "leave for Canada," NER leaders wrote when they introduced the Omega. "we choose to stay in America...and build an effective political movement to inaugurate the greater society that we believe in."22

Even with some sense of solidarity and community, individuals on their own are often vulnerable, and law enforcement officials were skilled at bringing pressure to bear on people one at a time. Resisters never reported being interviewed by only one FBI agent; they always worked in twos. Resisters who did not turn them away immediately could expect the standard questions about why they made their decision to resist or whether they had been coerced. Frequently. however. the conversation extended to discussions of the draft system and even the war. Often the agents disagreed with the resister about his duties as a citizen; tensions would rise. and the feds usually left saying something like, "you'll be hearing from us."'s

Still. although encounters with the FBI were remarkably similar from resister to resister. there were a few notable exceptions of resister defiance. Faculty and administrators at Yale Divinity School were so outraged at the disruption caused by agents tracking down resisters, they posted a note where the agents would see it: "Dear FBI, 'Let your foot be seldom in your neighbor's house, lest he become weary of you and despise you."' One resister attended a meeting with two agents in Boston wearing a

${ }^{22}$ Richard Hyland, "The Resistance: An Obituary,"Harvard Summer News, 8 Aug 1969, pp. 3-4; NER Newsletter, 15 Dec 1967, MKFP; NER Newsletter, 25 Oct 1967, MKFP; Ferber and Lynd, The Resistance, pp. 251-252.

${ }^{23}$ Dan Tilton, interview with author, 16 Jun 1997; Robert Bruen, interview with author, 13 Aug 1997; Hector interview, 9 Apr 1997. 
button that said, "J. Edgar Hoover Sleeps with a Night Light." The most celebrated FBIResistance meeting took place in the offices of the Boston University News between two agents and Alex Jack. Jack had been expecting a visit and he and his colleagues in the office were well prepared when the agents arrived. Jack welcomed the agents and invited them to sit down. Up to that point. Alex Jack seemed very accommodating, but before they could pose the first question. he turned the tables on them. As he sat down and put his feet up on the desk. he said. "Thank you for coming. I just have a few questions." Then he handed each of them a three page document called "FBI for the Resistance: Questionnaire." It included a waiver of Fifth Amendment rights not unlike the one agents often used with resisters, a questionnaire. and a pledge sheet that would. when completed, make the agents members of the Resistance. The questionnaire asked questions like "Do you believe the war in Vietnam is illegal, immoral, unjust, and not in the interests of America's national security?" and "Do you feel it is the patriotic and legal duty of the Bureau to investigate president Johnson. Secretary [of State] Rusk, Secretary [of Defense] McNamara, the Joint Chiefs of Staff, the CIA, and General Hershey for war crimes, crimes against humanity, treason...on the basis of the US Constitution, the UN Charter, the 1954 Geneva Agreements, and the Nuremburg Statutes?" After a few moments, the agents realized that Alex Jack was giving them a taste of their own medicine. They terminated the interview and left "in a huff." Following them, a group of Resistance "agents" teased them all the way to their car by looking them up and down, scribbling in 
note pads, and saying 'Ah, yes,' and 'very interesting,' until they drove off.."

News of this confrontation spread quickly within the antiwar community in

Boston. Bill Hunt wrote an article in Avatar. a leading underground newspaper in the city, which told the story of Alex Jack turning the tables on the FBI. The piece also included Hunt's own description of two FBI agents who had come to Avatar's offices and then left after failing to find the resister they sought for questioning. Hunt himself departed a few minutes later and, as he left the building, found the two agents jiggling a coat hanger through the window of their car; they were locked out of their car. He asked the G-Men if they would mind him photographing the scene but. when the agents begged him not to, he relented. Stories like this made great copy in movement newspapers. Another group of students at UMass-Boston followed Alex Jack's example. Soon after two agents sat down with a resister in an empty room. a group of the young man's supporters jammed into the room with several cameras, and photographed the agents in mid-sentence. The pictures later appeared on leaflets and in the student paper..$^{25}$

Although such instances of counter-harassment of federal agents soon entered Resistance lore because of their bravado and apparent playfulness, the perpetrators of these pranks took their actions seriously. At least some of those resisters felt, as Alex Jack later reflected, that since "the government was immoral and illegitimate," not only

24 "FBI For The Resistance: Questionnaire." leaflet, MKFP; Ferber \& Lynd, pp. 153-154; Jack interview, 21 Mar 1997; Bill Hunt, "The Resistance Turns the Tables," Avatar \#12, p. 4.

${ }^{25}$ Bill Hunt, "The Resistance Turns the Tables," Avatar \#12, p.4; NER Newsletter, undated (c. early Nov 1967), AJP. 
did non-cooperation make sense, but

now we were kind of moving into that vacuum where you're creating your own government - almost like a provisional authority in which you begin to assume in the name of humanity, or the Nuremburg statutes, or whatever, some kind of civil authority and put these people on record that their actions are being monitored.

The agents, and even Resistance supporters might have seen such episodes as pranks. but from the perspective of those who did it. -it was an exercise of legitimate counter authority," Jack said. ${ }^{\text {?6 }}$

Some Resistance activists, particularly those involved in day-to-day operations, eventually found humor in their relations with the FBI. Nan Stone recalls that, at first, meetings with the FBI could be fairly intimidating. FBI agents benefitted from a widely held image (bolstered by The FBI, the successful television show featuring Efrem Zimbalist, Jr.) that portrayed them as elite members of the law enforcement community. One generally shuddered at least a little when an agent introduced himself and said he needed answers to a few questions. After a while, however, that luster began to fade and Resistance activists grew more bold. "It got to be a game for us," recalled Stone. They learned to pick FBI agents out of a crowd - each agent usually standing incongruously among scores of young people in trench coat. fedora and sunglasses - and pose for them as the G-Men photographed demonstrators. Similarly, Bill Hunt recalls trying to hand out leaflets to FBI agents at a demonstration; when an agent asked him what he did for a living, Hunt, a graduate student in history at Harvard, told him he was that university's head of the Department of Anthropophagy (i.e., Cannibalism). In addition, resisters

${ }^{26}$ Jack interview, 21 Mar 1997. 
sometimes found FBI investigative methods and tactics to be amusing, such as the time Harold Hector found three agents. dressed as homeless men sleeping (or pretending to be asleep) in the hallway of his Cambridge apartment building. Although they were "dressed like bums," they were clean shaven, and still wore white socks and shiny wingtip shoes. After Hector yelled at them to get out of his hallway, he looked out the front window of his place and watched them all pile into a creme-colored car and speed away. "It was so crazy," he said, "It was even funny at the time." "27

At the same time that the FBI seemed inept, however. they also went to great lengths to investigate their targets. A reporter from the Harvard Crimson and a Resistance sympathizer once saw FBI agents standing outside the Arlington Street Church on a Monday night when the New England Resistance held a pot-luck supper. As resisters and supporters entered the church, agents would, the reporter claimed, "aim umbrellas at you and take your picture, click." Similarly, Nan Stone learned years later, when she first found photographs in her FBI file (which she acquired through the Freedom of Information Act), that agents had tailed her to a friend's wedding on Cape Cod, an event completely unrelated to draft resistance, and took pictures of her enjoying the celebration with friends. Stone and others also reported finding wiretap devices in their home phones and everyone in the New England Resistance believed that the office phones were bugged. Given the president's personal interest in the investigation of draft

${ }^{27}$ Stone interview, $28 \mathrm{Mar}$ 1997; Hunt interview, 31 Oct 1997; Hector interview, 9 Apr 1997. 
resistance, the use of such tactics on the part of the FBI seems plausible. ${ }^{28}$

These encounters with the FBI notwithstanding, the kind of information the FBI relayed back to Washington and the White House (though resisters could never hope to know the substance of it) is what should have concerned the Resistance most. Resisters would have been interested to know that. from the start, the president seemed a little perplexed about the nature of the protest directed at his administration by draft resisters. At an October 23 meeting with Secretary of State Dean Rusk, Secretary of Defense Robert McNamara, and Chairman of the Joint Chiefs of Staff, General Earle Wheeler, Johnson said. "I am concerned as to how we handle the draft card burners who are handing in their draft cards at various federal centers." The Resistance practice of allowing the burning of draft cards at ceremonies where cards were collected no doubt contributed to the president's confusion. The FBI capitalized on it. First. the Bureau challenged the Resistance's claim that 994 draft cards had been returned to the Justice Department on October 20. According to a memo sent to the president from Ramsey Clark, an FBI inventory of the fabricoid briefcase found 185 registration certificates and 172 notices of classifications, "which due to duplication appears to represent approximately 300 individuals." In addition, they found 14 facsimile registration cards. photostat sheets with reproductions of 155 registration certificates and notices of classification, an envelope containing the ashes of 67 draft cards, and numerous letters. statements, and discharge orders expressing antiwar and antidraft views. According to

${ }^{28}$ Richard Hyland, "The Resistance: An Obituary," Harvard Summer News, 8 Aug 1969, pp. 3-4; Stone interview, $28 \mathrm{Mar} 1997$. 
these figures, at most, 593 people turned in their cards on that day. By the time President Johnson met with Democratic Congressional leaders on October 31 , he felt comfortable using a figure of only 256 people and claimed that those individuals, according to the FBI, were "crazy people" with a history of being institutionalized. Furthermore, he said, informants in the Communist Party reported that 'the communists decided to do all they could to encourage demonstrations against the draft." The president told his audience that he did not want to sound like a "McCarthyite," but he believed the country was in "a little more danger than we think and someone has to uncover this information."29

The reference to Senator Joseph McCarthy is telling because. by 1967 . aides to the president frequently saw him exhibit a kind of paranoia regarding communist manipulation of Congressional opponents of the war as well as the antiwar movement itself. Speech writer Richard Goodwin later wrote that as early as 1965. "Johnson began to hint privately...that he was the target of a gigantic communist conspiracy in which his domestic adversaries were only the players - not conscious participants, perhaps, but unwitting dupes." As far as the president was concerned, this included not only antiwar activists, but doves in Congress, too. He used both the Federal Bureau of Investigation

${ }^{29}$ Minutes, Meeting. 23 Oct 1967. Tom Johnson's Notes of Meetings, Box I, LBJL; Ramsey Clark to LBJ, 2l Oct 1967, box 29, Clark papers. LBJL: Minutes, Congressional Democratic Leadership meeting, 31 Oct 1967, Meeting Notes File, Box 2 , LBJL; Richard Goodwin, Remembering America: $A$ Voice From the Sixties (Boston: Little, Brown, 1988) pp. 404-405. Note: Goodwin recalls a meeting at the LBJ ranch in which Johnson invoked the "mental institutions" and "McCarthyite" references. His quotations are nearly identical to those found in the meeting notes for the meeting on 31 October with Congressional leaders (which I found at the LBJ Library). It is not clear which is correct - or if both are correct - but I am relying on the meeting notes as my source. The mention of the communist party supporting draft resistance is, however, unique to Goodwin's story. Interested readers should refer to both sources. 
and, beginning in 1967, the Central Intelligence Agency to gather information on his critics and to especially seek to find communist ties to these people. Operation CHAOS. the illegal domestic spying program run by the CIA to gather information on the antiwar movement, relied on burglaries, interception of activists' mail, and wiretapping in investigating their targets. According to Eric Goldman, historian and special assistant to the president. Johnson claimed to have information from the FBI and CIA proving that the Soviets were manipulating certain antiwar senators. These senators, the president suggested, attended luncheons and social functions at the Soviet embassy; children of their staff people dated Russians. "The Russians think up things for the [antiwar] senators to say," Johnson argued. "I often know before they do what their speeches are going to say. ${ }^{.30}$

In the fall of 1967, the president's belief in communist control of opposition to his Vietnam policies became a frequent theme of meetings that addressed antiwar opinion and activism. Reports fed to Johnson by J. Edgar Hoover caused the president to believe firmly that those planning the march on the Pentagon were communists; he then leaked this information to the press in hopes of reducing the number of mainstream antiwar sympathizers from coming to Washington. In a meeting with congressional leaders a few days after the march. he read a "secret report" that allegedly proved that the demonstration's planners were Hanoi’s puppets. The report dealt primarily with a conference that had taken place in Bratislava. Czechoslovakia a few months earlier during

${ }^{30}$ Goodwin, p. 400; Wells, pp. 183-184; Robert Dallek, Flawed Giant: Lyndon Johnson and His Times, 1961-1973 (New York: Oxford, 1998), p. 367. 
which some of the activists, the report charged, had made contacts with the National Liberation Front and the North Vietnamese government. House Minority Leader Gerald Ford (R-MI) found the president's charges so compelling that, from the floor of the House, he remarked that the march had been "cranked up by Hanoi." Several days later, the president told Ramsey Clark. "I'm not going to let 200,000 of these people ruin everything for the $\mathbf{2 0 0}$ million Americans." Johnson wanted investigations into any antiwar activist "who leaves this country. where they go, why they are going, and if they're going to Hanoi, how are we going to keep them from getting back into this country." By mid-November when CLA Director Richard Helms presented a report concluding that "no significant evidence" existed to "prove Communist control or direction of the U.S. peace movement or its leaders," Johnson and several of his aides refused to believe it. They simply could not understand, as Joe Califano said, how "a cause that is so clearly right for the country... would be so widely attacked if there were not some [foreign] force behind it." Despite the evidence to the contrary, the president continued to press the FBI and CIA to investigate the antiwar movement for its ties to the communist world. ${ }^{31}$

The job of uncovering information on draft resistance belonged primarily to the FBI, though the accuracy of their intelligence remains unclear. Given the demographics of the resisters from Boston, the assertion that most of the people who had returned their draft cards were former mental patients seems silly. Perhaps only J. Edgar Hoover knew

${ }^{31}$ Frank J. Donner, The Age of Surveillance: The Aims and Methods of America's Political Intelligence System (New York: Knopf, 1980), pp. 259-261; Dallek, p. 490; Wells, pp. 204, 210; DeBenedetti, pp. 204-205. 
why the FBI characterized the protesters this way. The question of how many real draft cards were turned in. however, is another issue. Unfortunately, neither side (the resisters nor the government) can today support their own figures; the evidence is gone. ${ }^{32}$ Michael Ferber acknowledges that, although he brought genuine draft cards from Boston, the brief case left at the Department of Justice did contain photocopies of hundreds of other draft cards. These copies, he believes, came from many different parts of the country where resisters had turned in the originals to their local draft boards, FBI offices, and U.S. Attorneys; to be counted in the nationwide tally in Washington, these groups sent copies of the cards they collected and had already returned. From the administration's perspective, the facsimiles of draft cards did not constitute sufficient evidence for further investigation or prosecution. Stating the "true" number of cards left with John McDonough also helped to make the Resistance seem less significant as a force in the antiwar movement. If the FBI had its tigures right. 256 returned draft cards could not have seemed very significant to the White House. Nevertheless. the president wanted something done about it.

\section{Selective Service Responds}

On the evening of October 20, at a time when his concern over communist control of the antiwar movement seemed to reach a new level, the president continued to stew

32 The cards collected from across the country on October 20,1967 and left at the Justice Department were introduced as evidence in the trial of the Boston Five the following June and, as evidence in a federal trial, should be part of the public record today. Inexplicably. however, they are not among the records of the trial at the National Archives in Waltham, Massachusetts. Court officials speculate that the evidence was sent back to the FBI, but numerous Freedom of Information Requests and appeals have turned up nothing. Most likely, they were destroyed. 
over the draft card turn-in at the Justice Department. According to Joe Califano, he seemed genuinely bewildered about why anyone would want to burn a draft card and also wondered who the "dumb sonofabitch" was who "would let somebody leave a bunch of draft cards in front of the Justice Department and then let them just walk away." In fact, the day's events only reinforced the president's concern about the attorney general's commitment to prosecuting draft violators. Consequently. Johnson went after the resisters by another route. That night. in addition to instructing his attorney general to keep him informed about draft resisters, the president called the Director of Selective Service, to see if anything else could be done. Even before he had received the $\mathrm{FBI}$ 's analysis of the evidence left at Justice, Johnson gave Hershey "an earful" about the need to punish draft protesters. According to George Q. Flynn, an historian of the draft and Hershey's biographer, the old soldier responded by telling the president about the provision in the draft law that discussed the drafting of any registrant who becomes delinquent. In Hershey's view, turning-in or burning a draft card, both illegal forms of protest, seemed obvious cases of delinquency. "Johnson immediately approved the idea." Flynn tells us, "and instructed Hershey to send out the orders." Rather than contributing to a unified response to draft resistance on the part of the administration. this directive would ultimately lead to an embarrassing spat between Ramsey Clark and Hershey, and a more serious crisis over how to handle dissenters who targeted the draft. ${ }^{33}$

${ }^{33}$ Joseph Califano, The Triumph and Tragedy of Lyndon Johnson, pp. 198-200; George Q. Flynn, Lewis B. Hershey, p. 259; Flynn, The Draft. pp. 215-216; Note: Flynn has confirmed Johnson's involvement in the decision to draft resisters through various sources including Hershey Califano. Primary source documentation linking the president to this issue has not yet been uncovered. That said, the staff at the Lyndon Baines 
Following the orders of his Commander-in-Chief, Hershey moved to squash draft resistance the only way he-could. Just four days after Coffin and the others left the bag of draft cards at the Justice Department. the Selective Service chief issued Local Board Memorandum No. 85 which effectively established procedures for the drafting of draft resisters. It said, in part:

Whenever a local board receives an abandoned or mutilated registration certificate or current notice of classification which had been issued to one of its own registrants, the following action is recommended:

(A) Declare the registrant to be delinquent for failure to have the card in his possession

(B) Reclassify the registrant into a class available for service as a delinquent.

(C) At the expiration of the time for taking an appeal, if no appeal has been taken and the delinquency has not been removed, order the registrant to report for induction...

On October 26, Hershey followed this memo with a letter to all members of the Selective Service System. explaining the rationale for the new policy. Before laying out his argument, he emphasized that the military obligation for young men was universal and that deferments were given only "when they serve the national interest." The key determinant in his analysis of draft resistance derived from the assumption that "any action that violates the military selective service act or the regulations, or the related processes cannot be in the national interest." Therefore, he wrote, "it follows that those who violate them should be denied deferment in the national interest." Upon the receipt of information regarding illegal protest by a registrant, local boards, Hershey said, should

Johnson Presidential Library have begun releasing audio tapes of conversations held in the Oval Office and over the telephone during Johnson's presidency. My hope is that when the tapes for October 16 to 31,1967 are opened, we will finally hear this conversation between Hershey and LBJ. 
reopen the classification of the registrant and "classify him anew." He also asked local board officials to consider sending some cases to the nearest U.S. Attorney, but as Flynn notes, the board members had years of experience and they "knew the director preferred a draft action to a prison term." 34

When news of the Hershey directives surfaced in early November, it sparked a firestorm of protest. Scores of letters poured into the White House. Big city newspapers across the country criticized Hershey including the Boston Globe and the Boston Record American. The Globe 's editors wondered whether Hershey had "outlasted his usefulness" in attempting to use the United States Armed Forces as a "penal colony." The Director"s "meat axe approach" to draft resistance demeaned the draft act, they said. Even veterans groups felt disgraced by Hershey's action. Eugene D. Byrd, chair of the American Veterans Committee sent a telegram to the White House urging "the removal of General Hershey as Director of Selective Service System as essential to the national interest." Most of the protest focused on the vague wording of Hershey's letter. If, as Hershey declared, "any action" which violated Selective Service "processes" could be considered illegal and not in the nation's interest, critics envisioned thousands of youths being reclassified simply because they participated in a sit-in at a local board. They remembered the 1965 reclassification of student protesters at Ann Arbor, Michigan and

${ }^{34}$ Local Board Memorandum No. 85, 24 Oct 1967, Califano files, box 55, LBJL; Hershey to Members of SSS, 26 Oct 1967, National Security Defense files, ND 9-4, box 148, LBJL; 
did not want to see it repeated. ${ }^{\text {is }}$

Since Hershey's instructions to local boards originated in his conversation with the president. the general expected Johnson to back up his letters. Hershey, too. remembered the outrage over the reclassification of the Ann Arbor protesters. Therefore, he sought to solidify his position by authoring an executive order on the subject which he submitted to the White House for Johnson's signature, and thus. his endorsement. The executive order would have changed the regulations so that the definition of delinquency would include positive actions against the draft in addition to the standard provisions requiring a failure to register or appear for induction. Anyone disrupting the operation of a draft board. even through picketing or sitting-in. would become subject to prosecution. As the first draft of the executive order circulated around the White House, such sweeping language caused many aides to urge restraint. ${ }^{36}$

Severe criticism of Hershey also came simultaneously from the halls of Congress. Senators Edward Kennedy. Philip Hart. Mark Hatfield. Jacob Javits. and others cosponsored a bill to outlaw the drafting of protesters. In the House, John Moss, a Democrat from California, led the charge against the Director. In a series of letters to Hershey, Moss, then chair of the Foreign Operations and Government Information Subcommittee of the Committee on Government Operations, called repeatedly for Hershey's resignation. "Your October 26 'recommendations' to local Selective Service

${ }^{35}$ For letters, see National Security - Defense files, ND, Box 151, Nov - Dec 1967, LBJL; "Demeaning the Draft Act." editorial, Boston Globe, 9 Nov 1967, p. 14; Eugene Byrd telegram to LBJ, 11 Dec 1967, Hershey folder, Macy Files, LBJL.

${ }^{36}$ Flynn, Lewis B. Hershey, pp. 260-261. 
Boards concerning reclassification procedures," Moss wrote in the first missive, "can only serve to underscore once again your callous disregard and contempt for the law, the Constitution, and the rights of Americans...I cannot comprehend how a person in your position could exhibit so blatently [sic] a total lack of understanding of fundamental democratic principles." Hershey`s often dense and nearly incomprehensible responses to Moss only made matters worse. Moss finally responded to Hershey that his "unintelligble and wholly confused" reply demonstrated his "complete lack of understanding of the Selective Service Act and of the legal and constitutional provisions and limitations governing [Hershey”s] authority." He again urged Hershey to resign. ${ }^{37}$

Several aides to the president joined the chorus of protest regarding Hershey's directive and the executive order proposal. Although most of them felt the same contempt for the draft resisters as their boss. these advisers unanimously cautioned the president (through Joe Califano) that signing Hershey's executive order would be extremely ill-advised. Special counsel Larry Temple, deputy special counsel Larry Levinson, and White House aide Matt Nimetz each wrote to Califano urging the president

${ }^{37}$ Flynn, Lewis B. Hershey, p. 262; Moss to Hershey, 17 Nov 1967, Califano papers, Box 56, LBJL; Hershey to Mloss, 13 Dec 1967, Califano papers, Box 56, LBJL; Moss to Hershey, 15 Dec 1967, Califano papers, Box 56, LBJL. An example of Hershey's dense prose from the 13 Dec 1967 letter to Moss: "As I stated before, the charges which you have levied against the operation of the System are based on your underlying contention that actions or inactions inimical to the national interest because their objective is to defeat the purpose of the selective service law should be construed solely as violation of the criminal law and prosecuted as such, and that they cannot serve as a basis for local board action in carrying out the mandate of the law that a deferment is nothing but a temporary delay in consummating a man's statutory obligation to serve his country and that such delay can be granted only where it is clearly demonstrated that the national interest can be best served by such temporary delay." 
to rein in Hershey and to avoid issuing the executive order. All three emphasized that criminal courts - not draft boards - were the proper forums for imposing penalties on law breakers and that a prison sentence - not service in the armed forces - was the most appropriate punishment. "The obvious argument," wrote Temple, "is that if induction is to be used as a type of punishment here then what are the hundreds of thousands of young men who serve willingly being punished for?" Califano agreed. In a memo to Johnson. he wrote: "I believe it is important for you to stay out of this controversy" and recommended against the executive order. He advised the president in this way not because he thought Hershey had stepped out of line. In fact, Califano speculated that Hershey might actually have had the authority to reclassify draft resisters, and if he did. he wrote to the president, "then he should continue to proceed on that basis...and keep you out of it." Hershey, Califano urged. should be left to "carry the can" alone. ${ }^{38}$

Most important, however, the president's own attorney general, Ramsey Clark, disagreed with Hershey’s new policy and proposed executive order. It complicated matters that the two shared a long personal history. Hershey had known Ramsey Clark and his father, former Supreme Court justice Tom Clark, for years. When the elder Clark had been an assistant attorney general during the Second World War, he had prosecuted some of the earliest draft violation cases: he had also protested punitive reclassification of

${ }^{38}$ Memo to LBJ from Larry Temple, 16 Nov 1967, attached to memo to LBJ from Califano, 18 Nov 1967, Califano papers. Box 56, LBJL; Memo to Joe Califano from Larry Levinson, 8 Nov 1967, Califano papers, Box 55, LBJL; Memo to LBJ from Matt Nimetz, 16 Nov 1967. attached to memo to LBJ from Califano, 18 Nov 1967, Califano papers, Box 56, LBJL; Memo to LBJ from Joe Califano, 14 Nov 1967, Califano papers, Box 55 , LBJL. 
registrants at that time. In 1967, Tom Clark and Hershey were still working together (this time with the Boy Scouts of America on Operation Patrick Henry, a public speaking program for kids), but now Clark's son was the nation's chief law enforcement officer. Hershey did not mind telling people that he had known the current attorney general since young Ramsey's high school years. For his part, Clark believed Hershey was "a little nutty but basically sweet." On the other hand, the Director's new policies obviously had not been authorized by Congress and Clark believed that there were "grave doubts" about their constitutionality. Even if induction could be used as punishment, he wrote, "registrants are certainly entitled to procedural due process in the proceedings for determination of whether they have violated the law and should be punished." 39

Ramsey Clark's views on the prosecution of draft resisters originated in an understanding much deeper than the law, however. In 1944, Clark, joined the Marines at the age of seventeen (though he was ineligible to go overseas), but many of his friends chose to be conscientious objectors to the war. "In many ways. the most sensitive and thoughtful and good (if there is such a thing) people among my classmates were those who resisted," he reflected in 1998 . "And some of them were permanently hurt by the social ostracization" that resulted among their peers. It made a lasting impression on the future attorney general. Clark felt that the nation had "needlessly damaged many of [its] best young people," and that it should always seek to eschew doing so again. Inflicting such pain on people of conscience is not, he said, "a decent thing for a society to...expose

${ }^{39}$ Lewis B. Hershey, interview with Harry B. Middleton, 15 Dec 1970, pp. 17-18, LBJL; Ramsey Clark, interview with author, 6 Jan 1998; Ramsey Clark to Charles L. Schultze, draft letter, 14 Nov 1967, Califano papers, Box 55, LBJL. 
people to." In addition, Clark had seen enough draft law prosecutions to conclude that those who lacked money or status, "the poorer and defenseless" were the ones who went to jail:

And to see lonely youngsters (because it's finally lonely when it happens to you; you're by yourself even if all your buddies get indicted, too, you're by yourself) face this alone. face this without resources more times than not, face it without maturity or experience or background, is cruel and not productive of the best law because the law wouldn't be thoroughly considered; each case would just be processed through.

Clark felt a duty to "avoid injuring innocent people." Resisters, he believed, were not innocent in the sense that they had not broken any laws, but innocent in that they were "not engaged in an act of moral turpitude;" they were "acting on conscience and they were probably right." he said. About Vietnam era resisters, he later remarked: "These are the gentlest we have. And these are the ones that we should want to protect the most, perhaps. They tend to have more initiative - it's a hell of a lot easier to go than not to go." Consequently. he instructed all United States Attorneys that they were not to prosecute a case based on an acceleration of induction which was premised on draft resistance activity. ${ }^{+0}$

The attorney general's action - or inaction - displeased Johnson. Clark claims that the president leaned on him only lightly, yet Joe Califano's records recall a November 18 meeting between the president, Hershey and Clark in which Johnson started off by demanding to know why the Justice Department had prosecuted only 1,300 of 7,300 men who had been arrested for failing to report for induction. Clark, who today is certain that

${ }^{40}$ Clark interview, 6 Jan 1998; see also Tom Wells, The War Within, pp. 233-236. 
Hershey had been "pumping" the president with statistics on draft violators that were not being prosecuted, responded that many of these no-shows were unintentional and, therefore. should not have been arrested in the first place. When he concluded by saying that he was doing all he could under current law, the president blustered. "If you need more laws, submit your suggestions at once!" Shortly after the meeting, Johnson sent another memorandum to Clark detailing every criminal statute on sabotage, espionage, and interference with the government. He directed Clark to pass the information along to all United States Attorneys with instructions to prosecute anyone who participated in illegal acts covered by these laws. "If you need further legislation in this connection." Johnson again commanded. "please submit your suggestions at once." Indeed, when Congressman Mendel Rivers heard about Clark's concerns regarding punitive reclassifications, he said "if there exists the slightest doubt in the attorney general's mind that General Hershey's action is not fully supported by the law, he need only say so and I am certain the Congress will correct any deficiency. ${ }^{+41}$

Despite the president's intense interest in ensuring that draft resisters be pursued by the Justice Department, and his own role in encouraging Hershey to go after protesters notwithstanding, Johnson ultimately grew tentative on the issue of reclassifying resisters. He offered no public sign of support to Hershey and the general's executive order proposal never made it out of the White House. And when Johnson received advance warning of an unflattering New York Times article on Hershey in early December, he

"Clark interview, 6 Jan 1998; Wells, The War Within, p. 234; Califano, The Triumph and Tragedy of Lyndon Johnson, p. 201. 
brought Hershey together with Ramsey Clark again to issue a joint announcement on the subject which he hoped would lay to rest any more concerns regarding the director's memoranda on punitive reclassification. Before the White House released the statement, Johnson himself read it and. according to Joe Califano, approved "every word of it."42 Both Clark and Hershey compromised on the content of the communique. Hershey consented to leave lawful protesters alone. There would be no more Ann Arbors, a point repeatedly emphasized in most press reports. But Clark gave up even more. Despite his own experiences as a young man and his philosophical beliefs regarding the prosecution of those acting on conscience. the attomey general went along with Hershey's existing policy of reclassifying those who turned in their draft cards, and pledged the Department's cooperation in prosecuting those who refused an accelerated induction resulting from reclassification:

A registrant who violates any duty affecting his own status (for example. giving false information. failing to appear for an examination, or failing to have a draft card) may be declared a 'delinquent' registrant by his local draft board... When a person is declared to be a delinquent registrant by his local board, he may be reclassified and becomes subject to the highest priority for induction if otherwise qualified. If he fails to step forward for induction, he is subject to prosecution by the Department of Justice. This procedure is firmly established. approved by the courts, and has been followed since the enactment of the 1948 Selective Service Act, as well as under earlier Selective Service Acts.

The Justice Department, meanwhile, would not prosecute a draft resister simply for failing to possess his draft card. In addition. the statement indicated that the Department planned to form a special unit in the Criminal Division in Washington to oversee the

${ }^{42}$ Flynn, The Draft, pp. 217-218; Califano, pp. 201-202; 
prosecution of draft law violators. U.S. Attomeys across the country could expect to work closely with this new unit in bringing cases against draft resisters in their cities. ${ }^{+3}$

Most lawyers within the Justice Department regarded the joint statement as a victory for the Attorney General: it stopped Hershey from targeting demonstrators and made no commitment to prosecute men who returned their draft cards. Years later, however, as Ramsey Clark reflected upon his acquiescence to Hershey's reclassification and induction policy, he acknowledged the difficult situation in which he found himself during that period. Even though he saw draft card turn-ins as an issue of free speech and an expression of conscience, he felt obligated to uphold the Selective Service laws. Clark believed that if one accepted the idea of a conscription system like Selective Service (which he did because he thought it was "more compatible with civilian authority and government, and less likely to lead to militarism"), then the Selective Service rules had to be upheld. "As much as I opposed the war," he said, "the law has to have integrity. It has to do what it says even if what it says is wrong. I thought, therefore, that I had to act to protect the Selective Service System." ${ }^{\text {HH }}$

At the same time, however, Ramsey Clark took another approach to the draft resistance issue. He asked John Van de Kamp to head up the Criminal Division's new special unit on draft resistance, and rather than have him focus on individual draft law

43 "Joint Statement by Attomey General Ramsey Clark and Director of Selective Service Lewis B. Hershey," 9 Dec 1967, Califano papers, Box 55, LBJL; Flynn, The Draft, pp. 217-218; Califano, pp. 201-202.

44 John Van de Kamp describes the joint statement as a victory for the DOJ: Van de Kamp interview, 9 Jun 1998; Clark interview, 29 Apr 1998. 
violators, Clark instructed Van de Kamp to look into the existence of a possible conspiracy aimed at inducing young men to resist the draft. Clark was much more concerned with the notion that older advisers were soliciting draft-age men to resist the draft. Therefore, until the Department could make a determination on the conspiracy, Clark directed all U.S. Attomeys to suspend prosecution of men who had refused induction when the call to report was based on a reclassification stemming from a prior protest against the Vietnam War or against the Selective Service System. ${ }^{\text {t5 }}$

In the end, in spite of Clark's concessions, the joint statement did little to allay the controversy caused by General Hershey's October instructions to local boards. To the president's dismay, Hershey violated an agreement negotiated by Joe Califano that neither Clark nor Hershey would discuss the issue with the press. Within days, the Selective Service director told Neil Sheehan of the New York Times that the recent clarification did not invalidate his October letter. Furthermore, he acknowledged a fundamental difference of opinion between himself and the attorney general regarding the definition of delinquency. The original standard of delinquency required the failure of a registrant to perform some duty required of him by the Selective Service Act. But Hershey wanted to go after those who took some other form of positive action against the draft. This is where the disagreement with Ramsey Clark arose, he told Sheehan. "When a fellow goes into a draft board and pours ink on his own file, then there's no disagreement," Hershey said, "he's affecting his own status. But when he goes in and pours ink on his brother's

t5 Clark interview, 29 April 1998; Van de Kamp interview, 9 Jun 1998; McDonough interview, 3 Jun 1998. 
file - there's the disagreement." In the latter case, Hershey would declare the perpetrator delinquent and accelerate his induction process. Clark, on the other hand, would not assert delinquency, but would have him prosecuted for criminal conduct. Sheehan's piece caused further outrage among the war's critics the public and left Hershey backpedaling. ${ }^{+6}$

Suddenly, the "embarrassing public spectacle"of Clark and Hershey feuding challenged the already beleaguered president. Califano appealed to Johnson for some kind of decision, complaining that Hershey "keeps citing you [Johnson] to Ramsey and me as authority for his earlier memorandum." Still, the president tried to stay out of the way. Only when the presidents of eight Ivy League colleges and universities signed a letter of protest did Johnson instruct Califano to write to them with the pledge that he did not advocate using the draft as "an instrument to repress and punish unpopular views." This, too, did little to settle the issue. As Colonel Paul Feeney, the Massachusetts Director of Selective Service noted, the joint statement reinforced existing policy. Illegal forms of protest. he said, included nonpossession or mutilation of draft cards; therefore, anyone turning in or burning a draft card could expect to be reclassified and called for induction. Only the courts would be able to settle the issue once and for all, and it seemed apparent that in 1968 they would get their chance as dozens of draft resisters

${ }^{46}$ Neil Sheehan, "Hershey Upholds Induction Policy," New York Times, 12 Dec 1967, p. 16; Califano, pp. 202-203; Flynn, Lewis B. Hershey, p. 265; Flynn, The Draft, p. 218. 
challenged punitive reclassification across the country that fall. ${ }^{47}$

Each of the four thousand local draft boards in the United States, it seems, handled draft resisters differently. Unfortunately, the Selective Service System destroyed all of its local board records in the late 1970s when the agency went into "Deep Standby" status, making it impossible to learn how individual draft boards interpreted directives from General Hershey. But the anecdotal evidence that survives shows that some boards clearly took a hard-line approach. and immediately reclassified resisters per Hershey's instructions. By 1 Dec 1967, draft boards declared approximately 25 of the men who had turned in their draft cards at the Arlington Street Church delinquent and changed their classifications to 1-A. Eventually, almost two-thirds of Boston's draft resisters (64\%) received reclassification notices from their draft boards. ${ }^{48}$

When the New England Resistance realized that the government might first adopt this reclassification approach instead of, say, indicting resisters immediately for failure to carry their draft cards. the organization urged resisters to notify the Resistance office promptly if they thought their local boards might take that course. They then directed resisters to a group of lawyers who would plan an "aggressive legal injunction as soon as possible," before the resister received an induction notice. As the new year approached, more and more men needed the legal assistance offered by a growing number of antiwar

${ }^{47}$ Califano, pp. 202-203: Flynn, Lewis B. Hershey, p. 265; "Hershey's Order is Affecting Few," New York Times. 17 Dec 1967, p. 15.

48 Lewis Brodsky (SSS Public Affairs Officer) e-mail to author, 29 Apr 1998, author's files; From the 1997 survey of Boston draft resisters: 77 (63.6\%) out of 121 resisters were reclassified to $\mathrm{I}-\mathrm{A}$. 
lawyers. Of course, draft resisters simply could have let the Selective Service reclassify them and call them for induction; in turn. the resisters would refuse induction and. consistent with their goal of bogging down the court system, await prosecution (as some, indeed, did: see Chapter 7). The sense of strength derived from the October 16 service, however, led them to seek confrontation with the government not just in the courts, but anywhere they could find it. Legal injunctions against local boards fit neatly into the broader strategy of putting their bodies "upon the gears of the machine."

Some draft boards. however, did not follow General Hershey's instructions with the same degree of enthusiasm as others did. Many, it seems, actually tried to give resisters a second chance and, consequently, tested some resisters ${ }^{\circ}$ commitment to their cause. David Clennon, the Yale Drama School graduate student, and Bob Bruen, the Northeastern University undergraduate, both were offered new draft cards with their student deferments intact. In Bruen's case, his local board, located in Malden, Massachusetts, wrote to him to tell him that he should apply for a new draft card if he had lost or misplaced his originals. Three weeks later, when Bruen did not reply, they simply sent him a new card with his original deferment. Clennon's draft board in Waukegan. Illinois did the same thing (though without the preliminary letter). Here again, the Resistance had warned its members that their draft boards might try to tempt them, "bribe" them. "with a luxurious deferment or exemption." If that happened, Resistance leaders advised the rank-and-file to "treat it just like...the last one." Soon after receiving

49 The Resistance, National Newsletter \#2, 1 Dec 1967, MKFP; NER Newsletter, 25 Oct 1967, MKFP. 
a new card from his draft board, Clennon turned it in at ceremony in New Haven similar to the one at Arlington Street. A small number of resisters chose not to be so aggressive. Out of 121 resisters surveyed for this study, nineteen (15.7\%) either asked their draft board for a new draft card or accepted the unsolicited one sent to them. Bob Bruen, for instance, simply did nothing after his draft board sent him a new card. He did not carry it with him but neither did he send it back. Bruen figured that someone on his local board knew his father, a career military man. and decided to give him another chance; perhaps his father intervened on his own. To this day, Bruen is not sure why his draft board did not go after him. In any case, he decided not to return the new card back. "I just took it as it was pointless to push it." he said later, "because if they chose to pretend that I didn"t do anything wrong. they weren 't that interested." Draft boards did not have to worry about resisters who. for whatever reason, did not rise to the challenge and resist all over again. Naturally, this greatly simplified the situation for both the resister and his local board. ${ }^{50}$

In contrast, some resisters heard little or sometimes nothing from their local boards. Given the intensity of debate regarding official response to resisters in Washington, that some men would be altogether ignored seemed odd. After all, the strategy of turning in one's draft appealed to many men because they believed it made it easier for the government to track them down. Thirty years later, the reasons behind draft board inconsistencies are no more obvious, but the example of Boston's resistance

${ }^{50}$ Clennon interview, 12 Jun 1997; Bruen interview, 13 Aug 1997; NER Newsletter, 25 Oct 1967, MKFP; From the 1997 survey of Boston draft resisters: 19 $(15.7 \%)$ of $12 \mathrm{l}$ resisters accepted or asked for a new draft card. 
community offers some clues. In Boston. 27 out of 105 (25.7\%) men who turned in their draft cards (this does not include those who burned their draft cards) were not contacted at all by their draft boards following their act of defiance. The majority of this group were much older than the average resister. In fact. 12 of the 18 resisters over the age of 26 - two-thirds - were left alone by their draft boards. In these cases, it seems, local boards decided to go after the men more likely to be drafted once stripped of their deferments. In other instances, some draft boards appear to have steered clear of resistance movement leaders. Alex Jack's draft board, for instance, never contacted him after October 16 even though he was classified I-A when he returned his card. Bill Hunt, on the other hand, received a letter from his Akron, Ohio draft board demanding to know why they suddenly found themselves in possession of his draft card. They instructed him to explain himself either in Akron or at the nearest draft board. Rather than return to Ohio, Hunt visited the Cambridge draft board with a film crew led by Norm Fruchter of Newsreel. There he made a speech about the war to several bewildered draft board secretaries. He never heard from his draft board (or a U.S. Attorney) again. That Hunt held a fatherhood deferment ( $3-\mathrm{A})$ at the time may have contributed to his draft board's reluctance in punishing him. but it could be that the Akron draft board, like Alex Jack's. wanted nothing to do with a crusading draft resister. Drafting him would only make a martyr of him and give him a forum for more antiwar speeches. ${ }^{51}$

${ }^{51}$ From the 1997 survey of Boston draft resisters: 27 (25.7\%) of 105 resisters heard little or no response from their draft boards after turning in their cards; $12(66.7 \%)$ of 18 resisters over the age of 26 were never contacted by their local draft boards; Jack interview, 21 Mar 1997; Hunt interview, 31 Oct 1997. 
Perhaps the most striking instance of the government ignoring a draft resister (purposefully or not) occurred in the case of former Boston University News editor, Ray Mungo. During Mungo's tenure at the school paper, the News had become a leading critic of the Johnson Administration`s policies in Vietnam. Mungo's name and image became well-known throughout the city. After turning in his draft card on October 16, Mungo's Lawrence. Massachusetts draft board called him for induction (he was 1-A at the time of the turn-in). Mungo responded by doing just about everything he could to draw the government's ire. About 600 people turned out at the gates of the Boston Army Base on the morning of Mungo 's scheduled pre-induction physical and watched him stand on the hood of a car, tear up his induction papers and cast them into the frigid coastal wind. He never set foot on the base itself and thus did not appear for his physical. Despite this flagrant violation of the law, neither the Selective Service nor the Justice Department moved to punish him. He received additional orders for physicals and induction, and the FBI interviewed him several times, but nothing ever came of it. Today. Mungo is certain that his notoriety in Boston protected him from prosecution. "It was an open and shut case," he said. "I expected to be prosecuted...but they never prosecuted me...I can only conclude that they didn't want to give me the right to make a martyr out of myself ${ }^{+52}$

And so, for many resisters, the wait continued. In the first weeks and months following October 16. draft resisters were left with few clues about how the

52 Ray Mungo, interview with author, 13 Jun 1997; Ray Mungo, Famous Long Ago: My Life and Hard Times With Liberation News Service (New York: Citadel, 1990), p. 87. 
administration would react to their protest. The experience of earlier draft resisters like the men from the Committee for Non-Violent Action led the new resisters to believe that their dissent would be handled with dispatch by law enforcement authorities. After all. the CNVA men were indicted within a month of their protest. Yet, despite FBI interviews, no arrests or indictments followed October 16. Even the proposed response of Selective Service - the reclassification of resisters - clearly did not have the full support of everyone in Washington. Resisters had no choice but to wait. But as they waited, other consequences of their actions began to unfold. Family members, friends, employers, and others expressed concern. Resistance organizers. meanwhile, had to plan to settle in for a long fight with the government rather than a quick knockout. They needed more financial and moral support. Most important, they needed to maintain the momentum generated on October 16. 
Reproduced with permission of the copyright owner. Further reproduction prohibited without permission. 
CONFRONTING THE WAR MACHINE:

DRAFT RESISTANCE DURING THE VIETNAM WAR

BY

MICHAEL S. FOLEY

B.S.. Florida Institute of Technology, 1986

M.A.. University of New Hampshire, 1994

\section{DISSERTATION}

Volume II

\section{Chapters VI-LX}

Submitted to the University of New Hampshire in Partial Fulfillment of the Requirements for the Degree of

\section{Doctor of Philosophy}

in

History

May. 1999 


\section{TABLE OF CONTENTS}

CHAPTER

PAGE

VI. GETTING BY WITH A LITTLE HELP FROM THEIR FRIENDS. .274

All in the Family 280

Unexpected Consequences...................................................................286

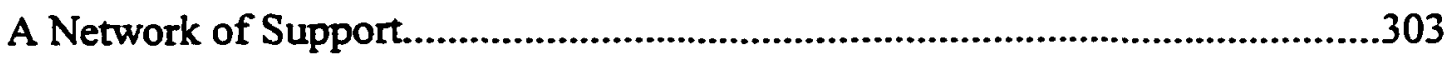

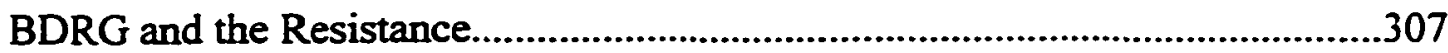

"Girls Say 'Yes' to Guys Who Say 'No'" ........................................................309

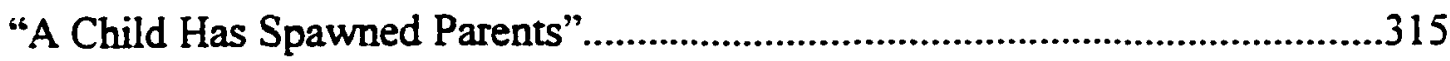

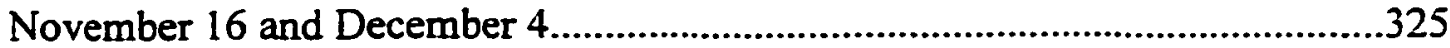

PART III: PEAKS AND VALLEYS

VII. "A NEW BEGINNING": CONFRONTATION, RENEWAL, AND TRIUMPH...336

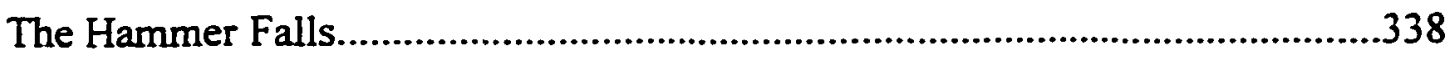

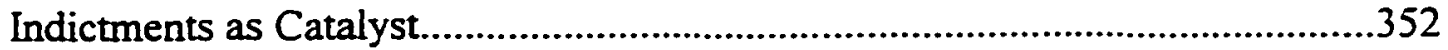

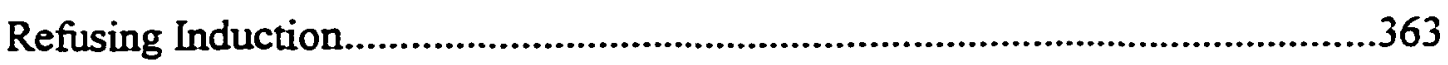

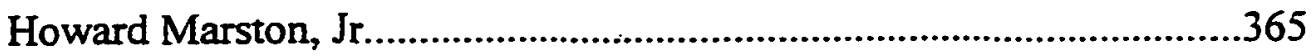

James Oestereich and Richard Hughes...........................................373

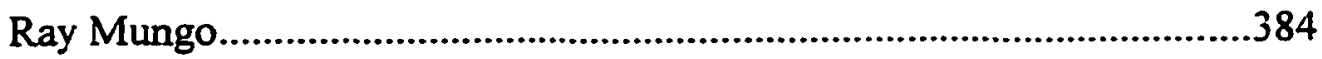

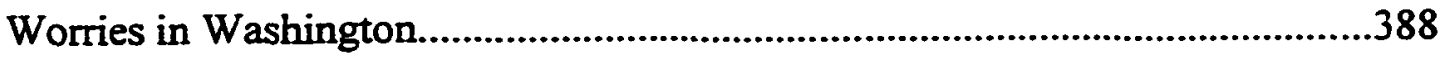

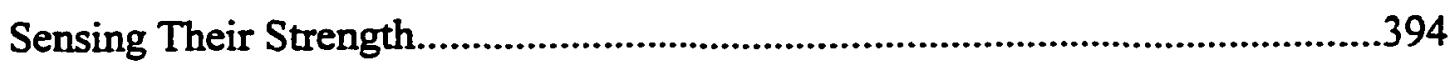

272 
VIII. SPRING 1968: A "HOTHOUSE ATMOSPHERE"

Death of a King and a World Upside Down.........................................................404

Sanctuary at Arlington Street.....................................................................................415

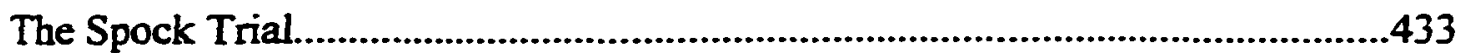

IX. BEYOND DRAFT RESISTANCE: NEW STRATEGIES AND LOOSE ENDS....460

So, You Say You Want a Revolution.....................................................................466

Hippies and High Schoolers..............................................................................472

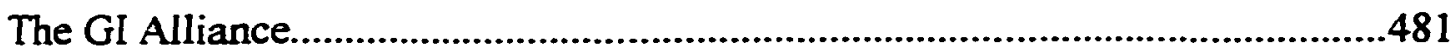

SUPPORT and Forgotten Resisters.............................................................510

EPILOGUE

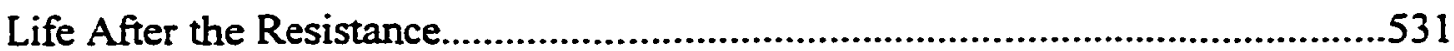

Looking Back

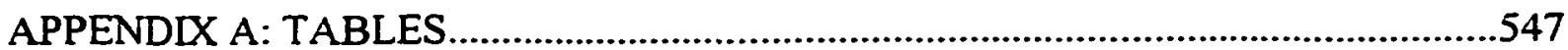

APPENDIX B: STATEMENT ON METHODOLOGY ................................................561

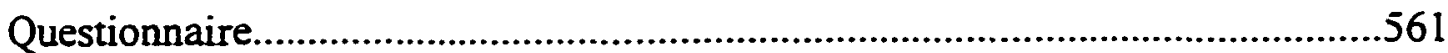

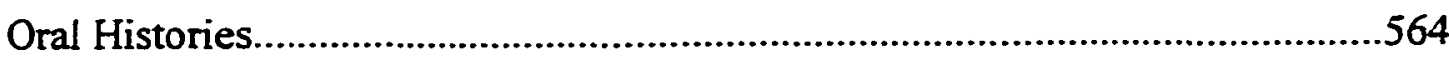

Sample Cover Letter and Questionnaire.............................................................56

APPENDIX C: A MEDITATION ON DRAFT RESISTANCE RESEARCH AND

PUBLIC MIEMORY

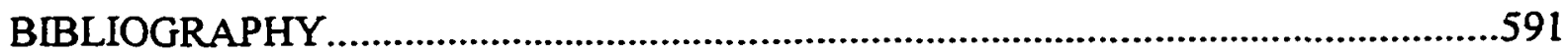

273 


\section{CHAPTER VI}

\section{GETTING BY WITH A LITTLE HELP FROM THEIR FRIENDS}

You all know me and are aware that I am unable to remain silent. At times to be silent is to lie. For silence can be interpreted as acquiescence.

$$
\text { Miguel de Unamuno, Salamanca, Spain, } 1936
$$

On the eve of the October 16 draft card turn-in at the Arlington Street Church, David Clennon wrote a letter to his parents from his New Haven apartment. He drank heavily that night. downing somewhere between a half-gallon and a gallon of cheap wine as he wrestled with the prospect of returning his draft card. He found himself, he later said, without "anybody that I could really confide in." After vomiting at least once, he dropped the letter to his folks and another to his Waukegan, Illinois, draft board into a street corner mailbox. Although Clennon awoke the next morning with a mean hangover, he drove to Boston with some friends and, inspired by Howard Zinn's speech, he turned in his draft card.'

A few days after the Arlington Street ceremony. Virginia and Cecil Clennon received their son's letter. They were not pleased. David's 16 year-old sister, Jean, immediately noticed the tension. Ordinarily, whenever her brother wrote home from Yale, her parents left the letters out for Jean to read. This time, however, they broke with protocol and when Jean inquired about the letter she knew had arrived, her mother withheld it. "Your brother's done something bad," she explained in a tone that Jean

\footnotetext{
' Clennon interview, 12 Jun 1997.
} 
understood to mean that there would be no further discussion. The 16 year-old walked away puzzled, wondering just what kind of crime her brother had committed.'

Virginia Clennon, in particular, always maintained her family's privacy assiduously and although no one knows the extent to which she and her husband discussed David's situation between themselves. to others she limited mention of it to brief one-sentence pronouncements. Jean, who lived in the same house, for example, last heard her mother refer to it that first night after the letter came. She said, simply, "your father is going out to see Dave," and they never talked about it again, even after her father returned from Connecticut. Likewise. Virginia brought up David's situation only rarely to her own sister Joan, and never mentioned it to her older daughter. Kathy, both of whom lived in Waukegan. too.'

Meanwhile. the tension between David and his parents sharpened. As Clennon's mother had told his sister. Cecil Clennon boarded a plane bound for New Haven within days of receiving the letter. There he hoped, as David later recalled, to "talk some sense" into his son. But the younger Clennon anticipated the visit and arranged for a meeting between his father and Yale chaplain. William Sloane Coffin. David figured that since his parents were "good Catholics," talking to a man of the cloth (event though Coffin was Presbyterian) might help his father to better understand his position. The meeting did not

2 Jean Kirkland, telephone conversation with author, 10 Sep 1998 (notes in author's files).

${ }^{3}$ Kirkland conversation, 10 Sep 1998; Kathy Bower, telephone conversation with author, 28 Jul 1998 (notes in author's files); Joan Dehmlow, telephone conversation with author, 24 Sep 1998 (notes in author's files). 
go well. Although it remained respectful. Cecil Clennon disagreed emphatically with Coffin's views of the war. He expressed his concern for his son's well-being and left without being comforted or persuaded by the pastor. Before he returned to Illinois. Clennon urged his son to seek a job teaching in the inner city; David's draft board would give him a deferment, he reasoned, and he would send money to David to support himself. The son refused and a kind of cold war began between them. ${ }^{+}$

The FBI soon made the crisis in the Clennon family even worse. Within weeks of the draft card turn-in. two agents from the Chicago field office knocked on the door of the Clennons house in Waukegan. They were not home. Undeterred, the agents went next door and spoke to their neighbors, inquiring about David. Naturally, word slowly began to spread that the son of Cecil and Virginia Clennon was in trouble with the FBI. It is unlikely that the FBI had any legitimate reason to inquire with anyone about David Clennon or his whereabouts. His case. no doubt, had been referred to them by his local board after receiving his letter and/or draft card; they had all the information they needed to find him. These visits were aimed more at pressuring parents into getting their sons to reconsider their actions. And a visit to the neighbors added a twist: the possibility that one's peers might learn of a son's illegal activities.'

The threat of such humiliation could be a powerful motivator. Except for David, the Clennons never told anyone else about the FBI visit. not even their daughters or other

+ Clennon interview, 12 Jun 1997; David Clennon, telephone interview with author, 17 Jun 1998.

${ }^{5}$ Clennon interveiw, 12 Jun 1997. 
relatives. Virginia Clennon, her sister said. "wanted everything to be right, to look right, to seem right...[she] didn "t want any crises in her life." Both her son's defiance and the potential embarrassment of a public trial caused considerable anxiety. "I sensed from her." David reflected years later. That it would be a profound humiliation just to have a son on trial for anything, never mind a matter of principle...she feared that there would be a tinge of the unpatriotic about it." David's sister Kathy confirmed that her parents "were extremely concerned with "what would people think?"' And so, when another Waukegan youth, Bill Drew, went on trial for "crimes" arising out of his own antiwar activism, but was supported by his parents. Virginia Clennon remarked to her sister that "of course the Drews are a house united whereas we are a house divided."

It would be a mistake. however. to view the Clennons' reaction to their son's draft resistance as rooted solely in a fear of public embarrassment, for the source of their response grew out of the complicated dynamics of familial relationships. According to David Clennon, his father was a dedicated family man. A veteran of World War II (he served in a clerical position in North Africa). Cecil Clennon worked as an accountant and later a data processing supervisor for the Johns Manville Corporation from 1946 until he retired. He worked 9 to 5 every day. rarely more, and always put his family first. He was very active in the Boy Scouts. serving as Scoutmaster of the Mount Vernon, New York troop to which David belonged. Under his father's guidance, David became an Eagle Scout at 13 and also won the Ad Altare Dei award for outstanding Catholic scout.

${ }^{6}$ Clennon interview, 17 Jun 1998; Bower conversation, 28 Jul 1998; Dehmlow conversation, 24 Sep 1998. 
Clennon's mother was a homemaker and local Democratic Party activist. Both of his parents were lifelong Democrats and encouraged their children to get involved in mainstream politics; in 1960. they urged David and his sister Kathy to campaign door-todoor in support of John F. Kennedy. In 1964 they, of course. supported Lyndon Johnson.

The Clennons, then. were an active. liberal, middle-class family, and in 1967, with the exception of David, they still believed in their president. Lyndon Johnson possessed more information than the general public knew, they thought, and must have good reason for pursuing the current course in Vietnam. Consequently, they very much disapproved of their son's protest - especially his method of protest - against the war. In addition. as members of the World War II generation, the Clennons harbored a strong sense of duty to one's country. Not only did Cecil Clennon serve in the war, but both of Virginia's brothers fought in it. too, including one who did not come home. Although David's sister, Kathy, believes today that her mother would have been devastated if David had been drafted, her Aunt Joan (Virginia's sister) thinks Cecil would have been proud to tell his friends that his son was in the Army.

Eventually, after many months of tension, Virginia and Cecil Clennon softened their position somewhat; they came to respect their son's views of the Vietnam war if not his tactics. Mrs. Clennon finally told David that she and her husband would stand by David even though they remained bewildered about his decision to choose draft resistance

${ }^{7}$ Clennon interview, 17 Jun 1998; Bower conversation, 28 Jul 1998.

${ }^{8}$ Clennon interview, 12 Jun 1997; Bower conversation, 28 Jul 1998; Dehmlow conversation, 24 Sep 1998. 
as his form of protest. They still hoped he would find some way to lodge his protest without being indicted, tried. and imprisoned. They feared for his safety and were concerned about the ramifications draft resistance might have for his future. Reflecting on it years later. David recalled his own confusion about their attitudes: "-I of course thought I was acting on values that I had learned from them."9

Although parental reaction varied significantly from one resister to another, many resisters found themselves trying, like David Clennon, to explain their actions to parents who either did not approve or did not understand. Some draft resisters did receive steady support from their parents. but others, hoping for comfort (if not validation) from their parents, found themselves confronted instead with ambivalence, disappointment, and sometimes hostility. In addition, many resisters did not anticipate the wider chain reaction that their protest often set off. Some were fired from their jobs; others were cajoled by friends who thought they had gone too far. The parishes where at least two seminarians worked erupted in controversy as some parishioners expressed outrage at the young ministers' protest while others rallied to their defense. Resisters expected that their protest would incur the wrath of their government, but this kind of extensive ripple effect often caught them off guard - and it made resistance more difficult.

At the same time that resisters faced the unpredictable reactions of non-resisters, however, support came from a growing number of citizens who decided to take up the cause of draft resistance. Older "adult" supporters. in particular. formed organizations designed to raise money to keep groups like the New England Resistance afloat and also

${ }^{9}$ Clennon interview, 12 Jun 1997. 
to pay for bail and court costs once the anticipated crack-down occurred. Lawyers and law students started groups that studied every intricacy of draft laws with hopes of challenging the legality of local draft board actions and certain Selective Service policies, especially punitive reclassification. These organizations and the people who joined them greatly bolstered the draft resistance cause in the weeks and months following October 16. Thus, as resisters awaited the federal government's official response to their protest, they confronted criticism and ambivalence from those to whom they traditionally looked for support while they were simultaneously sustained by new groups of people unknown to them before their resistance. This chapter examines the dynamics of those relationships and the effects they had on resisters and the draft resistance movement as a whole.

\section{All in the Family}

After October 16. many resisters learned that following through on their commitment to confront the draft and the war meant they also had to face repercussions that they did not at first anticipate. First among these was the effect of their resistance on their families, and especially their parents. To be sure, the responses on the part of parents varied considerably. but some patterns do emerge from data gathered in a survey of draft resisters conducted for this dissertation.. Most resisters` fathers, for example. disapproved on some level: 46 of 82 respondents (56\%) categorized their fathers as either disapproving (22) or strongly disapproving (24) of their resistance (see Table 6.1 in Appendix). Approximately 25 percent of resisters' fathers supported their sons while another 18 percent were identified as non-committal. In a mild contrast, resisters' 
mothers seemed slightly more tolerant of their sons' behavior: 47 percent disapproved of their resistance while 21 percent were non-committal and 32 percent approved. Only three couples split (i.e., mother and father disagreed), two of which featured a mother approving of resistance while her husband did not. But among couples who agreed with each other regarding their son's resistance. 36 disapproved to 18 approving - a 2 to 1 margin. ${ }^{10}$ The numbers do not tell the whole story, however; the reasons for disapproving or approving of a draft resister in the family varied greatly.

In some cases. such as David Clennon's, parents believed the government had more information than the general public knew and. therefore. could reasonably expect support from the citizens it represented. Ray Mungo, for example, saw his parents as "pretty apolitical." They toiled in factories in Lawrence, Massachusetts, and had always voted for the Democrats - especially the Kennedys. An 8 by 10 inch photograph of John F. Kennedy hung in the living room of their home. When their son, Ray (named after an uncle killed in France during the Second World War), resisted the draft from atop the hood of a car outside the Boston Army Base. Ray recalls, they were "freaked out." They did not want any of their three sons to go to Vietnam, but they likewise could not understand why one of them would try to get thrown in jail. Mungo's parents may not have liked the war in Vietnam, but they grudgingly maintained the attitude that one

${ }^{10}$ From the 1997 survey of Boston draft resisters: 116 resisters responded to the survey, though only 82 responded to the question about their father's reaction to draft resistance ( 34 were left blank or marked $N / A$ ) and 95 responded to the question about their mother's reaction. 
should obey one's government."

In other instances, draft resistance hit a family as the final blow in a series of indignities ultimately resulting in estrangement between a son and his parents. By the time Chris Venn resisted and prompted his extradition to Texas. his parents were resigned to accepting that he had - at 20 years old - stepped out from under their influence. No arguments resulted, but Venn's parents, although they went to El Paso, offered no support for his stand on the war or the draft. The philosophical gulf that existed between some resisters and their parents frequently meant that the issue went undiscussed. In rare cases, though, the initial disaffection created from draft resistance could be bridged. Neil Robertson's father, for example, at first saw his son's draft card turn-in as the culmination of troubles that began with his withdrawal from Dartmouth College. Robertson's parents chose to break off contact, and essentially "disowned" him. When Robertson informed his fellow resisters of his deteriorating relationship with his parents. one of them suggested that he send them a copy of Howard Zinn's book, Vietnam: The Logic of Withdrawal and the Selective Service memo on channeling. Two weeks later, his parents wrote a letter of apology and told him that they supported his resistance. In an amazing transformation, Robertson's mother soon got involved with antiwar and women's liberation activism; his father went to Chicago in August 1968 as a delegate for Eugene McCarthy but was arrested after leaving the convention to march with comedian and presidential candidate Dick Gregory. Neil Robertson then posted bail for his father. ${ }^{12}$

\footnotetext{
"Mungo interview, 13 Jun 1997.

12 Venn interview, 12 Jun 1997; Robertson interview, 24 Aug 1997.
} 
There is not much evidence to suggest that many parents did completely disown their sons because of draft resistance. The New England Resistance Master File noted that the parents of one resister from Northeastern University should not be contacted because, as the card read. they "don"t want anything to do with him." Such cases seem rare, however. What appears to have occurred more frequently is that resisters who knew their parents well enough to realize that resistance would not meet with their approval, consequently, chose not to discuss it with them. As one resister wrote. "while I never informed my parents of my 'activities.' if I had I'm sure their reaction would have fallen into the 'strongly disapproved' category." There did not seem to be much of a reason for a resister to talk about his resistance activity with parents who he knew would not understand or would not approve; they experienced enough stress just waiting for the FBI to visit. Debates with Mom and Dad over draft resistance would not improve the situation. This actually made matters easier for those resisters who expected disapproval. Resisters such as David Clennon who were not sure how their parents would respond, only to experience disapproval, suffered the most. "I thought they might well disapprove," Clennon reflected in 1998. "-I hoped they would understand. I hoped that they would see my actions as a reflection of values that I leamed from them."'s

Some parents could understand their sons' outrage over the war but disagreed with their method of protest. Total non-cooperation seemed too extreme. Virginia

${ }^{13}$ Master File, New England Resistance, AJP; Respondent number 105, 1997 survey of Boston draft resisters. Note: this propensity to resist without discussing it with parents may account for the high proportion of responses marked "not applicable" with respect to parental reaction; Clennon interview, 17 Jun 1998. 
Clennon thought David's willful surrender of his deferment was foolhardy. Similarly, Homer Jack, the father of New England Resistance founder Alex Jack, would have preferred that his son seek conscientious objector status while still protesting against the war. The parents of Michael Zigmond, a postdoctoral fellow at MIT, saw futility in the strategy of draft resistance. Michael and his comrades would never get enough men to resist the draft to actually slow or stop the war, they asserted. But Zigmond himself argued that if he wanted to continue speaking out against the war, doing so would be much easier if he refused to cooperate with the Selective Service than if he did submit to their rules. ${ }^{14}$

Most of all, parents of resisters just worried. They worried about their sons' safety and about their futures. When they learned of a son's decision to resist, the prospect of a prison sentence loomed most prominently in their minds. Most middle class parents could not bear to think of one of their children in a place as alien to their placid suburban lifestyles as a federal penitentiary. On one level, then, they quickly grew concerned with the physical protection of their law-breaking sons. This describes the parents of Ray Mungo and David Clennon. And this concern for safety was not limited to parents who disapproved of draft resistance. Indeed, several respondents indicated that although they supported them, their folks could not help but be nervous and anxious about the course of action chosen by their boys. One resister said that both of his parents were "fearful of the effects of a jail term on me," and another noted that his parents did

${ }^{14}$ Clennon interview, 12 Jun 1997; Jack interview, 21 Mar 1997; Zigmond interview, 29 Dec 1997. 
not want him to go to jail any more than they wanted him to go to Vietnam. Like parents who have given so much of themselves to raise a child until he is eighteen or nineteen years old only to see him drafted into the army, the parents of resisters feared losing their sons - not on a battlefield but in a prison. They also feared how American society might treat them years later, long after the war ended.

Resistance simply did not fit the vision of life that parents planned for their children. Harold Hector's family thought his draft resistance activity as both a resister and a draft counselor might keep him from ever getting a decent job. Women who worked in draft resistance organizations especially heard this line of thinking from their parents. The father of Connie Field. a full-time worker in the New England Resistance office after October 16. kept telling her that if she kept this kind of behavior up, she would never get a good position working for the government. Likewise, the parents of Bliss Matteson, an office manager for the Boston Draft Resistance Group, feared that she was losing out in the "career chase." Years later. Matteson's summary of the effect of her draft resistance work on her relationship with her parents seems to fit the experience of most participants: draft resistance, she said, "didn't really wreck our relationship, but I think it was very hard for them."1s

At the same time, of course, that 25 per cent or so of parents who supported their resister sons included the rare few who cut an image of fearlessness. Howard Marston of

${ }^{15}$ Mungo interview, 13 Jun 1997; Clennon interview, 12 Jun 1997; Respondents numbers 50 and 150, from the 1997 survey of Boston draft resisters; Hector interview, 9 April 1997; Connie Field, interview with author, 17 Jun 1997; Bliss Matteson, interview with author, 29 Aug 1997. 
Rockport, Massachusetts, took the position that until his son, Howard "Chick," Jr., reached the age of 21 , he and Chick's mother were responsible for him. Therefore, the elder Marston forbade his son to submit to the draft. Chick later recalled that he had his parents' "full support and then some." At times he felt that his parents - especially his father - "really pushed" him into resistance much stronger than he might have gone himself. By the time he refused induction (see Chapter Seven), Marston's father had become a virtual fixture on Boston TV newscasts and in the papers. Reporters found the flamboyant Marston. Sr., to be articulate and controversial so they covered his son`s draft case closely. Unlike Harold Hector's parents, who lamented that their son's activities might jeopardize his future, Chick Marston's father pushed him into those same endeavors. ${ }^{16}$

On the whole, very few parents took their support of their sons' resistance as far as Howard Marston. In fact. most disapproved of draft resistance and were frequently bewildered by their sons' actions. Resisters who hoped for support from home, then. often had to turn elsewhere. David Clennon found some comfort in regular telephone discussions with his Aunt Joan, but many resisters found that just as their parents disapproved, so too did others from whom they might ordinarily expect support. Sometimes resisters overestimated the amount of sympathy that they could hope for from others; they found that draft resistance could get pretty lonely.

\section{Unexpected Consequences}

If some resisters could have predicted a possible clash with their parents following

${ }^{16}$ Marston interview, 13 Dec 1997. 
their protest. others did not anticipate the fallout that resulted in their places of employment, their schools, or among others from whom they thought they could expect understanding. In one of its first post-October 16 newsletters the New England Resistance called on its readers to help assemble a job file for resisters "in the event they are fired." In just a short time, a few resisters had lost their jobs because of their expression of dissent and the Resistance hoped that sympathetic employers and friends would be able to provide temporary or permanent work for those who lost their jobs. ${ }^{17}$

The Reverend J. Michael Jupin. newly installed as an associate rector at an Episcopal church in Winchester, Massachusetts (8 miles north of Boston) learned the hard way about the combustible effect that could be generated by one man's decision to part with his draft card. News of Jupin turning in his registration certificate to William Sloane Coffin at the Arlington Street Church on October 16 hit his place of employment. the Parish of the Epiphany, like a tsunami. Neither Jupin, 25, nor the church's rector, the Reverend Jack Bishop, had any idea that they were about to set off a firestorm of protest when they announced Jupin's resistance in the weekly parish newsletter. Three Crowns of the Epiphany. Indeed, Bishop (who wrote the newsletter) sandwiched the rather matterof-fact announcement of Jupin's stand between other routine parish notes. He indicated that Jupin returned his draft card and wrote that the associate rector would report on his draft protest (and his experience in the march on the Pentagon) in a sermon on November 26. Here, however, Bishop misjudged his flock. Most parishioners, it turned out, could not wait over a month to hear from Jupin - or from Bishop. Not a few assumed that

\footnotetext{
${ }^{17}$ NER Newsletter, undated (c. Early Nov 1967), AJP.
} 
Jupin's resistance and Bishop's support of it had been planned ahead of time and felt insulted that the parish had not first been consulted. They demanded explanations almost as soon as the newsletters landed in their mailboxes. ${ }^{18}$

Both Mike Jupin and Jack Bishop arrived at Epiphany with a history of social activism. In the year or so that they had worked there. they sought to raise the parish's level of concern with respect to contemporary issues of social justice and, in particular, civil rights. Bishop came to Winchester in the autumn of 1966 straight from a sabbatical leave at the Episcopal Theological School in Cambridge where he worked under Harvey Cox. (A theologian and sociologist, Cox stressed making religious faith relevant in an increasingly secular American society. His first book. The Secular Ciry (1965), became a popular best seller.) Prior to his year in Cambridge, Jack Bishop had been active in the civil rights movement. He marched from Selma to Montgomery with Martin Luther King, Jr., and later did civil rights work in Boston. Early in 1967, Bishop went to Washington to join the first mobilization organized against the war by Clergy and Laity Concerned About Vietnam (CALCAV). Similarly, Mike Jupin had answered the Southern Christian Leadership Conference's call for college students to protest segregation in St. Augustine, Florida in April 1964, the month before King himself would bring national attention to that city's racist ordinances. In addition, Jupin had been protesting American involvement in Vietnam since November 1965 when he participated in the SANE-sponsored march on Washington. He first came to the Parish of the

18 Jack Bishop, interview with author, 11 Dec 1997; Michael Jupin, interview with author, 28 Dec 1997; "The Draft, Conscience, and the Church," Three Crowns of the Epiphany, 22 Oct 1967, pp. 1-2, Papers of Jack Bishop (hereafter cited as JBP). 
Epiphany soon after Jack Bishop; then in his last year at the Episcopal Theological School, he started as a student minister who became so well-liked by the congregation that they hired him as assistant minister when he graduated from seminary in June 1967. Given their personal histories, then. Mike Jupin's decision to resist the draft and Jack Bishop's readiness to support him did not seem unusual, at least not to the two of them. ${ }^{19}$

The parishioners, led by their wardens (elected representatives of the congregation), however, found these developments to be highly irregular. The two wardens, one a successful businessman and the other a retired Rear Admiral and veteran of World War II, asked Rev. Bishop for a special meeting on October 21. Almost immediately, the former Navy man defined this crisis as the worst the parish had known in its 85 year history. The two asked Bishop how they could "get rid of Mike." When a stunned Jack Bishop replied. "you get rid of the rector." the meeting ended at an impasse. $^{20}$

Bishop later said that he should have seen this kind of reaction coming. He viewed Winchester, a wealthy town, as a "very conservative suburb" that attracted highly educated working professionals from the city. The parish itself. made up of 1,200 baptized members, flourished economically. In one of his first meetings with the wardens the year before, one of the two suggested that Bishop bring the American flag forward for the singing of "God Bless America" at the start of every service. He refused. He later

${ }^{19}$ Bishop interview, 11 Dec 1997; Jupin interview, 28 Dec 1997.

${ }^{20}$ Rev. Jack Bishop, "Winchester: Crisis in Conscience," unpublished paper, 18 Dec 1967, p. 3, JBP. 
regarded this as representative of the parish's patriotism and a clear harbinger of the request for a meeting following the announcement of Michael Jupin's draft card turn-in. But Bishop did not notice it at the time. And in the meantime, he had been pleased with the way the church had responded to some initial social action work, especially with respect to civil rights. He had no idea what he and his assistant were walking into in the fall of 1967.21

On October 22, 1967, the day after the wardens sought Mike Jupin's removal, Jack Bishop spoke of the controversy from the pulpit. He noted that certain members of the parish had expressed deep concern over the draft card turn-in and that he wanted everyone to know that he supported Jupin in his protest. This did nothing to minimize the unrest. Over the next week, Bishop felt obliged to set aside almost all of his time for "countless meetings, appointments, telephone calls" to let parishioners air their complaints. One man. a respected Winchester physician and influential parish member. came to see Bishop in those early days. As the rector later recalled the story, the doctor told him, "Jack, I want you to know that I've been a member of this parish for twenty years and I've been close to the clergy all along, and my family has been raised here, and my kids have grown up here, and it means everything to us. And I have to say you're the worst thing that's happened [to this church]." On Thursday, October 26, the Vestry (a committee of nembers elected to administer the temporal affairs in the parish) convened a special meeting to discuss the participation of their clergy in antiwar activities.

2.

${ }^{21}$ Bishop interview, 11 Dec 1997; Bishop, "Winchester: Crisis in Conscience," p. 
Although two members of the Vestry had already resigned in protest, no fireworks erupted at this meeting. Instead. the group recommended that Bishop and Jupin address the issue squarely the following Sunday, October 29 , and that the entire parish be notified that this would be the focus of the services that day."2

On October 29, the parish finally heard from the assistant minister himself. In an address that lasted about 15 minutes, the Reverend Jupin detailed all of the factors that brought him to his decision to choose draft resistance. First, he discussed the "immoral" nature of the American war in Vietnam. He cited statistics putting the number of civilians killed to the number of soldiers at "somewhere between five and ten to one." More bombs had already been dropped by American planes on North and South Vietnam, he asserted, than on Germany during all of the Second World War. He described the relocation of nearly one million South Vietnamese civilians and the use by American forces of napalm and antipersonnel bombs on civilians. But he also explained to the parish that he did not make his decision to resist solely on the immorality of the American war effort. In addition, Jupin felt that the Johnson administration had not presented the public with a reasonable justification for the war. He argued that fighting the war to stop the spread of communism, a commonly held rationale for supporting the war effort, did not jibe with American policy toward other communist nations. After all, the United States traded with the Soviet Union and other Eastern bloc nations, he said. Nor did he accept the notion that Americans were fighting in Vietnam to contain China, noting that 1997.

${ }^{22}$ Bishop, "Winchester: Crisis in Conscience," pp. 2-5; Bishop interview, 11 Dec 
historically. China and Vietnam were at least distrustful of one another and frequently enemies. He had come to the conclusion, he said, that "the administration's arguments for our presence in Vietnam are totally inadequate." $" 23$

In fact, Mike Jupin had been opposed to the war since 1965 when American escalation of the war began in earnest. First he wrote protest letters to his Indiana congressman and Senators Hartke and Bayh. They assured him of their concern and their efforts to "do something about it." Yet, "that was two years ago," Jupin told his Winchester parish. "Nothing has happened but greater escalation." Since coming to Massachusetts, he had spoken with Senators Edward M. Kennedy, Edward Brooke, and his Congressman but had seen them do nothing serious to end the war. Since none of the traditional legal channels of protest seemed to be working, Jupin said, he and his friends began to contemplate nonviolent civil disobedience. He chose to violate Selective Service laws, he said.

because with others I firmly believe that what this administration is doing is evil and that as a follower of Jesus Christ and as a member of his Church I have no choice but to oppose evil. In this act I accepted the consequences of breaking the law of the land because I felt I must respond to a higher law of opposing evil which to me and many is a clear and present danger in this country.

Jupin also noted that even before committing themselves to draft resistance, he and his friends had been called "unpatriotic, cowardly, vicious, rebellious, un-American, and even treasonous." In response, he asked the congregation rhetorically, "where did democracy and freedom and individualism end in this country and unthinking blind

23 J. Michael Jupin, sermon, 29 Oct 1967, pp. 1-2, JBP. 
obedience to even that which may be evil begin?"24

Finally, the young minister acknowledged that he had misread the members of the Parish of the Epiphany. "I thought that my position was understood by most and that my action would be understood," he said. "In this I have erred and I am sorry." He also wanted them to know that he felt the greatest sympathy for those with loved ones in Vietnam. "I want them home and unhurt." he said. "I do not want to see all these American boys killed for what appears to me to be an absurd war." He closed by reminding his listeners that he had nothing to gain from draft resistance. He was not trying to "dodge" the draft; as a minister he could not be drafted. Instead, he asserted, -I do this as an act of conscience out of love for this nation and the desire that it truly search its heart, and know and do the will of God." Several weeks later, reflecting on the crisis with some detachment, Jack Bishop said that "October 29 surpassed any day I have known in its power and dignity."25

Jupin's sermon affected different parishioners in various ways. Following the 9:00 a.m. service, all members of the church were invited to the normally scheduled adult education class where they were given the opportunity to write down their personal reactions to the morning's service. More than 100 parishioners wrote comments - most of which have survived to this day in Jack Bishop's papers - and others sent letters over the subsequent week. A review of these comments reveals that a majority $(56 \%)$ of the parish supported Jupin's protest (See Table 6.2 in Appendix A). Some of these were very

${ }^{24}$ J. Michael Jupin, sermon, 29 Oct 1967, pp. 3-4, JBP.

${ }^{25}$ J. Michael Jupin, sermon, 29 Oct 1967, pp. 4-5, JBP. 
enthusiastic. One woman noted that "this may be the shot in the arm the parish needs!" Others were moved by Jupin's sermon. "We feel that Mr. Jupin has conducted himself with dignity and humility, and we have great respect for his commitment." wrote one couple. "His statement in church today was impressive in its clarity, intelligence, and concern for both the larger issues and the problem of his relationship with this particular parish."26

Still, a significant number of parishioners disapproved of Jupin's actions, some strongly. Nearly 20 percent were so upset that most called for some kind of disciplinary action. including firing Jupin. Several themes emerged from these responses, but three stood out: First. many parishioners simply could not tolerate an assistant minister who broke the law for any reason; second. some were concerned about the influence Jupin would have on the younger members of the parish; and third. many believed Jupin's own youth. immaturity, and naivete (not his conscience) were responsible for his resistance. Some critics incorporated all of these themes into their notes. "Responsible citizens," wrote one, "do not perform acts of treason and take the law into their own hands by either destroying or turning in their draft cards...I do not care to have my children taught disrespect for their country and its laws." Another woman was most concerned with the impact the event would have on her children. She wrote.

I must accept Mr. Jupin's action as an individual willing to accept whatever penalty the government wishes to impose...However, Mr. Jupin cannot behave solely as an individual while he is in a position of teaching and advising young people... We have three teenage children...Do I tell

${ }^{26}$ Written responses (numbers 89 and 124), Parish of the Epiphany, 29 Oct 1967, JBP, copies in author's files. 
them that in critical situations they should let their consciences be their guides, regardless of the law? Would it not be better - morally and ethically - to use their most conscientious efforts, within the law, to combat difficult situations?

Others were certain that Jupin did not know what he was doing. Some of them called the young minister "naive," "gullible," or described his resistance as "an uncounseled act of youth." One parishioner saw Red amid this apparent ignorance: "When well-intentioned but not very well-posted individuals...go out and preach and practice Civil Disobedience, and worse breaking the Law; they are dupes and instruments of [an] Anti-Christ by the name of Communism."27

Finally, the written responses indicated that the last large group of parishioners (about 17 percent) disapproved of Jupin's views and his methods, but did not think he should be punished for what amounted to an act of conscience. Like their fellow members who were more upset, this group also feared the example that draft resistance set for the younger members of the church and questioned using illegal methods to make a political point. But overall their criticisms were muted by their faith in freedom of expression and their admiration for anyone who stood up for his beliefs. At times. these parishioners showed an ambivalence which even they seemed to recognize and sometimes found frustrating. For instance. one man wrote that he. too. opposed the war and saw the loss of American lives as "horrendous and futile," but he remained unsure about how to effect a change in policy. "How to withdraw from Vietnam at this point is an enigma to me!" he said. Civil disobedience, he knew, was not the answer. "Thus, Mr.

${ }^{27}$ Written responses (numbers 105, 113, 13, 14, 117), Parish of the Epiphany, 29 Oct 1967, JBP, copies in author's files. 
Jupin, I agree with your opinion but not your method. But at least you have the courage of your conviction - which is more than most of us!"28

Despite some support for Jupin in the parish and the grudging respect paid to him even by some of those who disapproved of his behavior, Jupin's sermon on the $29^{\text {th }}$ did not quell the upheaval in the parish. In the middle of a service on November 1 , All Saints Day, several parishioners walked out in protest; three others refused to take Communion from the hands of a draft resister. Meanwhile, several people suggested that Jupin was a Communist and a dealer of marijuana. Jack Bishop, for his part, continued to meet with angry members of the church. including one of the wardens who hoped Jupin might consider getting a haircut as a gesture of goodwill. At the same time, the story began to creep into the local weekly newspaper, the Winchester Star in the form of readers' letters. Over several weeks in November, letter writers accused Jupin (though usually without naming him specifically) of being "Un-American," "disrespectful," and "fostering anarchy." Defenders responded with their own missives equating Jupin and his fellow draft resisters with participants in the Boston Tea Party, abolitionists, and Christ himself. One man said they were guilty only of the highest form of responsible patriotism." If it did nothing else, Michael Jupin's draft resistance provoked debate in a place that had not yet confronted the issue..$^{29}$

28 Written responses (number 32), Parish of the Epiphany, 29 Oct 1967, JBP, copies in author's files.

${ }^{29}$ Bishop, "Winchester: Crisis in Conscience," pp. 6-7; "Decries Clergy's Advocation of 'Lawlessness," letter, Winchester Star, 2 Nov 1967, p. 5; "For Clergymen Who Live As They Believe: Admiration," letter, Winchester Star, 9 Nov 1967, p. 7; "Our Obligation to Hear Critics of Administration," "Illegal Acts Lose Sympathy for the Peace 
Ultimately. Jack Bishop sought outside assistance to help placate the discontented in his parish. On November 4. he and the two wardens of the church visited with the Right Reverend Anson Pheips Stokes, Bishop of the Episcopal Diocese of Boston. Following two hours of productive discussion, Stokes agreed that he would speak to the Parish of the Epiphany. He came to Winchester on November 26. the Sunday of Thanksgiving weekend. The two services at which he preached were packed but the timing was not ideal; three days earlier Winchester learned that it had lost its second son in Vietnam. Marine Corporal Francis J. Muraco, known to friends as "Butch," and already a Purple Heart winner. died when he stepped on a land mine while on patrol duty in the province of Quang Tri. He was 21 years old and a "short timer" - due to come home in six weeks. As the $26^{\text {th }}$ approached, Jack Bishop worried about the juxtaposition of this war hero's funeral at St. Mary's, the Catholic church in town, with - in the same week - his own church's recruitment of Bishop Stokes to attend to its draft resistance crisis. $^{30}$

When Bishop Stokes came to Winchester and spoke at both services that Sunday, he said all the right things for people on opposite sides of the issue. Looking resplendent in his full Bishop's regalia, Stokes ascended to the pulpit and at first spoke generally

Cause,"and "'Gross Injustice' of War Justifies Counter Actions," letters, 16 Nov 1967, p. 6.

${ }^{30}$ Bishop, "Winchester: Crisis in Conscience," p. 8; Bishop interview, 11 Dec 1997; "Corporal Francis J. Muraco Killed In Action In Vietnam," Winchester Star, 30 Nov 1967, p. 1; Tom Greenwood, "A Fallen Hero's Power to Inspire," Boston Globe, 11 Nov 1998, p. A23. Note: in 1969, the town of Winchester named a new elementary school after Francis Muraco. 
about the Church's longstanding concern with war, its victims, and those who fight it. He noted that, historically, Christians frequently sought conscientious objector status or noncombatant options. He told the parish that he, personally, thought the turning-in or burning of draft cards "unnecessary and unwise." Nevertheless, Stokes continued. "if done prayerfully, after consultation and with a willingness to bear whatever criticism or penalty must be born," draft resistance could be "one expression of a desire to face the evil of war and to bear witness against it." After all, he said, "a man who gives up his card to the government is not doing a popular thing and he is certainly not avoiding any penalty."

Though apparently supportive of Michael Jupin's general stand of resistance. the Bishop gave clear signais that he understood how uncomfortable this kind of lawbreaking made some members of the parish. In certain cases, he counseled, thoughtful people use such measures to press their point. "Obviously, we must seek to avoid unlawful steps." he said, "except as a very last resort, as law and order are necessary for freedom." Stokes invoked the illegal methods of abolitionists - maintaining an underground railroad, for example - in the movement to end slavery. Although it might rankle their families, friends, and acquaintances, in difficult times there would always be a small number of people whose "strong convictions" would lead them to take "unusual measures" to underscore their position of protest. At last, the Bishop turned directly to the ongoing crisis at the Parish of the Epiphany:

The Reverend Mr. Jupin in his action at least reminds us of the complexity and importance of some of the issues. He let us hear clearly what many are saying secretly. He is concerned on a conscientious basis with a great 
contemporary issue. If we do not approve the form his protest takes, at least we can learn from his action the depth of concern of many people. I am sure that he is willing to recognize that on these issues no man can have easy or altogether satisfactory answers. I am sure that he is willing to bear the legal costs he may have to bear. He has not been furtive. He can help make us think, and I believe we can trust the processes of thought and discussion.... Let us in the name of Christ be big enough to understand and appreciate those whose concerns lead them to such actions as he has taken.

And, thus, Bishop Stokes concluded by emphasizing his themes of tolerance and maintaining - even in the face of disagreement - some level of harmony within the parish. Speaking extemporaneously following his prepared remarks, Stokes said, "It should be the glory of the Church that its men differ in their concern. [Jupin] may or may not be just in what he did...and we may disagree among us about this...but we pray God that out of it there may be a new unity here. not of opinion, but of concern." Here the Bishop sought some common ground on which the entire parish could stand. If there would be division over the method of Jupin's protest. perhaps, the Bishop argued. parishioners could at least agree that the war in Vietnam was an issue that warranted the attention of the Church, its members, and its clergy. "If together you tum your back on him now," Stokes warned, "it will indicate that you cannot tolerate all concern."jl

The Bishop's visit to the Parish of the Epiphany produced an almost immediate calming effect. Following the service, one parishioner approached Mike Jupin. "I understand better now," he said as he shook the assistant rector's hand. "I couldn't have done this before." About ten days later, after another meeting of the Vestry, the two

${ }^{31}$ Anson Phelps Stokes, "The Church and War," statement, 26 Nov 1967, JBP; "Bishop Anson Stokes Asks Epiphany For 'Unity In Concern," Winchester Star, 30 Nov 1967, p. 1. 
wardens issued a letter to all members which they hoped would bring the matter to a close. They enclosed copies of the Bishop's statement and a position paper on civil disobedience produced by the national House of Bishops in 1964. That document. written in response to the civil rights movement, made it clear that the Episcopal Church recognized the right of anyone to break laws "for reasons of informed conscience," as long as the person violated the law nonviolently, accepted the legal penalty, and exercised restraint in "using this privilege of conscience." Even so, the wardens included a paragraph in their letter noting that the clergy (Jack Bishop and Mike Jupin) had apologized for the unexpected "unrest they have caused." and assured parishioners that neither of them would take any similar future action without first consulting with the wardens and the Bishop. Therefore, they wrote, "it is the consensus of your Vestry that Mr. Jupin can continue effectively at Epiphany as Assistant Minister and as a leader of our youth." (In fact. the Vestry did not reach a complete consensus: two days later, the one person who voted against the continued employment of Mike Jupin became the third member of the Vestry to resign. $)^{32}$

The wardens and the remaining members of the Vestry hoped that the letter would begin a period of reconciliation and, indeed, in the weeks following the Bishop's visit, the clergy at the Parish of the Epiphany sought to establish a ministry that would foster greater communication, understanding and. as the Bishop had urged. a unity of concern.

\footnotetext{
${ }^{32}$ Fred Fove. "Bishop Defends Anti-Vietnam Cleric," newsclip (possibly Boston Record American), JBP; John K. Colony and William H. Buracker letter to parishioners of the Parish of the Epiphany, 7 Dec 1967. JBP; "On Christian Obedience," position paper of the national House of Bishops, 1964, JBP.
} 
The church, after all, had weathered the loss of several families, some of whom were longtime members, and also saw other parishioners withhold their pledges of financial contributions; at the end of the year approximately $\$ 12.000$ in pledges (out of about $\$ 82.000$ total) had been withheld by angry parishioners. In addition, there were simply sore feelings among members on both sides of the issue. Even the rector's two older sons. ages 10 and 12 , were teased and ridiculed by other children who heard about the controversy at their own dinner tables. The Vestry and the clergy now sought to heal those divisions. ${ }^{33}$

At the same time. however, the thrust of the wardens' letter insinuated that the two ministers, by apologizing. had admitted to making a mistake, to accidentally stirring up trouble; the Vestry now seemed unwilling (at least in this letter) to consider the larger implications of Michael Jupin's draft card turn-in as an act of protest and instead portrayed it as merely an error of judgement. As Jack Bishop and Mike Jupin moved forward with adult education classes designed to discuss ways to bridge the new divisions in the parish, this development weighed on Bishop. In mid-December, as he reflected on the crisis for the first time to a group of fellow ministers, Bishop told his colleagues that the swirl of controversy had been so intense that for most of the parish it may have obscured the most important issue: the Church's role in matters of war and peace. The frequent references to Mike Jupin's youth and naivete in the parishioners 'written responses supported this. Despite Bishop Stokes's hope that the church would unite in its 1997.

${ }^{33}$ Bishop, "Winchester: Crisis in Conscience," pp. 9-11; Bishop interview, 11 Dec 
concern regarding the war in Vietnam, the reconciliation within the parish, it seemed. would take place at the expense of confronting such difficult societal dilemmas. "In all of it, Jack Bishop later remarked, most parishioners "didn"t face the real issue." Instead. they focused on returning the church to its former noncontroversial state by pointing to aspects of Bishop's and Jupin's ministries that they could support. Several months later in May 1968, the Parish of the Epiphany did send a busload of volunteers to Washington to take part in the Poor People's Campaign, an undertaking that may not have happened before Jack Bishop and Mike Jupin began to turn the parish's attention toward contemporary issues, but it never returned to the issue of Vietnam. ${ }^{34}$

To Mike Jupin's relief. the Boston Globe at least seemed to soften its position on draft resistance in light of the Winchester controversy. The day after Bishop Stokes spoke at Epiphany, the Globe ran an editorial that used Jupin's situation as a basis for defending civil disobedience. In part. the paper issued a clarification that defined civil disobedience not as a "dissociation from society," but "an act of profound commitment to it." Some Americans, like Michael Jupin, saw the war in Vietnam, they said, "as so contrary to national ideals and personal beliefs as to warrant civil disobedience..." This was a point that resisters had been trying to make from the start but that had failed to receive much consideration from the press. "While not agreeing with them, we should not condemn them." the editorial concluded. "They are brave and honorable men." Such a characterization of draft resisters demonstrated an important shift in thinking at the

${ }^{34}$ Bishop, "Winchester: Crisis in Conscience," pp. 13-14; Bishop interview, 11 Dec 1997; Jupin interview, 28 Dec 1997. 
newspaper; only five weeks before, the editors had characterized the resisters of October 16 as "misguided," and possessing "little judgement."35

Michael Jupin now believes that if he had still been in seminary in October 1967. no outcry would have resulted. But his position in Winchester made his protest much more difficult. "I really hadn"t understood the move that I made. that I lived in a completely different community that would respond in a completely different way," he reflected. "Fools rush in," he chuckled."

\section{A Network of Support}

The New England Resistance and other advocates of draft-centered protest recognized that individual draft resisters might be left feeling isolated and alienated in the weeks and months following their initial act of defiance. Organizers knew that they could not realistically expect that an individual resister's depth of commitment might not wither under the weight of FBI visits. letters from draft boards, and the palpable concern of (if not alienation from) family and friends. Thus, as it became evident that the federal government did not plan the kinds of mass arrests or indictments that might act as a crucible from which Resistance solidarity would continue to grow spontaneously, members of the Resistance and other groups began to devote some of their energies to holding the movement together. This happened deliberately within groups like the New England Resistance but often, as in the case of some of the older supporters, it occurred

35 "The Limits of Protest," editorial, Boston Globe, 28 Nov 1967, p. 20; "The Resistance," editorial, Boston Globe, 17 Oct 1967, p. 16.

${ }^{36}$ Bishop interview, 11 Dec 1997; Jupin interview, 28 Dec 1997. 
organically as different people gravitated to draft resistance in the belief that it was the most effective way to protest the war.

Just like draft resisters themselves, those who were rallied to activism by the zeitgeist of draft resistance were children of the American Dream. Although many came to the cause with varied backgrounds and different expectations, in general, most supporters of draft resistance came from middle-class homes, were well-educated, and had a history of social movement activism. Frequently, they were older than the resisters themselves. The 1997 survey of draft resistance activists from Boston revealed an average age of 25 and a median age of 23 among the 68 respondents who could be classified not as resisters but as supporters. Nearly 50 percent were students followed by professors, the second largest group, who constituted approximately 15 percent of supporters (Table 6.3). In addition. as many as half of all supporters may have been women. $^{37}$

Those who stood behind resisters in their confrontation with the government came from the same kinds of homes and neighborhoods as the resisters did. Their parents were mostly professionals and proprietors (Table 6.4). 81 percent of supporters' fathers, for instance, held professional jobs or ran their own businesses. And although 40 percent of their mothers were homemakers, another 42 percent held professional positions or were entrepreneurs. Moreover, when supporters were asked about their class backgrounds,

37 In the 1997 Boston Draft Resistance Survey, 44 of the 68 supporters who responded were male; 24 were female (or $35 \%$ ). However, in the activist database assembled before administration of the questionnaire, I identified 127 non-resisters of whom 68 (or 54\%) were women. 
nearly 85 percent identified themselves as coming from middle class (47\%), upper middle class ( $36 \%$ ), or upper class (2\%) families (Table 6.5). Like resisters, then. other draft resistance activists came from the same social strata as those in power, as those responsible for American policies in Vietnam. In some cases, such as that of novelist James Carroll, whose father ran the Defense Intelligence Agency, draft resistance supporters were actually the children of the war makers. ${ }^{38}$

Resistance supporters from Boston came from varied backgrounds, most of which offered no hint that they would become activists. Although most of their parents identified themselves with a religious denomination ( $82 \%$ of fathers and $87 \%$ of mothers), only one parent, a Quaker, came from any of the historically pacifist sects (Table 6.6). Indeed, in addition to the 43 percent of supporters who came from homes in which at least one parent was a veteran of the armed services (similar to the 40 percent for resisters), $25 \%$ of the men who supported draft resistance in some way without also becoming resisters were themselves veterans (Table 6.7). Unlike the parents of resisters, however, more parents of supporters had a history of social activism and protest of their own ( $38 \%$ to $23 \%$ for parents of resisters), including 19 percent who had a parent active in a union. ${ }^{39}$

The parents of supporters, however. were more like resisters' parents in their less-

38 See James Carroll, An American Requiem: God, My Father, and the War That Divided Us (Boston: Houghton Mifflin, 1996).

${ }^{39}$ In the 1997 Boston Draft Resistance Survey, 26 of 68 (38\%) supporters came from homes in which at least one parent took part in some form of social activism. This figure includes 13 supporters (19\%) who came from homes in which at least one parent was a union member. 
than-radical political leanings. Although many of the activists viewed themselves as part of the New Left (69\%) (Table 6.8 ), their parents were overwhelmingly mainstream in their politics. In 75 percent of supporters' homes, both parents belonged to the same political party; 57 percent of these couples were Democrats (Table 6.9). Among the supporters themselves. although 46 percent identified themselves as either socialist. communist, or anarchist, 48 percent also were Democrats (Table 6.10). Again, by protesting against the draft in this way. many resistance supporters confronted an administration that either they or their parents (or both) had put in office. Even among those supporters who thought of themselves as New Leftists, nearly 43 percent were Democrats, too. ${ }^{+0}$ Their protest against the draft, then, had less to do with political affiliation or ideology than it did with outrage over the war.

The activism of draft resistance supporters also seems to have stemmed in part from earlier participation in protest movements. Compared to the draft resisters they supported. supporters came to draft resistance equipped with more impressive protest resumes. Out of 68 supporters surveyed only seven had no prior activist experience which means that nearly 90 percent of all supporters came to draft resistance with a previous history of activism (Table 6.11). Almost 21 percent had participated in Vietnam Summer, 34 percent were members of SDS, 56 percent had been active with various

to In the 1997 Boston Draft Resistance Survey, 19 supporters identified themselves as both a Liberal Democrat and a member of the New Left; 1 supporter identified himself as both a moderate Democrat and a member of the New Left. Therefore, 20 of 68 supporters (29\%) considered themselves Democrats and members of the New Left. Likewise, 20 of the 47 supporters (42.6) who identified themselves as part of the New Left also were Democrats. 
peace organizations, and 62 percent came from a background in the civil rights movement. This level of experience with other social movements fueled the rapid growth of a community of supporters for draft resisters in late 1967 and early 1968. As the New England Resistance gained more prominence through its demonstrations and draft card turn-ins, more and more men faced the pressures brought by the FBI, their draft boards, and often their parents. In Boston, groups of young supporters flocked to organizations like the Boston Draft Resistance Group or other draft counseling organizations, while older supporters joined organizations like Resist. All of these groups were critical to the ongoing efforts of draft resisters.

\section{BDRG and the Resistance}

In the fall of 1967 and winter of 1968. resisters could rely on a budding draft resistance community formed first and foremost by the alliance of the New England Resistance with the Boston Draft Resistance Group. By October and November. BDRG had firmly established itself as a leading antiwar and antidraft organization in Boston. They continued to mount Early Morning Shows, Horror Shows, and during this time saw their draft counseling efforts grow by leaps and bounds. Dozens of young men sought their services at their office on Columbia Avenue in Cambridge every day. More significant, the BDRG's initial reluctance to support draft card turn-ins gave way to a more general sense of collaboration.

In addition to the touch football games, social events, and Monday night dinners, both the NER and BDRG encouraged their members to work for each group and to turn out for each others' demonstrations and public events. An early Resistance newsletter 
noted that they were "working closely" with BDRG and that the two groups shared "considerable overlap in membership." The newsletter urged draft resisters to plan to do regular work for the BDRG when not occupied with a specific NER project. "Unless we are to do nothing but pull off spectacular demonstrations once a month, we must all be ready to do serious, steady, unspectacular work."

This kind of bipolar characterization of each group's mission ("spectacular" and "unspectacular") betrayed a certain snobbery on the part of the Resistance that served as counterpart to a similar strain of condescension directed at NER by some BDRG activists. "Tensions continue to exist," one BDRG newsletter noted, "between those who see draft resistance as essentially an act of moral witness and those who see it as an organizing program with broad implications for radical change." For several reasons, however, the two groups put their differences aside in the months following October 16. First, as BDRG counselor Charles Fisher later commented. "BDRG grudgingly admitted that the Resistance did attract attention and convert people." That attention resulted in financial assistance not only to the Resistance but also to BDRG whose fund-raisers, Fisher said, were "acutely aware of how much BDRG"s affluence" owed to soliciting donations from Resistance contributors. Furthermore, BDRG activists suggested that while Resistance chapters clashed with their draft counseling counterparts in other parts of the country, in Boston a gradual "convergence of attitudes." had occurred leading both groups to realize that their approaches were complementary. "It would seem that demonstrations can be an important adjunct to anti-draft organizing," a BDRG newsletter noted, "particularly by

${ }^{41}$ NER Newsletter, undated (c. early Nov 1967), AJP. 
creating a sense of a city-wide movement." Indeed, through the fall, BDRG saw its counseling caseload double, a development they attributed to participation in Resistance rallies and draft card turn-ins. By February, some in BDRG were starting to worry that the organization might be getting too "hung up on mass actions to the detriment of its ongoing organizing programs." In the early months of draft resistance, however, the sense of solidarity and camaraderie that resulted from collective action warranted the combined efforts of these organizations. Not a day went by, it seemed, when one could not find work to do for either BDRG or the Resistance. ${ }^{42}$

\section{"Girls Sav 'Yes' to Guys Who Say 'No""}

Among those who sought work in Boston's draft resistance movement were a significant number of women. Although the draft did not threaten women directly, the draft resistance movement attracted them for the same reasons it attracted draft-age men: it seemed like the most direct way to challenge the government's war policies.

The kind of work that women could find in draft resistance organizations, however, was frequently limited even within support roles. In 1967, women who chose to target the draft as their primary focus in protesting against the war in Vietnam generally had two options open to them. Some worked with the local Resistance organization while others chose to work with draft counseling groups like BDRG. (In time a smaller number joined groups of the so-called "Ultra-Resistance" in raiding draft boards to either steal or destroy draft files). For the most part, the male-centered

${ }^{42}$ BDRG Newsletter, 1 Feb 1968, MKFP; Charles Fisher, "Midwives to History: The Boston Draft Resistance Group," unpublished manuscript, Chapter IX, p. 10; papers of Charles S. Fisher (hereafter cited as CSFP). 
experience of the draft and resistance to it marginalized women within these organizations.

Even so, the dramatic public events staged by the New England Resistance attracted support from women, though they soon found themselves channeled into the most mundane work. On October 16. the first draft card turn-in yielded 214 cards with another 67 burned in the flame of a church candle. Although it went unnoticed by the mass of reporters in attendance. Nan Stone. a young Methodist minister then enrolled in Boston University's School of Theology. burned one of those cards; she was the only woman to participate in the ceremony. In fact. Stone had fought hard with the event's other organizers for the right to do so. In anticipation of mass arrests at the church, the planners decided that several people - including Nan Stone - would not participate, thus guaranteeing that someone would be available to arrange bail and find legal assistance for the others. But Stone, perhaps more than the others, felt a powerful need to somehow put herself at the same level of risk as the men. not only to demonstrate her passionate stand against the war, but also to prove herself an equal within this young organization. As she later recalled, "most of the guys sort of dismissed that...they looked at me as not having the risk that they had, 'cause I didn't have a draft card, wouldn't be drafted." Steve Pailet, one of the few sympathetic men. pushed for her participation and gave her his own card to burn. ${ }^{43}$

This episode is representative of the kind of treatment women could expect in

${ }^{43}$ Nan Stone, interview with author, Belfast, Maine, 28 Mar 1997; Alex Jack, interview with author, Becket, Massachusetts, 21 Mar 1997; Neil Robertson, interview with author, Skowhegan, Maine, 24 Aug 1997. 
those resistance organizations that made noncompliance their primary tactic. As Sara Evans has found in other New Left and civil rights organizations, women were most often limited to doing the "shitwork": typing, stuffing envelopes, and making coffee. The men who founded the Resistance. after all. conceived it as a kind of brotherhood of resisters. Like a college fraternity that admits women oniy as "little sisters," the New England Resistance welcomed "resister sisters" only in clearly defined support functions."

Still, some women like Stone were able to attain positions of influence in the New England Resistance, though it was a "continual struggle." First, they had to put up with frequent sexist allusions to women that appeared in NER literature. One leaflet intended for resisters, for instance, noted that organizers were planning a "huge, incredibly noisy, chick-laden" party for the night following the 3 April 1968 draft card turn-in. Another leaflet targeting GIs invited them to another gathering that would offer "beer and chicks and things." These attitudes were consistent with the prevailing understanding of women's place in draft resistance as articulated by some of the leading women in the movement. Folk singer Joan Baez, the wife of Palo Alto resister David Harris, perpetuated this mode of thinking when she coined the expression, "Girls Say 'Yes' to Guys Who Say 'No" "as a way of attracting more men to draft resistance. The down side of that campaign - which included posters of beautiful young women emblazoned with the Baez quote - appeared in the alienation it created among women who took their draft

4 Sara Evans, Personal Politics (New York: Knopf, 1979); Barrie Thorne, "Gender Imagery and Issues of War and Peace: The Case of the Draft Resistance Movement of the 1960s," in Dorothy McGuigan, The Role of Women in Conflict and Peace (Ann Arbor: University of Michigan Center for Continuing Education of Women, 1977), p. 56. 
resistance work seriously - only to be viewed as sex objects. ${ }^{\text {t5 }}$

In addition, women also had to overcome feelings of distrust and competition among other women. particularly if one was involved in a relationship with one of the men in the group. The men would often forget to tell Nan Stone about a meeting to which some of their girlfriends (who also worked in the office) would go. Stone resented one woman in particular, she said. "because she had this boyfriend that gave her...an in. somebody who would listen to her. She was paid attention to because of who she was fucking."

Interestingly, women who were involved in relationships with men in the NER today seem less likely to recall male chauvinism as a salient aspect of their experience. The consensus among these women seems to be, as one said, that "you weren't treated any differently than you were anywhere else in the Movement." Another is certain that women in the NER participated actively in the leadership of the organization: women -certainly spoke out at meetings whenever they wanted; there was no attempt to silence women. And I certainly didn 't feel that I wasn't a part of the organization nor that I couldn't speak up if I wanted to speak up...Power is in the hands of those who seize the power." Sometimes power is not so easily seized, however. Although women like Nan Stone did become (and all of the men now acknowledge this) an essential member of the

45 New England Resistance letter, 20 Mar 1968, collection of William Clusin (copy in author's possession); Thorne, "Women in the Draft Resistance Movement," p. 190.

${ }^{46}$ Nan Stone, telephone interview with author, 8 Oct 1997; Connie Field, interview with author, 17 Jun 1997. 
New England Resistance leadership, Stone notes, "I was never invited in to the inner circles, I had to push my way in. $\$ 7$

In the Boston Draft Resistance Group, the city's leading draft counseling organization, circumstances for women differed somewhat from those of the New England Resistance. Participation in BDRG was not gender coded in the same way that it was in the Resistance. Women made up at least half of the draft counselors and also took part in "Early Moming Shows" in which members of BDRG arrived at local draft boards to talk to potential draftees on the mornings that they were being bussed into the city for their physicals. Unlike draft card turn-ins and induction refusals, such activities were open to women.

BDRG women. however. disagreed then (as they do today) about the extent to which they participated in leading the organization. Generally, those who held one of the few paid staff positions claim to have experienced very little male-chauvinism. Both Sasha Harmon and Bliss Matteson, successive office managers for BDRG, agree that they never "felt any particular discrimination or any particular shutdown" in weekly steering committee meetings or in the office itself. They acknowledge. however, that if they had not had clearly defined roles as part of the office staff, they might have felt "at more of a disadvantage. ${ }^{* 18}$

Other women in BDRG recall the situation differently. The historian Ellen

${ }^{47}$ Field interview, 17 Jun 1997; Olene Tilton, interview with author, San Francisco, California, 16 Jun 1997; Nan Stone, interview with author, 28 Mar 1997.

${ }^{48}$ Sasha Harmon, telephone interview with author, 14 Sep 1997; Bliss Matteson, interview with author, Cambridge, Massachusetts, 29 Aug 1997. 
DuBois, who worked for BDRG while in graduate school, believes that although women such as Harmon and Matteson were influential, a fundamental inequality kept them and other women from “advancing beyond a certain point." Dana Densmore, Abby Rockefeller, and Roxanne Dunbar pushed this view further, charging that an "astonishing male hierarchy," most apparent in steering committee meetings. dominated BDRG. According to Densmore, "if a woman spoke up...there would be a dead silence for a few seconds, and then they would pointedly pick up exactly where they were before her comment." Such experiences led Densmore, Rockefeller, and Dunbar to leave BDRG in 1968 to form Cell 16, one of the first radical feminist groups in the country. ${ }^{49}$

Steering committee meetings at BDRG, like those at the New England Resistance, were notoriously long as decisions were reached by consensus rather than by majority rule. As a result, those who excelled in debate and carried themselves with confidence (the "highly aggressively verbal easterners...New Yorkers," according to one woman) often dominated these sessions. Although there were some exceptions. far fewer women felt comfortable with this kind of confrontational dynamic than men. One male BDRG founder remarked that he had always been proud of the organization's emphasis on this informal style of decision making until years later when he recognized that it resulted in a kind of "tyranny of informality" that yielded to a "charisma based" form of leadership. Since few women in those days were socialized to master the "mass-haranguing style"

${ }^{49}$ Ellen DuBois, interview with author, Los Angeles, California, 11 Jun 1997; Tekla Louise Haasl, "I Want to Knock Down the World:" A Study of Radical Feminism and Cell 16," (M.A. thesis, University of New Hampshire, 1988), 24-24, 29; Roxanne Dunbar-Ortiz, telephone interview with author, 17 Sep 1997. 
needed to make a point in meetings, men dominated decision making. ${ }^{50}$

Ultimately, the draft resistance movement attracted many women to its cause, though proportionately few lasted with groups like the New England Resistance, which emphasized noncompliance. Without a draft card to turn-in or burn. women were pushed to the margins in these organizations. They could never be seen as equal partners without taking the same risks as men. Therefore, the vast majority of the younger women who supported targeting the draft as their primary form of antiwar protest gravitated more toward draft counseling organizations; older women joined other support organizations that were either older and rooted in pacifism or newer and focused on raising money to support resisters.

\section{"A Child Has Spawned Parents"}

In the early weeks following October 16 , draft resistance organizers soon found out that they could count on encouragement from individuals and groups other than BDRG. Although an early New England Resistance newsletter boasted that for the "first time in history...a child has spawned parents," in fact many of the organizations that moved to ally themselves with draft resistance had been protesting against the war for a long time. Members of the Committee for Non-Violent Action and the American Friends Service Committee, for example. showed up at all NER demonstrations and draft card turn-ins. When Bill Hunt of BDRG and the Resistance later reflected on it, he remarked that in those first months after October 16 , resisters came to realize that they could always

${ }^{50}$ Sasha Harmon, telephone interview with author, 14 Sep 1997; Tim Wright, interview with author, Jamaica Plain, Massachusetts, 25 Aug 1997. 
count on the Quakers and other pacifists to be there. While liberals in the Democratic party might have shared the Resistance analysis of the war, Hunt said, most felt that nothing justified damaging the party; such individuals could not be expected to publicly back draft resistance. The AFSC and CNVA. however, were rooted in pacifism and although many resisters may not have been strict pacifists (e.g.. believers in the just war theory), their demonstrated opposition to the Vietnam War was sufficient to merit assistance. $^{\text {s! }}$

On the surface, though, the notion of a child spawning parents seemed more accurate with respect to Resist, the organization formed out of the Call to Resist Illegitimate Authority. Certainly, most of the older advisers of Resist, like those of the AFSC and CNVA, were long-time dissenters to American involvement in Vietnam; yet they acknowledged that the impetus to make draft resistance their main focus came in response to the actions of their younger counterparts. "We are certainly in an embarrassing position to be looking to the young to make our will effective," Paul Goodman wrote in the .Vew York Review of Books earlier in the year. "I am ashamed to be so powerless..."

Intellectuals were not in fact powerless to protest the war effectively; indeed, some had been trying to marshal support from colleagues for a long time. Noam Chomsky, in particular, chumed out numerous articles imploring his fellow academics to act. In the fall 1966 issue of the Harvard Educational Review. he wrote: "One can only

\footnotetext{
s1 Hunt interview, 31 Oct 1997.

52 Paul Goodman, “Appeal," New York Review of Books, 6 Apr 1967, p. 38.
} 
be appalled at the willingness of American intellectuals, who, after all, have access to the facts, to tolerate or even approve of the deceitfulness and hypocrisy [of the administration]." His most influential essay, "The Responsibility of Intellectuals," which appeared in the New York Review in February 1967, moved scores of academics to act in ensuing months. "It is the responsibility of intellectuals to speak the truth and to expose lies," he wrote. Regarding Vietnam, Chomsky implied, intellectuals had been content through the 1950s and 1960s to quietly accept the decisions of foreign policy and national security "experts" in successive administrations. In light of this inaction. Chomsky alerted his colleagues that "no body of theory or significant body of relevant information. beyond the comprehension of the layman...makes policy immune from criticism." He expected them to speak out against what he viewed as an obviously "savage American assault on a largely helpless rural population in Vietnam." 53

Although Chomsky issued this charge to the academic community in February, the actual catalyst for the intellectual community's activism - anticipation of the national draft card turn-in on October 16 - arrived only at the end of the summer. At that time the "Call to Resist Illegitimate Authority" began to pick up steam; scores of adoptive parents lined up to support the resisters. As Sandy Vogelgesang has written. Chomsky's strategy aimed to both stop the war and "resolve the larger dilemma of powerlessness which underlay the Vietnam experience." He hoped that the addition of older adults to the resistance movement would raise the economic and political stakes for the government

\footnotetext{
${ }^{53}$ Noam Chomsky, "Some Thoughts on Intellectuals and the Schools," in American Power and the New Mandarins, p. 315; "Responsibility of Intellectuals," in American Power and the New Mandarins, p. 324-325, 334-335.
} 
and would make it "impossible for the government to ignore the protesters." He then counted on what he called "the unpredictable effects of a really large-scale repression" of the resisters and their supporters to raise "questions about the range of meaningful political action." The popular outrage generated by this repression would. it followed. cripple the administration's capacity to wage war in Southeast Asia. ${ }^{54}$

Not all intellectuals agreed with Chomsky, however. As Vogelgesang points out, prominent intellectuals like Michael Harrington, Theodore Draper, and Michael Walzer thought intellectuals should stick to speaking and writing against the war rather than resorting to civil disobedience - even if it was nonviolent. Harrington, for instance, warned that trying to reach Americans through "middle class tantrums" of draft resistance risked turning the antiwar movement into a "morally self-satisfied but ultimately impotent cult." Walzer commented that no one could be "morally justified in acting (however heroically) in ways that defeat his own stated purpose." 55

Despite such criticism. a significant group of older advisers, mostly academics, moved ahead with a program to support draft resisters. Following the October 2, 1967 press conference announcing the "Call to Resist Illegitimate Authority," Columbia University economist Robert Zevin hosted a large group of the participants at the Columbia Faculty Club where they laid out plans for a new organization called Resist. As the first donations came in to support the Call. Zevin hired Herschel Kaminsky to

${ }^{54}$ Sandy Vogelgesang, The Long Dark Night of the Soul: The American Intellectual Left and the Vietnam War, (New York: Harper \& Row, 1974), pp. 127-128.

${ }^{55}$ Vogelgesang, The Long Dark Night of the Soul, pp. 135-136. 
open an office in New York. Meanwhile. in Washington on the eve of the Pentagon March, Resist held the first steering committee meeting at which the members administered grants to antiwar and draft resistance organizations. In their first newsletter (printed in early November), Resist organizers outlined their intention to mount two fundraising programs, one for general support and another to save money for a defense fund that they expected would be necessary once the government started indicting draft resisters. At this early stage, Resist members primarily wanted to continue to apply pressure on the administration. "We cannot emphasize too strongly the need to stay together...," they wrote. "On occasion when we have mobilized strength. we have made them back off or overreact, as in Hershey's recent pronouncements [in the October 26 memo], and thereby jeopardize their legal power." The advisers of Resist, like Resistance organizers, expected the government to try to intimidate them; they were challenged with successfully maintaining their momentum in the face of that intimidation. ${ }^{56}$

As members of Resist received their own visits from $\mathrm{FBI}$ agents and as some of the younger professors among them saw their own draft status changed (punitively), Resist responded with very public support for draft resisters. Chomsky, again writing in the New York Review, declared, "It is difficult for me to see how anyone can refuse to engage himself, in some way. in the plight of these young men." He suggested that older adults might help resisters through legal and financial aid, participation in demonstrations, learning to counsel potential draftees, and signing complicity statements.

${ }^{56}$ Paul Lauter, interview with author, 12 Jun 1998; Louis Kampf, interview with author, 10 Sep 1998; Resist Newsletter, No. 1, Nov 1967, Papers of Benjamin Spock [hereafter noted as Spock Papers], Syracuse University, Series II, Box 28. 
In addition, Resist sent over 100 letters to poets, writers, and other academics and activists, asking that they "add appearances for Resist to their scheduled speaking engagements." or that they offer to speak at Resist-sponsored events. From New York Resist and New York Resistance came a suggestion - modeled after the original Cornell graduated turn-in plan - that "students opposed to the war...be asked to sign a conditional pledge stating the minimum number of students (along a scale, from 1000 to 50,000 ) they would join in refusing the draft." The conditional pledge would allow each student to set a benchmark for himself as the point at which he would commit to possibly going to jail. "Those who need the reassurance of great numbers can set a high quota for participating," the planners said. "Those, who for whatever reason are ready to incur greater risk, can set a low quota." The project never got off the ground but it demonstrated the close relations between Resist and local Resistance organizations. ${ }^{57}$

By the middle of December, Resist leaders grew unhappy with Herschel Kaminsky and the inefficient operations of the New York office. They decided to move the office to Cambridge. Massachusetts where Louis Kampf, a professor of American Studies as MIT, believed the organization could easily find activists to run it. Kampf's confidence stemmed from his experience with a local organization called the Educational Cooperative which had attempted to set up a community school in Cambridge in 1966. Within the Educational Cooperative a young faculty group had formed, made up of at least ten people. This group. Kamp figured, was "ready-made" to handle running the new

${ }^{57}$ Noam Chomsky, "On Resistance," in American Power and the New Mandarins, p. 380; Resist Newsletter No. 2, 18 Dec 1967, Spock Papers, Series II, Box 28. 
Resist office. Paul Lauter, another expert in American Studies and an experienced political organizer from his work with the American Friends Service Committee and SDS, became national director for the organization and Kampf took on the role of associate national director. In January, Lauter, Florence Howe, and Kampf set up the new Resist office in Central Square in Cambridge, across from the Post Office. Not long after, a postal employee informed them that an FBI agent regularly staked out the Resist office from the attic story of the Post Office building. Henceforth, it became common practice for Resist staffers and volunteers to wave to the agent and mug for his camera as they entered and exited the office. ${ }^{58}$

Most important for draft resisters, Resist raised and distributed money to local draft resistance groups nationwide. Bob Zevin conceived the idea of a monthly pledge system that sustained levels of funding from the start, and when the indictments of the Boston Five came down in January 1968, the money came pouring in. Regular steering committee meetings were held, most often in New York, to make grant decisions. At first, most of the groups that applied for funding were well-known to the Resist leadership, but in an effort to spread the wealth more evenly, the steering committee divided the country into geographical zones and assigned each zone to one or two of the younger faculty volunteers. These regional representatives or "area people" as they were known, took responsibility for finding and communicating with local organizations that might need funding. Whenever possible. members of the steering committee and regional representatives accepted lecture invitations and found other reasons to travel as a way of

${ }^{58}$ Lauter interview, 12 Jun 1998; Kampf interview, 10 Sep 1998. 
scouting other parts of the country for potential grantees. ${ }^{59}$

As an organization; Resist was so concerned with avoiding disproportionate funding of local organizations (which they already knew so well) that the steering committee assigned two regional representatives just to Boston and environs. Hilde Hein and Saul Slapikoff, both of whom were on the faculty of Tufts University at the time, were charged with operating their own kind of mini-Resist just for Boston. As Hein recalls, they did all the outreach that other area people did but also were responsible for doing their own fundraising distinct from the national effort. "We did all the equivalents of bake sales," she recalled. She and Slapikoff organized art shows, concerts, and poetry readings to raise money for local groups. The money went back to Resist where funding decisions for Boston area organizations still were made by the steering committee. Of course, the New England Resistance and BDRG did their own fundraising, too, but Resist could always be counted upon for the largest regular donations (or grants) to such organizations. These funds contributed to paying the few paid office workers, helped pay the rent and other bills, and covered production costs for Resistance and BDRG newsletters and other literature. Although resisters were grateful for the moral support provided by older advisers, the financial benevolence of Resist and other individual patrons kept the draft resistance movement afloat; without it, the Resistance might have crumbled soon after October $16^{.0}$

${ }^{59}$ Lauter interview, 12 Jun 1998: Kampf interview, 10 Sep 1998; Hilde Hein, interview with author, 18 Sep 1998.

${ }^{60}$ Hein interview, 18 Sep 1998. 
Although Resist consistently buttressed the draft resistance movement over the next eighteen months, like their younger counterparts, the older organizers experienced their own divisions and strained internal relations. Not long after the organization began distributing grapts. the majority of the steering committee advocated expanding Resist's objectives to include the funding of other groups working for social change. While some members, notably Paul Goodman, thought the grants should be limited to draft resistance organizations, the others thought that draft resistance was meaningless outside of a broader context of the larger antiwar movement and other movements for peace and justice. Some of the younger draft resistance leaders themselves agreed with Goodman. At one point, about a dozen draft resistance leaders from different parts of the country crashed a steering committee meeting held at Paul Lauter's mother's house in New York. They demanded that Resist fund only draft resistance organizations. Noam Chomsky answered for the group by suggesting that the Boston draft resistance representatives present return to Cambridge and sift through Resist records to see if they could honestly disagree with any of the funding decisions. The steering committee never heard any complaints again. ${ }^{61}$

Resist's hierarchical organizational structure also created some tension, most notably around gender issues. Men dominated the steering committee, and although it included Florence Howe and Grace Paley. Hilde Hein was the only female regional representative in the organization. The staff, in contrast, consisted almost entirely of women who were, as Hein says, "just errand runners." It did not matter that the members

${ }^{61}$ Lauter interview, 12 Jun 1998; Kampf interview, 10 Sep 1998. 
of Resist were intellectuals; the men in the group were guilty of the same sexism as their younger draft resistance counterparts. Hilde Hein recalls that neither Florence Howe nor Grace Paley felt intimidated at steering committee meetings, but she did. "I certainly know that if we went around the room expressing opinions and I said something, nobody paid any attention. And if somebody two seats down repeated exactly what I had said and was male - it would be heard." In addition, though she did not think much of it at first, it later rankled her that male members of the steering committee asked her husband, George Hein, a chemistry professor at Boston University, to do some public speaking on behalf of Resist, instead of asking Hilde. "It suddenly dawned on me that this was a little odd," Hein remarked, particularly since she did so much more work for Resist than her husband. ${ }^{62}$

In spite of these difficulties. Resist's support of draft resistance. both financial and moral, helped to sustain the movement from the very start. As resisters faced counterprotesters, intimidating FBI agents, hostile draft boards, and often skeptical parents, the community of supporters that sprung up among their peers and especially among this group of older academics and advisors assuaged the internal doubts that naturally crept in when resisters felt most vulnerable. The resisters themselves created the movement and presented it as a fait accompli to their sympathetic older allies, who expanded the movement's reach and helped to carry it forward in the months following October 16.

${ }^{62}$ Kampf interview, 10 Sep 1998; Hein interview, 18 Sep 1998. 


\section{November 16 and December 4}

Emboldened by the euphoria of October 16 and the rush of support that followed, New England Resistance organizers steadily planned their next actions. Although the Resistance chapters across the country planned to carry out new draft card turn-ins on December 4, the NER wanted to move more quickly. They set the date for November 16 and began planning almost immediately after the Pentagon march. Thus, at the same time they sought to organize a worthy follow-up to their successful debut, resisters simultaneously encountered FBI agents seeking interviews, unhappy parents, friends and employers hoping to talk some sense into them. and new friends and acquaintances offering them support. The intensity of the times cannot be overstated. The Resistance office, still in Memorial Hall at Harvard. swirled with activity as the organization tried to keep track of their "members," provide work for everyone who wanted it. supply information to nervous resisters regarding government reaction, galvanize support for future draft card turn-ins, and raise money to pay for it all. In the last newsletter distributed before November 16. Resistance leaders described plans for a service similar to that of October 16 to take place at the Old West Methodist Church on Cambridge Street in the West End. It would be called "A Service of Conscience and Memorial for All Who Are Dead and Dying in Vietnam." The draft card turn-in would be followed by a march to the federal building in Post Office Square where Resistance representatives hoped to deliver the collected cards to Paul Markham, the United States Attorney. The newsletter strongly urged all resisters to attend.

\section{IT IS ESSENTIAL THAT EVERY OCTOBER 16 RESISTANT PLAN}


TO BE THERE. CUT CLASSES OR TAKE OFF FROM WORK IF YOU MUST. BUT BE THERE. RESISTANTS ARE NEEDED AS MARSHALS: THE FEDERAL AUTHORTTIES MUST SEE OUR STRENGTH, AND THE PUBLIC MUST KNOW WHO WE ARE NOW.

With a second act of mass civil disobedience coming so soon after the first. the New England Resistance hoped to send a message to both the government and their fellow citizens that said that more and more reasonable. responsible Americans were joining this growing movement. The confrontation between the federal government and the Resistance on November 16. they wrote. "will be on our terms, in the open and for the public to see."

When the day arrived, however, the event did not take place on their terms but the public still saw it. First, a major snowstorm the day before greatly hindered mobility within the city and surrounding towns. Instead of the expected turnout of 5,000 supporters, fewer than 500 showed up. Second, and most important, a scuffle broke out between supporters of the war and resisters, and it - rather than the strength of the movement - garnered all of the press coverage.

As the service began, approximately 450 people sat in the pews with a significant number of FBI agents and reporters on hand as well. The Reverend William Alberts opened by inviting the FBI men to sit in the front pews, rather than stand uncomfortably in the back; none of them responded. Father Larry Rossini, a Catholic Priest at the downtown Paulist Center and one of the organizers of the event, later recalled being more apprehensive at this event than at the October 16 service. "It was a smaller crowd but

${ }^{63}$ NER Newsletter, undated (c. early Nov 1967), AJP. 
there was more press. And the FBI was more obviously there. And I was very frightened. I did not know whether I was going to be arrested walking out of there and kind of put to shame by all these guys who were all Catholics...there was an emotional sense of betrayal that I felt on my part." Several of the agents blended in with news reporter cameramen as they swept the pews with motion picture cameras. One resister later remarked that "you got the feeling that the people who were systematically photographing every face with the flood lights had to be FBI agents but the people who were simply photographing the speakers or the [resisters] might well be working for the press. ${ }^{.64}$

Outside the church, Jozef Mlot-Mroz, the Polish Freedom Fighter, burned a Soviet flag before a growing crowd of counter-demonstrators. He then marched into the church with a sign that said, --Priests, Rabbis, Ministers, Start Fighting Communism. Don't Be Duped By the Reds." Harold Hector, the brawniest of the Resistance marshals, escorted Mlot-Mroz out of the church. A few minutes later, however, he returned - this time singing "God Bless America" at the top of his lungs. Again Hector removed him. This time, however, Mlot-Mroz struggled with Hector, and when they reached the top of the steps outside the church. the freedom fighter fell. In a scene reminiscent of the South Boston beatings, at least fifteen men surged toward Hector and began pummeling him.

Years later, Hector (who was never a pacifist) described what happened next:

I'm fighting now. I'm just up there throwing punches, landing - I'm doing all right - but I was grabbed and pulled down the steps. Got to the ground,

${ }^{64}$ Lawrence Rossini, interview with author, 5 Sep 1997; William Clusin, interview with author, 17 Jun 1997. 
and I'm still punching, but there's too many guys. Just too many. They grabbed me, kicked me, every which way...[I get up], the ground had little ice patches on it, so I was slipping and sliding. I was down on the ground and two guys held me and kicked me in the face and I went down. And I was trying to get back up and continue fighting and I was losing energy...I was just getting weak....And a cop, patrolman [James P.] Barry, broke through the crowd. He came in. held his hand up and they knocked him down.

Officer Barry called for back-up and soon 50 uniformed police officers arrived including a squad of helmeted police on horseback and two with German Shepherds. They

dispersed the crowd. When Hector finally got to his feet, he could feel the blood coursing from a gash on the side of his head. Several other participants suffered bloodied noses, some inflicted by Hector. Finally, the crowd cheered as police officers helped Hector into the police ambulance that would take him to City Hospital ${ }^{65}$

Inside the church, the draft resistance ceremony continued without incident. The Reverend Harold Fray acknowledged to those in attendance that although certain pitfalls accompanied any act of civil disobedience, the state of the war in Vietnam demanded that "acts of last resort" be seen as "appropriate modes of expression." Returning and burning draft cards. he argued, just might provide "the therapeutic shock required to revive our moral sensibilities numbed by the war." Fray told the audience that he was "convinced that the majority of these young men in the Boston area who are turning-in and burning their draft cards do so as genuine acts of moral conviction and conscience." When the

65 "Fists, Insults Fly at Hub Viet Protest," Boston Globe (Evening edition), 16 Nov 1967, p. 1; "Fists Fly at Hub Anti-War Rally," Boston Record American, 17 Nov 1967, p. 1; "Punches Swing, Cards Burn in Anti-Draft Rally, Boston Herald Traveler, 17 Nov 1967, p. 1; NER Newsletter, 15 Dec 1967, MKFP; Harold Hector, interview with author, 9 Apr 1997. 
ministers issued the call for draft cards, 54 new draft resisters (far fewer than the 1,000 organizers had hoped for) quietly turned-in their cards. Father Rossini. and Reverend Albert joined Jack Mendelsohn. Rabbi Herman Pollach, and Professor Hilary Putnam to receive the documents and looked on as another eight burned their cards at the altar. ${ }^{66}$

Although this service did not match the first one at Arlington Street in scale, it possessed much of the same electricity. Resisters walked up the center aisle silently, deliberately. Some of those who burned their cards paused to pray as they did it. "We really believed that these were movements of the spirit," Larry Rossini later commented about the Old West Church ceremony.

These were true religious events. This was not theater...I don't think I could have ever done it without a sense that this is the right thing to do...The emotion of the thing was that this was like being the early Christians in a hostile environment doing what they absolutely believed had to be done because if somebody didn't stand up for what was happening this craziness would never end and more and more people like this would get hurt. So there was a sense of righteousness about it... there was a belief that we were right. There also a sense that there really was a presence of the Spirit in these activities and that there was something important about the flame that was coming off the draft cards, that that was a Light and that that was a candle and that those burning draft cards were bringing a light of understanding and belief into the world.

The power of such sentiments greatly outweighed the concern that card burning might offend some of their fellow citizens. ${ }^{67}$

Besides, everyone knew that burning one's draft card was an illegal act; those few

66 "Fists, Insults Fly at Hub Viet Protest," Boston Globe (Evening edition), 16 Nov 1967, p. 32; "Punches Swing, Cards Burn in Anti-Draft Rally, Boston Herald Traveler, 17 Nov 1967, p. 36.

${ }^{67}$ Rossini interview, 5 Sep 1997. 
who chose that option expected to suffer the consequences. Bill Clusin, an MIT sophomore from Oak Park, Illinois, and one of the eight who burned his card at Old West, realized that the men who turned in their cards were more likely to be arrested but figured card burners might get picked up on the spot. Clusin felt that the government would be making a "very strong statement" if they arrested someone like him - an Eagle Scout and an outstanding student. So he decided to test them. "If they wanted to arrest me they could get evidence that what I had done was illegal," he recalled in subsequent years. "I was surprised that no one [who burned their cards] was arrested." When he made it back to Cambridge safely later that day, he began waiting to hear from the authorities. Since all eyes and cameras had been focused on him when he burned the card and Noam Chomsky, with whom he had taken a course at MIT. shook his hand afterward. he fully expected to be easily located and arrested. It could happen at any time. When it had not happened after six months or so, he stopped worrying. The FBI never caught up with Bill Clusin, instead choosing to pursue those men who turned in their draft documents. ${ }^{68}$

Another of the card burners from November 16 tried to make it easier for the government to punish him for his crime. In a letter to his Paterson, New Jersey draft board, Michael Levin, also a student at MIT, reported his crime and noted that he felt compelled to break the law in this way only after concluding that all of the other legal forms of protest in which he had taken part had accomplished nothing. "Time is running out," he wrote. Therefore, he continued,

${ }^{68}$ Clusin interview, 17 Jun 1997. 
I have pledged that I will not carry a draft card or classification notice, that I will not be inducted into the armed services of the United States, and that I will aid as many young people as possible, showing them the reasons why this is a right and moral thing to do, and offering any assistance that I can to shelter them from the legal consequences. In this way, I hope that we can do what our government will not do - end this awful war.

Levin deviated from standard Resistance strategy in promising to shelter other resisters "from the legal consequences;" the Resistance had originated in part with the objective of clogging the courts. Nevertheless, Levin's letter captured the spirit of Resistance protest and demonstrated that at least some draft card burners were willing to accept the price set by society for the commitment of such sins. ${ }^{69}$

Meanwhile, immediately following the service at the Old West Church, and in the aftermath of the melee outside, approximately 200 resisters and supporters marched the mile-long route to the federal building under police escort. As they walked. counterprotesters heckled and pelted them with snowballs. They carried signs that said, "Draft Hippies, Not Beer," and "We Want Soldier Power, Not Flower Power." When the group arrived in Post Office Square, more fights broke out, though the police - and their dogs quickly restored calm. While Lenny Heller (of Berkeley Resistance), Michael Ferber and Howard Zinn spoke to the crowd outside the building, four others - Rev. Fray, Neil Robertson and Alex Jack of the New England Resistance, and Louis Kampf of Resist went inside to deliver the draft cards and complicity statements signed by 140 people to the U.S. Attorney. Just as Ramsey Clark sent a substitute to refuse acceptance of the draft cards delivered to Washington on October 20, Paul Markham sent Assistant U.S.

${ }^{69}$ Michael Levin letter to Local Board No. 36, 19 Dec 1967, papers of Michael Levin (copy in author's files). 
Attorney William Koen to do the same. When Koen told the group that Ramsey Clark had ordered them not to accept the cards, the four men left them on his desk anyway. "Do with them as you see fit," one of them said. ${ }^{70}$

The next day, press accounts in all three Boston newspapers emphasized the fight outside the church and the burning of draft cards. Each carried multiple photographs (with at least one on the front page) of Harold Hector being beaten and with blood streaming down his face. The headlines were remarkably similar: "Fists, Insults Fly at Hub Viet Protest," read the Boston Globe; the Record American ran with "Fists Fly at Hub Anti-War Rally;" and "Punches Swing, Cards Burn in Anti-Draft Rally" greeted readers of the Herald Traveler. The Record American article reported a counter demonstration of 2,000 at the federal building, though this may have been a typographical error intended to say 200. a more accurate estimate according to New England Resistance members. That paper also claimed that construction workers stepped in to help (not punch) Hector, another point strenuously challenged by the Resistance in their next newsletter. In sum, the newspaper reports of the ceremony at the Old West Church conveyed very little of the Resistance's message. Their hopes of reaching more of the public through a confrontation with the government on the resisters' terms did not bear fruit. 5,000 people did not participate and 1,000 men did not part with their draft cards. Snow or no snow, measured against these expectations, the day could only be viewed as a

70 "Fists, Insults Fly at Hub Viet Protest," Boston Globe (Evening edition), 16 Nov 1967, p. 1; "Fists Fly at Hub Anti-War Rally," Boston Record American, 17 Nov 1967, p. 1; "Punches Swing, Cards Burn in Anti-Draft Rally, Boston Herald Traveler, 17 Nov 1967, p. I; The Resistance National Newsletter \#1, 24 Nov 1967, MKFP. 
setback. The Record American called it a "flop." For their part, New England Resistance organizers, reflecting on the day said "it was generally agreed that one month was not enough time to adequately engineer the confrontation." They now thought they should have waited until December 4 (like the rest of the country) to flout the government's will. $^{71}$

When December 4 did arrive, some New England Resistance activists from Boston joined their comrades in New Haven for another draft card turn in at Yale's Battel Chapel; others went to Manchester, New Hampshire to join other demonstrators from the CNVA and other groups in a large protest at the induction center there. The event in New Haven took place without incident. 1,200 people turned out and 35 new cards were turned in at the county courthouse following a march from the chapel. In Manchester. however. despite a promising start to the morning, things went horribly wrong. Approximately 300 to 400 demonstrators - a sizeable crowd - arrived at the induction center before $6: 30$ in the morning and as many as half of these, according to later estimates, may have been willing to commit civil disobedience by either blocking the inductees' bus or the entrance to the induction center. At about 8:30, however, the center made an announcement that no draftees were going to be inducted that day; local radio stations repeated the news. Upon hearing this, most of the protesters left. Shortly after 9:00, when most people had already departed, about 40 helmeted Manchester police

71 "Fists, Insults Fly at Hub Viet Protest," Boston Globe (Evening edition), 16 Nov 1967, p. 1; "Fists Fly at Hub Anti-War Rally," Boston Record American, 17 Nov 1967, p. 1; "Anti-Viet Protest at Church Fizzles," Boston Record American, 17 Nov 1967 (late edition), p. 5; "Punches Swing, Cards Burn in Anti-Draft Rally, Boston Herald Traveler, 17 Nov 1967, p. 1; The Resistance National Newsletter \#1, 24 Nov 1967, MKFP. 
officers suddenly arrived. They formed two lines guarding the steps of the induction center as a bus full of inductees arrived. The remaining 30 demonstrators ran quickly to link arms and block the steps, but it was useless. As the police pushed and shoved the protesters, the inductees double-timed it up the steps. Police then arrested 26 of the demonstrators. While they waited in the Hillsborough County Jail before posting bail, they could hear the irrepressible Jozef Mlot-Mroz leading fifty counterprotesters in chants of "Fee, Fi, Fo, Fum, we smell the hippie scum." Worst of all, the New England Resistance later learned that the bus had been full of enlistees not draftees. "We can never permit blunders like [that] in the future," the next newsletter said."

The year ended, then, with a disappointing setback. The promise of October 16, bolstered by a growing community of supporters, had been tempered in part by the negative reactions of parents and friends. and by the disappointment of the two subsequent demonstrations. Resistance leaders began to conclude that they might have to settle in for a long, protracted battle with the government. As it turned out, the government would not let them wait long before making the next move. The long, uncertain dance between draft resisters and the Johnson administration soon came to a close, and the Justice Department's own actions helped to spark a new round of activism in the early months of 1968.

72 "Bonehead Play of the Year," CNVA Newsletter, 15 Jan 1968, p. 2; NER Newsletter, 15 Dec 1967, MKFP. 
PART III

\section{PEAKS AND VALLEYS}

Reproduced with permission of the copyright owner. Further reproduction prohibited without permission. 


\section{CHAPTER VII}

\section{"A NEW BEGINNING": CONFRONTATION, RENEWAL, AND TRUMPH}

It is my firm belief that in the complex constitution under which we are living, the only safe and honourable course for a self-respecting man is, in the circumstances such as face me, to do what I have decided to do. that is, to submit without protest to the penalty of disobedience."

I venture to make this statement not in any way in extenuation of the penalty to be awarded against me, but to show that I have disregarded the order served upon me not for want of respect for lawful authority, but in obedience to the higher law of our being, the voice of conscience.

M.K. Gandhi, Champaran, India, 1917

After spending Christmas 1967 with his parents and sister in his hometown of Buffalo, New York. Michael Ferber returned to Boston and his quiet Beacon Hill apartment at 71 Phillips Street on Friday, January 5, 1968. As he cleaned the place and sorted through his mail he mused about his plans for the upcoming semester. Work with the New England Resistance, which had become all-consuming at times during the fall. had tapered off since early December and the group did not have another major event planned until the spring; he thought it might be time to "cool it a bit" anyway and focus again on the Ph.D. program that had brought him to Boston in the first place. Others could step up and take the lead in the Resistance - some already had - and that would give him time to pursue his studies. Late that afternoon, after settling in, he cracked open a beer and looked forward to a more relaxed couple of months. But then the phone rang:

"Hello?" Ferber answered.

"Mr. Ferber?"

"Yes." 
"This is United Press International. Do you have any comments about the indictment?"

"What indictment?" Ferber responded.

"Well, haven't you heard? You've been indicted by a Federal Grand Jury for conspiracy with Dr. Spock, William Sloane Coffin, Mitchell Goodman. and Marcus Raskin."

"No," a startled Ferber replied, he had not heard. He gave the reporter a comment, something defiant about the draft and resistance to it, and hung up. The telephone kept ringing that night and continued to ring off the hook over the weekend forcing him to leave for a few days. He quickly realized that his plans to "cool it" had just evaporated.'

News of the indictments stunned the nation and, especially, the antiwar movement. Draft resisters expected to be prosecuted eventually. but over the past two months the government seemed to be in no hurry. As more and more local boards reclassified resisters and called them for induction, it appeared that the Justice Department would wait for the resisters who refused induction and then prosecute cases individually. Few anticipated indictments on conspiracy charges, and those who did expected the local, draft-age organizers to be charged. No one expected the government to go after older advisers like Spock, Coffin, Goodman, and Raskin; they, after all.

'Michael Ferber, speech at Town Hall, NY, 14 Jan 1968, transcribed in FBI memorandum, Exhibit 33a, U.S. v. William Sloane Coffin, Jr., Michael Ferber, Mitchell Goodman, Marcus Raskin, and Benjamin Spock, CR 68-1, National Archives, Waltham, MA; Wells, The War Within, p. 231. 
followed the lead of the draft-age men who started the movement. Yet, although many feared that the indictment marked but the first stage of a wider government crackdown. many more looked to the impending trial with hope - hope that the confrontation with the administration over the immorality and illegality of the war that they had sought from the start, might now take place. That optimism. coupled with the growing number of resisters being called for and refusing induction in the winter and spring of 1968. fueled a new beginning for the draft resistance movement. If mistakes had been made in the fall and if interest in draft resistance had leveled off (and not everyone agreed on this), the federal government provided an unintended boost to the movement by indicting the "Boston Five," and through the ongoing reclassification and attempted inductions of resisters. By April. the organizations and supporters of draft resistance which were struggling to stay focused in December had transformed themselves into what one reporter called a draft resistance "industry." an industry that policy makers in Washington clearly had noticed.

\section{The Hammer Falls}

All five of the indicted men learned of the charges against them from the press, including Dr. Spock who saw his own photograph on the front page of a fellow subway passenger's newspaper that Friday as he returned home. Over the weekend they struggled to answer reporters' questions without having seen the actual indictment, though they at times turned the occasion to their advantage. Spock told reporters that he had "no qualms" about going to prison. "This trial," the 64 year old pediatrician said, "will better dramatize the illegal and immoral war in Vietnam, and if this trial will further my efforts 
to stop it so much the better." Likewise, Ferber, the youngest in the alleged conspiracy. argued that the indictments betrayed fear on the government's part and that their action would "galvanize the peace movement." Like Spock and "thousands of others in the Resistance," he said, "I am fully prepared to go to prison."?

On Monday, January 8, each defendant received official notice of his indictment and, for the first time, saw the government's charges. The indictments were handed down by a Boston grand jury to Judge W. Arthur Garrity, a former U.S. Attorney for Massachusetts who later gained notoriety as the judge at the heart of Boston's busing crisis. In the indictment of each man. the grand jury stated that "from on or about August 1, 1967, and continuously thereafter." William Sloane Coffin. 43-year-old chaplain at Yale, Michael Ferber, 23-year-old graduate student. Mitchell Goodman, 44-year-old novelist and teacher, Marcus Raskin, 33-year-old head of a Washington think tank, and Dr. Benjamin Spock :did unlawfully, wilfully, and knowingly, combine, conspire, confederate, and agree together and with each other...to commit offenses against the United States." Those offenses, the government contended, included: 1) counseling, aiding and abetting "diverse" draft registrants to "fail, refuse, and evade" service in the armed forces; 2) counseling, aiding and abetting registrants to "fail and refuse to have in their possession" their Selective Service registration certificates. and 3) their classification certificates; and 4) hindering and interfering "by any means" with the

2 "U.S. Indicts Dr. Spock, 4 Others," Boston Globe, 6 Jan 1968, p. 1. 
administration of the Selective Service. ${ }^{3}$

To support these charges, the indictment listed several "overt acts" committed by the defendants in furtherance of the alleged conspiracy. These acts included the participation of the four older men in signing and circulating the Call to Resist Illegitimate Authority, the participation of Coffin and Ferber in the October 16, 1967 service at the Arlington Street Church (where they "accepted possession" of draft cards), the presence of all five in the demonstration at the Justice Department on October 20, and the abandonment of the briefcase full of draft cards there by Coffin, Goodman, Raskin, and Spock (Ferber remained outside) and several others. Taken together, the government asserted, these five men conspired to "sponsor and support a nation-wide program of resistance to the functions and operations of the Selective Service System." The indictment acknowledged that they were not alone in taking part in these activities and repeatedly referred to "other co-conspirators, some known and others unknown to the Grand Jury." but by indicting only the five implied that they were the ringleaders. ${ }^{+}$

To a layperson unacquainted with the intricacies of conspiracy law, the government did not appear to have a strong case. Use of the word "conspiracy" conjured up dark images of criminals meeting in secret, plotting elaborate schemes over a long period of time. In fact, all of the draft resistance activities detailed as part of the indictment occurred publicly and rarely included all five defendants. Ferber, for instance.

${ }^{3}$ Indictment. U.S. v. Coffin, et al. CR-68-1, copy in MKFP; Note: complete text of the indictment also appears in the appendix of Jessica Mitford, The Trial of Dr. Spock, pp. 253-257.

+ Ibid. 
had been introduced to Coffin for the first time at Arlington Street, and had never even met the other three despite being present with them for the Justice Department rally. As a result, some within the draft resistance movement saw the indictments as evidence that the government had rushed to assemble its case. It was a reasonable supposition. Even John Wall, the Assistant U.S. Attorney in Boston who would prosecute the case, later admitted that when the case came to him from the Justice Department, it looked like it was "a jerry-built thing...put together at the last minute." Speculation on that point aside, the movement's reaction to the indictment determined the direction draft resistance would take in the coming months."

At first, the responses within the draft resistance community to the indictments ranged from wariness over what the government might do next to satisfaction that their movement had elicited such a strong response from Washington. Those who felt anxious were concerned that the indictments of these five might be just the first in a wave of repression aimed at squashing draft resistance and the antiwar movement. William Sloane Coffin cautioned that "there may be other indictments handed out, and a move to repress a great many people." If that happened, he said, then "it gets pretty serious." Indeed, predictions circulated that more than one hundred indictments would soon follow in San Francisco, New York. Chicago and other cities where draft resistance was strongest. Moreover, some rumors suggested that the indictments were timed to coincide with an American ground invasion of North Vietnam, that refrigerator units had been sited ten miles south of the DMZ, loaded with blood plasma to support such a

s John Wall, interview with author, 26 Jun 1998. 
mobilization. (By the end of the month, the world would learn that the opposite was true as North Vietnam launched attacks in dozens of offensives in the South during the Tet holiday.) The most persistent fear, however stemmed from predictions that the government repression had only just started. When the five defendants met in New York the week after being indicted - the first time ever that they did get together in the same room to plot strategy on anything - Michael Ferber remembers Marc Raskin being particularly despondent. Raskin believed the indictments were the first move in a planned "decimation of the intelligentsia," soon to be followed by indictments of Noam Chomsky, Dwight McDonald, Ashley Montagu, Susan Sontag, Howard Zinn, and on down the line. ${ }^{6}$

Not everyone in the antiwar movement agreed with Marc Raskin's dire predictions, but most were willing to grant that the government at least intended to scare people away from draft resistance and maybe from criticizing the administration altogether. Howard Zinn later said that he saw the indictments as typical of a political trial in which the government goes after prominent opponents in order to send a message to everyone else. "Whenever the government has moved against radicals," Zinn later commented, "it has usually taken the top leadership and used it as a kind of lesson for all the rest." Louis Kampf of Resist agreed. The government went after a representative group as a way of "scaring the shit out of everybody," he said. An editorial in Ramparts

${ }^{6}$ Ferber speech at Town Hall, NY, 14 Jan 1968, transcribed in FBI memorandum, Exhibit 33a, U.S. v. Coffin, et al, CR 68-1, National Archives, Waltham, MA; "Indictments protest Planned in Capital," Boston Globe, 8 Jan 1968, p. 1; Ferber interview with author, 16 Jun 1998. 
called the indictments an "act of repression" representing a "fundamental break with previous handling of opposition to the Vietnam war." Such "heinous repression of freedom at home." they wrote. -forebodes a greater desperation" on the part of policy makers. John Fuerst of SDS described the indictments as a "trial balloon for the government, a test of the antiwar movement's strength and militancy." In a prescient observation, he suggested that the most important factor in how this drama would play out would be the kind of defense adopted by the indicted men: “...it is unclear whether that defense will also be a defense of the program they supported; and if the defense of the men is separated from an active defense of draft resistance as such, then the government will know that the way is open for an attack on the resistance movement itself." Remaining defiant in the face of prosecution. Fuerst seemed to suggest, would demonstrate the movement's commitment and give the government pause. In any event, all such analyses of the indictments assumed that the administration planned a crackdown - one that could be imminent or that might not occur until after the trial. As Hilde Hein recalled, the notion that these five formed a conspiracy - the etymology of the word reduces to "breathing together" - was absurd. That said, if they could still be indicted for a conspiracy. she thought. "anybody could be indicted as a member of a conspiracy." Many in the movement grew anxious.

In reality, the government did not have any additional "repression" planned, and if

${ }^{7}$ Howard Zinn, interview with author, 6 Jul 1998; Kampf interview, 10 Sep 1998; "The Repression at Home," editorial. Ramparts, Feb 1968, p. 2; John Fuerst, "Resistance and Repression," New Left Notes, 15 Jan 1968, p. 1; Robert Pardun, "The Political Defense of Resistance," New Left Notes, 15 Jan 1968, p. 1; Hein interview, 18 Sep 1998. 
antiwar activists had been privy to the manner in which the Spock indictments originated, their concerns might have been eased. Investigation of the men who became known as the "Boston Five" did not start until December, after Attorney General Ramsey Clark and General Hershey issued their joint statement on the enforcement of Selective Service laws. As part of that communique, the Department of Justice announced the formation of a Special Unit in the Criminal Division that would handle draft cases. Clark chose John Van de Kamp to head up the effort. Van de Kamp, a former U. S. Attorney in Los Angeles, had been recruited by Deputy Attomey General Warren Christopher to become deputy director of the Executive Office of U.S. Attorneys only a few months before, and was present at the Justice Department meeting between John McDonough and the delegation bearing draft cards. Van de Kamp quickly put together a small team of lawyers to "look at if there was any overall conspiracy...any kind of national effort to persuade people, to induce them to evade the draft." Among the first activities they investigated were the counseling services offered by the American Friends Service Committee and other religious organizations, which the department found to be "very careful" about how they dispensed information "without getting into any kind of inducement that would bring them within any kind of criminal prosecution." At the same time, though, Van de Kamp's unit focused on the events of October 20 at the Justice Department. Eventually, that investigation led to the preparation of an indictment of a long list of people found to be pushing for a national draft resistance movement. The attorney general rejected it; he wanted it whittled down to a group of the individuals who 
were most involved. ${ }^{8}$

What is most interesting is who the government finally indicted as ringleaders. Of the five men chosen for prosecution by the Justice Department, only Michael Ferber was of draft age; the other four were older and, more important, had joined the movement as supporters, not draft resisters. As Mitch Goodman remarked, "the kids invented the Resistance movement, we came along behind." According to John Van de Kamp, John McDonough, and John Wall. however. the government felt obligated to go after the older advisers who were "inducing," "soliciting," "inciting," or "encouraging" draft age men to violate Selective Service laws. After all, these men invited it. The specific language used by Coffin on the Justice Department steps, for example, seemed to come right from the statute books. "We hereby publicly counsel these young men to continue in their refusal to serve in the armed forces," Coffin said. "And we pledge ourselves to aid and abet them in all the ways we can." Indeed, they were asking for it. But more important. the Department's interest in prosecuting these conspirators stemmed in large part from a concern that older, wiser men were urging younger, more impressionable men to break the law. That was not only illegal, it was offensive. Although Van de Kamp. McDonough. and especially Wall doubted the wisdom of the administration's Vietnam policies, none of them felt that it justified what these older advisers were trying to do by urging younger men to resist the draft. The Department, as Van de Kamp later noted, wanted to send a message that although speech would be tolerated. "inducing or

${ }^{8}$ John Van de Kamp, interview with author, 9 Jun 1998; Ramsey Clark, interview with author, 6 Jan 1998. 
procuring evasion" would not. To protect America's youth and the integrity of the draft laws, such individuals would have to be prosecuted. ${ }^{9}$

If the Justice Department truly interpreted the draft resistance movement this way, then they clearly misjudged it. The young men who founded the draft resistance movement, who worked in Resistance chapters across the country, who planned draft card turn-ins and sent the yield to Washington. did all of those things on their own, with and without the encouragement of older supporters. Only when the older men who circulated the Call to Resist Illegitimate Authority sought to raise their own personal stakes did they seek alliance with the younger men by suggesting that they be the ones to accept the returned draft cards and then convey them to the attorney general. By the time that idea occurred to William Sloane Coffin, the Resistance had already built considerable momentum in several cities across the nation. Of course, the younger men were happy to accept the support of the older partisans; it gave the entire movement an added air of credibility that could only help the cause, and their fundraising abilities proved invaluable, too. Ultimately, however, even a perfunctory review of the draft resistance movement should have made government investigators realize that the leaders of the movement were the resisters themselves. And although they could not be accused of counseling others to resist the draft (as at Arlington Street, Resistance organizers everywhere took careful steps to make sure every resister came to his position on his own) these younger men were certainly guilty of aiding and abetting the mass violation of

${ }^{9}$ Van de Kamp interview, 9 Jun 1998; McDonough interview, 3 Jun 1998; John Wall, interview with author, 26 Jun 1998; Mitford, The Trial of Dr. Spock, pp. 31, 271. 
Selective Service laws. In this context, indicting Michael Ferber made sense. They might also have indicted David Harris. Lenny Heller in California. Bill Dowling, Alex Jack, Neil Robertson. Nan Stone in Boston. and other Resistance leaders from Chicago, New York. and Philadelphia. Instead. though, the government created the Trial of Dr. Spock.

Resistance organizers likely would have refused the support of the older men and woman if they had known that the government would choose to target them instead of the resisters themselves. This unexpected response from the administration undermined the Resistance goal of bogging down the court system and filling the jails with America's youth. Then again. maybe someone in the Justice Department knew that.

The answer to this prosecutorial riddle apparently lay at the top. with the attorney general, Ramsey Clark. It turned out that no one outside the Department - and very few within it - understood the complicated motives behind Clark’s approval of this indictment. Years after the trial of the Boston Five, Clark acknowledged that he intentionally sought a draft resistance "control case" or "test case;" significantly, he wanted "a case that would justify deterring other aggressive actions" by the Department against individual draft resisters. Two motives led him to this particular case. First. as he later said, "the law always has to consider how you test an unpopular law" like the Selective Service Act. The law, he said, "has an obligation to protect governmental institutions, even when they're engaged in erroneous policy." Sounding almost utopian, Clark argued that in any society "that wants to be democratic and free," important issues like the war and the draft should be "vigorously debated" as early as possible. A draft 
resistance test case, therefore, would "ventilate the issues, escalate them where they can be seen, [and] provide vigorous defense" for the defendants - or so he hoped. Second, Clark felt he had a duty to avoid injuring "innocent" people like ordinary draft resisters who were not engaged in an act of moral turpitude, but were acting on conscience. Here. his own experience during World War II and the treatment of his friends who were conscientious objectors informed his decision. As he later put it:

The saddest thing to see is a youngster out in the boondocks who's a pacifist. There's no sympathy there for him, no support there for him, he's got no way to defend himself or protect himself, and it looks like the whole world is against him (perhaps his father feels he's a traitor, and his mother feels he's a coward, his buddies don't like him). He's got nothing and you come down on him with a prosecution that's just devastating.

Clark badly wanted to avoid prosecuting men like this. As an alternative, the Spock defendants were mature, "had thought things through for a long period of time, and had firm - even passionate - understanding and commitment of what they were doing and why." he reasoned. They also had the resources to mount a more adequate defense than an isolated young resister might have. The Department, Clark later commented. "could have ground up tens of thousands of youngsters and nobody would ever [have] notice[d] it." But here, Clark remarked, "with a famous baby doctor and a prominent chaplain of a major university, attention had to be paid." As he reflected on it years later, Clark still liked the plan. "I think it was sound government, sound law, and sound morality," he said. $^{10}$

By this time, Clark himself had turned against the war. Within the administration

${ }^{10}$ Clark interview, 6 Jan 1998; Ramsey Clark, telephone interview with author, 29 Apr 1998. Also see Wells, The War Within, pp. 234-237. 
his well-known opposition to Johnson's Vietnam policies rankled colleagues. Clark believed that the president left him off the National Security Council because of it and later admitted that his relationship with Johnson and others became "very strained." He remembered that the Foreign Intelligence Advisory Board claimed his resolute refusal to grant wiretaps of antiwar groups undermined "not only the war effort then but generally the national security of the country." By the time the administration left office, he had become a virtual outcast, a cabinet official not invited to any of the many going-away parties held in the final weeks. So. in early January 1968 , when the grand jury handed down indictments of the Boston Five, Clark recalls, the president and Joe Califano. in particular, were "genuinely and actually surprised." They did not think Clark would do it, especially on his own. The antiwar movement would have found this hard to believe since they were certain that $\mathrm{Dr}$. Spock could have been indicted only with the president's consent."

As the Department prepared the indictment. Clark brought in Erwin Griswold, the Solicitor General to look at the case. Clark especially wanted Griswold. whom he thought of as the "Grand Old Man of law school deans and legal scholarship," to vet the case for two reasons: "to be absolutely confident that it did not involve a violation of the First Amendment and that it was a proper use of the conspiracy statute." For one thing, he did not want the trial to become a free speech case. The central issues in the case had nothing to do with free speech. Secondly, Clark believed that, inherently, the five men charged were engaged in a conspiracy - well-intentioned or not. On many occasions,

"Wells, The War Within, p. 236; Clark interview, 6 Jan 1998. 
Clark had had numerous older people - college professors, lawyers, other draft counselors - appeal to him telling him that they wished Clark would prosecute them instead of the draft-age men. The trouble with that, as Clark saw it, however, was that even if the government prosecuted these people, it could not ignore "the principal who commits the ultimate act." The one time that the government could ignore the individual resisters would be when a "major effort...a continuing effort," involving "the same circulation of people," ringleaders who were more involved in trying to create opposition to draft registration and compliance. In this way, the conspiracy statute might actually protect the mass of individual resisters while targeting only those responsible for inciting these violations of the law. ${ }^{12}$

Since the events detailed in the indictment occurred in Washington, New York, and Boston, a Grand Jury could have been convened in any of those cities. The Department chose Boston. John Van de Kamp later explained that the government did not want to try what would inevitably be seen as a political case in Washington where politics would be most emphasized. Van de Kamp saw Boston as "more neutral grounds" and a place where they could make a strong case. In fact, Ramsey Clark had consulted with the United States Attorney in Boston, Paul Markham, about assigning the case to John Wall. At the same time that Van de Kamp and his team were working on the details of the indictment, Wall was in Washington working for Clark on special assignment investigating Congressman Adam Clayton Powell. (Wall eventually put together a persuasive case for indictment of Powell, but Clark chose not to pursue it). Wall returned

${ }^{12}$ Clark interview, 6 Jan 1998. 
to Boston and presented the Spock case to the grand jury for indictment. He recalls that one juror clearly sympathized with the five potential defendants. On occasion. this man would blurt out "Indict the president. why don't ya?!" or "It's an illegal war!" He did not persuade his peers, and the grand jury decided to indict the five men for conspiracy. ${ }^{13}$

The movement saw the decision to hold the trial in Boston differently. They believed that a jury in Washington would be predominantly African-American and less likely to side with the government. Likewise, a jury in Manhattan, a hot-bed of opposition to the war, might include Jews and minorities more inclined to acquit. A jury in Boston, in contrast, would be more likely to empanel conservative Catholic (Irish or otherwise) jurors who would be more eager to convict the five defendants. Years later, even John Wall, who did not have any role in the decision to bring the trial in Boston. said that he assumed the case was tried there for that reason: "A lot of Irish-Catholic conservatives here in Boston: they ${ }^{\circ} \mathrm{d}$ be more likely to get a conviction here than in Washington, DC or in New York."14

Although some in the antiwar movement worried that the indictments represented the first act in a growing wave of repression, others speculated that the Justice Department had done them a favor by choosing five clean-cut, articulate defendants and by trying the case in Boston. One week after being indicted, Michael Ferber told an audience, "maybe we have a friend in high places." He saw Boston as one of the best

${ }^{13}$ Van de Kamp interview, 9 Jun 1998; Wall interview, 26 Jun 1998.

${ }^{14}$ Ferber interview, 16 Jun 1998; Mitford, The Trial of Dr. Spock, p. 220; Wall interview, 26 Jun 1998. 
communities for the trial due to the strong church and academic support. Similarly, the choice of defendants made one wonder about a benefactor. "Why else would they pick a healer of babies, the best known doctor in the country, a chaplain at Yale, a novelist, a research assistant who is in the National Security Council, and me?" Ferber asked. They could have gone after a group of bearded, long-haired draft resisters, but "none of us has so much as a moustache." he said. ${ }^{15}$

\section{Indictments as Catalyst}

Indeed, rather than facing the trial with dread, many in the movement looked forward to it with great anticipation and also with high expectations for what it might accomplish in furtherance of their cause. Ramparts magazine declared that "the Spock case will undoubtedly be one of the most important political trials in American history." Echoing that sentiment, William Sloane Coffin told a reporter that he looked forward to "a really good confrontation with the government on the legality and morality of the war." Similarly, the Rev. Dick Mumma, Presbyterian chaplain at Harvard, told some other reporters that it pleased him that the issue had been joined, "that the legal confrontation" would at last take place. "A lot of the hope I have in the human race is pinned on these five indicted men," he explained. Michael Ferber later reflected: "I felt really good for the Resistance. I felt grateful that we had Spock in trouble, and Coffin...I thought this was the best thing for draft resistance that we could do." Though he knew the trial might draw some attention away from the resisters themselves, the idea of draft resistance

${ }^{15}$ Michael Ferber, speech at Town Hall, New York, 14 Jan 1968, Exhibit 33a, U.S. v. Coffin, et al, CR-68-1, National Archives, Waltham, MA. 
would get much more attention and it would be "a huge political problem for the government." In fact, he thought the administration was "really stupid to have done it." The idea of putting Dr. Spock in prison, he reasoned, should have been the last thing the government wanted. This sense of confidence shaped Ferber's reaction to the indictment when he finally received it in the mail. Accustomed to grading freshman English papers at Harvard, Ferber sat down with the indictment and, with red pen in hand, corrected it. He crossed out redundancies ("combine," "conspire," "confederate," and "agree"), marked the split infinitives ("to unlawfully, knowingly, and willfully, counsel, aid and abet") and circled misspelled words, especially "co-conspirator." in which the "co-" seemed superfluous. In the margins, he wrote. "You should do better. See me." He gave the whole indictment a grade of $\mathrm{C}$ - and mailed it back to the U.S. Attorney. ${ }^{16}$

Although such open acts of bravado were rare, the indictments did elicit a new sense of defiance and solidarity from draft resisters and the larger antiwar movement. In the days immediately following announcement of the indictments, Resist, the organization of older supporters that evolved out of the Call to Resist Illegitimate Authority, issued a complicity statement: "We stand beside the men who have been indicted for support of draft resistance. If they are sentenced, we, too, must be sentenced. If they are imprisoned, we will take their places and will continue to use what means we can to bring this war to an end." Among the signers were Martin Luther King, Jr., Noam

16 "The Repression at Home," editorial. Ramparts, Feb 1968, p. 2; "Draft Indictments Spur Calls for Strikes, Sit-Ins," Boston Globe, 7 Jan 1968, p. 1; "Indictments Protest Planned in Capital," Boston Globe, 8 Jan 1968, p. 1; Ferber interview, 16 Jun 1998; Coffin, Once to Every Man and Nation, p. 263; Mitford, The Trial of Dr. Spock, p. 4. 
Chomsky, Robert McAfee Brown, Dwight MacDonald, and Howard Zinn. In addition, Resist called for a nationwide academic strike during the trial and another march on Washington. Teach-ins were scheduled at universities around the country and the Resistance predicted that by spring another 10.000 men would turn in their draft cards. For many opponents to the war, their challenge had been met and now choices needed to be made. "If these five go to jail and thousands of others do not follow them, we can forget about serious opposition to the war and civil liberties in this country," a Ramparts editorial warned. "We are all on the spot...If these five men are conspirators, then we must become a nation of conspirators. If we do not stand with them. it is impossible to see where the repression at home, and the oppression abroad, will stop." The indictments served as catalysts for a closing of ranks, a renewal of that bold rebelliousness that launched the draft resistance movement. ${ }^{17}$

The groundswell of support for the five defendants and the draft resistance movement surprised even the most experienced political organizers. One week after the indictments came down, Resist organized an event at New York's Town Hall with the idea that the individuals could line up and sign the group's complicity statement on stage in a very public, dramatic fashion. As the day approached, Louis Kampf and others worried that the turnout might be too small. Instead, when the time came, people packed Town Hall and overflowed into the streets. The meeting never opened formally as people

17 "Draft Indictments Spur Calls for Strikes, Sit-Ins," Boston Globe, 7 Jan 1968; Michael Ferber, speech at Town Hall. New York, 14 Jan 1968, Exhibit 33a, U.S. v. Coffin, et al, CR-68-1, National Archives, Waltham, MA; "The Repression at Home," Ramparts, Feb 1968, p. 2. 
spontaneously began signing the statement and speaking into the microphone one at a time. "We couldn't keep people off the stage," Kampf recalled. "People just rushed up there wanting to sign up and made a lot of very heartfelt statements about overcoming fear." Even more significant, the money began pouring into Resist. Instead of scaring the draft resistance movement and the larger antiwar movement of which it was a part, the government opened the financial floodgates. "Financially," Kampf says, "it gave us the wherewithal to really set up a serious organization and be able to look to the future."18

In the hothouse atmosphere of the draft resistance organizing at this time, however, passions sometimes collided. Bill Dowling, original founder of the New England Resistance and. really, its de facto leader in the fail, saw the indictments as an opportunity to increase the coefficient of friction with the administration. Dowling suggested a massive sit-in at the federal courthouse in Boston on the day of the arraignment, scheduled for 29 January 1968. But some of his comrades disagreed. Ferber, in particular. saw the occasion of the indictments as an opportunity to broaden the Resistance's base of support, and to continue on the course of resistance already charted as they prepared for the confrontation with the government. Switching to new tactics at every new opportunity. just for the sake of creating ongoing discomfort for the administration, did not seem prudent. he thought. Ultimately, a kind of showdown occurred between Dowling and Ferber. After discussing Dowling's plans with the other defendants - all of whom concluded that the mass sit-in would be supernumerary at best, and counterproductive at worst - Ferber urged Dowling to reconsider. Dowling refused.

${ }^{18}$ Kampf interview, 10 Sep 1998. 
Standing in the falling snow in the middle of Harvard Yard, Dowling told Ferber that he and others intended to go ahead with the sit-in anyway. Ferber warned that he would have to come out against Dowling if he did. Disgusted, Dowling turned and walked away. On January 29, the sit-in did not materialize. Bill Dowling dropped out of the Resistance and he and Michael Ferber never spoke to one another again. ${ }^{19}$

Internal dissension rarely reached such levels within the New England Resistance, especially at this time when the indictments actually galvanized more fervent support for the cause. More and more supporters turned out for rallies and teach-ins in the weeks following the indictments. Donations streamed in to BDRG, to the New England Resistance, and especially to Resist which began giving out monthly grants to draft resistance organizations nationwide. Perhaps most telling, a new attitude of confidence could be discerned in public and in private. The tone of demonstrations clearly changed in January 1968. While the draft card turn-ins and demonstrations of the fall generally had been somber affairs, the rallies and turn-ins put on by the Resistance in the wake of the indictments were almost jubilant and raucous. This transition occurred most noticeably around the time of the arraignment for the Boston Five. On January 28, the night before the arraignments, two meetings took place that effectively marked the passage of one era to the next. Early in the evening, the First Church of Boston in the Back Bay held a service of support. 700 people came to hear William Sloane Coffin in a contemplative service not unlike those of the fall. But later that evening, the Resistance

${ }^{19}$ Ferber interview, 21 Apr 1998. Note: Bill Dowling has agreed to be interviewed for this project, but only after the defense of the dissertation. 
sponsored a rally (much like a college pep rally) at Northeastern University in support of the defendants. 2,200 people showed up to hear an all-star list of speakers that included Dr. Spock, Coffin. Paul Goodman. David Dellinger, Tom Hayden, Paul Lauter, Bill Hunt, and Harvard Professor $\mathrm{H}$. Stuart Hughes. A mood of both defiance and almost celebration permeated the entire evening. Each speaker elicited enthusiastic bursts of applause throughout the night, but one young man, Richard Wolcott, received the most thunderous ovation when he spontaneously stepped to the podium and told the crowd that he would refuse to be inducted into the armed forces the next day. The crowd basked in a new sense of solidarity and seemed emboldened by it. By the end of the night, another $\$ 1000$ had been raised to support draft resistance, and 350 people signed a complicity statement that would be sent to Ramsey Clark the next day. ${ }^{20}$

No day epitomized the draft resistance movement's new beginning like the day of the arraignment itself, January 29, 1968. By the time the five defendants arrived at the federal courthouse in Post Office Square. 1,200 to 1,500 supporters had been quietly picketing outside for more than an hour. They carried signs: "Join the New American Revolution," "Resist," “Napalm: Johnson's Baby Powder," "Don't Enlist, Resist." "Make Love, Not War," "End the Draft, Let Men Live," and the most clever one, "Dr. Spock Delivers Us Again!" A special detail of 30 police officers monitored the crowd while several FBI agents weaved in and out of the picket line with their cameras. Naturally, Josef Mlot-Mroz and his group of Polish Freedom Fighters provided the alternative viewpoint. In the battle of the placards. Mlot-Mroz offered his standard themes along

${ }^{20}$ Resistance National Newsletter \#5, 31 Jan 1968, MKFP. 
with some new signs aimed at the media: "Squash Communism Everywhere," "Burn, Baby, Burn: Your Draft Card. Your Birth Certificate, and Your Citizenship Papers," “Dr. Spock - Change Diapers, Not Foreign Policy," "Press-News-Media: It is High Time That You Gave U.S. the Truth About the Red Menace, $\$ 64,000$ Question: Who is Controlling You?," and "Why is the Press Always Slanted in Favor of the Reds \& Pinkos, Vietniks and X-niks?" Twelve members of the conservative Young Americans for Freedom also counter-protested."

Inside the courthouse, the five defendants appeared for a mere nine minutes before Judge Francis Ford. Only relatives of the defendants and reporters were allowed into the courtroom. Two newsmen from Tass, the Soviet news agency, sat in the back (the next day's Izvestia carried the headline: "Crime in Boston: Crude Reprisal Against American Patriots"). When asked for their plea by Deputy Clerk Austin Jones, each man answered "not guilty." Several observers noted that moments earlier, in an adjacent courtroom. 350 new citizens took the oath of citizenship - an oath that called on citizens to uphold the Constitution and to bear arms if necessary - from Judge Arthur Garrity. The judge set bail at $\$ 1,000$ for each defendant and told them that they could travel anywhere they wanted within the United States. Court officials then took the five defendants to be fingerprinted and then released them. At some point, word came that British actress Vanessa Redgrave had cabled her support. By the time the five emerged from the

21 "Dr. Spock Pleads Innocent," Boston Globe (Evening), 29 Jan 1968, p. 1; "Dr. Spock's Trial Set in March," Boston Globe, 30 Jan 1968, p. 1; photograph, BU News, 31 Jan 1968, p. 9; Bud Collins, "The New Generation's New Heroes," Boston Globe, 31 Jan 1968, p. 13. 
courthouse, the line of supporters had become so long that it stretched all the way around the massive Art Deco structure in a complete circle from Water Street to Devonshire. Milk, and Congress Streets. A crowd of supporters surrounded Dr. Spock as he stepped into the daylight, but then counter-protesters began shouting "traitor!" and "coward!" A snowball whizzed by Spock's head as many of the counter-pickets stormed into the crowd, grabbed signs from supporters and stomped them on the ground. The draft resistance sympathizers did not respond except for one who bloodied Josef Mlot-Mroz's nose and shoved him to the sidewalk after the freedom fighter called him a "red." Police kept the scuffles from escalating. and the crowd dispersed as the defendants rode from the courthouse to the Arlington Street Church for a 12:30 press conference. ${ }^{22}$

The scene at the Arlington Street Church at first appeared much like it did on October 16. As the defendants held their press conference in the basement below, a teach-in took place in the sanctuary of the church. Close to 1,000 people jammed the church. Spock told reporters that "the war in Vietnam is on trial just as much as we are. There is no question in our minds that we're not guilty because the war is illegal." The press conference adjourned as the teach-in upstairs ended and as the "Service of Rededication" began, the defendants walked triumphantly into the sanctuary where they were met with several minutes of deafening applause and cheering. After the invocation

22 "Dr. Spock Pleads Innocent," Boston Globe (Evening), 29 Jan 1968, p. 1; "Dr. Spock's Trial Set in March," Boston Globe, 30 Jan 1968, p. 1; "Izvestia Gives Hub Big Play," Boston Globe, 30 Jan 1968, p. 2; Bud Collins, "The New Generation's New Heroes," Boston Globe, 31 Jan 1968, p. 13; "1,200 at Anti-War Rally as Spock, 4 Others Plead," Boston Herald Traveler, 30 Jan 1968, p. 1; "Peace and Punches Mar Spock Hearing," Boston Record American, 30 Jan 1968, p. 3; "25 All Burned Up Over Spock Hearing," Boston Record American, 30 Jan 1968, p. 3. 
and once again singing Once to Every Man and Nation, Bill Hunt read excerpts from General Hershey's Channeling Memo. Denise Levertov then read a few of her poems, followed by Neil Robertson who read writings of nonviolent struggle by Gandhi.

The heart of the service, however, centered on the responsive reading led by Bob Hohler, Director of the Unitarian Universalist Laymen's League. The text of the readings, and the congregation's responses appeared in the order of service distributed to those in attendance and, notably. to the press. The readings and responses reflected the new era of draft resistance. They were critical of government policy and especially of the complacency of American citizens in the face of what they believed to be an obscenely immoral war. In a way, the readings were a vehicle for participants to confront their own past inadequacies in protesting the war while simultaneously renewing their commitment. "rededicating" themselves to constant vigilance in opposing the war. In part, the exchange went as follows:

Leader: What will we say to the world one day when it asks us why we paid not attention to the Vietnamese who for over a hundred years struggled for independence from the foreign power in their country?

Congregation: We did not care about people with yellow skins. We were busy building an empire by destroying people with red skins and enslaving those with black skins....

Leader: Why did we raise no cry of outrage when our government first sent planes to destroy the city of Vinh in North Vietnam?

Congregation: We believed the false reports and lies of our government. We felt secure because we had elected a President who promised peace. We buried ourselves in daily trivia and grew numb. We did not care...

Leader: Where were we when four men burned their draft cards in South Boston in 1965 [sic]? When over 200 men said No to the government in this church and in Old West Church last fall?

Congregation: We were hiding behind our student and ministerial 
deferments. We were seeking jobs that were in the 'national interest.' We were able to afford medical and psychological excuses. while our black, poor, and working class brothers were sent to die. We were working within the system. We were paying our taxes to make the system work.

Leader: The world will say that we were wrong and its judgement will be harsh upon us. The world will say that we should have disobeyed our leaders. History will remember us as 'Good Americans' as we remember those who acquiesced to the slaughter of the Jews as 'Good Germans.' Our children will not accept the excuse that we were only doing our job.

Congregation: We were wrong. But if it is not too late, we are ready now to act.

Leader: It is not too late. For although there are many we have ignored there are many others we can help...Today at the Boston Federal Court. five men were arraigned for conspiracy to aid and counsel others to resist the draft.

Congregation. We stand beside these men.

Leader: And tomorrow, and the day after, and every day until the war ends in Vietnam and our country turns to freedom and justice for all its people at home. thousands and thousands of young Americans will stand up and resist the machinery of war and racism.

Congregation: We pledge to work beside these young men. Their struggle is our struggle. Their fate is our fate. The world shall not say they stood alone.

When recited in unison, these passages. steeped in self-examination and dedicated to a renewed activism. produced a kind of catharsis among the participants that reinforced the growing sense of solidarity within the draft resistance movement. In this house of worship, they felt cleansed. ${ }^{23}$

The confidence that this renewed solidarity engendered manifested itself in the next phase of the service. Father Phillip Berrigan, under indictment himself for pouring

23 "Dr. Spock Pleads Innocent," Boston Globe (Evening), 29 Jan 1968, p. 1; "Dr. Spock's Trial Set in March," Boston Globe, 30 Jan 1968, p. 1; "1,200 at Anti-War Rally as Spock, 4 Others Plead," Boston Herald Traveler, 30 Jan 1968, p. 1; Order of Service of Rededication, leaflet, 29 Jan 1968. Spock Papers, Series II, Box 11. 
his own blood on the files of a Baltimore draft board. issued the "call to resist." In an apparent reference to the five indicted men seated in the first pew, Berrigan said: "Those of you coming forward to turn in your draft cards do not have to be encouraged by me if you're not already moved by the display of resistance here today." As the Boston Five looked on, Berrigan, the Reverend Richard Mumma. Rabbi Judea Miller of Temple Tilfereth in Malden, and David Dellinger stood in the chancel, prepared to commit the same acts for which the others had been indicted. A stream of young men, also following the example of those who had gone before them, moved up the center aisle of the church with their draft cards in hand. The first man to approach the older group of "aiders and abettors" was Patchen Dellinger, a Harvard Medical School student and son of the antiwar leader. He embraced his father and handed his draft card to him. Behind the younger Dellinger, the numbers of new resisters continued to grow, and as more joined the line, the spectators cheered louder and louder. The quiet, solemn procession of October 16 gave way to a more exuberant demonstration. According to one reporter who witnessed the scene, "the overflow crowd rocked the large church with applause." From the balcony, supporters flashed the V-for-victory sign and smiled their approval. Denise Levertov, sitting next to her indicted husband, Mitch Goodman, wiped tears from her eyes as the young men turned in their cards. ${ }^{24}$

Ultimately, 25 men joined the Resistance that day, a much smaller number than in the fall, but they defied their government in a ceremony that New England Resistance

24 "Dr. Spock's Trial Set in March," Boston Globe, 30 Jan 1968, p. 1; "1,200 at Anti-War Rally as Spock, 4 Others Plead," Boston Herald Traveler, 30 Jan 1968, p. 1; "25 All Burned Up Over Spock Hearing," Boston Record American, 30 Jan 1968, p. 3. 
leaders called "the most inspiring we have had yet." In a letter sent with the newly collected draft cards to Attorney General Ramsey Clark, Neil Robertson wrote: "You will please note that the Resistance has been neither intimidated nor deterred from its activity by the unjust indictments of the "Boston Five." Indeed, the Resistance seemed inspired. The indictments did, as some resisters predicted, galvanize support for the movement and Resistance leaders took advantage of the chance for a fresh start. The questionable tactics and public relations errors of the fall were absent on January 29. Resisters turned in draft cards - they did not burn them. No fistfights erupted on the steps of the church. And most salient, the climate of support shifted from somber and deliberate encouragement to something approaching revelry. Rather than intimidate the draft resistance movement. government "repression" offered proof to resisters that they had grabbed the administration's attention. Confrontation, whether in the form of the Spock indictments or, increasingly, in attempts to induct resisters, did not for the moment intimidate but, rather, gave the movement strength..$^{25}$

\section{Refusing Induction}

By the time the Spock indictments came down, draft resisters across the country had been receiving notices from their local Selective Service boards informing them that their draft classifications had been changed to 1-A, that they could now be drafted. Each draft board varied in its approach to resisters. Some tried to get them to reconsider.

25 "Dr. Spock's Trial Set in March," Boston Globe, 30 Jan 1968, p. 1; "1,200 at Anti-War Rally as Spock, 4 Others Plead," Boston Herald Traveler, 30 Jan 1968, p. 1; "25 All Burned Up Over Spock Hearing," Boston Record American, 30 Jan 1968, p. 3; NER Newsletter, 8 Feb 1968, MKFP. 
Others simply sent replacement draft cards (with the same classification) to the resister while still others chose to ignore the defiance of such registrants. Most draft boards, however, declared resisters delinquent, reclassified them to 1-A (if they were not already $1-A)$, and placed their names in the pipeline for future induction.

In early 1968. the Army called the first reclassified resisters for induction, and in doing so, offered the draft resistance movement new opportunities for confrontation. For the resister being called, the induction order raised his personal stakes considerably; noncompliance would certainly mean an indictment and probably prison time. Inductions were the ultimate test of a resisters' commitment to his cause. Resisters found it much easier to turn in a draft card in an act of fellowship with dozens of other men than they did standing up to the Army - to their own government - all alone in an induction center full of willing, or at least acquiescent, conscripts. Both the New England Resistance and the Boston Draft Resistance Group recognized this and took pains to provide support to resisters on the day of their induction refusals.

In January the Resistance and the BDRG described the coming induction refusals as marking "a new beginning" for the movement. On the one hand, given its experience with Early Morning Shows and Horror Shows, the BDRG felt comfortable confronting the Army on its own turf, and to this the New England Resistance added its ability to mobilize large numbers of supporters for big demonstrations. As the Army called more and more resisters for induction, large rallies at the Army base became commonplace and garnered widespread media attention. But in a practical sense, induction refusals - for the New England Resistance, in particular - solved one of the most significant dilemmas 
that the organization faced in the fall: the lack of day-to-day work for rank-and-file resisters. Equally important. Resistance leaders used induction refusals as motivational tools, dramatic confrontations that would show their determination to prove to the administration that it could not "silence the American people by resorting to intimidation and bogus conspiracy charges." In this respect, General Hershey's plan backfired. Instead of undermining the resistance movement, drafting resisters actually helped to sustain the confidence and optimism of the movement by providing a vehicle for ongoing struggle with the government. Resisters predicted that more "acts of repression" would follow as the government grew "progressively more frightened of its own people," but argued that "history will regard these men [resisters] and the thousands that are prepared to follow them as the authentic patriots of our time." As the movement looked ahead to the Spock trial. then, induction refusals helped to maintain the renewed momentum that draft resisters felt in the wake of the indictments. Although numerous draft resisters refused induction in the winter and spring of 1968 , three separate days at the Boston Army Base merit closer attention, for the men who resisted on those days - Howard Marston, Jr, James Oestereich and Richard Hughes, and Ray Mungo - ran the gamut from almost reluctant to flamboyant and their experiences as resisters demonstrate how varied life in the Resistance could be. ${ }^{26}$

Howard Marston, Jr.

The Selective Service had been calling draft resisters for induction at least since

\footnotetext{
26 "Statement of the Boston Draft Resistance Group," undated leaflet (c. 10 Jan 1968), CFP.
} 
1966 and maybe since 1965, but only on January 10, 1968 - two days after the Boston Five received their indictments in the mail - did one resister's induction refusal become the focus of a mass antiwar-antidraft protest. Unlike the lonely days of 1966 , when a handful of CNVA supporters picketed the Boston Army Base on the days that John Phillips, David Reed, David O'Brien. Gary Hicks, and David Benson each refused to be inducted, the cold winter day of Howard "Chick" Marston, Jr.'s induction saw hundreds of people turn out in the first Resistance reply to what they saw as the Johnson administration's attempt to intimidate them.

In many ways, Chick Marston made an unlikely draft resister. Marston and two of his friends applied to their draft board (local board 72 in Gloucester) for conscientious objector status over a year before he turned in his draft card on October 16. Their cases were still pending at the time, but Marston and his friends decided that, at that point, they could no longer cooperate at all with the Selective Service System. "I figured the time had come for someone to do something." Marston said later. Although his father, Howard Sr.. and two older brothers were veterans, they backed his decision to resist as did his pacifist mother. Marston`s father. in particular, supported his 20 year-old son so much that he practically took over Chick's resistance. ${ }^{27}$

The younger Marston would have resisted quietly, but his father led him into a more public role, as he became the first parent in the Boston area to announce that he would prohibit his son, a minor, from being drafted. Chick later described his father, a

27 "3 Cape Ann Men Join Draft Protest," Gloucester Daily Times, 20 Oct 1967, Scrapbook, Howard Marston, Jr., Papers (hereafter cited as HMP); Howard Marston, Jr., interview with author, 13 Dec 1997. 
surveyor from Rockport, as "the local left-wing nut." In the early 1950 s he had led demonstrations in Rockport's Dock Square protesting the Top Mast Restaurant's refusal to serve African-Americans. Later, in the sixties, he fired off letters to the Gloucester Daily Times charging that the American economy depended on war and the military industrial complex for its success. The elder Marston was "a great character." his son later said, though he could be "a little overbearing and pushy." Those traits became apparent when Mr. Marston pushed his son into making his resistance into a cause celebre and, thus, bringing unforseen consequences to his family. ${ }^{28}$

The New England Resistance and Boston Draft Resistance Group thoroughly (if hastily) planned Chick Marston's induction refusal in advance. First. organizers held a press conference for the Marstons on January 8 to which they invited a couple from Dorchester who had lost a son in Vietnam. The mother of the slain soldier, speaking for herself and her husband, a Marine veteran of World War II. offered the Marstons their complete support. "We feel the war is exceptionally cruel, immoral and absolutely unnecessary," she told the press. "It is a tragic waste" of both Vietnamese and American lives. she said. "We support our boys in Vietnam. We want them brought home alive, not dead - as was our only young son." Howard Marston, Sr. followed, telling the media that because Chick had not yet reached the age of 21 and was, therefore, a minor, he forbade him to go into the armed forces. In light of the Spock indictments, Marston noted that he realized he might be prosecuted for "counseling" his son in this way. "Friday's

\footnotetext{
28،"Draft Resistance Involves Quiet Rockport," editorial, Gloucester Daily Times, 6 Apr 1968, p. 4.
} 
indictments only made us a little more eager to act," he said. "It's an illegal and immoral war." The press conference produced the desired effect. Newspaper, television, and radio announced that Chick Marston, with the approval of his parents, would refuse induction two days later. ${ }^{29}$

Although draft resistance leaders envisioned a "new beginning" with the onset of the first induction refusals, resisters like Chick Marston still had to face some of the old hassles. When Marston arrived in Gloucester to wait for the train that would take him and his fellow draftees into Boston on January 10, the effect of the press conference and the calling of attention to his plans, became immediately apparent. A group of supporters (including John Phillips, recently freed from federal prison), passed leaflets while another group of hecklers shouted epithets at Marston and his comrades. One young man told a reporter that he came down just to see if a sniper would "shoot these idiots." Others shouted, "Let's see you burn your draft cards!" and "Go get a haircut," while one man said, "somebody ought to offer a medal for putting a bullet through your heads." If the Marstons did not expect this kind of hostility, when they got to Boston it became clear that passions would continue to rage at the Army base. ${ }^{30}$

Outside the Boston Army Base. a massive building on Boston Harbor. a crowd of more than 300 people braved sub-zero temperatures to cheer Chick Marston and Corey

29 "Boston Draft Protest Set," Boston Globe, 8 Jan 1968, p. 9; "Marston, 20, Says He Will Refuse Induction in Army." Gloucester Daily Times, 8 Jan 1968, Scrapbook, HMP.

30 "Marston Praised and Criticized for War Protest," Gloucester Daily Times, 10 Jan 1968, Scrapbook, HMP; "Gloucester Draftee Resists," Salem News, undated newsclip, Scrapbook, HMP. 
Brown. another man who planned to refuse induction that moming. The crowd had been generated largely by the efforts of the New England Resistance and the Boston Draft Resistance Group and many wore white armbands with the black omega symbol of the Resistance. But the large press contingent turned out to see the unusual sight of two parents accompanying their son to the base as he planned to refuse service in his nation's military. As the family approached the gates, they were mobbed by reporters and photographers. Howard Marston, Sr. told the crowd of press and supporters: "I've been opposed to the war all along. I demanded that he not go. He thinks the same way. I told him not to go, and he was amenable." Chick himself said little. His father stressed his primary theme - that he was taking responsibility for his son's actions. "I would like to see mothers and fathers across the country forbid their children to enter the service," he said. "I would like to see thousands and thousands more resisters." The ubiquitous Josef Mlot-Mroz rushed up to the elder Marston and called him a "communist stooge." 31 After Chick Marston and Corey Brown entered the base, demonstrators continued to tolerate the cold, perhaps because Mlot-Mroz had shown up with 30 of his fellow "freedom fighters" (his largest group yet), many of whom were armed with signs unloaded from the back of Mlot-Mroz's red Cadillac, all inscribed with the same fervently anticommunist messages for which they were well-known. Fistfights were

31 "Army Base Picketed by Anti-Draft Group," Boston Globe (Evening Edition), 10 Jan 1968, p. 1; “Army Delays On Resisters," Boston Herald Traveler, 11 Jan 1968; "Howard E. Marston, Sr. Speaks On His Son's Refusal to Be Inducted into the Army," NER leaflet, CFP; "“Stop Draft!' Cries Follow Indictments," BU News, 17 Jan 1968, p. 3; "Parents Back Boy Fighting Draft," newsclip from unknown newspaper, Scrapbook, HMP. 
probably inevitable. and several broke out before police stepped in. Two brawny counterprotesters stuffed a Resistance picketer headfirst into a snowbank while several others threw eggs. ${ }^{32}$

Inside, base officials separated Marston from the others and escorted him through the different stages of induction. After nearly six hours, however, Lieutenant Colonel Edward J. Risden. the base commander, sent both Marston and Brown home without asking them to take the oath of induction. Risden told the media that the Army needed to conduct investigations into the men's loyalty to their country, but would not be more specific. "I think that there probably was a reason [for the investigation], but I'm not at liberty to discuss it." he said. This development came unexpectedly; never before and never after did either draft resistance organization encounter this type of response from the base. Resistance activists expected Marston and Brown to emerge heroically from the base after rebuffing the Army. but they would have to wait until January 19 for a second attempt. $^{33}$

It is impossible to know exactly why Lt. Col. Risden sent Marston and Brown home but he may have been trying to buy some time while he sorted out his own mixed

32 "26 in Hub Inducted as 2 Protesters Are Sent Home," Boston Globe, 11 Jan 1968, p. 1; "Dr. Spock Invites Marstons to Dinner," Gloucester Daily Times, 11 Jan 1968, Scrapbook, HMP; "Peacenik 'Inducted' Into Snow," photograph, Boston Record American, 10 Jan 1968, Scrapbook, HMP; "Youths Lose Chance to Refuse Draft," Boston Record American, 11 Jan 1968, p. 5.

33 "Army Delays on Resisters," Boston Herald Traveler, 11 Jan 1968, Scrapbook, HMP; "26 in Hub Inducted as 2 Protesters Are Sent Home," Boston Globe, 11 Jan 1968, p.1; "Dr. Spock Invites Marstons to Dinner," Gloucester Daily Times, 11 Jan 1968, Scrapbook, HMP; " 2 Get Chance to Spurn Induction at Last," Boston Globe, 20 Jan 1968, p. 3. 
feelings about Vietnam. Risden, a veteran of World War II and Korea, served two tours in Vietnam. In 1957 and 1958 he went to Vietnam as an adviser and returned feeling good about American efforts there. But after another tour in 1966-1967 - this one a combat tour - Risden came home disgusted. American forces didn't know why they were there or who they were fighting, he thought. Complicating matters, Risden became base commander at the Boston Army Base in February 1967, just weeks after his own son Joe. 23 had been drafted. In short, Risden felt conflicted. On the one hand, he possessed a strong sense of duty and commitment, yet his anger about the war led him at times to be somewhat sympathetic to the antiwar movement. Eventually, he grew weary of it, and retired just weeks later on April 1, 1968.34

Although a large crowd of backers again appeared at the Army base when Chick Marston and Corey Brown returned on the $19^{\text {th }}$ and finally refused induction, the support offered little comfort. The entire ordeal. now drawn out over more than two weeks, had taken its toll on Marston, in particular. He later admitted to being "on the verge of a nervous breakdown through it all." Unlike his father, who loved the spotlight, Chick "couldn't handle the cameras and the interviews." He would have preferred to resist quietly. While he fully expected to go to jail, the publicity added a completely new dimension to it, one that put a tremendous strain on his family. "I hated the whole thing," he later said. "Hated it."

${ }^{34}$ Edward J. Risden, Jr. (Son of Lt. Col Edward J. Risden), telephone conversation with author, $24 \mathrm{Jul} 1968$ (notes in author's files).

${ }^{35}$ Marston interview, 13 Dec 1997. 
Part of the reason he hated his draft resistance experience derived from the very public manner in which it was carried out and the constant harassment and torment it brought to his family through it all. According to Marston, the head of his draft board called to tell his family that he had information suggesting that their phones were tapped. Marston also claims that, during this same period, much of the mail the Marston family received had already been opened. Other letters - hate mail - came addressed to "Chicken" Marston. In addition, Marston and his sister, Deb, recall the day that a local Boy Scout leader led his troop in a march up the their street so they could throw rocks at the Marston house. All of this added up to a tense household. Marston's mother was a "nervous wreck." especially when faced with reporters seeking interviews. "She"d start shaking uncontrollably," her son later said. ${ }^{36}$

Eventually, the U.S. Attorney in Boston, after indicting Marston and bringing him to trial in the fall of 1968 , dropped the case due to mishandling of Marston's classifications by the Selective Service. The legal challenge that Howard Marston, Sr. wanted never materialized and a technicality ended it all. The press and, for the most part, the draft resistance movement missed the dismissal. Just like that, the ordeal ended with no fanfare. though it left Chick Marston "close to a breakdown when it was all over." Years later, he told of being "lost for quite a while" and doing his best to leave that past behind. He found it difficult to see how useful his resistance had been and did

\footnotetext{
${ }^{36}$ Howard Marston, Jr. and Deborah Jelmberg, interview with author, $13 \mathrm{Dec}$
} 1997. 
his best to forget the entire experience for the next thirty years. ${ }^{37}$

For the draft resistance movement in January 1968, however. Chick Marston's induction refusal played an important role in building momentum. helping to further intensify the commitment of many resisters and activists in the wake of the Spock indictments. Just as Chick's father dominated his draft resistance, the movement coopted it for its own purposes.

\section{James Oestereich and Richard Hughes}

If Chick Marston's induction refusal experience slipped beyond his control, Jim Oestereich and Dick Hughes cheerfully invited the New England Resistance and Boston Draft Resistance Group to capitalize on their day of noncompliance a month later. Neither Oestereich nor Hughes knew each other before February 26, 1968. their date of induction, but when both approached the BDRG and NER for help in their refusals (Oestereich had already done some work for NER), the groups paired them together for promotional purposes. Two resisters always beat one. A leaflet produced jointly by the two organizations featured photographs of each man with a brief statement encouraging other inductees and draft-age men to join them. "I have chosen to take a stand against the Selective Service System which presently functions as an accomplice to mass murder," Oestereich wrote in the definitive style of so many resisters. "It is very clear to me and the thousands who stand with me that this war is wrong - - and we will not return to our

\footnotetext{
${ }^{37}$ Marston interview, 13 Dec 1997.
} 
everyday lives until the war is over." ${ }^{\text {;8 }}$

Although they arrived at their date of resistance and their evaluation of the war with the same sense of clear-eyed moral righteousness, Hughes and Oestereich came from very different backgrounds. Oestereich. a seminarian at Andover-Newton Theological School, turned in his draft card at the Arlington Street Church on October 16. Soon after, his Cheyenne, Wyoming draft board. acting on the instructions of General Hershey, changed his classification from 4-D, the ministerial exemption, to 1-A. Like so many editorial writers did in the days after Hershey's memorandum to local boards, Oestereich questioned the legality of his reclassification. After consultation with Vern Countryman at Harvard Law School. Oestereich contacted the American Civil Liberties Union which. under the leadership of Melvin Wulf, jumped at the chance to challenge the reclassification in court. By the beginning of the new year, Oestereich brought suit against his local draft board in U.S. District Court in Denver. The Court dismissed the complaint and the Court of Appeals quickly affirmed the lower court's decision. In late February, as the date of his induction approached, Oestereich and Wulf waited to learn if the Supreme Court would hear the case. ${ }^{39}$

Dick Hughes. a teaching fellow in the Theater Department at Boston University, on the other hand, did not turn in his draft card. His local board in Pittsburgh,

${ }^{38}$ James Oestereich, interview with author, 20 Dec 1997; Richard Hughes, interview with author, 7 January 1998; "We Won't Go" leaflet, 26 Feb 1968, James Oestereich Papers (hereafter cited as JOP).

${ }^{39}$ Oestereich interview, 20 Dec 1997; Oestereich v. Selective Service System, 393 U.S. 233 (1968). 
Pennsylvania granted his request for conscientious objector status $(1-0)$ even though, as a former Catholic, he did not belong to any of the faiths traditionally recognized by the Selective Service for that deferment. In October 1967, however, Hughes apparently ran afoul of his local board when his new employer, the Theatre Company of Boston, applied for an occupational deferment for him. The board denied the request and kept his status as $1-0$, but then sent his file to the Selective Service state headquarters for "review and advice" for reasons that remain unclear. The state headquarters immediately recommended a challenge to Hughes's conscientious objector status, and without notifying him in advance. his local board reclassified him to $1-A$ at their next meeting (December 18, 1967). Even under General Hershey's new guidelines for handling draft resisters. Hughes had done nothing to compromise his draft status - no turned-in draft card, no draft board sit-ins, no polemical letters to his local board. Hughes could only guess that they objected to his attempt for an occupational deferment with a theater company. Meanwhile, throughout the fall, he became more and more "obsessed" with the war for, as he later remarked, "it was becoming a distraction from the acting world." He attended numerous teach-ins, got to know Howard Zinn well (in part because he dated Zinn's daughter, Myla, for a while), and read the $B U$ News, all of which influenced his thinking about the war and the draft. When the actor Peter Ustinov spoke at Boston University and took questions from the audience, Hughes asked him if he had, in the course of his career, ever jeopardized his work because he felt he had to take a stand over a certain issue; the crowd booed the question, but Ustinov quieted them with a thoughtful answer, saying that although he had never been faced with such a dilemma, he 
sympathized with American students who were. In the end, when the Pittsburgh draft board responded to Hughes's inquiry about his changed status with an induction notice, Hughes decided he would go and he would refuse. ${ }^{+0}$

On February 26, 1968, a throng of some 350 people picketed the Boston Army Base in support of Oestereich and Hughes. They had marched from the Boston Common through Downtown Crossing, then all the way down Summer Street to the Boston Army Base. The crowd included ministers and seminarians, all in clerical collars, from Andover-Newton; faculty and students from Boston University; and a large contingent from BDRG and the Resistance. Howard Zinn spoke to the crowd as did the two resisters. Jim Oestereich arrived not knowing how the day would end for him. He and his lawyer feared that if he refused induction it might jeopardize his court case, but accepting induction was not an alternative. In the days leading up to the induction, Melvin Wulf contacted Supreme Court justice Byron White and asked for the induction to be stayed until the Court decided if it would hear the case. On the morning of February 26, they had not heard. In spite of this confusion, Oestereich made a strong public statement to the crowd outside the base, one that conveyed the urgency and moral rigidity endemic to the movement:

I have come to the Boston Army Base this morning for one reason alone - to say NO to this government's policy in Viet Nam.

I have come to say that the securities of being a student, a minister, or a citizen in this land are worth nothing unless I can also affirm the duties and rights of moral and political protest when that country engages

${ }^{+0}$ Hughes interview, 7 Jan 1998; Copy of Richard Hughes's SSS File, Local Board 14, from Hughes FBI file, Richard Hughes Papers (hereafter cited as RHP); Richard Hughes, e-mail to author, 8 Jul 1998. 
in disastrous and illegal actions against an underdeveloped nation of the world community.

I can no longer study, teach, nor live in this society until we have brought enough pressure upon this government to force an end to this war and the initiation of a positive program for peace and equality in a world torn by our fatal misunderstandings and blind destructiveness.

I have renounced my ministerial immunity to stand with these men. like Richard Hughes, who have chosen to risk their lives and their futures in the most concrete act remaining to us - the severing of our relationship with an illegal system in pursuit of an unjust war. ${ }^{41}$

Once inside, the pair of resisters followed instructions while doing their irreverent best to disrupt the proceedings enough to attract the attention of the other inductees. When base officials administered an intelligence test to the men, Oestereich raised his hand and said, "Uh. listen, I'm looking at this test, sir, but I don't see any questions about the legality of the Viemam war. Shouldn't that be on here if that's where we're going?" Nonplused draftees looked at him as though he had lost his mind. Similarly, Dick Hughes elicited bewildered expressions as he filled out one of the numerous forms provided. and asked: "If you're refusing induction, do you have to fill out question number...?"42

Not long after Oestereich entered the base, the base commander, Lt. Col. Risden pulled him aside to tell him that word had just arrived from the Supreme Court that his induction had been stayed. Oestereich, prepared for this eventuality, produced a statement for Risden to sign. The statement prepared by his lawyer as a means of protecting him from any miscommunication or foul play, asserted that Oestereich had

${ }^{41}$ Oestereich interview, 20 Dec 1997; Hughes interview, 7 Jan 1998; Oestereich statement, 26 Feb 1968, JOP.

${ }^{42}$ Oestereich interview, 20 Dec 1997; Hughes interview, 7 Jan 1998. 
appeared as ordered. that he had not interfered with the induction of other registrants and that Risden was now ordering Oestereich to leave the premises because of the injunction staying the order of induction. The demonstrators outside cheered when Oestereich emerged with the news. They then marched back into downtown where they picketed the federal courthouse in Post Office Square briefly before breaking up. ${ }^{\text {t3 }}$

Inside, Dick Hughes went through the rest of the Army's procedures and then refused induction. He stood with about 40 other men in the room in which all inductees took the oath of service. An officer told them that the oath was binding and irrevocable. When he called each man's name. each stepped forward in symbolic acceptance of the oath. They left Hughes until the end and when they called his name, he stepped backward. They called his name again. and again he refused. A soldier then took him out of line and explained that if he did not step forward he would be committing a crime. When Hughes again refused to comply. base officials asked him to write and sign a statement indicating that he had intentionally refused induction. Thanks to the FBI and the Freedom of Information Act. the statement that Hughes wrote has been preserved. On a blank piece of paper. Hughes began with a quote that he had memorized from the London newspaper, The Sun, regarding the recent American destruction of the South Vietnamese village, Ben Tre: "What meaning is left in language when the Americans claim to save a town by destroying it? [After the assault on Ben Tre, Air Force Major Chester Brown of Erie, Pennsylvania explained to the Associated Press that "it became

${ }^{43}$ Oestereich interview, 20 Dec 1997; Copy of statement prepared for base personnel, 26 Feb 1968, JOP; "200 Peace Pickets Protest 2 Inductions," Boston Globe (Evening edition), 26 Febr 1968, p. 4. 
necessary to destroy the town in order to save it," noting that he thought it "a pity about the thousands of civilians who were killed and left homeless.] Can President Johnson and Ho Chi Minh reach the stature to understand that any military gains will count for nothing in the face of horrors like Ben Tre, a town devastated by fighting? If not, history in the end will record of them that they made a desert and called it peace." Hughes then wrote, extemporaneously, a statement that equaled the force of Oestereich's moming speech:

I deeply believe this war is wrong. I deeply believe the present draft law is wrong. After what I consider to be sincere and painful selfexamination. I see no other choice.

I cannot, regretfully, reconcile this war and the draft law to my deepest desires: freedom to choose, human survival, and service to principle. I have searched for other alternatives. I have found none. There are none.

Thus it seems evident to me that all of us, as a nation, must face the inevitable question. 'throughout history, and perhaps even now, have not the greatest crimes against humanity happened through silence?'

I, Richard Hughes, on this day 26 Feb 1968 refuse induction into the Armed Forces of the United States. The above statement speaks for my motivations.

[signed]

Richard Michael Hughes.

When he finished, a base official escorted him to the door and allowed him to leave. The demonstrators were long gone (he had been inside almost all day). and the grey clouds overhead produced a light rain. Hughes later described it as "a very sad moment in a way." He walked down a rainy, empty street with only the tall street lights for companions. By the time a $B U$ News reporter caught up with him later that night, however, Hughes had gained some perspective. He recognized the individual nature of resistance now. "It's important to realize that decisions like this [resistance] are 
tremendously personal," he told the reporter. "But you just have to know that the sin is not the choice, but in not choosing."

Dick Hughes soon carried his draft resistance over into what Howard Zinn later called one of the "most imaginative" expressions of protest made by an antiwar activist in America. Rather than wait for the imminent indictment and prosecution for violation of Selective Service laws, Hughes picked up and left the country. But he did not go to Canada, as more than 30,000 American draft evaders did; nor did he go to Mexico or Sweden, nations to which another 2,000 Americans fled. No. He did what probably no other resister did: he went to South Vietnam. In March, having secured a visa from the South Vietnamese embassy in Washington (based on reporter credentials provided by the $B U$ News), Hughes wrote a letter to the FBI and left it on his desk in his apartment. He told them that he could be reached in Saigon, care of the Joint United States Public Affairs Office (JUSPAO). He packed two sets of clothes, and with a couple of friends drove someone's car across the country for pay. Hughes stopped in Pittsburgh to see his family, but did not tell them where he planned to go. He sent them a post card from Con Thien. Not long after his parents received the post card, the FBI visited his father, then director of Lands and Buildings in the Mayor's cabinet in Pittsburgh, at his office. When the FBI agents asked about his son's whereabouts (they apparently never entered Hughes's Boston apartment), Hughes's father gave them the post card. The agents left

t4 Hughes interview, 7 Jan 1998; "Teaching Fellow Refuses Induction," BU News, $28 \mathrm{Feb} 1968$, p. 1; Statement written at request of Army personnel at Boston Army Base, 26 Feb 1968, FBI file, RHP. Note: for more on the destruction of Ben Tre, see: "The Slaughter Goes On," New Republic, 24 Feb 1968, p. 13. 
without asking further questions. ${ }^{\text {t5 }}$

Although Hughes went to Vietnam as a reporter, he intended from the start to do some kind of social work. At first, he did do some reporting and helped establish Dispatch News, the agency that later aided Seymour Hersh in breaking the story of the My Lai massacre. But ultimately he settled into social work, starting a home for orphaned boys in Saigon that eventually grew into the Shoeshine Boys Foundation, a network of houses set up in Saigon and Danang to house the boys and teach them the trade of shining shoes. The operation continued to grow every year. When Dick Hughes finally left Vietnam in August 1976, the last American to leave, his operation had grown to six homes in Saigon and two in Danang, housing a total of 300 kids. Over 1,500 boys passed through his centers in those eight years. In addition, they owned two farms on which some of the boys worked and developed an extensive program aimed at reuniting children with their parents after the war ended. By the time the foundation disbanded, scores of boys had been reunited with their families. ${ }^{16}$

According to FBI records, in November 1968, John Wall of the Boston U.S. Attorney's office informed Selective Service and the FBI that he would not prosecute Hughes. He believed Hughes to be "sincere in his beliefs" and that he had been reclassified, probably unfairly, the year before. It did not matter, because Hughes stayed

${ }^{45}$ Howard Zinn, interview with author, 6 Jul 1998; Hughes interview, 7 Jan 1998.

${ }^{46}$ Hughes interview, 6 Jul 1998; "Vietnam Street Children Getting Better Care, American Says," New York Times, 9 Aug 1976, p. 2. 
in Saigon for another eight years. ${ }^{47}$

Jim Oestereich`s story did not unfold quite as dramatically as Dick Hughes's, but followed its own twists and turns. As a seminarian preparing for a ministerial career. Oestereich's decision affected his fellow seminarians as well as members of the United Parish in Lunenburg. where he served as vouth minister. Although Oestereich received mixed reactions from fellow students at Andover-Newton, the faculty there supported him without equivocation. At a chapel forum on the issues raised by Oestereich's upcoming induction refusal, Dean George W. Peck announced that the faculty had voted unanimously to "express its faith in Mr. Oestereich"s integrity," and defended his right to object to the war and the draft in this way. In particular, the faculty and Dean Peck found Oestereich's reclassification to be most offensive, "utterly contradictory of what is finest in the American tradition." He urged even those who did not "take an unequivocal stand against the war" to speak out against this kind of "mindless repression." "We are dangerously close to a course of action with regard to men like Mr. Oestereich which is more in keeping with the Nazism we condemned at Nuremberg than with the liberty and respect for conscience of which this nation boasts," he said. "No war, however just, is worth that. ${ }^{-48}$

Outside the city, at his suburban church in Lunenburg, however, Oestereich faced a situation not unlike that which confronted Michael Jupin in Winchester. Though the RHP.

${ }^{47}$ Hughes interview, 6 Jul 1998: FBI memo on Hughes induction refusal, FBI file, ${ }^{48}$ Oestereich interview, 20 Dec 1997; Statement by Dean George W. Peck, 23 Feb 1968, JOP. 
United Parish did not erupt when Oestereich turned in his draft card. it came apart at the seams when he went to refuse induction. Three days after Oestereich had been sent home by the Army. the church held a meeting to which more than 100 people came. According to newspaper reports, most in the crowd were outraged by Oestereich's stand. Active duty military men, members of veterans groups, parents of servicemen, and many others spoke. Oestereich claims that some of the people there were members of the John Birch Society and that more than one had pistols tucked in their trousers. When one man made an analogy between the American Revolution and the Vietnam War. Oestereich told him that the analogy did not fit. unless they likened American involvement in Vietnam to the British role in the Revolution. The whole crowd, or so it seemed, groaned in response. As in Winchester, many of Oestereich's critics feared his influence on the young people and wanted him removed immediately. The minority of those who spoke in Oestereich's defense, however, were members of the youth groups; they told the others that the seminarian had never tried to impose his views on them and that they rather admired the stand he took on the war. Eventually, however, Oestereich realized he had to resign. The issue so polarized the parish that he feared his draft resistance might lead to the removal of the two ministers. Ultimately, though, his resignation did not save the church. It remained split until one minister took those who supported Oestereich's position and started a "people's ministry" in nearby Fitchburg. Oestereich, meanwhile, waited for the Supreme Court to hear his case. ${ }^{49}$

49 "Youth Leader Defends Position on Refusal to Enter Armed Forces," Fitchburg Sentinel, 1 Mar 1968, p. 16; Oestereich interview, 20 Dec 1997. 
Ray Munge

On March 6, 1968 Ray Mungo refused to be inducted into the service in a manner that stood in stark contrast to his predecessors. While the Resistance movement (and his father) essentially took over Chick Marston's induction refusal and used if for their own purposes, and later worked in concert with Jim Oestereich, Dick Hughes and other resisters in planning their refusals, the two draft resistance organizations basically grabbed onto Mungo's coattails and went along for the wild ride he orchestrated on his own. Mungo's notoriety as former editor of the BU News made him unique among resisters. He could easily mobilize large numbers of activists and attract the attention of the media in ways that no other resister could. Chick Marston's induction refusal made the front page of Boston newspapers, but subsequent refusals, like the Oestereich/Hughes one, turned up deeper and deeper in each paper; Ray Mungo's induction refusal put draft resistance back on the front page.

Outrageous leaflets announced Mungo's act of noncompliance well in advance. They announced that Mungo would refuse induction into "Lyndon Johnson's Army" while simultaneously accepting induction into "Sergeant Pepper's Brigade." Mungo promised a rock band, parade, and speech from Howard Zinn, followed by blueberry pancakes after the demonstration. Then, in an uncharacteristic (for the Resistance) paragraph, the leaflet predicted that "lots of pretty girls will publically say yes to guys who say no." that "young girls will be violated!," and that "resisters and inductees alike will goose the sergeants!" Moreover, it said, "Josef Mlot-Mroz's BOMB PEKNG sign will flip over and say LBJ SUCKS just as the cameras zoom in" and pledged that they 
would plant 8,000 marijuana seeds on the grass surrounding the base, while noting that one resister threatened to “dump two buckets of his own shit (he's been saving it for weeks!) in the path leading to the base." It concluded as irreverently as it began with two cryptic slogans: "Fuck the Apocalypse!" and "Rise up and abandon the creeping meatball!" This kind of mixing of protest with countercultural impiety, though it anticipated one direction in which the Resistance would go later in the year, did not represent current movement dynamics. But it sure caught people's attention. ${ }^{50}$

Shocking or not, the advance publicity resulted in more than 600 demonstrators gathered outside the Boston Army Base to see Ray Mungo say no to his country. Mungo, wearing a marching band jacket not unlike those worn by John, Paul, George, and Ringo on the Sgt. Pepper's album cover, appeared at his Lawrence draft board and took the train with 12 other inductees to Boston. Before the bus carrying the men from the train station could enter the base. however. Mungo got off and, to the cheers of his huge audience. climbed on top of the hood of a car. Instead of entering the base and going through the motions like Oestereich and Hughes, Mungo tore up his induction notice and flung the pieces into the air. "I have nothing to say to the U.S. Army," he said. "I have nothing to say to the U.S. government. I have no intention of playing their games. But, oh baby, is this ever a refusa!!" Although the rock band did not materialize (too expensive), and passing truckers leaned on their horns as Mungo spoke, the event took on a carnival atmosphere. In the midst of Mungo's hippie-goofing, he attempted to interject his analysis of the war and resistance to it:

\footnotetext{
50 “Spock's Flocks Rock!” leaflet on Mungo induction refusal, CFP.
} 
People around the world are saying tonight, Thank God there are some Americans left who are men and women, and not robots and murderers...

It is no longer necessary to say the war is wrong, brutal, economically inspired. imperialistic. etc. Everybody who knows the war knows these things. It is important to point out that Johnson. Rusk. McNamara know these things too. It is even more important to realize that Johnson continues this war because his value system sees money and power and land and self-aggrandizement as naturally good and desirable things. He has thus forfeited his humanity, and we should be prepared to regard him at all times as a beast. The war itself is the greatest and most powerful statement against war.

When he finished, the crowd marched from the base up Summer and Winter Streets, to Tremont and Boylston, to the Arlington Street Church, where the blueberry pancakes, like the band, did not appear. Marchers settled for doughnuts and coffee as they listened to Howard Zinn talk about the war. Following the huge turn-out and genuinely raucous confrontation at the Army base, Zinn told the demonstrators that the Resistance would continue to grow and that they would be successful in ending the war. "I am confident that very soon we are going to bring this war to a screaming halt." he said. ${ }^{5 !}$

In the late winter of 1968 , with induction refusals - bolstered by a solid group of supporters, taking place on an almost weekly basis - Zinn's prediction seemed reasonable to many within the draft resistance movement. For one, the earlier uncertainty of the Boston draft resistance movement gave way to a more intense, hothouse atmosphere in which the actions of the New England Resistance and Boston Draft Resistance Group

SI "600 Back Draft Resister Here." Boston Globe (Evening Edition), 6 Mar 1968, p.1; "600 March as Ex-BU Editor Refuses Draft," Boston Globe, 7 Mar 1968, p. 2; Avatar\#21, 15 Mar-28 Mar 1968, p. 1; "BU Draftee Rips Up Induction Papers," Boston Record American, 7 Mar 1968, p. 2; "The American Ethic Must Fail," BU News, 13 Mar 1968, p. 10. 
clearly dictated the direction of the city's larger antiwar movement and which continued to attract considerable publicity. In early February, the New England Resistance, buoyed by the indictments and recent successes, finally moved into its own office on Stanhope Street in Boston, right behind Boston City Police Headquarters. Meanwhile, the BDRG saw the numbers of men seeking counseling reach new highs while their counselor training courses continued to attract more than they could handle. This climate of activism also proved fertile for the birth of new organizations related to draft resistance. John Phillips, not long out of prison, formed the Prisoner's Information and Support Service (PISS), an organization of ex-convicts (sent to prison for draft resistance) aimed at demystifying prison experience for resisters. As more and more men were reclassified and called for induction, such support became more necessary. March also saw the founding of the Committee for Legal Research on the Draft (CLRD) a new agency established by law students and lawyers to provide attorneys handling draft cases with all of the technical information on the draft and military law they might need. Meanwhile, donations poured into Resist and thousands continued to sign the Call to Resist $(15,000$ by the end of March) and complicity statements admitting to "crimes" equal to those of the Boston Five $\left(28,000\right.$ by the start of the trial). ${ }^{52}$

No doubt some of the movement's intensification derived from a sense among many that they could be facing prison time. Many felt, like Marc Raskin, that the Spock

52 NER Newsletter, 8 Feb 1968, MKFP; BDRG Newsletter, Mar 1968, BTP; "ExCons Talk!," Avatar \#20, 1 Mar - 13 Mar 1968, p. 7; “Ex-Cons Talk!," Avatar \#21, 15 Mar - 28 Mar 1968, p. 7; "An Interview with Louis Kampf," Avatar \#22, 29 Mar - 11 Apr 1968; Ferber \& Lynd, The Resistance, 124. 
indictments portended greater repression and that could mean jail not only for resisters but for those who backed them. As Harvard philosopher Hilary Putnam later remarked, since no one knew who would be prosecuted next. "there was a great hurry to get something accomplished" on all fronts. Many of these organizations and efforts, therefore, became the foci of activists" lives. Even social time usually occurred in the offices of these organizations or in coffee shops in which conversation never drifted far from political concerns and the war. Those in the Resistance movement sensed their strength as the spring approached and felt a simultaneous urgency to use it to their advantage and, they hoped, bring the draft and the war to an end. ${ }^{53}$

\section{Worries in Washington}

Draft resisters and their supporters might not have felt so rushed to press their confrontations with the government if they had known how much they had already affected Vietnam policy making. They could not know that as their movement gained momentum in the late winter of 1968 . the Johnson administration was reconsidering its strategy in Vietnam, in part because it feared greater noncompliance with the draft.

In fact, many factors contributed to the reevaluation of policy in Vietnam. First, and most important, the Ter Offensive launched by the North Vietnamese on January 30 (the day after the Boston Five arraignment) stunned the administration and the nation. Military and administration claims that victory lay just around the corner were dashed by a well-orchestrated offensive that hit 36 of 44 provincial capitals and 64 of 242 district towns, as well as 5 of South Vietnam's 6 autonomous cities. In Saigon, one of those

\footnotetext{
${ }^{53}$ Putnam interview, 18 Dec 1997.
} 
autonomous cities, the enemy even penetrated the walls of the American embassy compound. As more and more Americans began to wonder about the efficacy of a continued American presence in Vietnam, the president sent the chairman of the Joint Chiefs of Staff, General Earl Wheeler, to South Vietnam to assess the situation. Wheeler. like General William Westmoreland, commander of American forces in Vietnam, argued that the American and South Vietnamese had routed North Vietnamese and Viet Cong forces in the wake of their initial assaults, though fighting continued. Indeed, the enemy continued to display remarkable tenacity, particularly in urban areas. American and South Vietnamese forces were spread thin as they attempted to contain the fighting. As a result, on February 26 (the same day Dick Hughes and Jim Oestereich refused induction), Wheeler cabled Secretary of Defense McNamara with General Wesmoreland's additional troop requests. which amounted to another 206,000 men by the end of the calendar year. The next day, presidential aide Harry McPherson wrote "We are at a point of crisis." 54

That troop request initiated reassessments by numerous former supporters of American policy in Vietnam, especially at the Pentagon. It happened that Westmoreland's request came during a changing of the guard in the Department of Defense. Robert McNamara, no longer the staunch defender of the war that he had been on top of that car in Harvard Yard only a year before, resigned in the fall of 1967 and stepped down officially on February 28,1968 . The troop request issue then fell into the

${ }^{54}$ Dallek, Flawed Giant, pp. 506-513; Walter Isaacson and Evan Thomas, The Wise Men, (New York: Knopf, date) pp. 700-703; Townsend Hoopes, The Limits of Intervention. (New York: McKay, 1969), pp. 159-161; Harry McPherson Notes, Meeting of Advisors on Vietnam, 27 Feb 1968, Meeting Notes File, Box 2, LBJL. 
lap of the new secretary of defense, Clark Clifford. When Clifford took office, President Johnson named an Ad Hoc Task Force on Vietnam to review the Westmoreland request and examine the potential ramifications at home. The president made Clifford chairman of the committee. Although considerable debate ensued, most on the committee began questioning for the first time American ability to win the war - even with the additional 206,000 troops. $^{55}$

One theme that consistently rose to the top emphasized declining public support for the war. Phil Goulding, undersecretary of defense for public affairs, warned of increased draft resistance if the additional troops were approved in two separate memos (March 2 and March 4). "Until a few weeks ago, the people were being told that we were moving toward victory." Goulding wrote. "No one was suggesting extra troops, hardships, more spending, Reserve call-ups, high draft calls and increased casualties. Now, suddenly, the picture has changed and all of these emergency, hardship measures are required." Under the category, "Problems We Can Anticipate in U.S. Public Opinion," Goulding dedicated one sub-section to draft resistance. "Increased draft calls will accentuate demonstrations, on and off campuses," he wrote. Noting that the Selective Service laws had just been changed making graduate students eligible for the draft, Goulding said, "now it gets worse. Again, it [the additional troops request] was not anticipated. Letters to Congress will pour in." This memo eventually made it to the

${ }^{\text {ss }}$ Hoopes, The Limits of Intervention, pp. 171-181. 
president's desk as part of a package assembled by Clifford. ${ }^{56}$

Clark Clifford received similar warnings from other quarters. Undersecretary of the Air Force Townsend Hoopes wrote a lengthy memo to the new defense secretary on March 14. "At the present level the war is eroding the moral fibre of the nation, demoralizing its politics, and paralyzing its foreign policy," he argued. "A further manpower commitment to SVN would intensify the domestic disaffection, which would be reflected in increased defiance of the draft and widespread unrest in the cities." Hoopes had turned completely against continued escalation of the war. He strongly urged Clifford to consider a negotiated settlement. He concluded: "Anything resembling a clear-cut military victory in Vietnam appears possible only at the price of literally destroying SVN, tearing apart the social and political fabric of our own country, alienating our European friends, and gravely weakening the whole free world structure of relations and alliances..." In addition, another aide wrote to Clifford that "it will be difficult to convince critics that we are not simply destroying South Vietnam in order to 'save' it, or that we genuinely want peace talks" if the president were to grant Westmoreland's request. "This growing disaffection accompanied, as it certainly will be, by increased defiance of the draft and growing unrest in the cities because of the belief that we are neglecting domestic problems runs great risks of provoking a domestic crisis of unprecedented proportions." These concerns over public opinion, coupled with

${ }^{56}$ Phil G. Goulding memo to Clark Clifford, "Possible Public Reaction to Various Alternatives," part of package: "Alternative Vietnam Strategies Back-Up Material," c. 2 Mar 1968, Clark Clifford Papers, Box 2, LBJL; Phil G. Goulding memoranda to Clark Clifford, "Problems We Can Anticipate in U.S. Public Opinion," 4 Mar 1968, Clifford Papers, Box 1, LBJL. 
unsatisfactory answers from military leaders regarding a timetable for victory, quickly turned Clifford from hawk to dove. Clifford soon agreed that the troop request should be denied and that the first steps toward a negotiated peace be taken, but he needed a little more help before he could take his case to the president. 57

That extra boost came from a group of advisers whose opinions Johnson had sought and valued time and again. The Wise Men, as they were known, were generally older, elder statesmen all of whom had served their country faithfully in earlier administrations. They included Dean Acheson, secretary of state under President Truman; Averell Harriman, former ambassador to the Soviet Unions; General Maxwell Taylor, chairman of the Joint Chiefs under President Kennedy: Supreme Court justice Abe Fortas; McGeorge Bundy. former national security advisor: George Ball, former undersecretary of state who had lobbied Johnson to end the war before resigning the previous year; Henry Cabot Lodge. ambassador to South Vietnam under President Kennedy; Douglas Dillon. former Treasury secretary; United Nations Ambassador and former Supreme Court justice, Arthur Goldberg; Omar Bradley, World War II Commander and chairman of the Joint Chiefs during the Korean War; Arthur Dean, chief Korean War negotiator; John McCloy, Assistant Secretary of War during World War II; Cyrus Vance, formed Deputy Secretary of Defense; and General Matthew Ridgeway, the venerated Korean War leader. When Johnson had convened the Wise Men in November

57 Townsend Hoopes memo to Clark Clifford, 14 Mar 1968, pp. 8, 12, Clifford Papers, Box 1, LBJL; "The Case Against Further Significant Increases in U.S. Forces in Vietnam," memo, undated, Clifford Papers, Box 1, LBJL. Note: the 14 Mar Hoopes Memo is heavily excerpted in Hoopes, The Limits of Intervention, pp. 187-196. 
1967, they assured the president that his present policies in Vietnam were sound. But at their next meeting - one recommended by Clifford in large part because he knew that several were changing their minds about Viemam just as he had - on March 25 and 26. 1968, the Wise Men offered new advice. Confronted for the first time with sobering data from the field and reports of potential domestic unrest, many of the Wise Men reconsidered their support of the war. Senator Mike Mansfield and Assistant Secretary of Defense Paul Warnke, in particular, raised concerns about an increase in draft resistance to the group. Acheson, whose voice carried the most weight with the president, argued forcefully against the additional troops and urged that withdrawal begin by summer's end. $^{58}$

Of course, the president's advisers did not argue against Westmoreland's troop request solely because they feared more draft resistance. Many other factors were considered. The importance of the Tet Offensive, especially, in these reconsiderations cannot be overstated; without Tet, public opinion would not have concerned policy makers in the way it did. The prospect of imminent victory disappeared and the growing criticism at home limited the administration's options. As Acheson put it, "We can no longer do the job we set out to do in the time we have left [before the public's patience is exhausted], and we must take steps to disengage." The declining credibility of policy makers who had for too long presented optimistic projections to the nation hurt the

${ }^{58}$ Hoopes, The Limits of Intervention, pp. 214-218; Isaacson and Thomas, The Wise Men, pp. 700-703; Memo from Mike Mansfield, re: "Reports of requests for an additional 200,000 men in Viet Nam," included in Meeting with Special Advisory Group, Cabinet Room, 26 Mar 1968, Meeting Notes File, Box 2, LBJL; Small, Johnson, Nixon, and the Doves, pp. 147, 270n. 
hawks' case the most. Still, the commitment shown by draft resisters in the fall, and their increased defiance following the Spock indictments unquestionably resonated with those administration officials who pointed to a potential increase in noncompliance as a risk of continued escalation. In the end, it all added up to deescalation, though Johnson biographer Robert Dallek argues that the president's shift to a slow withdrawal strategy "came not from what his briefers said...or what some of the Wise Men counseled." Instead, Dallek says. Johnson realized on his own that the war had stalemated and that it could not be won without "an escalation that would risk a domestic and international crisis unwarranted by the country's national security." Draft resistance would have been at the heart of that domestic crisis. ${ }^{59}$

\section{Sensing Their Strength}

Resisters and draft resistance activists remained unaware of the impact they had in Washington. As far as they were concerned, the war continued unabated and resistance and confrontation continued to be the only reasonable response. In March, however. following Ray Mungo's raucous demonstration at the army base, momentum began to sputter. Just as draft resistance saw six to eight intense weeks in the fall followed by a near month-long lull in December, the renewed Resistance of January and February slowed to catch its breath for a few weeks in March. Organizers found that maintaining that kind of energy could be very difficult to do for long periods of time and that a certain boom-bust cycle seemed to occur organically.

\section{2.}

${ }^{59}$ Isaacson and Thomas, The Wise Men, pp. 700-703; Dallek, Flawed Giant, p. 
In March, though, other variables contributed to the break in the action following Mungo's induction refusal. Most of all, the candidacies of Eugene McCarthy, who nearly beat the president in the New Hampshire primary on March 12, and Robert Kennedy who joined the race several days later, attracted the attention of antiwar activists everywhere and, for the time being, took the spotlight off of draft resistance. This concerned some in the movement, but they hoped that the huge draft card turn-in and rally scheduled for April 3 would "restore the balance, and give some needed impetus toward continuing activity in the summer." Despite their recent successes in garnering publicity for the movement, the trademark impatience of draft resistance activists led them to constantly question their methods and effectiveness. As Martin "Shag" Graetz, the editor of the BDRG newsletter, noted, "a strong feeling of 'What's Next?"” could be detected running through the movement at the time. As a result, BDRG and the Resistance planned a series of workshops at the Arlington Street Church for April 4, following the big demonstration and turn-in on the common on the $3^{\text {rd }}$. A "new" renewal appeared to be in order. $^{60}$

Then, on the night of March 31 , without warning, the news arrived that Lyndon Johnson would not run for another term as president. Johnson's speech stunned the nation. The American people heard their president put the war (and peace) ahead of politics. First, he announced a bombing halt that he wished might lead to negotiations with the North Vietnamese. "With our hopes and the world's hopes for peace in the balance every day," the president had said, "I do not believe that I should devote an hour

${ }^{60}$ Editorial, BDRG Newsletter, Apr 1968, p. 2, BTP. 
or a day of my time to any personal partisan causes or to any duties other than the awesome duties of this office." Johnson's approval ratings shot up dramatically in the wake of the speech as pundits, Democrat and Republican alike, applauded his selfless, patriotic act. ${ }^{61}$

Whatever the complicated motives for Johnson's withdrawal, antiwar and draft resistance activists saw it as a vindication of their protests against the war. They believed that their unrelenting challenges to the administration's war policies had created a climate of friction intolerable to most Americans. The president's speech had, after all. referred to "division in the American house tonight" and asked that the country guard against "divisiveness and all its ugly consequences." While many of their fellow countrymen - like Johnson himself - no doubt continued to fault the resisters and activists for this tension, more and more began to blame the president and the war for the disruption in American life. A Gallup Poll from mid-March showed that Johnson's approval rating for his handling of the war had fallen to just $26 \%$ of the public; $63 \%$ disapproved. "-Lyndon Johnson's refusal to run for a second term." a New England Resistance statement said, "is a clear admission that the policy in Vietnam, already responsible for 20,000 dead American soldiers and countless Vietnamese, is indefensible." At last, it seemed to those in the movement, they were making progress. Therefore, when Johnson withdrew, the antiwar and draft resistance community in cities

${ }^{61}$ Dallek, Flawed Giant, pp. 529-530. 
like Boston rejoiced. ${ }^{62}$

On the night that the president announced his withdrawal from the presidential race, a spontaneous celebration erupted in Boston. About 700 students poured out of dormitories and apartments at Harvard University and began an impromptu parade across the river to Boston University. They crossed the Harvard Bridge, turned down Commonwealth Avenue and began calling for BU students to join them. Another 400 people joined the march by the time it spilled into Kenmore Square. In a scene more reminiscent of a New Orleans street party, the crowd (some of whom were in their pajamas) sang "Ding, Dong, the Wicked Witch is Dead" and other songs to the accompaniment of trumpets, drums, cymbals, and the honking horns of cars. As the march grew to more than 2.000 people, they chanted "Hey. Hey. what do you say? LBJ dropped out today!" They marched down the tree-lined mall of Boston's most picturesque avenue to the Public Gardens and the Common. Boston police aided in stopping traffic at the cross streets along the way, but became anxious when the crowd arrived at the State House. Michael Ferber, Bill Hunt, and Neil Robertson of the Resistance heard one police officer calling for dogs on the radio. It was 2:30 in the morning, the march did not have a permit, and some of the police looked tense. As the three Resistance leaders arrived at the head of the crowd on the steps of the State House. one police captain, recognizing them from earlier demonstrations, turned on his radio and said, "Ah, thank God the anarchists are here! Now everything is under control." When

${ }^{62}$ Wells, The War Within, p. 253; George Gallup, The Gallup Poll, Vol. III, p. 2114; "Johnson's Speech Fails to Divert Resistance Rallies," BU News, 3 Apr 1968, p. 11. 
someone handed Ferber a bullhorn, he said, "This is not a time for political speeches.

This is a time for celebration. ${ }^{\text {i }}$ 3

Although the party at the State House ended abruptly when the skies opened and literally rained on their parade, the movement's enthusiasm carried over to the April $3^{\text {rd }}$ rally and draft card turn-in on the Common. As one reporter described it, the uncharacteristically mild, sunny weather, and the afterglow of Johnson's withdrawal "gave a carnival air to the rally" of over 5.000 people (the New England Resistance estimated the crowd at 12,000 ) gathered on Flagstaff Hill. Many carried single flowers, jonquils or roses, to symbolize their desire for peace. Over the course of the two hour rally, they listened to speakers describe Johnson's "abdication" as a partial victory and criticize the McCarthy and Kennedy campaigns for failing to ask if America had any right to be in Vietnam at all. Out of the usual speakers (Howard Zinn, Noam Chomsky, Staughton Lynd, etc.), only Michael Ferber's remarks survive thanks to FBI agents who recorded it for use in his upcoming trial. The challenges that Ferber made to the "men waging the war" demonstrate just how confident and emboldened the events of the previous three months had made the Resistance:

Let them face that either the war stops and the draft stops, or they will find that this country can no longer be governed. Let them face the prospects of thousands and thousands of men refusing induction this spring and summer. Let them face riots on American Army bases, desertions in Europe, and mutinies in Vietnam. Let them face the exodus of hundreds every week to Canada and let them face, what is worst for them - the

${ }^{63}$ Ferber and Lynd, The Resistance, p. 155; "Students Celebrate LBJ Move With Harvard Square Parade," Boston Globe, 1 Apr 1968, p. 11; "Johnson Quits; Thousands Cheer," BU News, 3 Apr 1968, p. 1; Michael Ferber, remarks at $30^{\text {th }}$ anniversary reunion of Boston draft resistance. Arlington Street Church, 16 Oct 1997. 
return of men by the hundreds from Canada to join the Resistance. If that is what they want to face, then we are ready, stronger today than ever to give it to them.

When he finished, new draft resisters came forward to turn in their cards. At over 60 similar rallies across the country, more than 1,000 men gave up their draft cards; 235 of them came from Boston. ${ }^{64}$

If state or federal regulations required the Resistance to file quarterly performance reports like other organizations and businesses, draft resistance activists could rightfully have claimed that the first quarter of 1968 and the first few days of the second quarter were their best yet. The indictments of Spock. Coffin, Goodman, Raskin, and Ferber galvanized the movement to greater confrontation and engendered greater solidarity in January; induction refusals from January through March sustained the momentum creared by that solidarity; and the president's decision to drop out of the presidential race seemed to validate their critique of the war while providing a glimmer of hope that peace could be achieved. By every standard. the Resistance thrived as it never had coming into April. The movement continued to attract regular press attention, increasing numbers of men were turning in their draft cards and committing themselves to noncompliance, huge numbers of people came out to demonstrations to support those men, and public opinion

64 "Foes Hold Anti-Viet Protest on Common," Boston Globe (Evening edition), 3 Apr 1968, p. 6; "Common Mobbed; 235 Turn in Draft Cards," Boston Globe, 4 Apr 1968, p. 2; Ferber and Lynd, The Resistance, p. 222 (Note: Ferber and Lynd contend that more than 500 cards were turned in; I have not been able to corroborate that figure. Contemporaneous Resistance statistics put the number at "more than 200."); Ferber speech on Common, FBI Memo, 25 Apr 1968, File Boston 25-25171, Exhibit, U.S. v. Coffin, et al, CR-68-1, National Archives, Waltham, MA; Thorne, "Resisting the Draft," pp. 149-150. 
was souring on the war. The antiwar movement seemed to be making headway, and draft resistance led the charge. Louis Kampf. professor of American Studies at MIT and a leader of Resist, gave all the credit for Johnson's decision and for the shifts in public opinion to the Resistance. "These young men were the vanguards of the peace movement." he told the $B U$ News. "They got people like me involved. They galvanized the peace movement. They made this country an intolerable place. ${ }^{\text {nts }}$

What he did not know at the time, and what no one in the movement could know, was that the draft resistance movement peaked on April 3rd. For on the very next day, the sunny, exuberant, self-assurance that resisters and their supporters had cultivated over the previous months began to unravel as events beyond their control pushed and pulled the movement in new directions.

65 “Johnson's Speech Fails to Divert Resistance Rallies," BU News, 3 Apr 1968, p. 11. 


\section{CHAPTER VIII}

\section{SPRING 1968: A "HOTHOUSE ATMOSPHERE"}

Without civil morality communities perish; without personal morality their survival has no value.

\section{Bertrand Russell, "Individual and Social Ethics" Authority and the Individual, 1949}

New England Resistance activists learned from previous experience that new resisters usually yearned for direction - and an ongoing sense of solidarity - in the aftermath of their first act of resistance. Consequently, on April 4, 1968, the day after their biggest draft card turn-in, Resistance leaders, as promised, held a series of workshops and teach-ins at the Arlington Street Church. After a full day of sessions, one last panel convened on the stage in the basement of the church to discuss strategy and ways of sustaining the strength of the movement. Based on the events of the last several days and especially the previous 36 hours. the panelists and the more than 50 men and women in the audience were upbeat. Much work remained to be done, they knew, but momentum now appeared to be on their side. Lyndon Johnson's decision not to run for reelection and the growing numbers of people turning out for Resistance rallies gave them reason to be optimistic. The mood would not last.

That same night in Memphis, Tennessee, Martin Luther King, Jr. stepped out on to the second floor balcony of the Lorraine Motel where an assassin's bullet cut him down. Soon after, the technician in charge of recording the Arlington Street Church panel's discussion for WBUR (the Boston University radio station) leaned out of his 
makeshift booth to the right of the stage and informed the crowd that King had just been shot. The audience and panelists gasped as one, as though someone punched each of them in the stomach simultaneously. It hurt. Silence followed, then scattered weeping and prayer. And when the WBUR man emerged a few minutes later with the news that King was dead, the shock turned to outrage. The New England Resistance and the entire draft resistance movement in Boston would never be the same. Almost immediately after receiving word of King's death, the Resistance began to fragment.'

No social movement takes place in a vacuum; it constantly seeks to engage the broader society of which it is a part and likewise must react to other significant developments in it. Over the next ten to twelve weeks, through April, May, and June, an almost constant string of dramatic external events - local, national, and international followed King's assassination. The cumulative effect of these developments created a powerful centrifugal force that started to pull the draft resistance movement in several new directions, away from its original mission and identity. Resistance activists continued to target the war in Vietnam, but in what seemed an increasingly apocalyptic climate, they started to expand their critique of the war to encompass a much broader indictment of American society.

The impatience and urgency that characterized the movement from its inception now served as fuel for its fragmentation. In the weeks following Johnson's "abdication," it became clear that the war and the draft would go on. Casualties mounted along with draft calls. Frustrated with the apparent failure to achieve their goals of an end to the war

' Nan Stone, interview with author, 28 Mar 1997. 
and the draft. Resistance activists began to think that the evils of both were rooted in more systemic problems. King's murder and other events seemed to confirm this. Their "analysis" grew more complicated if not more sophisticated. American society as a whole, not just the Johnson administration or the "war machine," was responsible for injustices and inequities at home and abroad. Resistance rhetoric, therefore, changed markedly from a critique based on the "immorality" and "illegality" of this particular war to wholesale charges of American racism and imperialism. And as they looked around the country - and the rest of the world - they saw other young people (students mainly) who, upon reaching the same conclusions, were moving beyond resistance, sometimes to revolution.

Although New England Resistance leaders did not see themselves as revolutionaries in the Spring of 1968. they did feel that they were part of a worldwide student movement. something much larger than a mere challenge to the American system of conscription. In this climate, their agenda slowly began to diversify. They reached out to new constituencies, especially blacks and GIs, and slowly moved away from challenges to the draft system. Paradoxically. this change in the tenor of the movement took place just as the Spock Trial, the most prominent manifestation of the original resistance spirit. opened. For months, resisters and supporters had been looking forward to the big event the "political trial of the century" some called it - with great anticipation. Yet rather than serving as a potential counterbalance - a centripetal force - to the strain pulling the movement apart, the trial of the Boston Five only hastened its splintering. By July 1968 , the first mass draft card turn-in of October 16, 1967 seemed a lifetime away. 


\section{Death of a King and a World Upside Down}

Perhaps more than any other branch of the antiwar movement, draft resistance followed closely the examples of Martin Luther King, Jr. and the civil rights movement. That King had been a national public figure since 1956 meant that most in the draft resistance community became politically and socially aware as the civil rights leader reached the peak of his influence. They remembered the 1963 March on Washington and King's "I have a dream" speech. More important, many resisters and supporters cut their activist teeth in civil rights and, like the earlier movement, draft resistance (in Boston, especially) saw a convergence of religious and political activists working together for a common goal. Not only were churches important to both movements, but the New England Resistance modeled their strategy and tactics - always emphasizing nonviolence - after examples from the civil rights movement. Just as King sought in 1963 to end segregation in Birmingham by filling the jails there with children, draft resisters were prepared to bog down the court system and fill America's prisons with the draft age kids of the middle class. King himself all but came out in support of draft resistance in the last year, and when the Boston Five were indicted, he said, "If Dr. Spock and Michael Ferber are jailed, then I should be jailed as well." As Gandhi had been to King, King was to the New England Resistance. According to Neil Robertson, King's death had a "massive impact" on the organization. To lose him so violently rocked the New England Resistance to its foundation.?

\footnotetext{
2 "Card Turn-In Opposes Racism," The Resistance, 8 Apr 1968, p. 1; Robertson interview, 7 Aug 1998.
} 
New England Resistance leaders immediately moved to assist the AfricanAmerican community in keeping order and safety in their neighborhoods in the wake of King's death. As cities across the country burned in response to the terrible news, the New England Resistance, through its one black leader, Harold Hector, stayed in touch with the Black United Front (BUF) in Roxbury and aided them with medical supplies, food and water. When rumors were spread that white firefighters entering Roxbury might be shot by snipers, members of the New England Resistance broke into the downtown campus of the University of Massachusetts and "liberated" all the fire extinguishers for use by members of the BUF. Although tensions were high, widespread rioting did not break out in Roxbury.;

At the same time, the New England Resistance took the lead in organizing a coalition march in memory of Dr. King and called for a three day student-faculty strike to have teach-ins on racism in America. On April 5, more than 15.000 people, mostly white, marched from the Common past the State House through downtown streets to Post Office Square. (As the crowd moved into the square, they noticed that the flag atop the courthouse flapping at full staff. Chants of "Lower it! Lower it!" rose up through the canyon of office buildings followed, minutes later, by cheers when someone lowered the stars and stripes to half staff.) It was one of the biggest marches the city had ever seen. The student-faculty strike did not come off as successfully, though there were several

\footnotetext{
3 "Roxbury Riot Prevented," The Resistance, I May 1968, p. 2, RCP; Stone interview, 28 Mar 1997; Joel Kugelmass, interview with author, 16 Jun 1997; William Hunt, interview with author, 31 Oct 1997.
} 
well-attended teach-ins and workshops. ${ }^{4}$

Most striking, the draft card turn-in scheduled as the culmination of the three day strike offered the first indications that the Resistance program would be widening. "-It took the death of Dr. King...to bring home to the New England Resistance the connection between the war in Vietnam and racism." a spokesman said. Resisters suggested that attacks on the draft doubled as attacks on institutionalized racism. "The Resistance intends to undermine the institution pampering the middle-class while it uses black bodies for an ugly war," they said. Therefore, on April 10, another eighteen men turned in their draft cards at the Arlington Street Church. These were, of course, men who could have performed this act just a week before with hundreds of others on the Common, yet they did not; it took King's assassination to push them over the edge. Bob Shapiro, an antiwar activist at MIT. had considered turning in his draft card for months. but always hesitated - until April 10. Even though he favored SNCC's approach to civil rights over King s, the murder of this nonviolent man "demanded some kind of very strong response," he later said. "The response I decided on was to become more active in the antiwar movement than I already was and to just basically say 'no' to the government." In life, Martin Luther King, Jr. had deeply influenced the lives of many in Boston's draft resistance community, but in death King drove them to see what he had

+:15,000 March Here - Mostly White," Boston Globe, 5 Apr 1968, p. 10; "AntiDraft Group Calls for Student-Faculty Strike," Boston Globe, 8 Apr 1968, p. 3.

5 "Anti-Draft Group Calls for Student-Faculty Strike," Boston Globe, 8 Apr 1968, p. 3; "Card Turn-In Opposes Racism," The Resistance, 8 Apr 1968, p. 1, RCP; Robert Shapiro, interview with author, 13 Aug 1997. 
always hoped white America would see: that racism, poverty, militarism, and materialism were *interrelated flaws...evils rooted deeply in the whole structure of [American] society." The night of King's death resident Resistance poet Jim Havelin wrote a poem that, in retrospect, shows that draft resistance activists finally saw (if some did not already) the connections King was making:

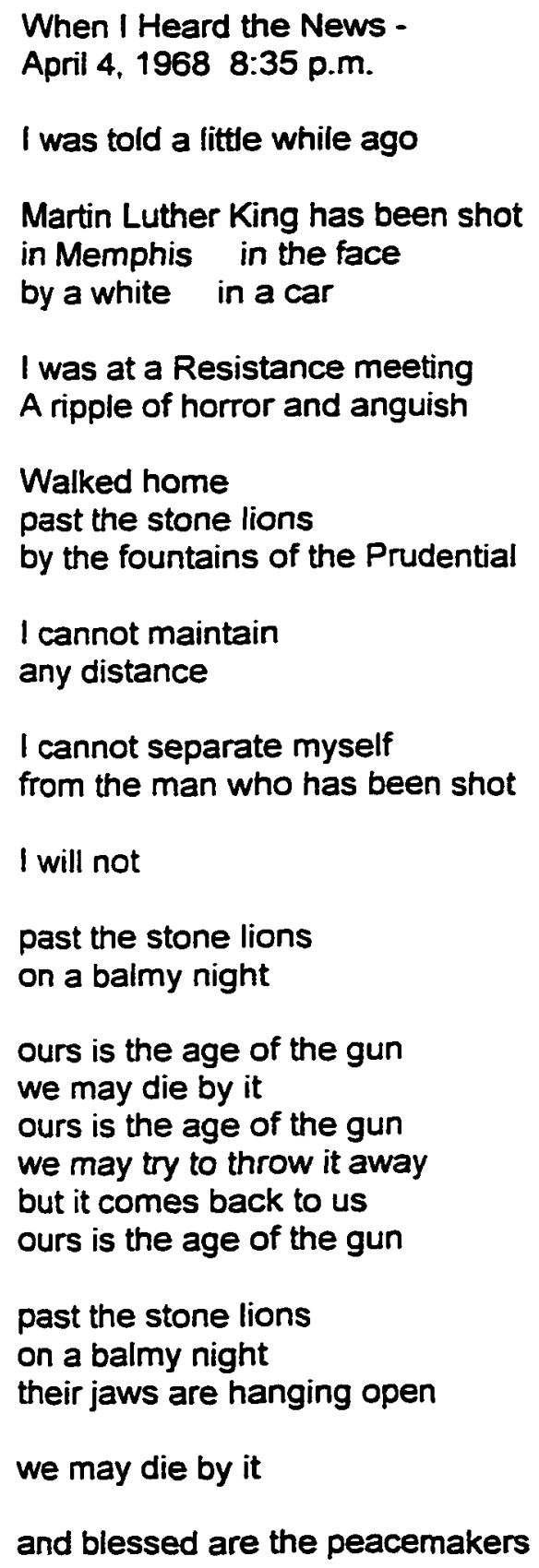




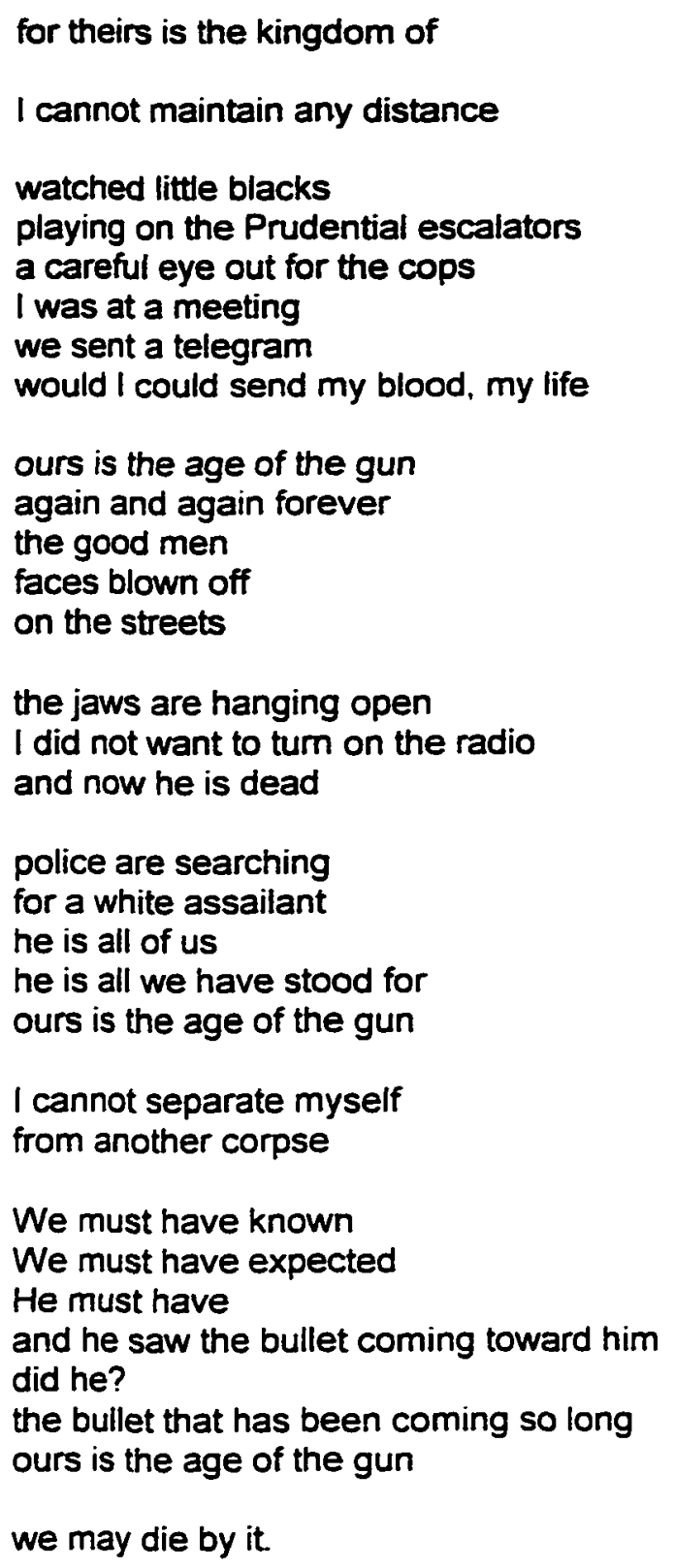

Havelin's poem conveyed an anguish felt by almost everyone in the draft resistance movement. That anguish, coupled with a sense of guilt for having failed to connect racism with the war before, contributed to a new urgency that led the New England Resistance to completely alter its focus in the coming weeks. ${ }^{6}$

${ }^{6}$ Martin Luther King, Jr., "A Testament of Hope," originally published in Playboy 16 (Jan 1969), reprinted in James M. Washington, A Testament of Hope: The Essential 
For the rest of April and into May, combating racism became the organization's newest priority. An editorial in The Resistance laid out the rationale for this shift:

Dr. Martin Luther King's death is not the accident of one white man with a gun in the right place at the right time. His death is the expression of a society for whom destruction is a tactic, racism is a policy...Dr. King made the connection between racism and the war. He drew the lines between the slaughter in the city, teaching us that it is the same mind that napalms Hue and bivouacs in Detroit...thus we have seen that our struggle against the draft and the war must be as well a struggle against racism in the white community. We have all lost a leader.

Even Resist, the organization of adult advisers, soon identified their "job" as "push[ing] the political offensive against the war and against racism." It was a remarkable transformation. $^{7}$

Despite the Resistance's visceral response to King's death, however, the organization's interest in racial issues manifested itself primarily in print. For example. although some Arlington Street Church members joined forces with black leaders in a demonstration that became known as Tent City at the end of April, few if any resisters took part. Over three days, more than 40 men and women camped out in a parking lot in Boston's South End to protest urban renewal programs that resulted in demolition of low cost housing and the relocation of families to other neighborhoods. The demonstration had nothing to do with draft resistance. of course, but given the Resistance's new focus on racism one might have expected the New England Resistance to join the Tent City

Writings and Speeches of Martin Luther King, Jr., (San Francisco: Harper Collins, 1986), p. 315; Jim Havelin, "When I Heard the News," poem, The Resistance, 5 Apr 1968, p. 6, RCP.

7 "King Dies," The Resistance, 8 Apr 1968, p. 1, RCP; Resist Newsletter \#12 (Jun 1968), p. 2, Box 28, BSP. 
demonstration. ${ }^{8}$

No sooner did Resistance leaders begin to emphasize new education programs on racism, however, did other events beyond their control again alter the climate in which they worked. On April 23, students at Columbia University protested against the school's "manifest destiny" policy by which the university historically purchased property in the low-income neighborhood of Morningside Heights, demolished it, and built new university buildings (in the previous ten years, more than 7,000 residents -85 percent of whom were black or Puerto Rican - were displaced in this manner). In particular, Columbia's plans to build a gymnasium in the area set off protests that began with the occupation of the administration building. Hamilton Hall, and the holding of a dean in his office for more than 24 hours. Over the next week, more than 1,000 students occupied several more buildings (declaring them "Liberated Zones") as the protest escalated into a rebellion against the Vietnam War and Columbia's affiliation with the Institute for Defense Analysis (IDA), a weapons research organization. On April 30, between 2:30 and 5:30 a.m., New York City police stormed the occupied buildings, brutally beating many of the unarmed demonstrators. They arrested 712 and left 148 injured. The rest of the student body, though more moderate in their views, were outraged by the police tactics. On May 6, when the university reopened, thousands of students took part in a general boycott of classes that shut the school down until May 16, when President Grayson Kirk accepted their demands that formal charges against students be dropped.

8 "23 Arrested In So. End Protest," Boston Globe, 27 Apr 1968, p. 1; Bob Hohler, interview with author, 11 Dec 1997. 
On May 21, students again occupied Hamilton Hall to protest the disciplining of four SDS leaders. Again, the police came: They arrested 138 , and the university later suspended 66 , taking care to notify the offenders' draft boards that they were no longer eligible for student deferments."

The Columbia students' protest of two major issues - one rooted in a racially insensitive expansion program and another relevant to the war - mirrored the concerns of draft resistance activists in Boston. And although no one in Boston suggested the occupation of university buildings as a method of protest in April and May of 1968, the example of Columbia changed their sense of what was possible. "Liberated Zone" would soon become part of the New England Resistance vocabulary.

Even more astounding than the battles at Columbia were the strikes and riots led by students in several European countries. In Czechoslovakia, students and writers ushered in the Prague Spring, a new culture of free and uncensored expression, and were the most outspoken supporters of Alexander Dubcek's reform government. In Madrid, students and workers joined forces in calling for democratic, economic, and educational reforms. Extensive rioting eventually crippled the city through much of early May, when the fascist government of General Francisco Franco brought in the civil guard to break up the protests. And over the same period, furious rioting occurred in Berlin and elsewhere in West Germany following the attempted assassination of German student leader Rudi Dutschke.

9 Jerry L. Avorn, et al, Up Against the Ivy Wall: a History of the Columbia Crisis (New York: Atheneum, 1969); Terry Anderson, The Movement and the Sixties, p. 199. 
But none of these uprisings stunned the world more than the general strike that evolved from student protests in France. In early May, contemporaneous with the Columbia uprising, students at the Sorbonne in Paris, sparked by protests at Nanterre, began street demonstrations to demand the reform of what one observer called the "totally outdated and medieval structure of the university." When police entered the Sorbonne for the first time in its 700 year history, and beat and arrested hundreds of students, a fullscale uprising began. Most Parisians were shocked by the police brutality and sympathized with the students. Ten days of street demonstrations followed, culminating in the violent Night of the Barricades on May 10. That night, in anticipation of a police offensive, as many as 30,000 marchers followed French revolutionary tradition and ripped up paving stones in the Latin Quarter - the same stones used in 1848 and 1871 - and overturned cars as they built more than 50 barricades in the winding streets surrounding the university. In the middle of the night. the police came with incendiary grenades and the same CS gas used by American forces in Vietnam. They clashed with the students all night. 367 people were injured, and 460 were arrested as the police went from door to door, taking anyone with black hands, gas spots on their clothes, or visible wounds.

A huge number of French workers and professionals joined the general strike that resulted from the May 10 fighting. Eventually, some 9 million French citizens went on strike not just to support the students, but to demand better wages, a roll back of government bureaucracy and la participation in the daily decisions affecting their lives. On May 29, de Gaulle fled to West Germany; it appeared that his government would fall, that students and workers had forged a revolution. But the old general came back the 
next day, and in a powerful four-minute television address all but sucked the life out of the rebellion. He dissolved Parliament, called for general elections and mobilized the military under local prefects. In response, an estimated 700,000 Gaullist supporters rushed to march on the Champs Elysees; the momentum had shifted. Ultimately, a combination of concessions to workers from the government - a 35 percent increase in the minimum wage and increased participation in industry - and the strain created by a lack of social services (e.g., no mail, no garbage collection. and inconsistent public transportation) weakened the strike and caused the majority of the French population to give up on the students. ${ }^{10}$

In New England, however. the French students' example contributed to a kind of intersection of radical thought that converged in the New England Resistance. On the one hand, Resistance activists continued to despair over the state of the war and race relations in America. Despite Lyndon Johnson`s promise to seek negotiations with the North Vietnamese, fighting raged on. Five hundred sixty two American GIs died in one week in the middle of May - the worst week yet - and another 2,225 were wounded. The judge in the upcoming trial of the Boston Five ruled that arguments about the immorality and illegality of the war would not be admitted because he thought them irrelevant to the charges. In addition, racial tensions continued to flare in Boston and in other parts of the

${ }^{10}$ There are several good books on the tumultuous year of 1968 . For descriptions of events in Europe, I have relied especially on two: Ronald Fraser, ed., 1968: A Student Generation in Revolt (New York: Pantheon, 1988), pp. 203-230; David Caute, The Year of the Barricades: A Journey Through 1968 (New York: Harper \& Row, 1988), pp. 81 85, 185-210, 211-258. In addition, see Herbert Marcuse, "On the French Revolt," Boston Free Press, No. 5, p. 5, AJP. 
country. Three hundred black students took over the Boston University administration building demanding more emphasis on African-American history and increased financial aid to black students. In Roxbury, someone stabbed Jozef Mlot-Mroz in the chest when he taunted a crowd of people boarding buses bound for the Poor Peoples March in Washington with a placard reading, "I am Fighting Poverty. I Work. Have You Tried It? It Works." He later recovered but the incident demonstrated the extent to which violence was becoming commonplace. On the whole, the political climate appeared to be getting worse rather than better, and tensions seemed to rise almost daily. "

At the same time, the example of so many students flexing their collective muscle at Columbia and in Europe led some in the Resistance to see themselves as part of a worldwide movement for revolutionary change. Draft resistance activists found inspiration in the student uprisings in Europe, and especially the general strike in France. In a telegram to the students at the Sorbonne. New England Resistance leaders wrote:

The Resistance in America has been inspired by your victories and salutes your alliance with the workers of France. We share your determination to rid society of inequality and exploitation. Like you, we are recalling our country to its revolutionary heritage. The movement for human liberation is becoming international, and the future is ours.

Vive la Resistance! Vive la Revolution!'?

This kind of rhetoric marked a significant shift in objectives from the early days of

11 :562 GIs Killed - Worst Week," Boston Globe, 17 May 1968, p. 1; "One-Man Picketer, Mlot-Mroz, Critically Stabbed in Roxbury," Boston Globe (Evening Edition), 10 May 1968, p. 1.

12 "To the Union des Etudients Francais at the Liberated Sorbonne," telegram to French students from the Resistance, reprinted in Boston Free Press, first edition (c. late May 1968), p. 7, RCP. 
October 16. At that time, Resistance leaders sought only to hamstring the draft and end American involvement in Vietnam. No one raised the ambitious prospect of ridding society of "inequality and exploitation." nor did anyone describe noncompliance with the draft as part of a "movement for human liberation." But times had changed, and New England Resistance leaders increasingly saw the roots of American racism and imperialism embedded deep within the structure of their society. "Moral witness began to be spoken of less as something noble than as something educational or as a tactic," Hilary Putnam, the Harvard philosopher and New England Resistance supporter, later said. "One felt the need for what was called 'an analysis.' Originally one did not feel that need. I thought: 'the war [is] wrong and I'm not going to be complicit in an evil war." But after several months, when it became clear that draft resistance had not moved the country materially closer to withdrawal from Vietnam, and that more and more resisters were being called for induction - and would be prosecuted for refusing - then, Putnam recalled, "people started producing analyses and debating these analyses." For the first time, Marxist interpretations of the war and race relations began to dominate discussion and soon the Resistance started to reflect leftist leanings more overtly than ever before. ${ }^{13}$

\section{Sanctuary at Arlington Street}

As the Spock Trial opened in late May, the New England Resistance's intellectual shift became more apparent. On the very first day of the trial, Resistance leaders declared the Arlington Street Church a "liberated zone," and accepted two men, a convicted draft

\footnotetext{
${ }^{13}$ Putnam interview, 18 Dec 1997.
} 
resister and an AWOL GI, into the first "sanctuary" there. They then issued a "manifesto" that clearly showed their turn from a more limited focus on the institutions responsible for both the war and the draft to a broader indictment of American society. First, they were critical of themselves: "We have failed to expose the social origins of American foreign policy, to identify the economic interests responsible for exploitation at home and abroad," they wrote. "As a result, our analysis has remained superficial and conciliatory." Therefore, the leadership explained. "the time has come for the Resistance to present a radical critique of the nature of our society..." The critique that followed shaped Resistance activism for the rest of the year:

The myth of American affluence conceals enforced want, prosperity undercut by the anxiety of constant indebtedness, and the emptiness of the lives of those who have attained wealth and power. Meanwhile, private industry poisons our atmosphere, pollutes our rivers, and squanders our resources.

But even this pseudo-prosperity is based on a global system of exploitation which further corrupts the fabric of American society. Imperialism requires the maintenance of a gigantic military establishment. the distortion of men's lives through conscription or the fear of it, and the perversion of a desire for law and order into a rationalization for and defense of an intolerable status quo.

This focus on economic inequality, "the emptiness" of people's lives, and on militarism smacked of Port Huron-era SDS rhetoric more than anything else the New England Resistance had ever produced. Even if many of their members thought of themselves as part of the New Left when the Resistance was born the previous fall, the language of the New Left never dominated discussion as much as it did now. ${ }^{14}$

14 "A Manifesto: The Resistance and the Draft," Boston Free Press, first edition (c. late May 1968), p. 2, RCP. 
Although the New England Resistance's revision of its agenda derived most directly from the intensity of the times, and the radical examples of their contemporaries. a gradual change in leadership also facilitated it. Of the ten people who signed the new manifesto, only three - Bill Hunt, Nan Stone, and Neil Robertson - had been involved with draft resistance since the previous summer. The other original "founders" of the New England Resistance were noticeably absent: Bill Dowling left in January because of disagreements over strategy; Alex Jack remained active in draft resistance but focused all of his energies on the biweekly newspaper. The Resistance, which merged into the Boston Free Press at the time of the trial; and Wichael Ferber had not been very active on the local level since his indictment arrived. Like the other defendants Ferber spent most of his time at speaking engagements around the country which he felt obligated to accept as a way of helping other local Resistance groups. By the time of the trial then, Jack and Ferber, the two men most responsible for injecting their Unitarian-based sense of morality (even though both were also products of the New Left) no longer exerted much influence on the day-to-day operations of the New England Resistance.

Two other men, Ira Arlook and Joel Kugelmass, assumed more responsibility and, with Bill Hunt, gradually pushed the organization further to the left. Arlook and Kugelmass knew each other from Stanford and were friends of David Harris and some of the other original Resistance founders there. They came to draft resistance less from a New England-style civil disobedience perspective than from a California New Left slant. Connie Field, another of the manifesto's signers, later remarked that she, Arlook, and Kugelmass, saw their work with the New England Resistance more as "Movement work" 
than draft resistance work alone; they always felt part of something much bigger and interrelated, a Movement that included other forms of antiwar work, civil rights, black power, the student movement, and eventually women's liberation. For them, especially, the broadening Resistance program made sense. ${ }^{\text {is }}$

With the issuance of the new manifesto and the simultaneous opening of the first sanctuary at the Arlington Street Church, the New England Resistance appeared also to be growing more militant, particularly when compared with the well-mannered defendants in the Spock Trial across town. The manifesto concluded by stating, "we shall resist the enforcement of the laws we oppose" and pledged not to "allow" the government to arrest the two men for whom they organized the sanctuary. It may or may not have been an issue of semantics, but these sweeping statements certainly appeared to be more radical than any earlier pronouncements. What did resisting the "enforcement of the laws we oppose" mean? It sounded dangerously vague. Likewise, promising not to allow the government to take the two men in sanctuary implied that arresting officers might face physical resistance, maybe violence. To some outsiders, then, this tone seemed to add to the apocalyptic nature of the times. As a result, Joel Kugelmass found himself defending the organization during the sanctuary. "We're not anarchists," he told a reporter, "because we're not interested in destroying the social system, but in building a new order. We want an order based on equality, such as equality between the sexes, races, economic equality, educational equality, not to blur the individual differences, but to give every individual a truly equal chance..." Consistent with the new Resistance line, Kugelmass mentioned

${ }^{15}$ Connie Field, interview with author, 17 Jun 1997. 
nothing about the draft or the war, and focused on bigger issues. "We don't live in a democratic society," he said, "but in an oppressive shadow of democracy in which a few people determine the policies and programs of the country and give the majority of Americans the false impression that they have a say." Although the New England Resistance hinted at some of these themes in their publications in April and early May, the change of course charted by the organization only became obvious to those outside it when the first sanctuary opened at Arlington Street. ${ }^{16}$

The possibility of sanctuary, the granting of asylum by a church to a draft resister or AWOL serviceman, had been in the air for months. As early as October 16, William Sloane Coffin urged churches and temples to grant sanctuary in his Arlington Street Church sermon. But only as the Resistance searched for new tactics beyond draft card turn-ins did it become more likely. Once again, Robert Talmanson, 21, the CNVA activist who burned his card outside the federal courthouse in June 1966 and who later made the first efforts to start a Resistance chapter in Boston, found himself at the center of a new phase of draft resistance in the city. In the middle of May, the United States Supreme Court refused to hear Talmanson's appeal of his conviction for draft card burning, and so the first sanctuary began with him. Army Sp 4 William Chase, 19, a high school dropout and former garbage collector from Dennis, Massachusetts, joined Talmanson in sanctuary. Chase had served as a clerk in Cam Ranh Bay for nine months but on three occasions sought psychiatric discharges from the Army; all were denied.

${ }^{16}$ Daniel P. Juda, "The Draft a Rallying Point for N.E. Resistance Group," Boston Sunday Globe, 2 Jun 1968. 
Later, Chase went Absent Without Leave for 20 days and when the Army did not discharge him - instead ordering him to report to Fort Lewis, Washington - Chase again went AWOL and soon gravitated to the Resistance looking for help. ${ }^{17}$

In some ways, Chase represented a sizeable number of alienated servicemen. GI desertions continued to plague the American military in 1968 after record numbers fled the Army and Marines in 1967. According to historian Richard Moser, the rate of Army AWOL cases jumped from 57.2 per thousand in 1966 to 78 per thousand in 1967. Total desertion from the Army (absence over 30 days) climbed from 14.9 per thousand in 1966 to 21.4 in 1967. The Marines fared little better, with desertion rates increasing from 16.1 per thousand to 26.8 per thousand from 1966 to 1967 . Altogether, Moser reports, the military listed 40,277 men as deserters by June 30,1967. Many of those men wound up in Sweden or in Canada (though Canada had an extradition agreement with the U.S. in such cases), but none took the course Bill Chase did in seeking the assistance of a civilian antiwar group to publicly announce his desertion as a way of protesting the war. In subsequent months. dozens of servicemen followed Chase's lead, possibly because they believed that the publicity might keep the military from channeling them to either the stockade or Vietnam. But Chase had no idea what would happen when he joined Talmanson at the Arlington Street Church. He knew only that he did not want to go back

17 "Two War Resisters Get Church Asylum," Boston Globe (Evening Edition), 20 May 1968, p. 1; "Anti-War Pair Spend Second Day Sheltered in Church," Boston Globe, 21 May 1968, p. 15; "“I Know They Will Be Coming...I Know I Will Be Going to Jail," Boston Globe, 24 May 1968, p. 27. 
to Vietnam. ${ }^{18}$

The Reverend Jack Mendelsohn learned of his church's distinction as the first one in the country to offer sanctuary to a serviceman when he saw the front page of the Los Angeles Times. Mendelsohn was in California lobbying religious leaders on behalf of Robert Kennedy's presidential campaign. Before going to Los Angeles, Mendelsohn sensed that a sanctuary request might be in the offing. Fearing that such a request might come in while he was in California and without the approval of the church's Prudential Committee, he told Victor Jokel, his executive assistant, to put the man in Mendelsohn's office (rather than in the sanctuary of the church) until he got back. The L.A. papers made it clear that Jokel granted sanctuary to Bill Chase and Robert Talmanson in the actual sanctuary of the church. and dozens of other people were supporting them there. Mendelsohn immediately called Jokel and "cussed him out," but Jokel was "pretty defiant" and pledged to go on with the sanctuary. Mendelsohn eventually caught a flight back to Boston. missing Kennedy's victory in California - and his assassination, another event that contributed to the chaotic social and political landscape of 1968 America. $^{19}$

In fact, Victor Jokel made the decision to host the first sanctuary at Arlington Street almost unilaterally. He did have the support of Ed Harris, the associate minister, and Bob Hohler, a "lay minister" of the church and executive director of the UnitarianUniversalist's Laymen's League. but he did not consult with the Prudential Committee

${ }^{18}$ Richard Moser, The New Winter Soldiers: GI and Veteran Dissent in the Vietnam Era (New Brunswick: Rutgers University Press, 1995), pp. 75-77; Resist Newsletter \#14 (29 Jul 1968), p. 8, BSP.

${ }^{19}$ Mendelsohn interview, 19 Dec 1997. 
which represents the parishioners. Ralph Conant, the chairman of the Prudential Committee learned of Jokel's plans by chance but opted not to intervene because he wanted to avoid "unfortunate consequences of a confrontation with the New England Resistance movement." If not supportive of draft resistance, some members of the church - like Conant - were resigned to seeing such activities take place in their church. The sanctuary eventually tested limits of their patience..$^{20}$

The tradition of sanctuary dated to ancient times and had been used extensively as late as the Middle Ages. In the Book of Kings, when King David's son and military commander, Joab, took refuge from King Solomon's soldiers, he did so in a tent containing the Ark of the Covenant, a holy place. In 693, the King of West Saxons (England) declared that anyone who committed a capital crime could save himself from the penalty of death if he took asylum in a church. This legal basis for sanctuary lasted in England until 1623, when an act of Parliament abolished it. Still, when Victor Jokel opened the sanctuary at Arlington Street. he emphasized that no one expected it to have any legal force, nor did he think it should. Instead, he noted, "this historic concept, as renewed today, has the force of a moral imperative on the side of life and man at a time when, through well-meaning but tragic misguidance, the leadership of our country, gutting its ideals, indicts its patriots and acts as executioner for thousands of this

${ }^{20}$ Mendelsohn interview, 19 Dec 1997; Ralph W. Conant, "Report of the Chairman of the Prudential Committee to the Annual Meeting of the Corporation," 12 Jun 1968, ASC Files. 
generation of young men - American and Vietnamese of both sides."21

For the resisters and their community of supporters, the Arlington Street event represented a new and exciting tactic. To many, sanctuary offered a creative re-direction for the Resistance, something new (and newsworthy) to do in place of draft card turn-ins. Although sanctuary dated to ancient times. the first one at the Arlington Street Church appeared rooted in values that dated to the origins of European settlement in New England. Over the course of ten days, the participants treated the church more like a meetinghouse where, as in seventeenth-century New England, a community would meet to tend to all of its business, not just its religious instruction.

Within hours of its start. the sanctuary began to take on a life of its own. At times, it seemed like an ongoing teach-in. At other times, the crowd focused on preparing for the authorities who would inevitably come. On occasion it also took on the characteristics of a big party. On the first night, several hundred people turned out for dinner in the church basement. Organizers showed films of past draft card turn-ins and musicians played the blues for the crowd. A couple of nights later the rock band Earth Opera (led by future bluegrass greats Peter Rowan and David Grisman) performed on the stage in the basement of the church. More than 70 people spent the first night in the church awaiting the police and the crowds grew each night. Every day people could be found sleeping, eating, cooking, giving speeches, and having "endless conversations." Some roamed around trying to keep everyone's spirits up, trying to build solidarity. And

"Joseph M. Harvey, "Talmanson Used Ancient Tradition in Seeking Sanctuary in Church," Boston Globe, 26 May 1968, p. 28; Victor Jokel, "The Meaning of Asylum," The Resistance, 15 Jun 1968, p. 4, RCP. 
reporters mingled throughout the building interviewing as many participants as they could. Joel Kugelmass later called it "a very beautiful thing," because of the range of people who got involved. In addition to diehard activists, he said. some members of the church helped, and several suburban women came in with sandwiches for everyone. Here again, by using the church, the New England Resistance immediately attracted new supporters. The sanctuary began to be "self propagating," Kuigelmass noted."

No one knew exactly when the authorities would come, who they would be, or how they would handle the crowd of supporters vowing to prevent their removal. In the first few days, Colonel Paul Feeney of the Selective Service told reporters that Bill Chase, the AWOL serviceman, was "the Army's problem," thus implying that the Army would have to apprehend Chase. U. S. Attorney Paul Markham said that he hoped he would not have to use U.S. Marshals to apprehend Robert Talmanson, but "if it comes to that we will have to do our duty." After a couple of days, Victor Jokel promised that the imminent showdown between the activists in the church and the authorities would be "a moral confrontation only" and participants agreed to meet police or marshals only by blocking their way - by standing or sitting - with the intention of avoiding violence.

When they finally came, however, it escalated into much more than that. ${ }^{23}$

22 "Anti-War Pair Spend Second Day Sheltered in Church," Boston Globe, 21 May 1968, p. 15; "Pair in Church 'Sanctuary' Say Next Move Up to U.S.," Boston Globe, 22 May 1968, p. 15; Kugelmass interview, 16 Jun 1997.

23 "Deserter, Card Burner in Church," Boston Globe, 21 May 1968, p. 9; "AntiWar Pair Spend Second Day Sheltered in Church," Boston Globe, 21 May 1968, p. 15; "Pair in Church 'Sanctuary' Say Next Move Up to U.S.," Boston Globe, 22 May 1968, p. 15; "Entire 4 Hours of Melee Detailed by 2 Reporters," Boston Globe, 24 May 1968, p. 27. 
The confrontation came on May 22, the third day of the sanctuary. Each day, as supporters grew more and more exhausted, they anticipated the arrival of the authorities. At approximately noon on the $22^{\text {nd }}$, about 250 supporters gathered in front of the Arlington Street Church. sensing an imminent encounter. They were right. At 3:15, as Resistance look-outs used walkie-talkies to communicate with those inside, a police officer began redirecting traffic off Arlington Street onto Newbury Street, thus preventing cars from passing in front of the church. At 3:30, just as films of the October 16 draft card turn-in were being shown by prosecutors across town in the Spock Trial, a Resistance activist with a bullhorn yelled "here they are" as a car bearing Paul Markham and three U.S. Marshals arrived at the church. Markham (who several resisters in later years misidentified as Ramsey Clark) and the marshals walked up the front steps of the church and entered the sanctuary. There. Father Anthony Mullaney of St. Phillips Rectory in Roxbury met the four men and told them that they were about to "violate a moral sanctuary." He stressed to Markham, especially, that if they passed the crowd of supporters and took Robert Talmanson, the U.S. Attorney and his marshals would be cooperating with a law that Mullaney and everyone else in the church believed to be immoral. The government men listened politely and then stepped past the priest. Robert Talmanson observed the scene from high above the sanctuary floor. He stood at the massive mahogany pulpit, over which someone had draped a large felt banner emblazoned with the large black Omega symbol of the Resistance. and read a brief statement. One could have heard a pin drop as the marshals approached Talmanson and told him that they were placing him under arrest. Talmanson replied that he would not 
resist and fell limp into the arms of the marshals. There had been no violence, just the promised moral confrontation, and they carried Talmanson from the pulpit. ${ }^{24}$

Order began to unravel, however, as the marshals attempted to leave the church. For some reason, Markham and the marshals elected not to go out the way they came in. and instead took Talmanson outside via a side door that led to an alley that runs down the right side of the church, bisecting the block from Arlington to Berkeley Streets. When the marshals emerged with Talmanson, they met the crowd of supporters who had moved from the front of the church down the alley and now stood before them with their arms interlocked. The path to their car was blocked. For approximately 45 minutes, the action stalled as Markham and the marshals plotted what to do next. Talmanson sat on the ground reading Chinese poetry with marshals standing on both sides of him. The protesters sang "the Battle Hymn of the Republic," "America," "We Shall Not Be Moved," and other civil rights songs. As a steady rain began to fall, shouts of "You're beautiful, man," and "We love you" buoyed the spirits of the arrested man.

At about 4:15, demonstrators could see that the marshals had a new plan. Fifteen Boston police officers suddenly emerged from the opposite direction of the protesters. In the late 1960s, the Ritz Carlton Hotel still operated a parking lot that guests entered from Newbury street but which also bordered the alley in which the protesters were confronting Talmanson's captors. The police arrived there and moved up the alley to offer support to their federal counterparts. They did not wear riot gear or carry tear gas guns. Eventually,

24 "Police Haul Draft Resister from Church," Boston Globe, 23 May 1968, p. 1; "Entire 4 Hour Melee Detailed by 2 Reporters," Boston Globe, 24 May 1968, p. 27; Keith Maillard, "Confrontation," Boston Free Press, Third Edition, pp. 6-7, AJP. 
some 25 police officers arrived at the Ritz parking lot aided by another six who walked down Newbury Street from Arlington to give them support. The marshals picked up Talmanson and once again tried to move him through the crowd, now numbering several hundred. When that failed. they quickly turned toward the parking lot and. with police officers forming a barrier between the marshals and the protesters, they whisked Talmanson to a waiting squad car. Along the way, several officers pushed protesters to the ground. Tensions quickly heightened.

The police and marshals did not get Talmanson into the car fast enough, as supporters ran to sit down in front of the police car. Michael "Walrus" Colpitts laid himself out across the hood of the car while two women lay on its roof. When it became clear that there would be another delay in the action, some protesters ran into the church to get blankets and coats for the crowd to use in shielding themselves from the rain. Most were soaked to the skin. During the calm, a helicopter flew over the crowd. When one resister yelled, "Look out! Here comes the napalm!" even some of the police officers laughed.

Finally, however, the police made it clear that they meant business and were growing tired of the confrontation. A police wagon pulled up in front of the parking lot on Newbury Street. Then. all at once. the marshals pulled Talmanson from the surrounded police car and the crowd of police officers formed a phalanx that pushed through the crowd to bring the arrested man to the wagon. Officers pulled the two women from the top of the car by their hair, and as they moved through the crowd some clubbed and punched the sitting or standing demonstrators; others sprayed them in the 
face with mace. Some demonstrators were kicked or trampled. The police later denied using night sticks on the demonstratoris, but participant and eyewitness accounts confirmed that the 20 protesters who were hurt suffered primarily from being clubbed and punched by police. One reporter for the Boston Free Press, an underground newspaper. evaluated tapes, still photographs and witness accounts, and concluded that the violence was "police-originated." The reporter noted that "although the police were tugged at. pushed and obstructed. at no time did any Resistance demonstrator strike or attempt to strike a police officer."

Not every police officer participated in the beatings. John Phillips, no stranger to such frenzies, later recalled that he shook hands with Deputy Superintendent Joseph Saia "in the middle of the carnage that was going on underneath us" because Saia was so obviously trying to "control things, control his officers." Likewise, Dan Tilton, who had been sitting in front of the car. recalled that after a "beefy" policeman grabbed him and threw him (practically through the air) to the ground, another cop held Tilton down on the ground, and said, "I don't want to be a part of this. Just stay where you are." Despite these examples of police restraint. many Resistance activists now feared that the Boston police had reached their limit. Historically, the New England Resistance had always been grateful that Boston police handled demonstrations and crowds better than their counterparts in other cities. Following the melee in the Ritz parking lot, however, activists suspected that Boston cops might start responding like Oakland or New York City police. In any case, the physical confrontation, coupled with the arrest of 16 demonstrators, added up to a stunning end to Robert Talmanson's sanctuary, and set an 
example that activists hoped would not be repeated when the Army came for Bill Chase. ${ }^{25}$

From one perspective, the skirmish with police bolstered the level of attention already being paid to draft resistance as a result of the ongoing Spock Trial. After the dust settled from the clash outside the church. Michael Ferber arrived in the middle of a meeting called by the New England Resistance to discuss how to handle the military authorities who would undoubtedly be coming for Bill Chase; "We are all over the city," Ferber triumphantly told the crowd that after spending the day in court (where the prosecution showed films of the October 16 draft card turn-in) and walking through the Boston Common and Public Gardens, listening to the buzz. When one reporter entitled her mid-June article "The Boston Happening," it referred not just to the trial. Draft resistance and discussion of it seemed to dominate the city's discourse. ${ }^{26}$

Editors at the Boston Globe, however, offered an alternative view of the sanctuary altercation in an editorial called, "Can We Keep Out Cool?" The Globe, like some resisters, feared that the violence hitherto seen in other parts of the country had now spread to Boston. "Is this result inevitable?" they asked. "Isn't it possible for demonstrators to make their points and police to carry out their duties without spilling

2s "Police Haul Draft Resister from Church," Boston Globe, 23 May 1968, p. 1; "Globe Reporter Saw Clash From Start to Finish," Boston Globe, 23 May 1968, p. 11; "Draft Resiste Lost in Poetry," Boston Globe, 23 May 1968, p. 2; "Entire 4 Hour Melee Detailed by 2 Reporters," Boston Globe, 24 May 1968, p. 27; Keith Maillard, "Confrontation," Boston Free Press, Third Edition, pp. 6-7, AJP; Ed Harris, interview with Eugene Navias, 27 Oct 1994, ASC Oral History Project; "Participant Accounts," Boston Free Press, Third Edition, p. 8; Phillips interview, 29 Aug 1997; Arlook interview, 12 Aug 1998; Tilton interview, 16 Jun 1997.

${ }^{26}$ Arlene Croce, "The Boston Happening," National Review, 18 Jun 1968, p. 602. 
blood? Or is violence so much a part of the American heritage that real, mutual nonviolence still doesn't have a chance in our society?" It appeared, then, that the apocalyptic mood that seemed to be sweeping the world wherever young people congregated, might have migrated to Boston, too. ${ }^{27}$

Four days later, as Bill Chase and his supporters awaited his capture, the Resistance suffered another blow. On May 27, just a week after agreeing to hear Jim Oestereich's suit against his Cheyenne, Wyoming, draft board. the United States Supreme Court ruled seven to one against draft resister David O'Brien. O'Brien, one of the four men beaten on the South Boston courthouse steps in March 1966, had had his lower court conviction overturned by the First Circuit Court of Appeals on the grounds that burning one's draft card constituted "symbolic" speech and that the 1965 law prohibiting the destruction of draft cards violated the First Amendment. The appellate court ruled that although $O$ 'Brien could be convicted for failure to carry his card, he could not be tried for burning it. The Supreme Court, however, disagreed and overturned the appeal. Chief Justice Earl Warren, writing for the majority, argued that when speech (the burning of the card) and "non-speech" (non-possession of the card) are combined in the same action, and the government has a reasonable interest in limiting the non-speech element, then the "incidental limitation on First Amendment freedoms" is reasonable. To clarify, Warren wrote:

We think it clear that a government regulation is sufficiently justified if it is within the constitutional power of the government: if it furthers an important or substantial governmental interest; if the governmental interest

27 “Can We Keep Our Cool?" editorial, Boston Globe, 24 May 1968, p. 20. 
is unrelated to the suppression of freedom of expression; and if the incidental restriction on alleged First Amendment freedoms is no greater than is essential to the furtherance of that interest.

The Court, therefore, did not disagree with the lower court's characterization of a draft card burning as "symbolic" speech. but found that the Selective Service System had a substantial interest in "an efficient and easily administered system for raising armies." O'Brien undermined that interest, the Court asserted, once he failed to possess his draft card. $^{28}$

For draft resisters, the only silver lining in the O'Brien ruling came from the lone dissenter, Justice William O. Douglas (Justice Thurgood Marshall did not participate in the case), who suggested that the Court order the case to be reargued on the broader issue of whether the military draft is permissible at all in the absence of a declaration of war. He then asked several rhetorical questions from the bench that stunned the assembled media: "Is the war in Vietnam a constitutional war? Is it constitutional to have an 'executive' war? Is it constitutional to have an 'executive-declared' war? Is it not entirely up to Congress to declare war?" Antiwar activists. of course, wanted answers to these questions, too. ${ }^{29}$

Still, Justice Douglas's dissenting opinion offered small solace to draft resistance activists in Boston. After the promising start of the Talmanson-Chase sanctuary, they found themselves bloodied by police batons and discouraged by a court system that

28 United States v. O'Brien 391 U.S. 367 (1968).

${ }^{29}$ United States v. O'Brien 391 U.S. 367 (1968); "Draft Card Burning Upheld As Crime in 7-1 Court Ruling," Boston Globe (Evening edition), 27 May 1968, p.1. 
seemed to favor the government over its citizens. David O'Brien himself suggested that the Court's decision in his case, combined with the recent conviction of Father Philip Berrigan and three others in Baltimore (for pouring blood on draft files) and the ongoing trial of Dr. Spock, demonstrated that the United States and its courts were "moving toward an authoritarian state." Two days after the O'Brien decision came down, Bill Chase turned himself in to authorities at the federal building in exchange for a promise of psychiatric tests; it was an anticlimactic end for those hoping to milk the sanctuary for more publicity. In addition, Resistance leaders put plans for future sanctuaries at the Arlington Street Church on hold when the church lost its insurance. (It turned out that an executive from Aetna Insurance witnessed the Talmanson arrest and ensuing commotion from his window in the Ritz Carlton Hotel and immediately called his office to have them drop the Arlington Street Church's \$1.4 million in fire insurance and public liability coverage). All in all, despite frequent mention in the press. the Resistance seemed to have gone a little flat as more and more members grew disillusioned, unable to plan for the future existence of the organization. There would be more sanctuaries and new attempts at anti-draft organizing, but as Ira Arlook later commented, in the swirl of events that made 1968 such a watershed year, "no one had...a sense of how to keep [their] bearings with respect to the war. That was lost for a while." As an organization, the New England Resistance slipped almost rudderless into the murky summer waters of $1968 .^{30}$

${ }^{30}$ Arlene Croce, "The Boston Happening," National Review, 18 Jun 1968, p. 601 ; "Chase Gives Up; Promised Mental Aid," Boston Globe, 30 May 1968, p. 17; "NER Position Paper," undated (c. Jan 1969), BTP; Mendelsohn interview, 19 Dec 1997; Minutes, Special Meeting of the Prudential Committee, 28 May 1968, ASC Files; George Whitehouse, interview with Joan Goodwin, 16 May 1994, ASC Oral History Project, p. 


\section{The Spock Trial}

As the New England Resistance wrestled with its plans for the future in the late spring of 1968, the trial of Dr. Spock, William Sloane Coffin, Michael Ferber, Mitchell Goodman, and Marcus Raskin took place in the federal courthouse downtown. The trial put draft resistance on the front pages of newspapers across the country for three and onehalf weeks, yet, in some ways, it could not have been more irrelevant to the local draft resistance effort. Certainly, it provided several opportunities for demonstrations and for sustaining press attention to draft resistance. but ultimately, it did nothing to help the Resistance rediscover its focus regarding the war. For several reasons, the trial turned out to be a chore for the defendants and a bore for an antiwar movernent that expected fireworks.

The most persistent criticism of the trial centered on the strategy of the defense. Like almost everyone in the antiwar movement, the five defendants looked forward to the trial as an opportunity to attack the administration's conduct of the war. When the indictments came down, each man made public comments about putting the war, and thus the administration. on trial. Ultimately. however, the "Boston Five" (as they became known through the press) were confounded by the unwieldy conspiracy charge and the expectation that the judge would limit their attempts to raise larger, legal and moral issues surrounding the war.

The defendants considered three options. First, they could take a Gandhian

17; Ralph W. Conant, Report of the Chairman of the Prudential Committee to the Annual Meeting of the Corporation," 12 Jun 1968, ASC Files; Arlook interview, 12 Aug 1998. 
approach. If they were not allowed to address the larger issues of the war and make their own charges of American violation of the Geneva Accords and American war crimes, or raise Constitutional issues regarding an undeclared war and the inequities of the draft, then they would stand mute and take their punishment. This idea resonated most with Coffin and Ferber. to whom further civil disobedience appealed on both a religious and practical basis. Not only did taking one's punishment follow more consistently the examples of Socrates, Thoreau, Gandhi, and King, but they believed that the sight of Dr. Spock entering prison - handcuffed and in overalls - would prove extremely embarrassing to the administration. Michael Ferber later recounted that if the court would not allow the defendants to raise the larger issues of the war, then he thought the five defendants should stand mute. "The jury would be instructed to convict, the judge would sentence us, and we would march off to prison as heroes. with a huge antiwar movement making us into martyrs. Dr. Spock with his head held high marching into Danbury Prison. I thought it was great." 31

The second option would have seen the five defendants plead not guilty and then act as their own lawyers. The press coverage of William Sloane Coffin, veteran and exCIA operative, interrogating government officials about the nature of the war in Vietnam or of Dr. Spock questioning government witnesses in his Connecticut Yankee accent might have amounted to a stunning public relations victory. As Jessica Mitford pointed out, however, political trials often end with guilty verdicts and the best defendants can

\section{3.}

${ }^{31}$ Mitford, The Trial of Dr. Spock, pp. 76-77; Wells, The War Within, pp. 232- 
hope for is a solid appeal; letting the defendants defend themselves could only undermine the appeals process.

Finally. the third option - the one they chose - was to wage a full-scale defense with a team of lawyers. Although this strategy implied their acceptance of the legitimacy of a system that they long ago declared illegitimate, in the end they decided to stand trial. They embarked upon this course for several reasons. For one, if the government did indeed plan a "decimation of the intelligentsia," as Marc Raskin feared, then the mounting of a solid defense might delay further onslaughts. In addition, all five men strongly believed that they were not part of a conspiracy, at least in the ordinary sense of the word. They barely knew each other after all, and never stood in the same room together until they met for the first time at the New York apartment of Leonard Boudin, Spock's lawyer. The attorneys also argued that the case would give them the opportunity to challenge the use of conspiracy law against peace groups, something that appealed to all of the defendants. Moreover, although they admitted to giving moral and symbolic support to draft resisters, the Boston Five denied counseling or urging young men to resist the draft. Thus, because they could not in good conscience plead guilty to charges of conspiracy to counsel draft resistance, the Boston Five chose to assemble a team of lawyers whom they hoped would beat the government at its own game. ${ }^{32}$

When the indictments first came down in January, the American Civil Liberties Union jumped at the chance to represent the Boston Five. Melvin Wulf, the national

32 Joseph Sax, "The Trial," Michigan Daily, 4 Jun 1968, reprinted in Resist Newsletter \#13 (Jul 1968), p. 4, Box 28, BSP; Mitford, The Trial of Dr. Spock, pp. 76-77; Ferber interview, 16 Jun 1998. 
legal director for the ACLU and Jim Oestereich's lawyer in his Supreme Court case, described the Spock indictments as "a major escalation in the administration's war against dissent," and announced that the ACLU would assemble a team of lawyers to handle the case on a pro bono basis. The organization quickly developed cold feet. however, and the national board quashed Wulf's plans to help the five indicted men. An official statement claimed that the case went beyond civil liberties largely because the organization had hitherto "assumed the draft laws were constitutional." The Civil Liberties Union of Massachusetts (CLUM), the state affiliate of the ACLU, broke ranks and offered its services to the defendants anyway. When affiliates in New York, California, and New Jersey also protested, the ACLU held another board meeting on March 2 and voted to support the defense of the Boston Five with legal and financial help. In later years, this crisis came to be seen as a critical test for the ACLU - one that it ultimately passed - but at the time, it hardly mattered to the defense. Lawyers for each of the defendants had been on the job for weeks and the ACLU's final resolution of the matter made little impact. ${ }^{33}$

The Boston Five, acting individually, chose what turned out to be an eclectic mix of attorneys to represent them. Some were high profile, nationally-known lawyers, while others practiced only in Boston and came to the case through the Civil Liberties Union.

${ }^{33}$ Jessica Mitford, "The Role of the American Civil Liberties Union in the Case of the Boston Five," Appendix 6 in The Trial of Dr. Spock, pp. 272-274; remarks of Marcus Raskin at Massachusetts Civil Liberties Union dinner in honor of the $25^{\text {th }}$ anniversary of the Spock Trial, 2 Oct 1993, Park Plaza Hotel, Boston (see "Conspiracy! Bill of Rights Dinner," 1993 videotape made of the meeting, copyright Roger Leisner, Radio Free Maine). 
Marc Raskin, for instance, secured the services of Telford Taylor, a law professor at Columbia University best known as the chief American prosecutor in the Nuremberg War Crimes tribunal. (Taylor, in turn, retained Calvin Bartlett, a 35 year veteran of the Boston courts, to work with him.) Dr. Spock hired Leonard Boudin of the New York firm of Rabinowitz, Boudin, and Standard, a firm known as much for its left-leaning politics as for its capable representation. The firm, for example, represented the Cuban government in all litigation with the American government. In thirty years of work, Boudin (whom Jessica Mitford referred to as "a sort of Clarence Darrow of the appellate bar") represented many clients called to testify before the House Un-American Activities Committee and Senator Joseph McCarthy's committee investigating suspected communist subversives. Not long betore the Spock case, he successfully took up the case of Julian Bond, civil rights leader and state legislator from Georgia, who, because of his outspoken opposition to the war in Vietnam, found himself removed from his seat by the House of Representatives there. The Reverend Coffin, with the help of Yale law professor Abe Goldstein, hired James St. Clair, a highly regarded Boston attorney who had once assisted Joseph Welch as counsel for the Army in the Army-McCarthy hearings and who would later gain more notoriety as one of Richard Nixon's attorneys during the Watergate scandal. The last two defendants. Michael Ferber and Mitchell Goodman, availed themselves of the services of William Homans and Edward Barshak, respectively, both CLUM lawyers with longstanding interest in and experience with civil liberties 
cases. $^{34}$

Despite the formidable array of legal talent, the defense ceased to act in unified fashion once the lawyers took over. Not only did some of the attorneys lean on their clients, urging them to refrain from the kind of public antiwar activity that got them indicted, but they did not work well together. Each lawyer filed his own motions for his client and generally kept his trial strategy to himself. As the trial approached, it appeared that the Boston Five could not even conspire to forge a united defense..$^{35}$

The failure to conduct a cohesive defense put the defendants at somewhat of a disadvantage when confronted with an efficient prosecution. Assistant U.S. Attorney John Wall, whom one observer described as "a cross between a fox terrier and a young bloodhound," presented the case. Only one other person, Joseph Cella of the Justice Department, sat next to Wall at the prosecution's table. Wall grew up in a working-class family in nearby Lynn. He put himself through Boston College while working nights at a Lynn tannery, and later went to law school at Columbia University. He joined the organized crime division of the Justice Department in 1963 under Attorney General Robert Kennedy and, while in Washington, completed a Masters degree in labor law at Georgetown. Although he enjoyed the work in organized crime. he wanted to get more trial experience, knowing that it could lead to a job in Boston. At the time, Kennedy oversaw a program in which he sent some young lawyers to the US Attorney's office in

\footnotetext{
${ }^{34}$ Mitford, The Trial of Dr. Spock, pp. 78-84; Ferber interview, 16 Jun 1998; Coffin interview, 28 Aug 1997.

${ }^{35}$ See records of U.S. v. Coffin, et al, CR-68-1, National Archives, Waltham, MA; Ferber interview, 16 Jun 1998; Mitford, The Trial of Dr. Spock, p. 82.
} 
Washington to get trial experience, and after a year in the program, U.S. Attorney Arthur Garrity hired Wall in Boston.

From 1964 to 1966 , John Wall handled a variety of cases, primarily focusing on fraud. But when the Assistant U.S. Attorney handling Selective Service cases left the office in 1966. Garrity told Wall that he wanted him to take over. Wall protested. Although he had served as a paratrooper in Korea between college and law school, he opposed American involvement in Vietnam and sympathized especially with religious objectors, like Jehovah's Witnesses. to the war. Garrity responded that unless Wall could tell him that he was morally opposed and could not in good conscience prosecute draft cases, he would have to take the assignment. Wall could not go that far. He considered himself a "Lyndon Johnson liberal Democrat" and would have preferred that the nation's resources be marshaled to "doing good" at home rather than "supporting dictators and butchers all around the world [simply] because they say they're anticommunist," but, "in those days," he later recalled. "it never occurred to me that -hey, this [the draft] is morally wrong." He took the appointment to handle draft cases and long before the New England Resistance rose to prominence, Wall prosecuted John Phillips, David O'Brien, David Benson, Gary Hicks, David Reed, and Robert Talmanson. All were convicted and sent to prison. ${ }^{36}$

In December 1967, John Wall received a call from Attorney General Ramsey Clark regarding the Spock case. Clark and Wall had worked together over the last several

${ }^{36}$ Croce, "The Boston Happening," National Review, 18 Jun 1968, p. 602; Wall interview, 26 Jun 1998. 
months as Wall led a Justice Department probe into allegations of financial misconduct by Congressman Adam Clayton Powell. After conferring with Paul Markham, the U.S. Attorney who replaced Arthur Garrity in Boston, Clark tapped Wall tc prosecute the case. $^{37}$

In April, at a hearing on pretrial motions, it became immediately clear that John Wall would benefit from the judge selected for the case. At 85 years of age, Judge Francis J. W. Ford's career spanned the entire century. Ford grew up in South Boston and worked his way through Harvard, graduating with Franklin Delano Roosevelt in 1904. He served on the Boston City Council under James Michael Curley during and after the First World War. In 1933, Roosevelt made Ford a federal prosecutor and five years later appointed him to the bench. Throughout his tenure on the bench, critics charged that Ford's experience as U.S. Attorney "left him with at least some noticeable sympathy for the prosecution's point of view." The old jurist interpreted the law with remarkable consistency over the years. Just as he religiously followed a daily lunchtime routine that included dining on a hard-boiled egg and an apple followed by a walk, he never wavered in his belief in the sanctity of the law. As the Boston Five would soon learn, when someone broke a law, no matter what the law, motive mattered not a whit to Judge Ford. ${ }^{38}$

Moments after taking his seat in the courtroom for the pretrial hearing, Judge Ford

${ }^{37}$ Wall interview, 26 Jun 1968.

${ }^{38}$ Mitford, The Trial of Dr. Spock, p. 169; "Courthouse's Squeaky Wheels of Justice Recalled," Boston Globe, 23 Aug 1998, p. B4. 
announced that he would not allow the defense to invoke the Nuremberg principles during the trial. Moreover, he said. debates over the legality of the war and the draft were irrelevant to the facts of the case and would not be permitted. Just like that, with stunning dispatch, Ford quashed the defendant's principal hopes for their case. Henceforth, the entire proceeding could only fall short of the antiwar movement's expectations. A direct (or indirect) legal challenge to the administration's policies in Vietnam would not happen, at least not in this trial. ${ }^{39}$

When the first day of the trial arrived a few weeks later, the defendants, though they "radiated confidence in the justness of their cause" according to one writer, quickly found themselves at an even greater disadvantage when they saw the prospective jurors. Of the 88 people milling about in the corridors outside the courtroom, only five were women. In a trial in which the most recognizable defendant was a world renowned baby doctor. the almost complete absence of women, those most likely to have read Baby and Child Care, caused Leonard Boudin to protest vociferously. He called the clerk of the court to the stand to explain how he selected this unlikely mix of men and women. The clerk informed the court that he did not follow a formula for random selection but instead looked up in the air, and put his finger down on the voter registration list. He said he realized that the result made him "look like a misogynist," but stood firm that the calling of so many men did not occur deliberately. When Coffin's attorney, James St. Clair suggested that the clerk might occasionally skip over a woman's name because the court generally excused housewives more often than men (thus creating more paperwork),

${ }^{39}$ Mitford, The Trial of Dr. Spock, p. 91. 
Judge Ford finally stepped in and ended the questioning. By the time the lawyers finished with their selections and had expended all of their challenges, the Boston Five sat across the courtroom from an all-male jury..$^{+0}$

The government presented its case first. In methodical fashion. John Wall took the jury through the series of events that the prosecution saw as the framework for the conspiracy. He described the early October press conference announcing the Call to Resist Mlegitimate Authority. (At one point in this discussion he mentioned Noam Chomsky, but said that he was "not here today to my knowledge." When Boudin objected and pointed out that Chomsky indeed sat at that moment in the courtroom, Wall responded ominously: "At least he is not sitting in the bar as a defendant [pause] today.) He showed films of the October 16 draft card turn-in and burning at the Arlington Street Church, and entered into evidence enlarged photographs of draft cards collected there. Wall put John McDonough of the Justice Department on the witness stand to describe the conveyance of the draft cards to the Attorney General. The Assistant U.S. Attorney also presented the fabricoid briefcase, photostats of the cards, as well as the ashes from one of the cards (reconstructed by the FBI and secured between two pieces of glass) as government exhibits. In total, the prosecution scrupulously presented evidence detailing the overt acts for which the defendants were indicted. Of course, the defendants did not deny that they committed any of these acts; indeed, they had performed them publicly with hope of gaining the government's attention. Still. they thought, these events hardly constituted a conspiracy. "The government has bitten off less than it can chew," one

${ }^{40}$ Mitford, The Trial of Dr. Spock, pp. 97-99. 
court observer said. ${ }^{41}$

Indeed, the government failed to mention the one event that might have been more fairly characterized as evidence of a conspiracy. On October 2, 1967, shortly after holding the press conference that announced the Call to Resist at New York's Town Hall, a large group of the signers of that statement went to the Columbia University Faculty Club, where they had reserved a room - again, without trying to hide anything. According to Noam Chomsky, the group held a meeting at which they "worked out the details of what [the government] would call the conspiracy." They planned the formation of their organization, Resist, and how it would operate. They lined up the key contact people for the organization around the country and worked out networks of communication. None of the overt acts listed in the Spock indictment provided evidence of a conspiracy in the way that this meeting did. Yet, it never came up in the trial. ${ }^{+2}$

Nevertheless, the legal standards for proving the existence of a conspiracy made it easy to convince the jury in this case. As John Wall eventually explained in his closing argument, members of a conspiracy do not have to know one another nor does the conspiracy have to take place in secret. Each member of a conspiracy merely has to "have knowledge of the aims and purposes" of the conspiracy, and "agree to those aims and purposes," he said. At that point, each participant "becomes liable for all future and past acts" of the conspiracy. Furthermore, Wall argued, if the government proved that the

${ }^{41}$ See transcripts of U.S. v. Coffin, et al, CR-68-1, National Archives, Waltham, MA; Mitford, The Trial of Dr. Spock, pp. 96-134; Daniel Lang, "The Trial of Dr. Spock," The New Yorker, 7 Sep 1968, p. 48.

${ }^{42}$ Chomsky interview, 20 May 1997. 
Boston Five conspired to commit just one of the acts with which they were charged, then that would be sufficient for a guilty verdict; the prosecution did not have to prove that the defendants conspired to commit all of the acts listed in the indictment. To better illustrate his points, Wall dissected the plot of a popular 1956 film. In director Stanley Kubrick's The Killing, actor Sterling Hayden's character. Johnny Clay, schemes to rob a racetrack. He recruits several others individually to assist him and, for the most part, tells them only of their role in the plan; they do not know about the others that Clay has enlisted. He hires someone who, posing as a disabled veteran, parks in the parking lot at the track and shoots the favorite horse in the race as a way of creating a diversion. Likewise, Clay employs a bartender at the track and another man to get into an argument with one another and have it escalate into a fight as a second diversion. As the public and the police scramble to find out what is happening, Clay goes to the window of a teller he has hired to gain access to the money. He stuffs the cash into a duffle bag and throws it out a window to a policeman whom he recruited to make the getaway with the loot. ${ }^{43}$

Each of the characters in the film knew that they were involved in a plot to rob the racetrack and, by participating, approved of the plan. As John Wall explained to the Spock jury, even though few of these characters knew each other, all were part of a conspiracy. Therefore, Wall finally stressed, the jury should regard as irrelevant the persistent claims of the Boston Five's lawyers that most of them barely knew each other and, in some cases, did not meet until after they were indicted. From the government's

43 "Closing Argument to the Jury by Mr. Wall," U.S. v. Coffin, et al, CR-68-1, transcript of trial, vol. 18, pp. 93, 96, 98-100. 
perspective. the actions of the five defendants met the legal standards for establishing a conspiracy. All of them knew that they were involved in a national effort to undermine the Selective Service System and affirmed it by taking part in the overt acts outlined in the indictment. Case closed.

When the government rested its case, then, it had established that the defendants did, indeed, take part in the series of events culminating in the draft card turn-in at the Justice Department. As the defense began to present its case, most notably by putting the defendants on the stand. the prosecution's objective - consciously or not - seemed to shift from trying to prove conspiracy to trying to prove that the defendants were guilty of urging, convincing, inducing, even pushing draft age men into draft resistance. This development seemed to catch the defense off-guard, for the indictment did not charge the Boston Five with the actual acts of counseling, aiding, and abetting draft-age men to resist the draft; rather, it charged them with conspiracy to counsel, aid, and abet. The government's new emphasis suited the cross-examination of the defendants better than focusing on the existence of a conspiracy, which the defendants would only deny and which the government believed it already proved. As the testimony of several of the defendants soon demonstrated, the strategy worked.

The Reverend William Sloane Coffin, Jr. took the stand first and gave the first clues that the defense would not only be forbidden to address the larger issues important to the antiwar movement but that the kind of defense waged would be disappointingly lawyerly and timid. James St. Clair, Coffin's attorney, took his client through the events described by the prosecution as making up the conspiracy and asked Coffin why he took 
part in the October 20 Justice Department demonstration and draft card turn-in. Coffin replied that first, he wanted to show "moral support," for the resisters; second, he hoped it would "force" the government to prosecute him and others for violation of the Selective Service Act, thus bringing about a trial in which the legality of the war and the draft could be challenged; and third, he hoped that his presence would help the draft resistance movement to "win the hearts and minds of the American people." But when St. Clair asked him if he believed the turning-in of draft cards would undermine the Selective Service, he answered "Certainly not." "Why not?" asked St. Clair. "Because turning in of draft cards speeds up induction....it leads to reclassification." Defense supporters squirmed. Did he really believe that? First of all, no one knew that General Hershey would order punitive reclassifications and accelerated inductions for those who turned in their cards until a few weeks after October 20. Second, as Jessica Mitford pointed out, was the jury "really supposed to think that Mr. Coffin's purpose in handing over the draft cards was to clear the way for inducting the registrants into the armed forces," as St. Clair's line of questioning seemed to suggest? ${ }^{\text {th }}$

On the stand. Coffin continued to equivocate and backtrack. He did not appear to be the same man who earlier suggested standing mute and defiantly marching off to prison. In the most dramatic example of this, John Wall zeroed in on the power of Coffin's oratory to move young men to commit crimes. Wall started by eliciting from Coffin that he had worn his clerical robe during the October 16 service at Arlington Street

${ }^{44}$ U.S. v. Coffin, et al, CR-68-1, transcript of trial; "Coffin Outlines Protest Goals," Boston Globe (Evening edition), 31 May 1968, p. 6; Mitford, The Trial of Dr. Spock, p. 139. 
Church and that he had spoken from the pulpit there.

Wall: "Did you consider it at least a partially religious ceremony?

Coffin: Yes.

Wall: And the turning in of draft cards, did you consider that a religious act?

Coffin: In many ways, very religious.

Wall: Were there other skilled speakers?

Coffin: Yes.

Wall: It might even be said that they were moving speakers?

Coffin: That's correct.

Wall: Did it occur to you that these moving speakers, and particularly you, might move others with weaker spines to turn in their draft cards?"

Coffin: No.

Wall: It didn't?

Coffin: It did not.

Wall: It never entered your mind.

Coffin: There might have been an outside chance but their decisions had already been made.

Wall: Oh. You already knew the decisions had been made.

Coffin: That was my understanding.

Wall: You're sure that not even one person turned in his draft card because of the moving speeches?

Coffin: I said there was an outside chance, but that was not my purpose.

The jury, however, had seen film of Coffin's speech as well as his other address at the

Justice Department; and if they didn ${ }^{\circ}$ remember it, Wall reminded them. For example,

on October 20, Coffin told the crowd that the law of the land was clear:

The National Selective Service Act declares that anyone "who knowingly counsels, aids, or abets another to refuse or evade registration or service in the armed forces...shall be liable to imprisonment for not more than five years or a fine of ten thousand dollars or both.'

We hereby publicly counsel these young men to continue in their refusal to serve in the armed forces as long as the war in Vietnam continues, and we pledge ourselves to aid and abet them in all the ways we can. This means that if they are now arrested for failing to comply with a law that violates their consciences, we too must be arrested, for in the sight of that law we are now as guilty as they.

Whether or not Coffin intended it, a reasonable person could easily envision a young man 
being inspired to turn in his draft card after hearing such language from a man of his stature. And Coffin's response that he never considered the power of his speeches to move people to resist the draft seemed disingenuous. ${ }^{+5}$

In later years, William Sloane Coffin acknowledged that he walked a fine line between counseling, aiding and abetting. "I felt very strongly that I personally had never counseled," he reflected, "because I didn't think it was my role as chaplain at Yale University to counsel people to turn their draft cards in...For me as a pastor, that would have been wrong." Instead, he sought to limit his participation to aiding and abetting those who had already made up their minds. Still, he admitted, "aiding and abetting is an indirect form of counseling." When others saw someone of Coffin's standing aiding and abetting others, "the implication is that these guys are the really conscientious ones" and anyone wanting to be thought of in that way, would follow suit. ${ }^{46}$

John Wall thought Coffin made a terrible witness. "He did an awful lot to win my case for me," the prosecutor said. Indeed, Wall believed that Coffin could have swung the case and at least secured a hung jury if only he had maintained his defiance and pleaded the rightness of his cause. Wall previously witnessed Coffin at his oratorical best and admired the "musicality and poetry of his words." but to his "dismay and disappointment," Coffin waged a "lawyer's defense," and that, Wall pointed out, "was not what the movement needed at the time." If, instead, Coffin had "preached to that jury and acknowledged legal responsibility...he'd have been magnificent," Wall later

\footnotetext{
${ }^{45}$ U.S. v. Coffin, et al, CR-68-1, transcript of trial.

${ }^{46}$ Coffin interview, 28 Aug 1997.
} 
commented. "But to get up there and try to weasel...he guaranteed at least his own conviction. ${ }^{947}$

Coffin's testimony showed the influence of his lawyer, and soon the entire defense became regarded as too lawyerly by their supporters and even by the defendants themselves. As the government relentlessly asserted that the defendants, through their speeches and actions, were inducing and inciting draft resistance among young men, the defense responded that they were only stating their opinions, exercising their First Amendment right of free speech, and offering their support to any man who already decided to resist. In his closing arguments. Leonard Boudin told the jury that the case raised questions of "freedom of speech, of association, of assembly and even of the freedom of the press." Thus, the defendants, all of whom passionately opposed the war, and all of whom a reasonable person would expect to be actively working to stop the war (rather than just talking about it). seemed now to be saying that they were only speaking, that they really were not doing anything of consequence. It rang hollow to most everyone in the courtroom. During the trial, William Sloane Coffin told Daniel Lang of The New Yorker, "I wanted a trial of stature. I wanted to test the legality of the war and the constitutionality of the Selective Service Act. I wanted a trial that might be of help to selective conscientious objectors. But this - what is it?"48

Indeed, Mitch Goodman, in particular, gave the impression during his testimony that the group really had not accomplished many of its objectives because of

\footnotetext{
${ }^{47}$ Wall interview, 26 Jun 1998.

${ }^{48}$ Lang, "The Trial of Dr. Spock," p. 53.
} 
disorganization and miscommunication. He described how Coffin forgot to sign and forward the letter requesting an October 20 2 th appointment with Ramsey Clark back to Goodman and told the amusing story about his and Ben Spock's repeated attempts to get arrested for civil disobedience at a chaotic demonstration in Manhattan. It became so laughable that Michael Ferber at one point during the trial wrote a note and passed it down the table to his fellow defendants: "The defendant Ferber makes a motion for severance on the grounds of incompetence on the part of his co-conspirators who, the testimony has shown, were unable, despite their best efforts, to conspire, combine, confederate, or agree to do anything, and in general could not organize their way out of a paper bag."

These lighter moments and a general air of support helped to sustain the defendants through more than three weeks of testimony. Certainly, Boston's new reputation as the center of the draft resistance universe (thanks to the trial, the sanctuary. the O'Brien decision, and a draft board raid at Boston's Customs House - all of happened in the same three week period) buoyed the defendants, too. Probably more than anyone, Michael Ferber enjoyed going to court every day. Years later he recalled his daily routine to an historian:

Every weekday morning during the trial I would just put on my coat and tie, walk out my door... wind my way through Beacon Hill, come down through the Boston Common, go by my lawyer's house, and the two of us would march over to the Federal Court a few blocks away. He knew everybody, because he was an old Boston Brahmin, and I ended up knowing everybody because my picture was in the paper and I had all

${ }^{49}$ U.S. v. Coffin, et al, CR-68-1, transcript of trial; Mitford, The Trial of Dr. Spock, p. 150. 
these people coming up and saying, 'Congratulations.' So I felt more like a citizen of Boston, like someone who really belongs in the city. I felt like this was Athens: this was a real city-state, a public, and I was...exercising my political rights. I loved that feeling...

A considerable amount of socializing also took place both at and away from the courthouse during the trial. The defendants ate lunch with reporters or friends almost every day. One afternoon. William Sloane Coffin's mother arrived (she came to the trial every day) with a huge picnic basket, which she laid out at the end of an empty corridor so that the defendants could enjoy it in peace. In addition, John Kenneth Galbraith, the Harvard economist, held a cocktail party at his home during the trial that attracted many people associated with the antiwar movement. During the party, Jessica Mitford, then working on a book about the trial, approached Mitch Goodman and a few other people and, looking around the room, said, "My dears, isn't it lovely? Just like a cruise." So, despite the disappointing course of the trial itself, the community of support that seemed to grow out of it cheered the defendants' spirits. ${ }^{50}$

Ultimately, however, the trial could only disappoint. Not only did Judge Ford completely prohibit the defense from putting the war and the administration on trial. but the defendants' secondary goal of taking their message to a wider public likewise fell flat. Although the judge allowed the defendants to testify as to their "state of mind" at the time they took part in their draft resistance activities (as distinct from their motives), very little

${ }^{\text {so }}$ Wells, The War Within, p. 233; Ferber interview, 16 Jun 1998; Mitchell Goodman, remarks made at the Massachusetts Civil Liberties Union dinner in honor of the $25^{\text {th }}$ anniversary of the Spock Trial, 2 Oct 1993, Park Plaza Hotel, Boston (see "Conspiracy! Bill of Rights Dinner," 1993 videotape made of the meeting, copyright Roger Leisner, Radio Free Maine). 
of it filtered through the media to the general public; only those who carefully combed their daily newspaper for such details could get beyond the government-fostered image of older men manipulating younger ones to break the law. Finally, for much of the antiwar movement, a defense predicated on claiming First Amendment freedoms seemed to minimize the importance of civil disobedience and of increasing the coefficient of friction until the war ended. The jury seemed to sense it, too. With the exception of Michael Ferber and especially Dr. Spock, the defense strategy created the impression that the defendants were putting aside their principles just to get off.

John Wall highlighted this contradiction in his closing arguments. On the one hand, he seemed to hold Spock in high esteem, telling the jury that "the defendant Spock on the stand was a man who appeared to be telling the truth, appeared to be hiding nothing...I submit on the evidence that the man convicted himself on the stand - that's for you to decide." Wall later added that "if Dr. Spock goes down in this case, he goes down like a man, with dignity, worthy of respect." At the same time, however, the prosecutor charged that "there [were] others in this case, other defendants, who didn't appear to be so candid." He reminded the jury that in December 1967, Coffin appeared on the television news show Contact, and told the anchor that if a prosecutor asked him if he aided and abetted these people in turning in their cards, Coffin said, "Yes, I did." This differed sharply from the response to a similar question during the trial. ${ }^{5 i}$

In closing arguments, the defense attorneys remained generally satisfied to press the free speech line, though the two CLUM lawyers attempted to make larger points. Ed

${ }^{s 1}$ U.S. v. Coffin, et al, CR-68-1, transcript of trial, vol. 18, pp. 108-109, 113, 118. 
Barshak reminded the jury of the ongoing war in Vietnam, noting that its existence had been present in the "atmosphere of this courtroom" throughout the trial. And although the judge would not allow discussion of the legality or morality of the war and the draft, Barshak asked the jurors to judge the conduct of the defendants against the context of the war and the divisions it created in American society. Bill Homans, after attempting to portray his client, Michael Ferber, as unacquainted with his co-defendants and absent from many of the events described by the prosecution, finished his closing argument by raising the issue of individual morality and its place in a civil society. "Few are willing to brave the disapproval of their fellows, the censure of their colleagues, the wrath of their society," he said. "Moral courage is a rarer commodity than bravery in battle or great intelligence. Yet it is the one essential vital quality of those who seek to change a world that yields most painfully to change." He urged the jury to find Ferber not guilty. 52

On June 14, 1968, the jury returned its verdict. After seven hours of deliberation, the 12 male jurors found William Sloane Coffin, Benjamin Spock, Mitchell Goodman and Michael Ferber guilty of all charges except counseling draft age men to turn-in their draft cards. At the same time, they acquitted Marcus Raskin, whom they suggested had been only minimally involved in the events outlined in the indictment. (Certainly, the propensity of Justice Department officials and the prosecution to confuse Raskin with Arthur Waskow, his partner at the Institute for Policy Studies, helped Raskin's case). On the whole, the convictions of the other defendants surprised few in the movement. No

52 U.S. v. Coffin, et al, CR-68-1, transcript of trial; Mitford, The Trial of Dr. Spock, pp. 182-184. 
one really expected them to be acquitted. Defendants in political trials rarely win; therefore, the four convicted men pledged to forge ahead with a lengthy appeal process. Meanwhile, Judge Ford scheduled the four convicted men for sentencing on July $10 .^{53}$ Soon after the trial ended, Judge Ford called John Wall and Paul Markham to his chambers to discuss sentencing. Ford told the two prosecutors that he wanted to be sure that the Justice Department intended to recommend prison sentences for the convicted men. He did not say why, but made it clear that suspended sentences would not be acceptable in this case. Wall informed the judge that he planned to meet with Ramsey Clark on the matter. According to Wall, Ford said, "Well, if he's not going to recommend time, I don"t want to hear anything from you [at the sentencing]." Wall assured Ford that he would personally convey the judge's view to the Attorney General. ${ }^{\text {st }}$

In general, John Wall and Paul Markham agreed that the defendants should get some prison time. If the convicted men received no punishment for their crimes, they thought, then what did it all mean? What was the point of the trial? Wall and Markham were almost certainly representative of the most Justice Department officials in holding these views, but not everyone agreed.

Solicitor General Erwin Griswold, for one, encouraged Ramsey Clark to act with restraint. In a letter dated July 2. 1968, Griswold told Clark that he had now won all the he could win from the Spock case. More important, he wrote, "from now on...you can

53 "Spock, 3 Others Guilty; l Acquitted," Boston Globe, 15 Jun 1968, p. 1; "Mistaken Identity for Raskin?" Boston Globe, 15 Jun 1968, p. 3; Mifford, The Trial of Dr. Spock, pp. 196-206.

${ }^{54}$ Wall interview, 26 Jun 1968. 
only lose."

You can lose a little by playing it too soft. You can lose a great deal, I think, by being too severe. This is a very delicate area, and there are large sections of the public who are much concerned and troubled.

It is clear that the defendants have broken the law. It is equally clear that they did it, rightly or wrongly, for reasons of conscience, - and that conscience has a great hold on Americans, for reasons rooted in our history and tradition.

If the defendants are treated as common criminals, many persons will rally to their support. More important than that, though, as I see it, is the fact that this would be neither wise nor just. Officers of the government must uphold the law. But they need not do it with a heavy hand. What is called for in this situation, I think, is a firm but gentle pressure. If the officers of the government act with restraint, there is hope of restraint on the other side...

Advice like this coming from a legal scholar of Griswold's stature carried considerable weight with an attorney general who shared his sensibilities. 55

As with the original decision to bring an indictment against the Boston Five, Ramsey Clark possessed a more complex view of the Spock Trial than anyone else in the Justice Department. Griswold may have been one of only a few who understood the attorney general's position. As the highest ranking law enforcement officer in the land. Clark believed (in spite of his own doubts about the war and the draft) that Selective Service laws had to be upheld. The Spock Trial did that. Punishment, though, stood as a separate issue and Clark maintained that the government and the law "should act with extreme sensitivity" in deciding it, "not with vengeance or harshness." He felt strongly about this, particularly in cases in which the defendants "acted from moral conviction." In a 1998 interview, Clark compared the Spock Trial to the hearings then being held by

\footnotetext{
${ }^{55}$ Memo to Ramsey Clark from Solicitor General Erwin Griswold, 2 Jul 1968, Personal Papers of Ramsey Clark, Box 123, LBJL.
} 
the Truth and Reconciliation Commission in South Africa. "Whether right or wrong, [the Spock defendants] acted from concern for others," he said. "A just or decent law doesn't punish people for that." Instead, Clark explained, like South Africa's Truth and Reconciliation Commission, the courts should "insist on accountability" and reveal the truth. After that. he said, "You don't seek vindictive punishment, you seek reconciliation." In the Spock Trial. Clark explained. "the conviction vindicated the law.... [but] this country ought to be greater and stronger than to feel you send somebody like that to prison. They not only weren't a threat to us in any way, they were our hope."56 In a $21 / 2$ hour meeting in Washington before the sentencing, Ramsey Clark explained his philosophy on punishment in the Spock case to John Wall and Paul Markham. He asked Wall to recommend suspended sentences to Judge Ford and even offered to talk to the judge himself if Wall preferred. But Wall accepted the assignment and when he returned to Boston he delivered the news to the judge. Before Wall could even finish telling Ford that the Department would recommend suspended sentences, the judge bellowed "I don't want to hear anything from anybody!" Clark also sent a letter to Judge Ford asking him to hand down suspended sentences, but when the sentencing date arrived, Ford would not accept and the government did not make a formal sentencing recommendation. 57

On July 10,1968, Judge Ford sentenced the four convicted members of the

${ }^{56}$ Clark interview, 6 Jan 1998; Clark interview, 29 April 1998. Note: Clark mentions the South Africa example in the $6 \mathrm{Jan} 1998$ interview.

57 Wall interview, 26 Jun 1998; Clark interview, 6 Jan 1998. 
Boston Five to two years in prison. In addition, he fined the three older men $\$ 5,000$ each. When Ford fined Michael Ferber $\$ 1,000$, the youngest defendant quipped that he received the "student discount." Before passing sentence, Judge Ford allowed the defense lawyers and their clients to make one last statement. Each of the attorneys recommended suspended sentences, again inconsistent with original Resistance notions of filling the jails. When given the opportunity to speak, both Dr. Spock and the Reverend Coffin declined. Mitch Goodman expressed his concern for young people who not only lived with the Vietnam War every day, but who also faced the prospect that "all life on earth may be extinguished" by nuclear war. Then one of those young people, Michael Ferber, went to the lawyer's lectern and made a brief, defiant statement: "Your Honor, I have nothing to say that might mitigate my punishment," he said. "I only wish to point out that I have been part of no conspiracy, but rather I have been part of a movement, a movement led by my generation." The movement, Ferber explained, originated in his generation's "horror and disgust" at some of the things carried out by their government at home and abroad. He further criticized those in the government who decided that the movement. which was "created out of love for what our country might be," now could be characterized as criminal. "I cannot leave the movement," he declared as he finished. "I will remain working in it. I have no regrets."

By July 1968, the movement in which Michael Ferber pledged to continue working no longer existed in its original form. Since the April $3^{\text {rd }}$ draft card turn-in on

58 "Spock, 3 Others Sentenced to 2 Years," Boston Globe (Evening Edition), pp. 1, 3; Mitford, the Trial of Dr. Spock, pp. 208-209. 
Boston Common, external events and conditions beyond their control overtook the draft resistance movement. The personal risk-taking that characterized draft resistance in its earliest stages receded as the movement turned in new directions. Over the summer a new pattern of activism began to develop that emphasized education over individual risk taking. Rather than adopting a strategy of direct action to combat racism, for instance, the New England Resistance satisfied itself with incorporating the issue into its written and spoken rhetoric. The Boston Five likewise chose a defense strategy aimed at educating the public about the war in Vietnam rather than adopting a more militant approach that, though it surely would have landed them in prison, would have done more to embarrass the Johnson administration. Instead of reinforcing the central tenets of draft resistance. the defendants, thanks largely to their legal advisors, lost sight of those tenets. Finally, the new sanctuary movement created a sense of personal risk but only for the men taking asylum. Police beatings notwithstanding, sanctuary supporters risked little; instead, their presence served primarily to attract the press and, in turn, introduce the public to the sight of GIs and antiwar activists collaborating to protest against the war. These were longterm strategies now, each with a hint of revolutionary possibility. Activists worked not simply for a draft resistance organization in Boston, but for a worldwide student movement.

The new directions that the New England Resistance took were not unwelcome or seen as an admission of failure. Certainly, there were some who disapproved of abandoning more radical, confrontational tactics. On July 10 , shortly after the Spock Trial sentencing, David Dellinger, and antiwar leader and himself a draft resister during 
World War II, spoke on the Boston Common. He urged Resistance supporters to stay militant because he feared that if antiwar and antidraft sentiment grew too soft, it would no longer be a deterrent to American policy makers. On the other hand, those who continued to be active with the New England Resistance were excited about the new directions of the movement. After all, how long could one expect the press to cover repeated draft card turn-ins? The movement needed a fresh approach. Outreach to GIs and high school students soon became top priorities; the building of a mass movement designed to fill the jails with America's middle class sons, bog down the court system. and impair the draft soon became a memory. As a result, the New England Resistance dwindled from an organization claiming more than 500 members to one made up of no more than 20 full-time activists. The new organizing required fewer people to carry it out. 
CHAPTER DX

\section{BEYOND DRAFT RESISTANCE: NEW STRATEGIES AND LOOSE ENDS}

He has honor if he holds himself to an ideal of conduct though it is inconvenient, unprofitable, or dangerous to do so.

Walter Lippmann, A Preface to Morals, 1929

Twelve days after Judge Ford passed sentence on the Spock defendants and David Dellinger voiced concern about the withering antiwar challenge to the administration, another rally demonstrated that, in Boston at least, Dellinger's fears were misplaced. Far from growing complacent, leaders of the New England Resistance and other groups with whom they were allied made it obvious that they were only growing more militant. Many now spoke of "revolution."

Ostensibly, the Monday, July 22, 1968, demonstration on the Boston Common had been organized as a forum for Eldridge Cleaver, the Black Panther leader and presidential candidate of the Peace and Freedom Party. But Bill Hunt, the longtime BDRG and New England Resistance leader, used his time at the rostrum to ruminate on the revolutionary potential of draft resistance. "The draft resistance movement," Hunt argued, "means the beginning of what may become a white revolutionary left in this country." The convictions of Spock, Goodman, Coffin, and Ferber, he said, could be taken as "a measure of the threat we pose to the system." This threat and the movement Hunt envisioned were in their embryonic stages, however. As he stood side by side with several Black Panthers, members of what he called "the one authentic revolutionary force in America," Hunt acknowledged that the "galactic" distance between the Panthers and 
the Resistance in terms of "dedication and risk":

When you hand in your draft card - to take the most radical action performed by the white left so far - you face five years in jail. But the members of your local draft board don't jump in unmarked patrol cars, armed to the teeth with the latest in western genocidal technology, and lay in ambush for you. The Oakland pigs do exactly that to the Black Panthers.

True enough. White draft resisters - and they were mostly white - did not face the same kind of physical threat that black revolutionaries encountered. But Hunt saw in draft resistance the potential for developing a white revolutionary movement because it constituted an organized effort to fight a system through which draft age men were "channeled, coerced, and brutalized." More broadly, he said, that brutalization also came in the form of the "banality and mental torment" of most people"s daily lives. As long as "the System" proved successful in getting whites to focus their "aggression" on blacks, hippies, and "commies" in Vietnam. Hunt asserted, then no one would notice that they were "suffocating to death at home."

In Boston, on the other hand. Hunt pointed to "a new climate of insurgency" growing out of three forces: the draft resistance movement, the defense of resisters in sanctuary, and a new development, "the defense of free speech on the Common." In recent weeks, Boston, like San Francisco the year before, experienced an unprecedented influx of young people, most of whom spent all of their time on the Boston Common. The press called them "hippies," and the name seemed to fit. Indeed, the young people called themselves the "hip community;" they gathered on the Common, smoked pot, and RCP.

1 "Resistance and the Panthers," The Resistance, undated (c. 15 Aug 1968), p. 7, 
listened to the music of Jimi Hendrix, the Jefferson Airplane, and the Grateful Dead (among others). And they did not do much else, except to make the residents of nearby Beacon Hill and the Back Bay uncomfortable.

In response to the hippie presence. the city instituted a midnight curfew on the Common, and over the weekend of 20 - $21 \mathrm{July}$, the Boston Police Department launched several raids on the hip community there. They arrested 83 people, all of whom came before Muncipal Court judge Elijah Adlow on Monday morning, 22 July. Adlow openly scomed the hippies as menaces to the city. "To look at these people," he sneered, "you'd think the fence fell down around the insane asylum." He accused them of turning the Common into a "festering sore," and asked rhetorically, "Is our beautiful Boston going to become a disaster area?" Despite his contempt for them personally, the judge gave probation to 44 of the defendants (whose cases were adjudicated in small groups) and declared six to be not guilty of the charges against them. He fined the remaining "hippies" $\$ 20$ each. ${ }^{2}$

Several of those arrested and sentenced by the Judge were leading figures in the New England Resistance. When the police round-up started on Saturday, the Resistance treated it as another manifestation of illegitimate authority in action, and staged a sit-in. This demonstration signaled a new willingness or propensity on the part of the Resistance leadership to tackle issues outside their traditional scope of protest. Thus, just as the escalating war and the draft had created an urgency among draft resisters to challenge the

2 "Hippies Draw Fines for Defying Curfew," Boston Globe (Evening), 22 Jul 1968, p. 3; "Judge Chastises, Penalizes Hippies," Boston Globe, 23 Jul 1968, p. 1. 
administration nine months before, the Spock trial verdicts, the recent assassinations, police and military attacks on student protesters around the world, and the ongoing war drove the New England Resistance to expand their mission.

Bill Hunt's speech about the white revolutionary left, therefore, characterized the hippies' challenge to the curfew as part of the growing "climate of insurgency" started by the draft resistance movement. More important, however, Hunt suggested that the crackdown by Boston Police and Judge Adlow (whom he called "Pig Adlow") amounted to political repression. "The Man" sees the new climate of insurgency, Hunt charged, and he plans to put a stop to it... We all know what it means when a government declares a curfew. We've seen it used in every black rebellion, and we've seen it imposed in Saigon. It means denying the streets to the people, tightening up on the small space people have to organize and fight for social change.

He urged his audience to resist the curfew. The Constitution. Hunt said, provides for free assembly. "We're going to tell Mayor [Kevin] White and Pig Adlow - tonight. tomorrow, for as long as it takes - that if we can't have free assembly, then there's going to be no peaceable assembly in Boston, Massachusetts." The targets of resistance thus widened from a narrow focus on the Selective Service and the Johnson administration to all authority - including local authority - deemed illegitimate. ${ }^{3}$

This rhetoric - the talk of revolution, identification with the Black Panthers, calling police officers and a judge "pigs" - echoed some of the points made in the Resistance "manifesto" printed in late May, but it expressed a new militancy. Staughton

3 "Resistance and the Panthers," The Resistance (newspaper), undated (c. 15 Aug 1968), p. 7, RCP. 
Lynd, the radical historian and one of the leading intellectual supporters of the Resistance, later lamented this shift. Hunt's praise for the Black Panthers and use of the word "pigs" in reference to the police, signaled a "change from the thoughtworld of October 16. 1967, after which the New England Resistance had thanked the Boston police for being different from Berkeley's." Years later, Bill Hunt characterized his inflammatory rhetoric as a product of a very depressing time for the antiwar movement. The highest profile opponents of the war were either being killed (Martin Luther King, Jr., Robert Kennedy) or given prison sentences (Spock, Coffin, Goodman, and Ferber). Despite Eugene McCarthy's early strength in the Democratic primaries, the party seemed poised to give the nomination to Vice President Hubert Humphrey. Indeed. rumors circulated that Lyndon Johnson still planned to secure the nomination through a "draft Johnson" campaign that would exploit the instability of the party at the coming convention in Chicago. Moreover, student protests were being defeated around the world and, even in Boston, students had clashed with police at the first sanctuary. According to Hunt, "We all went through a fairly apocalyptic phase, and I remember saying things on the Boston Common that I wish I hadn't said (I don't think they had any great lasting effect), but I thought, you know, we just really need a revolution."

This chapter argues that the moral clarity that had for so long fueled the urgency and impatience - of the draft resistance movement now pushed it in new directions and, ultimately, away from targeting the draft altogether. New England Resistance organizers never wavered in their commitment to end the war, but they did grow frustrated that all of

\footnotetext{
${ }^{4}$ Lynd and Ferber, The Resistance, pp. 224-225.
} 
their hard work had not had much effect. The draft card turn-in strategy of October 16 anticipated immediate prosecutions and convictions of draft resisters, but the Justice Department subverted that plan by pursuing only a handful of "ringleaders" while waiting for the rank-and-file draft resisters to refuse induction after being reclassified by their local draft boards. Meanwhile, American troop strength in Vietnam remained at peak levels, and thousands of Americans and Vietnamese continued to die.

The exasperation that accompanied this realization fused with the accumulating sense of rage that Resistance leaders felt in the wake of the seemingly relentless flow of shocking events - assassinations, riots, and crushed student rebellions - that punctuated 1968. Consequently, the New England Resistance leadership altered the organization's approach, and to some extent, broadened its mission. First, the group expanded its opposition to the war and the administration to a more general critique of the fundamental structure of American society. The literature they produced now attacked American "imperialism" and "capitalism" more stridently than ever before. The war, in turn, became a symptom of much deeper social problems. Second, to confront these larger issues, the Resistance sought to enlarge its constituency. They began new programs, the largest of which were aimed at helping disgruntled American servicemen find alternatives to service in Vietnam and informing high school students about the war and the draft. Open resistance to the draft no longer possessed much strategic value. Instead, these new measures followed a more typical New Left example of community organizing.

As the New England Resistance turned its attention to other tactics, the organization shrank in size. A core group of about 20 activists worked full-time on their 
new projects. And although each new sanctuary organized by the Resistance required hundreds of bodies to be successful, most rank-and-file resisters stopped participating in regular work at the Resistance office. When a federal grand jury began handing down indictments on draft resisters at the end of the summer, the vast majority of men who turned in their cards over the previous twelve months, for a variety of reasons, went unprosecuted. Those whom prosecutors did indict received little support from the New England Resistance, and a new organization called SUPPORT stepped in to make up for this absence. As 1969 dawned, organized draft resistance no longer existed in Boston, and the organization most associated with it faded from public view.

\section{So. You Sar You Want a Revolution}

By the time the Spock sentences were announced, a sense of frustration permeated the New England Resistance office. The trial of the Boston Five had proved especially disappointing and anticlimactic. A growing militancy hung in the air. Bob Shapiro, the MIT student who turned in his draft card after Martin Luther King's assassination, began working steadily in the Resistance office just as this shift in atmosphere occurred. Years later, he recalled that by the time he joined the organization that summer, many of his colleagues there "termed themselves 'revolutionaries' and not just draft resisters." This change occurred, he said, because "we just felt like we were banging our heads against the wall." Neil Goldberg, an October 16 resister and a draft counselor at Boston University confirmed this in a July 1968 interview. "I now consider myself to be a fullfledged revolutionary instead of just a radical," he said. "As a radical I felt that it was possible to move the conscience of the country...[but] nothing we can do seems capable 
of stopping Johnson. It's not going to stop through moral protest." Therefore, Goldberg asserted, "the only way change can occur is by changing the structure" of American society.

The intellectual context for the New England Resistance thus changed over the summer as the group reached a general consensus on the necessity of revolution. Jim Oestereich, the seminarian who had been moved to tears when he returned his draft card on October 16 exemplified this shift in perspective. In an August 1968 article in The Resistance, Oestereich wrote admiringly of the Black Panthers and noted that "white radicals" faced "the difficult job of moving from symbolic and token protests to organizing the revolution." To achieve this metamorphosis, the Resistance must, he argued somewhat vaguely, "totally organize against the oppressive institutions of this society," and move the country "toward a complete transformation of the American economy and political system." Ten months earlier, Oestereich could scarcely have imagined making such a statement, but now, as the prospects for peace continued to prove illusory, wholesale change seemed the only answer. ${ }^{6}$

On the one hand, Goldberg's and Oestereich's analyses betrayed a disappointment with the mass of their fellow citizens who had not been moved by the example of draft resisters to rise up in opposition to the war. But the two resisters also did not hold the rest of America responsible, individually or personally, for this failure. Instead of

s Shapiro interview, 13 Aug 1997; Larry Berren, et al, "The Resistor," unpublished paper, undated (c. July 1968), MKFP.

6 Jim Oestereich, "The Black Panthers, P.F.P., and the Movement, The Resistance, undated (c. 15 Aug 1968), p. 7, RCP. 
charging their fellow citizens - and especially fellow citizens opposed to the war - with possessing inadequate moral standards, Goldberg and Oestereich blamed "the system" for numbing the sensibilities of most Americans. Under a more just economic and political system, they seemed to contend, the American people would have immediately recognized the Vietnam War as immoral and illegal, and quickly demanded its end. The American consumer-capitalist system, however, had alienated so many that the Resistance message got through to proportionately few ordinary people. "Everywhere we find people," Goldberg noted, "who find their lives meaningless, even those who work in the middle class...this is because they have been exploited." As a result, the Resistance would have to go to the heart of the problem and overthrow "the system" responsible for this exploitation and alienation. ${ }^{7}$

As the Democratic National Convention loomed in the not-too-distant future, and as antiwar organizers from across the country planned to descend on Chicago to protest against the war during the convention, some in the New England Resistance saw in the convention an opportunity to press this point. On the eve of the convention, Joel Kugelmass wrote an article in The Resistance in which he celebrated two popular radical slogans: "Let the People Decide," and "The Streets Belong to the People." For Kugelmass, the time to "live by those slogans" had arrived. Specifically, he wrote, "it is time to take to the streets and start making decisions." Chicago, he predicted, "will be a

\section{Movement."}

7 Berren, et al, "The Resistor"; Oestereich, "The Black Panthers, P.F.P., and the 
mess, but it will be a beginning."

Most antiwar activists who went to Chicago did not expect their confrontation with the party in power to lead to a restructuring of American society, much less a revolution. Despite Abbie Hoffman's and Jerry Rubin's widely publicized threats to dump LSD in the city's water supply and carry out other stunts with their fellow Yippies (short for Youth International Party), the overwhelming majority of protesters came simply to demonstrate against the Democratic Party which appeared poised to nominate Lyndon Johnson's vice president, Hubert Humphrey, for president. Many of them supported Eugene McCarthy's candidacy and, thus, could in no way be considered revolutionaries.

Although a few members of the New England Resistance went to Chicago, most stayed home. Regardless, the chaos of the Chicago police riots shocked everyone in the organization. As a parallel drama unfolded in Prague, Czechoslovakia. with Soviet tanks crushing a student-led democratic uprising, millions of Americans witnessed the Chicago police use what Connecticut Senator Abe Ribicoff referred to as "Gestapo tactics" on young people in the streets outside the convention center. As Bill Hunt and Rosemary Poole watched the beatings of unarmed antiwar protesters on television in Boston, they sank into a state of despair. Poole mused about catching the next plane to Chicago, strapping dynamite to her body, and destroying the biggest building she could find. "People were just boiling with rage," Hunt later remembered. And that, he said, was "not

8 Joel Kugelmass, "Electoral Politics: The Art of Retaining Power," The Resistance, undated (c. 15 Aug 1968, p. 5, RCP. 
the best mood" for making political decisions."

By the fall, a year after the first draft card turn-in at the Arlington Street Church, the frustration and anger that the Resistance leadership felt fueled a reassessment of the organization's goals and strategies. At an 18 October 1968 general membership meeting, the leadership presented a statement of theory, strategy, and organization. In some ways. it echoed the "manifesto" produced in May, but it went further:

The Resistance should immediately and clearly state that American society is characterized by institutions that are under the sovereign control of a corporative ruling class; that its economic system, capitalism, is exploitative; that the government of the U.S. is by nature oppressive and that its policy of containing communism and promoting foreign investment is economically, diplomatically, and militarily imperialistic.

The Resistance should claim as its object nothing less than a total transformation of this society that will leave every remaining institution in the collective control of those whose lives depend on it. ${ }^{10}$

With this statement, there could be no doubt that the New England Resistance now openly identified itself with a socialist. if not anarchist, solution to not only ending the war but altering the fundamental economic and political structure of American society. As Dan Tilton, an older resister and office IWW historian, wrote around the same time: "It is time for the Resistance to state clearly that not only is capitalism insane, but more importantly that socialism is the only possible alternative." Much had changed in a year.

${ }^{9}$ Hunt interview, 31 Oct 1997.

10 "Proposed Basic Theory, Strategy and Organization for the New England Resistance," paper presented at NER general membership meeting, 18 Oct 1968, BTP. RCP.

"Dan Tilton, "Socialism and Human Freedom," The Resistance, Oct 1968, p. 8, 
Even so, all of this talk of revolution did not translate easily into practice. As this intellectual shift took place over the summer, the New England Resistance engaged in numerous new projects beyond draft resistance, but none could be seriously characterized as revolutionary. On the one hand, demonstrations grew more radical and strident. The Soviet invasion of Czechoslovakia in August provoked intense protests on the Common. and the appearance of Hubert Humphrey led to a "Dump the Hump" rally at Downtown Crossing and a clash with Boston police at the Statler Hilton. Through events such as these, the Resistance continued to make its presence known and continued to confront the public with the Vietnam War, but it did not materially move Boston or America closer to revolution.

Discussion of overthrowing the existing structure of American society, consequently, added up to little more than what historian Terry Anderson has termed the "rhetorical revolution." 12 The Resistance newspaper, newly revamped over the summer. reflected this tension between rhetoric and action. In an explanatory editorial, one unnamed writer wrote of the organization's realization that a "fundamental restructuring of American society" would be needed to overcome American imperialism and racism. "Only through revolution can we end the manipulation and distortion of our lives," he wrote. "Only through revolution can we hope to realize the possibilities for human freedom latent in the advanced state of American technology." He then turned his attention to more practical matters, saying one major task for revolutionaries is the "elevation of consciousness," presumably their own and that of others. As a result, the

${ }^{12}$ Anderson, The Movement and the Sixties, p. 202. 
New England Resistance now sought to "engage in other programs as well as draft resistance which reveal the illegitimacy of the authority over us and build a spirit of unified struggle."13

\section{Hippies and High Schoolers}

At the start. the group moved to elevate the consciousness of their own members and supporters. In early July, they started the Resistance Free School as a way to promote open investigation of a variety of topics. The Free School offered an alternative to the usual university education which, they argued, "cultivat[ed] individuals who consider Establishment needs over and above human needs." Most courses were taught seminar style, and revolved around common readings, with meetings often held at the house or apartment of the instructor (often a Resistance leader). Some of the courses offered focused on lighter topics such as "Conversational French," "Rock and Jazz Drumming," and "Woodwork and Cabinet Making," but most addressed contemporary issues or political theory; these courses included "American Labor History," "Origins of Radical Thought," "Comparative Revolutionary Development," "Hippies and the New Left," "the Writings and Theories of Herbert Marcuse," "the Media and the Movement," and "Black Nationalism, White Racism, and Black Power," and others. Most of these courses did not last through the summer, and some met only once or twice before folding, but the notion of a free school that challenged prevailing assumptions about education exemplified the

\footnotetext{
13 “Multi-Issue," The Resistance, undated, (c. !5 Aug 1968), p. 2, RCP.
} 
new Resistance goal of rebelling against the basic structure of American society. ${ }^{14}$

Into this climate stepped the "hip community" on Boston Common. Traditionally, most antiwar activists held hippies in contempt: rather than challenging American society, hippies seemed to be "dropping out" of society all together. As two BDRG activists said, they regarded hippies as "hopelessly individualistic" and as "people who didn't work." Moreover, the hippie lifestyle, especially the use of drugs, made them easy targets for government repression. Nevertheless, the Boston Common curfew issue brought the New England Resistance into an alliance with the hip community. On one level, they were attracted to the Common confrontation because of the free assembly issue at stake, but on another level, the hippies appeared to be a step ahead of the draft resistance community in rebelling against the fundamental structure of American society. To typical New Left charges that hippies were counter-revolutionary because they would not "get off their asses," Neil Robertson, one of the Resistance leaders arrested during the police sweeps of the Common, offered a defense: "The hippie is, de facto, leading a different life, a life that is resulting in increasing worry among the merchants of Charles Street, and the residents of Beacon Hill." To those residents of Boston's finest neighborhoods, "the hippie is a threat," Robertson argued. "He ain't buying and he ain't producing." In short, the hip community rejected everything about mainstream

14 New England Resistance letter re: the Free School, undated (c. Early Jul 1968), MKFP; Mary Fenstermacher, "Transcendance: NER Free School," The Resistance, undated (c. 15 Aug 1968), p. 8, RCP; Joel Kugelmass, "Free School," Boston Free Press, undated (c. 11 Jul 1968), p. 12, RCP; Olene and Dan Tilton interview, 16 Jun 1997. 
America. ${ }^{15}$

The leading spokesman of the Common's hip community, Ben Morea, made the Resistance-hippie alliance even easier to understand. Morea came to Boston from New York as a member of the Lower East Side collective, Up Against the Wall, Motherfucker. The name came from a line in a LeRoi Jones poem (the following line is: "This is a stickup'), and the group represented an unusual hybrid of anarchist political theory and countercultural direct action programs. As Todd Gitlin notes, the Motherfuckers organized as an "affinity group," a cultural and political representation of what society would look like after the revolution. They were hippies, but they were also revolutionaries. In Boston, Morea told reporters, "The existence of our community represents both an alternative to the present system and a means for its destruction." The hip community, he said. "rejects old middle-class values, especially that of the consumer life," while simultaneously making possible "a fuller and more complete life." This kind of rhetoric dovetailed well with the New England Resistance's own arguments for overthrowing existing society, thus facilitating an partnership between the two groups. As Morea concluded, "we feel that the existence of the hip community itself is fighting the Establishment."16

The relationship with the hip community soon became a burden to the Resistance,

15 Wright interview, Aug 1997: Hector interview, 1997; Neil Robertson, "Hippies and the New Left," The Resistance, undated (c. 15 Aug 1968), p. 6, RCP.

16 Todd Giltin, The Sixties: Years of Hope, Days of Rage, revised ed., New York: Bantam, 1993), pp. 238-241; "Up Against the Wall, Mother Fucker," Boston Free Press, $8^{\text {th }}$ Edition, undated (c. 1 Aug 1968), p. 7, AJP. 
however. First, the situation simply seemed unmanageable. Hundreds of hippies wound up sleeping in the basement of the Arlington Street Church every night, and dozens of others turned the Resistance office on Stanhope Street into a "crash pad." As Neil Robertson eventually realized, "it was a mistake to try to organize hippies" who generally eschewed any kind of organization. Worse than that, the situation grew violent when a group of toughs beat up several of the Motherfuckers on the Common. During the fracas, someone stabbed a Vietnam veteran who had joined the fight against the hippies. Police arrested Ben Morea for the stabbing and preparations for his court case quickly overshadowed the ongoing confrontation over the Common curfew. When the Resistance held a press conference for Morea to refute the charges, a full contingent of Boston reporters covered it, but the next day, not one story on the subject appeared in the papers or on television. Ultimately, for the Resistance. the hippies on the Common became a distraction that lasted much of the summer. "We just kind of got swept up in it," Bob Shapiro later said, and soon found themselves wishing the situation would just go away. ${ }^{17}$ In addition to the Resistance Free School and the Resistance-hippie alliance, the New England Resistance expanded its programs into some of Boston's suburbs over the summer. Small groups of Resistance activists fanned out to nearby towns such as Malden, Watertown, Newton and Belmont, as well as to those in outlying areas like Lexington, Concord, Hingham and Attleboro, aiming to elevate the consciousness of young men and women who lived there. The quality and success of these programs

${ }^{17}$ Ed Harris, interview with Eugene Navias, 27 Oct 1994, ASC Oral History Project, ASC Archives; Barrie Thorne, "Resisting the Draft," p. 83, Robertson interview, 7 Aug 1998; Shapiro interview, 13 Aug 1997. 
varied from place to place, and few of them left any record of their work. The Concord project is the exception to this generalization. There, in a town which boasted of its Revolutionary heritage and its association with Henry David Thoreau, a group of three activists formed the Concord Area Resistance Summer (CARS), a local organization that quickly grew to about 50 active local members.

From the start, CARS distinguished itself from the larger, more brazen Boston organization that spawned it. Rather than focusing on demonstrations or draft card turnins, it took a more methodical approach to educating the community of young people in Concord about the war and the draft. On one level, organizers said, they sought to "make people remember the war, no matter how hard they are trying to forget it."18 At the same time, however, CARS hoped to achieve much more. They envisioned a three point progression that began with raising the consciousness of individual young people in the community. This, they hoped, would lead to the elevation of a community consciousness (the second point), that would provide the foundation for a "lasting and viable organization within the community, oriented towards change through direct action" (the third point)..$^{19}$

If they ultimately sought to create a community organization that practiced direct action, CARS itself relied on other means to carry out its program. Aside from one

18 "CARS Mechanics," newsletter \#2, undated (c. 20 Jul 1968), BTP. Note: Indeed, the issue of complacency regarding the war faced most peace organizations as the entered the summer of 1968; Lyndon Johnson's announcement that he would not seek reelection created in many Americans a false sense that the war's end would come soon.

19 “Concord-Summer, 1968," newsletter, undated (c. Jun 1968), BTP. 
protest staged outside the Concord draft board offices toward the end of the summer, the group avoided demonstrations. As Süsan Starr, a Concord resident who became a CARS mainstay, later remarked, "you don't demonstrate in the suburbs; people don't like it." Instead, CARS did a lot of leafleting, and canvassing - looking for young men classified 1-A or high school men about to register for the draft. To these men, CARS offered draft counseling services. Many of the Concord residents who joined CARS came from the local Quaker meeting house, and therefore from a tradition of draft counseling. In addition, CARS adopted the Boston Draft Resistance Group's of taking counseling to pre-inductees via the Early Morning Show. They also hosted a dance and several poetry readings, staged some guerrilla theater, and held regular Monday night dinners at the Friends' meeting house. Finally, like the New England Resistance, CARS began its own Free School. They offered five courses, all of which were open to anyone who wanted to attend: The Draft - It's Organization and Functions; The Tragedy Called Vietnam; Aesthetic Critiques of America; The Urban Scene; and Afro-American History and White Racism. This wider array of programs aimed to reach as many people as possible. ${ }^{20}$ On the whole, however, CARS did not receive a warm reception in Concord or in the surrounding towns. Local police frequently harassed them, including at least one arrest for distributing leaflets at a supermarket. The suburbs, it seems, were places where most people did not expect to be confronted with information about the Vietnam War, and when they encountered CARS activists, it annoyed many of them. One woman

20 Susan Starr, interview with author, 4 Aug 1997; "Concord Area Resistance Summer Activities," in "Concord-Summer, 1968," BTP; "CARS Mechanics," vol. 1, no. 4, undated (c. Jul 1968), BTP 
complained to police that a spontaneous guerrilla theater performance - in this case a play based on the lyrics to the Fugs' song, "“Kill for Peace" - spoiled her picnic by the historic Old North Bridge. At times, supermarket customers reacted with hostility to leafleters, and on more than one occasion, groups of high school students threatened CARS activists with their fists. At the end of the summer, the organization lamented that it had not reached more than approximately 300 young people outside the group. They could take solace in knowing that they had radicalized a core group of local youth who had gravitated to CARS over the summer and who would take their politics with them to college in the fall. Furthermore, it appeared in September that a lasting community antiwar organization would take the place of CARS."t

CARS and the other suburban groups did set themselves apart from other similar organizations in its reliance on an overwhelmingly female membership. Five years after Betty Friedan articulated the grievances of millions of American women alienated within their roles as "homemakers," most women in affluent suburbs such as Concord continued to fill that role or, at most, held part-time jobs. Just as nineteenth century middle-class women participated in voluntary associations and women's clubs then, some middle-class women in the greater Boston area joined antiwar organizations like CARS. Although they did most of the "shit-work" that their female counterparts in the New England Resistance and BDRG did, women in CARS actually took on more obvious leadership roles as well. Susan Starr, for example, edited and wrote much of the monthly newsletter,

21 "CARS Mechanics," vol. 1, no. 4, BTP; "CARS Mechanics," vol. 1, no. 5, undated (c. Sep 1968), BTP; Starr interview, 4 Aug 1997. 
CARS Mechanics. and another women, Beth Navon. came to Concord as one of the three original organizers and exercised considerable influence within the CARS leadership." At the end of the summer, despite the mixed success of the suburban programs, the New England Resistance decided to make high school outreach and organizing one of its top priorities. Several factors instigated this new approach. First, over the summer, dozens of high school students from Boston and surrounding towns had called and stopped by the New England Resistance looking for information on the draft. In many cases Resistance staffers sent these people to BDRG for counseling, but the numbers made an impression. Second, the suburban programs had uncovered enough alienation among students to warrant continued action on this front. Third, and most important, Resistance leaders believed something had to be done to "offset the oppressive public education system." Here, in keeping with their revolutionary aims of restructuring American society, the Resistance attacked high schools as "instrument[s] of social channeling, devoted not to the development of individual creativity, but to standardization." To challenge the "inculcation of discipline and conformity" imposed on students in Bay State high schools, the Resistance resolved to take its antiwar and revolutionary messages to young people in these schools. By year's end, the New England Resistance operated high school organizing projects in several Boston schools and in more than 20 suburbs. $^{23}$

22 Start interview, 4 Aug 1997; "CARS Mechanics," vol. 1, nos. 2, 4, \& 5, BTP.

23 "The Resistance: Audacious System to Beat the System," Boston Globe 2 Jul 1968; NER Newsletter, Jan 1969, MKFP; Arlook interview, 12 Aug 1998. 
The high school programs initiated in the fall met with more success than their summer antecedents in large part because of a change in tactics conceived by Ira Arlook. Rather than raising the issues of the war and social channeling to high school students through multiple programs. Arlook narrowed the focus to one tactic: bringing Vietnam veterans into the high schools to speak with students as part of an "anti-recruitment program." Since the first sanctuaries of May and June, the New England Resistance had been steadily establishing good relations with Vietnam veterans who returned to the United States and began working, individually and collectively, against the war.

Although historians typically treat the GI and veteran antiwar movement in isolation from its civilian counterpart, the draft resistance movement, through its sanctuary organizing and this high school program, effectively formed a partnership between the two groups. Without the veterans, it is highly unlikely that school administrators would have granted permission to Resistance organizers enter their facilities and talk with students. These same administrators, however, generally proved eager to arrange student audiences for veterans. Therefore, Arlook encountered little resistance in his efforts to organize assemblies at which a veteran would speak with students about his experiences in Vietnam. Frequently, these discussions would take place after Arlook played a U.S. Government propaganda film such as "Why Vietnam?" or "Your Tour in Vietnam" for the students; the veteran would then describe how his experience differed from the film portrayals. ${ }^{24}$

24 NER Newsletter, Jan 1969, MKFP; NER Newsletter, Feb - Mar 1969, MKFP; Arlook interview, 12 Aug 1998. 
Once the Resistance had established "a little beachhead" in a high school, Arlook and others continued to help sympathetic students reach out to their classmates through additional events and often by starting an "underground" newspaper in the school. Although there is no way to measure the effectiveness of the Resistance's high school organizing, Arlook and others believed they were at least successful in offsetting the work of the armed services recruiters, and more salient, they were certain that they were educating students about the oppressive nature of not only their high schools and the draft, but of American society in general. Eventually, in the spring and summer of 1969. Arlook and others came to regard this kind of work as so important that they moved into some of these communities to do full-time school and neighborhood organizing. By then, the New England Resistance had abandoned all draft resistance efforts, and internal divisions had rendered the organization defunct, but the connections with veterans and high school students had provided a solid base for organizing in new directions. ${ }^{25}$

\section{The GI Alliance}

At the same time that the New England Resistance turned its attention to high school organizing, the group's work with GIs and veterans blossomed into a sanctuary movement that continued to garner headlines for the organization and, more important, laid the foundation for a new GI support program. It is puzzling that historians have virtually ignored the sanctuary movement and given only cursory treatment to the alliance formed between civilian and GI antiwar activists. Perhaps it has been too easy to accept the stories that portray returning soldiers as mistreated by civilian opponents of the war;

${ }^{25}$ Arlook interview, 12 Aug 1998; Robertson interview, 24 Aug 1997. 
images of long-haired protesters spitting on Vietnam veterans or calling them "baby killers" endure in the American consciousness despite a lack of documentation to support their veracity. ${ }^{26}$ And certainly there is plenty of evidence that many American servicemen, some even opposed to the war, regarded the largely middle-class, studentled. antiwar movement with contempt. ${ }^{27}$ In any case, the GI and veteran antiwar movement is typically treated in isolation from the civilian movement, as if the two did not, could not, cooperate. But they did. Long before the United States Serviceman Fund and GIs United Against the War were founded, and even longer before Vietnam Veterans Against the War rose to prominence, the draft resistance movement established strong relations with servicemen and veterans. The Resistance benefitted from the moral authority that a soldier brought to the antiwar movement, and the GIs and veterans profited from the organizational skills of the civilians.

After the first sanctuary at the Arlington Street Church in late May 1968, enlisted men "came out of the woodwork," looking for help from the New England Resistance. In June, Resistance activists organized sanctuaries in churches in Providence, Rhode Island. and Wellesley, Massachusetts, both of which ended with authorities dragging their quarry over blockades of supporters. In early August, the Friends' Meeting House in Cambridge granted asylum to another GI who remained there more than two weeks before the

26 The image of antiwar protesters spitting on returning veterans has recently been challenged persuasively in Jerry Lembcke, The Spitting Image: Myth, Memory, and the Legacy of Vietnam (New York: New York University Press, 1998). Lembcke, a Vietnam veteran and a sociologist at Holy Cross argues that not one single instance of an antiwar protester spitting on a veteran has ever been convincingly documented.

27 See Appy, pp. 223-224, 298-299, 301-306. 
authorities came to get him. Sanctuary soon swelled into a movement even beyond New England. By mid-summer draft resistance groups and other antiwar organizations hosted sanctuaries in Ohio, New York, Pennsylvania, and Califormia. Resistance organizers quickly recognized the value of sanctuary in reaching a new constituency: enlisted men. ${ }^{28}$ This new interest in the plight of American GIs represented a significant shift in Resistance attitudes toward military men. The draft resistance movement (and, indeed, the antiwar movement in general) had long assumed that anyone strongly opposed to the Vietnam War would never enter the military. As Nan Stone later noted in a speech she gave on numerous occasions, however, it eventually became obvious to members of the Resistance that young men enlisted or submitted to the draft for many reasons, "most of which have nothing to do with agreement with U.S. foreign policy." Specifically, Stone said, the Resistance learned that servicemen usually narrowed their enlistment decision down to one of four motives. Many men feared that being drafted would leave them with no choice regarding the branch of service in which they would serve; recruiters promised "choice, not chance" if one enlisted before being drafted. Some men, especially those from poorer families, enlisted as a step toward economic advancement. And others were attracted by recruiting campaigns that promised opportunities to learn specific vocational skills and to see the world. American society, finally, indoctrinated so many men, especially working-class men, with expectations that they should join the service as a way to learn loyalty, courage, and citizenship. Organizations such as the Boy Scouts (who

28 Resist Newsletters, 29 Jul 1968 and 27 Aug 1968, Spock Papers, Series II, Box 28; "Support Your American Way of Life," WIN 1 Oct 1968, p. 11, AJP. 
taught military-like discipline), and the American Legion (a veterans organization which gave out annual citizenship awards to young men), Stone argued, fostered this sense of obligation in many young men. ${ }^{29}$

It took Bill Chase, the AWOL soldier to whom the Arlington Street Church granted sanctuary, to get the Resistance to think about soldiers differently. Chase, who had served in Vietnam for nine months, described the war and military service in ways that few civilians could. Resistance activists soon developed a new appreciation for GIs and their own channeling experience, and likewise began to understand the options available to working-class men in a new light. That draft resisters had suffered the antagonism of many working-class men now did not seem so unreasonable; the privileges that came with being a middle-class college student included insulation from the kind of physical harm that working-class soldiers in Vietnam faced every day. Even if a GI opposed the war, he sometimes could not tolerate college students protesting against a war about which they knew so little. Sanctuary and other outreach to GIs, therefore, fostered a new understanding - and eventually an alliance - between civilian and military dissenters. ${ }^{30}$

By the fall of 1968 , sanctuary and GI outreach became the most prominent antiwar work done by the New England Resistance. Sanctuary had strategic value in that

29 Nan Stone, "GI Support Speech," undated, Nan Stone papers, copy in author's files.

${ }^{30}$ Stone, "GI Support Speech;" For an interesting discussion of the various factors contributing to GI resentment of antiwar protesters, see Appy, Working-Class War, pp. 299-306. 
it continued to attract media and public attention to the war and also to American servicemen who opposed it. In addition, Resistance activists hoped that sanctuaries would attract some of the high school students the organization was trying to organize at the same time. Moreover, Resistance organizers believed that the GIs who took sanctuary would actually be helped by it once apprehended by authorities; the attention garnered with each sanctuary; they reasoned would prevent the military from railroading the deserters into the stockade. When they did wind up in the stockade, Resistance activists visited them regularly and tried to arrange legal and financial assistance. Most important, sanctuary preserved the confrontational nature of Resistance opposition to the war. A showdown with authorities ended each sanctuary, but Resisters hoped that the specter of U.S. marshals, FBI agents, or military police apprehending an American serviceman amid a crowd of nonviolent, peaceful demonstrators would affect public opinion.

Although every sanctuary held in the Boston area and across the country over the summer took place in a church, the New England Resistance entered the fall hoping to extend the reach of sanctuary into more secular institutions. Three sanctuaries - at Harvard, Boston University, and MIT - grabbed the public's attention and brought hundreds of people into contact with the Resistance for the first time.

On September 22, Marine Corporal Paul Olimpieri, 21 years old and twice wounded in Vietnam, took sanctuary in the Andover Hall Chapel at Harvard Divinity School. It was the first time that a college or university had offered sanctuary to an American serviceman. In comments to the media, the seminarians, several of whom were members of the New England Resistance, noted that although they were part of an 
academic community, they had little to teach about their civilization "to a man who has already experienced some of the worst our society has produced." Instead, they concluded, "we have a great deal to learn from him."31

More important. however, the sanctuary organizers, reflecting the Resistance's more recent critique of the America system, described Olimpieri's sanctuary not simply as an act of protest against the war, but as a challenge to an oppressive society. "We know that divinity schools are open to the privileged few who qualify, and closed to others," they wrote in a press release. "Today, in opening this chapel to a man oppressed by a militarist society, we are looking forward to a day when privilege no longer closes its doors to the oppressed." Likewise. in a separate statement, the New England Resistance described Olimpieri's sanctuary in the context of a new alliance between 'those forces struggling to create a society in which men can be free." Both draft resisters and GIs like Olimpieri were "completely opposed to subjugation and bondage." Consequently, they said, "we mean to seize and maintain control of our lives and the use to which they are put."32

For his part, Paul Olimpieri limited his criticism to the military and to the war. The son and younger brother of Marines, he had grown up in Fairfield, Connecticut. After graduating from Andrew Ward High School in June 1965, Olimpieri apprenticed in a nearby machine tool factory. He also played the drums in a local rock-and-roll band

31 Harvard Divinity School Press Release, 22 Sep 1968, MKFP.

32 Harvard Divinity School Press Release, 22 Sep 1968; NER press release, 22 Sep 1968, MKFP. 
and hoped to forge a career as a professional musician. By April 1966, however, with the threat of the draft hanging over him, Olimpieri enlisted in the Marine Corps. Six months later he landed in Da Nang. On the first day of his sanctuary at Harvard, he told reporters that he believed he had been "brainwashed" on the "use of physical torture" in boot camp. And by the time he left for Vietnam, he "couldn't wait to see action." -I considered myself a superhero," he said, "ready to free a country that was threatened by a Communist takeover." When he arrived in Vietnam, however, he decided that the "South Vietnamese Army [was] a joke" and that most South Vietnamese civilians did not want American forces there. After suffering wounds to his chest, arm, and ear in two separate firefights. Olimpieri found himself in a military hospital with "plenty of time to brood." Although his country thanked him for his pains with two Purple Hearts, he soon turned against the war. $^{33}$

Stationed temporarily at Quonset Naval Air Station in Rhode Island, Olimpieri had read about the earlier sanctuaries in Boston and Providence. Sometime after going AWOL on August 30, he decided to contact the New England Resistance who provided preliminary legal advice before referring him to a lawyer. After consulting with the attorney, Olimpieri persisted in choosing to make his protest publicly, and the resisters at Harvard Divinity School soon won the privilege of granting him sanctuary. By the time they took him in, Olimpieri had begun to adopt a new appearance, sporting a month's worth of new dark hair with a matching thin moustache and goatee. He wore sandals

33 "Marine Seeks Sanctuary at Harvard Divinity," Boston Globe 23 Sep 1968, p. 1; "Harvard Silent on Sanctuary," Boston Globe, 24 Sep 1968, p.1; "Marine Explains Why He Dropped Out," Boston Globe, 24 Sep 1968, p. 7. 
with an olivd-drab Marine jacket (to which he cheerfully pinned an Omega button). On the day he arrived in Cambridge. he figured the authorities would wait until he became classified officially as a deserter on September 30 before arresting him. ${ }^{34}$

A decorated war hero like Olimpieri brought a certain moral authority to the draft resistance movement that those who had not seen combat could not provide. The seminarians publicly thanked him for seeking sanctuary with them. Harvey Cox, the venerated theologian, told reporters that the sanctuary "thrilled" him. "I'm grateful to Paul for giving us something to rejoice about," he said. Olimpieri's stories captivated his supporters. With each conversation, they learned more about the realities of fighting in Vietnam and about the realities facing working-class men faced with few alternatives to the draft. Equally important, however, Olimpieri condemned the war and the Marines. He described a Marine Corps run by "lifers who are sadistic, sick people who couldn't make it on the outside." Moreover, he criticized the American presence in Vietnam. "I don't think we have the right to decide which form of government the Vietnamese should have," he said on the first day of his sanctuary. "I feel if they don"t want communism, they can win without our help like we won our revolutionary war." By claiming sanctuary, Olimpieri concluded, he sought "to tell other military personnel and civilians what is really going on" in the Marines and in Vietnam. "I'm not a coward (I was awarded two Purple Hearts), but I still believe the military and the war are bad."35

34 "Marine Explains Why He Dropped Out," Boston Globe, 24 Sep 1968, p. 7.

35 "Marine Seeks Sanctuary at Harvard Divinity," Boston Globe, 23 Sep 1968, p. 1; Harvard Divinity School Press Release, 22 Sep 1968, MKFP. 
Perhaps comments such as these led military authorities to grab Olimpieri before he attained deserter status. In the quickest end to a sanctuary to date, Military Police entered Andover Hall at 5:55 a.m. on Tuesday, September 24 (less than 48 hours after Olimpieri arrived) and, aided by Harvard police, entered the chapel. Divinity School Dean Krister Stendahl, also on hand, accepted the arrest warrant. The MPs found Olimpieri in a small second floor room behind the organ. He was chained to his wife, Lynn, and six seminarians, but the MPs came prepared. They produced a pair of bolt cutters, cut the chain, and carried him out. A piece of chain dangled from his leg as he left. Olimpieri spent the day at the Charlestown Navy Yard and anticipated a transfer back to Quonset. ${ }^{36}$

Then a most remarkable thing happened. Olimpieri renounced the seminarians at Harvard and the New England Resistance. On Tuesday evening, little more than twelve hours after being arrested, Paul Olimpieri stepped out onto the freshly cut lawn in front of the Marine barracks at the Charlestown Navy Yard, and held a press conference for print and television reporters. Flanked by his wife, his brother, and a new attorney, Olimpieri appeared nervous. Instead of the moustache and goatee, his face was clean shaven. One could practically see the starch in his pressed khaki uniform, and on his breast hung two Purple Heart medals. The sandals and the Omega button he wore that morning were gone. His hands trembled as he read a prepared statement. "After careful consideration of my actions in the last few days, I consider them to be a mistake." he said. He claimed

36 "Military Seize AWOL Marine in Harvard Divinity Chapel," Boston Globe (Evening Edition), 24 Sep 1968, p. 1; "Police Arrest Olimpieri Who Condemns Students," Harvard Crimson 25 Sep 1968, p. 1. 
that he had been "used by various groups to publicize their political goals, whatever they may be." Upon reflection, he no longer wanted to be associated with those groups. "I am just beginning to realize that things can be done through the proper channels," he concluded. "I found this out the hard way, and I hope that other servicemen will learn from my mistake." ${ }^{37}$

In a community which had grown used to watching resisters and supporters march off to jail defiant and unrepentant, Olimpieri's change of heart came as a shock. Few believed it conveyed his true feelings. "Paul would never say anything like this," one Resistance spokesman said. "The Marines obviously used some sort of coercion." The New England Resistance immediately issued a statement denying the charge that they had somehow used Olimpieri for their own ends. "We presented him the offer of sanctuary at the Harvard Divinity School and he readily accepted." The group also noted that they had tried to talk Olimpieri out of sanctuary and claimed that "he was well aware of the risks." But Olimpieri told reporters that he - not the Marines - called the press conference and wrote his statement. The Resistance simply could not resolve the old Paul Olimpieri with the new one. He refused to see his Resistance attorney and any communication with the organization. It was a terrible setback..$^{38}$

The surprising end to the Harvard sanctuary exposed some shortcomings of the sanctuary strategy. Unlike draft card turn-ins in which a large number of people assumed

\footnotetext{
37 "Sanctuary Marine Says He’s All Wrong," Boston Globe, 25 Sep 1968, p. 1.

38 "Police Arrest Olimpieri, Who Condemns Students," Harvard Crimson, 25 Sep 1968, p. 1. Note: To date, I have been unable to locate Paul Olimpieri to get his side of
} the story. 
an equal amount of risk, sanctuaries placed most of the risk on the man or men taking asylum from the military. No one expected the authorities to ignore such open defiance of the law, and although members of the Resistance community attempted nonviolently to block the inevitable arrest, the man who took sanctuary faced the punishment alone. In addition, in spite of hopes that the public nature of sanctuary would somehow protect the arrested man from unfair treatment by the military, once the police took him away, he became virtually inaccessible. Sanctuary continued to promote public confrontation with the government but not on the same scale as draft resistance did earlier.

These failings notwithstanding, several more sanctuaries - usually prompted by an individual serviceman seeking an alliance with the Resistance - took place in the fall of 1968. Just one week after the Harvard sanctuary ended, a new one started across the Charles River at Boston University. It started with the Committee of Concern for Vietnam, a small group of students in the BU School of Theology led by Alex Jack, Bob Winget, and George Collis. On October 2, at the usual daily service in Marsh Chapel, the congregation of approximately 100 people sang "A Mighty Fortress Is Our God," a hymn that one commentator called "Martin Luther's anthem of spiritual patriotism." The CCV then announced that it had offered sanctuary to two servicemen: Ray Kroll, an 18 year-old Army private, AWOL from Fort Benning, Georgia since July; and Private Thomas Pratt, a 22 year-old Marine more recently AWOL from Quonset Naval Air Station, and a friend of Paul Olimpieri. Both Kroll and Pratt had sought out the New England Resistance after seeing publicity from earlier sanctuaries. The Resistance, in turn, put them in touch with 
the $\mathrm{CCV} .{ }^{39}$

With the Harvard sanctuary fresh in their minds, the New England Resistance did their best to demonstrate that they were not manipulating these two soldiers. On the first day of the sanctuary, Ray Kroll, a soft-spoken young man of slight build - and also sporting a freshly cultivated moustache - told reporters that he went looking for the New England Resistance only after he came to the decision that he "could not take part in the armed forces without going against [his] moral convictions." "I would like to make it quite clear," Kroll continued, "that the Resistance and the School of Theology are not using me in any way for anybody's gain except mine." In addition, Thomas Pratt, a clean-cut, all-American looking Marine from Norwalk, Connecticut, said, "I chose sanctuary so I could make a stand, so I could tell people how the servicemen feel about the war." He knew the risks, he said. "I am ready to face the consequences."

But like his friend Paul Olimpieri, Pratt soon changed his mind. At the end of the first day in Marsh Chapel, during which the number of students "protecting" Kroll and Pratt had not yet reached 100, Pratt left with his parents. He claimed to be "disenchanted with the circus setting," and said that he had only wanted to make a protest against the war. Two days later, in the custody of the Marines again, Pratt held a press conference similar to Olimpieri's. He said that he realized he had been "inexperienced and naive" in his thoughts and actions. He also accused the Resistance of exploiting him. "I feel I was

39 "Marsh Chapel Held as Draft Sanctuary," BU News, 2 Oct 1968, pp. 3, 9; "20 Sympathizers Protect Awol Soldier in Sanctuary at B.U.," Boston Globe (Evening Edition), 2 Oct 1968, p. 5.

to "Marsh Chapel Held as Draft Sanctuary," BUNews, 2 Oct 1968, pp. 3, 9. 
used by the Resistance for their own purposes and gains," he said. "I have been on unauthorized absence status and expect to face the consequences of my action," he concluded. "I sincerely hope the Marine Corps will give me another chance."

Members of the New England Resistance now began to suspect that they were being played for fools. That two Marines - indeed two friends - both stationed at Quonset Naval Air Station, took sanctuary separately only to attack the people who had helped them smacked of betrayal at best and intentional sabotage at worst. Ray Kroll, who remained at Marsh Chapel, lashed out at Pratt and Olimpieri. "I have little doubt in my mind that both Paul Olimpieri and Thomas Pratt were plants," he told reporters. He suggested that the military sent the two to infiltrate the Resistance as agents provocateurs. ${ }^{42}$

Some still believed that the Marines had coerced the two men into recanting their previous statements. but in the tense atmosphere of the time, few doubted that the government might try to subvert their efforts by planting informants in the organization. An informal game called "Who's the fed?" developed around this time, especially among the inner circle of long-time activists in the New England Resistance. Barrie Thorne, a Ph.D. candidate in the Brandeis sociology department and a member of both the Boston Draft Resistance Group and the Resistance, recalls the day when she heard about the

41 "20 Sympathizers Protect AWOL soldier in Sanctuary at B.U.," Boston Globe, 2 Oct 1968, p. 5; "Marsh Chapel Held as Draft Sanctuary," BU News, 2 Oct 1968, pp. 3, 9; "Marine Recants Statements Made During BU Sanctuary," Boston Globe, 5 Oct 1968, p. 21. 1968 , p. 21.

42 "Marine Recants Statements Made During BU Sanctuary," Boston Globe, 5 Oct 
game and realized no one ever played it in front of her. Most people knew that she was writing her doctoral dissertation on the draft resistance movement, but in suspicious times, some apparently viewed her graduate work as a perfect front for an informant. She frequently conducted casual interviews with draft resisters and supporters, gathered leaflets and other written materials, and always took field notes. Alex Jack confirmed that he had heard people speak of her in this way. And even Thorne acknowledged that it sometimes looked bad. At one point. she got into the habit of sneaking off to write her notes in private. One night as she and several others finalized the production of the Resistance newspaper, she went to the bathroom and scribbled notes as she sat on the toilet. When someone opened the door accidentally, she later recalled, it was the "quintessential moment of shame and discovery." She had been caught, she said, "literally with my pants down!"43

Fears of government penetration of the Resistance did not, however, slow the momentum of the BU sanctuary which was beginning to shape up as the largest to date. The crowd of supporters steadily grew each day from fewer than 100 to more than 1,300 as expectations of Ray Kroll's arrest heightened. Like the Arlington Street Church sanctuary, the gathering took on a life of it's own. Howard Zinn later characterized it as an "ongoing free speech exercise...sort of like a 24 hour-a-day teach-in." At an open microphone, clergy gave sermons; resisters, academics, and anyone who wanted to, spoke to the crowd. The Resistance showed films about the war, and several bands played music at night. In the basement, approximately 20 doctors and residents, and six nurses

43 Thome interview, 28 Oct 1997. 
staffed a makeshift medical center. Zinn brought one of his Government classes to the chapel and led them in a discussion of "making a public symbolic declaration of resistance to the war, and the inadequacy of normal political procedure." Although at least one disturbance broke out in the balcony of the chapel one night (several men claiming to be Vietnam veterans tore up prayer books and showered the sleeping students with debris and epithets), the sanctuary gathered momentum with each passing day. At one point, an optimistic Zinn commented to a reporter that if the sanctuary continued to be successful, and "if people continue to appear seeking sanctuary," then the BU sanctuary "may be permanent."

In the end, however, the FBI had other ideas. At 5:30 in the morning on Sunday, October 6, sanctuary supporters sleeping on the floor and in the pews awoke to a voice shouting, "This is the FBI. We will give you 15 seconds to clear the aisle." The time limit expired quickly as the students turned to see 120 federal agents streaming into the chapel. As the first agent walked down the aisle, he turned to the others behind him and noted that the students were not resisting their presence; the agents would not have to move them, he suggested. A wave of agents started down the aisle, picking up students anyway. Sam Karp of the Resistance went to the microphone and told everyone to remain seated and silent. "Remember our commitment to nonviolence," he said to the crowd. "Stay limp. This is their way." Slowly, the agents moved through the crowd,

44 "Marsh Chapel Held as Draft Sanctuary," BU News, 2 Oct 1968, pp. 3, 9; "20 Sympathizers Protect AWOL Soldier in Sanctuary at B.U., Boston Globe (Evening Edition), 2 Oct 1968, p. 5; "B.U. Sanctuary Continues for Soldier," Boston Globe, 3 Oct 1968, p. 3; "500 Keep B.U. Vigil Awaiting GI Arrest," Boston Globe (Evening Edition), 4 Oct 1968, p. 2; Zinn interview, 6 Jul 1998. 
placing and sometimes tossing students into the pews. The sanctuary participants remained nonviolent. "No one in that place lifted a finger to resist them," Joann Ruskin. a BU junior said immediately after the raid. "It was the most beautiful thing."

If the FBI agents were not rough with the crowd in the chapel, they were not as kind to BU television crew or Ray Kroll. After clearing a path through the sanctuary, several agents ran to the room where WBTU was filming the action, smashed open the door, and destroyed the film. Another group of agents found their way to the room where Kroll and about ten others had spent the night on cots. "Where is Ray Kroll?" they demanded. Someone asked for a warrant. "Is Ray Kroll here?" the agents asked again. Kroll identified himself and again asked for a warrant. "Don't worry about that," an agent responded. Three agents grabbed him and tried to lift him to his feet as he went limp. "Walk," one of them shouted. "Get up and walk, damn you. Walk you bastard." One witness said one agent yanked back on Kroll's hair as another pushed his head in the opposite direction. Photographs on the front page of the Boston Globe and BU News the next day show four FBI agents, all middle-aged wearing coats and ties, whisking him down the steps of Marsh chapel. The two agents on either side of him held his arms tightly; Kroll winced as one of the agents, smiling, twisted the deserter's fingers in an unnatural position. Two other agents squeezed his neck from behind and pushed the entire group through a path cleared by Boston police toward a waiting car. As Kroll attempted to go limp one last time, Ted Polunbaum, a Newsweek reporter, heard one 
agent say to Kroll, "Stand up or we'll kill you, you bastard."45

Although everyone involved in the sanctuary expected it to end in Ray Kroll's arrest, when it finally happened, it stunned many of them anyway. The FBI and the Boston Police Department had just given a demonstration in the use of power. The students knew that they had power, too, but Kroll's "bust" reminded them that the state had more and it knew how to use it. Although the BU confrontation with authorities did not include the violence of the Arlington Street Church sanctuary clash, in some ways, the end of this sanctuary proved more depressing.

In an article in the $B U$ News, Alex Jack, the veteran activist and New England Resistance founder. expressed a new level of despair. The experience of this sanctuary (which he had planned) led him to openly urge revolution. "The Sanctuary at Marsh Chapel has shown, simply, that there can be no sanctuary," he wrote.

There is no sanctuary from oppression, from racism, from militarism. The Marsh Chapel sanctuary, as previous sanctuaries, has shown that the U.S. government, the armed forces, the police, the University and the corporate interests they serve will never voluntarily stop killing people in Vietnam... They will not be deterred for conscience sake from dragging young men off to make war in protection of their illicit activities.

For the American state, the BU sanctuary showed that "no place is sacred," Jack concluded. "No rights are inviolable. No people or humanity is sacrosanct." If the government felt it had to, he wrote, "they will slaughter us all." The only solution to this condition, he argued, was the creation of a new society in which "exploitation is structurally impossible, where power is returned and exercised by the people, where there

45 "Asked for a Warrant, They Just Stepped Over Me," BU News, 9 Oct 1968, pp. 3, 8; "AWOL Soldier Seized at BU," Boston Globe, 7 Oct 1968, p. 3. 
is no distinction between religion, politics or art, where in short there are no sanctuaries because no on is oppressed." Only a revolution could create the society he described. and Jack urged others to join him. "We are the children of the most monstrous and destructive society in history, a society that has no conception of or respect for human needs, a society that will annihilate the planet before sharing its wealth, a society without sanctuary for any of its victims." He concluded by calling for his generation to "rise up and utterly destroy this universe..." ${ }^{n 6}$

Alex Jack's radical stance and participation in the organization of the Marsh Chapel sanctuary got him dismissed from the BU School of Theology. When the sanctuary first opened, the university and School of Theology administrations expressed surprise and made it clear that "the university...will abide by the laws of the land." In fact, the sanctuary constituted just one episode in a growing list of conflicts between the School of Theology and its students. Debates over curricula, grades, and the students' role (or lack thereof) in these issues had been simmering for some time, and a rift between students and faculty was widening. In contrast to the Harvard Divinity School's reaction to the Andover Hall sanctuary, when the BU sanctuary took place, not one School of Theology professor came to the chapel to show support for it. When it ended, the School saw Alex Jack as one of the ringleaders of all of this disruptive behavior and singled him out for punishment. They based his suspension on his failure to inform the School of the sanctuary plans and for failure to seek permission to use the chapel for that purpose. Only Ray Kroll, who received a sentence of three months' hard labor and who

\footnotetext{
${ }^{46}$ Alex Jack, "The Politics of Confrontation," BU News, 9 Oct 1968, pp. A2-A3.
} 
was docked two-thirds of his pay for the three months, received a harsher punishment. ${ }^{47}$

Unlike Alex Jack, however, most rank-and-file participants did not regard the BU sanctuary as a failure. Many believed that it had brought good publicity to the antiwar movement and bad publicity to the war and the government. Most important, Howard Zinn suggested, the sanctuary inspired close to 1,500 people to act on an issue of principle. "The most we can do if we don't liberate the world. is to liberate the spot of ground on which we stand," he said the day after the FBI bust. "We can find victory in the act of struggling for what we know is right. These five days have been days of victory. We ought to be glad they happened." Looking to the future, Louis Kampf of Resist argued that, like draft card turn-ins, sanctuaries drew people together and gave them "a sense of responsibility to each other." Too often, he noted, that sense of responsibility was fleeting. But "if resistance to the war...is to be deepened," and "if our sense of purpose is to be taken seriously," rather than worrying about elections (which few in the movement did, given the candidacies of Hubert Humphrey, Richard Nixon, and George Wallace), "resistance and peace groups might better spend their time developing strategies for building communities of resistance." No one knew how to do this, exactly, but continued outreach to GIs and providing symbolic sanctuary to those who wanted it. Kampf implied, could be key ingredients. Soon, some of Louis Kampf's

47 "Cultural Revolution at School of Theology," Up Against the Cross, issue \# 1 (Nov 1968), AJP; Jack interview, Mar 1997; "Kroll, AWOL GI of BU Sanctuary, Gets 3 Months Hard Labor," Old Mole, vol. 1, \#4, 5 Nov 1968, p. 3. 
own students soon responded to his call. ${ }^{+8}$

To outside observers, in spite of the ignominious ends of the Harvard and Boston University sanctuaries, the sanctuary "movement" no doubt appeared to be growing as it spread from one school to another, each one larger than the last. Three weeks after Ray Kroll's arrest, students at the Massachusetts Institute of Technology organized another sanctuary, but this time it took on a secular tone. For the first time, instead of hosting the AWOL GI in a church or chapel, the MIT Resistance - an offshoot of the New England Resistance - provided asylum in the student center.

Although the draft resistance movement in Boston had attracted some students from MIT over the past year. the university itself had seen very little antiwar protest before the sanctuary. Compared to Harvard and BU, the campus at MIT was one of Boston's quietest. This relative calm could be attributed in part to MIT's connection with the war effort. In 1968, for instance, MIT earned the distinction of being the only university on a list of 100 organizations receiving the largest dollar value contracts from the Defense Department. In 1969, the Pentagon effectively underwrote eighty percent of MIT's budget. ${ }^{+9}$ Two operations - the Lincoln Laboratory and the Instrumentation Laboratory - spent most of this money. The Lincoin Lab occupied facilities provided by the Air Force at Hanscom Field in nearby Lexington and specialized in advanced research

48 "It had Salami and Donuts, But Spirit Sustained Chapel," BU News, 9 Oct 1968, p. A4; "A Sense of Responsibility," Resist Newsietter, 28 Oct 1968, p. 2, MZP.

49 Dorothy Nelkin, The University and Military Research: Moral Politics at MIT (Ithaca: Cornell University Press, 1972), p. 20; 1969 statistics cited in Kenneth J. Heineman, Campus Wars: The Peace Movement at American State Universities in the Vietnam Era (New York: NYU Press, 1993), p. 13. 
in electronics, radar and radio physics, and information processing. Scientists used technology developed at the Lincoln Lab to design several major early-warning air defense systems and ballistic missile defense systems in use in the late 1960s. At the Instrumentation Lab (or I-Lab, as it was known), researchers developed the Multiple Independent Reentry Vehicle (MIRV), probably the most noted (and eventually the most controversial) program at the university. The MIRV was a high accuracy ballistic missile that could carry multiple nuclear warheads capable of annihilating several targets as far apart as 100 miles. It became perhaps the most obvious symbol of the university's ties to the Pentagon. ${ }^{50}$

In addition to designing new technologies for modern warfare, faculty in other departments actively supported the American war effort in Vietnam. Many within the university community, for instance, knew that the Central Intelligence Agency openly funded MIT's Political Science Department in the early 1960s, and maintained a formal relationship through the late 1960s. In fact. the department kept a villa in Saigon where graduate students worked on pacification projects and other American political/military programs for their dissertations. ${ }^{51}$

Finally, the apparent complacency of most MIT students also inhibited antiwar activism on campus. "The typical student," Noam Chomsky later noted, "is someone

so Michael Klare, ed., The University-Military Complex: A Directory and Related Documents (New York: North American Congress on Latin America, 1969), p. 13, Steve Shalom papers (copy in author's files); Nelkin, p. 48.

51 Noam Chomsky, "The Cold War and the University," in Chomsky, et al, The Cold War and the University, (New York: New Press, 1997), p. 181; Shalom interview, 18 May 1997; Chomsky interview, 20 May 1997; Kampf interview, 11 Sep 1998. 
who was the only kid in Peoria who studied Quantum physics when everyone else was playing football...and when they come here they tend to be kind of isolated from one another and also from the faculty." In short, even after all of the shocking events of 1968 , most MIT students seemed to be sleepwalking through the war years. ${ }^{52}$

At the same time, however, a small number of dissidents - some students and faculty - had actively opposed the war for a long time. Most notably, Noam Chomsky and Louis Kampf - even before writing the Call to Resist Illegitimate Authority and long before they became key figures in the formation of Resist - taught a course outside their departments on their own time called "Intellectuals and Social Change." The course covered both contemporary foreign policy and domestic issues, and challenged students to consider the role of intellectuals in taking sides on the important questions of the day. Anyone could take the course, and more and more did as the war progressed. By fall 1968, almost all of the individuals responsible for organizing the MIT sanctuary had taken that course. In addition, a small group of students who had worked with the New England Resistance over the summer formed the MIT Resistance. From the beginning of the fall semester, these students plotted to hold a sanctuary on campus.

The first sanctuary attempt at MIT fell apart even before it started. An Army friend of Ray Kroll's named George (the rest of his name has been lost to history) contacted Steve Pailet at the New England Resistance during the BU sanctuary. He, too, wanted to make his stand by seeking symbolic asylum surrounded by enthusiastic supporters. As Pailet and Bob Shapiro of MIT Resistance worked out details for a

52 Chomsky interview, 20 May 1997. 
sanctuary at MIT, they arranged for George to stay at the Cambridge home of two sympathizers for a few days. But George blew it. One night, he called his girlfriend and told her how to reach him. He did not know it, but the young woman's father had listened in on the conversation. Acting on the father's tip, Military Police burst into the sympathizers' house and dragged George off to the nearest stockade. The homeowners were furious, and the sanctuary plans evaporated for more than a week until a new GI volunteered for it. ${ }^{53}$

Another Army friend of Ray Kroll finally took sanctuary at MIT on October 29, 1968. John M. "Mike" O'Connor, 19, came from Goldsboro, North Carolina where he enlisted in the Army to avoid being jailed on a marijuana possession charge. In April 1968, he went AWOL from Fort Eustis, Virginia for 50 days and spent two months in the stockade there as a result. After regaining his freedom in August, he again went AWOL on September 14. A few days into Ray Kroll's sanctuary began at Boston University, O'Connor visited his friend at Marsh Chapel and approached the New England Resistance about joining it. Sanctuary organizers anticipated Kroll's arrest at any time, however, and urged $O^{\prime}$ Connor to wait for another sanctuary opportunity. ${ }^{54}$

MIT Resistance organizers wanted their sanctuary to symbolize a new level of militancy by separating the concept of sanctuary from its longstanding religious context. Instead of granting Mike $\mathrm{O}^{\prime}$ Connor sanctuary in the campus chapel as students at Harvard

${ }^{53}$ Shapiro interview, 13 Aug 1997.

54 "Students Guard GI at MIT," Boston Globe, 30 Oct 1968, p. 47; "12 Days of Sanctuary at MIT,"Resist Newsletter, 2 Dec 1968, p. 1, RSP; Shapiro interview, 13 Aug 1997. 
and BU had done, Bob Shapiro reserved an immense space, the Sala de Puerto Rico, in the student center for the sanctuary. In part, this occurred simply as a practical matter; the Sala was the only large place on campus that could be reserved without disrupting the plans for other nonpolitical events. ${ }^{55}$ When 700 people showed up the first night (a Tuesday), it confirmed the need for a large space. By Saturday night, November 2, more than 1,200 supporters spent the night, most of them sleeping in sleeping bags, and waiting for the FBI. ${ }^{56}$

The appeal of the MIT sanctuary derived in part from the magnetism of Mike O'Connor himself. As the editors of MIT's student newspaper, The Tech, noted after his arrest, $\mathrm{O}^{\prime}$ Connor, perhaps more than any other GI in a Boston area sanctuary, seemed to know what he was doing. On the first day of the sanctuary, he made it clear to his supporters and the media that he understood the probable consequences of his actions. By taking sanctuary, he acknowledged, he would probably spend more time in the stockade than if he simply turned himself in. "To me it is worth it," he asserted. "I feel that if I can convince 100 people that the war is wrong, that it is an injustice against the basic freedoms of our country, then I will gladly serve the extra time." Rather than leave the country, O'Connor said "If there is something wrong with [the country], we should try to change it. Then, in an obvious reference to Paul Olimpieri and Thomas Pratt,

55 The MIT Resistance probably would not have met with much success if they had organized the sanctuary in the beautiful but very small chapel on campus. Designed in 1955 by the eminent architect Eero Saarinen, the Kresge Chapel is located not far from the student center, but could have housed fewer than 100 people comfortably.

56 "12 Days of Sanctuary at MIT," Resist Newsletter, 2 Dec 1968, p. 1, RSP; Shapiro interview, 13 Aug 1997. 
O'Connor said that he realized that he would probably be forced to retract all of his statements upon his arrest. He told the crowd, however, that his was a "statement of the heart," that they should remember it, and that with their help he would be able to withstand any coercion. In the event that he did "weaken and make any statements against this community," he urged his supporters to disregard them and "remember me for what I write and say while I am free." 57

The MIT sanctuary developed over several days in much the same fashion as the Arlington Street Church and Marsh Chapel sanctuaries. On the second day of the event, some faculty brought their classes to the Sala de Puerto Rico as an expression of solidarity; Louis Kampf, for instance. taught his Proust class against the backdrop of the sanctuary. That night, several bands played and organizers showed a few short films produced by Newsreel, the underground film collective. Abbie Hoffman made an appearance at one point. Through it all the numbers of people taking part ebbed and flowed until Thursday night when more than 1,000 people claimed a space in the Sala. That night, as participants discussed reviewed their guidelines for greeting the authorities. a large number of people suggested that the sanctuary abandon its nonviolent approach. Members of the Living Theater, fresh from a performance at Kresge Auditorium, attempted to provoke some of the students into occupying some of the administration offices. Fearing a violent clash when the authorities arrived, $O^{\prime}$ Connor asked for a vote on the issue of nonviolence saying that if the crowd voted for a direct confrontation, he

57 "Statement of Jack M. O'Connor, undated (c. 29 Oct 1968), RSP; Resist Newsletter, 20 Dec 1968, p. 8, Spock papers, box 28. 
would turn himself in to the Army; they voted for nonviolence. Still, anxiety grew steadily over the next few days. Three technically adept students worked out seven different telephone and walki-talkie systems to give a warning of any raid that might take place; meanwhile, someone armed with a ham radio patrolled the Charles River by boat looking for federal agents or military police. ${ }^{58}$

By Friday and especially Saturday, most people were physically and emotionally exhausted. Mike O'Connor in particular seemed to be suffering from the effects of too little sleep. Resistance organizers could not believe that the FBI or Army had not yet come to arrest O'Connor, but on Sunday night, after waiting for six days, they declared victory and sent everyone home. O'Connor went to sleep in a small room on the fourth floor of the student center while Resistance leaders placed the sanctuary in the best light possible. They had been successful, they argued, in protecting O'Connor for six days; he had explained his position on television, radio, and in the papers; and it raised the political consciousness of a campus formerly considered passive. In reality, few knew what to do when the authorities did not do what they were supposed to do. With another group needing the Sala for a formal dance, and, more important, O'Connor exhausted, they decided to pack it in. ${ }^{59}$ A week later, on November 10, Military Police from Fort

58 "12 Days of Sanctuary at MIT," Resist Newsletter, 2 Dec 1968, p. 1, RSP; "Sala Sanctuary Established," The Tech (MIT), 1 Nov 1968, p. 1; Bill Berry, "Am I a Slave?" Old Mole, 5 Nov 1968, p. 5; Shapiro interview, 13 Aug 1997; Kampf interview, 10 Sep 1998.

59 "12 Days of Sanctuary at MIT," Resist Newsletter, 2 Dec 1968, p. 1, RSP; "O'Connor's Sanctuary Ends," The Tech, 8 Nov 1968, p. 1; "Six-Day MIT Sanctuary Ends Quietly Without Bust," Harvard Crimson, 4 Nov 1968, p. I; Shapiro interview, 13 Aug 1968. 
Devens finally arrived and arrested O'Connor. Thus, as Neil Robertson wrote soon after, the MIT sanctuary "ended in confusion after a gradual atrophy." After a January trial, a military court sentenced him to four months of hard labor and forfeiture of two-thirds of his pay over that time; the judge then added another four months remaining from his previous suspended sentence for going AWOL the second time. ${ }^{60}$

Mike O'Connor's sanctuary thoroughly transformed the activist climate at MIT. Noam Chomsky, who initially thought the sanctuary would fall flat and attract little student support, later remarked that to his "amazement" the sanctuary "just galvanized the whole campus." It "completely changed the mood of the whole university," he recalled. "It's never changed since, or never gone back." Indeed, in the wake of the sanctuary's end, many students commented on the new consciousness of students. Bill Berry, an MIT Resistance organizer, argued that MIT students were now suddenly questioning their role in society. He gave an example of a student who would now be more likely to turn down a lucrative job at General Dynamics and do scientific work that would help society in stead of creating new and more efficient destructive technology. Previously isolated students now felt exhilarated by the sense of community that they experienced with faculty and their fellow students. Nevertheless, a handful of critics also began to criticize the tactic of sanctuary. ${ }^{6 i}$

60 "Sanctuary Terminated by Arrest," The Tech, 12 Nov 1968, p. 1; Neil Robertson, "The Politics of Sanctuary," Nov 1968, p. 8, RCP; O'Connor sentence described in "Up Against the Wall Street Journal," 16 Apr 1969, p. 15, RSP; Shapiro interview, 13 Aug 1997.

${ }^{61}$ Chomsky interview, 20 May 1997; Bill Berry, "Am I a Slave?" Old Mole, 5 Nov 1968, p. 5. 
The MIT sanctuary turned out to be the last significant sanctuary in the Boston area. Although students at Brandeis University offered sanctuary to another soldier in early December; the authorities' willingness to all but ignore it and let it sputter out on its own, again undermined the protest value of the event. By January, the Resistance started to shift its focus on GIs away from sanctuary to lower-profile outreach. Organizers admitted that beyond the publicity that sanctuaries garnered, and the growing numbers of students on Boston campuses who turned out for such events, these events actually played into the hands of the military. The public nature of the GI's protest had no mitigating effect on his punishment; indeed, it may have made matters worse. ${ }^{62}$

Consequently, the New England Resistance decided to intensify its GI outreach program. On Friday nights, Resistance members walked a few blocks from their Stanhope Street office to the Greyhound bus terminal on St. James Street. There they sought out soldiers traveling for the weekend and gave them copies of Viernam GI, the antiwar newspaper aimed at GIs (published in Chicago); a few people also spent their Friday nights at Logan Airport for the same reason. In addition, Resistance activists tried to make contact with disgruntled soldiers to offer counseling on how to get discharges or apply for conscientious objector status. They handed out flyers to parties and invited GIs

${ }^{62}$ NER Newsletter, Jan 1969, MKFP; NER Newsletter, Feb-Mar 1969, MKFP. Note: The Brandeis sanctuary for Sp/4 John Rollins, AWOL from Ft. Clayton, Panama began on 4 December and lasted two weeks. On 19 December, Rollins and the sanctuary community dissolved the sanctuary and went to Ft. Devens to distribute leaflets to GIs. There Military Police arrested him. 
to visit the Resistance office. ${ }^{63}$ In one of the most ambitious strands of the outreach program, Nan Stone and Joel Kugelmass made several visits to bars and clubs in the Combat Zone (Boston's red light district), where they could usually expect to encounter plenty of alienated servicemen and frequently someone who had gone AWOL. Stone and Kugelmass then offered help in the form of lawyers and counselors. Since their antiwar experience had taught them something about the reach of the federal government, Stone and Kugelmass usually encouraged AWOLs to turn themselves in with the help of movement lawyers. In a few rare instances, however, Stone and others in the Resistance participated in a sort of underground railroad with other antiwar organizations as a way of getting deserters out of the country. ${ }^{64}$

Resistance members who had been part of the movement since its beginning regarded this shift to GI outreach as an indication of the organization's maturity. "As we all became a little more astute about what we were doing," Nan Stone later recalled, "we did get much more of a sense of how guys could end up in the military and even in Vietnam without believing in the war." Many servicemen, they learned, felt they had no choices. Gradually, in the second half of 1968 and into 1969, Resistance activists stopped looking at servicemen as potential enemies. And so the organization continued

63 NER Newsletter, Jan 1969, MKFP; NER Newsletter, Feb-Mar 1969, MKFP; Stone interview, 8 Oct 1997; Kugelmass interview, 16 Jun 1997; Shapiro interview, 13 Aug 1997. Note: In some ways, the Resistance began duplicating the Boston Draft Resistance Group's GI Outreach program; BDRG, for example, had been distributing Vietnam $G I$ at bus stations since the summer of 1968 .

64 Kugelmass interview, 16 Jun 1997; Stone interview, 8 Oct 1997; Tiltons interview, 16 Jun 1997; Robertson interview, 7 Aug 1998. 
to direct its attention toward expanding the circumference of its circle of supporters to men serving in America's armed forces. ${ }^{\text {is }}$

This change in constituency, however, resulted in two unintended consequences: the virtual abandonment of the hundreds of men who returned their draft cards in late 1967 and the first half of 1968, and the ultimate decline of the New England Resistance. When the Resistance turned away from draft card turn-ins to devote more and more time and resources to high school organizing and the sanctuary movement, it made no formal announcement. Newsletters and The Resistance newspaper no longer carried information on draft card turn-ins and instead included articles laced with revolutionary rhetoric and critiques of imperialism and capitalism. For the rank and file draft resister, the future seemed less clear, and the group to whom one might ordinarily look for guidance had moved in a new direction. As a result, several draft resisters created a new organization to meet that demand.

\section{SUPPORT and Forgotten Draft Resisters}

The U.S. Attorney's Office in Boston, consistent with Ramsey Clark's wishes, waited until after the Spock Trial ended to indict ordinary draft resisters. Between August and December 1968, a grand jury handed down 48 indictments of men who had refused induction when called. As Michael Zigmond, who had turned in his card at the Old West Church on November 16, 1967 and was among the 48 indicted, later recalled, "Now that people had refused induction, the movement... wasn't all that interested in them. Their political act had happened and what happened to them afterwards was of no

65 Stone interview, 8 Oct 1997; Kugelmass interview, 16 Jun 1997. 
particular political interest, I think." Zigmond approached the New England Resistance and Resist about providing some kind of support for the indicted men but got little in the way of a response. "My attitude was, maybe it isn't political, but it's sort of the other side of the Veterans Administration System," Zigmond reflected. "You know, we've served our time in the front lines, we refused induction, people ought to care about us now. Whether it's political or not doesn't matter." Frustrated by the indifference of movement leaders, Zigmond and his wife Naomi, along with a few other indictees formed an organization called SLPPORT (which was always spelled in capital letters) to raise money for legal expenses and travel expenses incurred by family members visiting a resister in prison. ${ }^{66}$

Michael Zigmond was somewhat older than most Resistance organizers. Two months before turning in his draft card. Zigmond turned 26, making it very unlikely that he would ever be drafted. Moreover, he had earned his Ph.D. from Carnegie Tech and at the time of his resistance held a postdoctoral fellowship at MIT. The war and his immunity from it weighed heavily on him, however, (see Chapter 4 ) and he decided to risk his safe status by returning his draft card to the Justice Department. His Arlington, Massachusetts, draft board quickly reclassified him and called him for induction. On the Friday of Memorial Day Weekend 1968, Zigmond, accompanied by his wife and parents, arrived at the Boston Army Base and found that he was the only person scheduled for induction that day (a tactic often used on troublemakers so they would not have the

66 "A Year of Support," SUPPORT Newsletter, Aug 1969, p. 1, MZP; Zigmond interview, 29 Dec 1997. 
opportunity to proselytize to other draftees). Although he had allergies, flat feet, and terrible vision, he passed the physical: He did better on the IQ test. When a psychiatrist asked him questions during the psychological examination, Zigmond reported feeling a little depressed and anxious. When the doctor asked why, Zigmond responded, "Because at the end of this day I'm going to commit a felony." And so he did. As his wife, Naomi, and his parents watched through a glass picture window, Zigmond refused to step forward on three separate occasions. Two FBI agents interviewed him after the ceremony and released him. The affair took all day. ${ }^{67}$

As the Zigmond family walked the long walk from the induction center to the Boston Army Base exit, they heard a trumpet begin to play the familiar refrain of "Taps." Nearby, an old soldier slowly started to lower the American flag. But when he saw the Zigmonds walking - instead of stopping to observe the sacred ceremony - he began shouting at them. They walked on. The man yelled. The trumpeter played until the end. ${ }^{68}$

In the fall of 1968, Michael and Naomi Zigmond assumed more prominent roles in the Boston antiwar movement by starting SUPPORT, which drew its membership from several other organizations such as the American Friends' Service Committee, Resist, BDRG. Mass Pax, the New England Resistance, and the Prisoners Information and Support Service. The impulse to form SUPPORT came in part from attending the late summer trials of a few men who had refused induction. "Some of those who had been

${ }^{67}$ Zigmond interview, 29 Dec 1997.

${ }^{68}$ Zigmond interview, 29 Dec 1997. 
surrounded by 5,000 supporters on the Boston Common were left standing alone," a SUPPORT newsletter charged. "Court rooms (which hold about 35 people) were filled only with difficulty..." Those who did attend trials realized that many of the men on trial were very young, often poor, frequently did not understand the judicial process, and rarely had more than one supporter attending the trial. Thus, SUPPORT got started by coordinating groups of people to go to each draft resistance trial. "The resistance movement must now decide whether the government will be allowed to continue to carry off non-cooperators quietly," they said as the number of indictments climbed through the fall. The objective, since the media did not cover the trials at all, would be to make each one a focus for political action and, consequently, a story worth covering. ${ }^{69}$

In contrast to the growing activist program of the Resistance, SUPPORT offered a fairly narrow array of services which, for the indicted men, were very important. Each week, the Zigmonds and their one paid staff person, Carol Neville, combed the newspaper for announcements of indicted men. Then, in most cases, SUPPORT lined up someone from the indictee's own community to contact the young man and offer information on legal and financial assistance. Often resisters could enlist the aid of an attorney through the Committee for Legal Research on the Draft, an organization started by Harvard Law School students. Supporters assigned to each case also were responsible for coordinating support for the indictee in his own community, by circulating petitions,

69 "A Guide for Indictees and Counselors," SUPPORT leaflet, Mar 1969, p. 2. MZP; "Draft Refusal Indictments Coming," Old Mole, 12 - 22 Sep 1969, p. 17; "ThirtySix Men Indicted Since August," SUPPORT Newsletter, 25 Nov 1968, p. 1, MZP; "A Year of Support," SUPPORT Newsletter, Aug 1969, pp. 1-2, MZP. 
organizing rallies, and encouraging others to attend the man's trial. SUPPORT's work did not stop with a conviction, however; resisters found guilty could expect frequent letters and postcards from supporters while in prison and, maybe most important. SUPPORT supplied travel money to families who wanted to visit their sons in prison. ${ }^{70}$

The irony is that most of the men who benefitted from SUPPORT's assistance had not taken part in the draft resistance movement at any time over the previous year. By December 1968, Zigmond realized that all but four or five of the men indicted since August were men whose draft boards had denied their conscientious objector requests and, in turn, decided to refuse induction rather than violate their consciences. That said, this distinction did not distract SUPPORT from its work in any way. It seemed clear that indictments would eventually be issued for men who had openly defied the draft as part of the resistance movement and subsequently refused induction. Moreover, SUPPORT activists knew just how important their work was to the families they had already helped. One couple who had received money to travel to Allenwood, Pennsylvania to visit their imprisoned son wrote a letter to Michael and Naomi Zigmond that conveyed their gratitude: "[We're] certain that just knowing that there are people like yourself on the outside that have not forgotten about him is enough to give him the courage and reassurance that he so needs right now." Letters like that inspired continued activism

\footnotetext{
70 "Draft Refusal Indictments Coming," Old Mole, 12-22 Sep 1969, p. 17; "A Year of Support," SUPPORT Newsletter, Aug 1969, p. 2, MZP; Zigmond interview, 29 Dec 1997.
} 
regardless of the resister's movement credentials or lack thereof. ${ }^{71}$

In the end, however, it turned out that the U. S. Attorney in Boston secured proportionately few indictments - and even fewer convictions - of draft resisters who turned in their draft cards at one of the gatherings organized by the New England Resistance in 1967-68. Thirty years later, the reasons for this are not altogether clear. After the flurry of indictments at the end of 1968 , no Boston area draft resister was indicted in all of 1969. Assistant U.S. Attorney and Spock Trial prosecutor John Wall recalls "an avalanche of [draft] cases" overwhelming his office, and suggests that many cases simply "fell through the cracks." The department just did not have the resources to pursue every draft resister. That may have been the case, but the evidence shows that several variables probably factored into the ultimate resolution of each draft resister's case. The final determination of each resister's future usually derived from decisions made by either the resister himself, his draft board, or a judge.

Until now, many in the draft resistance community have believed that once the New England Resistance abandoned draft card turn-ins as its primary tactic for confronting the government, most resisters who had lost their deferments as a result of their protest sought to have them renewed. When sociologist Barrie Thorne completed her dissertation in 1971 , she reported that although "there were no certain figures, only cumulative hearsay and general impression," most in the movement guessed that at least half - and as many as three-fourths - of Boston's draft resisters "had gone back on their

71 "Local Support Efforts," SUPPORT Newsletter, 2 Dec 1968, p. 2, MZP; Mr. \& Mrs. William F. Curry letter to Michael Zigmond, 20 Jan 1970, MZP; see also Elizabeth Powers letter to Michael Zigmond, 26 Jan 1970, MZP. 
pledge of non-cooperation." These figures seem inflated when one considers, as Michael Ferber and Staughton Lynd did, that between the fall of 1968 and the spring of 1970 some four hundred men had refused induction in Boston; as of March 1970, none of those men had been indicted. "a fact," Ferber and Lynd noted, "for which no one has offered a good explanation." These men no doubt included some of those who had begun their draft resistance odyssey by turning in their draft cards at a New England Resistance organized ceremony, but most of them probably refused induction on their own.

Draft resisters who completed the 1997 survey conducted for this dissertation provide the first clear indication of how the cases of Boston's draft resistance community turned out. Table 9.1 shows what happened to draft resisters after they turned-in their draft cards. Most local draft boards followed General Lewis Hershey's instructions and reclassified draft resisters once they received their draft cards. Out of 102 survey respondents, $77(75.5 \%)$ report being reclassified to $1-\mathrm{A} ; 56(54.9 \%)$ of these men later received orders to report for induction into the armed services. Nine men (six of whom were 26 or older and one of whom was a veteran) heard absolutely nothing from their draft boards. Only $15(14.7 \%)$ avoided reclassification by seeking or accepting a duplicate draft card or a new deferment, but another 11 of the men who were reclassified 1-A also secured new deferments before they could be called for induction (see Table 9.2).

Since the government chose not to prosecute men for turning in their draft cards, they generally waited until a draft resister refused induction before pursuing an indictment. Table 9.3 presents data on the Boston draft resisters who received induction 
notices after having their classifications changed to I-A. Thirty of 53 respondents went through with their original plan and refused induction, while another 14 who might have refused induction failed their pre-induction physicals. Only nine of the men called for induction avoided their own personal showdowns at the Boston Army Base by seeking and receiving a new deferment before their induction date. Therefore, when these nine men are added to the 26 men who escaped reclassification and/or an induction call by accepting a duplicate draft card or new deferment, it totals approximately one-third $(34.3 \%)$ of the draft resisters in the sample.

Resisters compromised on their original commitment to refuse induction for a variety of reasons, but generally it came down to two considerations. First, many realized that even if every man who turned in his draft card in late 1967 and early 1968 refused induction, it would not stop the war. As one resister commented on his survey: "I had hoped, naively, that I would be on of hundreds of thousands, on October 16 or later, who refused to serve, and that my act would, with others, lead to a quick end to the war. Eight months later, I reluctantly concluded it wasn't going to happen." David Clennon. the Yale graduate student, likewise recalls the doubt that many resisters had about their original strategy by the middle of 1968 . When he was called for induction in June 1969 , he took advantage of his fragile psychological state to secure a note from his psychiatrist that effectively won him a new deferment. At the same time, Clennon acknowledges that he "began to doubt whether I could handle 32 months in prison." This is the second most common reason for seeking a new deferment: self-interest. In Clennon's case, more than a year of anxiety had accumulated in the wake of his draft card turn-in (which led him to 
the psychiatrist in the first place) and he doubted he could cope with prison. As another resister wrote, "People were no longer doing this (turning in cards) and there seemed to be a general feeling that it was pointless to go to jail over it...Fear of going to prison was also a major factor." $"$ r

Today, many of the draft resisters who chose not to refuse induction still have mixed feelings about their decision and some regret it altogether. David Clennon has called his new deferment "a real copout." Although he had "taken this big step and...stood my ground for about a year, year and a half," he said, he then "copped out and took the middle class road to get out of the draft." Similarly, Larry Etscovitz, the Boston University student who spontaneously turned in his draft card at the Arlington Street Church on October 16 , admits giving in to his fear when he accepted a $1-Y$ deferment at his pre-induction physical. He now regards his initial act of resistance as "an inviolate moment in an otherwise very gray scenario of self-preservation in moving from one extreme to another." When he turned in his card, he says, "I felt I was committed to an irrevocable course of protest." But the government kept "dangling carrots" in front of him to make it easy to back out. These offerings - of duplicate cards, new deferments, etc. - "became more and more enticing as my tolerance for being in a state of chaos got less. I got scared," he says. "Let's just be straight about it. I got scared...and I regret it to this day. I really do."'

72 Written comment, 1997 Boston Draft Resistance Survey, respondent \#42, author's files; Clennon interview, 12 Jun 1997; Written comment, 1997 BDRS, respondent \#31, author's files.

${ }^{73}$ Clennon interview, 12 Jun 1997; Etscovitz interview, 12 Aug 1997. 
What the men who avoided an induction-ceremony confrontation did not know was that with each passing year, prosecutors found it increasingly difficult to bring draft resistance cases to trial and to win them when they did. Table 9.4 shows that in 1966, the U.S. Attorney in Boston won 16 convictions or guilty pleas from a total of 26 indicted draft resisters. That amounts to a $62 \%$ success rate. But by 1968 , the situation had changed dramatically. The department won only 8 convictions or guilty pleas out of 50 indictments, or a $16 \%$ success rate. This drop can be attributed in part to an increase in the number of indicted men who left the country (17) - again, almost all of the indicted men refused induction individually, not as part of a draft resistance movement that strongly discouraged immigration - but it also resulted from mistakes made by draft boards. Sometimes, bureaucratic errors were sufficient to keep a case from being prosecuted (or to get it dismissed), but it seems reasonable to attribute the dearth of prosecutions (only 12 of the 30 men surveyed who refused induction were prosecuted) to an understanding that several draft resistance cases had attracted the attention of the Supreme Court which was expected to rule on several issues germane to such cases. Indeed, several major judicial decisions, three of which stemmed from Boston draft resistance cases, were handed down in late 1968 and 1969.

Not long after a Cheyenne, Wyoming draft board reclassified Jim Oestereich, the Andover Newton seminarian, to 1-A, Oestereich engaged the services of the American Civil Liberties Union who filed suit against the Selective Service in federal court to prevent Oestereich's induction on the grounds that his local board had punished him through a punitive reclassification without due process. The District Court dismissed the 
complaint and the Court of Appeals affirmed it, in part because the Selective Service Act of 1967 stated that there should be no pre-induction judicial review of the classification record of any registrant. In May, however, the Supreme Court agreed to hear the case. In October, Oestereich's attorney, Melvin Wulf, of the ACLU, argued the case before the Court. General Hershey used the draft to punish dissenters of national policy, Wulf argued, and consequently deterred many unknown persons from expressing any view at all. In addition, Wulf reiterated his original charge that punitive reclassification was unconstitutional..$^{74}$

On December 16, 1968, in what was hailed as a landmark decision. the Court ruled in favor of Jim Oestereich. The Court focused on Oestereich's status as a ministerial student and the draft exemption that his draft board had granted him. As distinct from the II-S student deferment which theoretically postponed a registrant's obligation to serve in the armed forces., the 4-D classification exempted the registrant from military service for as long as he was a divinity student or minister. "Once a person registers and qualifies for a statutory exemption." Justice William O. Douglas wrote for the Court, "we find no legislative authority to deprive him of that exemption because of conduct or activities unrelated to the merits of granting or continuing that exemption." Douglas described the conduct of the Cheyenne draft board as "basically lawless," and asserted that Oestereich's reclassification and induction order were no different in constitutional implications than if the board called a minister or another "clearly exempt

74 A good summary of the chronology of the Oestereich case is given in Morgan David Arant, Jr., "Government Use of the Draft to Silence Dissent to War," Peace \& Change 17:2 (April 1992), pp. 147-171. 
person" for induction "(a) to retaliate against the person because of his political views or (b) to bear down on him because of his religious views or his racial attitudes or (c) to get him out of town so that the amorous interests of a Board member might be better served." A few weeks later, Douglas commented, "There is no suggestion in the current draft law that the Selective Service has free-wheeling authority to ride herd on registrants, using immediate induction as a disciplinary or vindictive measure."76 The draft resisters, it seemed, had won this one.

In fact, however, the Court did not rule that punitive reclassifications were inherently unconstitutional (as Melvin Wulf had argued). The decision applied only to the reclassification of registrants with ministerial exemptions. The Court's judgement said nothing about reclassification of other registrants resulting from protest activity. In Boston, Jim Oestereich learned of the decision on the morning of the $16^{\text {th }}$ when a UPI reporter called him at the American Friends Service Committee office. Oestereich, who had been filled with so much emotion when he turned in his draft card, and who had been basically run out of Lunenburg where he had been a youth minister, now had something to cheer about. Others cautioned against getting too optimistic. Michael Zigmond reminded readers of the SUPPORT newsletter that the Oestereich decision amounted to "victory on the narrowest possible grounds." He feared that piecemeal victories such as this might undermine some of the outrage that fueled the movement. "Any victory is

75 Oestereich v. Selective Service System Local Board No. 11, Cheyenne, Wyoming, et al., 393 U.S. at 237.

${ }^{76}$ Flynn, Louis B. Hershey, p. 267. 
important," he wrote. "Yet we must be careful. Too many of us are still uncomfortable in our new anti-establishment roles, all too ready to return to our old lives at the slightest hint of a bombing halt or a favorable court decision"

Still, the Oestereich decision offered a glimmer of hope that the Court might yet clamp down on the Selective Service's use of the draft as punishment for protesters. A year later, two decisions effectively expanded the Oestereich ruling to all draft resisters. In Gutknecht v. United States the Court ruled in the petitioner's favor in a case in which Gutknecht's draft board accelerated his induction schedule, effectively trying to take him out of order (he was already classified I-A) after he left his draft card on the steps of the Federal Building in Minneapolis on October $16,1967 .^{78}$ And in the decision for Breen $v$. Selective Service Board No. 16, issued the same day as the Gutknecht decision. the Court decided that the draft board had acted unconstitutionally when it reclassified Timothy Breen, a student at Boston's Berklee College of Music for failure to possess the draft card he had returned at the Arlington Street Church on October 16. "We fail to see any relevant practical or legal differences between exemptions and deferments," Justice Hugo Black wrote, thus extending the Court's judgement in Oestereich to cover all registration classifications. ${ }^{79}$ Collectively, the three decisions held that punitive reclassification by local draft boards was unconstitutional.

\footnotetext{
7 Oestereich interview, 20 Dec 1997; "Oestereich Decision," SUPPORT Newsletter, 16 Jan 1969, MZP.

78 Gutknecht v. United States, 393 U.S. 295.

79 Breen v. Selective Service Local Board No. 16, Bridgeport, Connecticut, et al., 396 U.S. 460.
} 
A third court ruling in a Boston case further undermined the Selective Service's channeling system. In the case of United States v. Sisson, U.S. District Court Judge Charles Wyzanski, who had presided over many draft resistance cases in the previous four years, issued a ruling that said the Selective Service law's identification of certain religions as the only ones acceptable for the granting of conscientious objector status discriminated against non-religious objectors. John Sisson, a resident of Lincoln, Massachusetts held a II-S student deferment until he graduated from Harvard in 1967. His West Concord draft board reclassified him I-A in November and called him for induction in April 1968. At the time, Sisson worked for the Southern Courier, a civil rights movement newspaper associated with Harvard in Montgomery, Alabama. In February 1968, while still in Alabama. Sisson had written to his draft board requesting an application form for conscientious objector status, but decided not to complete it because he did not fit the religious profiles required for that classification. At his trial he said he refused induction because he believed that "the United States military involvement in Vietnam is illegal under international law as well as under the Constitution and treaties of the United States" and that his "participation in that war would violate the spirit and letter of the Nuremberg Charter." On the basis of his knowledge of the Vietnam War, Sisson concluded, "I could not participate in it without doing violence to the dictates of my conscience." It was the most common of arguments among draft resisters. So many resisters came to their stand in the fall of 1967 or spring of 1968 after having their CO applications denied because they were not Quakers. The Sisson decision at last 
acknowledged their stand. ${ }^{80}$

Judge Wyzanski, who many court observers believed had long been seeking a case such as this, issued an arrest of judgement in the guilty verdict against Sisson in deciding that the defendant could not be criminally convicted in the case because he was a legitimate conscientious objector. In a lengthy opinion, Wyzanski raised the question of selective objection to war, an issue long important to the draft resistance community, repeatedly pointed to Sisson's sincerity. "On the stand, Sisson was diffident, perhaps beyond the requirements of modesty," the judge wrote. "He was entirely without eloquence. No line he spoke remains etched in memory. But he fearlessly used his own words, not mouthing formulae from court cases or manuals for draft avoidance." Wyzanski highlighted Sisson's sense of social obligation in working for the Courier and applying to the Peace Corps, and in prose that heartened all draft resisters, outlined in detail Sisson's moral development.

Sisson's table of ultimate values is moral and ethical. It reflects quite as real, pervasive, durable, and commendable a marshaling of priorities as a formal religion. It is just as much a residue of culture, early training, and beliefs shared by companions and family. What another derives from the discipline of a church, Sisson derives from the discipline of conscience...He was as genuinely and profoundly governed by his conscience as would have been a martyr obedient to an orthodox religion.

In short, Wyzanski said, the 1967 draft law discriminated against "atheists, agnostics, and men like Sisson," who were motivated in their objection to conscription "by profound

80 John Sisson, interview with author, 13 Jul 1998; United States v. John Heffron Sisson, Jr., 294 F. Supp. 511. 
moral beliefs which constitute the central convictions of their beings."8I The United States appealed to the Supreme Court, but the Court let the decision stand without hearing it.

With these important cases working their way through the federal court system, it is not surprising that prosecutors in Boston relaxed the pace of draft resistance indictments after December 1968. Even before the Breen and Gutknecht decisions, a reasonable person could have deduced that the Oestereich ruling would make winning any of these cases more difficult. Ultimately, of the thirty men in this study's sample who refused induction, only twelve were prosecuted and only five of them were convicted. ${ }^{82}$ Therefore, for a variety of reasons - from illegal behavior on the part of local draft boards and self-preservation on the part of resisters - only five (roughly 4\%) of the 121 draft resisters who responded to the survey issued as part of this study went to prison. This record is virtually identical to the the national average which convicted $8,750(4.2 \%)$ out of 209,517 accused draft offenders. ${ }^{83}$

Ironically, the court victories and the Justice Department's general lack of success

${ }^{81}$ U.S. v. Sisson, 294 F. Supp. 511 . Note: in some ways, Wyzanski's decision echoed an earlier Supreme Court decision in the case of U.S. v. Seeger, 380 U.S. 163 (1965), in which the court held that Seeger, an atheist, could not be denied conscientious objector status because he did not belong to one of the religious groups outlined in the Selective Service law. Wyzanski's decision differed from the Seeger decision in that it allowed for selective conscientious objection; that is, a registrant could decide which wars to fight in and which not to.

82 Of the thirty men who refused induction who completed the 1997 survey, 18 were not prosecuted. Of the twelve men who were prosecuted, five were convicted, three acquitted, and four others saw their cases dismissed

${ }^{83}$ Statistics cited in Baskir and Strauss, Chance and Circumstance, p. 69. 
came as the draft resistance movement in Boston came to an end. The source of the Resistance's disintegration could be attributed to finances as well as intemal divisions that could not be bridged. First, by moving away from draft card turn-ins and their natural following of middle-class men, the Resistance gave up its main source of funding: suburban liberals. Even if they were inclined to donate money to the Resistance, the working-class families of GIs had fewer resources to share with the antiwar movement than middle-class supporters of draft resistance initially did. In August 1968, the Resistance needed to send out a special letter soliciting more funds. "At a time when we must expand our operations, we are in danger of bankruptcy," the letter said, noting that the organization was $\$ 2,000$ in debt and operated on a $\$ 3,500$ monthly budget. By January, the monthly budget had dropped to $\$ 2,000$, but debts now tallied close to $\$ 3,000$. One year before, the Resistance enjoyed the prominence accorded Boston's leading antiwar organization, but now, as they acknowledged in their January 1969 newsletter, few knew what had happened to them. The "desperate financial straits" they found themselves in would not improve. ${ }^{84}$

In the spring, the New England Resistance finally folded. The end came after Penney Kurland (who had been active with the Resistance since the BU sanctuary) returned from the national Resistance conference in Bloomington, Indiana. There she had met many other women from other Resistance groups across the country. They shared their experiences and realized that they were all being marginalized within their 1969, MKFP.

Michael Ferber letter to supporters, Aug 1968, MKFP; NER Newsletter, Jan 
organizations in the same ways. When they left Bloomington, they pledged to one another that they would confront the men in their organizations on the gender inequities in the movement. In Boston, this confrontation between the men and women of the New England Resistance led to the collapse of the organization. Although some men expressed contrition over the way the group had treated women, the women decided that the formation of their own resistance was more important than continuing with their present course. The remaining six or eight women left the organization and went on to form Boston's first consciousness-raising groups. The New England Resistance soon voted to become a chapter of Students for a Democratic Society. By summer, they were forced to move out of the Stanhope Street office. Neil Robertson, Steve Pailet, and Ira Arlook started driving taxi cabs to raise money to pay off the remaining Resistance debts. On August 2, 1969, in the saddest footnote to the history of the New England Resistance, a passenger shot and killed Pailet in a robbery that the police never solved. ${ }^{85}$

Even before the New England Resistance dissolved, most of the remaining activists felt burned out. The organization's revolutionary rhetoric from the previous summer had given way to cautious approval for positive court decisions. The intensity of 1968 had taken its toll on the movement. Now, in 1969, Richard Nixon took over a war that showed few signs of ending.

But it would be too easy to dismiss the last half of 1968 and the early months of

85 Barrie Thome, "Resisting the Draft," p. XX; Kurland interview, 21 Feb 1999; Stone interview, 28 Mar 1997; Robertson interview, 7 Aug 1998. 
1969 as a period of fitful searching for new strategies to end the war. In fact, Boston's draft resistance community, though diminished in size, made several important advances over that period. First, the alliance with servicemen and their emphasis on GI dissenters ushered in a new phase of antiwar protest in which GIs and veterans - with whom the public associated a moral authority that they never granted civilian protesters - eventually came to dominate the movement against the war. The sanctuaries organized by the Resistance attracted considerable publicity to antiwar servicemen, and GI outreach helped sustain soldiers who opposed the war. Second, the network of supporters pulled together by SUPPORT kept alive dreams of a real resistance community in which the whole group supported individuals and their families in time of need, especially during trials and once resisters were sent to prison. Finally, the Resistance could take some credit for protecting the civil liberties of draft-age men when federal courts and the Supreme Court ruled against the government's misuse of the draft. In his memoirs, Richard Nixon wrote that he regarded draft resisters as cowards, but he also admitted that they affected the way he approached the war. When he instituted a lottery system for the draft and reassigned the aging General Hershey, he did so in part to undermine the antiwar movement. As Resistance activists moved on to other forms of protest, or drifted away from the movement, most (even if they felt emotionally spent) took some satisfaction in knowing that, try as it might, the government had not been able to ignore them. 


\section{EPILOGUE}

In the battle for freedom...it is the struggle for, not so much the attainment of, liberty, that develops all that is strongest, sturdiest, and finest in human character.

Emma Goldman

"What I Believe," 1908

On Saturday, October 18, 1997, about three dozen alumni of Boston's draft resistance community assembled at the Arlington Street Church for a reunion marking the thirtieth anniversary of the first draft card turn-in. Most of those in attendance still lived in the Boston area or elsewhere in New England, but some drove many hours to get there; and two - Dan Tilton and David Clennon (with his wife Perry) - flew in from California. Most of those in attendance were at least a little grayer, a little heavier, or a little balder, and maybe looked more like their parents now than they did during the sixties, but. for the most part, they recognized one another immediately. There were plenty of hugs to go around.

In typical Resistance fashion, the day-long event was characterized by an intentional lack of structure. Save for dinner plans - catered by one of the best Vietnamese restaurants in town - the afternoon was set aside for catching up. After a period of mingling and informal discussion, the group formed a massive circle so that each person could present a brief update on what he or she had been doing for the last thirty years. And that's how it went - at first. Each person talked about their careers and their families. Slowly, however, each successive presentation went longer, as more and more individuals began to reflect on their days in the Resistance. Many of them had 
clearly been giving some thought to their history as the reunion approached, and they now ruminated on how their experience with draft resistance affected their lives. The original five minute limit on testimonials soon stretched to fifteen or twenty minutes.

Several of the resisters openly regretted that they had not either followed through with their resistance all the way to prison, and/or that they had not really stayed active in political issues since the late 1960 s. The way they made these confessions - sheepishly, conveying a genuine sense of shame - elicited an immediate response from the others who, like a big brother offering reassurance to a younger sibling, made it clear that the community did not judge them harshly. Going to prison, someone mentioned, did not stop the war. And, although few of those in attendance still committed civil disobedience with any regularity, it did not mean that they did not still lead political lives. No one, for example, confessed to working for a defense contractor or to "selling out" to Wall Street. Moreover, as Rosanne Aversa, a former BDRG counselor, said that day, one might think that one has not lived a "political life," but personal decisions about how to raise children - and, in her case as a public school librarian, referring students to books on Emma Goldman instead of Woodrow Wilson - are political acts.

The purpose of this epilogue is to extend the thirtieth anniversary discussion at the Arlington Street Church to a wider population of the draft resistance community. Relying primarily on data gleaned from the 1997 Boston Draft Resistance Survey and oral history interviews, it is clear that most former resisters and their supporters have defied the stereotype of a sixties activist who in the 1980s became yuppies concerned only about the accumulation of personal wealth. They may not be marching in the streets, but their view 
of the world remains largely consistent with that of their youth.

\section{Life After the Resistance}

In 1969 , a new president took office promising to end the war in Vietnam. During the election campaign he promised "Peace with Honor." But despite initiating a gradual troop withdrawal program and altering the draft selection process to a lottery system (both in 1969), Richard Nixon actually began expanding the war during his first year in office. Within weeks of taking up residence in the White House, Nixon widened the air war to include thousands of secret sorties over Cambodia. A year later, he sent ground forces into Cambodia, thus triggering protests more widespread and intense than any of his predecessors had experienced. There would be no peace with honor. By the time the United States signed the Paris Peace Accords in January 1973, Richard Nixon's administration had seen another 20,553 American soldiers die along with 107,000 South Vietnamese troops and more than half a million enemy soldiers; civilian casualties from 1969 to the end of 1972 may have reached one million.

For the men and women who made up Boston's draft resistance community from 1966 to 1969 the passing of their movement did not signal an end to their activism. Although Nixon initiated the draft lottery and troop withdrawals in part to "lessen the steam behind student protest," and although the larger antiwar movement certainly experienced some lulls, most former draft resistance activists found plenty of opportunities to register their opposition to the war long after the Resistance disbanded. Campus protest continued to grow throughout the greater Boston area, and the October

\footnotetext{
1 Flynn, The Draft, p. 243.
} 
15, 1969 Moratorium - a national day of protest in which citizens all across the country stayed home from work and school to register their opposition to the war - attracted 100,000 people to a rally on the Boston Common. It was the largest demonstration in the city's history. On the same day, doctors in white lab coats collected signatures for antiwar petitions outside the historic Old South Church; 400 lawyers gathered at Faneuil Hall to protest against the war. As several historians later wrote: for one day, at least, it became patriotic to demonstrate. ${ }^{2}$

Ultimately, the 1997 survey found that at least two-thirds of the Boston draft resistance community stayed active in the antiwar movement as draft resistance tapered off. $^{3}$ Some former draft resisters and their supporters joined other antiwar organizations such as the Indochina Peace Campaign, the Coalition for Peace and Justice, the Fifth Avenue Peace Parade Committee, the U.S. Servicemen's Fund, and many others. John Phillips and Suzy Williams, both of whom had been beaten on the South Boston Courthouse steps in 1966, joined what became known as the "Ultra-Resistance," raiding draft boards, often in broad daylight, and destroying thousands of I-A files. ${ }^{+}$Others, less

2 Zaroulis and Sullivan, Who Spoke Up?, pp. 269, 271-272; see also DeBenedetti, An American Ordeal. pp. 255, 257, for a similar assessment.

3 When asked what they did immediately after the draft resistance movement, 120 of $185(64.9 \%)$ respondents said they "remained active in antiwar movement." In addition, however, Table E.I shows that 142 of $184(77.2 \%)$ activists said that they were at least "somewhat involved" in "other Vietnam antiwar movement activities." It seems reasonable, therefore, to say at least two-thirds of the former draft resistance community remained active in protesting against the war.

4 Note: Williams actually carried out her first draft board raid at Boston's Customs House with Frank Femia, another CNVA member, aided by John Phillips, in June 1968, during the Spock Trial. Phillips later achieved further renown as a member of 
bold, worked for town referendums against the war. Eventually, the Massachusetts legislature passed a bill in April $1970^{-}$that would allow Massachusetts men to refuse combat if Congress did not first declare war as required by the Constitution. The new law empowered the state attorney general to bring any such case directly to the United States Supreme Court for a ruling. The sponsors hoped, therefore, to get the Court to rule on the constitutionality of the Vietnam War. But in November, 1970 the Court refused to hear the first Massachusetts case based on this law. As Nancy Zaroulis and Gerald Sullivan noted, "thus failed one more attempt to end the war through the system." And so, some people continued to work outside the system. One respondent to the 1997 survey wrote that even though he felt "completely exhausted, physically, emotionally and financially, after the movement," he continued to withhold payment of his income taxes until fall $1972 .^{6}$

In addition to continuing their commitment to antiwar activism, some members of the draft resistance community went on to other social and political activism that did not pertain to the war. Almost all of the women who participated in the 1997 survey ( 21 of 25 or $84 \%$ ) went on to join the women's movement. They formed the city's first consciousness raising groups and eventually founded the influential Bread and Roses

the so-called Chicago 15, when he joined Philip Berrigan in a massive nighttime raid of Chicago's Selective Service offices. Williams served a year and a half in prison (bracketed around an escape) and Phillips spent two and a half years in prison for their actions.

' Zaroulis and Sullivan, Who Spoke Up?, p. 315.

6 Respondent \#71, Boston Draft Resistance Survey, 1997. 
collective.' A handful followed Ira Arlook into the working-class communities of Lowell, Lynn, Lawrence, New Bedford, Fall River and Boston's Mission Hill neighborhood to do community organizing. ${ }^{8}$ Very few gravitated to the Progressive Labor Party, a Maoist offshoot of SDS largely credited with the demise of BDRG and Harvard SDS. ${ }^{9}$ And not one respondent to the 1997 Boston Draft Resistance Survey aligned himself or herself with Weatherman, the most extreme SDS splinter group. Critics of the 1960s generation generally inflate the importance of Weatherman, an organization which, thanks to several successful bombings, attracted considerable media attention from 1969 to 1971 , and likewise overstate the extent to which many radicals dropped out of society to live together in communes. Here again, the survey upsets these misconceptions. Of 185 respondents, only $20(10.8 \%)$ stated that they moved into a commune after their draft resistance days. Few, it turned out, were prepared to drop out altogether.

Although some draft resistance activists have certainly mellowed in their political and ideological stands over the last thirty years, very few hung on to the American political pendulum through much of its sweep from left to right. Table E.l (see Appendix A) shows that the draft resistance community which counted not a single Republican

7 DuBois interview, 11 Jun 1997; Field interview, 17 Jun 1997; Katz interview, 2 Mar 1999; Kurland Lagos interview, 21 Feb 1999; Stone interview, 28 Mar 1997; Thorne interview, 28 Oct 1997.

8 Arlook interview, 12 Aug 1998; Robertson interview, 24 Aug 1997.

98 (4.3\%) out of 185 respondents said they joined PL after their resistance days, 1997 Boston Draft Resistance Survey. 
among its adherents (as represented by the survey's respondents) when the movement waned now counts eight (4.8\%). More significant is that the large number of men and women who identified themselves as anarchists, socialists, or communists has decreased, though nearly one-third continue to use these labels. An attendant increase in the proportion of "liberal Democrats" in the survey population has resulted from this development. ${ }^{10}$

Over the years, the overwhelming majority of Boston's draft resistance community have chosen to participate at one time or another in other social causes and protest activism. Table E.2 shows the extensive variety of this work. Although no single issue has galvanized this group of people to protest as fervently as the Vietnam War once did, a significant number of them have taken part in the environmental movement, the anti-nuclear movement, and in protests against American involvement in El Salvador and Nicaragua in the 1980s. Only 16 of $185(8.6 \%)$ survey respondents have not participated in any type of social or political activism since the Vietnam War. Thus, it would appear that a certain faith in the power of social movements and grassroots organizing persists among those former draft resisters and their supporters.

That said, there are some indications of ambivalence about social movements, too. Though it is no doubt unfair to judge other forms of activism against the antiwar movement, the survey results clearly demonstrate that to the extent that most respondents have participated in other movements, the level of involvement has generally been lower

$1032(31 \%)$ of 103 anarchists, socialists, and communists among the population now list themselves as liberal Democrats. 
than during the war (see Table E.2). The average number of individuals from this sample who characterize their activism as "somewhat involved." for example, is more than three times the number who described themselves as "very involved," and twice the number of those "moderately involved." Of course the reasons for this could be numerous. As one person wrote on their questionnaire, his paucity of involvement today derives "not from [lack of] conviction, but lack of time." I2 It is a common sentiment.

Maybe more important is a slight undercurrent of cynicism regarding social movements. One survey respondent wrote that while she believes activism could affect real change in America one day, she also thinks that the "collective will necessary to mobilize people now" is absent. "Apathy, self-centeredness, runs too deep," she said. Mike Jupin, the associate rector who caused such a stir at his Winchester church in 1967 says now that his experience opposing the war in Vietnam led him to develop "a certain amount of cynicism about political processes and the difficulty of bringing about change." For one, arguments made on both sides of issues "are much less intellectual than they are emotional," which makes it difficult to move others. More important, he says now, however, is that he learned how "incredibly resistant to change" is any system. "It's just very difficult," he laments. "I'm not nearly the activist that I once was."

This skepticism notwithstanding, most resisters and those who joined them in the

"The mean for each level of involvement was calculated only for the causes and social movements listed in Table E.l, save the Moral Majority and Christian Coalition (which, between them, attracted only one person from this group). The mean for "very involved," is 9.67; for "moderately involved," 15.86; and for "somewhat involved," 33.24.

12 Respondent \#56, 1997 Boston Draft Resistance Survey. 
draft resistance movement still possess a strong faith in the ability of ordinary people to effect change in American society. Täble E.3 shows that an overwhelming majority of this group agrees that social movements can be potentially effective vehicles for social change in contemporary America. One former resister commented that, although the United States is currently experiencing a period of "moral and political crisis," and although "the potential for social movements now seems low," he firmly believes that "nothing else will bring us toward being a country of justice and peace." 13 This sentiment is echoed by another former resister, now a minister, who sees social movements as the most obvious manifestation of what he calls "the struggle." The objectives of the struggle - which engages "people of good will from all communities" - are "human liberation and...acting against that which oppresses people." ${ }^{4}$ Naturally, some among the old draft resistance community are not as sanguine. One former draft counselor wryly remarked. "Chomsky says movements do have an effect [in shaping society], but TV and the mall seem to have more effect."'s Moreover, another Resistance supporter argues, "the media does not like movements today." He believes that the social movements of the 1960 s benefitted from a positive media coverage - an assumption that some of his former colleagues would challenge - that cannot be expected today. "Social change is boosted by the marriage of movement and media, and I just don't see that happening any time soon,"

\footnotetext{
13 Respondent \#126, 1997 Boston Draft Resistance Survey.

14 Respondent \#33, 1997 Boston Draft Resistance Survey.

is Respondent \#79, 1997 Boston Draft Resistance Survey.
} 
he concluded. ${ }^{16}$ Overall, however, the survey indicates that a vast majority of respondents still believe in the power of social movements, and many no doubt agree with the former resister who said they are "the only hope."17

Finally, whether social movements are the only hope or not, the career choices of former draft resistance advocates in many ways seem to reflect their concerns with social issues or facilitate their examination and discussion of them (see Table E.4). Far and away the most popular current occupation of this group is in academia and teaching. More than thirty percent of respondents to the 1997 survey indicated that they currently teach at the colleges and universities or in a local school system. Professions in which the welfare of others is a primary concern also dominate the list of occupations. For instance, in addition to the noticeable number of physicians, psychiatrists, and psychologists ( $9 \%)$ in the group, a number of respondents work and often run non-profit or charitable organizations: Nan Stone is the director of a regional AIDS relief organization; Ray Mungo is a social worker; Gary Hicks is a tenant organizer; and others list their occupations as patient advocate, child welfare worker, community arts program director, and cooperative housing organizer. Likewise, another ten percent are involved in artistic endeavors, whether as actors (David Clennon, Dick Huges, and Harold Hector), film makers (Connie Field, and Tim Wright) or artists and writers. There is therefore, an apparent leaning away from mainstream work in the business world, and although there are a significant number of doctors and lawyers in this group, most of the professional

\footnotetext{
16 Respondent \#83, 1997 Boston Draft Resistance Survey.

17 Respondent \#99, 1997 Boston Draft Resistance Survey.
} 
categories lean toward the liberal arts. As many of those who attended the 1997 reunion remarked, their work has turned out tō be a natural extension of the activism of their youth. They remain engaged with major issues of the day and are concerned about the young, the poor, and the alienated.

\section{Looking Back}

The positive view of social movements that most former resisters and supporters maintain today no doubt stems in part from a sense that they waged a struggle that was at least partially successful thirty years ago. Not only do they disagree overwhelmingly with conservative critics who charge that the 1960s generation was primarily "destructive," or that the antiwar movement was ineffective and actually prolonged the war (thus causing more deaths), but the vast majority believe that the draft resistance movement ended the draft and helped to end the Vietnam War (see Table E. 5).

The validity of these claims is still the subject of debate in some circles. In his historical survey of American draft law violators from 1658 to 1985 , Stephen Kohn describes the Vietnam War era draft resistance movement at the one that "finally succeeded." He credits draft resisters with causing the "collapse" of the nation's draft system. Likewise, Lawrence Baskir and William Strauss conclude in their landmark study of the Vietnam War generation that if the Resistance did not bring the war to an end or bog down the court system with draft cases, it at least jammed prosecutors' offices. ${ }^{18}$ The present study, as indicated especially in Chapter Nine, did not reach the same

18 Kohn, Jailed for Peace, p. 142; Baskir and Strauss, Chance and Circumstance, p. 67. 
conclusion: in Boston at least, proportionately few draft resisters faced the threat of prosecution. Nevertheless; George Q. Flynn, the leading historian on the modern draft and Louis Hershey's biographer - and certainly not an antiwar movement partisan acknowledges that the Nixon administration's decision to reform and ultimately end the draft came in reaction to the draft resistance movement and its success in publicizing the unfairness of a system of conscription that called the poor and underprivileged in disproportionate numbers. ${ }^{19}$ At a time when most Americans believed the draft should continue after the war ended (and fewer than one third favored an all volunteer force), ${ }^{20}$ Nixon moved to institute the lottery and later terminated the draft altogether. In his memoirs, Nixon admits that although he regarded draft resisters as cowards, they did influence his decisions in these matters, if only because he wanted so badly to subvert their efforts and those of the larger antiwar movement. ${ }^{21}$

In later years, the elimination of the draft has been criticized by those who regard military service as one of the few duties of citizenship in America that fosters a sense of civic responsibility in those who participate. Historian John Chambers, for instance,

19 Flynn, The Draft, pp. 181, 236.

20 A January 1969 Gallup Poll found that $62 \%$ of Americans thought the draft should continue after the Vietnam War ended, and that only $32 \%$ favored the idea of an all volunteer force. Flynn, The Draft, p. 237.

${ }^{21}$ Richard Nixon, No More Vietnams (New York: Arbor House, 1985), pp. 102, 125. In addition to reforming and ending the draft, the Nixon administration used the CIA illegally and the FBI unethically in infiltrating the antiwar movement with the aim of destroying it. See Flynn, The Draft, p. 237; Ward Churchill and Jim Vander Wall, The COINTELPRO Papers: Documents from the FBI's Secret Wars Against Domestic Dissent (Boston: South End Press, 1990). 
argues that Nixon unintentionally "further reduced the symbolic importance of American citizenship." Elimination of the draft, he notes, "diluted a preeminent feature of political membership - the sense of shared sacrifice and patriotic commitment to a common goal." Although the vast majority of respondents to the draft resistance survey do not agree that compulsory military service would help to create a greater sense of civic responsibility in America today, 22 the question produced a bounty of qualifying statements. Most of those who commented acknowledge a dilution in social responsibility over the last generation and would favor a system of compulsory service for young Americans that, like the plan proposed by Robert McNamara in 1967, included non-military options. In addition, several resisters commented that the All Volunteer Force that evolved out of the end of the draft is no more equitable than the deferment-riddled system of conscription they fought to abolish. Wealthy and better educated men and women do not enter the military on the same scale as (and, therefore, do not bear the same burdens for their country as) poorer and less educated men and women who are drawn to serve by promises of educational and employment opportunities otherwise unavailable to them. Thus, whether the draft resistance movement caused the collapse of the draft or not, its elimination has had consequences that some former resisters find troubling. ${ }^{23}$

The claim that draft resistance helped shorten the war is another matter of some

22 When asked if they agree or disagree that "compulsory military service would help to bring a greater sense of civic responsibility in contemporary America," 150 (87.7\%) of 171 respondents disagreed. Only four agreed strongly. 1997 Boston Draft Resistance Survey.

23 Respondents \#1, 19, 40, 53, 61, 73, 82, 93, 121, 132, 144, 146, 151, 155, 157, $160,169,178,1997$ Boston Draft Resistance Survey. 
contention. Claims that a draft resistance movement that essentially folded in 1969 helped to stop a war that continued until January 1973 seem at first a bit overstated. The war did grind on for another four years after all, and as Thomas Powers wrote in the years immediately following the war, opponents of the war had to come to grips with the reality that the American government abandoned its policy in Vietnam not because the antiwar movement had persuaded most Americans to oppose the war - or because the war was simply wrong - but because the Vietnamese would not yield after more than a decade of fighting. Indeed, this issue is at the heart of Adam Garfinkle's argument that the antiwar movement failed totally in its efforts to move public opinion against the war and that it succeeded only in dragging the war out longer. But Garfinkle does not address draft resistance within the antiwar movement or issues of manpower allocation at all in his analysis, and, more important, he does not consider the issue of conscience in a civil society. ${ }^{24}$

In 1967 and 1968, draft resistance raised the stakes of fighting the Vietnam War. Draft resisters and everyone who supported them waged their protest at a new level of intensity that not only incurred significant risks for participants, but also forced the Johnson administration to finally take notice of - and respond to - a growing community of opposition. Maybe most important, as the Selective Service made matters worse by punitively reclassifying resisters, and as the Justice Department prepared to prosecute these men, key officials in the Pentagon and the State Department pointed to an expected surge in draft resistance if the president granted General Westmoreland's request for

${ }^{24}$ Powers, The War at Home, p. xv; Garfinkle, Telltale Hearts, 
206,000 additional troops. That is the most obvious evidence that the draft resistance movement helped to rein in the war effort.

And here Garfinkle may yet be right: by preventing the fulfilment of that troop request and, more significant, by causing foreign policy officials to worry about the antiwar movement, perhaps the antiwar movement was guilty of contributing to a longer war. We can never know, of course, but at the end of the day, it is not a particularly meaningful question. The more important question revolves around the moral issue of a citizen's responsibility to his country when the government is engaged in behavior that he deems "illegal," "immoral," or "obscene." Should he remain passive, as Garfinkle's argument seems to imply, in hopes that the war will end sooner than if he took to the streets in protest? As one resister asked rhetorically, "what would have happened without the movement? Would we have nuked Vietnam? Destroyed half the world in our anticommunist obsession? Despite rampant revisionism, history has born us out. Communism self-destructed without us having to bomb Russia, China, etc. Governments evolve without war." It is significant that he emphasizes the draft resistance movement's role in deterring an even wider war in Vietnam or elsewhere, for even among those who believe their efforts in the Resistance did not help end the war, most agree that, as another resister wrote on his survey, the Resistance "served only as a counterbalance to keep the war from being wider...from being more vigorously fought."s

Noam Chomsky argues that one of the greatest legacies of the Vietnam era

2s Respondent \#19, 1997 Boston Draft Resistance Survey; Respondent \#59, 1997 Boston Draft Resistance Survey. 
antiwar movement is that it set an example for others to follow. When Ronald Reagan began to build a "counterinsurgency" program in El Salvador just as John F. Kennedy had done in South Vietnam, his administration eventually had to back off, Chomsky says, because "there was just an uprising all over the country - nobody was going to tolerate it." Soon, the Reagan administration moved to a program of "clandestine terror," that Kennedy and Johnson, operating at a time when most Americans did not generally question their government's foreign policy, never had to consider. That, Chomsky concludes, is a major change. ${ }^{26}$

Beyond a general sense that the draft resistance movement helped to end the war (as indicated in Table E.4), when asked to reflect on the significance of the movement, most former resisters and supporters speak about its personal impact rather than its political one. Chris Venn, who ultimately went to prison following an accumulation of run-ins with the law over draft resistance and fighting police in Berkeley's battle for People's Park, says now that turning in his draft card "defined who I am ever since." Although his mother criticized him for his draft resistance saying he would never get the GI Bill or the kinds of house loans afforded veterans, Venn always regarded the "standing up for principles, [and] understanding the consequences of it," as the most valuable lesson of draft resistance. Ray Mungo likewise wrote in 1970 that regardless of what happened with his battles with the draft he hoped "never to regret having handled it as I did - uncompromisingly but kind of cavalierly." "It's something I'm doing," he concluded, "maybe the only thing, for my self-respect." Others, like David Stoppelman,

${ }^{26}$ Chomsky interview, 20 May 1997. 
who also did prison time, now regret the effect his draft resistance had on his family, and is not so sure that resisting the draft was the right thing to do.

Most activists, however, regard their draft resistance work as invaluable in that it taught them how make difficult choices based on principle, and that doing so did not signal "the end of the world." They could survive it. "Although I'm older now and...we pay our taxes and we have this average sort of urban lifestyle," Jim Oestereich says now, "I know that tomorrow, if I had to hit a barricade, I know how to do it. And I'd know how to make the decision, and I'd know how to live with it. Those are things I didn't know before [resisting the draft]." Jack Bishop, the rector at Winchester's Parish of the Epiphany when Mike Jupin's draft resistance caused controversy, regards that crisis as "the turning point" in his life. "It's awfully hard to move forward without constant reference to 1967 and what it meant to me as a priest," he said. "It certainly pointed out that if one is going to take a personal stand, that that's going to require an awful lot of energy: spiritual, mental, emotional, and physical - the whole works." Perhaps the survey comments of one other resister come closest to conveying how most feel today about their draft resistance experience: "Would I do it again? Depends on the circumstances. I did not like being illegal, but I still thought the war and the draft were wrong, wrong enough to demand civil disobedience. I like to think that I would still be willing to break a bad law. But I don't know...you get awfully comfortable. Like E.M. Forster, I hope I would have the guts to betray my country."27

27 Oestereich interview, 20 Dec 1997; Bishop interview, 11 Dec 1997; Respondent \#60, 1997 Boston Draft Resistance Survey. 
Finally, a common sentiment among members of the Boston draft resistance community is that the movement introduced them to some of the finest people they have ever met and taught them something about the essential qualities of a good human being and a decent society. Their interpretations of their participation in the movement to end the war in Vietnam echo the characterization of struggle made by Emma Goldman in the epigraph at the top of this epilogue. "The emphasis on values, feelings, human rights, justice, the collective spirit," Penney Kurland says, "have formed how I view the world, how I raise my children, and hopefully, how I treat others in both my personal and professional life." Bill Bischoff, the then-Harvard graduate student, veteran, and resister remembers it the same way. He gets the last word: "It was gratifying to be associated with as many people of high moral caliber and intellectual caliber as I was involved with. I really, in later years, I've missed that."28

${ }^{28}$ Penney Kurland Lagos, e-mail to author, 25 Feb 1999; Bischoff interview, 5 Jan 1998. 


\section{APPENDIX A}

\section{TABLES}

Table 4.1: Selective Service Classifications of Resisters in New England, Fall 1967

\begin{tabular}{|l|r|r|}
\hline \multicolumn{1}{|c|}{ Classification } & N & \multicolumn{1}{c|}{$\%$} \\
\hline 1-A (Available for service) & 35 & 17.5 \\
\hline 1-D (Reserve or ROTC) & 1 & .5 \\
\hline 1-O (Conscientious Objector) & 4 & 2.0 \\
\hline 1-S (Student) & 1 & .5 \\
\hline 1-W (Conscientious Objector) & 1 & .5 \\
\hline 1-Y (Physical or mental) & 23 & 11.5 \\
\hline 2-A (Occupational) & 2 & 1.0 \\
\hline 2-S (Student) & 85 & 42.5 \\
\hline 3-A (Hardship or dependent) & 6 & 3.0 \\
\hline 4-A (Prior active service) & 13 & 6.5 \\
\hline 4-D (Minister or divinity student) & 13 & 6.5 \\
\hline 4-F (Not qualified for military service) & 11 & 5.5 \\
\hline 5-A (Overage) & 3 & 1.5 \\
\hline Refused to register & 2 & 1.0 \\
\hline Totals & 200 & $100 \%$ \\
\hline
\end{tabular}

Source: New England Resistance "Master File," Papers of Alex Jack. 
Table 4.2: Resisters' Parents' Level of Education

\begin{tabular}{|l|c|c|c|c|}
\hline $\begin{array}{l}\text { Highest Level of Education } \\
\text { Achieved }\end{array}$ & $\begin{array}{c}\# \\
\text { Fathers }\end{array}$ & $\begin{array}{c}\# \\
\text { Mothers }\end{array}$ & $\%$ \\
\hline Some grade school & 6 & 5.1 & 3 & 2.6 \\
\hline Completed grade school & 4 & 3.4 & 3 & 2.6 \\
\hline Some high school & 6 & 5.1 & 9 & 7.7 \\
\hline Completed high school & 18 & 15.4 & 26 & 22.2 \\
\hline Some post high school training & 10 & 8.5 & 9 & 7.7 \\
\hline Some college & 16 & 13.7 & 19 & 16.2 \\
\hline Completed college & 13 & 11.1 & 27 & 23.0 \\
\hline Some graduate school & 7 & 6.0 & 4 & 3.4 \\
\hline M.A. or M.S & 7 & 6.0 & 11 & 9.4 \\
\hline Professional degree & 16 & 13.7 & 5 & 4.3 \\
\hline Master's plus additional grad work & 3 & 2.6 & 0 & 0.0 \\
\hline Doctorate & 11 & 9.4 & 1 & 0.9 \\
\hline Total & 117 & $100 \%$ & 117 & $100 \%$ \\
\hline Soure: & & & & \\
\hline
\end{tabular}

Source: 1997 Boston draft resistance survey.

Table 4.3: Resisters` Parents' Occupations

\begin{tabular}{|l|c|c|c|c|}
\hline Occupational Code & \# Fathers & $\%$ & $\#$ Mothers & $\%$ \\
\hline Semiskilled or unskilled & 5 & 4.3 & 2 & 1.7 \\
\hline Skilled & 13 & 11.3 & 1 & 0.9 \\
\hline Farmer & 2 & 1.7 & 0 & 0.0 \\
\hline Clerical or Sales & 15 & 13.0 & 20 & 17.2 \\
\hline Proprietor & 13 & 11.3 & 2 & 1.7 \\
\hline Professional & 67 & 58.3 & 31 & 26.7 \\
\hline Homemaker & 0 & 0.0 & 60 & 51.7 \\
\hline Total & 115 & 99.9 & 116 & 99.9 \\
\hline
\end{tabular}

Source: 1997 Boston draft resistance survey. 
Table 4.4: Resisters' Class Status

\begin{tabular}{|l|c|c|}
\hline Class Description & \# Resisters & $\%$ \\
\hline Working-class & 12 & 10.0 \\
\hline Lower middle-class & 13 & 10.8 \\
\hline Middle-class & 53 & 44.2 \\
\hline Upper middle-class & 40 & 33.3 \\
\hline Upper class & 2 & 1.7 \\
\hline \multicolumn{1}{|c|}{ Total } & 120 & 100 \\
\hline
\end{tabular}

Source: 1997 Boston draft resistance survey.

Table 4.5: Religious Affiliation of Resisters and Their Parents

\begin{tabular}{|l|c|c|c|c|c|c|}
\hline \multicolumn{1}{|c|}{ Denomination } & $\begin{array}{c}\# \\
\text { Fathers }\end{array}$ & $\begin{array}{c}\% \\
\text { Fathers }\end{array}$ & $\begin{array}{c}\# \\
\text { Mothers }\end{array}$ & $\begin{array}{c}\% \\
\text { Mothers }\end{array}$ & $\begin{array}{c}\# \\
\text { Resisters }\end{array}$ & $\begin{array}{c}\% \\
\text { Resisters }\end{array}$ \\
\hline Roman Catholic & 11 & 9.7 & 14 & 12.1 & 5 & 4.2 \\
\hline Baptist & 0 & 0.0 & 1 & 0.9 & 0 & 0.0 \\
\hline Congregational & 6 & 5.3 & 5 & 4.3 & 3 & 2.5 \\
\hline Episcopal & 16 & 14.2 & 17 & 14.7 & 7 & 5.9 \\
\hline Lutheran & 1 & 0.9 & 1 & 0.9 & 1 & 0.8 \\
\hline Methodist & 8 & 7.1 & 10 & 8.6 & 4 & 3.4 \\
\hline Presbyterian & 11 & 9.7 & 10 & 8.6 & 3 & 2.5 \\
\hline Unitarian-Universalist & 10 & 8.8 & 12 & 10.3 & 15 & 12.7 \\
\hline Quaker & 0 & 0.0 & 0 & 0.0 & 4 & 3.4 \\
\hline Mennonite & 0 & 0.0 & 0 & 0.0 & 0 & 0.0 \\
\hline Jehovah's Witness & 0 & 0.0 & 0 & 0.0 & 0 & 0.0 \\
\hline Jewish & 27 & 23.9 & 29 & 25.0 & 18 & 15.3 \\
\hline Agnostic & 8 & 7.1 & 5 & 4.3 & 30 & 25.4 \\
\hline Atheist & 10 & 8.8 & 6 & 5.2 & 20 & 16.9 \\
\hline Other & 5 & 4.4 & 6 & 5.2 & 8 & 6.8 \\
\hline
\end{tabular}




\section{Total}

113

99.9

116

100.1

118

99.8

Source: 1997 Boston Draft Resistance Survey

Table 4.6: Veteran Status of Resisters and Their Parents

\begin{tabular}{|c|c|c|c|c|c|c|}
\hline Veteran Status & $\begin{array}{c}\# \\
\text { Fathers }\end{array}$ & $\begin{array}{c}\% \\
\text { Fathers }\end{array}$ & $\begin{array}{c}\# \\
\text { Mothers }\end{array}$ & $\begin{array}{c}\% \\
\text { Mothers }\end{array}$ & $\begin{array}{c}\# \\
\text { Resisters }\end{array}$ & $\begin{array}{c}\% \\
\text { Resisters }\end{array}$ \\
\hline Veteran & 48 & 39.7 & 3 & 2.5 & 8 & 6.6 \\
\hline Non-Veteran & 73 & 60.3 & 118 & 97.5 & 113 & 93.4 \\
\hline Total & 121 & 100 & 121 & 100 & 121 & 100 \\
\hline
\end{tabular}

Source: 1997 Boston Draft Resistance Survey

Table 4.7: Political Leanings of Resisters and Their Parents

\begin{tabular}{|l|c|c|c|c|c|c|}
\hline Political Identity & $\begin{array}{c}\# \\
\text { Fathers }\end{array}$ & $\begin{array}{c}\% \\
\text { Fathers }\end{array}$ & $\begin{array}{c}\# \\
\text { Mothers }\end{array}$ & $\begin{array}{c}\% \\
\text { Mothers }\end{array}$ & $\begin{array}{c}\# \\
\text { Resisters }\end{array}$ & $\begin{array}{c}\% \\
\text { Resisters }\end{array}$ \\
\hline $\begin{array}{l}\text { Conservative } \\
\text { Republican }\end{array}$ & 15 & 13.0 & 6 & 5.2 & 1 & 0.9 \\
\hline Moderate Republican & 27 & 23.5 & 28 & 24.1 & 1 & 0.9 \\
\hline Moderate Democrat & 21 & 18.3 & 28 & 24.1 & 6 & 5.1 \\
\hline Liberal Democrat & 41 & 35.7 & 46 & 39.7 & 48 & 41.0 \\
\hline Socialist/Communist & 4 & 3.5 & 4 & 3.4 & 29 & 24.8 \\
\hline Anarchist & 1 & 0.9 & 1 & 0.9 & 17 & 14.5 \\
\hline No preference & 3 & 2.6 & 3 & 2.6 & 7 & 6.0 \\
\hline Other & 3 & 2.6 & 0 & 0.0 & 8 & 6.8 \\
\hline \multicolumn{1}{|c|}{ Totals } & 115 & 100.1 & 116 & 100 & 117 & 100 \\
\hline
\end{tabular}

Source: 1997 Boston Draft Resistance Survey 
Table 4.8: Parents with Shared Political Leanings

\begin{tabular}{|l|c|c|}
\hline Political Identity & Number of Couples & Percent of Couples \\
\hline Both Republican & 29 & 32.2 \\
\hline Both Democrat & 56 & 62.2 \\
\hline Both Socialist/Communist & 4 & 4.4 \\
\hline Both Anarchist & 1 & 1.1 \\
\hline \multicolumn{1}{|c|}{ Totals } & 90 & 99.9 \\
\hline
\end{tabular}

Source: 1997 Boston Draft Resistance Survey

Table 6.1: Parents' Views of Their Sons' Draft Card Turn-In

\begin{tabular}{|l|l|l|l|l|l|l|l|}
\hline Parent & N/A & $\begin{array}{l}\text { Strongly } \\
\text { Disapprove }\end{array}$ & Disapprove & $\begin{array}{l}\text { Non- } \\
\text { Committal }\end{array}$ & Approve & $\begin{array}{l}\text { Strongly } \\
\text { Approve }\end{array}$ & Total \\
\hline Father & 35 & 24 & 23 & 16 & 13 & 10 & 116 \\
\hline Mother & 22 & 19 & 27 & 22 & 21 & 11 & 116 \\
\hline & 57 & 43 & 50 & 38 & 34 & 21 & 232 \\
\hline
\end{tabular}

Source: 1997 Boston draft resistance survey. Note: Although 121 draft resisters responded to the questionnaire, only 86 answered questions regarding their fathers; 99 answered questions about their mothers. Therefore, the percentages that appear in the text are based on $N=86$ and $N=99$.

Table 6.2: Parish of the Epiphany (Winchester, Massachusetts) Reaction to the Rev. Michael Jupin's Draft Card Turn-in

\begin{tabular}{|l|c|c|}
\hline Reaction & \# of Parishioners & \% of Parishioners \\
\hline Approval & 73 & 55.7 \\
\hline $\begin{array}{l}\text { Disapproval in favor of } \\
\text { disciplinary action }\end{array}$ & 25 & 19.1 \\
\hline $\begin{array}{l}\text { Disapproval but not in } \\
\text { favor of punishing Jupin }\end{array}$ & 22 & 16.8 \\
\hline Other & 11 & 8.4 \\
\hline Totals & 131 & $100 \quad$ \\
\hline
\end{tabular}

Source: Written Responses, Parish of the Epiphany, 29 Oct 1967, Papers of the Reverend Jack Bishop 
Table 6.3: Supporters' Occupations

\begin{tabular}{|l|l|l|}
\hline Occupation & $\mathrm{N}$ & $\%$ \\
\hline Students & 33 & 48.5 \\
\hline Academics & 10 & 14.7 \\
\hline Other & 25 & 36.8 \\
\hline Total & 68 & 100 \\
\hline
\end{tabular}

Source: 1997 Boston draft resistance survey.

Table 6.4: Supporters' Parents' Occupations

\begin{tabular}{|l|c|c|c|c|}
\hline Occupational Code & \# Fathers & $\%$ & $\#$ Mothers & $\%$ \\
\hline Semiskilled or unskilled & 1 & 1.7 & 2 & 3.1 \\
\hline Skilled & 4 & 6.8 & 0 & 0.0 \\
\hline Farmer & 1 & 1.7 & 0 & 0.0 \\
\hline Clerical or Sales & 5 & 8.5 & 9 & 14.1 \\
\hline Proprietor & 15 & 25.4 & 4 & 6.3 \\
\hline Professional & 33 & 55.9 & 23 & 35.9 \\
\hline Homemaker & 0 & 0.0 & 26 & 40.6 \\
\hline \multicolumn{1}{|c|}{ Total } & 59 & 100 & 64 & 100 \\
\hline
\end{tabular}

Source: 1997 Boston draft resistance survey.

Table 6.5: Supporters' Class Status

\begin{tabular}{|l|c|c|}
\hline Class Description & \# Supporters & $\%$ \\
\hline Working-class & 6 & 9.1 \\
\hline Lower-Middle-Class & 4 & 6.1 \\
\hline Middle-Class & 31 & 46.9 \\
\hline Upper-Middle-Class & 24 & 36.4 \\
\hline Upper-Class & 1 & 1.5 \\
\hline Total & 66 & 100 \\
\hline
\end{tabular}

Source: 1997 Boston draft resistance survey 
Table 6.6: Parents of Supporters, Religious Affiliation

\begin{tabular}{|l|c|c|c|c|c|c|}
\hline Denomination & $\begin{array}{c}\# \\
\text { Fathers }\end{array}$ & $\begin{array}{c}\%: \\
\text { Fathers }\end{array}$ & $\begin{array}{c}\# \\
\text { Mothers }\end{array}$ & $\begin{array}{c}\% \\
\text { Mothers }\end{array}$ & $\begin{array}{c}\# \\
\text { Supporters }\end{array}$ & $\begin{array}{c}\% \\
\text { Supporters }\end{array}$ \\
\hline Agnostic & 6 & 10 & 5 & 7.8 & 16 & 24.6 \\
\hline Atheist & 5 & 8.3 & 3 & 4.7 & 22 & 33.8 \\
\hline Baptist & 1 & 1.7 & 2 & 3.1 & 0 & 0.0 \\
\hline Roman Catholic & 8 & 13.3 & 7 & 10.9 & 4 & 6.2 \\
\hline Christian Scientist & 1 & 1.7 & 0 & 0.0 & 0 & 0.0 \\
\hline Congregational & 2 & 3.3 & 2 & 3.1 & 0 & 0.0 \\
\hline Episcopalian & 4 & 6.7 & 5 & 7.8 & 1 & 1.5 \\
\hline Jewish & 18 & 30 & 19 & 29.7 & 10 & 15.4 \\
\hline Lutheran & 0 & 0.0 & 1 & 1.6 & 0 & 0.0 \\
\hline Methodist & 1 & 1.7 & 4 & 6.3 & 0 & 0.0 \\
\hline Mormon & 1 & 1.7 & 1 & 1.6 & 1 & 1.5 \\
\hline Presbyterian & 6 & 10 & 5 & 7.8 & 1 & 1.5 \\
\hline Unitarian & 5 & 8.3 & 6 & 9.4 & 7 & 10.8 \\
\hline Quaker & 0 & 0.0 & 1 & 1.6 & 1 & 1.5 \\
\hline Other & 2 & 3.3 & 3 & 4.7 & 2 & 3.1 \\
\hline Total & 10 & 100 & 64 & 100.1 & 65 & 99.9 \\
\hline Source: & 1997 Boston & 1.7 & & \\
\hline
\end{tabular}

Source: 1997 Boston Draft Resistance Survey

Note: Of the 60 fathers, 49 or $81.7 \%$ identified themselves with a religious domination. Similarly, 56 of 64 mothers $(87.5 \%)$ identified themselves with a religious domination. In contrast, of 65 supporters, 27 or $41.5 \%$ identified themselves with a religious domination. 
Table 6.7: Veteran Status of Supporters and Their Parents

\begin{tabular}{|l|c|l|}
\hline Veterans & $\mathrm{N}$ & $\%$ \\
\hline Supporters & 11 & $25.0 \%^{*}$ \\
\hline Fathers & 29 & $42.6 \%^{* *}$ \\
\hline Mothers & 1 & $1.5 \%$ \\
\hline Both Mother and Father & 1 & N/A \\
\hline
\end{tabular}

Source: 1997 Boston Draft Resistance Survey

Note: *Out of 44 maie supporters. 11 were veterans.

** Out of 68 fathers, 29 were veterans.

Table 6.8: Supporters' Self-Identification

\begin{tabular}{|l|c|l|}
\hline Label & N & $\%$ \\
\hline Hippie & 5 & 7.4 \\
\hline Politico & 23 & 33.8 \\
\hline Activist & 51 & 75 \\
\hline Revolutionary & 23 & 33.8 \\
\hline Member of Counterculture & 27 & 39.7 \\
\hline Part of New Left & 47 & 69.1 \\
\hline
\end{tabular}

Source: 1997 Boston Draft Resistance Survey

Table 6.9: Parents of Supporters, Political Affiliation

\begin{tabular}{|l|l|l|}
\hline Political Affiliation & N & $\%$ \\
\hline Mother and Father Both Republican & 18 & 35.3 \\
\hline Mother and Father Both Democrat & 29 & 56.9 \\
\hline Mother and Father Both Communist/Socialist/Anarchist & 4 & 7.8 \\
\hline Totals & $51^{*}$ & 100 \\
\hline
\end{tabular}

Source: 1997 Boston Draft Resistance Survey

* Of 68 supporters, the parents of 51 (75\%) both belonged to the same political affiliation. 
Table 6.10: Supporters, Political Affiliation

\begin{tabular}{|l|r|r|}
\hline Political Affiliation & N. & \multicolumn{1}{l|}{$\%$} \\
\hline Conservative Republican & 0 & 0 \\
\hline Moderate Republican & 0 & 0 \\
\hline Moderate Democrat & 1 & 1.8 \\
\hline Liberal Democrat & 28 & 49.1 \\
\hline Communist/Socialist & 22 & 38.6 \\
\hline Anarchist & 6 & 10.5 \\
\hline Total & 57 & 100 \\
\hline
\end{tabular}

Source: 1997 Boston Draft Resistance Survey

Table 6.11: Supporters' Prior Activism

\begin{tabular}{|l|r|l|}
\hline Type of Activism & $\mathrm{N}$ & $\%^{*}$ \\
\hline SDS & 23 & 33.8 \\
\hline Campus or Community Peace Activism & 38 & 55.9 \\
\hline Campus or Community Vietnam Summer & 14 & 20.6 \\
\hline Campus or Community Civil Rights Activism & 42 & 61.8 \\
\hline No Activist Experience & 7 & 10.3 \\
\hline
\end{tabular}

Source: 1997 Boston Draft Resistance Survey

* Note: Based on population of 68 respondents 
Table 9.1: In the Wake of Draft Card Turn-Ins

\begin{tabular}{|l|c|c|}
\hline Action & Number & Percentage \\
\hline Reclassified to 1-A, but no Induction Notice & 21 & 20.6 \\
\hline Reclassified to 1-A and Sent Induction Notice & 56 & 54.9 \\
\hline Resister Retrieved Original Draft Card Before Sent to DOJ & 2 & 2.0 \\
\hline Resister Asked Draft Board for New Draft Card & 3 & 2.9 \\
\hline Draft Board Sends Duplicate Card Unsolicited & 4 & 3.9 \\
\hline Resister Applied for and Received New Deferment & 6 & 5.9 \\
\hline Resister Left the Country & 1 & 1.0 \\
\hline Resister Heard Nothing from SSS or DOJ & 9 & 8.8 \\
\hline \multicolumn{1}{|c|}{ Totals } & 102 & 100 \\
\hline
\end{tabular}

Source: 1997 Boston Draft Resistance Survey

Table 9.2: Resisters Reclassified to 1-A But Who Did Not Receive an Induction Notice

\begin{tabular}{|l|c|c|}
\hline Action & Number & Percentage \\
\hline Applied for and/or Accepted a New Deferment & 11 & 52.4 \\
\hline Joined Oestereich Lawsuit & 2 & 9.5 \\
\hline Left the Country & 1 & 4.8 \\
\hline Heard Nothing Further from SSS or DOJ & 7 & 33.3 \\
\hline \multicolumn{1}{|c|}{ Totals } & 21 & 100 \\
\hline
\end{tabular}

Source: 1997 Boston Draft Resistance Survey

Table 9.3: Resisters Reclassified to I-A and Who Did Receive an Induction Notice

\begin{tabular}{|l|c|c|}
\hline Action & Number & Percentage \\
\hline Refused Induction & 30 & 56.6 \\
\hline Failed Physical or Other Induction Test & 14 & 26.4 \\
\hline Applied for New Deferment After Reclassification & 9 & 17.0 \\
\hline \multicolumn{1}{|c|}{ Totals } & 53 & 100 \\
\hline
\end{tabular}

Source: 1997 Boston Draft Resistance Survey 
Table 9.4: Draft Resistance Indictments and Prosecutions in Boston. 1966-1968

\begin{tabular}{|l|c|c|c|}
\hline & -1966 & 1967 & 1968 \\
\hline Indictments & 26 & 25 & 50 \\
\hline Fugitives & 3 & 4 & 17 \\
\hline Convictions or Guilty Pleas & 16 & 12 & 8 \\
\hline Acquittals and Dismissals & 2 & 3 & 18 \\
\hline Dismissals for Compliance & 5 & 6 & 2 \\
\hline Pending & - & - & 5 \\
\hline
\end{tabular}

Source: SUPPORT Newsletter, Jan 1970, p. 4, Papers of Michael Zigmond.

Table E.1: Political Affiliation of Draft Resistance Community Then and Now

\begin{tabular}{|l|c|c|c|c|}
\hline Political Affiliation & $\begin{array}{c}\text { Immediately } \\
\text { After Draft } \\
\text { Resistance }\end{array}$ & $\%$ & Today & $\%$ \\
\hline Conservative Republican & 0 & 0 & 2 & 1.2 \\
\hline Moderate Republican & 0 & 0 & 6 & 3.6 \\
\hline Moderate Democrat & 5 & 3.0 & 9 & 5.4 \\
\hline Liberal Democrat & 46 & 27.5 & 72 & 43.1 \\
\hline Socialist/Communist & 71 & 42.5 & 39 & 23.4 \\
\hline Anarchist & 32 & 19.2 & 14 & 8.4 \\
\hline No Preference & 10 & 6.0 & 13 & 7.8 \\
\hline Other & 3 & 1.8 & $12^{*}$ & 7.2 \\
\hline Total & 167 & 100 & 167 & 100.1 \\
\hline
\end{tabular}

Source: 1997 Boston Draft Resistance Survey. ${ }^{*}$ Note: The labels used to identify their politics today include: "Progressive populist," "social democrat" (2), "propeople/community," "revolutionary," "autonomist," "Green" (2), and "maverick humanist." 
Table E.2: Level of Activism in Other Causes and Movements After Draft Resistance (includes draft resisters and supporters)

\begin{tabular}{|c|c|c|c|c|}
\hline Cause or Movement & $\begin{array}{c}\text { Very } \\
\text { Involved }\end{array}$ & $\begin{array}{l}\text { Moderately } \\
\text { Involved }\end{array}$ & $\begin{array}{l}\text { Somewhat } \\
\text { Involved }\end{array}$ & $\begin{array}{c}\text { Not } \\
\text { Involved }\end{array}$ \\
\hline Other Vietnam Antiwar Activities & 67 & 42 & 33 & 42 \\
\hline Student Movement & 22 & 23 & 24 & 118 \\
\hline Women's Movement & 17 & 25 & 43 & 103 \\
\hline Gay \& Lesbian Rights Movement & 8 & 16 & 23 & 138 \\
\hline Farm Workers Movement & 2 & 11 & 49 & 123 \\
\hline Labor Organizing & 14 & 10 & 26 & 135 \\
\hline Pro-Choice Movement & 9 & 16 & 41 & 119 \\
\hline Pro-Life Movement & 1 & 5 & 6 & 173 \\
\hline Environmental Movement & 14 & 34 & 45 & 92 \\
\hline Common Cause & 0 & 6 & 20 & 159 \\
\hline Anti-Nuclear Movement & 16 & 15 & 53 & 101 \\
\hline Nuclear Freeze & 7 & 7 & 36 & 135 \\
\hline Contemporary Draft Resistance & 0 & 3 & 17 & 165 \\
\hline Contemporary Peace Movement & 9 & 17 & 44 & 115 \\
\hline $\begin{array}{l}\text { 1980s Central American Antiwar } \\
\text { Movement }\end{array}$ & 23 & 22 & 40 & 100 \\
\hline Anti-Apartheid Movement & 11 & 19 & 47 & 108 \\
\hline Moral Majority & 0 & 1 & 0 & 184 \\
\hline Christian Coalition & 0 & 0 & 0 & 185 \\
\hline Socialist Movement & 9 & 14 & 23 & 139 \\
\hline Democratic Party & 9 & 24 & 42 & 110 \\
\hline Republican Party & 0 & 1 & 1 & 183 \\
\hline Libertarian Party & 0 & 1 & 2 & 182 \\
\hline Local Electoral Campaigns & 12 & 27 & 46 & 100 \\
\hline
\end{tabular}




\begin{tabular}{|l|c|c|c|c|}
\hline State Electoral Campaigns & 8 & 19 & 37 & 121 \\
\hline National Electoral Campaigns & 12 & 18 & 36 & 109 \\
\hline
\end{tabular}

Source: 1997 Boston Draft Resistance Survey

Note: In addition to the causes listed in this table, respondents listed a total of 24 other causes with the following receiving multiple mentions: Race relations (4); Native American rights (2); Anti-poverty/welfare rights (6); children's rights (2); community organizing (4); health care (2); Palestine liberation (2); prison rights (3); and Green Party (2).

Table E.3: Resisters' and Supporters' Current Views on the Effectiveness of Social Movements

\begin{tabular}{|l|c|c|c|c|}
\hline Subject & $\begin{array}{c}\text { Strongly } \\
\text { Agree }\end{array}$ & Agree & Disagree & $\begin{array}{c}\text { Strongly } \\
\text { Disagree }\end{array}$ \\
\hline $\begin{array}{l}\text { Social Movements Were Very Effective } \\
\text { Vehicles for Social Change in 1960s }\end{array}$ & 90 & 81. & 11 & 0 \\
\hline $\begin{array}{l}\text { Social Movements Are Potentially } \\
\text { Effective Vehicles for Social Change in } \\
\text { Contemporary America }\end{array}$ & 80 & 98 & 3 & 1 \\
\hline $\begin{array}{l}\text { Social Movements Based on Moral } \\
\text { Witness are Potentially Effective }\end{array}$ & 64 & 92 & 17 & 3 \\
\hline $\begin{array}{l}\text { Social Movements Based on Non- } \\
\text { Violence are Potentially Effective }\end{array}$ & 72 & 98 & 6 & 2 \\
\hline
\end{tabular}

Source: 1997 Boston Draft Resistance Survey

Table E.4 Resisters' and Supporters' Current Occupations

\begin{tabular}{|l|c|c|}
\hline Occupation & Number & Percent \\
\hline Professor or other academic job & 47 & 25.8 \\
\hline Teacher or librarian & 12 & 6.7 \\
\hline Physician/Psychiatrist/Psychologist & 16 & 8.8 \\
\hline Non-profit/charity/activist & 13 & 7.1 \\
\hline Artist/Actor/Author/Film & 19 & 10.4 \\
\hline Attorney or Judge (1) & 10 & 5.5 \\
\hline Ministers or Priests & 9 & 4.9 \\
\hline
\end{tabular}




\begin{tabular}{|l|c|c|}
\hline High Tech & 8 & 4.4 \\
\hline Skilled Labor & 5 & 2.7 \\
\hline Clerical or sales & 5 & 2.7 \\
\hline Self-employed & 6 & 3.3 \\
\hline Farmer & 1 & 0.6 \\
\hline State/local government & 3 & 1.7 \\
\hline Professional - other & 17 & 9.3 \\
\hline Retired & 5 & 2.7 \\
\hline Unemployed & 6 & 3.3 \\
\hline Totals & 182 & 99.9 \\
\hline
\end{tabular}

Source: 1997 Boston Draft Resistance Survey

Table E.5: Resisters' and Supporters' Current Views on the 1960s and the Success and Failure of the Draft Resistance Movement.

\begin{tabular}{|l|c|c|c|c|}
\hline Subject & $\begin{array}{c}\text { Strongly } \\
\text { Agree }\end{array}$ & Agree & Disagree & $\begin{array}{c}\text { Strongly } \\
\text { Disagree }\end{array}$ \\
\hline $\begin{array}{l}\text { The 1960s Generation Was a } \\
\text { Destructive Generation }\end{array}$ & 5 & 1 & 53 & 120 \\
\hline $\begin{array}{l}\text { The Antiwar Movement was Ineffective } \\
\text { and Actually Prolonged the War }\end{array}$ & 1 & 3 & 53 & 124 \\
\hline $\begin{array}{l}\text { The Draft Resistance Movement } \\
\text { Brought About the End of the Draft }\end{array}$ & 30 & 79 & 55 & 4 \\
\hline $\begin{array}{l}\text { The Draft Resistance Movement } \\
\text { Helped to End the Vietnam War }\end{array}$ & 80 & 93 & 4 & 3 \\
\hline
\end{tabular}

Source: 1997 Boston Draft Resistance Survey 


\section{APPENDIX B}

\section{STATEMENT ON METHODOLOGY}

The primary goal of this dissertation is to recover the history of a social movement that to date has been largely overlooked by historians. More narrowly, the dissertation seeks to capture the experiences of draft resisters and their supporters in a way that preserves individual stories while also making generalizations possible. Consequently, two of the most important sources used in this study are a questionnaire and dozens of oral history interviews. The purpose of this appendix is to describe the ways in which these sources were created and used in gathering data for this dissertation.

\section{Questionnaire}

The sheer number of participants in Boston's draft resistance movement made a questionnaire necessary. Hundreds of (indeed, probably more than a thousand) people made up this grassroots movement, and in an attempt to understand their collective experience - as opposed to focusing on experiences of a small number of "representative" participants - a blending of sociology and history became necessary.

The first step in this process required the gathering of as many names of draft resisters and other movement participants as possible. After combing through the newsletters and internal memoranda of several key organizations (e.g., the New England Resistance, the Boston Draft Resistance Group, Resist, SUPPORT, etc.), a "Master File" of draft resisters dating to circa January 1968, underground newspapers, mainstream newspapers, and other sources, I compiled a list of close to 600 names. 
Locating all of these people thirty years later proved to be one of the biggest challenges of the project. I put together a database that listed all of the names that I had found and any other information that I knew about each person, such as what organization(s) he or she worked with, university, hometown, etc. Beginning with Michael Ferber and many of the other former leaders of the New England Resistance, I circulated copies of the database to dozens of movement participants looking for leads. At the same time, an article by James Carroll in the Boston Globe elicited calls from many other activists who also helped to provide leads - and added more names to the list. Meanwhile, using an internet site called Switchboard.com, which carries the nation's telephone listings, I began to systematically move through the list of names, using all the information at my disposal, to get solid addresses for as many people in the database as possible. This proved to be tremendously successful, especially in cases in which the activist I was seeking had an unusual name; it was much more difficult to find someone with a common name using this resource. Frequently, I mailed a letter to five or six people with the same name, hoping I would catch the right one. Sometimes it worked and other times it did not (see Appendix C). Finally, after almost a year of this kind of detective work, I turned to the alumni offices at approximately 40 colleges and universities, who confirmed that they had addresses for some of the people whom I still had not found.

In the end, I decided to proceed with the administration of the questionnaire when I had a list of 310 people for whom I or their alumni office had a solid address. Of the 310 who received the questionnaire, 185 completed and returned it (59.7\%), a very 
respectable response rate.

The questionnaire aimed to capture the experience not just of draft resisters but also of those who worked in the movement in various capacities to support their efforts. Consequently, certain portions of the questionnaire (see below) were tailored for certain types of individuals. Rare was the person who was able to answer every question on the survey. Everyone was asked to complete the sections pertaining to their backgrounds and personal history, as well as questions about what they have done since the end of the draft resistance movement.

The diverse nature of the population made it necessary to tabulate the data gleaned from the questionnaire in several different ways. As the tables in Appendix A show, data tabulated for Chapters 4 and 9 dealt only with resisters, and data tabulated for Chapter 6 pertained only to supporters. For the Epilogue, I tabulated data for the entire population. It is important to note here that of the 185 respondents, 121 were draft resisters. That is, these respondents had either turned in a draft card, burned a draft card, or refused induction. The remaining 64 respondents, therefore, participated in the draft resistance movement in a variety of what can be called, for lack of a better term, support roles. This include members of BDRG, other draft counselors, ministers, sanctuary participants, older advisers (such as those in Resist), etc. At the same time, however, I made the decision to include four of the 121 resisters in the supporter population as well. Three of the four individuals were older men (in their early to mid-thirties) who primarily acted in roles that I defined as support roles, but who turned in their draft cards as well. The fourth person is a woman who was extremely active in the movement, and who also 
burned a colleague's draft card at the Arlington Street Church. In these few unusual cases, it seemed appropriate to include their data in analyses of both resisters and supporters.

A copy of the questionnaire and a sample cover letter are included at the end of this appendix.

\section{Oral Histories}

To supplement the data mined from the questionnaire responses and numerous manuscript sources, interviews with a wide range of participants was also necessary. Most of those interviewed completed the questionnaire (usually before the interview, though a few interviews were conducted as exploratory discussions for the purpose of conceptualizing the questionnaire), but some did not - either because they chose not to or because they were located long after the questionnaire was administered.

All of the interviews have been recorded on audio tape and at some future date will be deposited at the Swarthmore College Peace Collection in Swarthmore, Pennsylvania, where they will eventually be available to other researchers. At the start of each interview, every interviewee was asked to complete an informed consent form and a deed of gift form agreeing to the eventual transfer of the tape to Swarthmore.

In conducting these interviews, I sought to touch on many of the issues raised in the questionnaire, but I also tried, to the extent possible, to elicit spontaneous story telling from each interviewee. As any oral historian can testify, some interviews go brilliantly and others do not. Memories can be crystal clear and they can be very hazy. And recollections that seem crystal clear can be quite inaccurate. In all cases, I have tried to 
corroborate stories told in interviews with other sources, print or oral. At times, however, I have used material gleaned from only one interview, but only in rare cases in which the verisimilitude of the account seemed reasonably unassailable. To my regret, there are at least a few remarkable stories that I have elected to leave out of the present narrative for lack of corroboration. If and when I find other supporting evidence for these stories, they will be added to a later draft.

In the end, I have sought to fuse the historian's traditional archival research with the sociologist's approach to examining large demographic groups. And although I am satisfied that this was the most useful and fruitful course to take, I must acknowledge its inherent limitations. In questionnaires, for instance, there are always questions that should have been asked but were not, and the issue of those who did not return the questionnaire always lingers. One hopes that even if every person to whom the questionnaire was sent had completed and returned it, the results would not be materially different than those presented here, but it is worth pondering. For example, when I assert in the Epilogue that most former draft resistance activists have continued to be active and have not "sold out," it is possible that some persons did not return the survey exactly because they did "sell out." It is impossible to know. The best one can do is to try to avoid overstating conclusions based on such data and to seek supporting evidence elsewhere. The variety of sources used in this dissertation has made that process relatively easy. 


\title{
UNIVERSITY OF NEW HAMPSHIRE
}

Department of History

College of Liberal Arts

Horton Social Soience Center

20 College Road

Durham, New Hampshire 038243586

(603) 862-1764 FN: (603) 862-0178

10 June 1997

\begin{abstract}
Mr. John Doe
P.O. Box XXXX
\end{abstract}

Boston, MA 02134

Dear Mr. Doe,

My name is Michael Foley. I am a Ph.D. candidate here at the University of New Hampshire and am currently writing a dissertation on the history of draft resistance in Boston during the Vietnam War. I found your name among the records of the New England Resistance which indicate that you turned in your draft card at the Old West Church on November 16,1967. I am contacting you through your alumni office in hopes that you will be willing to take part in my study.

It is my belief that the draft resistance movement has not received sufficient attention in our histories of the antiwar movement. Yet it was a vital part of the larger movement. My goal is to use Boston as a case study for the draft resistance movement and to focus on the participants more than on a traditional description of events. To that end, I have been working with records from different organizations associated with draft resistance in Boston; but to get a better understanding, I will be interviewing some participants and sending questionnaires to as many participants as I can locate.

As you will see from the questions on the survey, I am interested in understanding all varieties of experience. It is important that historians explore how different people from different backgrounds came to the same movement, how they experienced that movement, and how it ultimately affected their lives. I realize that, for some people, participation in the draft resistance movement was a deeply personal, sometimes painful, experience. If this was the case for you, I hope that you will still consider at least completing this questionnaire. One of the problems with many studies of social movements is that they rely too heavily on the experience of leaders and others who have predominantly positive feelings for the movement. I want to understand the whole draft resistance story (the good and the bad ), so I hope to have a high response rate to this survey.

Finally, let me add that your responses to questions on this survey will remain absolutely confidential. I will not, under any circumstances, use any survey respondent's name in my oral or written interpretations of the survey results. Furthermore, I will not respond to any requests from the media or the government for information that I collect.

I hope that you will enjoy participating in this study, and would appreciate it if you would rerum the completed questionnaire within five days, if that is possible (otherwise, please return it as soon as you can). I have included a postage paid envelope for that purpose. 
The success or failure of this project is heavily dependent upon the cooperation of people like you It is my sincere hope that you will take a few minutes (generally no more than 30 minutes) to participate in a study that I hope will help recover an important part of our history, one that can teach us lessons important to our future. Please call me with any questions or comments you have regarding this questionnaire or the dissertation research as a whole. My number is 603.437.0513. Thanks very much.

Sincerely,

Michael S. Foley

Note: This questionnaire and dissertation have been approved by the University of New Hampshire Institutional Review Board for the Protection of Human Subjects in Research.

\section{ADDITIONAL ENDORSEMENTS:}

Michael Ferber, Professor of English, University of New Hampshire

I have been working closely with Michael Foley for over a year, and I am confident he will do a serious, thoughtful, responsible job of his research into draft resistance. He is entirely sympathetic with what we tried to do in 1967-70-I think he would have been one of us--but he has the scholarly detachment to pose certain questions of our movement and to place it in certain contexts that I, at least, would not have been able to do. You'll like him if you meet him.

He'll write a good book. Please give him what help you can.

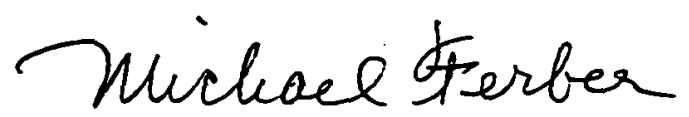

Michael Ferber

June 1997

Howard Zinn, Professor Emeritus, Boston University
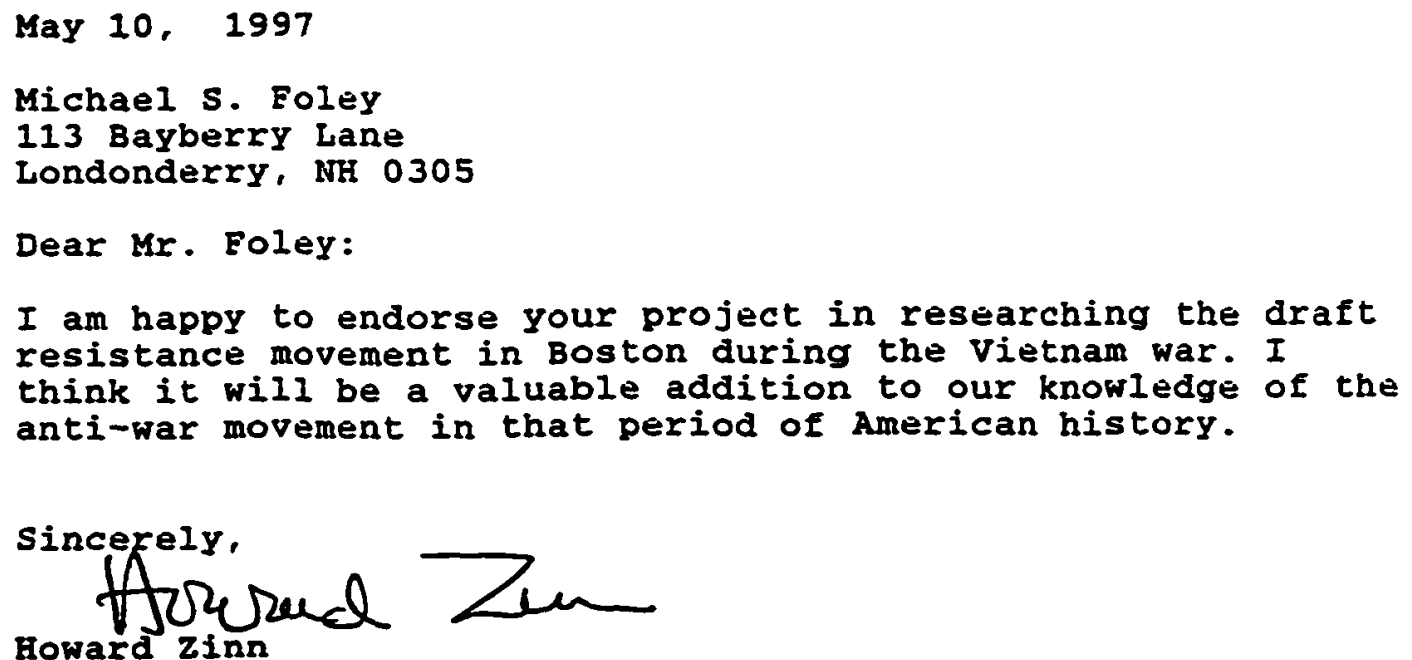
Boston Draft Resistance During the Viemam War: A Questionnaire

Please respond to all questions that apply to your experience. You may include comments at any point.

Draft Resistance Activity

1. With which draft resistance organizations did you work? (Circle as many as apply)

1. None (resisted as an individual)

2. Boston Draft Resistance Group

3. New England Resistance

4. RESIST

5. SUPPORT

6. Prison Information and Support Service

7. Committee for Non-Violent Action

8. American Friends' Service Committee

9. A campus-based draft counseling group

10. East Coast Conspiracy to Save Lives

11. Other:

2. Of these groups, was there one with which you worked more than the others? Which one?

1. None (resisted as an individual)

2. Boston Draft Resistance Group

3. New England Resistance

4. RESIST

5. SUPPORI

6. Prison Information and Support Service

7. Commitree for Non-Violent Action

8. American Friends' Service Cormmittee

9. A campus-based draft counseling group

10. East Coast Conspiracy to Save Lives

11. Other:

3. In what kinds of draft resistance activities did you participate?

1. Draft counseling (e.g., out of an office such as BDRG or AFSC, or on a college campus)

2. Turned-in draft card

3. Bumed draft card

4. Refused induction

5. "Early Moming Shows"

6. "Horror Shows"

7. Community outreach (e.g., door-to-door canvassing of potential draftees)

8. GI outreach

9. Sancularies

10. Draft board raids (to steal or destroy files)

11. Other 
Please answer the following questions only if you turned-in your draft card, burned your draft card, and/or refinsed induction. Othervise, please proceed to question \# 20.

4. What was your draft stanus at the time yoü tumed-in or burned your draft card?

1. Did not turn-in or burn my draft card

2. 1-A. Draft eligible

3. 1-A-O. Conscientious objector available for noncombatant duty only

4. 1-O. Conscientious objector available for civilian work only

5. 1-S. Deferred to end of school year

6. 1-Y. Physical or mental deferment

7. 2-A. Occupational deferment

8. 2-C. Agricultural deferment

9.2-S. Student deferment

10. 3-A. Deferred because of dependants

11. 4-B. Officials deferred by law

12. 4-C. Alien deferment

13. 4D. Minister or ministerial student

14. 4-F. Not qualified tor any service

15. 5-A. Overage

5. When and where did you turn-in or burn your draft card? Please circle.

1. Did not turn-in or burn my card

2. October 16, 1967 at the Arlington Street Church

3. November 16, 1967 at the Old West Church

4. December 4, 1967 at Bantell Chapel, Yale University

5. January 29, 1968 at the Arlington Street Church (day of the Spock arraignments)

6. April 3, 1968 on the Boston Common

7. November 14, 1968 on the Boston Common

8. Independently mailed my card to the Justice Dept., Selective Service, or draft board 9. Other (specify)

10. Other

6. How did you first hear about this event?

1. Did not turn-in or bum my card

2. Friend or acquaintance told me about it

3. Farnily member told me about it.

4. Heard about it through news reports (television, radio, newspaper)

5. Saw a poster or leaflet

6. Happened upon it as I was walking by

7. Other (specify) 
7. What happened to you after you tumed-in or burned your draft card? (Please circle all that apply)

1. The FBI interviewed me.

2. The FBI interviewed one or both of my parents about me

3. The FBI interviewed other members of my family about me

4. The FBI interviewed friends about me

5. The FBI interviewed my employer about me

6. Draft board changed my draft starus to I-A (draftable), but I never received an induction notice

7. Draft board changed my draft stanus to I-A (draftable), and I later received an induction notice

8. I retrieved my draft card from the people to whom I had given it.

9. I asked my draft board to issue another draft card to me.

10. I applied for and received a deferment.

11. I left the country

12. I accepted induction

13. I refused induction

14. Other

$\begin{array}{cc}\text { Yes } & \text { No } \\ 1 & 2 \\ 1 & 2 \\ 1 & 2 \\ 1 & 2 \\ 1 & 2 \\ 1 & 2 \\ 1 & 2 \\ 1 & 2 \\ 1 & 2 \\ 1 & 2 \\ 1 & 2 \\ 1 & 2 \\ 1 & 2 \\ 1 & 2\end{array}$

8. If you later applied for or accepted a deferment, which deferment did you receive?

1. Did not later apply for a deferment

2. 1-A-O. Conscientious objector available for noncombatant duty only

3. 1-O. Conscientious objector available for civilian work only

4. l-S. Deferred to end of school year

5.1-Y. Physical or mental deferment

6. 2-A. Occupational deferment

7. 2-C. Agricultural deferment

8. 2-S. Student deferment

9. 3-A. Deferred because of dependants

10. 4-B. Officials deferred by law

11. 4-C. Alien deferment

12. 4-D. Minister or ministerial student

13. 4-F. Not qualified for any service

14. 5-A. Overage

9. If you later left the country, please name the country to which you moved.
1. Did not leave the country
2. Canada
3. Mexico
4. Sweden
5. Other

10. If you later accepted induction, please name the branch of service into which you were inducted.
1. Did not accept induction
2. Army 3. Navy
4. Air Force
5. Marine Corps
6. Coast Guard
7. National Guard 
11. Based on the following scale of 1 to 5 , please rate your father's reaction to events listed.

\begin{tabular}{|c|c|c|c|c|c|c|}
\hline & $\begin{array}{c}\text { Not } \\
\text { Applicable }\end{array}$ & $\begin{array}{l}\text { Strongly } \\
\text { Disapprove }\end{array}$ & Disapprove & $\begin{array}{l}\text { Non- } \\
\text { Committal }\end{array}$ & Approve & $\begin{array}{l}\text { Strongly } \\
\text { Approve }\end{array}$ \\
\hline $\begin{array}{l}\text { 1. When I turned in/burned my } \\
\text { draft card }\end{array}$ & 1 & 2 & 3 & 4 & 5 & 6 \\
\hline $\begin{array}{l}\text { 2. When I reurieved my draft card } \\
\text { or asked my draft board for a new one }\end{array}$ & e & 2 & 3 & 4 & 5 & 6 \\
\hline 3. When I applied anew for a deferment & 1 & 2 & 3 & 4 & 5 & 6 \\
\hline 4. When I left the country & 1 & 2 & 3 & 4 & 5 & 6 \\
\hline 5. When I accepted induction & 1 & 2 & 3 & 4 & 5 & 6 \\
\hline 6. When I refused induction & 1 & 2 & 3 & 4 & 5 & 6 \\
\hline
\end{tabular}

Comments:

12. Based on the following scale of $I$ to 5 , please rate your mother's reaction to events listed.

\begin{tabular}{|c|c|c|c|c|c|c|}
\hline & $\begin{array}{c}\text { Not } \\
\text { Applicable }\end{array}$ & $\begin{array}{l}\text { Strongly } \\
\text { Disapprove }\end{array}$ & Disapprove & $\begin{array}{l}\text { Non- } \\
\text { Committal }\end{array}$ & $\begin{array}{c}\text { Approve } \\
5\end{array}$ & $\begin{array}{l}\text { Strongly } \\
\text { Approve }\end{array}$ \\
\hline $\begin{array}{l}\text { When I nurned in/burned my } \\
\text { draft card }\end{array}$ & & & & & & \\
\hline $\begin{array}{l}\text { When I retrieved my draft card } \\
\text { or asked my draft board for a new one }\end{array}$ & $\mathbf{l}$ & 2 & 3 & 4 & 5 & 6 \\
\hline When I applied anew for a deferment & 1 & 2 & 3 & 4 & 5 & 6 \\
\hline When I left the country & 1 & 2 & 3 & 4 & 5 & 6 \\
\hline 5. When I accepted induction & 1 & 2 & 3 & 4 & 5 & 6 \\
\hline 6. When I refused induction & i & 2 & 3 & 4 & 5 & 6 \\
\hline
\end{tabular}

Comments:

13. Which of the following descriptions best characterizes the moment at which you turned-in or burned your draft card?

1. It was not spontaneous; I had planned to tum in my card that day.

2. It was somewhat spontaneous; I had been thinking about tuming in my card, but was not committed to it until the moment I did it.

3. It was completely spontaneous; I had not been considering turning in or burning my card until the moment I did it.

Please comment (further description of your decision): 
14. If you later asked for your card back, or accepted a new one from your draft board, or sought a deferment. please rank the following factors that may have contributed to this decision.

1. Disapproval of parent(s) regarding open : confrontation with the government

2. Disapproval of sigmificant other reganding open confrontation with the government

3. Knew people who had been drafted or enlisted; didn't want to "betray" them

4. Turned in/burned my card impulsively, thought better of it soon after

5. Possibility of prosecution

6. Possibility of being drafted

7. Concern for how it might affect career

8. Concerned about being perceived as unpatriotic or cowardly

9. No longer viewed resistance as a useful antiwar strategy

10. Other

11. Other

Imp

\section{Not mportant}

1

1

I

I

I

1

I

I

I

1
Somewhat

2

2

2

2

2

2

2

2

2

2

2

$\begin{array}{cc}\text { Important } & \begin{array}{c}\text { Very } \\ \text { Important } \\ 3\end{array} \\ 3 & 4 \\ 3 & 4\end{array}$

4

4

4

4

4

4

4

4

4

Please comment (further description of your decision):

15. If you later left the country, please rank the following factors that may have contributed to this decision.

$\begin{array}{cccc}\begin{array}{c}\text { Not } \\ \text { Important }\end{array} & \begin{array}{c}\text { Somewhat } \\ \text { Important }\end{array} & \text { Important } & \begin{array}{c}\text { Very } \\ \text { Important }\end{array} \\ 1 & 2 & 3 & 4 \\ 1 & 2 & 3 & 4 \\ 1 & 2 & 3 & 4 \\ 1 & 2 & 3 & 4 \\ 1 & 2 & 3 & 4 \\ 1 & 2 & 3 & 4 \\ 1 & 2 & 3 & 4 \\ 1 & 2 & 3 & 4\end{array}$


16. If you later accepted induction, please rank the following factors that may have contributed to this decision.

1. Disapproval of parenu(s) regarding open :confrontation with the government

2. Disapproval of significant other regarding open confrontation with the government

3. Knew people who bad been drafted or enlisted; didn't want to "betray" them

4. Possibility of prosecution

5. Just seemed like the right thing to do

6. Concern for how it might affect career

7. Concerned about being perceived as unpatriotic or cowardly

8. Hoped to organize antiwar activity within the military

9. No longer viewed resistance as a useful antiwar strategy

10. Other

11. Other

Impor
1
1
1
1
1
1
1
1
1

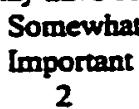

i

1

l

1

i

i

I

1

1

$\begin{array}{cc}\begin{array}{c}\text { Very } \\ 3\end{array} & \begin{array}{c}\text { Important } \\ \text { Impont }\end{array} \\ 3 & 4 \\ 3 & 4 \\ 3 & 4 \\ 3 & 4 \\ 3 & 4 \\ 3 & 4 \\ 3 & 4 \\ 3 & 4 \\ 3 & 4 \\ 3 & 4\end{array}$

Please comment:

17. If you later refused induction, please indicate which of the following actions applied to your case (by circling) and the approximate date of each:

1. Refused induction

2. Prosecuted

3. Acquitred

4. Convicted

Approximate Date

18. If you were convicted of charges of violating draft laws, please describe your sentence.

19. If you were sentenced to prison time, please indicate in which prison(s) you served and approximate dates. 
Please answer the following questions only if you worked as a draft counselor. Otherwise please proceed to question 25.

20. For which draft counseling organization did you work?

1. Boston Draft Resistance Group

2. American Friends' Service Committee

3. Central Committee for Conscientious Objectors

4. A campus draft counseling organizations (please specify)

5. A church counseling center (please specify)

6. Other (please specify)

21. Using the following descriptions of demographic groups, please rate from 0 to $100 \%$ the approximate proportion of men whom you counseled.

1. White college students

2. Minority college students

3. Middle-class white men not in college

4. Middle-class minority men not in college

5. Working class white men not in college

6. Working class minority men not in college

7. Other

22. What did your parents think of your participation in the movement as a draft counselor?

Mother:

$$
\begin{aligned}
& \text { Not } \\
& \text { Applicable }
\end{aligned}
$$

1

Not
Applicable

l
Strongly

Disapprove

2

Strongly

Disapprove

2

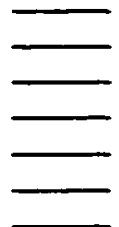

23. If reaching draft-age men who were not college students was part of your organization's goal, please note the extent to which you believe the draft counseling efforts of your organization were successful on that count.

$\begin{array}{rcccc}\text { Not a } & \text { Unsuccessful } & \begin{array}{c}\text { Somewhat } \\ \text { Successful }\end{array} & \text { Successful } & \begin{array}{c}\text { Very } \\ \text { Successful }\end{array} \\ 1 & 2 & 3 & 4 & 5\end{array}$


24. If you participated in Early Morning Shows or Horror Shows with BDRG, were you ever arrested? If so, please indicate how many times you were arrested and the result of these arrests (i.e., were you fined, prosecuted, etc.)

Number of times arrested
1. Charges dropped 2. Fined
3. Prosecuted
4. Acquitted
5.Convicted
6. Sentenced to jail time
7. Sentenced to community service
8. Did not participate in such events

Background Information: The following questions apply to ALL survey participants.

25. Date of Birth:

26. Sex: Male Female

27. Race/Ethnicity:

1. White

2. African-American

3. Hispanic

4. Asian-American

5. Other

28. The following is a list of levels of education. Please indicate the highest level of education attained by your parents and yourself at the time of your involvement with draft resistance.

1. Some grade school

2. Completed grade school

3. Some high school

4. Completed high school

5. Some post high school training, but not college

(e.g., technical school)

6. Some college

7. Completed college

8. Some graduate work

9. M.A. or M.S.

10. Professional degree (J.D., M.D., etc)

11. Masters degree plus work for higher degree

12. Doctorate (Ph.D., Ed.D, etc.)

$\begin{array}{ccc}\text { Father } & \text { Mother } & \text { Self } \\ 1 & 1 & 1 \\ 2 & 2 & 2 \\ 3 & 3 & 3 \\ 4 & 4 & 4 \\ 5 & 5 & 5 \\ & & \\ 6 & 6 & 6 \\ 7 & 7 & 7 \\ 8 & 8 & 8 \\ 9 & 9 & 9 \\ 10 & 10 & 10 \\ 11 & 11 & 11 \\ 12 & 12 & 12\end{array}$

29. What kind of job did your father have at the time you became involved with draft resistance? First, give a brief name or title for his work such as electrician, engineer, accountant, etc.

Father: 
30. In addition, please circle the answer category which best fits your father's occupation at that time:

1. Semiskilled or unskilled worker (truck driver. factory worker, ete.)

2. Skilled worker (foreman, cook, machinist, carpenter, etc.)

3. Farmer (owner-operator or renter)

4. Clerical or sales position

5. Proprietor, except farm (i.e., owner of a business)

6. Professional (reacher, chemist, doctor, etc.) or managerial position (department head, postmaster. police chief, etc.)

7. Don't know

31. What kind of job did your mother have at the time you became involved with draft resistance? First, give a brief name or title for his work such as electrician, engineer, accountant, etc.

Mother:

32. In addition, please circle the answer category which best fits her occupation at that time:

1. Semiskilled or unskilled worker (truck driver, factory worker, etc.)

2. Skilled worker (foreman, cook, machinist, carpenter, etc.)

3. Farmer (owner-operator or renter)

4. Clerical or sales position

5. P:oprietor, except farm (i.e., owner of a business)

6. Professional (teacher, chemist, doctor, etc.) or managerial position (department head, postmaster, police chief, etc.)

7. Don't know

33. Which description would best characterize your family at the time you became involved with draft resistance?

1. Working class

2. Lower middle class

3. Middle class

4. Upper middle class

5. Upper class

34. Below is a list of political preferences. Please indicate which most closely describes the position of your parents and yourself prior to your involvement with draft resistance.

1. Conservative Republican

2. Moderate Republican

3. Moderate Democrat

4. Liberal Democrat

5. Socialist/Communist

6. Anarchist

7. No political preference

8. Other

$\begin{array}{ccc}\text { Father } & \text { Mother } & \text { Self } \\ 1 & 1 & 1 \\ 2 & 2 & 2 \\ 3 & 3 & 3 \\ 4 & 4 & 4 \\ 5 & 5 & 5 \\ 6 & 6 & 6 \\ 7 & 7 & 7 \\ 8 & 8 & 8\end{array}$


35. Did either of your parents belong to a trade union?

$$
\text { No Yes }
$$

$\begin{array}{llll}\text { Father } & 2 & 1 & \text { Name of Union: } \\ \text { Mother } & 2 & 1 & \text { Name of Union: }\end{array}$

36. Did either of your parents participate in any kind of social activism before your participation in draft resistance? Please describe:

37. At the time you became involved in draft resistance were you a veteran of the armed services? Were either of your parents veterans at that time?

$\begin{array}{lll}\text { You } & \text { 1. Yes } & \text { 2. No } \\ \text { Mother: } & \text { 1. Yes } & \text { 2.No } \\ \text { Father: } & \text { 1. Yes } & \text { 2.No }\end{array}$

38. If you or either parent was a veteran, please indicate of which branch?

$\begin{array}{cccccccc}\text { You: } & \begin{array}{c}\text { Not a } \\ \text { Veteran }\end{array} & \text { Ammy } & \text { Navy } & \text { Air Force } & \begin{array}{c}\text { Marine } \\ \text { Corps }\end{array} & \begin{array}{c}\text { Coast } \\ \text { Guard }\end{array} & \begin{array}{c}\text { National } \\ \text { Guard }\end{array} \\ \text { Mother: } & \begin{array}{c}\text { Not a } \\ \text { Veteran }\end{array} & \text { Ammy } & \text { Navy } & \text { Air Force } & \begin{array}{c}\text { Marine } \\ \text { Corps }\end{array} & \begin{array}{c}\text { Coast } \\ \text { Guard }\end{array} & \begin{array}{c}\text { National } \\ \text { Guard }\end{array} \\ & 1 & 2 & 3 & 4 & 5 & 6 & 7 \\ \text { Father: } & \begin{array}{c}\text { Not a } \\ \text { Veteran }\end{array} & \text { Amny } & \text { Navy } & \text { Air Force } & \begin{array}{c}\text { Morps } \\ \text { Corne }\end{array} & \begin{array}{c}\text { Coast } \\ \text { Guard }\end{array} & \begin{array}{c}\text { National } \\ \text { Guard }\end{array} \\ & 1 & 2 & 3 & 4 & 5 & 6 & 7\end{array}$


39. If you or either parent was a veteran, please indicate in which American wars any of you saw active combat duty in any of this country's wars (up to and including Vietnam)?

\begin{tabular}{|c|c|c|c|c|c|c|c|c|}
\hline \multirow[t]{2}{*}{ You: } & $\begin{array}{l}\text { Not a } \\
\text { Veteran }\end{array}$ & $\begin{array}{l}\text { No Cembat } \\
\text { Duty - }\end{array}$ & $\begin{array}{l}\text { World } \\
\text { War I }\end{array}$ & $\therefore \begin{array}{l}\text { World } \\
\text { War II }\end{array}$ & Korea & Lebanon (1957) & $\begin{array}{l}\text { Dominican } \\
\text { Republic (1965) }\end{array}$ & Vietnam \\
\hline & I & 2 & 3 & 4 & 5 & 6 & 7 & 8 \\
\hline \multirow[t]{2}{*}{ Mother: } & $\begin{array}{l}\text { Not a } \\
\text { Veteran }\end{array}$ & $\begin{array}{l}\text { No Combat } \\
\text { Duty }\end{array}$ & $\begin{array}{l}\text { World } \\
\text { War I }\end{array}$ & $\begin{array}{l}\text { World } \\
\text { War II }\end{array}$ & Korea & Lebanon (1957) & $\begin{array}{l}\text { Dominican } \\
\text { Republic (1965) }\end{array}$ & Vietnam \\
\hline & 1 & 2 & 3 & 4 & 5 & 6 & 7 & 8 \\
\hline Father: & $\begin{array}{l}\text { Not a } \\
\text { Veteran }\end{array}$ & $\begin{array}{l}\text { No Combar } \\
\text { Duty }\end{array}$ & $\begin{array}{l}\text { World } \\
\text { War I }\end{array}$ & $\begin{array}{l}\text { World } \\
\text { War II }\end{array}$ & Korea & Lebanon (1957) & $\begin{array}{l}\text { Dominican } \\
\text { Republic (1965) }\end{array}$ & Viemam \\
\hline & 1 & 2 & 3 & 4 & 5 & 6 & 7 & 8 \\
\hline
\end{tabular}

40. At the time you became involved in draft resistance, were you or either of your parents members of any veteran's organizations? If yes, which ones?

You:
2. No
1. Yes
3. American Legion
4. VFW
5. Other

Mother
2. No
1. Yes
3. American Legion
4. VFW
5. Other

Father.
2. No
1. Yes
3. American Legion
4. VFW
5. Other

41. What was your occupation at the time you became involved with draft resistance? First, give a brief name or title for your work such as electrician, engineer, accountant, etc.

42. In addition, please circle the answer category which best fit your occupation at that time:

1. Semiskilled or unskilled worker (truck driver, factor worker, etc.)

2. Skilled worker (foreman, cook, machinist, carpenter, etc.)

3. Farmer (owner-operator or renter)

4. Clerical or sales position

5. Proprietor, except farm (i.e., owner of a business)

6. Professional (teacher, chemist, doctor, etc.) or managerial position (department head, postmaster, police chief, etc.)

7. Student

8. Don't know 
43. If you were a student, please indicate where you were studying at the time you became involved with draft resistance.

In which year of school were you at the time you became involved with draft resistance?

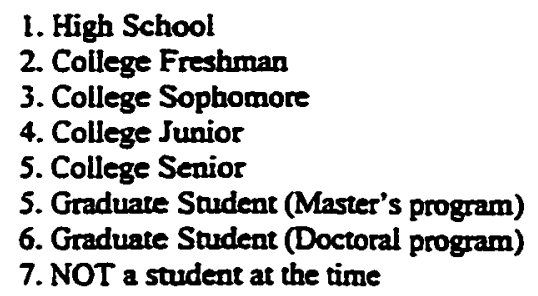

1. High School

2. College Freshman

3. College Sophomore

4. College Junior

5. College Senior

5. Graduare Student (Master's program)

6. Graduate Student (Doctoral program)

7. NOT a student at the time

Please circle your major or field of expertise at that time
1. English
2. Philosophy
3. Sociology
4. History
5. Anthropology
6. Political Science
7. Psychology
8. Business
9. Biology
10. Physics
11. Chemistry
12. Engineering
13. Linguisties
14. Foreign Langrage
15. Religion/Theology
16. Law
17. Medicine
15. Other

\begin{abstract}
1. Roman Catholic or Orthodox Catholic
2. Baptist

3. Episcopal

4. Lutheran

5. Methodist

6. Presbyterian

7. Unitarian

8. Quaker

9. Mennonite

10. Jehovah's Wimess

11. Jewish

12. Agnostic

13. Atheist

14. Other (specify)
\end{abstract}

44. Below is a list of religious preferences. Please circle the ones which most closely describe the preference of your parents and yourself at the time you became involved with draft resistance. Circle all that apply.

$\begin{array}{ccc}\text { Father } & \text { Mother } & \text { Self } \\ 1 & 1 & 1 \\ 2 & 2 & 2 \\ 3 & 3 & 3 \\ 4 & 4 & 4 \\ 5 & 5 & 5 \\ 6 & 6 & 6 \\ 7 & 7 & 7 \\ 8 & 8 & 8 \\ 9 & 9 & 9 \\ 10 & 10 & 10 \\ 11 & 11 & 11 \\ 12 & 12 & 12 \\ 13 & 13 & 13 \\ 14 & 14 & 14\end{array}$


45. Please circle those activities in which you were involved prior to draft resistance:

\section{On Campus:}

1. Performing arts

2. National Sudent Association

3. Student govermment

4. Fratemity/sorority

5. Academic clubs or honor societies

6. Religious groups or activities

7. School newspaper

8. Athletics

In the Community:

1. Religious groups or activities

2. Civil rights organizations or activities

3. Peace organizations or activities

4. Vietnam Summer
9. SDS

11. Peace organizations or activities

12. Viemam Summer

13. Civil rights organizations or activities

14. Other political organizations (e.g. Young Democrats, Young Republicans, Friends of SNCC, etc.)

15. Others (please describe)

46. Please rank the following factors in terms of how important each one was to your decision to get involved with draft resistance.

1. Religious beliefs

2. Friends or acquaintances

3. Past social activism

4. News reports of draft resistance

5. Parents

6. Organizations of which you were a member (please name)

5. Volunteer work

6. Others (please describe)

$\begin{array}{cccc}\begin{array}{c}\text { Not } \\ \text { Important }\end{array} & \begin{array}{c}\text { Somewhat } \\ \text { Important }\end{array} & \begin{array}{c}\text { Very } \\ \text { Important }\end{array} & \begin{array}{c}\text { Important } \\ 1\end{array} \\ 1 & 2 & 3 & 4 \\ 1 & 2 & 3 & 4 \\ 1 & 2 & 3 & 4 \\ 1 & 2 & 3 & 4 \\ 1 & 2 & 3 & 4 \\ 1 & 2 & 3 & 4 \\ 1 & 2 & 3 & 4 \\ 1 & 2 & 3 & 4 \\ 1 & 2 & 3 & 4\end{array}$

47. Did any of your close friends become involved with draft resistance at the same time or after you did?
1. Yes
2. No

48. During the time that you were involved in draft resistance only, would you have identified yourself as:

$\begin{array}{lll}\text { 1. A hippie } & \text { 1. Yes } & \text { 2. No } \\ \text { 2. A politico } & \text { 1. Yes } & \text { 2. No } \\ \text { 3. An activist } & \text { 1. Yes } & \text { 2. No } \\ \text { 4. A revolutionary } & \text { 1. Yes } & \text { 2. No } \\ \text { 5. Part of the counterculture } & \text { 1. Yes } & \text { 2. No } \\ \text { 6. Part of the New Left } & \text { 1. Yes } & \text { 2. No }\end{array}$


49. Please circle the number for the response that most accurately reflects your view of the following statement regarding women in the draft resistance movement.

$\begin{array}{llll}\text { Don't Strongly } & \text { Strongly } \\ \text { - Know Agree Agree Disagree Disagree }\end{array}$

1. Although women were not draft eligible they played an important role in the draft resistance movement

2. Women often attained positions of leadership in draft resistance organizarions

3. Women sometimes attained positions of leadership in draft resistance organizations

4. Women often participared in determining important policy and procedure issues in draft resistance organizations.

5. Women were marginalized in the draft resistance movement and mostly limited to clerical work

6. Women were encouraged to participate in draft resistance organizations primarily as a way of attracting more men to the movement.

$\begin{array}{lllll}1 & 2 & 3 & 4 & 5 \\ 1 & 2 & 3 & 4 & 5 \\ 1 & 2 & 3 & 4 & 5 \\ 1 & 2 & 3 & 4 & 5 \\ 1 & 2 & 3 & 4 & 5 \\ 1 & 2 & 3 & 4 & 5\end{array}$

50. What did you do immediately following your experience with draft resistance? If you went in the service or served time in prison, please indicate what you did immediately after you left the service or got out of prison. Please circle all that apply.

1. Went to/finished graduate school

2. Remained active in antiwar movement

3. Became active in women's liberation movement

4. Joined a commune

5. Joined Progressive Labor

6. Joined Weatherman

7. Employed as

8. Other (please specify)

51. Please list all the political or "movement" organizations, including local groups, to which you belonged from the end of your draft resistance work until the end of the war in 1975. 
52. Please check the appropriate space to indicate your level of involvement in the following movements or political activities since your participation in draft resistance.

1. Other Vietnam Antiwar Movement activities
2. Student Movement
3. Women's Movement
4. Gay and Lesbian Rights Movement
5. Farm Workers Movement
6. Labor Organizing
7. Pro-Choice Movement
8. Pro-Life Movement
9. Environmental Movement
10. Common Cause
11. Anti-Nuclear Movement
12. Nuclear Freeze
13. Contemporary Draft Resistance
14. Contemporary Peace Movement
15. I980s Central American Antiwar Movement
16. Anti-Apartheid Movement
17. Moral Majority
18. Christian Coalition
19. Socialist Movement
20. Democratic Party
21. Republican Party
22. Libertarian Party
23. Local Electoral Campaigns
24. State Electoral Campaigns
25. National Electoral Campaigns
26. Others (please describe)
- D

53. Are you presently employed? No

$\begin{array}{cccc}\begin{array}{c}\text { Very } \\ \text { involved }\end{array} & \begin{array}{c}\text { Moderately } \\ \text { involved }\end{array} & \begin{array}{c}\text { Somewhat } \\ \text { involved }\end{array} & \begin{array}{c}\text { Not } \\ \text { involved }\end{array} \\ 1 & 2 & 3 & 4 \\ 1 & 2 & 3 & 4 \\ 1 & 2 & 3 & 4 \\ 1 & 2 & 3 & 4 \\ 1 & 2 & 3 & 4 \\ 1 & 2 & 3 & 4 \\ 1 & 2 & 3 & 4 \\ 1 & 2 & 3 & 4 \\ 1 & 2 & 3 & 4 \\ 1 & 2 & 3 & 4 \\ 1 & 2 & 3 & 4 \\ 1 & 2 & 3 & 4 \\ 1 & 2 & 3 & 4 \\ 1 & 2 & 3 & 4 \\ 1 & 2 & 3 & 4 \\ 1 & 2 & 3 & 4 \\ 1 & 2 & 3 & 4 \\ 1 & 2 & 3 & 4 \\ 1 & 2 & 3 & 4 \\ 1 & 2 & 3 & 4 \\ 1 & 2 & 3 & 4 \\ 1 & 2 & 3 & 4 \\ 1 & 2 & 3 & 4 \\ 1 & 2 & 3 & 4 \\ 1 & 2 & 3 & 4 \\ 1 & 2 & 3 & 4 \\ 1 & 2 & 3 & 4 \\ & 2 & 3 & 4\end{array}$

54. Please list all major jobs you have had from the present back to 1969.

Years of Employment

\ob

From Ie


55. Please circle the number which best characterizes your political stance:

$\begin{array}{cc}\begin{array}{c}\text { You } \\ \text { Immediately After }\end{array} & \begin{array}{c}\text { You } \\ \text { Doday Resistance }\end{array} \\ 1 & 1 \\ 2 & 2 \\ 3 & 3 \\ 4 & 4 \\ 5 & 5 \\ 6 & 6 \\ 7 & 7 \\ 8 & 8\end{array}$

56. Please list all political or movement organizarions, including local groups, to which you currently belong. (Please include any ostensibly nonpolitical organizations through which you participate in political activities, e.g., churches.)

57. Are your currently involved in any social movements?

$$
\text { 1. Yes 2. No }
$$

If yes, which ones?

58. How did your experience in the draft resistance movement affect decisions that you made later in life? Please circle the number for the response that most accurately reflects your view of the following statements.

1. My participation in draft resistance and/or related social

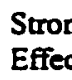
movements affected my choice of mate(s).

2. My participation in draft resistance and/or related social movements affected my choices about work.

3. My participation in draft resistance and/or related social movements affected my choices about having children.

4. My participation in draft resistance and/or related social movements affected my choices about religion.

(If your religious affiliation has changed from the denomination marked in question 44 , please indicale your current religious affiliation)

$\begin{array}{cccc}\begin{array}{c}\text { Strong } \\ \text { Effect } \\ 1\end{array} & \begin{array}{c}\text { Some } \\ \text { Effect }\end{array} & \begin{array}{c}\text { No } \\ \text { Effect } \\ 2\end{array} & \begin{array}{c}\text { Not } \\ \text { Applicable }\end{array} \\ 1 & 2 & 3 & 4 \\ 1 & 2 & 3 & 4 \\ 1 & 2 & 3 & 4\end{array}$


59. Please circle the number for the response that most accurately reflects your view of the following statements.

$\begin{array}{cccc}\begin{array}{c}\text { Strongly } \\ \text { Agree }\end{array} & \text { Agree } & \text { Disagree } & \begin{array}{c}\text { Strongly } \\ \text { Disagree }\end{array} \\ \text { I } & 2 & 3 & 4 \\ 1 & 2 & 3 & 4 \\ 1 & 2 & 3 & 4 \\ 1 & 2 & 3 & 4 \\ 1 & 2 & 3 & 4 \\ 1 & 2 & 3 & 4 \\ 1 & 2 & 3 & 4 \\ 1 & 2 & 3 & 4 \\ 1 & 2 & 3 & 4\end{array}$

1. In the 1960 s, social movements were very effective vehicles of social change.

2. Social movements are potentially effective vehicles of social change in contemporary America.

3. The 1960 s generation was a destructive generation

4. Social movements based on moral wimess are potentially effective vehicles for social change in contemporary America

5. Social movements rooted in non-violence are potentially effective vehicles for social change in contemporary America

6. The draft resistance movement brought about the end of the Vietram era draft.

7. The draft resistance movement contributed to bringing the Vietnam War to an end.

8. The antiwar movement was ineffective and actually prolonged the war

9. Compulsory military service would help to create a greater sense of civic responsibility in contemporary America

Please comment in more detail: 


\section{Current Information (optional)}

In contacting many survey participants, I have been aided by numerous college alumni relations departments. As a resulh I do not have current adtresses for many respondents. My hope is that you will be willing to complete this section, particularly if you are open to being interviewed, but let me again assure you that information from individual surveys will be completely confidential. I plan to use only the aggregate results of this surver, I will not, under any circumstances, connect names to individual survey responses, nor will I share such information with anyone else.

Interviews generally take no more than 2 hours. In most cases, interviewees will be identified on tape and in transcripts, however, anonymity can be arranged if desired.

60. Are you willing to be interviewed?

1. I am willing to be interviewed

61. Name:

62. Address:
2. I am not willing to be interviewed

\section{Phone:}

64. E-mail:

THANKS VERY MUCH FOR COMPLETING THE QUESTTONNAIRE!

Again, any help you could provide in locaring other individuals who participated in draft resistance in Boston would be greatly appreciated. Please list any addresses you can provide.

Also, do you have any draft resistance related archives (including, pamphlets, leaflets, newsietters, photographs, diaries, correspondence) that you would be willing to share with me?

ADDITIONAL COMMENTS: 


\section{APPENDLX C \\ MEDITATIONS ON DRAFT RESISTANCE RESEARCH}

\section{AND PUBLIC MEMORY}

For the past two years. I have frequently been reminded of the controversial and misunderstood nature of the historical events that I write about in this dissertation. When people ask about the subject of my research, almost inevitably they interpret it as a study of draft "dodgers," make comments about Bill Clinton and Dan Quayle, and sometimes wonder aloud why I would even be interested in such people. Others understand quite well the difference between draft resistance and draft dodging but still can barely contain their contempt. For example, in the course of explaining the process for calling up certain papers in a collection at the Lyndon Johnson Presidential Library, one archivist only partially in jest used the name "Idiots Against the Draft" as an example of an organization that might have some letters in President Johnson's correspondence files.

The most hostile responses, however, have come from people I have never met. In the course of trying to locate hundreds of former draft resistance movement participants, I unexpectedly irritated, angered, and frustrated about a dozen people who felt compelled to call me or write to me to complain. This Appendix is included here because I think some of those responses shed a little light on how draft resistance and the antiwar movement of the 1960s still is perceived by some segments of the American population today. 
In the course of trying to locate hundreds of former draft resisters and other participants in Boston's draft resistance movement, I had to master some of the skills of the private detective. Using an internet site called Switchboard.com (which lists the entire nations phone listings and addresses) I successfully located dozens of people whose names I had found in a variety of manuscript and published sources. Frequently, however, I could not determine if a person who had the same name as a former activist was the person I sought. Often I could not narrow it down to fewer than seven or eight people all of whom had the same name. Consequently, on a case by case basis, I sometimes decided to send an introductory letter to, say, all seven people named John Doe to inquire if any of them were the John Doe who had participated in the draft resistance movement in Boston. If I sent seven letters, of course, it meant that at least six were going to the wrong person - maybe all seven - and so I tried to make it clear in the opening paragraph of each letter that I was not sure if I had sent the letter to the right person. Not knowing there would ever be any need to do so, I did not keep track of the number of duplicate letters that I sent out, or even how many names in my database received this treatment. I did, however. begin to track the responses fairly soon after I began receiving them.

In most cases, I received very courteous (what I would call "neutral") responses to my inquiries either by phone call, e-mail. or letter. Out of a total of 51 responses, 36 were neutral, written simply to inform me that I had not found the correct person. One of those was a man who called me directly because he feared he might not receive an expected 
government security clearance if his name could be found out there, even erroneously, on a document identifying him as a draft resister. I told him that I doubted it would be a problem, but he could have the FBI call me if there was any confusion on the issue. In addition to the neutral responses, another five responses were positive, expressing interest in the project and wishing me well with the work.

At the same time, however, another 10 individuals called or wrote to express their disapproval of draft resistance and, sometimes, their disapproval of my project. In spite my attempts to make it clear that I did not know if I was writing to the correct person, some recipients interpreted my letter as some kind of accusation that they were draft resisters or were somehow on an official list of American draft resisters. "Please insure that my name and address is not on your list. I would hate to be in any way associated with this group," wrote one man. Another scribbled, "I have never participated in any draft card turn-in ceremony. I [sic] never been to Boston. How my name got in your file, I don't know. Please remove it! I have serviced [sic] my country. And proud of it and I was not drafted. I enlisted." Several, it turned out, were veterans of World War II, the Korean War, and the Vietnam War, and each made sure to express their pride in having served their country and their "disdain" for those who did not. One former Marine wrote to the president of the university demanding that his name be removed from the records I cited, and urged the president to caution her faculty "to be more thorough in their efforts to communicate with 'possible participants' especially with such a controversial subject as "draft resistance."

Some phone calls and letters were particularly vituperative. One man called to 
tell me that his middle initial was different from the man I sought. He concluded the conversation by saying his namesake "ought to be shot, that's what I say." Another wrote "I was shocked to receive your letter wondering if I was one of the contemptible scum you are trying to locate. I served twenty-two years in the Army, and you are free to do your research due to the efforts of people like me. I find it hard to imagine that someone would attempt to develop a history of a group of self-centered 'useful fools,' to quote Lenin." Another veteran wrote that he believed civil disobedience to be a "synonym for anarchy" and that he regarded draft resisters as cowards, including, he said, "our draftdoging [sic] president." He went on to criticize the "army of second-guessers who simply can't comprehend the magnitude of the Soviet Menace to our way of life," and especially to the United States. "It is so easy for the cloistered $\mathrm{PhD}$," he wrote, "to ruminate over the way it should have been with present knowledge. It is quite another thing to have been there, and been fully informed on what the Reds would have done to all of us, had they been able to do the job."

This is, obviously, a pretty unscientific sampling of public opinion, but it does offer some food for thought. Maybe most important is that the overwhelming number of people who took the time to contact me did so considerately and expressed no value judgements about draft resisters or historians who study them. This fact alone leaves me hopeful that a history of the draft resistance movement will at least be considered by open-minded people. The more angry responses point to the issues of loyalty, patriotism, and freedom that I first raised in the introduction. For these individuals, there can be no compromise on the question of one's obligation to one's country, and as one man 
implied, to the American "way of life." It is at least an understandable position to take. My hope, however, is that this history of draft resistance will complicate the definitions of loyalty, patriotism, and the American way of life. Those who opposed the war, and were willing to commit civil disobedience as a way of confronting the government officials responsible for the war, did so out of a belief that dissent can be patriotic, and their actions would help to preserve some of the finest qualities of that American way of life. 


\section{BIBLIOGRAPHY}

:

\section{Primary Sources}

\section{MANUSCRIPT COLLECTIONS}

Arlington Street Church Archives. Arlington Street Church, Boston.

William Bischoff Papers. Personal collection.

The Reverend Jack Bishop Papers. Personal collection.

Fred Bird Papers. Personal collection.

Boston Committee for Non-Violent Action Papers. Swarthmore College Peace Collection.

The Reverend John Boyles Papers. Personal collection.

Joseph Califano Papers. Lyndon Baines Johnson Presidential Library.

Robert Chalfen Papers. Personal collection.

Ramsey Clark Papers. Lyndon Baines Johnson Presidential Library.

Clark Clifford Papers. Lyndon Baines Johnson Presidential Library.

Michael Colpitts Papers. Personal collection.

Warren Christopher Papers. Lyndon Baines Johnson Presidential Library

Michael Ferber Papers. Personal collection.

Charles S. Fisher Papers. Personal collection (now deposited at Swarthmore).

Richard Hughes Papers. Personal collection.

James D. Hunt Papers. Personal collection.

Alex Jack Papers. Personal collection. 
Tom Johnson's Meeting Notes (used by permission). Lyndon Baines Johnson Presidential Library.

John W. Macy, Jr. Papers. Lyndon Baines Johnson Presidential Library.

Howard Marston, Jr. Papers. Personal collection.

Meeting Notes File. Lyndon Baines Johnson Presidential Library.

National Security - Defense Files. Lyndon Baines Johnson Presidential Library.

James Oestereich Papers. Personal collection.

Resist Papers. Trinity College. Hartford, CT.

David Satz Papers. Personal collection.

Robert Shapiro Papers. Personal collection.

Benjamin Spock Papers. Bird Library, Syracuse University.

Nan Stone Papers. Personal collection.

Barrie Thorne Papers, 1967 - early 1970s. Michigan State University Library.

White House Central Files. Lyndon Baines Johnson Presidential Library.

Michael Zigmond Papers. Personal collection.

\section{ORAL HISTORY INTERVIEWS}

Ira Arlook, 12 August 1998, by telephone from Washington, DC

William Bischoff, 5 January 1998, New York, NY

Rev. John Bishop, 11 December 1997, Boston, MA

Robert Bruen, 13 August 1997, Newton, MA 
Daniel Brustein, 30 December 1997, by telephone from Cleveland, $\mathrm{OH}$

Noam Chomsky, 20 May 1997, Cambridge, MA

Ramsey Clark, 6 January 1998, New York, NY

Ramsey Clark, 29 April 1998, by telephone from New York, NY

David Clennon, 12 June 1997, West Hollywood, CA

David Clennon 17 June 1998, by telephone from Santa Monica, CA

William Clusin, 17 June 1997, Stanford, CA

Rev. William Sloane Coffin, 28 August 1997, Strafford, VT

Michael Colpitts, 6 April 1997, Raynham, MA

Ellen DuBois, 11 June 1997, Los Angeles, CA

Roxanne Dunbar-Ortiz, 15 October 1997, by telephone from San Francisco, CA

Lawrence Etscovitz, 12 August 1997, Durham, NH

Michael Ferber, 10 February 1997, Durham, NH

Michael Ferber, 21 April 1998, Durham, NH

Michael Ferber, 16 June 1998, Durham, NH

Connie Field, 17 June 1997, Berkeley, CA

Mark Gerzon, 18 July 1997, by telephone from Boulder, CO

Alexandra Harmon, 14 October 1997, by telephone from Seattle, WA

Harold Hector, 9 April 1997, Boston, MA

Hilde Hein, 18 September 1998, Newton, MA

Gary Hicks, 7 December 1997, Boston, MA

G. Robert Hohler, 11 December 1997, Boston, MA 
Richard Hughes, 7 January 1998, New York, NY

William Hunt, 31 October 1997, by telephone from Canton, NY

Alex Jack, 21 March 1997, Becket, MA

Rev. J. Michael Jupin, 28 December 1997, by telephone from Columbus, OH

Louis Kampf, 10 September 1998, Cambridge, MA

Sue Katz, 2 March 1999, by telephone from London, England

Joel Kugelmass, 16 June 1997, Sacramento, CA

Penney Kurland Lagos, 21 February 1999, by telephone from Washington, DC

Paul Lauter, 12 June 1998, Hartford, CT

Howard Marston, Jr. and Deborah Jelmberg, 13 December 1967, Gloucester, MA

Bliss Matteson. 29 August 1997, Cambridge, MA

Allegra May, 12 August 1997, Portsmouth, NH

John McDonough. 3 June 1998, by telephone from Cupertino. CA

Rev. Jack Mendelsohn, 19 December 1997, Maynard, MA

Ray Mungo, 13 June 1997, Gardena, CA

James Oestereich, 20 December 1997, by telephone from Minneapolis, MN

John Phillips, 29 August 1997, by telephone from Albuquerque, NM

Hilary Putnam, 18 December 1997, Cambridge, MA

Neil Robertson, 24 August 1997, Skowhegan, ME

Neil Robertson, 22 December 1997, by telephone from Skowhegan, ME

Neil Robertson, 7 August 1998, by telephone from Skowhegan, ME

Lawrence Rossini, 5 September 1997, Concord, MA 
Steve Shalom, 18 May 1997, Little Falls. NJ

Robert Shapiro, 13 August 1997, New̄ton, MA

John Sisson, 13 July 1998, Lincoln, MA

Susan Starr, 4 August 1997, Boston, MA

Nan Stone, 28 March 1997, Belfast, ME

Nan Stone, 8 October 1997, by telephone from Belfast, ME

David Stoppelman, 8 December 1997, Natick, MA

Barrie Thorne, 28 October 1997, by telephone from Berkeley, CA

Daniel and Olene Tilton, 16 June 1997. San Francisco, CA

John Van de Kamp, 9 June 1998, by telephone from Pasadena, CA

Christopher Venn, 12 June 1997, Hermosa Beach, CA

Jannik von Rosenvinge, 8 October 1997, by telephone from Bellingham, WA

John Wall, 26 June 1998, Boston, MA

Xenia Williams, 28 August 1997, Barre. VT

Timothy Wright, 25 August 1997, Jamaica Plain, MA

Michael and Naomi Zigmond, 29 December 1997, Woods Hole, MA

Howard Zinn, 6 July 1998, Cambridge. MA

Anonymous Female \#1, 9 October 1997

\section{UNRECORDED PHONE CONVERSATIONS}

Kathy Bower, 27 July 1998

Ramsey Clark, 13 Mar 1996 
Joan Dehmlow, 16 Sep 1998

Jean Kirkland, 11 September 1998

Edward Risden, Jr., 24 July 1998

\section{OTHER ORAL HISTORY SOURCES}

Arlington Street Church Oral History Project:

W. Edward Harris, interview with Eugene Navias, 27 Oct 1994.

Jack Mendelsohn, interview with Ann Friend, 29 Feb 1992.

Karl Dan Sorensen, interview with Carolyn Harrigan, 1 Dec 1993.

George Whitehouse, interview with Joan Goodwin, 16 May 1994

Lyndon Johnson Presidential Library:

Lewis Hershey, interview with Harry B. Middleton, 15 Dec 1970.

Joseph Califano, interviewed by Michael Gillette, 5 Jan 1988, Personal Papers of Joseph Califano, Box 131, LBJL

\section{PUBLISHED DOCUMENTS}

Avatar, Boston, MA. various issues, 1967-1968

Boston Globe, Boston, MA 1965-1969

Boston Herald Traveler, Boston, MA, 1965-1969

Boston Record American, Boston, MA, 1965-1969

BU (Boston University) News, Boston, MA, 1966-1969

Broadside and Free Press, Boston, MA, various issues, 1968-1969 
Harvard Crimson, Cambridge, MA, 1966-1969

New York Times, New York, NY, 1965-1969

The Old Mole, Boston, MA, various issues, 1968-1969

The Resistance, Boston, MA, various issues, 1968 - 1969

The Tech (MIT), Cambridge, MA, fall 1968

\author{
CASE FILES, U.S. DISTRICT COURT RECORDS. NATIONAL ARCHIVES, \\ WALTHAM, MA \\ United States v. William Sloane Coffin. Jr., et al. \\ United States v. Peter Crews. \\ United States v. Gary Hicks. \\ United States v. Howard Marston, Jr. \\ United States v. David O'Brien. \\ United States v. John J. Phillips. \\ United States v. Eugene Povirk. \\ United States v. David Reed. \\ United States v. John Heffron Sisson. Jr. \\ United States v. David Stoppelman. \\ United States v. Robert Talmanson.
}

\title{
UNITED STATES SUPREME COURT OPINIONS
}

Timothy Breen v. Selective Service Board No. 16, Bridgeport, Connecticut, et al., 393 
U.S. 460 (1969).

Gutknecht v. United States, 393 U.S. 295 (1969).

James Oestereich v. Selective Service Board No. 11. Cheyenne, Wyoming, et al., 393 U.S. 234 (1968)

United States v. David O'Brien, 391 U.S. 367 (1968)

United States v. Daniel Seeger, 380 U.S. 163 (1965)

\section{Books and Essays}

Avorn, Jerry L., et al, Up Against the Ivy Wall: a History of the Columbia Crisis (New York: Atheneum, 1969)

Bellow, Saul. Dangling Man (New York: Penguin, 1996) originally published by Vanguard, 1944

Camus, Albert. The Stranger (New York: Vintage. 1988) trans. By Matthew Ward. Originally published by Librairie Gallimard, 1942.

Chapman. Bruce K. The Wrong Man in Uniform: Our Unfair and Obsolete Draft and How We Can Replace It (New York: Trident Press, 1967).

Chomsky, Noam. American Power and the New Mandarins (New York: Pantheon, 1967).

-2.-The Trials of the Resistance (New York: New York Review, 1970).

Coffin, William Sloane, and Morris I. Liebman. Civil Disobedience: Aid or Hindrance to Justice? (Washington: American Enterprise Institute for Public Policy Research, 1972).

Dowd, Douglas. "The Strength and Limitations of Resistance," in Stephen Halpert, ed., Witness of the Berrigans (Garden City. NY: Doubleday, 1972).

Goodman, Mitchell, ed. The Movement Toward a New America: The Beginnings of a Long Revolution (New York: Knopf, 1970).

Johnson, Barry. "Seminarian in "The Resistance," Christian Century (3 Jan 1968) 85:1517. 
Lynd, Alice. We Won't Go: Personal Accounts of War Objectors (Boston: Beacon Press, 1968).

Lynn, Conrad. How to Stay Out of the Army: A Guide to Your Rights Under the Draft Law (New York: Monthly Review Press, 1968).

Mailer, Norman. The Armies of the Night (New York: Signet, 1968).

Melman, Seymour. In the Name of America (Annandale, Va: Turnpike Press, 1968).

Raskin, Marcus, and Bernard B. Fall. The Vietnam Reader: Articles and Documents on American Foreign Policy and the Vietnam Crisis (New York: Random House. 1965).

Tatum, Arlo. Guide to the Draft (Boston: Beacon Press, 1970)

-, ed. Handbook for Conscientious Objectors (Phila: CCCO, 1970).

"U.S. Draft Policy and Its Impact." Congressional Quarterly, Washington, DC, 1968

U.S. National Advisory Commission on Selective Service. In Pursuit of Equity: Who Serves When Not All Serve? (Washington: GPO, 1967).

U.S. Selective Service System. Annual Reports (Washington: GPO, 1964-1976).

Zimmer, Timothy. Letters of a Conscientious Objector (Valley Forge, PA: Judson Press, 1969).

\section{Secondary Sources}

Alonso, Harriet Hyman. Peace as a Women's Issue: A History of the U.S. Movement for World Peace and Women's Rights (Syracuse: Syracuse UP, 1993).

Anderson, Martin, ed. The Military Draft: Selected Readings on Conscription (Stanford, CA: Hoover Institution Press, 1982).

Anderson, Terry H. The Movement and the Sixties: Protest in America From Greensboro to Wounded Knee (New York: Oxford UP, 1995).

-.. The Sixties (New York: Longman, 1999).

Appy, Christian. Working-Class War: American Combat Soldiers in Vietnam (Chapel Hill: University of North Carolina Press, 1993). 
Arant, Morgan David, Jr. "Government Use of the Draft to Silence Dissent to War: A Case of Punitive Reclassification," Peace \& Change 17 (April 1992): 147-171.

Baskir, Lawrence M., and William A. Strauss. Chance and Circumstance: The Draft. The War and the Vietnam Generation_(New York: Knopf, 1978).

Berkowitz, William R. "The Impact of Anti-Viemam Demonstrations Upon National Public Opinion and Military Indicators," Social Sciences Research 2 (Mar 1973): $1-4$.

Bloom, Lynn Z. Doctor Spock: Biography of a Conservative Radical (Indianapolis: Bobbs-Merrill, 1972)

Blum, John Morton. Years of Discord: American Politics and Society. 1961-1974 (New York: Norton, 1991).

Bolton, Charles D. "Alienation and Action: A Study of Peace Group Members." American Journal of Sociology 78 (Nov 1972): 537-61.

Breines, Wini. Community and Organization in the New Left, 1962-1968: The Great Refusal (New Brunswick: Rutgers University Press, 1989).

Burner, David. Making Peace with the 60s (Princeton: Princeton UP, 1996).

Cagan, Leslie. "Women and the Anti-Draft Movement," Radical America. Sep/Oct 1980.

Califano, Joseph. The Triumph and Tragedy of Lyndon Johnson (New York: Simon and Schuster, 1991).

Capps, Walter H. The Unfinished War: Vietnam and the American Conscience (Boston: Beacon, 1982).

Carroll, James. An American Requiem: God, My Father, and the War That Divided Us (Boston: Houghton Mifflin, 1996).

Caute, David. The Year of the Barricades: A Journey Through 1968 (New York: Harper \& Row, 1988).

Chambers, John Whiteclay II. To Raise An Army: The Draft Comes to Modern America (New York: The Free Press, 1987)

Chomsky, Noam, et al. The Cold War and the University: Toward An Intellectual History of the Postwar Years (New York: New Press, 1997). 
Churchill, Ward and Jim Vander Wall. The COINTELPRO Papers: Documents from the FBI's Secret Wars Against Domestic Dissent (Boston: South End Press, 1990).

Coffin, William Sloane. Once to Every Man: A Memoir (New York: Atheneum, 1977).

Dallek, Robert. Flawed Giant: Lyndon Johnson and His Times, 1961-1973 (New York: Oxford, 1998)

Davis, Flora. Moving the Mountain: the Women's Movement in America Since 1960 (New York: Simon \& Schuster, 1992).

DeBenedetti, Charles with Charles Chatfield. An American Ordeal: The Antiwar Movement of the Vietnam Era (Syracuse: Syracuse UP, 1990).

DeBenedetti, Charles, "A CIA Analysis of the Anti-Vietnam War Movement: October 1967," Peace and Change 9: 1 (Spring 1983), pp. 31-41.

Echols, Alice. Daring to Be Bad: Radical Feminism in America, 1967-1975 (Minneapolis: Univ. of Minnesota Press, 1989).

Elliff, John T. Crime, Dissent, and the Attorney General: The Justice Department in the 1960s (Beverly Hills: Sage, 1971)

Evans, Sara. Personal Politics: The Roots of Women's Liberation in the Civil Rights Movement and the New Left (New York: Knopf, 1979).

Farber, David. The Age of Great Dreams: America in the 1960s (New York: Hill and Wang, 1994).

-.-.. Chicago '68 (Chicago: University of Chicago Press, 1988).

Ferber, Michael and Staughton Lynd. The Resistance (Boston: Beacon, 1971)

Fisher, Charles S. "Midwives to History: The Boston Draft Resistance Group," unpublished manuscript, 1971.

Fisher, Randall M. Rhetoric and American Democracy: Black Protest Through Vietnam Dissent (Lanham, Md.: UP of America, 1985).

Flynn, George Q. Louis B. Hershey: Mr. Selective Service (Chapel Hill: University of North Carolina Press, 1985).

----. The Draft, 1940-1973 (Lawrence: University Press of Kansas, 1993). 
Foner, Eric. The Story of American Freedom (New York: Norton, 1998).

Fraser, Ronald, ed. 1968: A Student Generation in Revolt (New York: Pantheon, 1988).

Friedland, Michael B. Lift Up Your Voice Like a Trumpet (Chapel Hill: University of North Carolina Press, 1998).

Garfinkle, Adam. Telltale Hearts: The Origins and Impact of the Vietnam Antiwar Movement (New York: St. Martin's, 1995).

Gaylin, Willard. In the Service of Their Country: War Resisters in Prison (New York: Viking, 1970).

Gitlin, Todd. The Sixties: Years of Hope, Days of Rage (New York: Bantam, 1987)

-The Twilight of Common Dreams: Why America is Wracked By Culture Wars (New York: Henry Holt, 1995).

Goldman, Eric. The Tragedy of Lyndon Johnson (New York: Knopf, 1969).

Gottlieb, Sherry Gershon. Hell No We Won't Go!: Resisting the Draft During the Vietnam War (New York: Viking, 1991).

Goulding, Phil G. Confirm or Deny: Informing the People on National Security (New York: Harper \& Row, 1970).

Gray, Francine du Plessix. Divine Disobedience: Profiles in Catholic Radicalism (New York: Vintage, 1971).

Haasl, Tekla Louise. "'I Want to Knock Down the World': A Study of Radical Feminism and Cell 16," M.A. thesis, Univ. Of New Hampshire, 1988.

Haig-Brown, Alan. Hell No, We Won't Go: Vietnam Draft Resisters in Canada (Vancouver: Raincoast Books, 1996).

Halstead, Fred. Out Now! A Participant's Account of the American Movement Against the Vietnam War, 2nd ed. (New York: Pathfinder, 1991).

Hall, Mitchell K. Because of Their Faith: CALCAV and Religious Opposition to the Vietnam War (New York: Columbia UP, 1990).

Harris, David. Dreams Die Hard (New York: St. Martin's, 1982). 
-.. Our War: What We Did in Vietnam and What it Did to Us (New York: Random House, 1996).

Hauser, Thomas. Mfuhammad Ali: His Life and Times (New York: Touchstone, 1991).

Heath, G. Lewis. Mutiny Does Not Happen Lightly: The Literature of the American Resistance to the Vietnam War (Metuchen, NJ: Scarecrow, 1976).

Heineman, Kenneth J. Campus Wars: The Peace Movement at American State Universities in the Vietnam Era (New York: NYU Press, 1993).

Hensley, William E. "The Vietnam Anti-War Movement: History and Criticism," Ph.D. diss., Univ. of Oregon, 1979.

Hoopes, Townsend. The Limits of Intervention (New York: McKay, 1969).

Horowitz, Irving. The Struggle is the Message: The Organization and Ideology of the Anti-War Movement (Berkeley: Glendessary Press, 1972).

Irons, Peter. The Courage of Their Convictions: Sixteen Americans Who Fought Their Way to the Supreme Court (New York: Free Press, 1988).

Isaacs, Arnold R. Vietnam Shadows: The War, Its Ghosts, and Its Legacy (Baltimore: Johns Hopkins UP, 1997).

Isaacson, Walter, and Evan Thomas. The Wise Men: Six Friends and the World They Made (New York: Simon and Schuster, 1986).

Jack, Homer. Homer's Odyssey: My Quest for Peace and Justice (Becket, Mass.: One Peaceful World, 1996).

Katz, Milton S. Ban the Bomb: A History of SANE, the Committee for a Sane Nuclear Policy, 1957-1985 (New York: Greenwood, 1986).

Katz, Neil H. "Radical Pacificsm and the Contemporary American Peace Movement: The Committee for Non-Violent Action, 1957-1967," Ph.D. diss., Univ. of Maryland. 1974.

Kenniston, Kenneth. Young Radicals: Notes on Committed Youth (New York: Harcourt Brace, 1968).

Kohn, Stephen M. Jailed for Peace: The History of American Draft Law Violators, 16581985 (New York: Praeger, 1987). 
Levy, Peter B. The New Left and Labor in the 1960s (Chicago: University of nlinois Press, 1994).

Lewis, Lionel S. Cold War on Campus: A Study of the Politics of Organizational Control (New Brunswick, NJ: Transaction Books, 1988).

Lembcke, Jerry. The Spitting Image: Myth, Memory, and the Legacy of Vietnam (New York: New York University Press, 1998).

Lipset, Seymour Martin. Rebellion in the University (Boston: Little, Brown, 1972).

Liston, Robert. Greeting: You Are Hereby Ordered for Induction...the Draft in America (New York: McGraw Hill, 1970).

Long, Priscilla, ed. The New Left: A Collection of Essays (Boston: Extending Horizons, 1969).

Lyons, Paul. Class of '66: Living in Suburban Middle America (Philadelphia: Temple UP, 1994).

--.- New Left, New Right, and the Legacy of the Sixties (Philadelphia: Temple UP, 1996).

-2.-. "Toward a Revised Story of the Homecoming of Vietnam Veterans," Peace and Change 23 (April 1998), pp. 193-200.

Lyttle, Bradford. The Chicago Anti-Vietnam War Movement (Chicago: Midwest Pacifist Center, 1988).

MacPherson, Myra. Long Time Passing: Vietnam and the Haunted Generation (New York: Doubleday, 1984).

Maier, Thomas, Dr. Spock: An American Life (New York: Harcourt Brace, 1998).

Malbin, Michael. "Conscription, the Constitution and the Framers, An Historical Analysis." 40 Fordham Law Review 805 (1972).

Matusow, Allen J. The Unraveling of America: A History of Liberalism in the $1960 \mathrm{~s}$ (New York: Harper \& Row, 1984).

McAdam, Doug. Freedom Summer (New York: Oxford, 1988). 
Menashe, Louis and Ronald Radosh, eds. Teach-ins U.S.A.: Reports, Opinions, Documents (New York: Praeger 1967 ).

Merklin, Lewis. Those Chose Honor: The Problem of Conscience in Custody (New York: Harper \& Row, 1974).

Miller, James. Democracy is in the Streets: From Port Huron to the Siege of Chicago (New York: Touchstone, 1987).

Miller, Melissa and Philip Shenk. The Path of Most Resistance_(Scottdale, PA: Herald Press, 1982).

Mitford, Jessica. The Trial of Dr. Spock (New York: Knopf, 1969).

Morse, Stanley J. and Stanton Peele. "A Study of Participants in an Anti-Vietnam War Demonstration," Journal of Social Issues (1971), 27 (4):113-36.

Moser, Richard. The New Winter Soldiers: GI and Veteran Dissent During the Vietnam Era (New Brunswick: Rutgers University Press, 1996).

Moskos, Charles C., and John Whiteclay Chambers II, eds. The New Conscientious Objection: From Sacred to Secular Resistance (New York: Oxford UP, 1993).

Mungo, Ray. Famous Long Ago: My Life and Hard Times With Liberation News Service (1970; reprint, New York: Citadel Underground, 1990).

Nelkin, Dorothy. The University and Military Research: Moral Politics at M.I.T. (Ithaca: Cornell University Press, 1972).

O'Sullivan, John The Draft and Its Enemies: A Documentary History_(Urbana: U of Illinois $\mathrm{P}, 1974$ ).

Peck, Abe. Uncovering the Sixties: The Life and Times of the Underground Press (New York: Pantheon, 1985).

Phillips, Donald E. Student Protest: An Analysis of the Issues and Speeches (New York: University Press of America, 1985).

Polner, Murray, and Jim O'Grady. Disarmed and Dangerous: The Radical Lives and Times of Daniel and Philip Berrigan (New York: Basic Books, 1997).

Powers, Thomas. Vietnam: The War at Home (Boston: G.K. Hall and Company, 1984). Reprint, originally published in 1973 in NYC by Grossman. 
Remnick, David. King of the World: Muhammad Ali and the Rise of an American Hero (New York: Random House, 1998).

Rorabaugh, W. J. Berkeley at War: the 1960s (New York: Oxford, 1989).

Sale, Kirkpatrick. SDS (New York: Vintage, 1974).

Schalk, David F. War and the Ivory Tower: Algeria and Vietnam (New York: Oxford. 1994).

Seidenberg, Willa, and William Short. A Matter of Conscience: GI Resistance During the Vietnam War (Andover, MA: Addison Gallery of Art, 1992).

Simons, Donald. I Refuse: Memories of a Vietnam War Objector (Trenton: Broken Rifle Press, 1992).

Shafer, D. Michael. The Legacy: The Vietnam War in the American Imagination (Boston: Beacon Press, 1990).

Small, Melvin. "The Impact of the Antiwar Movement on Lyndon Johnson, 1965-1968: A Preliminary Report," Peace and Change 10 (Spring 1984).

-.-. Johnson, Nixon and the Doves (New Brunswick, NJ: Rutgers UP, 1988).

Small, Melvin, and William D. Hoover, eds. Give Peace a Chance: Exploring the Vietnam Antiwar Movement (Syracuse: Syracuse UP, 1992).

Smith, Christian. Resisting Reagan: The U.S. Central America Peace Movement (Chicago: University of Chicago Press, 1996).

Southern Conference Educational Fud "An Enemy of the People: How the Draft is Used to Stop Movements for Social Change" (Louisville, KY: SCEF, 1968)

Surrey, David S. Choice of Conscience: Vietnam Era Military and Draft Resisters in Canada (New York: Praeger, 1982).

Swerdlow, Amy. Women Strike for Peace: Traditional Motherhood and Radical Politics in the 1960s (Chicago: U of Chicago P, 1993).

Taylor, Clyde, ed. Vietnam and Black America: An Anthology of Protest and Resistance (Garden City, NY: Doubleday, 1973). 
Thorne, Barrie. "Resisting the Draft: An Ethnography of the Draft Resistance Movement," Ph.D. diss., Brandeis Univ., 1971.

-.-. "Protest and the Problem of Credibility: Uses of Knowledge and Risk-Taking in the Draft Resistance Movement of the 1960s," Social Problems (Dec 1975).

--.. "Women in the Draft Resistance Movement: A Case Study of Sex Roles and Social Movements," Sex Roles 1, No. 2, 1975, pp. 179-195.

-2.. "Gender Imagery and Issues of War and Peace: The Case of the Draft Movement in the 1960s," in Dorothy McGuigan, The Role of Women in Peace and Conflict Resolution (Ann Arbor: University of Michigan Center for Continuing Education of Women, 1977).

Tischler, Barbara, ed. Sights on the Sixties (New Brunswick: Rutgers University Press, 1992).

Tollefson, James W. The Strength Not to Fight: An Oral History of Conscientious Objectors of the Vietnam War (Boston: Little, Brown, 1993).

Tracy, James. Direct Action: Radical Pacifism From the Union Eight to the Chicago Seven (Chicago: University of Chicago Press, 1996).

Turner, Fred. Echoes of Combat: The Vietnam War in American Memory (New York: Doubleday, 1996).

Unger, Irwin. The Movement: A History of the American New Left, 1959-1972 (New York: Dodd, Mead \& Co., 1974).

Useem, Michael. Conscription, Protest, and Social Conflict: The Life and Death of a Draft Resistance Movement (New York: Wiley, 1973).

Vogelgesang, Sandy. The Long Dark Night of the Soul: The American Intellectual Left and the Vieinam War (New York: Harper \& Row, 1974).

Wells, Tom. The War Within: America's Battle Over Vietnam (Berkeley: University of California Press, 1994).

Westby, David L., and Richard G. Braungart. "Class and Politics in the Family Backgrounds of Student Political Activists," American Sociological Review 31 (Oct 1966): 690-692. 
Williams, Roger Neville. The New Exiles: American War Resisters in Canada New York: Liveright Publishers, 1971).

Witcover, Jules. The Year the Dream Died: Revisiting 1968 in America (New York: Warner Books, 1997).

Wittner, Lawrence S. Rebels Against War: The American Peace Movement, 1933-1983 (Phila: Temple UP, 1984).

Zahn, Gordon C. War, Conscience, and Dissent (New York: Hawthorn Books, 1967).

Zaroulis, Nancy and Gerald Sullivan. Who Spoke Up? American Protest Against the War in Vietnam, 1963-1975 (Garden City, NY: Doubleday, 1984).

Zinn, Howard. You Can't Be Neutral on a Moving Train: A Personal History of Our Times (Boston: Beacon, 1994).

Zisk, Betty H. The Politics of Transformation: Local Activism in the Peace and Environmental Movements (Westport, CT: Praeger, 1992). 


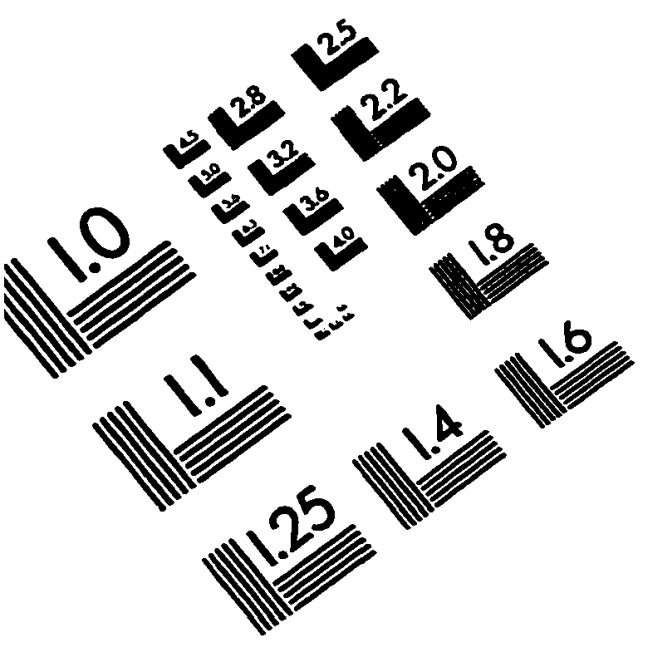

\section{IMAGE EVALUATION TEST TARGET (QA-3)}
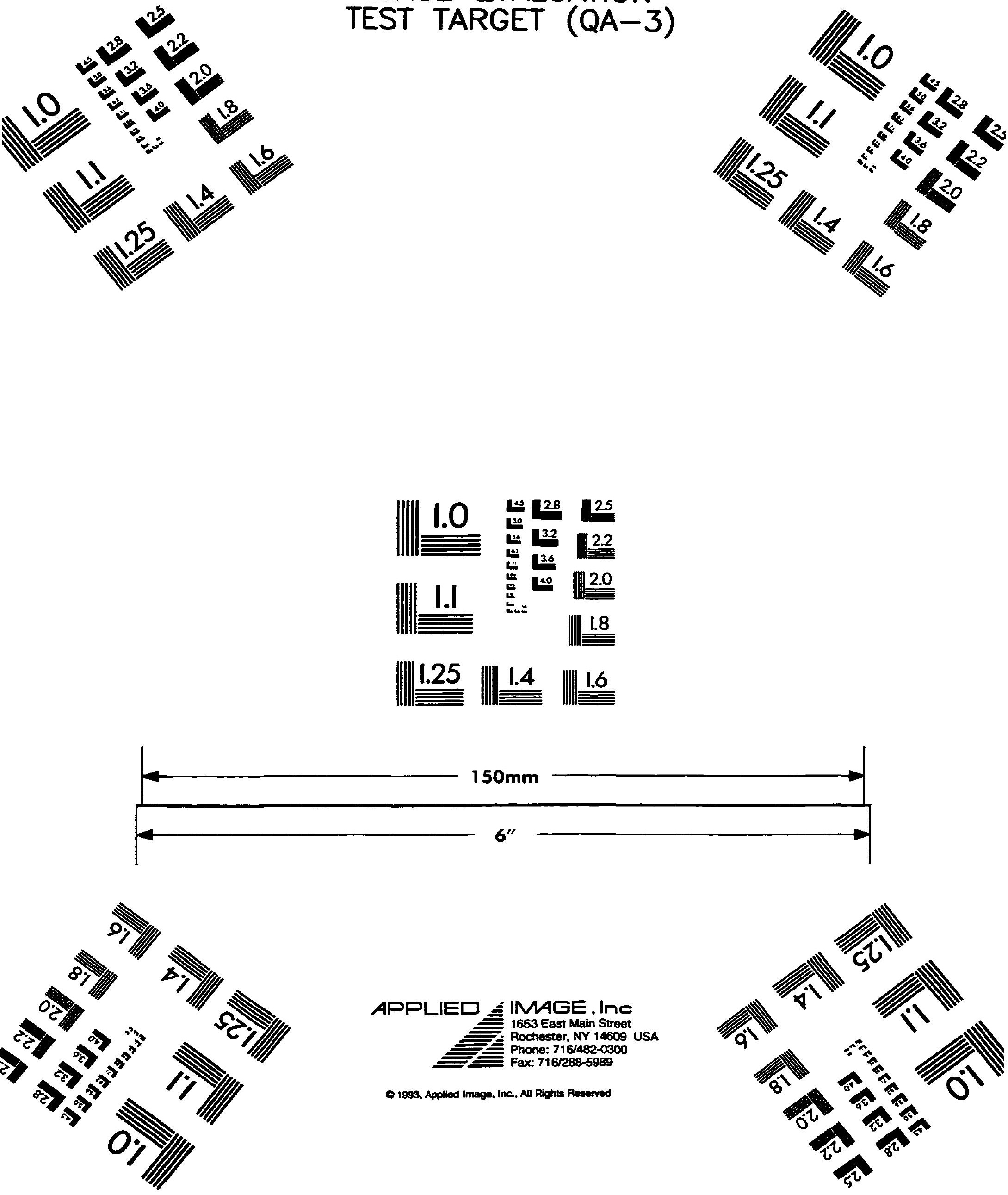